\title{
unesp
}

UNIVERSIDADE ESTADUAL PAULISTA

"JÚLIO DE MESQUITA FILHO"

Faculdade de Ciências e Letras

Campus de Araraquara - SP

\section{MIGRAÇÃO E TRABALHO NA CONTEMPORANEIDADE: OS HAITIANOS NO OESTE DO PARANÁ}


CLAUDIMARA CASSOLI BORTOLOTO

\section{MIGRAÇÃO E TRABALHO NA CONTEMPORANEIDADE: OS HAITIANOS NO OESTE DO PARANÁ}

Tese de Doutorado, apresentada para banca do Programa De Pós-Graduação em Ciências Sociais da Faculdade de Ciências e Letras Unesp/Araraquara, como requisito para obtenção do título de Doutora em 2019.

Linha de pesquisa: Trabalho e Movimentos sociais

Orientador: Marcelo Santos

Bolsa: CAPES 
Bortoloto, Claudimara Cassoli

Migração e trabalho na contemporaneidade: os haitianos no Oeste do Paraná / Claudimara Cassoli Bortoloto - 2019 $349 \mathrm{f}$.

Tese (Doutorado em Ciências Sociais) — Universidade Estadual Paulista "Júlio de Mesquita Filho", Faculdade de Ciências e Letras (Campus Araraquara)

Orientador: Marcelo Santos

1. Migração haitiana no oeste do Paraná. 2. Globalização e seus efeitos sobre o processo migratório. 3. Frigoríficos e trabalhadores migrantes.

I. Título.

Ficha catalográfica elaborada pelo sistema automatizado com os dados fornecidos pelo(a) autor(a). 


\section{MIGRAÇÃO E TRABALHO NA CONTEMPORANEIDADE: OS HAITIANOS NO OESTE DO PARANÁ}

Tese de Doutorado, apresentada para banca do Programa De Pós-Graduação em Ciências Sociais da Faculdade de Ciências e Letras Unesp/Araraquara, como requisito para obtenção do título de Doutora em 2019.

Linha de pesquisa: Trabalho e Movimentos Sociais

Orientador: Doutor Marcelo Santos

Bolsa: CAPES

Data da Defesa : 01/03/2019

MEMBROS COMPONENTES DA BANCA EXAMINADORA:

Presidente e Orientador: Marcelo Santos

Universidade Estadual Paulista Júlio de Mesquita Filho - UNESP

Membro Titular: $\quad$ Renata Medeiros Paoliello

Universidade Estadual Paulista Júlio de Mesquita Filho - UM

Membro Titular: Sidney Antonio da Silva

Universidade Federal do Amazonas -UFAM

Membro Titular: $\quad$ Eric Gustavo Cardin

Universidade Estadual do Oeste do Paraná - Unioeste

Membro Titular: Joaquín Arango

Universidad Complutense de Madrid

Local: Universidade Estadual Paulista

Faculdade de Ciências e Letras

UNESP - Campus de Araraquara 


\section{unesp \\ UNIVERSIDADE ESTADUAL PAULISTA \\ Câmpus de Araraquara}

ATA DA DEFESA PÚBLICA DA TESE DE DOUTORADO DE CLAUDIMARA CASSOLI BORTOLOTO, DISCENTE DO PROGRAMA DE PÓS-GRADUAÇÃO EM CIÊNCIAS SOCIAIS, DA FACULDADE DE CIÊNCIAS E LETRAS - CÂMPUS DE ARARAQUARA.

Aos 01 dias do mês de março do ano de 2019, às 14:00 horas, no(a) Anfiteatro D, reuniu-se a Comissão Examinadora da Defesa Pública, composta pelos seguintes membros: Prof. Dr. MARCELO SANTOS - Orientador(a) do(a) Departamento de Antropologia, Política e Filosofia / Faculdade de Ciências e Letras de Araraquara, Profa. Dra. RENATA MEDEIROS PAOLIELLO do(a) Departamento de Antropologia, Política e Filosofia / Faculdade de Ciências e Letras de Araraquara, Prof. Dr. SIDNEY ANTONIO DA SILVA do(a) Departamento de Antropologia / Universidade Federal do Amazonas, Prof. Dr. ERIC GUSTAVO CARDIN do(a) Departamento de Ciências Sociais / Universidade Estadual do Oeste do Paraná, Prof. Dr. JOAQUÍN ARANGO do(a) Departamento de Sociología Aplicada / Universidad Complutense de Madrid, sob a presidência do primeiro, a fim de proceder a arguição pública da TESE DE DOUTORADO de CLAUDIMARA CASSOLI BORTOLOTO, intitulada Migração e trabalho na contemporaneidade: os haitianos no Oeste do Paraná. Após a exposição, a discente foi arguida oralmente pelos membros da Comissão Examinadora, tendo recebido o conceito final:

f assinada pelos membros da Comissão Examinadora.

Prof. Dr. MARCELO SANTOS

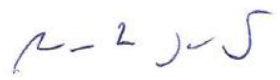

Profa. Dra. RENATA MEDEIROS PAOLIELLO

Participacão por Videoconferência

Prof. Dr. SIDNEY ANTONIO DA SILVA

Prof. Dr. ERIC GUSTAVO CARDIN lan - b.an

Participacão por Videoconferência
Prof. Dr. JOAQUNNARANGO

Faculdade de Ciências e Letras - Câmpus de Araraquara - 


\section{DEDICATÓRIA}

Dedico esse trabalho a todos migrantes que estão vivendo em outros países, que, em nome do controle das fronteiras deparam-se com situações sub-humanas de vida, e, por isso, enfrentam cotidianamente a crise humanitária, de insensibilidade, de violência e de transgressão dos direitos humanos.

Dedico a todos haitianos no Brasil, em especial àqueles que vivem no Município de Cascavel que, desde a chegada dos primeiros, nos brindam com sua cultura, com a diversidade e nos ensinam que respeitar, tolerar e integrar ainda podem ser verbos de ação possíveis de ser assimilados para a construção de valores sociais que conduzam a sociedade a conviver em um mundo mais humano em que a cidadania universal seja a regra em detrimento de nacionalismos.

Aos meus pais, Maria e José, irmãos Christiane, Flávio e Bruno, cunhados e sobrinhos, que me apoiaram para que eu concluísse esse trabalho, chegando a conquista do primeiro título de doutora de nossas famílias.

À professora Leila Menezes Stein em memória. Tentei construir um trabalho a altura do seu pensamento, da sua corrente teórica e de intervenção na realidade ao privilegiar uma compreensão crítica dos trabalhadores imigrantes no Oeste do Paraná.

Ao governo Lula que, no seu primeiro mandato, prometeu à sociedade a formação de milhares de doutores e o restabelecimento da ciência e tecnologia com a recuperação das Universidades do sucateamento vivido nos anos 1990. Hoje, eu posso dizer com orgulho que estou entre esses doutores e que, assim como milhares de outros, represento o filho do pobre que não mediu esforços para alcançar melhores condições de vida e, através dos estudos, conseguir um espaço na sociedade, mas sem nunca deixar de reconhecer, por outro lado, todas as oportunidades abertas para que isso fosse possível.

À comunidade da UTFPR - Universidade Tecnológica Federal do Paraná - Campus de Medianeira. Que todo conhecimento aqui produzido possa ser compartilhado e disseminado em forma de aprendizado com melhores aulas, projetos de pesquisa e extensão.

À Laura e à Karina, que souberam esperar, que foram privadas da minha presença em muitos momentos especiais e que foram, para mim, combustíveis para que eu pudesse seguir e concluir. 


\section{AGRADECIMENTOS}

É chegado o momento de lembrar e agradecer a todos aqueles que, junto comigo, de alguma forma, participaram da história deste doutorado. E não consigo medir ou economizar palavras para falar sobre todas as pessoas que, apesar das adversidades, sempre acreditaram que eu seria capaz de atingir meus propósitos, que torceram e comigo comemoraram esta grande conquista.

Inicialmente, agradeço à Leila Menezes Stein, minha primeira orientadora, mas que hoje não se encontra mais entre nós. Desde a seleção do doutorado, ela acreditou neste projeto, que versa sobre a luta e organização dos trabalhadores, sobretudo dos imigrantes, no Brasil, e comigo aceitou o desafio de desenvolvê-lo. Em sua memória, onde quer que esteja, meus agradecimentos.

À banca de qualificação desta tese, que fez elucidações, críticas e importantes apontamentos para que eu pudesse seguir e finalizar.

Ao meu orientador, o professor Marcelo Santos, que não hesitou em aceitar o desafio de orientar a construção desta tese no meio do percurso. Sua ação pode ser representada, metaforicamente, como aquele que se depara com um labirinto, com muitos caminhos, e que, para encontrar saídas diante das possibilidades existentes, reorganizou os horizontes e as possibilidades. Para chegar até a saída, não foi fácil, pois houve muitos obstáculos. Mas você me ajudou a focar, a encontrar um nexo, a chegar a um resultado que hoje se concretiza nesta tese. Seu trilhar privilegiava o método de pesquisa, o rigor teórico, sem diminuir a minha autonomia frente às recomendações indicadas e respeitando meus próprios limites. Tendo em vista tudo isso, apenas resta-me agradecê-lo.

Um agradecimento especial à banca de defesa desta tese. Primeiramente, sou grata ao professor Sidney A. Silva, que desde a qualificação deu importantes contribuições que foram fundamentais para finalização desse trabalho. Também agradeço à professora Renata Medeiros Paoliello pela interlocução teórica iniciada na disciplina de Teorias Sociais, aprofundada nos apontamentos dessa tese.

Ao professor Eric Gustavo Cardin, foi uma satisfação tê-lo como um dos membros da banca, muito obrigada pelo diálogo ao longo desses anos e por compartilhar comigo os resultados desta pesquisa, o que é um privilégio para mim.

Agradeço também a meu querido orientador do doutorado sanduíche, o professor Joaquin Arango, da Universidade Complutense de Madrid, na Espanha. É um imenso prazer ter uma das grandes referências mundiais na área de migração como membro de julgamento 
deste trabalho. Obrigada, querido professor, por compartilhar comigo tanto conhecimento, e, sobretudo, pela sua humildade e forma de como me recebeu na Espanha. Estabelecemos muito mais que uma relação formal entre orientanda e orientador, pois compartilhamos sentimentos de afeto e amizade, rompendo as relações formais da academia. Estar na Espanha sob sua orientação, interlocução teórica, certamente, foi um dos grandes êxitos e acertos deste doutorado. Com o mesmo carinho, agradeço à professora Eliza Brey, pela atenção e por me introduzir na Universidade Complutense de Madrid, sou muito grata pelo diálogo, indicações de referências, e por toda dedicação no período em que estive nessa universidade.

Também não poderia deixar de agradecer àqueles que foram objeto desta pesquisa - a comunidade haitiana no Brasil, sobretudo os que estão no Oeste do Paraná e que vivem em Cascavel. Meu muito obrigada a todos que participaram desta pesquisa e que me confiaram suas narrativas. Também sou grata aos diversos tradutores que deram voz aos que não dominavam a língua portuguesa. Desejo que este estudo exerça o papel social de levar para a sociedade de Cascavel, e demais que tiverem contato com esse estudo, informações sobre suas condições de vida, e possa servir como meio de sensibilização e denúncia de situações atuais, de preconceito e exclusão social. Espero que este trabalho logre mudanças que possam vir da sociedade e do poder público, com vistas a garantir aos imigrantes condições de inserção, integração e reconhecimento social.

Às redes de apoio que foram fundamentais para a realização desta pesquisa - a Cáritas Arquidiocesana de Cascavel, a Pastoral do Migrante, e a rede étnica de haitianos do município - que intermediaram a relação entre o pesquisador e o objeto de pesquisa.

Não poderia deixar de mencionar a importância de pessoas que, desvinculados das redes sociais, possuem contatos com os haitianos. Entre elas destaco o amigo Leonardo Henrique do Nascimento - Léo, que, em razão do seu envolvimento com os haitianos, por viver e trabalhar em um dos bairros mais habitados por eles em Cascavel, permitiu que eu chegasse até eles para realizar muitas das entrevistas que fazem parte dessa pesquisa.

A todos os professores que tive a oportunidade de conhecer quando cursei as sete disciplinas do programa de pós Graduação em Ciências Sociais da Unesp - Araraquara.

À Universidade Tecnológica Federal do Paraná - UTFPR, câmpus de Medianeira, que viabilizou meu afastamento, primeiramente parcial desde 2015 e posteriormente integral entre 2017 e 2018 para a conclusão das atividades do doutorado. Destaco o apreço de todo o corpo de docentes e amigos do Departamento de Ciências Humanas, Letras, e Artes - DAHLA, da UTFPR Medianeira, verdadeiros companheiros de trabalho, que não hesitaram em tornar possível meu afastamento. Meus agradecimentos a cada um de vocês. 
O presente trabalho foi realizado com apoio da Coordenação de Aperfeiçoamento de Pessoal de Nível Superior - Brasil ( CAPES) - Código de Financiamento 001. Agradeço também pela oportunidade de bolsa de doutorado Sanduíche pelo programa PDSE, que, por quatro meses, possibilitou a realização de parte desta pesquisa em Madri, na Espanha. Essa experiência foi fundamental para a interlocução com pesquisadores que são importantes referências teóricas e metodológicas desta tese.

Agora, é o momento agradecer àqueles que vivenciaram comigo o lado mais difícil desta tese, repleto de tensão e ansiedade. Somente relações afetivas nos permitem suportar os momentos difíceis, pois, para mim, o percurso foi marcado por muitas dificuldades, e não foi fácil chegar até aqui. E, já que mencionei o doutorado sanduíche, aproveito o ensejo para agradecer aos grandes amigos que esse estágio fora do país me proporcionou. Faço um agradecimento mais que especial à jornalista mais “top" e mestranda no El País, Beatriz Jucá Coutinho; à artista doutoranda em Artes, Mariela Sobrinho; e ao meu maravilhoso psicólogo, doutor Pedro Santos. Com esse grupo fui capaz de conversar sobre assuntos diversos, de aprender coisas que não sabia, de ter conversas intelectuais, dividir angústias e descobrir o novo. A sorte de encontrar estudantes da pós graduação de diferentes áreas, conviver na mesma casa foi wanderful, maravilhoso e sensacional. A vocês, meus queridos amigos, muito obrigada! Foram quatro meses em que pude compartilhar sentimentos tão profundos que, talvez, uma vida inteira não poderia oferecer.

Ainda agradeço à amiga Merari Montoya, professora da Universidade Autônoma do México, com quem vivenciei uma troca de amizade e conhecimento científico, e construí uma grande e fiel amizade. À querida Natália, outra mexicana maravilhosa. À Raquel Ferreira, Juliana Maioli, Paula e Yolanda, a presença de cada uma de vocês foi um afago nesse período longe da família e do Brasil.

No percurso desses quatro anos de doutorado, várias amizades se agregaram e foram ombros onde pude descansar o corpo e a alma. Certamente, várias pessoas fizeram de Araraquara não somente a morada do sol, mas cidade do calor humano e da solidariedade. Então, meu muito obrigada aos queridos amigos da Moradia Estudantil, que me acolheram por algumas noites.

Eu costumo chamar os ombros que acolhem de amigos. E eles foram algumas das coisas boas que o doutorado me deu, penso que as melhores. A partir das relações acadêmicas construímos amizades, cheias de afeto e cumplicidade, que permanecerão fixas como uma árvore que cria raiz, e tende a ser cada vez mais forte devido à solidariedade e aos sentimentos afetivos que resultaram dessas relações. Agradeço, especialmente, ao querido amigo Luiz 
Bispo, com quem pude compartilhar tantos desafios, dialogar sobre a academia e as coisas da vida. A você, meu amigo, sou grata por tudo.

Outra que merece homenagem é Carmen Agá, um daqueles seres humanos do bem que, com um gesto nobre e de preocupação com o outro, organizou o primeiro encontro entre alunos da pós-graduação da Unesp de Araraquara no ano de 2015. Na ocasião, ela e demais alunos de Araraquara se colocaram à disposição para conhecer as demandas e necessidades dos colegas que vinham de outras cidades e Estados. Enquanto representante de um grupo de alunos, a Carmem se dispôs a auxiliar com informações ou o que mais fosse preciso. Atitudes como essas são fundamentais para alunos recém-chegados, e, para mim, foi importante o acolhimento que tive, pois através dele fui levada para a Moradia estudantil, e, depois disso, foi feito o convite para que eu permanecesse na sua quitinete quando estivesse em Araraquara. Pessoas como a Carmen ensina a corrente do bem, da solidariedade e do significado da empatia, de cada um de nós se importar com o outro.

Deparar-se com pessoas boas, amigas e solidárias estava no meu percurso, e elas não paravam de chegar. Foi assim que me aproximei da minha querida amiga Andrea Brito. Com ela, compartilhei amizade, casa e abrigo, e ainda fomos parceiras de produção intelectual e de viagens para congressos. Entre nós foi construída mais uma árvore da amizade. Seriam poucos os adjetivos para expor a admiração e o carinho que tenho por ti. Araraquara, na sua pessoa, foi generosa para mim, e apenas boas lembranças posso compartilhar, além de momentos de ansiedades, daqueles sentimentos que somente dividimos com verdadeiros amigos.

Aos amigos Jorge, Anderson, Marcelo e Raul, sempre prestativos, obrigada por todo carinho, atenção e preocupação que dedicaram a mim.

Entre as coisas boas do doutorado, também está mais uma grande amiga, a Valdirene, ou Val, colega de turma, pessoa simples e intelectual que me ajudou em muitos momentos desta tese, com sentimentos de afeto ao compartilhar conhecimentos e também angústias. Nossa filosofia sempre foi a solidariedade, e como a gente se deu bem nessa parte! Rompemos continentes e seguimos firmes como uma mão que segura a outra. Você foi importante intelectual para mim, além de ser uma daquelas pessoas em que a humildade mais uma vez vem à tona, chamando minha atenção para o fato de que esses valores são raros e, por isso, tão importantes de ser cultivados.

No percurso da pesquisa de campo, tive o contato com alguns haitianos, entre os quais destaco Jean, Romário, Celeux, Judite, Nelma, Jymi, Claudete e Josefa. Muitos deles a 
imigração já levou para outros lugares, mas permanece a amizade e a cumplicidade de vocês, que foram fundamentais para o desenvolvimento desta pesquisa.

À Rosangela Ferreira, que no decorrer desta pesquisa estava na condição de funcionária da Caritas, mas que já goza de aposentadoria e se dedica como voluntária na Pastoral do Migrante. Muito obrigada por compartilhar seus saberes e por propiciar o contato com muitos dos entrevistados. Como dizem vários autores, as instituições religiosas no Brasil são a porta de entrada para muitos pesquisadores das imigrações. E partilhar contigo momentos de construção desta tese foi uma grande possibilidade de aquisição de conhecimento e aprendizado.

À Ana Karina Sartori, pela tradução do resumo e transformação em abstract, sua presteza e disponibilidade são coisas daqueles amigos que estão sempre conosco, juntos nas causas políticas e científicas.

Nesse trajeto, outro grande amigo que cruzou o meu caminho o Augusto Mugnai - ou Guto, professor de História da Unipar. Nossa amizade foi para além do espaço formal da pesquisa, pois nos tornamos cúmplices e conselheiros um do outro. Pelo fato de vivenciarmos uma mesma situação, a de doutorandos que pesquisam temas tão sensíveis e delicados, colocávamo-nos em contato e em profundo diálogo afetivo, acadêmico e teórico. Sua amizade foi outro grande presente que este doutorado me proporcionou.

Aos grandes amigos Shiderlene, Tiago, Angela, Célio, Nelva, Ricardo, Iná, Gracy Kelly agradeço pelo apoio, carinho, sensibilidade e preocupação. Foi importante cada mensagem de tranquilidade, como também a disposição em ouvirem meus murmúrios e lamentações. Ter amizades como essas foi fundamental. Por mais que, em muitas situações, me parecia estar em um barco sozinha e a deriva no mar, os amigos me resgatavam, e me faziam ver que sempre existe a possibilidade de regressar e encontrar a margem.

Não poderia deixar de mencionar pessoas que contribuíram com a fase final da tese, lendo com precisão o texto, ajudando a identificar seus problemas de compreensão e coesão, bem como de ortografia. Assim, com carinho agradeço ao amigo Conrado Pereda Minucelli, sua leitura e as ricas observações tecidas foram fundamentais no momento que eu já não percebia os problemas da escrita. Além de você agradeço ao revisor ortográfico Jonathan Chasko pelo precioso trabalho de revisão ortográfica.

Ao Grupo de pesquisa GPPS da Unioeste, que em 2018 com a leitura do livro 1 de o Capital de Karl Marx, proporcionou reflexões profundas muitas das quais foram incorporadas nessa pesquisa ao mesmo tempo que me permitia trazer reflexões da tese e discuti-las. Assim 
agradeço aos amigos e companheiros de estudo: Liliam, Nelson, Katarina, Alex, João, Aline, Christiani, Paulo e Queli, estudar com vocês sempre me proporciona profundo aprendizado.

Aos funcionários da Secretaria de Pós Graduação em Ciências Sociais da Unesp de Araraquara que sempre foram atenciosos e eficientes, sendo um importante suporte para alunos que estão tão distantes como eu.

Aos funcionários da Biblioteca da Unesp de Araraquara, lugar especial de tantas horas de estudo nos momentos sem aula, em especial ao José, pessoa educada e sempre disponível para ajudar a localizar os livros.

Aos integrantes do Comitê de Ética da UNESP e a assistente administrativa Maíra pela disponibilidade e eficiência nas informações, quais facilitaram a organização da documentação e tramitação para aprovação.

Agradeço em especial a minha família, que viveu comigo as maiores aflições, agonias, mas que também compartilhou os momentos de êxitos e felicidade, como a seleção para o doutorado, o alívio da qualificação, a felicidade do doutorado sanduíche, o retorno ao Brasil, e a finalização dessa tese. Sou grata a todos vocês, pais, irmãos, agregados, tios e primos, enfim, a toda família Cassoli e Bortoloto. Também agradeço à minha família do coração, formada por Margarida Lopes, Dinda Eva, Maria e Sérgio. É com imenso carinho que dedico a todos vocês o primeiro título de doutorado das nossas famílias, Cassoli e Bortoloto. Estamos chegando a um status antes nunca pensado e, por isso, esta tese é sinônimo de luta, coragem, esforço e muita dedicação, e representa um pouquinho de cada um de vocês.

Em especial, agradeço a minha irmã Christiani e meu cunhado Nardel, que fizeram leituras do texto, e, com olhar atento, acompanharam a construção deste trabalho, agora concluído. E também agradeço à querida Chaiane Medeiros por todas as leituras e apontamentos.

Ao meu querido Lindomar, que chegou como uma surpresa da vida e do amor, me deu a segurança e outros aportes necessários para superar a aflição e ansiedade da reta final.

Agradeço à Karina Fernanda Bortoloto, que realmente compartilhou comigo noites, finais de semana, feriados, enfim, todos os dias que eram, para nós, dias de estudo, algo muito normal para uma doutoranda e para uma aluna do curso de Medicina. E com a gente foi assim, quatro anos de um partilhar de lutas e conquistas, mas também de ansiedades, medos, aflições, noites mal dormidas e tantos sentimentos bons e ruins que se fizeram intensos no contexto desses quatro anos. Nós sofremos juntas a ansiedade dos estudos, da copa do mundo de 2018 e de uma das eleições presidenciais mais tumultuadas da nossa história com um vencedor arcaico, retrógrado dono de muitas pechas e estereótipos que tentei descontruir aqui. 
Lutamos juntas pelo Ele não, mas infelizmente a história não se faz sob nossas escolhas, mas pelas circunstancias determinadas, como dizia o Velho Marx. A você, filha querida, que foi criada por uma mãe estudante e trabalhadora, agradeço pelo apoio de sempre e peço desculpas por tantas ausências. Por fim, gostaria de lembrar um serzinho que não é humano, mas que desempenhou tanto afeto e cumplicidade que me dava força para enfrentar o desanimo e o cansaço, ao meu cãozinho Kevin. Ele chegou no percurso do doutorado, e, enquanto escrevia a tese, rodeava meus pés. Seria pouco descrever o quanto um animal de estimação faz a diferença no percurso de um aluno de pós-graduação, por ser aquele companheiro sempre disponível, que está contigo em todos os momentos, até naquela caminhada de quase meianoite, quando se conclui uma parte importante da produção e se sente a necessidade de sair e espairecer. Esses animais tornam nossa produção menos isolada e nos dão, sem cobrar o retorno de afeto, fidelidade, amizade e muito companheirismo. Assim recomendo que todo aluno de pós graduação tenha um bicho de estimação, dentre eles, indico o cachorro, super amigão. 


\section{MOVIMIENTO}

Apenas nos pusimos en dos pies

Comenzamos a migrar por la sabana

Siguiendo la manada de bisonte

Más allá del horizonte, a nuevas tierras lejanas

Los niños a la espalda y expectantes

Los ojos en alerta, todo oídos

Olfateando aquel desconcertar

Paisaje nuevo, desconocido

Somos una especie en viaje

No tenemos pertenencias, sino equipaje

Vamos con el polen en el viento

Estamos vivos por que estamos en movimiento

Nunca estamos quietos

Somos tras humantes, somos

Padres hijos nietos y biznietos de inmigrantes

Es más mio lo que sueño que lo que toco

Yo no soy de aquí, pero tu tampoco

Yo no soy de aquí, pero tu tampoco

De ningún lado, de todo $\mathrm{y}$, de todos

$$
\text { Lados un poco }
$$

Atravesamos desierto, glaciares, continentes

El mundo entero de extremo a extremo

Empecinados, supervivientes

El ojo en el viento y en las corrientes

La mano firme en el remo

Cargamos con nuestras guerra

Nuestras canciones de cuna

Nuestro rumbo hecho de versos

De mi graciones, de hambrunas

Así ha sido desde siempre, desde el infinito

Fuimos la gota de agua, viajando en el meteorito

Cruzamos galaxias, vacíos, milenios

Buscamos oxigeno, encontramos sueños

Apenas nos pusimos en dos pies

Y vivimos en la sombra de la hoguera

Escuchamos la voz del desafió

Siempre miramos al rió, pensando en la otra rivera

Somos una especie en viaje

No tenemos pertenencias, sino equipaje

Nunca estamos quietos, somos tras humantes

Somos padres hijos nietos y biznietos de inmigrantes

Es más mio lo que sueño, que lo que toco

Yo no soy de aquí, pero tu tampoco

Yo no soy de aquí, pero tu tampoco

De ningún lado, de todo y, de todos Lados un poco

Los mismo con las canciones

Los pájaros, los alfabetos

Si quieres que algo se muera Déjalo quieto

Música de George Drexler 


\section{RESUMO}

Essa pesquisa analisa o processo de imigração e trabalho dos Haitianos no Oeste do Paraná. Os primeiros imigrantes chegaram em 2012 trazidos do Acre por empresários locais para suprir a carência de trabalho manual inicialmente na construção civil. A falta de mão de obra delineou as primeiras migrações de haitianos para a região, fortalecida posteriormente com as redes de apoio. Por meio de pesquisa qualitativa, com utilização da pesquisa de campo, foram realizadas 60 entrevistas a fim de testar a hipótese se os empreendimentos frigoríficos privados têm contribuído para atrair a imigração haitiana no Oeste do Paraná. O município de Cascavel-PR foi selecionado como amostra por ser a cidade com o maior número de haitianos do Estado. Como resultados dessa pesquisa, destacam-se: a desconstrução do mito da crise migratória e sua importância enquanto ideologia para ocultar a existência de uma crise humanitária, com políticas estatais reduzidas ao fechamento das fronteiras e transgressão dos direitos humanos. Os imigrantes haitianos no Oeste do Paraná são força de trabalho substituta e disponíveis nos frigoríficos com organização produtiva baseada no fordismo/taylorismo que demandam mão de obra abundante, trabalho simplificado e intensa exploração da força de trabalho. Também constatou-se a vinculação dos frigoríficos à globalização, os quais sob o pseudo conceito de cooperativas, ocultam a presença de trustes na região ao passo que os representam e definem o preço da força de trabalho nos frigoríficos. Como consequência desse mesmo processo, ocorre dessa forma a captura do Estado pelas grandes corporações por meio de investimentos públicos consubstanciados de diversas ordens, enquanto o Estado se mantém praticamente ausente na formulação de políticas de migração. Esse estudo demonstrou também a importância do fluxo migratório haitiano para a construção de políticas migratórias, com destaque para o visto humanitário e a Nova Lei de Migração vigente desde Novembro de 2017. Essa Lei incorpora os direitos humanos e visa superar a pecha até então presente no Estatuto do Estrangeiro que concebia o imigrante como ameaça nacional. Além disso, destaca os desafios de ser imigrante na periferia, pautado nos baixos salários, na redução dos ganhos, elevado custo de vida, e alto índice de desemprego entre haitianos, o que tem precarizado as condições de vida no Brasil. Ademais, a pesquisa identificou a hegemônica incorporação dos haitianos no frigorífico Coopavel e simultaneamente constatou o fechamento do sistema produtivo nos demais setores do Município. A submissão do trabalho em frigoríficos se coloca como única alternativa de inserção produtiva, quando essa também não se fecha. Associado à manutenção de picos migratórios desde 2014, um quantitativo de $58 \%$ dos entrevistados chegaram diretamente em Cascavel, o que caracteriza a importância das redes de apoio como familiares e étnicas para impulsionar esse fenômeno na região.

Palavras-chave: imigração haitiana, globalização, trabalho, frigoríficos. 


\begin{abstract}
This research analyses the process of immigration of Haitians to the West of Paraná. The first immigrants from Haiti came in 2012, brought from the state of Acre by local employers to work in civil construction to overcome the labour shortage in this field. The process of immigration was later strengthned by local support nets. Through qualitative research and field research, 60 interviews were made in order to test the the following assumption the local cold stores have been contributed to push the immigration process through in the West of Paraná. The city of Cascavel was chosen as a sample because it is the city where there are the largest number of Haitians in the state. As a result of this research, it is worth stressing the dispelling of the myth of the migration crisis and its importance as an ideology created to hide the existence of a humanitarian crisis, with state policies reduced to borders closing and transgression of human rights. The Haitian immigrants in the West of Paraná are a substitute and available labour force to work in the cold stores, which productivity is based on the Fordism and Taylorism. The work is simplified and the exploitation of the labor force is intense. It was also found the link between the cold stores and globalization. The cold stores also hide the presence of trusts in the region under the false concept of a farm cooperative. They represent and define the price of the labour force in the cold stores. As a result of this process, there is a capture of the State funds by the great corporations. Although they use substantiated public investments, the State government is practically absent in creating migration policies. This study has also demonstrated the importance of the Haitian migratory flow to the creation of migratory policies as the Humanitarian Visa and the New Law of Migration, applicable since 2017. This law incorporates the human rights and intends to overcome the vision of the immigrant as a national threat. The present study highlights the challenges of been an immigrant in the suburbs, with low pay, limited profits, high living expenses and high unemployment profits, which have been cause precarious living conditions in Brazil. Also, this research identified the hegemonic integration of Haitians in Coopavel cold store and concurrently found the closing of the productive system in other areas of the city to them. The submission of the work in the cold stores, when it is available, becomes the only labour alternative to the immigrants. Associated to the maintance of the migratory peak levels since 2014, an amount of 58\% of the surveyed came directly to Cascavel city, which shows the importance of family and ethnic support nets to boost this phenomenon in the region.
\end{abstract}

Key words: haitian immigration, globalization, work, cold stores 


\section{LISTA DE FOTOS}

Foto 1 Haitianos trabalhando em frigoríficos. 104

Foto 2 Quitinetes habitadas por haitianos em Cascavel. 136

Foto 3 Penteado haitiano penyen ti très lage antrelase. 137

Foto 4 Penteado haitiano: penyen ti kouri. 137

Foto 5 Operações financeiras BNDES. 156

Foto 6 Operações diretas e indiretas automáticas BNDES. 157

Foto 7 Operações de pré-embarque contratadas entre 2002 a setembro de $2018 . \quad 159$

Foto 8 Número de estrangeiros considerados migrantes, segundo principais 190 países de nascimento, por ano de entrada, Brasil - 2010-2016.

Foto 9 Número de empregos formais segundo setor de atividade econômica. 203

Foto 10 Cadeia avícola. 207

Foto 11 Frigoríficos no Oeste do Paraná 1963-1970. 218

Foto 12 Emissão de carteiras de trabalho dados por países 2010-2016. 226

Foto 13 Principais atividades econômicas desenvolvidas por estrangeiros. 231

Foto 14 Pichação em estabelecimento em Cascavel. 249

Foto 15 Pichação de Ponto de ônibus em Cascavel. 251

Foto 16 Missa com a comunidade haitiana 12 de Fevereiro de 2017.

Foto 17 Reunião com haitianos atividade realizada pela Pastoral do Migrante $12 \quad 274$ de Fevereiro de 2017.

Foto 18 Reunião com haitianos atividade realizada pela Pastoral do Migrante 2 de 275 Fevereiro de 2017.

Foto 19 Cáritas Arquidiocesana de Cascavel, 26 de maio de 2017.

Foto 20 Cáritas Arquidiocesana de Cascavel,26 de maio de 2017278

Foto 21 Setores e vagas de trabalho Regional de Cascavel. 290 


\section{LISTA DE GRÁFICOS}

Gráfico 1 Operações indiretas automáticas BNDES/COOPAVEL 158

Gráfico 2 Índices de migração em Cascavel Paraná de 2012 a $2017 \quad 189$

Gráfico 3 Primeira cidade a chegar no Brasil 192

Gráfico 4 Principais motivadores da migração haitiana em Cascavel 197

Gráfico 5 Situação de trabalho entre os haitianos entrevistados Cascavel $2017 \quad 230$

Gráfico 6 Emprego setor formal, informal, autônomo e desemprego entre os 234 homens haitianos.

Gráfico 7 Emprego setor formal e desemprego entre as mulheres haitianas. 235

Gráfico 8 Setores de incorporação do trabalho feminino formal. 236

Gráfico 9 Setores e índices de incorporação dos haitianos no mercado de 242 trabalho formal em Cascavel e Região 2017.

Gráfico 10 Tem interesse de voltar para o Haiti. 267

Gráfico 11 Transferência de remessas para o Haiti Governo Federal período 2010269 a Maio de 2017 em milhões de reais

Gráfico 12 Recebe ajuda financeira para sobreviver atualmente. 270

Gráfico 13 Índice de empregabilidade nos diferentes Frigoríficos em Cascavel. 283 


\section{LISTA DE TABELAS}

Tabela 1 Quantidade da população imigrante haitiana cadastrada no 122 SINCRE de 2009 a 2017

Tabela 2 Total de imigrantes inscritos na Agência do Trabalhador e 252 colocados no mercado de trabalho em Cascavel 2012 a 2016

Tabela 3 Imigrantes inscritos na Agência do Trabalhador de Cascavel por 253 gênero

Tabela 4 Imigrantes inscritos na Agência do Trabalhador por idade - 254 Cascavel 


\section{LISTA DE ABREVIATURAS E SIGLAS}

ACIC

ACNUR

BNDES

CNIg

CARITAS

COOPAVEL

IBGE

SEASO

SEMDEC

SINCRE

SINDUSCOM

SINTRIVEL
Associação Comercial Industrial de Cascavel

Agência da ONU para Refugiados

Banco Nacional do Desenvolvimento

Conselho Nacional de Imigração

Caritas Arquidiocesana de Cascavel

Cooperativa Agroindustrial de Cascavel

Instituto Brasileiro de Geografia e Estatística

Secretaria Municipal de Assistência Social

Secretaria Municipal de Desenvolvimento de Cascavel

Sistema Nacional de Cadastro e Registro de Estrangeiros

Sindicato da Indústria da Construção Civil do Estado do Paraná

Sindicato dos Trabalhadores da Construção Civil de Cascavel 


\section{SUMÁRIO}

1. INTRODUÇÃO

1.1 Aspectos metodológicos 35

1.1.1 Roteiro da Tese

2. CAPÍTULO I - GLOBALIZAÇÃO: EFEITOS E OS IMPACTOS SOBRE 40 A MIGRAÇÃO

2.1 As migrações contemporâneas: crise migratória ou humanitária? 40

2.1.1 A era da catástrofe: a mobilidade humana como consequência das grandes $\quad 48$ guerras

2.1.2 A era fordista, difusão do capital e incorporação dos contingentes 58 migratórios

2.1.3 Globalização e seus efeitos sobre a migração $\quad 67$

2.1.4 Dependência econômica e seus impactos na inovação tecnológica no 83 Brasil

3. CAPÍtUlo II - HAITIANOS NO OESTE DO PARANÁ: UMA 95 COMPREENSÃO DO PROCESSO MIGRATÓRIO E SUA VINCULAÇÃO COM OS FRIGORÍFICOS

3.1 Estado e migrações transnacionais 95

3.1.1 O Brasil como nova rota migratória haitiana 107

3.1.2 Imigração haitiana: primeiros indícios da mobilidade no Oeste do Paraná $\quad 120$

3.1.3 Cascavel no contexto da globalização: frigoríficos e a integração 124 econômica mundial

3.1.4 Imigração haitiana e a commodity da agroindústria de proteínas 142

3.1.5 O Brasil: políticas de migração como reação do Estado aos grandes fluxos 161

migratórios no contex to da globalização

3.1.6 A nova lei de Migração: conquistas e impasses para a promoção dos 172 direitos migratórios a partir dos grandes fluxos de haitianos no Brasil

4. CAPÍTULO III - TRABALHO EM FRIGORÍFICOS NO OESTE DO PARANÁ: IMPULSIONADORES DA IMIGRAÇÃO HAITIANA

4.1 Imigração haitiana: delineadores para a mobilidade no Oeste do Paraná

4.1.1 A cadeia produtiva de frigoríficos: monopólio internacional e exploração 187 da força de trabalho sob o ritmo do desenvolvimento tecnológico

4.1.2 O trabalho em frigorífico e a demanda de trabalhadores suscetíveis ao trabalho simplificado

4.1.3 Trabalho em frigoríficos: a rotatividade como aspectos de atração da mão de obra haitiana

4.1.4 Haitianos no Oeste do Paraná, a transferência do preconceito de cor e a reprodução de estruturas arcaicas de desigualdade social

4.1.5 Envio de remessas entre as periferias e a precarização de vida dos haitianos no Brasil

4.1.6 Organização das redes de apoio a imigrante haitianos em Cascavel Paraná

4.1.7 Haitianos em Cascavel e setor produtivo: embates para a sobrevivência 
5. CONCLUSÃO

REFERÊNCIAS BIBLIOGRÁFICAS

APÊNDICES $\quad 328$

APÊNDICE A - Questionário de entrevista com haitianos 329

APÊNDICE B - Requerimento ao RH da Coopavel sobre a contratação de 331

haitianos

APÊNDICE C - Requerimento de dados sobre haitianos feito à Agência do 332

Trabalhador de Cascavel

APÊNDICE D - Requerimento de dados sobre haitianos feito à Secretaria de Assistência Social de Cascavel

APÊNDICE E - Requerimento de dados sobre haitianos feito à Secretaria de Saúde de Cascavel

ANEXOS

ANEXO A - Parecer do Comitê de Ética em Pesquisa aprovado

ANEXO B - Termo de consentimento livre e esclarecido

ANEXO C - E-mail de retorno do RH sobre a contratação de haitianos pela

Coopavel

ANEXO D - Registros ativos de haitianos realizados na Polícia Federal, entre os anos de 2009 a 2017

ANEXO E - Dados quantitativos da Polícia Federal sobre haitianos no Brasil e no Paraná

ANEXO F - Memorando da Secretaria de Estado da Justiça, Trabalho e Direitos Humanos sobre a colocação de estrangeiros em postos de trabalho no Paraná

ANEXO G - Dados da Relação Anual de Informações Sociais (RAIS)

ANEXO H - Transferências pessoais do Brasil para o Haiti em 2016 e 2017, de acordo com o Banco Central do Brasil 


\section{INTRODUÇÃO}

Os novos fluxos migratórios, por envolver uma grande quantidade de países e pessoas que se deslocam de um país, região, ou continente para outro, tem, por essas características, despertado maior atenção de representantes políticos e governos para a migração contemporânea, que vem sendo interpretada por eles como "crise migratória".

No entanto, esse problema não se relaciona com a seguridade daqueles que se atrevem a cruzar as fronteiras do seu país de origem impulsionados por motivos que vão desde as migrações forçadas, em razão de violência, pobreza, perseguições e catástrofes naturais, ou mesmo pela busca de melhores condições de vida, segurança e trabalho.

A mobilidade humana sofre reações positivas ou negativas que se relacionam com a concepção que os governos têm em relação aos migrantes, que podem ser considerados desejados ou indesejados, conforme a demanda do processo produtivo. Se há necessidade de capital humano ou força de trabalho estrangeira, abrem-se as fronteiras e se justifica a imigração como necessária ao desenvolvimento econômico do país. Se o capital humano não é necessário, fecha-se a fronteira e se justificam as políticas de controle como necessárias para garantir a segurança nacional, dada a concepção do estrangeiro como ameaça nacional, que põe em risco não somente a segurança, mas também a homogeneidade cultural de um povo ou país (CASTLES, HASS; MILLER, 2014).

Estudos mais recentes sobre o tema mostram grande mobilidade na Ásia, África e a América Latina no século XIX e início do século XX, ensejadas, sobretudo pelo desenvolvimento de transportes, comunicação e tecnologia, que facilitam a mobilidade e colocam a migração internacional como uma dinâmica central dentro da globalização.

Nesse contexto, a expansão de novas rotas migratórias é impulsionada com a globalização, e, de acordo com Alves (1999), Santos (2004) e Ianni (2002), esse fenômeno dá significado a ampliação do capital, caracterizada pela maior liberdade do mercado e transformações nas relações de trabalho, engendradas a partir da década de 1970 como uma alternativa para superar a crise capitalista.

Nessa perspectiva, esta pesquisa busca estudar a imigração haitiana para Cascavel, no Estado do Paraná, à luz das transformações no mundo do trabalho impulsionadas pela globalização. Esse fenômeno se coloca como central para as transformações das relações de trabalho, ao desenvolver a mobilidade do capital e de pessoas.

O desenvolvimento da pesquisa revelou como a migração está estritamente vinculada às transformações produtivas mostradas, sobretudo, nos frigoríficos, entendidos como os 
principais incorporadores da mão de obra haitiana no Oeste do Paraná. Desse modo, a relação entre imigração e o trabalho mostra como Cascavel se insere no âmbito da migração internacional.

A produção e transformação de proteínas em frigoríficos é uma das novas commodites produzidas na região, e tem sido responsável pelo crescimento de parte significativa da economia. Assim, os referidos imigrantes se colocam em um contexto de imigração internacional, produzida em massa no Haiti desde 1914, com a ocupação do país pelos Estados Unidos, expelindo desde então, os haitianos, que passam a migrar massivamente para alguns países que se tornaram as principais rotas: Estados Unidos, França e Canadá.

O Haiti tem se convertido em um importante exportador de mão de obra para esses países, no entanto a essas rotas foi adicionado o Brasil, que, desde 2010, passou também a receber esses imigrantes. Eles chegaram como refugiados ou imigrantes ambientais, devido ao terremoto ocorrido no país naquele ano, o que desencadeou um processo migratório contínuo até o presente momento.

Baeninger (2016) ressalta que 2010 marca o contexto migratório dos haitianos para o Brasil, com sua inserção na rota da imigração transnacional do século XXI, e reforçou um novo cenário migratório, que passa a se dar entre países periféricos. Embora outros países já estivessem inaugurado a migração entre periferias, os haitianos no Brasil tem se constituído no mais expressivo dentre os demais grupos migratórios.

Para Baeninger (2016), essa compreensão requer análises sobre as transformações das relações de trabalho, bem como da situação política, social e econômica dos países que se deparam constantemente com a mobilidade humana, como os de origem, trânsito e destino dos imigrantes.

Os maiores volumes migratórios do Haiti para outras regiões do mundo ocorrem após os anos 1970, e indicam, além de outros fatores, a hegemonia de redes formadas em países industrializados e desenvolvidos como impulsionadores de migrações forçadas, ambientais e econômicas. É certo afirmar que as redes de apoio formadas por migrações anteriores são fundamentais para o desencadeamento de grandes fluxos migratórios, no entanto, o caso dos haitianos no Brasil demonstra que as primeiras levas de imigrantes não contaram com essas redes.

Indica-se que a imigração haitiana para o Brasil foi formada em decorrência de alguns fatores como o crescimento econômico, relações geopolíticas entre os países, fechamento das fronteiras tradicionais, além do discurso do Brasil como país acolhedor, que impulsionaram e 
fizeram do Brasil uma nova rota que, até 2010, quase não havia sido explorada, e que, desde então, formaram as redes que dão suporte para impulsionar imigrações recentes.

Nesse sentido, cabe analisar que os países exportadores de mão de obra possuem uma vinculação intrínseca com o sistema produtivo, mas não se limita a ele, pois não existem somente imigrantes econômicos, mas há uma totalidade de elementos que fazem do trabalho um impulsionador do sistema migratório.

Assim se explica e delineia a organização produtiva de antigas rotas migratórias, cujas relações de trabalho se baseavam no fordismo/taylorismo e requeriam grande leva de imigrantes para ocupar o processo produtivo, geralmente com a execução de trabalhos manuais. Essas transformações das relações produtivas desencadearam mudanças significativas no processo migratório, que direcionarão os novos fluxos diante do fechamento das fronteiras tradicionais.

Esses países passam por reestruturação produtiva que altera as relações de produção sem que isso signifique a mudança deles na divisão internacional do trabalho, mas tais mudanças baseadas no neofordismo, toyotismo, flexibilização e a terceirização, são novos termos que traduzem aspectos da globalização, que significa a reorganização do capital. Esse fenômeno foi amplamente agilizado e generalizado com base nas técnicas eletrônicas, automatização, robótica e concretiza a reestruturação do capitalismo, em termos geográficos e históricos. A fábrica global pode ser simultaneamente realidade e metáfora. Expressa não só a reprodução ampliada do capital em escala global, compreendendo a generalização das forças produtivas, mas também a globalização das relações de produção (IANNI, 2002).

Enquanto isso, a produção fordista/taylorista dava lugar à organização produtiva toyotista, baseada na produção de just in time, na qual mercadorias personalizadas são produzidas conforme a demanda, a organização produtiva é submetida a um ritmo de trabalho polivalente, viável a partir da inovação tecnológica.

Esse novo cenário dispensava um grande número de trabalhadores, que já os diminuíam em decorrência da maior inovação tecnológica, com a substituição do trabalho vivo pelo trabalho morto. A forma de implementação dessas reformas em cada país dependeu da sua própria organização. Mas é certo que o toyotismo se disseminou pelo mundo, assim como foi o fordismo/taylorismo em períodos anteriores.

Estudiosos sobre esse tema no Brasil inferem que, aqui, diferente de outros países que substituíram a produção fordista/taylorista pelo toyotismo, houve uma mescla das três formas de organizações produtivas. Permaneceu, em algumas áreas, a produção fordista/taylorista, com grande capacidade de inovação tecnológica, o que intensificou a produção em série, 
associada à diversificação da produção, conforme a demanda requerida. Assim como o capital se dissemina, também se amplia o deslocamento de populações, impulsionado pela globalização.

Os fluxos migratórios do século XXI expressam, cada vez mais, importante papel no cotidiano social e nas relações de trabalho. Isso porque não se deixam constituir apenas como um aspecto de mobilidade de pessoas, mas por representarem aspectos da mobilidade de força de trabalho, que impactam diretamente nos fluxos financeiros e nas relações de produção, com reflexo na divisão internacional do trabalho (SASSEN, 2014). Nesse sentido, a presente pesquisa se propõe a analisar em que medida a globalização e a transformação produtiva, com impacto no mundo do trabalho, incide na imigração haitiana em Cascavel, no Paraná.

O interesse por esse tema decorre da rápida e intensa migração dos haitianos no Município de Cascavel. Estes, desde 2012, impõem o fenótipo negro, a linguagem diferenciada, vestes e roupas coloridas, e ocupam os diversos espaços da cidade, dando vida e mudando a imagem étnica e racial de uma região marcada pela ideologia da colonização planejada, formada, em grande parte, por descendentes de italianos e alemães, advindos do sul do Brasil.

As análises a respeito dos processos migratórios indicam, como pressupuseram Castles, Hass e Miller (2014), que há uma recepção positiva dos imigrantes pelo sistema produtivo em períodos de vigência da forma de organização produtiva fordista/taylorista. Essa organização produtiva, pautada nas características do trabalho em série, monótono e repetitivo, desde suas origens, exige grande demanda de trabalhadores enquanto o toyotismo marcado pela automatização e robótica tem dispensado essa mão de obra.

O fechamento das fronteiras nos países mais tradicionais da migração haitiana tem se justificado frente à "crise migratória", ou invasão de estrangeiros, como um mecanismo de redirecionamento que joga para o imigrante a responsabilidade pelo desemprego estrutural, e moralmente justifica o que é imoral: a recusa deles nesses países, reordenando seus estoques para outros rincões do mundo, como o Brasil.

O sistema produtivo baseado no fordismo/taylorismo, impulsionado pelas indústrias de transformação de carnes no Oeste do Paraná, ao demandar grande quantidade de mão de obra, pode ter contribuído para impulsionar a imigração haitiana para o Município, constituindo-se como importante espaço de redistribuição desses imigrantes no Brasil, já que os processos produtivos destes frigoríficos se baseiam no modelo fordista.

Castles e Miller (2004) ressaltam que a imigração, uma vez iniciada, será contínua, podendo apenas variar em maiores ou menores fluxos. Aqui não apenas as redes serão 
fundamentais para essa continuidade, sendo o maior protagonista da condição e capacidade de inserção produtiva, quando, diferentemente de outros setores produtivos, continua a demandar mão de obra.

O processo produtivo em frigoríficos baseados na organização do trabalho sob os princípios fordistas são funcionais para a incorporação da imigração de haitianos para a região Oeste do Paraná. Esses imigrantes passaram a atender à carência desse setor de frigoríficos, visto que os trabalhadores nacionais o rechaçam devido ao trabalho desqualificado, monótono e desvalorizado. Diante da oportunidade de outras possibilidades laborais, os frigoríficos são descartados pelos trabalhadores nacionais, ao passo que os imigrantes se colocam como um importante exército industrial de reservas, disponíveis para um setor que tem na rotatividade de mão de obra um dos principais fatores do trabalho degradante. Trata-se de um setor produtivo que, pelas próprias condições de organização e trabalho desqualificado, insere imediatamente aqueles que se submetem a ele, pois dispensa conhecimentos mais elaborados para ser desempenhado.

A pesquisa pretendeu concentrar um conjunto de questões que permitem relacionar a vinculação dos imigrantes haitianos com frigoríficos, de forma a identificar se esse setor tem atraído as primeiras migrações e se mantém vínculo com sua continuidade, uma vez que se identifica na pesquisa o período migratório que vai de 2010 até 2017.

O estudo busca, ainda, relacionar aspectos macrossociológicos como a globalização, entendida como um meio hegemônico de disseminação do capital, que tem na transformação das relações produtivas um importante elemento constituinte, para, então, perceber suas nuances e como são reproduzidas ou impactam na perspectiva de micro análise.

Ainda acerca da opção pelo município de Cascavel, ela justifica-se pela inserção da cidade no sistema global a partir de três fenômenos. O primeiro são as relações produtivas com a formação de cadeias ligadas a oligopólios mundiais, que resultam na produção e exportação de um tipo específico de mercadorias, como a transformação de carnes ou proteínas, com incorporação de grande contingentes de mão de obra. Outro se refere à projeção internacional via exportação, assim como a incorporação de inovação tecnológica compatível com as relações hegemônicas de produção baseadas no fordismo/taylorismo. E, por último, a inserção massiva de haitianos em sua máquina produtiva, que fez de Cascavel o maior receptor de imigrantes haitianos no Estado do Paraná.

A imigração haitiana no Brasil está prestes a completar uma década em 2020. Anteriormente a 2010, outros países foram rotas de maior fluxo migratório de haitianos. Magalhães (2016) e Mamed (2017) ressaltam que os grandes fluxos começaram a migrar do 
Haiti para outros países a partir de 1914, em decorrência da ocupação do país pelos Estados Unidos.

A transformação industrial, econômica e o crescimento do Brasil garantiu-lhe o status de sexta economia mundial até 2014. Isso contribuiu para acender os holofotes do país como nova rota migratória, possível de ser explorada, dado o maior recrudescimento das leis de migração, com fechamento das fronteiras nas rotas até então consolidadas.

As crises econômicas são sempre utilizadas para fechar as fronteiras ou para expelir os imigrantes dos países. Hobsbawm (2012) ressalta que essa é uma tragédia histórica de épocas de crise, que dispensa seres humanos mais rapidamente do que a economia de mercado os insere. O Brasil recebeu, desde 2010, um contingente massivo de imigrantes haitianos, formando o maior fluxo migratório em cem anos (ZENI; FILIPPIM, 2016). Ao mesmo tempo em que as principais rotas receptoras fecharam suas fronteiras a partir da crise econômica de 2008, essa mão de obra foi considerada adequada pelo empresariado brasileiro, que se viu diante da carência de trabalhadores em um país que vinha apresentando índices positivos de crescimento econômico.

A prosperidade econômica viabiliza o aquecimento produtivo e, contraditoriamente, em alguns contextos de maior crescimento econômico, permite que trabalhadores nacionais escolham outros postos de trabalho disponíveis. Isso não significa que melhores condições econômicas eliminem a superação de relações degradantes de trabalho, bem como elevação de salários, mas permite ao trabalhador escolher uma ocupação menos degradante, sobretudo no que concerne às condições de trabalho.

Nesse quesito, destaca-se o setor de frigoríficos, que teve na disponibilidade de haitianos nas fronteiras do Brasil uma alternativa para substituir, em determinadas situações, a mão de obra demandada pelo setor, bem como a partir dela, formar um exército de reservas de trabalhadores disponível conforme sua demanda. A disponibilidade desses trabalhadores nas fronteiras do país despertou o interesse de vários setores produtivos, que passavam por carência ou escassez de mão de obra nacional.

Em outra perspectiva, Baeninger e Peres (2017) abordam o estudo da imigração haitiana no Brasil a partir do conceito de imigração de crise, entendida tanto pela condição do Brasil e sua incapacidade de enfrentar esse grande fluxo, bem como devido às situações que delineiam os novos movimentos migratórios, baseados em fenômenos sociais condicionados a problemas políticos, civis, econômicos, religiosos, ideológicos e humanitários.

A ampliação desse fenômeno incorpora os imigrantes considerados refugiados, além de imigrantes solicitantes de refúgio e com refúgio humanitário, condições jurídicas baseadas 
em convenções internacionais. É importante salientar que, a partir desses lugares inseridos na lógica da produção global, desencadeia-se uma nova configuração migratória, internacional e nacional, com diversas modalidades de fluxos migratórios, incluindo-se os movimentos migratórios de refugiados e daqueles relacionados à crise humanitária ou mesmo ambiental.

À medida que novas localidades se inserem na lógica global, as migrações internacionais vão se intensificando, correspondendo às transformações oriundas da reestruturação do capitalismo global da inserção dos países na geopolítica mundial e suas políticas migratórias com importantes papéis assumidos por essas localidades na divisão internacional do trabalho.

Nessa perspectiva, Santos (2004) aponta a importância da migração como um sistema global translocal e transnacional de reprodução social, com articulações entre lugares de origem e destino, através de um sistema de classes global e transnacionalizado. De acordo com o autor, a reprodução social de imigrantes também passa a ser globalizada, com a migração internacional produzindo a intersecção entre os processos locais de reprodução social. Nessa perspectiva, para Baeninger e Peres (2017), a migração de crise interconecta a reprodução social de uns e outros no contexto global das desigualdades sociais.

Assim, ser imigrante haitiano no Brasil remete à migração transnacional com sua reprodução social globalizada. Para além dos espaços da América do Norte, parte da Europa e países caribenhos, a imigração é intensificada na América do Sul, o que tende a contribuir para a ampliação das relações de exploração.

Castles e Miller (2004) acreditam que a desvalorização da mão de obra é um problema comum entre os imigrantes de várias partes do mundo. Na periferia, a perspectiva é ampliar essa exploração no contexto das migrações transnacionais, com a intensificação do exército de reservas, sendo esse elemento importante para a manutenção dos baixos salários.

O fechamento das fronteiras nas consolidadas rotas dinamizam as migrações entre países periféricos, intensificando a reprodução da força de trabalho e exploração característica desses países, associado a exploração da mão de obra migrante tendencialmente rebaixada por essa condição, indispensável ao sistema quando disponível. A inserção social também se faz pela inserção laboral, fundamental para garantir as condições mínimas de reprodução. Nessa perspectiva, os haitianos foram redistribuídos nas fronteiras do país, delineados pela necessidade do sistema produtivo que insere localidades como o Haiti e Cascavel na produção global.

Entre esses setores produtivos no Paraná, destaca-se o de processamento de matériasprimas, como frigoríficos, além da construção civil, responsável pela busca dos primeiros 
haitianos documentados na fronteira do Brasil com a Bolívia. Nessa perspectiva, a pesquisa visou testar a hipótese se o setor produtivo delineado pelo agronegócio, especificamente os frigoríficos, atraíram a migração haitiana para Cascavel.

O Município, por meio da produção e exportação de carnes para vários países, intensifica sua inserção na economia global, já dinamizada pela produção e exportação de grãos. O processamento de carnes in natura aumentou a demanda de trabalhadores e fez da imigração haitiana uma força de trabalho substitutiva na falta de trabalhadores nacionais. Além disso, essa mão de obra é também mais propícia a índices maiores de exploração, devido a condição de imigrantes e toda vulnerabilidade que estão submetidos quando estão em outro país diferente do de origem. Assim, a dinâmica da globalização, embora materialize a dinamização e projeção de empresas nacionais, que passam a dominar hegemonicamente o mercado nesse sistema produtivo vinculadas às redes oligopólicas, não se limita a eles, mas abrange a própria estrutura produtiva que delineia esse reordenamento produtivo e garante a produtividade no contexto da organização fordista/taylorista.

O ramo produtivo de frigoríficos requer a inovação tecnológica como premissa para se manter no mercado, no entanto, essa inovação não suprimiu os padrões produtivos fordistas/tayloristas, os quais mantiveram e aprimoraram, via tecnologia, o trabalho em série, repetitivo e monótono. Desse modo, afirmar a predominância de relações de trabalho pautadas no fordismo/taylorismo não significa a existência de um complexo industrial marcado pelo anacronismo e falta de inovação tecnológica.

Há um amalgama entre inovação tecnológica para manutenção da produção fordista/taylorista com elementos do toyotismo, mantendo a dependência de grande número de trabalhadores, mesmo tendo incorporado novas formas de organização produtiva, como aquelas marcadas pelos padrões produtivos toyotistas.

Essa pesquisa contemplou diversas fontes e buscou fazer das narrativas objeto primário de investigação, de forma a recuperar e compreender a implicação do agronegócio, representado por frigoríficos, na imigração de haitianos para o Oeste do Paraná. Esse propósito levou à realização de 60 entrevistas com haitianos em Cascavel, o que corresponde a $1,2 \%$ desses migrantes no município. Esse número foi delimitado pelo alcance das entrevistas realizadas no campo.

As entrevistas viabilizaram o levantamento dos dados estatísticos, que foram compilados conforme as variáveis apareciam nas respostas, e também considerando as experiências e trajetórias desses migrantes, que, com seus relatos, foram lapidando narrativas 
sobre migração, os percursos e as principais motivações que os trouxeram para Cascavel. Depois de compilados os dados, eles foram analisados.

Este estudo produziu fontes primárias, por meio das entrevistas e depoimentos orais. As variáveis contempladas pela entrevista produzem dados qualitativos, além dos relatos de experiência, como forma de recuperar a relação entre migração e trabalho. Simultaneamente, delineia a necessidade ou intencionalidade desta pesquisa, cujo resultado pretende, além de cumprir a função científica, ser usado como instrumento político, entendendo-se que seus dados podem ter apropriação e utilização pelos entrevistados.

Mais uma vez, as redes de apoio se colocam como essenciais para o processo migratório. Fazem parte dessas redes instituições que, na ausência de políticas estatais de acolhimento e inserção social, prestam atendimento aos imigrantes, o que se traduz em uma ação generalizada em todo o Brasil. A tendência nacional de atuação das redes sociais como amparadoras e auxiliadoras do processo migratório, em suas diferentes fases, também foi preconizada pela Cáritas Arquidiocesana de Cascavel, pela Pastoral do Migrante e pela Igreja Anglicana, que se constituíram referências importantes para os imigrantes haitianos em Cascavel, assim como as redes étnica e familiar.

Além do apoio institucional, a maior parte desta pesquisa foi viabilizada pela rede de contatos entre os próprios haitianos. Aí se insere a rede de apoio familiar ou étnica, com os contatos estabelecidos pelos entrevistados, que indicaram outras pessoas para compor a amostra.

Algumas questões permearam o levantamento de variáveis que buscaram identificar a relação dessa imigração com o setor de frigoríficos, como: quais os principais motivadores da migração para Cascavel? Qual a primeira cidade a chegar no Brasil? Essas questões, muitas vezes, se complementavam a outras, pois, ao relatar o que motivou a migrar, o imigrante traçava a trajetória sobre a imigração no Brasil. Elas traduzem anseios e trajetórias, evidenciavam se Cascavel já fazia ou não parte dos planos migratórios ou se surgiu como uma possibilidade não programada frente a outras situações, como a necessidade de ter para onde ir e a conquista de um trabalho.

É escasso o volume de estudos que tratam da imigração de haitianos para o Oeste do Paraná, mas o pouco referencial teórico infere sobre a vinculação entre o setor produtivo de frigoríficos e imigração, já que esse setor demanda mão de obra constante devido a rotatividade de trabalhadores que insere e exclui do sistema produtivo. Por isso, busca-se compreender a relação entre imigração de haitianos para Cascavel e a vinculação de empresários do setor de frigoríficos na região com a seguinte questão: Foi trazido por algum 
empresário para trabalhar em Cascavel? Assim, retoma-se qual a origem da migração, se ela está vinculada ou não com determinadas atividades produtivas e a ausência de trabalhadores manuais. Essa questão é chave para identificar os primeiros imigrantes que chegaram ao município atraídos por empresários, bem como para avaliar o atual período de imigração, de modo a compreender se ele continua estável e se tem aumentado ou diminuído.

A ocupação produtiva é outra questão fundamental para conhecer quais setores produtivos estão incorporando os haitianos no Oeste do Paraná, através de questões que consideram a atual ocupação laboral, em que atividade trabalha e se essa é formal ou informal. Essa questão, além de delinear o universo ocupacional da mão de obra haitiana nessa amostra, revela as condições de trabalho que estão submetidos os imigrantes na região.

Conhecer a função laboral executada no Haiti foi fundamental para entender a atividade desempenhada pelos imigrantes no Brasil e sua satisfação em realizá-la. Ao serem inquiridos sobre que trabalho realizava antes de vir para o Brasil, os imigrantes foram levados a revelar as experiências de trabalho e suas condições no país de origem, muitas vezes colocadas como impulsionadoras do processo migratório, que se relaciona, por vezes, a questões econômicas.

O período de recorte desta pesquisa tem início em 2010, devido à migração massiva de haitianos para o Brasil, especialmente após o terremoto ocorrido nesse ano, conforme indicam vários pesquisadores (FARIA, 2016; MARTINS, 2014; SILVA S., 2016a; SILVA P., 2016; ASSIS E MAGALHÃES, 2016; OLIVEIRA e SILVA S., 2016).

Pensar a imigração no contexto da globalização não significa negar sua existência em períodos anteriores. É salutar relembrar que ela acompanha a dinâmica do capital desde o seu surgimento, em um primeiro momento, com a imigração de trabalhadores do campo para a cidade, e, posteriormente, via processo de colonização. Destaca-se que a imigração e sua importância seguem a lógica da dinâmica das relações de trabalho, pois o fechamento e a abertura de fluxos migratórios ocorrem conforme a demanda do capital.

O caráter metabólico do sistema capitalista se manifesta nas mudanças dessa sociedade, com a reconfiguração e o desenvolvimento das forças produtivas. Nos anos 2000, foi intensificada a imigração pelo mundo, e o Brasil não ficou alijado desse fenômeno. O país recebeu considerável número de imigrantes, provenientes, sobretudo de países periféricos.

Nesse contexto, o Estado brasileiro criou algumas legislações a fim de regularizar a situação de pessoas que entram no país em situações irregulares. É o caso da Normativa $n^{\circ} 97$ de 2012, que outorgou o visto humanitário para haitianos. Essa foi a legislação mais expressiva, mas é considerada uma lei contraditória, já que impôs cota anual de vistos 
expedidos no Haiti e, tampouco reconheceu o refúgio ambiental, colocando todos os imigrantes haitianos na condição de imigrantes laborais. Portanto, a referida norma jurídica ignora e nega o refúgio a quem, de fato, tem direito, e não reconhece o refúgio ambiental, o que consiste em uma estratégia para não abrir precedentes para outros imigrantes o solicitarem, diante de enfrentamentos de situações semelhantes. A despeito disso, é preciso reconhecer que a normativa em questão regularizou a situação de milhares de imigrantes que estavam nas fronteiras do país, permitindo a redistribuição dos mesmos em território nacional.

Baeninger e Peres (2017), ao avaliarem a situação específica do Brasil aos grandes fluxos de haitianos, apresentam o conceito de migração de crise, devido à característica específica da política brasileira que, através do visto humanitário, busca resolver a situação da crise migratória. A migração de crise está ancorada em situações que conduzem os novos movimentos migratórios, como problemas políticos, civis, econômicos, religiosos, ideológicos e humanitários. A ampliação desse fenômeno incorpora distintas formas de refúgio, como o humanitário e o ambiental. Essas classificações se amparam nas condições jurídicas, e são baseadas em convenções internacionais.

Conforme Vinente (2016), a fronteira é destacada como um importante espaço do processo migratório e sempre foi para os imigrantes um local de passagem, embora muitos deles não tenham ideia de para onde ir após saírem dela. Assim, os primeiros a chegar rumaram por destinos não planejados e definidos pelo próprio processo migratório. Nessa conjuntura, Cascavel se tornou rota de mobilidade dos primeiros fluxos de imigrantes haitianos que chegaram ao Brasil e, conduzidos por redes produtivas, como empresas, os imigrantes foram levados para trabalhar no município. Posteriormente, foram construídas outras redes de apoio, como a familiar e a étnica, que se tornaram protagonistas da continuidade do processo migratório.

Os primeiros imigrantes que adentraram o interior do Paraná por redes produtivas povoaram a cidade de novos habitantes, estrangeiros e negros que falam outra língua, têm outros costumes e uma identidade étnica e racial muito peculiar, o que difere das características dos moradores autóctones da região.

Entende-se que o processo migratório está associado ao contexto internacional, dado pelas transformações no mundo do trabalho, e intensificado em razão da abertura econômica e mobilidade humana, viabilizadas pela globalização. A relação entre migração e transformações no mundo do trabalho, delineadas pela globalização, são centrais nesta pesquisa. Exemplo disso é a inserção do município de Cascavel no mercado mundial, com a exportação de carnes para vários países, bem como pela expressão dos monopólios através de 
redes produtivas que ligam o interior do Estado do Paraná ao espaço global. Isso aumentou a demanda de trabalhadores no município e fez da imigração haitiana uma força de trabalho substitutiva dos trabalhadores nacionais.

A pesquisa de campo voltou-se para as redes de apoio institucionais, como a Pastoral do Migrante e a Cáritas, e também às redes de apoio familiares e étnicas. Para a realização deste estudo, foi necessário contar com haitianos que já falavam português, para que pudessem ser tradutores daqueles que não possuíam domínio sobre a língua. Além disso, realizei um curso inicial de francês, que me permitiu maior aproximação com esses grupos de haitianos, com a pronuncia de algumas frases que me possibilitaram estabelecer os primeiros contatos e identificar entre eles os que falavam ou entendiam minimamente o português.

Quando chegava nos conjuntos de quitinetes, onde se concentravam muitas famílias de imigrantes, cumprimentava-os com essa frase: bonsoa comen sava? E com outra conseguia identificar se algum haitiano falava português: cualquer on parle portugais? Nisso, aparecia entre eles os que dominavam a língua portuguesa, e, dessa forma, fui selecionando, pelo domínio da língua, os haitianos que me ajudaram a entrevistar os demais e me auxiliaram como intérpretes. Essa estratégia permitiu que os entrevistados fossem falando com outros haitianos e, dessa forma, foi se desenvolvendo a pesquisa.

Como as entrevistas foram determinadas pelo campo, os haitianos ordenavam quando elas iam ocorrer, o que, geralmente se realizava nos finais de tarde, sábados, domingos ou em algumas manhãs. Assim que as primeiras entrevistas eram realizadas, as demais já eram agendadas. Ao todo, foram realizadas 60 entrevistas, que possibilitaram o conhecimento das especificidades do fluxo migratório em Cascavel.

Os processos migratórios são delineados por diversos fluxos, em diferentes períodos. Com a pretensão de desbravar esse fenômeno no contexto atual, pesquisar a imigração e o trabalho dos haitianos no Oeste do Paraná foi um desafio. Por isso, a metodologia adotada neste trabalho não se restringe a um caminho único, como coloca Demartini (2005), mas se vale de diversos instrumentos metodológicos e fontes, delineadas conforme as demandas de investigação impostas pelo próprio objeto. As incursões históricas demarcam a natureza desta pesquisa, embora as fontes utilizadas sejam as mais variáveis possíveis.

O conhecimento sobre a trajetória de um fluxo migratório é relevante para se apropriar de suas especificidades. No entanto, Dermatini (2005) ressalta a importância de mergulhar em um contexto delimitado, que permite a melhor compreensão de sua complexidade. A autora recupera a denominação de imigrantes ou aqueles que vagueiam pelo mundo em busca de melhores condições de vida e de trabalho. 
A compreensão desse fenômeno é feita pelas entrevistas, cuja amostra não constatou haitianos vivendo em Cascavel anteriormente a 2012. Da mesma forma as notícias que tratam dos haitianos na cidade também datam esse mesmo ano, como demonstram (GONÇALVES, 2012) e (FAG, 2012). Autores que refletem sobre a metodologia dos estudos migratórios tendem a considerar a importância de fazer das entrevistas um complemento das fontes escritas.

Esta pesquisa, que se debruça sobre o tema migração de fluxos haitianos para o Brasil e seu desdobramento no interior do Paraná, abre mão da metodologia das migrações por gerações, embora esse seja um importante recurso utilizado por muitos autores, como enfatiza Demartini (2005). No entanto, devido à recente migração de fluxos haitianos para o Brasil, ainda não é possível utilizar essa metodologia. Por isso, neste estudo, optou-se por focar as fases migratórias, observadas em estudos que traçam o perfil do imigrante haitiano, como indica Silva S. (2016a).

Ao traçar o perfil dos imigrantes, Silva S. (2016a) identifica as seguintes fases. A primeira delas é composta por homens entre 20 e 35 anos, com escolarização média. Em um segundo momento, o autor destaca a consolidação das redes migratórias como aquelas que dão suporte ao imigrante, e, também, as de reintegração familiar, com a presença de mulheres solteiras e grávidas, além de alguns grupos familiares completos, como crianças, menores de 18 anos e idosos. Do ponto de vista do status conjugal, há um predomínio de homens solteiros que afirmam ter filhos no Haiti. Esse perfil, ou as diferentes fases migratórias são reproduzidas em Cascavel, cuja realidade não se diferencia das fases apontadas por Silva S. (2016a).

O contexto da pesquisa de campo proporcionou observar as vivências desses imigrantes, ao realizá-la entre o final do mês de abril e início do mês de junho, observei as dificuldades desses imigrantes em enfrentar as baixas temperaturas, em razão da falta de roupas e cobertas para se agasalharem. À angústia enquanto pesquisadora, colocada pelo campo e pela instabilidade de conseguir ou não ter desempenho nas entrevistas, eram somados outros sentimentos, como o testemunho das precárias condições de sobrevivência, marcadas também pelo clima, fazendo do inverno mais um desafio a ser vencido por esses imigrantes.

Em nenhum momento me deparei com haitianos passando fome ou morando na rua. Isso porque há entre eles solidariedade, o que faz com que aqueles que têm comida e abrigo compartilhem seus bens com aqueles que enfrentam alguma necessidade. Verifica-se, pois, que situações de pobreza, manifestas na escassez de alimentos e nas pequenas moradias 
compartilhadas por muitas pessoas, assim como a falta de abrigos, são problemas comuns enfrentados pelos haitianos. E esses problemas se tornavam mais acentuados ou não, a depender do acesso desses imigrantes haitianos ao sistema produtivo brasileiro, ou mesmo das ajudas que recebem de outros haitianos, que moravam no Brasil e no Haiti.

Minha experiência de ter trabalhado por mais de oito anos na área social da Prefeitura Municipal de Cascavel já havia permitido o meu contato com a pobreza extrema, como também a consciência da sua existência como um problema estrutural. Logo, não deixei de executar ações paliativas, mesmo sabendo que não resolveria um problema maior, em vista da grande demanda por auxílio que me apresentava no desenvolvimento da pesquisa. Fiz campanhas na internet para arrecadação de agasalhos, cobertas e alimentos. Entretanto, isso foi suficiente para atender apenas casos pontuais. Mas o problema era recorrente nas dezenas de famílias com as quais me deparei no transcorrer da pesquisa.

Ao realizar as entrevistas, recordava-me de uma das passagens da obra "O Povo Brasileiro", de Darcy Ribeiro (1995), quando o autor relata a felicidade como um sentimento que define o povo brasileiro, que se sobressai às difíceis condições de vida. Essa era a minha percepção em relação aos haitianos quando visitava suas moradias, as queixas sobre a vida no Brasil comumente se restringiam ao preconceito, à falta de trabalho e aos baixos salários.

A colocação profissional é entendida como fundamental para compensar o processo migratório, tendo em vista a necessidade de custear as despesas para permanecer no Brasil, e, logo, prover o envio de remessas para os que ficaram no país de origem, ou garantir condições para retornar à casa de origem, quando fosse esse o desejo do imigrante. Nas visitas, a frase "amiga, não tem trabalho" era comum nos depoimentos.

Esses episódios revelam o elevado índice de desemprego entre os haitianos, como será demonstrado no terceiro capítulo desta tese. A solidariedade daqueles que trabalham não é somente em relação com quem ficou no Haiti, mas com aqueles que estão no Brasil. Fato parecido foi observado na Espanha, quando estive no país por um período de cinco meses, para a realização de doutorado sanduíche. As principais ruas de Madrid estão tomadas de moradores de ruas, mas não se observa, entre eles, a presença de negros. Esse seria outro tema ou objeto de investigação, sobretudo porque a Espanha tem sido uma importante rota marítima de africanos. Mas o contato com alguns trabalhadores negros imigrantes, vendedores ambulantes, pelas Ruas de Madrid, levou à observação de um aspecto comum entre eles e os 
haitianos no Brasil: a solidariedade e as moradias compartilhadas, que lá os fazem ocupar as ruas para o trabalho informal como vendedores de mercadorias. ${ }^{1}$

A realidade desses haitianos em Cascavel aparece nos capítulos que seguem nesta tese. $\mathrm{Na}$ realização da pesquisa de campo, além da solidariedade entre eles, constatou-se a alegria de um povo que, diante das imensas dificuldades que lhes são impostas em razão de sua condição de imigrantes, longe de sua pátria e familiares, fazem do Brasil uma extensão do Haiti. A alegria, aspecto destacado por Ribeiro (1995) ao se referir ao povo brasileiro frente às imensas dificuldades de condições de vida, é também identificada nesta pesquisa entre os haitianos.

As situações vulneráveis às quais estão suscetíveis no processo migratório e o enfrentamento das mesmas os tornam revolucionários, conforme exprime Mezzadra (2005). Isso porque rompem com as fronteiras nacionais, que colocam a ambivalência à medida que a tensão entre realidade que oprime e a busca por liberdade ganha centralidade na discussão teórica e política.

A diferença entre os fluxos migratórios, bem como sua existência em diferentes períodos e incursões, são aspectos que delineiam as peculiaridades que fizeram de Cascavel a cidade com maior número de recepção de imigrantes, entre as demais cidades do Estado do Paraná. Esta pesquisa, que tinha como uma das justificativas desse estudo a cidade de Cascavel como a mais numerosa no que se refere à recepção de haitianos no Oeste do Paraná, foi alterada. De 2016 a 2018, além de Cascavel ser a cidade do Oeste do Paraná com maior número de imigrantes haitianos, ela é, em 2018, a cidade do Estado com o maior número desses imigrantes (BRASIL, 2018a), (CATVE,2017a).

\subsection{Aspectos metodológicos}

Este estudo privilegiou a pesquisa de campo, com a finalidade de aprofundar o conhecimento sobre a realidade específica da migração de haitianos em Cascavel e a sua vinculação com os frigoríficos. Para isso, foram utilizados vários mecanismos de acesso ao campo, que permitiram a observação participante por meio das entrevistas.

A pesquisa foi concretizada por meio de narrativas orais, coletadas em entrevistas feitas com 60 haitianos residentes no município de Cascavel, através de questionário

\footnotetext{
${ }^{1}$ Longe de generalizar que comunidades étnicas negras não estão na rua por conta da cor, o que se observa em ambos países é o considerável número de imigrantes negros, que possuem comunidades étnicas organizadas a
} 
semiestruturado. O objetivo foi revisitar a memória desses sujeitos com a utilização de fonte de pesquisa primária, com entrevistas de trabalhadores que se colocam como protagonistas de sua história. Assim, buscou-se compreender em que medida essas experiências relacionam trabalho e imigração; a quais experiências de trabalho estão sujeitos esses imigrantes; e como elas impulsionam a continuidade da mobilidade, seja deles próprios ou de familiares, para outras regiões do Brasil ou, ainda, para outros países.

Buscou-se, também, quantificar os dados que surgiram nas entrevistas orais e demonstrá-los em gráficos e análises, que constituem a parte quantitativa desta pesquisa. Somado a isso, tem-se a pesquisa qualitativa, que apresenta a análise teórica dos fenômenos, revisão bibliográfica, além das análises dos gráficos e demais dados apresentados.

As técnicas de pesquisa se alteram com o tempo, acompanhando o desenvolvimento tecnológico, o que repercute nos métodos e utilização de novos instrumentos de coleta de dados. É o caso da utilização do celular para realização das entrevistas. Como esse aparelho faz parte da vida cotidiana dos imigrantes, cumpre mais que a função de comunicação, pois viabiliza as vinculações imagéticas em tempo real entre quem fica e quem migra. Isso fez das redes sociais um dos principais agentes no momento da pesquisa, diminuindo formas de constrangimento presentes anteriormente, com a utilização do clássico gravador. O celular estava ligado, próximo ao entrevistado, mas ele também possuía o seu objeto, o que fazia do aparelho do entrevistador apenas mais um dos inúmeros que todos possuíam. Desse modo, tem-se uma diminuição importante dos possíveis episódios de constrangimento no momento da entrevista. $\mathrm{O}$ acesso aos aparelhos celulares é uma tendência mundial, que se apresenta como uma nova tecnologia, cuja qualidade e componentes variam entre as diferentes classes sociais. Conforme Medeiros (2016), nove em cada dez brasileiros possui aparelho celular, sendo que $57 \%$ da população tem smartphone, o que permite a comunicação instantânea de imagens audiovisuais. Esse instrumento permite relações sociais construídas pelo que se ouve e imagina, mas, também, pelo que permite ser visto.

Durante a realização das entrevistas, percebeu-se que todos os imigrantes que portavam celulares possuíam smartphone, um objeto de extrema importância para a conexão das experiências migratórias. Esse aparelho viabiliza diminuir as distâncias com imagens que cumprem a função de reunir as famílias e tornar as separações menos dolorosas, tanto para os que foram como para os que permanecem nos países de origem.

ponto de se auto protegerem das mazelas sociais. No Brasil ou na Espanha não foi identificado ainda, a presença deles morando nas ruas. 
Além da produção de fontes primárias, foram utilizadas fontes secundárias como referencial teórico. Foram levantados dados na Agência do Trabalhador de Cascavel, Polícia Federal e Prefeitura Municipal, Banco Central do Brasil, Conselho Nacional de Imigração (CNIg), Instituto Brasileiro de Geografia e Estatística (IBGE), no Serviço Público Federal e Serviço de Informação ao Cidadão - SINCRE, além de notícias veiculadas na mídia impressa e televisiva sobre imigração haitiana no Brasil e em Cascavel. Esses dados foram confrontados com a pesquisa de campo.

Ademais, esta pesquisa busca cumprir a função de extrair dados sobre a realidade desses imigrantes no município de Cascavel, para servirem como instrumentos de fortalecimento da organização coletiva. É olhando para os erros que se pode reordenar as táticas de ação na realidade, sem a pretensão de superar os desafios e dificuldades dos haitianos em Cascavel.

Nessa perspectiva, a pesquisa objetiva fornecer dados científicos que contemplam a questão, de forma a denunciar as situações de preconceito historicamente herdadas - como preconceito de cor, que impede os negros de ascensão social - que são transpostas para os imigrantes haitianos, além da reprodução da anacrônica visão do imigrante como ameaça à segurança nacional. Embora o conflito entre capital e trabalho seja uma constate do capitalismo, não impede que se possam desenvolver meios para possibilitar melhores condições de vida e trabalho no Brasil. Na perspectiva do capitalismo periférico, essa condição perpassa os valores sociais, que, difundidos e denunciados, têm a função de minimizar atitudes de preconceito e xenofobia. É preciso atuar como instrumento de denúncia frente à realidade encontrada, com vistas a nela intervir.

As condições de preconceito e xenofobia, expressas nas relações sociais, traduzem-se no mercado de trabalho, o que reforça a exclusão imposta pelo capitalismo a partir da máquina e incorporação de ciência e tecnologia no sistema produtivo. A organização depende, sobretudo, de mobilizar a sociedade, com vistas a recuperar o fortalecimento do Estado. Isso resulta, para os imigrantes, em maiores possibilidades de acesso às políticas voltadas para inserção social e reconhecimento de direitos, em detrimento das atuais políticas restritas ao controle das fronteiras.

Com o propósito de refletir sobre a imigração haitiana em Cascavel e sua relação com os frigoríficos, esta pesquisa se divide em três capítulos, delineados a seguir.

\subsubsection{Roteiro da Tese}


O Capítulo I apresenta uma discussão sobre a globalização e seus impactos na migração, sendo esse fenômeno uma das principais alterações das transformações nas relações de trabalho. Com esse propósito ressalta a evolução das forças produtivas impulsionadas pelas mudanças que se desdobraram na revolução industrial.

Considerando esse contexto de mudanças, esse capítulo visa investigar os impactos das transformações das relações produtivas sobre a migração. Para tanto, será feita uma discussão sobre as transformações estruturais a partir das grandes mudanças do processo produtivo, para então perceber a estreita relação entre ela e a migração, ressaltando a mobilidade dos grandes fluxos migratórios. Essa análise é fundamental para que se possa compreender a presença dos haitianos no Brasil, e mais especificamente, no Oeste do Paraná.

Por sua vez, o segundo capítulo desta tese contempla a discussão sobre a globalização e as transformações no mundo do trabalho, abordando aspectos como a imigração haitiana para o Brasil. Nessa perspectiva, faz-se necessário conhecer a história política, econômica e cultural do Haiti, assim como a formação secular da diáspora, associado a sua posição de país dependente na divisão internacional do trabalho, cuja mão de obra imigrante constitui um importante aspecto da economia do país.

Esse capítulo objetiva também analisar o objeto de estudo a partir da vinculação entre macro e micro sociologia, com destaque para a globalização e sua manifestação no Oeste do Paraná. É evidenciado a inclusão da região no sistema global via processamento de carnes com ênfase no abate de aves em frigoríficos, e a vinculação da imigração haitiana a essa commodity. Por fim, é feita uma discussão sobre o desenvolvimento econômico de um dos frigoríficos na região de Cascavel, principal incorporador de mão de obra haitiana, e sua vinculação com o mercado financeiro global, por meio de sua projeção internacional a partir de financiamento público via Banco Nacional do Desenvolvimento (BNDES). Essa análise permite observar a direção dos recursos públicos para interesses privados, bem como revela a ausência do Estado brasileiro na promoção de políticas migratórias.

O terceiro capítulo trata da pesquisa de campo e tem por objetivo testar a hipótese deste trabalho, que é verificar se o setor de frigoríficos tem impulsionado a imigração de haitianos para Cascavel. No capítulo em questão, pretende-se intensificar a discussão sobre as principais transformações empreendidas no Oeste do Paraná, o que levou ao desenvolvimento econômico da região, marcado pela hegemonia da planta produtiva de cadeias avícolas.

Os dados quantitativos desta pesquisa foram obtidos através de entrevistas realizadas com 60 imigrantes haitianos que viviam no município de Cascavel desde o ano de 2012 até junho de 2017. Para testar a hipótese desta pesquisa, centrou-se atenção na imigração de 
haitianos para a região, tendo como premissa as relações de trabalho e sobrevivência na cidade, de forma a identificar se esse processo está condicionado aos frigoríficos da região, ou seja, se eles atuam como agentes de atração desses imigrantes.

Quando se vincula o setor produtivo à imigração e se testa sua capacidade de atração para a região, não se pretende reduzir a compreensão desse fenômeno à via economicista, compreendida pelo viés teórico Push-Pull. O que se procura é delinear, pelo fator trabalho, os condicionantes que perpassam a ele, que vão muito além de fatores estritamente econômicos, e estabelecem relações interdependentes devido à garantia da existência e de mínimas condições de vida pelo trabalho.

A pesquisa tenta estabelecer ainda a intrínseca relação entre teorias macro e micro sociológicas, evidenciando a interdisciplinaridade, sendo essa uma das principais características da sociologia das migrações, que não tem um campo específico de conhecimento, mas se constitui como o diálogo entre as várias ciências e suas contribuições para a compreensão desse complexo fenômeno. Esse estudo se caracteriza, dessa forma, pela interdisciplinaridade, pelos diferentes elementos que perfazem a história dos sujeitos que se constituem agentes de um mesmo processo, que é a migração, sob diferentes formas de viver.

Nessa mesma perspectiva, Cardin (2013) considera a importância do diálogo entre as teorias macro e micro sociológicas, sem que essas últimas sejam reduzidas a investigações de caráter biográfico, individual e racional do indivíduo; como também não descartem as relações de apoio, as incertezas sobre o conhecimento e características específicas da localidade. Essas análises, portanto, não devem se limitar ao viés econômico, que desconsidera a trajetória e as representações do sujeito.

Com propósito de observar a relação entre imigração e o setor de frigorífico, a pesquisa consta de 30 perguntas, sendo algumas delas centrais para revelar a hipótese referida acima, com questões que possibilitaram o levantamento de variáveis para desvelar a relação da imigração com o setor de frigoríficos em Cascavel como já apresentado.

Por fim, a pesquisa também buscou analisar a aceitação e inclusão dos imigrantes haitianos em outros setores produtivos, bem como a viabilidade do trabalho realizado no Brasil para a manutenção da diáspora haitiana. Essas questões evidenciam os motivadores e a vinculação da mobilidade interna dos primeiros haitianos com o sistema produtivo de frigoríficos, bem como delineia os impactos de ser negro e imigrante, e também a interferência de fatores estruturais, como o histórico preconceito de cor e de classes, e como isso se transfere para os haitianos no Oeste do Paraná. 


\section{CAPÍTULO I \\ GLOBALIZAÇÃO: EFEITOS E OS IMPACTOS SOBRE A MIGRAÇÃO}

\subsection{As migrações contemporâneas: crise migratória ou humanitária?}

As migrações do passado e do presente possui dinâmicas e contextos diferentes, no entanto, a ascensão do capitalismo impulsionou esse processo sobretudo com a revolução industrial, guerras, reestruturações produtivas com o fordismo/taylorismo e a globalização, mudanças que corroboraram para a mobilidade humana como um fenômeno comum.

Entre os marcos de transformações ocorridas no mundo merecem destaque as grandes guerras do século XX, período que estimulou o maior deslocamento humano. Esses eventos nefastos fizeram cair por terra a teoria de que se vive no século XXI a era da crise migratória. $\mathrm{Na}$ verdade, está-se diante de uma grande crise humanitária, produzida pelos mesmos princípios da era das catástrofes ou das grandes guerras. A crise não está na mobilidade, marcada pela quantidade de pessoas que se deslocam de seus países de origem e chegam a diversas outras localidades, mas sim na recusa e indiferença de países e populações aos milhares de imigrantes, movidos por guerras, catástrofes ambientais e perseguições políticas.

Nessa perspectiva, este capítulo delineia a relação entre as transformações produtivas e imigração. Para tanto, considera-se o vigor do fordismo/taylorismo, que se espalhou pelo mundo em um contexto de migrações massivas, sobretudo no período posterior à Segunda Guerra Mundial. Ainda, é tecida uma discussão sobre a globalização como meio de superação da crise dos anos 1970 e seus efeitos na transformação das relações de trabalho.

Esse capítulo ressalta ainda a interferência desse processo nas relações produtivas, que variaram conforme a perda da soberania nacional com a redução da autonomia estatal frente às grandes empresas ou corporações financeiras. Em um contexto de reestruturação produtiva e diminuição de postos de trabalho, a imigração se coloca como principal problema, adequada para justificar as contradições do capital como desemprego estrutural, e discursos populistas que empreende ações governamentais de cunho nacionalista, que tende a criminalizar os imigrantes, considerando-os inimigos comuns e produtores das mazelas sociais.

Os grandes fluxos migratórios compreendem a chamada era das migrações, como classificaram Clastles e Miller (2004), pois envolve diferentes países e pessoas, ao passo que a imigração ganha centralidade nas agendas governamentais e políticas com a criminalização da migração. 
A sociedade contemporânea dá outros indícios de explicação do processo migratório atual diferente daqueles que ocorreram no passado. Isso porque, embora a migração seja comum, ou parte da subjetividade humana, ela reflete as mudanças estruturais delineadas pela própria sociedade e decorrem de outras causas que a forjaram no passado.

Ao discorrer sobre o complexo fenômeno migratório do século XXI, Canales (2017) chama a atenção para sua peculiaridade que requer dos estudiosos desse fenômeno análises sobre o que tem causado a mobilidade, bem como se apropriar das inúmeras teorias ou explicações que delineiam cada período, para, então, compreender que o contexto atual dos grandes fluxos migratórios marca outro momento da sociedade contemporânea. Essa sociedade, que já não é mais aquela do final do século XIX, mas compreende o contexto da sociedade pós-industrial do século XX e a transição para o século XXI, marcado e adentrado pela era global e pós-moderna.

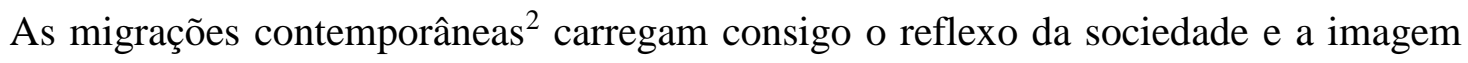
que se produz dela em determinadas épocas e contextos. Assim, elas foram inicialmente entendidas como meio de adquirir novos alimentos, passando posteriormente a ser um instrumento de dominação de um povo sobre outro com a extensão de seus territórios, sejam por tribos maiores que cresciam por expansão e dominação, bem como colonizações intensificadas com as navegações marítimas (Sala, 2004).

A mobilidade humana é dialética e segue o curso das transformações humanas e sociais, o que permite inferir que não haverá sociedade ou país livre dela, já que perfaz a subjetividade humana. Entendendo a subjetividade como sinônimo de busca por liberdade, Mezzadra (2005) ressalta que a mobilidade compreende a identidade universal ou a concepção do migrante como cidadão do mundo.

Nessa mesma direção, ao discutir sobre as formas de poder global e seus nefastos impactos para a sociedade, Ianni (2003) ressalta a importância da construção de uma outra sociedade global, que tem a disseminação mundial como característica na perspectiva do sujeito universal.

Mas nem sempre a mobilidade tem a liberdade subjetiva como impulsionador do deslocamento. Na maioria das vezes, a mobilidade é coibida pelas relações materiais que a inviabiliza de se realizar, e fazem com que muitas pessoas se disponham a situações de risco, submetidos a tráficos, coiotes ou outros oportunistas que visam apenas aferir lucros diante da

\footnotetext{
${ }^{2} \mathrm{O}$ conceito migrante relaciona os sujeitos que deixam seus países de origem (emigrantes) e aqueles que estão nos países ou regiões receptoras (imigrantes), o deslocamento é o único elo entre esses dois termos emigrante e imigrante expresso aqui por migrante.
} 
vulnerabilidade do migrante. Em diversas situações, a mobilidade forçada está desvinculada dos interesses subjetivos imigrantes, que, a princípio, resistem em abandonar seu país ou região de origem, sendo essa uma alternativa frente a outros motivos que o levam à expulsão.

No século XXI, o que tem se colocado como crise migratória é uma tentativa de criar um ineditismo que não existe sobre a mobilidade humana. Castles e Miller (2004) acreditam que a transformação da migração em uma questão política, ou o que Arango et al. (2007) mencionam como concepção de fato social pautado na ameaça, acirra-se a partir do episódio de 11 de setembro de 2001, quando passam a ser aplicadas medidas que contribuem para transformar a mobilidade internacional como uma questão de segurança nacional, quando o estrangeiro passa a ser encarado como ameaça nacional.

O rechaço aos imigrantes foi uma ação comum entre a maioria dos países centrais, reforçado pelo fechamento das fronteiras em nome da "segurança nacional", bem como pelo sensacionalismo midiático, que, diante das tragédias recorrentes, sobretudo no mediterrâneo, colocavam os imigrantes como um mal a evitar, já que demandavam mínimas garantias de direitos humanos dos Estados nacionais.

Assim, os sobreviventes de grandes empreendimentos migratórios passam a empreender uma nova luta, que não implica somente no trânsito e nos desafios colocados por ele quando estão se deslocando. O grande desafio passa a ser, despois de chegar no local de destino, nele permanecer. A crise, conforme expressaram Arango et al. (2017), está na reação das sociedades em aceitar e integrar os milhares de imigrantes, o que requer o reconhecimento comum do gênero humano, tanto pelos que recebem e se sensibilizam, como pelos que chegam, com sua humanidade posta à prova.

Assim, rechaçar é imoral, porém se impõem como uma moralidade necessária para se contrapor ao imigrante que deve ser recusado, restando a ele a penúria e condições deprimentes de sua humanidade.

Nesse sentido, faz-se necessário enfrentar alguns mitos como o de crise migratória que se coloca como verdade estabelecida quando a realidade tende a desconstrui-lo. É extremante necessária a retomada da compreensão da migração, desde o século XVIII, período marcado pela revolução das relações produtivas, que impactaram no deslocamento massivo de milhares de pessoas do campo para a cidade, com o surgimento da máquina a vapor e a apropriação privada dos meios de produção no âmbito rural e urbano. O êxodo rural, estilo de mobilidade ainda em curso na sociedade contemporânea, foi o resultado mais contundente da perda de controle dos trabalhadores sobre o processo produtivo, com consequente expropriação dos meios de produção (WILLIAMS, 1988; HOBSBAWM, 2012). 
De acordo com Thompson (2002), na sociedade inglesa do século XVIII, a terra era o principal meio de produção e, portanto, sinônimo de poder. Embora houvesse as grandes propriedades sob o domínio da gentry, classe dominante do período, havia também as terras comunais, que, por seu uso comum, não possuíam um dono específico, e, portanto, eram instrumento de trabalho coletivo dos camponeses plebeus.

Já no auspício do capitalismo, a legislação dos cercamentos foi crucial para expropriar os trabalhadores pobres, tornando legal e "moral" a apropriação daqueles que, através do dinheiro, poderiam comprar suas terras e expulsar os trabalhadores dela. A terra, ainda principal meio de produção do século XVIII, marcava a separação de classes e os diferentes interesses que elas projetavam sobre sua apropriação. Para os plebeus ou pobres da época, era um meio de garantir a subsistência, enquanto que, para a gentry, classe dominante representada pelos senhores donos de terras, era uma mercadoria, elemento fundamental que lhes garantia status e condição de classe dominante.

Por outro lado, as terras comunais, antes de serem tomadas, expressavam uma noção alternativa de posse, por meio de direitos, usos triviais e particulares que eram transmitidos pelo costume, como propriedade dos pobres. Sua transferência se fazia através do direito comum, baseada nos costumes herdados de geração para geração, e que, por meio da lei de cercamentos, tornaram os camponeses estranhos em suas próprias terras.

A sociedade capitalista nascente impôs grandes mudanças na cultura e nas relações de trabalho, que passaram a ser baseadas, principalmente, na disciplina e no controle do tempo. As migrações massivas ocorreram, e, com elas, a resistência a toda lógica de exploração, sob os moldes dessa nova sociedade.

Williams (1988) entende o contexto de grandes aglomerações na cidade pensado não apenas como ampliação do número de pessoas que habitavam os novos ou antigos espaços urbanos, agora revigorados com a indústria, mas como espaços de reprodução de relações sociais intermediadas por experiências rurais e urbanas. Os novos habitantes da cidade passam a construir uma relação com esse espaço a partir de costumes e trajetórias delineadas pelo campo, que são interferidas por novas relações de tempo, disciplina e produção, ditadas pela vida na cidade.

As migrações massivas pautadas no êxodo rural no século XVIII, como expuseram Thompson (2002) e Williams (1988), não livraram os séculos precedentes das migrações forçadas, de caráter intercontinental, ocasionadas pelas grandes guerras.

A dimensão das migrações forçadas na vida das pessoas fez Hobsbawm (2012) alcunhar os períodos entre 1914 e 1959 de era das catástrofes, quando três aspectos mudaram 
qualitativamente e reordenaram a sociedade. O primeiro deles foi a queda do eurocentrismo, devido a redução da população europeia e seus descendentes para um sexto da população mundial, em um período em que imigrantes das regiões pobres da Europa se deparavam com os muros anti-imigração nos EUA. Além da redução populacional e migração europeia, também houve o deslocamento de parques industriais para outras regiões do mundo.

A segunda compreende o período entre 1914 e 1990, com a globalização, denominada por Hobsbawm (2012) como unidade operativa global. Nesse contexto, houve redução de velhas economias nacionais a atividades transnacionais; transformações significativas de certas atividades econômicas e técnicas; e alterações nas operações da ciência em importantes aspectos da vida privada, devido à inimaginável aceleração da comunicação e transportes.

A terceira incorpora toda a ideologia adequada às transformações em curso, com exacerbação do individualismo ou desintegração de antigos padrões voltados para o relacionamento social humano; e com o fortalecimento de indivíduos cada vez mais egocêntricos, devido aos valores reforçados pela satisfação individual, do lucro e do prazer (Hobsbawm, 2012).

Essa tese centrará suas discussões nos efeitos das duas últimas etapas, a globalização e os aspectos ideológicos e individualistas sobre a migração contemporânea. O objetivo é compreender como a mudança proporcionada pela globalização, enfatizada sobretudo nas alterações das relações de trabalho e domínio do capital financeiro, faz-se sob o auspício do individualismo exacerbado, ideologia compatível com essa reordenação que produz impactos nefastos sobre a imigração haitiana em Cascavel, no Paraná.

A mobilidade vinculada à meritocracia, uma das ideologias resultantes desse individualismo e reforçada na era do século XXI é um fator a mais para nomear o imigrante indesejado, que, desprovido de direitos, é considerado desintegrado socialmente, e responsabilizado pelo seu fracasso, e, logo, pelas mazelas sociais. Isso oculta os reais motivos de segregação que sofrem nas sociedades receptoras, bem como os motivos que os levaram a migrar.

O capital, no bojo das crises de 1970 e 2008, teve profundas sequelas, como a intensificação das contradições refletidas no desemprego em massa, desequilíbrio entre superprodução e consumo, inovações tecnológicas com produção da liofilização ${ }^{3}$ exacerbada e precarização do trabalho. Essas situações são justificadas na politização da migração, que

\footnotetext{
${ }^{3}$ Liofilização é conceituado por Antunes (2003) como substituição do homem pela máquina e precarização das relações de trabalho.
} 
coloca o imigrante como responsável pelas mazelas da sociedade e o considera como ameaça a segurança nacional.

Três episódios se destacam em 2018 e podem ser citados como exemplos de compreensão da imigração como ameaça. Um deles foi a recusa do governo italiano em aceitar que o navio Aquarius atracasse no país após resgatar mais de 600 imigrantes no mar Mediterrâneo, ação essa respaldada em legislações que proíbem que navios atraquem no território italiano (EL PAÍS, 2018). Outro caso foi a política de tolerância zero de Donald Trump, que, por meio de um decreto sancionado em junho de 2018, ordenou a separação de crianças mexicanas de seus responsáveis, quando flagradas em situação irregular e de imigração entre as fronteiras desse país. Essa atitude gerou comoção e manifestações de repúdio em todo o mundo (TAVARES, 2018). E, por fim, a expulsão de venezuelanos, por brasileiros, na fronteira do norte do Brasil com a Venezuela (FÉLIX E COSTA, 2018).

Essas situações vieram à tona no momento da pesquisa, evidenciando a imprevisibilidade de lidar com novos dados e fontes para pesquisadores que se submetem a fazer análises de objetos do tempo presente. Por outro lado, demonstram como os Estados Nacionais tem se consubstanciado em um dos maiores violadores dos direitos humanos, ao instituir legislações que negam aos imigrantes direitos mínimos enquanto seres humanos.

O que todas essas situações, que ocorrem em diferentes continentes, têm em comum? Certamente, a criminalização da imigração e a violação dos direitos humanos pelo Estado. As reações da população brasileira seguem uma onda xenofóbica internacional que se fortalece frente à falta de garantias e inseguranças delineadas pelo capital, dando margem para discursos que responsabilizam os imigrantes pelas mazelas sociais, com o fortalecimento de partidos xenófobos e de extrema direita.

Além disso, no caso brasileiro, a ausência e indiferença do Estado na garantia de mínimas políticas de recepção, asilo e integração, leva consequentemente a intensificação de contradições e precarização de vida dos imigrantes que permanecem no país, como pobreza extrema, miséria, abandono, desemprego, prostituição, dentre outros. Dessa forma, se o Estado não reage, não acolhe e não integra, a xenofobia tende a aumentar, fortalecendo a pecha que carregaram nas legislações até a desabilitação do Estatuto Estrangeiro que concebia o imigrante como ameaça nacional.

As ações, que antes se limitavam em invasões e tentativas de piorar as condições de vida de imigrantes venezuelanos nos abrigos, se desdobraram em um ato de expulsão deles na fronteira, sendo escurraçados ao som do hino nacional, refletindo o máximo da xenofobia e fascismos anti-imigrantes. As comoventes cenas expressam as duras migrações entre países 
periféricos, as quais impõem muito mais dificuldades, sobretudo devido à ausência do Estado que prioriza como ação não agir, contribuindo para a precarização das restritas políticas para brasileiros e repassando para o cidadão o papel de fazer valer suas leis nas fronteiras, que a olho nú parecem invisíveis, mas que vão se materializando pelas ações humanas.

Migrar entre países periféricos do sistema capitalista torna as experiências dos grandes fluxos ainda mais arriscadas com acentuada exclusão de imigrantes em países como o Brasil, marcado pela intensa desigualdade social. Esse assunto, será analisado com mais propriedade no capítulo III, ao se referir às experiências migratórias de haitianos no Oeste do Paraná.

Em um contexto de desemprego estrutural, o imigrante ganha evidência e aparece como motivo das contradições que se acirram na sociedade. Esse fenômeno foi denominado por Arango (2017) de politização da migração, justamente porque a concebe como um "problema social", colocada como ameaça seja para a segurança no que concerne à concorrência entre imigrantes e nacionais no mercado de trabalho, seja em relação a associação de imigrantes com fatos vinculados à violência provocada por terroristas e a ameaça a homogeneidade cultural que o discurso conservador sustenta existir.

Arango (2017) ao tratar sobre a política espanhola e o êxito dela em combater a politização da imigração, ressalta o sucesso do envolvimento da sociedade no debate sobre a imigração, que proporcionou o que denominou ser a recepção e aceitação de imigrantes pelos espanhóis como tranquila e sossegada, diferindo-se dos demais países europeus que tende a marginalizar o imigrante. Segundo o autor, isso se deve à linha dorsal da imigração na Espanha, que é o envolvimento da sociedade civil e a publicização do debate em diferentes esferas sociais.

No Brasil, o quase nulo envolvimento entre sociedade e imigração deu margens para que discursos de homofobia e ódio fossem incorporados como propostas de campanha eleitoral em 2018, em que o presidente eleito ${ }^{4}$ divulga resolver o problema da imigração com medidas de combate a ela, sobretudo pela via da negação de vistos e combate a entrada, como já fazem a maioria dos países no mundo. Associado ao fraco envolvimento da nossa sociedade com a questão imigratória, a concepção histórica do imigrante como ameaça nacional, bem como a indiferença do Estado quanto a mínimas políticas de chegada e recepção desses

\footnotetext{
${ }^{4}$ Após turbulento processo eleitoral marcado por propagandas anti-imigrante, armamentistas como formas de combate a violência associadas a projetos neoliberais, o candidato eleito Jair M. Bolsonaro (Partido Social Liberal), antes mesmo de sua posse, causou a saída de milhares de médicos cubanos contratados pelo programa Mais Médicos, por declarações feitas antes mesmo de assumir a presidência da República em Janeiro de 2019, as quais conduziram o governo Cubano a retirar os médicos do Brasil desde novembro de 2018.
} 
imigrantes, estimulam os conflitos de preconceito e xenofobia já vigentes na sociedade brasileira.

Dessa forma os grandes fluxos migratórios e sua recepção na maioria dos países hoje tem sido uma das maiores contradições do capital, visto que ao contrário do que se pretende reforçar como crise migratória, o mundo está diante de uma crise humanitária ${ }^{5}$. Crise essa, reforçada pelos Estados que majoritariamente restringem suas políticas migratórias a contenção e controle das fronteiras em detrimento da recepção, asilo ou integração.

A criminalização da imigração ou o que conforme já discutido como crise migratória, só existe quando a vemos como crise humanitária, acentuada nas situações de vulnerabilidade em que passam os imigrantes quando tem na recepção da população o mais alto de todos os muros, sendo um resultado da própria ineficiência estatal, que lança para a população que, alimentada pelo ódio, assume em certas circunstâncias essa responsabilidade. Isso acarreta atitudes carregadas de hostilidade e preconceito o que tem se constituído em conflituosas relações entre brasileiros e haitianos, sobretudo onde esses fluxos se concentram.

Em 2018, a aversão aos grandes fluxos no Brasil se remete aos venezuelanos, mas ocorreram e ainda ocorrem com bolivianos desde os anos 1980, e mais recentemente com haitianos, sendo esses os grandes fluxos migratórios destacados pela literatura no Brasil.

Longe de considerar o imigrante como vítima ou taxar todos como não integrados nas sociedades receptoras sem a pretensão de generalizar, de fato a exclusão deles sobressai como um aspecto comum (ARANGO et al. 1017).

Sua desintegração social torna-se uma reação naturalizada por essa sociedade que a vê como uma medida necessária frente à "ameaça" que ele pode oferecer. Os efeitos ideológicos disso são nefastos, com a precarização de suas condições de vida e sobrevivência nas sociedades receptoras.

Assim, reafirma-se que a crise migratória é um dos efeitos ideológicos que colocam nos grandes fluxos migratórios a responsabilidade pelas mazelas sociais, quando na verdade elas são parte da própria estrutura social, das contradições produzidas em uma sociedade economicamente injusta e desigual, e de um Estado ausente no que se refere à promoção de mínimas políticas de integração.

\footnotetext{
5 A definição de crise humanitária que trataremos aqui, trata-se das situações de precariedade que vivem os imigrantes nos países de trânsito e chegada no processo migratório. É certo salientar a necessidade do cuidado com esse termo, já que o mesmo está sendo utilizado como justificativa de intervenção em determinados estados por países centrais. A esse exemplo, destaca-se o caso da Venezuela, que sob esse mesmo discurso tem sido ameaçada de intervenção internacional, quando na verdade se tem outros propósitos sobre o país do que a real preocupação com a crise humanitária.
} 
Os números e a ênfase nos grandes fluxos migratórios do século XXI, ainda estão aquém do que se produziu em termos de mobilidade, essa foi muito mais intensa em períodos anteriores a esse século, e atualmente se evidencia numa crise humanitária devido a não integração e a precária condição de vida em que se deparam milhares de pessoas nos países de trânsito e receptores, bem como sua exposição a ataques e expulsões originárias por civis.

\subsubsection{A era da catástrofe: a mobilidade humana como consequência das grandes guerras.}

Ao tratar sobre os maiores volumes migratórios do mundo, Castles, Hass e Miller (2014) reafirmam que eles datam o período entre 1846 e 1939, com destaque à Primeira Guerra Mundial que forçou o deslocamento de mais de 59 milhões de pessoas da Europa para os Estados Unidos e estima-se que esses dados ainda sejam superiores às migrações contemporâneas.

De acordo com esses autores, o período entre 1850 a 1914 foi caracterizado pelos estudiosos ocidentais como aquele que inaugurou as migrações transatlânticas. No entanto, as mobilidades de longa distância começaram depois de 1945 e se expandiram a partir da década de 1980 envolvendo todas as regiões do mundo.

Estudos mais recentes sobre o tema mostram grande mobilidade na Ásia, África e na América Latina no século XIX e início do século XX, ensejadas sobretudo pelo desenvolvimento de transportes, comunicação e tecnologia que facilitam a mobilidade e tem colocado a migração internacional como uma dinâmica central dentro da globalização (SALA, 2005; CASTLES, HASS E MILLER, 2014; ARANGO et al. 2017).

Embora a mobilidade sempre tenha percorrido a história das sociedades, a partir da industrialização, ela ganhou uma nova forma, em consonância com as estruturas sociais. Rompeu-se com a unidade territorial e institucional entre a casa e o lugar, e se dotaram de novos conteúdos as fronteiras geográficas, políticas e culturais dos Estados.

Sala (2005) pontua uma série de migrações internacionais ao longo dos últimos séculos. O primeiro deles teve início na Inglaterra, e ocorreu de meados do século XIX até 1914, com a emigração europeia para várias partes do mundo, como América e Austrália, o que foi resultado do liberalismo econômico. A ideologia liberal considerava a liberdade migratória como um dos princípios da nova organização social. Desse modo, o século XIX foi um período de mínimas intervenções estatais sobre as migrações transfronteiriças, de modo 
que a regulação do tema não foi desenhada para frear os fluxos, como ocorreria no início do século XX e XXI.

Ao se referir ao período entre 1816 a 1965, Eric Hobsbawm (2012) contabiliza 74 guerras, dentre as quais, as quatro primeiras ocorreram no século $\mathrm{XX}$, com destaque para a Primeira e Segunda Guerra Mundial, a guerra do Japão contra a China em 1937-1939 e a guerra da Coréia (1950-1953), as quais foram responsáveis pela eliminação de mais de um milhão de vidas cada uma.

Como dizia Hobsbawm (2012), o século XX especificamente em 1914 com a Primeira Guerra Mundial inaugurou a era do massacre intensificada com a Segunda Guerra que juntas produziram uma enxurrada de destroços humanos, cujo impacto levou esse autor a alcunhar esse século de era das catástrofes.

Esses episódios indicam que não há como pensar em migração a partir do século XX sem estabelecer a correlação desse fenômeno com as grandes guerras, as quais por meio da violência foram verdadeiras carnificinas humanas, ao passo que produziram simultaneamente as imagens do pesadelo tecnológico que atormentaram dia e noite a geração seguinte com ameaça e ataques de armas químicas como: “[...] gás venenoso e bombardeio aéreo após 1914, a nuvem do cogumelo e da destruição nuclear após 1945" (HOBSBAWM, 2012, p. 59).

Todo o aparato tecnológico serviu indiscriminadamente para ceifar a vida de milhares de pessoas e muitas das que sobreviveram viam na fuga uma alternativa para preservar a vida sem se tornar mais um entre o número de mortos e feridos.

Os números sinalizam que só na Europa mais de 40,5 milhões de pessoas foram deslocadas com a Segunda Guerra, excluindo os trabalhadores forçados da Alemanha e os fugitivos do exército soviético cujos dados computados podem ser ainda maiores (SALA, 2005).

A Primeira Guerra já havia produzido experiências de deslocamento ou eliminação massiva de populações, a exemplo do quase total extermínio da população Arménia pela Turquia, cujos dados remetem a 1,5 milhões de pessoas mortas, e ecoou como um forte sinal da capacidade de destruição dos armamentos, expandida com a Segunda Guerra Mundial.

Hobsbawm (2012) ressalta ainda que apesar do grande impacto das guerras, somava-se a ela outros episódios como a matança de mais de cinco milhões judeus com a perseguição nazista, números esses que ainda permanecem em disputa. A opressão, que expulsou mais de 13 milhões de alemães do seu território com a invasão da Polônia e União Soviética.

Nesse sentido, a Segunda Guerra e o nazismo propiciaram a fuga em massa dos europeus, tendo sua dimensão tão expressiva que a Alemanha chegou a fazer uma lei de 
retorno aos judeus em período próximo ao das perseguições, dando-os a garantia de lar e cidadania, ignorada diante da violência sofrida.

O retorno se tornou uma possibilidade recusada por muitos diante do medo e das sequelas deixadas pela guerra e nazismo. Por sua vez, a guerra da Coréia considerada por Hobsbawm (2012) como um subponto da Segunda Guerra Mundial, produziu mais de cinco milhões de deslocados. Em períodos equivalentes, devido a criação do Estado de Israel, 1,3 milhões de palestinos também perderam seu território, ao passo que por outro lado viabilizou a migração de mais de 1,2 milhões de judeus, a maioria deles também refugiados.

O mundo se deparou, assim, com a conflituosa e polêmica criação do Estado de Israel, justificado como a concretização do direito de retorno de milhares de judeus atingidos pela diáspora judaica em períodos anteriores com a expulsão de milhares deles de suas terras no Oriente Médio, sempre relembrada e reforçada pelo movimento Sionista ${ }^{6}$.

O contexto de repressão dos palestinos e acolhimento dos judeus deu ao Estado de Israel a dupla interpretação, do ponto de vista desse povo, significava devolver suas terras sagradas de onde foram forçados a abandonar, cujo retorno sob os auspícios da ONU permitiu desde 1948 com a criação do Estado de Israel a acolhida de mais de 1,2 milhões de judeus perseguidos e sobreviventes do Holocausto.

Enquanto se constituía como uma justiça aos injustiçados era também produtora dela, à medida que para dar território aos judeus expropriava e expulsava milhares de palestinos, situação que não fora resolvida até hoje e tem gerado eminentes conflitos na região (HOBSBAWM, 2012).

Ao descrever sobre os efeitos da guerra e porque denomina a primeira parte do século XX como era das catástrofes, Hobsbawm (2012) ressalta que:

Em resumo, a catástrofe humana desencadeada pela Segunda Guerra Mundial é quase certamente a maior na história humana. O aspecto não menos importante dessa catástrofe é que a humanidade aprendeu a viver num mundo em que a matança, a tortura e o exílio em massa se tornaram experiências do dia a dia que não mais notamos (HOBSBAWM, 2012, p.58).

O autor enfatiza a naturalização da violência como um aspecto que tem se tornado comum para a humanidade. Embora importante, mas não única, a mobilidade humana se deu também em outros continentes para além do território europeu, como episódio ocorrido frente

\footnotetext{
${ }^{6}$ SIONISMO - Movimento nacionalista que visava criar o Estado Judaico na Palestina após a diáspora dos Judeus expulsos pelos Romanos, o que os obrigou a espalhar-se pelo mundo.
} 
a descolonização da Índia que acarretou a morte de dois milhões de mortos e provocou o refúgio de e mais de 15 milhões de pessoas. Além dos dois milhões que morreram na guerra civil que sucedeu nos anos posteriores, tudo isso somado aos 5 milhões de coreanos deslocados com a guerra da Coréia.

Assim como expressou este autor, o século XX testemunhou através desses episódios o que denominou de democratização da guerra à medida que se tornava compulsória devido à naturalização dos conflitos, em que qualquer instabilidade viria a ser um conflito de guerra e concomitantemente tornava a vida civil alvo estratégico.

A impessoalidade da guerra fora assim manifestada através de atos decididos por autoridades em gabinetes, as quais desconsideravam seus impactos sobre a vida de milhares de civis que se convertiam em alvos principais quando mirados e atingidos por todo tipo de aparato e arsenal tecnológico.

Os civis foram então a cobaia de teste e aplicação de toda essa tecnologia, ao passo que a fuga dos que sobreviviam significava a única reação quando já não era mais possível resistir. Ela foi então um meio necessário ou única tentativa de preservar a própria vida.

A guerra que envolveu quase a totalidade do globo teve por consequência a naturalização da violência, em que a matança e a expulsão compulsória são alguns elementos vigentes nos países em guerra, ao passo que oculta e não questiona a ação do próprio Estado como genocida e formador de apátridas.

Embora não sejam os números únicas provas dos fatos históricos, pois eles são sempre questionáveis e incertos, contraditoriamente expressam dados concretos desses episódios. Constituem dessa forma importante referência sobre a quantidade de mortos e deslocados na era da catástrofe, desmistificando a pecha da migração como "crise migratória" que no contexto dos séculos XX e XXI reforça a terceira etapa das ideologias necessárias para ocultar os atuais contextos de milhares de pessoas que migram e arriscam suas vidas diante da vulnerabilidade imposta pelo processo migratório, da política de controle e fechamento das fronteiras, bem como situações atuais de perseguição e toda violência da guerra.

É nessa perspectiva que Gomarasca (2017) analisou a contraditória reação da Europa, principal protagonista da mobilidade humana no passado via a violência da guerra e sua atual resistência na recepção de milhares de imigrantes que chegam ao continente fugindo da perseguição e violência da guerra na África e Ásia.

A inescrupulosa recusa se faz sob a pecha da imigração como crise ou invasão de imigrantes, como já discutido anteriormente. No entanto, Gomarasca (2017) acrescenta que esse continente tem forjado os dados como um meio de impressionar com os números a 
assimilação do imigrante como ameaça pela sociedade e por meio dele justificar medidas de controle migratório via necessidade de impedir a "invasão de imigrantes" e, por sua vez, seu acolhimento.

Embora as tragédias humanas, bem como o deslocamento não necessitem hoje de que se forjem dados, pois eles são visíveis, noticiados e vistos a olho nu, seu número hoje ainda está muito aquém de alcançar os dados que a própria Europa já produziu em termos de expulsão.

A recusa e a resistência da Europa é também enfatizada por importantes líderes políticos de países que um dia foram grandes receptores de imigrantes europeus, como o Expresidente do Uruguai Pepe Mujica (2017), que enfatiza a dívida colossal da Europa sobretudo com países colonizados, muitos dos quais já foram receptores de Europeus pobres, fugitivos das guerras mencionadas, as quais no século XXI se dão ao direito de resistir a incorporar imigrantes em situações equivalentes às já enfrentadas pelos europeus.

Mujica (2017) compreende a negação dos imigrantes nos século XXI pela Europa como uma surpresa da história. O continente que um dia expeliu sua população, atualmente se constitui como o mais rico e tecnologicamente avançado e se recusa e enfatiza sua pretensa dificuldade de integrar aqueles que chegam hoje fugindo das Guerras da Síria, Ásia e África e veem na corajosa travessia para a Europa a única condição de sobreviver.

É certo que as novas rotas migratórias se evidenciam também pela localização geográfica, o que torna compreensível a migração entre esses continentes tendo a Europa como destino, por ser ela também geograficamente possível. Nessa mesma perspectiva, Fleming (2014) ressalta a falsa impressão de que a Europa é o destino desses imigrantes. Se referindo ao caso da Síria, essa autora ressalta a humanidade de acolhimentos de países menores e vizinhos, a exemplo do Líbano, com uma população de quatro milhões de habitantes, recebendo aproximadamente 1 milhão de sírios.

Arango et al. (2017) ressaltam o expressivo número de imigrantes chegados à Espanha através de viagens fadadas ao fracasso, às quais se enveredam pelas águas do mar Mediterrâneo, arriscando a vida nas pateras (barcos infláveis) frente à imponência das águas. Acrescenta que são antes de tudo, sobreviventes de triplos episódios, como o abandono forçado dos países de origem, da força das águas do Mediterrâneo frente a frágil condição de deslocamento, e o intenso desafio de ser ou não incluído nas sociedades receptoras se as alcançam com vida.

Ainda de acordo com Mujica (2018) não há como compreender a história da humanidade sem os processos migratórios, que, para o bem ou para o mal, contribuíram para 
a formação de sociedades, da cultura e da política. Ainda conforme esse ex-presidenciável, em um tempo não muito distante, ou décadas atrás, países como o México pobre de 1939, recebeu só naquele ano quase um milhão de imigrantes oriundos da Espanha, mais de quarenta mil chegaram no Uruguai, e 200 mil na Argentina, e não há país latino-americano que não tenha recebido milhares deles, particularmente europeus, que com seus barcos cheios de "gringos" pobres enchera a américa e construíram a cultura, o idioma e a estrutura desses países (MUJICA, 2018).

Assim, de acordo com Mujica (2018), a Europa, que tem uma dívida colossal, pelas contas que abriu e nunca foram pagas com o colonialismo europeu na África, a expansão britânica com seu império no mundo, fazem sobrar elementos para incompreensão do egoísmo expressado na recusa como um valor que se multiplica nesses países.

As migrações forçadas não são discutidas no sentido do que as provocam ou produzem, e sim as consequências que são entendidas na presença deles na sociedade, ou meros fatos da mobilidade. Ainda conforme esse autor, associado à exploração exacerbada, apropriação e expulsão de milhares de pessoas de suas terras, o planeta também dá sintomas de esgotamento da produção ampliada em escala global fazendo com que pessoas fujam das guerras, da fome e das catástrofes ambientais, que são consequência desse processo.

Essa perda de valores, pautado na moralização do imoral, foi denominada por Hobsbawm (2012) como exacerbação do individualismo como ideologia única, ou por Gomarasca (2017) como ações antiéticas para sustentar o imoral como moralmente necessário.

Para este autor, quando a Europa se deparou com aproximadamente 21 milhões de imigrantes - número recorde até 2015 , teve que desmoralizar a solidariedade humana frente a desobrigação para com eles, já que a ameaça nacional é um valor moral.

Assim, tem-se a "moralidade do rechaço", que oculta questionamentos sobre o que levam as pessoas a migrar. É cômodo e confortável inverter valores, sobretudo porque as contradições não realizam os anseios prometidos. Castles e Miller (2004), Arango et al. (2017) e Sala (2004) ressaltam que isso tem sido fundamental para reforçar a ideia que associa o estrangeiro como ameaça nacional, e faz do imigrante o mais importante problema desde a guerra fria.

Seu impacto está nas políticas de Estado que fizeram do fechamento das fronteiras a justificativa para garantir a "segurança nacional”, frente ao estrangeiro invasor e terrorista. 
La migración tiene una perspectiva internacional : los movimientos de personas a gran escala surgen del acelerado proceso de integración global, que se facilita por un mejor transporte y la proliferación de médios impresos y electrónicos, conduce también a la migración. La migración internacional no es una invención de finales del siglo $\mathrm{XX}$, ni siquiera de modernidade un de sus disfarces gemelos del capitalismo y el colonialismo (CASTLES E MILLER, 2004, p. 14).

A imigração resgata aos tempos remotos da história humana, porém ela tem sido potencializada com expressivo crescimento depois de 1945, e de maneira particular desde os anos 1980 e ocupa um lugar de primeira importância nas mudanças globais.

Conforme os autores, algumas razões contribuem para a ampliação da imigração, como a crescente desigualdade de riquezas entre o norte e o sul, as pressões políticas, ecológicas, ou demográficas que podem atuar como forças que empurram a imigração, dado a busca de refúgio fora de seu país e a criação de novas áreas de livre comércio que causam movimentos de mão de obra. O que impulsiona "Los estados un el mundo enterro se verán cada vez más afectados por la migración internacional, sea como sociedades receptoras, como países de emigración o como las dos cosas” (CASTLES E MILLER, 2004, p. 15).

Não há dados exatos sobre a quantidade de migrantes no mundo, porém algumas instituições apontam segundo os autores como um crescente movimento que tem se estendido de maneira significativa dando continuidade em volume antes e depois da Primeira Guerra Mundial.

Conforme dados da ONU, atualmente há mais de 258 milhões de migrantes no mundo (GRAYLEY,2017). Desses, 68 milhões são refugiados. De acordo com estimativas divulgadas pela Agência Nacional da ONU para Refugiados, ACNUR (2018), até 2017 uma pessoa era obrigada a deixar seu lar a cada três minutos. Ao mesmo tempo que cresce anualmente o número de refugiados, amplia inversamente o fechamento das fronteiras com os índices de acolhimento pelos países.

Nessa perspectiva, dados da ACNUR (2017) inferem a queda de 54\% nas cotas de assentamento para refugiados entre os países em 2017, com reassentamento de 102.800 refugiados com ou sem assistência, números esses, insignificantes quando comparados às elevadas taxas de pessoas deslocadas nesse ano, que excedeu a 2.9 milhões de mobilizações forçadas, chegando ao total de 68,5 milhões de pessoas atualmente deslocadas forçosamente decorrentes de perseguições, conflitos e violência generalizada, o que indica atingir recordes anuais de crescimento (ACNUR,2017). 
A imigração envolve quem migra e quem fica no país e afeta os migrantes, as sociedades de origem, de trânsito e as receptoras. "Hay pocas personas en los países industriales o en los menos desarrollados en la actualidad que no tengan una experiência personal de la migración y sus efectos; esta experiência universal se ha convertido en la marca de la era de la migración” (CASTLES E MILLER, 2004, p. 15).

Estamos diante de um sistema complexo de controle das fronteiras que ao contrário de reduzir a migração, tem potencializado e redirecionado novos fluxos migratórios, os quais delineiam muitas vezes outras rotas para chegar aos maiores receptores, bem como fazem emergir novos países nessas condições. As políticas de migração, quando restritas ao controle, tendem a intensificar a vulnerabilidade de migrantes a grupos e redes que potencializam a migração clandestina. De acordo com Gomarasca (2017), a Europa concilia contraditoriamente a retórica humanitária com a necessidade de controle da fronteira como medida de segurança na qual se deve defender a restrição migratória.

A ausência do Estado e sua limitação no empreendimento de políticas de imigração centradas, quando existem, no controle sobre as fronteiras, em detrimento da recepção, asilo e integração, leva à construção de outros muros, como já apresentados anteriormente. Muros esses que não se fazem mais sob grandes construções, mas se erguem e se estruturam simbolicamente por humanos desumanizados com a recusa e xenofobia, e se constituem na mais perfeita harmonia da contenção. O Estado reduz gastos, se mantém indiferente aos imigrantes hostilizados pela própria população imbuída do mesmo preconceito, repúdio e xenofobia que tem alimentado as atitudes de parte das sociedades em relação aos imigrantes.

Dessa forma o que é atualmente alcunhado de "crise migratória", conceito difundido principalmente na Europa e EUA, por serem os principais receptores de imigrantes, nada mais é que um mito, que funciona como estratégia do capital para responder às suas contradições. Assim como a meritocracia, que coloca o desemprego como um problema do sujeito que não tem qualificação, a imigração é vista como uma ameaça, seja por reforçar o exército de reservas e desempregados, ou com a identificação deles a segurança nacional e homogeneidade cultural.

Nem sempre a migração ocupou esse papel de destaque ou foi considerada uma das questões mais pertinentes das agendas políticas do século XX e XXI. Arango et al. (2017) utilizam a metáfora migração no olho do furacão para expressar a atenção da mídia e do mundo ao processo migratório e a construção da falsa ideia de crise migratória sustentada nas recentes tragédias humanas e pela acentuada relevância com que partidos políticos 
conservadores, xenófobos e de extrema direita fazem da mobilidade e das desgraças alheias para fortalecer discursos anti-imigratórios e o fechamento das fronteiras.

Assim, o que no início do século XXI se afirma como uma "crise migratória", trata-se de um vago codinome intencionalmente alarmante e ameaçador reintroduzido como novo, ao passo que oculta a verdadeira crise existente, a humanitária. A desumanização devido às condições do processo migratório que vai desde a saída do migrante de seu país de origem até a precária recepção no país de destino, tem sido sensacionalizada. As tragédias humanas não conseguiram ainda mobilizar a opinião pública de forma a considerar medidas de proteção e abrigo dos direitos humanos, mas são entonadas como situações que forjam a moralidade do fechamento das fronteiras, ao passo que nega e mantém milhares de pessoas em situações de penúria.

$\mathrm{Na}$ verdade, fazem desse fenômeno que é uma ação eminentemente humana, com pouco ineditismo, uma resposta às contradições do capital, quando lança para o imigrante a responsabilidade por suas mazelas e da sociedade.

Arango et al. (2018) ressaltam que o que se entende por crise é a situação de penúria que se submetem milhares de migrantes para empreender um processo migratório, que fazem delas uma das tentativas de sobrevivência, clamam a recepção, asilo ou integração e, quando vencem a batalha de chegar com vida, após a empreitada de migrar, se submetem a situações de penúria nos campos de refugiados ou abrigos, comumente precários nos países de destino.

Por isso não se pode falar em crise migratória a não ser que se considerem as situações e precarizações das condições de vida e humanidade em que estão submetidos os imigrantes.

Vive-se, no entanto, um período de politização da migração frente à desgraça de milhares de pessoas que tem em comum a fuga de zonas de perigo, vítimas da violência seja da natureza como os imigrantes ambientais, ou da própria ganância humana.

Diante dessas situações, Gomarasca (2017) ressalta que aos países receptores não basta justificar eticamente o direito de acolher, geralmente pautado na contradição entre solidariedade e segurança nacional, isso deve passar pela condição da compaixão humana. À medida que o indivíduo tem acesso a um país como uma casa, todos os demais direitos virão como consequência.

Ao contrário de politizar a migração e fazer dela um problema pautado na crise enfatizada pela mobilidade humana, outra ética voltada para a sociedade e os benefícios da migração devem ser considerados. Isso é possível mesmo no âmbito de uma sociedade capitalista, dada a capacidade de solidariedade e sensibilização da sociedade. Embora essa sociedade gere por sua característica o egocentrismo, individualismo e apatia, é possível 
contraditoriamente dentro dos limites dessa sociedade a existência de valores que alcancem a humanização refletidas na tolerância, no respeito as diferenças e na empatia com o outro. $\mathrm{O}$ capítulo III, enfatizará alguns exemplos como as redes de apoio étnicas e sociais, bem como o princípio da solidariedade entre os imigrantes são fundamentais no processo migratório dos haitianos no Brasil, e se constituem como exemplos concretos desses valores. É possível dessa forma, além de políticas públicas, ou da ação delas para essa promoção, a criação de uma nova ética no tratamento dos imigrantes, sabendo que sua total liberdade e respeito só acontecerá quando transcendermos as fronteiras geopolíticas com a internacionalização de uma sociedade de iguais.

Ao traçar os benefícios da imigração para os países receptores e emissores, Reitz (2007) aponta três pontos positivos que se destacam, sobretudo nos países clássicos de imigração, como Estados Unidos, Canadá e Nova Zelândia ${ }^{7}$, ou seja, os aspectos positivos nos campos social, econômico e cultural. Esses benefícios expressam, inclusive, a prosperidade desses países no mundo moderno.

Nessa perspectiva, Arango et al. (2017) inferem que, embora tenha a imigração outras valorizações para além das econômicas, é inegável a importância da relação entre imigração e economia, como seus efeitos positivos sobre o crescimento do Produto Interno Bruto - PIB, impacto favorável entre segmentos laborais complementares, dentre outros. Embora o cenário atual seja de politização da imigração que coloca o imigrante como ameaça nacional, países como Austrália, Nova Zelândia e Canadá podem oferecer positivas experiências de integração e como lidar com esse fenômeno numa contraposição ao rechaço como tem feito grande parte dos países, inclusive o Brasil, a exemplo demonstrado da ação dos venezuelanos expulsos.

Em suma, migrar sempre esteve presente na história humana, o que enseja a compreender o contexto das migrações no período pós guerra, cujos migrantes foram essenciais para a reconstrução e urbanização dos países. Até que a mão de obra era necessária, a migração não era um problema, no entanto isso muda com o fechamento das fronteiras frente às novas migrações causadas sobretudo por perseguições e guerras, fenômenos tão presentes assim como hoje em outros momentos da nossa história.

Além disso, os migrantes que perfazem no século XXI os grandes fluxos migratórios com destaque para bolivianos, haitianos e venezuelanos carregam consigo a origem de países periféricos pobres, com população majoritariamente negra e indígena, estereótipos que no

\footnotetext{
7 Autores como Arango et al. (2017), Castles e Miller (2004) denominam de países clássicos de imigração aqueles em que tem a imigração como base de sua formação, com quase metade da população constituída por imigrantes.
} 
Brasil desde sempre são considerados inferiores e fora do padrão do imigrante desejado, comumente branco, colonizador e descendente europeu.

\subsubsection{A era fordista, difusão do capital e incorporação dos contingentes migratórios.}

Associado a era das catástrofes, o século XX foi marcado pela era do ouro na Europa com a forte ação do Estado de bem estar e direitos sociais até o auspício da crise do Petróleo de 1973, que ensejou o fortalecimento da criação de uma economia única cada vez mais integrada e universal.

É visto até agora que as migrações são conclamadas até que tenham funcionalidade ao capital, por ser uma alternativa necessária tanto para o migrante que fugia das guerras bem como para os países que necessitavam deles para a sua reconstrução ou dinamização econômica.

As mudanças relatadas acima perfazem uma pequena reflexão sobre o processo migratório, que atualmente envolve novo contexto. Nesse sentido, Canales (2017) vai além e ressalta que quando se refere às migrações internacionais, elas perpassam tanto os países e sociedades de expulsão como os países de trânsito, até a acolhida dos migrantes nos países de recepção que as colocam no centro do debate e das agendas sociais e políticas. As propostas variam entre as diversas índoles que incorporam discursos entre aqueles que propõem o controle total das fronteiras e a criminalização dos migrantes, como aqueles que apoiam o livre trânsito de pessoas e os benefícios do multiculturalismo.

Nessa perspectiva, esse fenômeno ambíguo, que não é novo, mas saudável para as sociedades, tem diferenças e características de acordo com os períodos históricos em que se manifesta, além de refletir as próprias transformações da sociedade.

No entanto, ao analisar diferentes períodos e contextos do processo migratório, percebe-se que há dentre outros fatores, uma relação intrínseca entre as migrações e as dinâmicas de estruturação do modo de produção capitalista. As maiores taxas migratórias se dão em períodos compatíveis a essas reestruturações da mesma forma que imigrantes foram a principal mão de obra a desempenhar o processo de trabalho requerido por sociedades receptoras.

Alves (2006) denomina essas transformações de primeira, segunda e terceira revolução industrial, em que a primeira se caracteriza pelo surgimento da grande indústria, nos primórdios do século XIX à última metade do século XX. A segunda revolução industrial é marcada pela vigência das formas de racionalização do trabalho emergidas com o fordismo 
e taylorismo, enquanto a terceira se caracteriza pela automação, robótica, trabalho polivalente, desenvolvimento do toyotismo, globalização e neoliberalismo, produção e acumulação flexível.

Após a revolução industrial, que desencadeou a migração crescente da população do campo para a cidade, o fordismo/taylorismo fora considerado o mais dinâmico fenômeno de continuidade do desenvolvimento dessas forças produtivas e permaneceu hegemônico até a década de 1970. Essa reordenação produtiva incorporou grande parte dos trabalhadores migrantes, quando num primeiro momento foram deslocados desde a Primeira Guerra Mundial, período de surgimento do Fordismo nos Estados Unidos.

O Fordismo/taylorismo não pode ser explicado sem considerar sua importância no contexto da crise de 1914 e visava cumprir dois objetivos centrais: o de ser uma estratégia para conter a indisciplina do trabalho e simultaneamente ampliar a produtividade do trabalhador.

O capital então se reorganiza a partir do reordenamento das relações de trabalho. Em um contexto pós-revolução industrial, o fordismo foi a expressão mais sublime de superação de antigas formas de dominação a partir do controle e inovação delas.

A expansão desse modo de racionalização da produção foi uma estratégia para impulsionar a produção capitalista que necessitava não só de busca de novos mercados consumidores, mas também de impor uma nova disciplina do trabalho associada à inovação tecnológica.

O fordismo, método de racionalização do trabalho foi desenvolvido por Henry Ford em 1914, se caracterizou pelo sistema de cinco dólares com intensificação dos princípios de cientifização do trabalho, já desenvolvido por Frederick Taylor, que prescrevia a organização de tarefas com a fragmentação dos trabalhadores, submetendo-os aos padrões rigorosos de tempo e estudo do movimento. A separação entre gerência, concepção e controle já haviam sido desenvolvidas em outras indústrias, e fora apropriado por Ford que os implementou em sua fábrica de automóveis, porém o que a distingue das demais indústrias é o seu reconhecimento de que a produção em massa inaugura um novo sistema de organização do trabalho, uma nova política de controle e gerência (ANTUNES, 2003).

Os novos métodos de trabalho são inseparáveis de um novo modo específico de viver e de pensar a vida. Ford acreditava que o poder corporativo poderia construir o novo tipo de homem. O dia de oito horas e cinco dólares, obrigava a disciplina do trabalho, além de permitir renda e tempo de lazer suficiente para o trabalhador consumir a produção em massa. 
É certo que a cooperação, como já dizia Marx (2004), é um fenômeno presente desde os primórdios da sociedade capitalista quando nas manufaturas surgiu pela primeira vez o trabalho cooperado. Diferentemente de outras formas anteriores, o trabalho cooperado é tratado por Marx (2004) como uma nova tecnologia que permitiu a reunião de vários trabalhadores destituídos dos meios de produção, os quais passaram a trabalhar de forma cooperada e simultânea, sob o domínio de um mesmo capitalista. Assim, diferente do que foi o trabalho do artesão que produzia sozinho uma mercadoria pelo domínio de várias etapas do processo produtivo, não a produzia mais na manufatura, onde nenhuma mercadoria resultava sem o trabalho cooperado e parcial (MARX, 2004).

Ford se apropriou da cooperação nascida ainda no bojo da manufatura, bem como da incorporação de ciência e tecnologia no sistema produtivo que lhe deu condições de aprimorar os mecanismos para desprover o trabalhador do comando sobre o processo produtivo, ao passo que produzia sobre ele maior controle e domínio sobre seus ritmos e movimentos. De acordo com Bosi (2016), os pressupostos da divisão do trabalho implementados na linha de montagem da fábrica de Ford responsável pela produção em série foi transplantado de frigoríficos, sendo essa uma experiência empírica observada por Ford, que posteriormente fora levada e aprimorada em sua indústria de automóvel.

Associado a racionalização de formas de organização do trabalho, pode-se inferir que Ford readaptou de forma a otimizar maior exploração sobre os ritmos e movimentos dados a destreza e agilidade já potencializados com a aplicação de conhecimento científico e trabalho cooperado via compensação do resultado desse próprio esforço com o recebimento de 5 dólares ao final de cada dia.

O estímulo produtivo de cinco dólares ao dia, embora representasse um complemento significativo na renda, marcada por baixos salários desde a implementação do fordismo em 1914, não seduziu o trabalhador que via na intensificação de seu esforço a degradação de seu corpo, o esgotamento de suas capacidades, chegando muitas vezes a mutilações de seus membros corporais ou a morte por exaustão. Isso fazia com que a luz dessas condições degradantes e intensificação do processo produtivo via gratificação "compensação de cinco dólares" não parecia incialmente tão sedutora como se pretendera, a própria resistência dos trabalhadores ao fordismo expressava essa realidade (HARVEY, 1989).

No entanto, esse processo de disseminação do fordismo como modelo hegemônico de organização produtiva no seio da sociedade capitalista não se efetivou de forma rápida e simples. Harvey (1989) ao discutir sobre isso enfatiza a grande resistência por parte dos trabalhadores para a implementação do fordismo, dificultando sua disseminação no período 
entre guerras devido às próprias características do trabalho rotinizado e longas jornadas de trabalho, com a exigência simultânea de habilidades manuais e perda de controle do trabalhador sobre o ritmo e organização do processo produtivo.

Associado a isso, o autor ressalta a intensa rotatividade do trabalho, com a utilização quase que exclusiva da mão de obra imigrante, que exigia por sua vez uma revolução nas relações de classe frente a participação do Estado que viabilizou as condições legais para implantar os princípios científicos na produção, bem como a punição daqueles trabalhadores resistentes às relações de trabalho fordistas. Dessa forma a intervenção estatal era fundamental para conceber as novas regulamentações a fim de atender os requisitos da produção fordista e acomodar sua disseminação na Europa, com tímido início nos anos 1930 e consolidação nos anos 1950.

Essa consolidação não se fez sem a ação estatal, que depois de 1945 aperfeiçoou de forma mais eficiente a combinação entre repressão aos trabalhadores e políticas sociais com o modelo Keynesiano, o que conduziu a maturidade do fordismo como um regime de acumulação plenamente acabado e distinto.

Assim, o modelo produtivo fordista/taylorista hegemônico na maioria desses países do mundo requeria mão de obra massiva, viabilizava a incorporação massiva de imigrantes que eram rapidamente incluídos no sistema produtivo $^{8}$. Esse processo produtivo até os anos 1970 foi hegemonicamente caracterizado pelo fordismo/taylorismo com produção em série, padronizada e em grande escala. A onda industrial fordista foi consequência da internacionalização do modelo evidenciado, sobretudo pela recuperação industrial do Japão e Alemanha no pós-guerra, substituição de importações em países latino americanos associado à excessiva produção das multinacionais nos países do leste asiático.

Ao mesmo tempo que se expandia, a industrialização fordista produzia limitações devido a grande capacidade produtiva e um consumo que já não lhe acompanhava, então "A crise manifestou-se fundamentalmente como falta de demanda efetiva por produtos, sendo nesses termos que a busca de soluções começou” (HARVEY, 1989, p.122).

Nesse ínterim, já era necessário que a ampla produção de mercadorias e seus grandes estoques fossem alteradas, adequando sua produção conforme a demanda, ao mesmo tempo que reunia condições favoráveis de inovação tecnológica e diminuição do quadro de

\footnotetext{
${ }^{8}$ Investigar a inserção laboral de imigrantes haitianos em países como EUA, França e Canadá, rotas tradicionais de migração seria outro projeto de pesquisa, que se desdobraria desse, quiçá poderá ser feito em uma outra oportunidade de pesquisa.
} 
trabalhadores, dando início a mais nova etapa da reestruturação produtiva via substituição fordismo/taylorismo para a organização toyotista.

Não há como falar em transformação produtiva sem a relacionar como uma das etapas da globalização, que se inicia com ela e se concretiza com o Estado neoliberal. Por isso, sintetizamos uma discussão que perpassa as transformações históricas das relações de trabalho, a partir da revolução industrial com a migração massiva do campo para a cidade, seguida da era das catástrofes associada ao fordismo como nova etapa do desenvolvimento produtivo no início do século XX, para então culminar com a discussão sobre a transição do fordismo/taylorismo para o toyotismo. Essa última etapa privilegia a ênfase no papel do Estado nesses diferentes contextos, sua abertura ao capital financeiro com implementação de políticas neoliberais, sendo essas duas últimas etapas, concomitantes da globalização.

Esse fenômeno tão complexo, mas marcante de uma nova etapa do capitalismo com a hegemonia das grandes corporações com domínio mundial e o protagonismo do capital financeiro, foram garantidos pelo Estado que foi essencial para consolidar a hegemonia do grande capital em detrimento dos direitos sociais e fragmentação da classe trabalhadora.

Antunes (2003) ressalta que a década de 1980 se apresenta como o período em que os países de capitalismo avançado, bem como de economia dependente passaram por intensas transformações no mundo do trabalho. Tais mudanças emergem num contexto de inovação tecnológica, como automação, robótica e a microeletrônica, que invadiram o universo fabril, transformando as relações de trabalho e de produção. A intensidade delas variou conforme o contexto de cada país ou região.

O fordismo e o taylorismo mesclam-se com novas experiências, ou novas formas de organização e processos produtivos, como o neofordismo, neotaylorismo e pós fordismo. $\mathrm{O}$ autor cita as experiências da chamada terceira Itália ${ }^{9}$, onde grandes empresas reduziram seu quadro a partir de inovações tecnológicas, com a extensão da produção artesanal e também, o Japão que substituiu o modelo fordista/taylorista pelo Toyotismo, assim destaca:

Novos processos de trabalho emergem, onde o cronômetro e a produção em série e de massa são "substituídos" pela flexibilização da produção, pela especialização flexível", por novos padrões de busca de produtividade, por novas formas de adequação da produção à lógica do mercado (ANTUNES, 2003, p. 24).

\footnotetext{
9 Compreende-se por terceira Itália a formação de redes de empresas e criação de distritos industriais desencadeadas nesse país.
} 
Conforme o autor, o fordismo taylorismo não foi totalmente substituído em todas as regiões produtivas. Essas mudanças estruturais vão estar associadas ao desenvolvimento produtivo de cada país ou região ou, até mesmo, da adaptação deles a novos arranjos produtivos (HARVEY, 1989).

Ao discorrer análises sobre essas transformações das relações de trabalho, Sassen (2014) ressalta que elas foram uma expressão da globalização, bem como do reordenamento do capital, uma das evidencias da transformação crescente de novas áreas com brusca expansão de modelos de extração e lucro, tendo a terceirização como uma característica comum nas cidades globais.

In contrast, outsourcing is about spaces for routinized production of ensa ória, mass call centers, standardized clerical work, and more, all off it massive and stardized. Both these types of spaces are among the most strategic factors in the making of today's global economy, besides intermediate sectors such as transport (SASSEN, 2014, p. 19).

Santos (2002) ressalta a globalização como terra de ninguém, dada a intensa submissão dos Estados ao ordenamento global do capital, com a perda de autonomia ao passo que intensifica as relações de subordinação às grandes corporações financeiras, o Estado é uma forma específica de distribuir o poder, com a capacidade reforçada de ordenar. Há, assim, uma separação entre poder social em relação à coletividade, o que não se dá de forma casual, mas é resultado do esforço contínuo do Estado e de seu investimento como aparelho para depurar, transferir e condensar o poder social. Portanto, o Estado é o único que organiza burocrática e hierarquicamente as relações de poder na sociedade.

Nesse contexto houve não só a perda de soberania estatal, mas também a derrota dos movimentos operários radicais que ressurgiram no período pós guerra e prepararam o terreno político para os tipos de controle de trabalho e de compromisso que possibilitaram o fordismo. $\mathrm{O}$ ataque ao sindicalismo foi um meio de deter a resistência dos trabalhadores quando simultaneamente permitiu o fordismo se estabelecer de forma hegemônica ditando as relações de trabalho inicialmente nos EUA, e posteriormente no mundo.

Houve uma cooperação dos sindicatos com as técnicas fordistas de produção expressas na pressão dessas instituições que acuavam os trabalhadores a assimilar a cooperação fordista para ter em troca várias conquistas sociais, mesmo que isso custasse sua exaustão. Assim, os trabalhadores foram acuados nos sindicatos, às vezes por meio do exercício do poder estatal 
repressivo para trocar a cooperação nas empresas, pautados na disciplina, por ganhos reais de salários de acordo com o sistema fordista de produção.

As ações do Estado no pós-guerra foram as mais variadas nos diferentes países, desenvolveram um crescimento econômico estável com um aumento dos padrões materiais de vida por meio de uma combinação entre o Estado de bem estar social via administração econômica Keynesiana e controle das relações de salário (HARVEY, 1989).

Conforme discutido antes, o século XX produziu a era da catástrofe com o extermínio de pessoas e a mobilidade humana daqueles que sobreviveram a ele, é interessante compreender que ela não foi ruim para todos os países.

Para os EUA, por exemplo, as guerras foram visivelmente satisfatórias, propiciou a esse país exorbitante taxa de crescimento, sobretudo na Segunda Guerra, com índices que chegaram a $10 \%$ ao ano, o mais rápido de todos os tempos. Essa vantagem que os EUA lograram, sobretudo com a Segunda Guerra, se deu porque era o principal arsenal dos seus aliados, ao passo que não se envolveu diretamente na guerra, mas a financiava por fora, enquanto organizava simultaneamente a expansão da economia, alcançando globalmente o status e importância mundial.

Em 1914 já auferia o título de maior economia mundial, embora não fosse a dominante. Enquanto as guerras o tornavam mais forte, enfraquecia por outro lado seus concorrentes, o que o conduzia como nova hegemonia mundial conquistada com o fim da Segunda Guerra (HOBSBAWM, 2012).

Ao mesmo tempo em que se tornou uma potência econômica mundial, se constitui também como potência militar. O desenvolvimento de uma não se faz sem a outra, pois ser uma potência militar lhe permite a subsunção dos demais países à sua hegemonia com o monopólio da produção e fornecimento de armas militares.

O protecionismo a esse legado militar é usado atualmente como garantidor da segurança mundial, que pelo armamento que possui, intervém através dele em países seja para impedir a produção de armamentos e a concorrência nessa área ou mesmo para apropriação das riquezas nacionais de países submissos ou resistentes à sua tirania (HOBSBAWM, 2012).

Contudo, os EUA foram os reais vitoriosos da Primeira e Segunda Guerra Mundial, e passou a ver na abertura de investimento de mercado estrangeiro uma absorção de sua produção, sobretudo na Europa. Além do consumo da produção de seus excedentes por países atingidos pela guerra, se colocou como financiador da reconstrução deles. Ao assumir o papel de banqueiros do mundo em troca da abertura de mercados de capital e de mercadorias sob o 
poder das grandes corporações, garantiu simultaneamente a internacionalização do fordismo, reforçada com as ações do Estado nação para viabilizá-lo.

Houve uma disseminação desigual do fordismo à medida que cada Estado procurava seu próprio modo de administração das relações de trabalho, a política monetária e fiscal, das estratégias de bem estar, e de investimento público, limitados internacionalmente pelas relações de classes e externamente pelo grau de posição que ocupavam na economia mundial.

Dessa forma, houve uma adequação das necessidades do fordismo se ampliar pelo mundo para além das fronteiras americanas, ao passo que a Europa se tornou, devido aos impactos da guerra, um dos espaços propícios para isso, garantidos sobretudo pelo investimento estatal. Os EUA financiavam agora não mais as armas para a destruição de guerra desse continente, mas sua reconstrução, ao passo que a Europa aderia o fordismo/taylorismo adequado à reconstrução e intervenção estatal com as políticas keynesianas, estimuladas como sempre pela sombra dos Estados Unidos que mais uma vez financiou esse processo.

Harvey (1989) ressalta que a reestruturação produtiva é compreendida como uma das etapas da globalização, maneira de reorganização do capital pautado na disseminação de grandes corporações industriais e produtivas pelo mundo, viabilizadas por financiamentos via capital financeiro dos EUA. Ao se colocar como viabilizador da reconstrução de países centrais e financiador da industrialização dos países periféricos impôs simultaneamente a dependência da hegemonia financeira desses países conforme seus interesses.

Entre 1945 e 1973, houve um novo período da história migratória nas sociedades ocidentais, baseado na evolução das leis que impuseram diferentes estágios a esse fenômeno, resultante da reconstrução de países, bem como da retomada de desenvolvimento econômico sob os auspícios dos EUA que via empréstimos e garantia a implementação de uma forte presença estatal na economia europeia. Esses fatos, provocaram profundas transformações na direção dos fluxos migratórios, já potencializados como ressaltado anteriormente com a era das catástrofes ou das grandes guerras, perseguição nazista e descolonização da Índia.

Depois da Segunda Guerra Mundial, houve investimentos e extensão da produção, com rápido crescimento industrial e ampliação da demanda por trabalho. A imigração teve no Estado de Bem Estar Social uma resposta positiva com a inserção produtiva dos imigrantes, ainda que essa fosse uma solução necessária devido à disponibilidade dessa mão de obra frente à destruição e demanda por trabalhadores para a reconstrução dos países atingidos pela guerra. Já ressaltado anteriormente, ao mesmo tempo em que os países expeliam os migrantes 
para outros rincões no mundo ou entre a própria Europa, não houve até os anos 1970 maiores preocupações por parte dos Estados em reprimir a migração.

Ao contrário disso, na Europa, os anos dourados, promoveram por meio da ampla intervenção estatal, emprego e crescimento econômico, com pleno destaque para a participação dos imigrantes.

David Harvey (1989) discutiu sobre as transformações políticas econômicas do capitalismo no século XX, dadas com a crise de 1973 e a transição do Fordismokeynesianismo para a acumulação flexível. Tal sistema de organização do trabalho encontrou no deslocamento temporal e territorial a alternativa que precisava para superar o acúmulo ou excesso de produção.

Associado à crise econômica, com implicações profundas na exportação e industrialização, o Centro Europeu abriu as fronteiras devido à demanda de imigrantes para a produção industrial. Promoveu-se, então, uma política denominada de "portas abertas", com algumas restrições de trabalhadores. Houve canalização da força de trabalho para certos setores produtivos, limitação da reagrupação familiar e deportação de trabalhadores considerados "indisciplinados" (SALA, 2005).

A admissão e residência eram controladas por governos de Estados receptores. O modelo se ajusta conforme os países e suas políticas de convites, ou o que Sala (2005) denomina de Gastarbeiter. Essa política prevê a permanência dos trabalhadores enquanto sua mão de obra seja necessária, de modo que eles eram convidados para trabalhos temporários.

O processo de descolonização atraiu a população para Grã-Bretanha, França, Bélgica e Holanda. Embora tivessem fortes vínculos com as sociedades de acolhida, os europeus, oriundos de diferentes regiões da Europa, apresentavam uma herança cultural e étnica diferente da população autóctone, transformando sociedades europeias homogêneas em multiculturais.

No período pós-guerra, segundo Sala (2005), não houve qualquer interesse em diminuir a imigração, pois ela servia à demanda do sistema produtivo. Por outro lado, esse trabalhador era visto como passageiro, pois prevalecia a crença da viabilidade do retorno, o que contribuiu para a ausência de esforços ou interesses na permanência desses imigrantes. Essa posição limitada do imigrante como sujeito de passagem e possível retornado, fez com que os governos não criassem oportunidades para sua integração na sociedade, o que acarretou na falta de desenvolvimento de infraestrutura para estrangeiros.

As políticas de imigração foram delineadas pelas elites, de acordo com as necessidades do mercado laboral e da política exterior. Porém, o período de conciliação entre 
migração e sistema produtivo a partir da Guerra Fria, fizeram os países Europeus, assim como Canadá e Estados Unidos passassem a receber, com restrição, refugiados políticos.

O objetivo era limitar seu número, com baixos custos econômicos e fortes impactos políticos. A Rússia, desde os anos 1920, não reconhecia a liberdade migratória, e adotou uma política de impedimento de saídas. A falta de reconhecimento da liberdade de imigração se baseou na visão do Estado em considerar os cidadãos como seus empregados e servidores.

A proibição serviu a determinados interesses políticos, sobretudo para o controle interno da dissidência. As medidas foram adotadas em todo o Leste Europeu e as pessoas que reivindicavam imigrar eram perseguidas, discriminadas e podiam perder seus empregos e moradias, além de serem excluídas de certos serviços sociais.

\subsubsection{Globalização e seus efeitos sobre a migração}

A crise do petróleo, nos anos 1970, teve grande repercussão na economia dos países desenvolvidos, que se submeteram a importantes processos de estruturação laboral e tecnológica. Essa nova etapa foi definida pelos estudos imigratórios como aquela que barrou duas décadas de intenso recrutamento de mão de obra. Sua continuidade foi tímida, seguindo acordos bilaterais com contratação em setores específicos e de imigrantes que chegavam como consequência da reunificação familiar. Os países da Europa Meridional ${ }^{10}$ se transformaram, pela primeira vez na história, em países de imigração, e começaram a receber imigrantes advindos da África, Ásia e América Latina.

As crises cíclicas são próprias da engrenagem do sistema capitalista, que se fortalece e reestrutura frente a elas e, em específico aos anos 1970, esse processo se dá com reorganização das forças produtivas via substituição do modelo fordista/taylorista pelo toyotismo. A expressão foi flexibilização das relações de trabalho, associando o ataque ao Estado de Bem Estar Social nos países onde ele existira e, desenvolvimento tecnológico que foram as forças impulsionadoras para a superação da crise quando esse sistema parecia dar sintomas de esgotamento.

Nessa perspectiva, Santos (2004) ressalta que cada momento do capital é antecedido e sucedido por crises. No contexto dos anos 1970, a globalização surgiu como um importante

\footnotetext{
${ }^{10}$ A Europa meridional é também chamada de Europa Mediterrânea, composta por países situados no sul ou no extremo ocidente como Portugal com influências climáticas oceânicas, e países banhados pelo mediterrâneo como Espanha, Itália Grécia e Turquia. Inclui também pequenos países como Vaticano, Mônaco, San Marino, República de Malta e Andorra, além de arquipélogos como Açores, Madeiras e as Ilhas Canárias.
} 
recurso ideológico e uma profícua resposta como enfrentamento de uma das maiores crises cíclicas, promovendo assim um rearranjo do sistema capitalista (SANTOS, 2004).

Dessa forma, o Estado assumiu novos papéis com a atualização de poderes institucionais que por meio do capital corporativo ajustou as velas para com maior precisão fazer dos ventos contrários um motor para seguir em direção à lucratividade. $\mathrm{O}$ equilíbrio entre a tensão do trabalho organizado viabilizado pelo grande capital corporativo por meio do Estado formou, após muita luta, a base de poder da expansão do pós guerra. A repressão estatal foi assim duplicada no contexto da utilização da força física intensificada com legislações que forçavam a maior produtividade adequada às demandas do fordismo.

Contudo, Bauman (1999) considera essa nova ação estatal como perda de soberania, à medida em que ela foi apropriada por essas grandes corporações industriais e financeiras, que não só a dominaram para se ampliar, mas intensificaram a subordinação de outros Estados. A função do Estado ficou, então, restrita a sua capacidade de policiamento da ordem. Como expressa o autor, "A própria distinção entre o mercado interno e o global ou, mais genericamente, entre o 'interior' e o 'exterior' do Estado, é extremamente difícil de manter senão no sentido mais estreito, de "policiamento do território e da população"” (BAUMAN, 1999, p. 73).

Essas transformações na estruturação das relações de trabalho são resultantes da reorganização do capital, também chamadas de formas de racionalização do processo produtivo que envolve inovação e aperfeiçoamento das forças produtivas, para melhor controle e intensificação dos ritmos de trabalho e produtividade do trabalhador, ampliando as relações de expropriação dos meios de produção, intensificadas com maior alienação. Se o imigrante foi essencial para desempenhar a ampliação do fordismo/taylorismo quando esse modelo de racionalização de trabalho se difunde pelo mundo, ele continua no século XXI sendo imprescindível em organizações produtivas que ainda mantém a produção baseada nesses princípios produtivos.

Nesta pesquisa delineamos como a imigração contemporânea pretende ser tratada como um processo contínuo de desenvolvimento do capital, dada principalmente pelas transformações no mundo do trabalho. Ela se relaciona com o sistema produtivo porque visa analisar em que medida os frigoríficos têm contribuído para estimular a imigração de haitianos em Cascavel, Paraná.

Esse setor se insere no sistema global como resultado da inovação tecnológica advinda da importação de ciência e tecnologia de países centrais, os quais, simultaneamente, viabilizam a ampliação da produção, exportação de carnes para várias partes do mundo, 
incorporação de mão de obra estrangeira e, em alguns casos, devido a projeções internacionais promovidas pelo Estado, conforme discutiremos nos próximos capítulos. Essas empresas embora localizadas em um país periférico foram projetadas internacionalmente, incorporando tanto mão-de-obra estrangeira disponível no Brasil, bem como em outros países.

Contudo, as mudanças do mundo do trabalho possuem diferentes teorias explicativas, dentre elas a ideia de fim do trabalho e do proletariado como consequência ou resultado dessas transformações no espaço produtivo.

Dentre os representantes teóricos dessa corrente, Antunes (2005) se refere a André Gorz, Claus Offe, Habermas, dentre outros. Visando reforçar a tese da centralidade do trabalho, Antunes $(2003 ; 2005)$ desenvolveu vários escritos que não buscavam desmerecer essas mudanças, mas ressaltá-las a partir de uma perspectiva contrária do que sustentavam esses pensadores. Antunes (2003) compartilha com eles a ideia de que as mudanças estruturais levariam cada vez mais a substituição do homem pela máquina, ou do trabalho vivo pelo morto, tratado também como liofilização, mas ao contrário de eliminar o trabalho, o capital o degrada, visto que depende dos trabalhadores para a sua própria valorização por meio da intensificação da mais valia, com o retorno de outras formas de trabalho ainda mais degradantes, como o trabalho escravo, a terceirização, a quarteirização, etc.

Conforme Marx (2004), há um limite do capital na exploração do trabalho, por isso ele necessita produzir mecanismos de exploração para otimizar ainda mais o processo laboral com a ampliação da intensidade dos ritmos e movimentos, sem que isso seja diretamente percebido pelo trabalhador. No fordismo/taylorismo houve uma compensação de cinco dólares ao dia com metas individuais para amenizar a percepção dos impactos da intensificação produtiva, enquanto na era pós-fordista, o simples fato de ter trabalho já é uma forma de introjetar nos trabalhadores a disciplina e a maior produtividade.

Nessa perspectiva, Alves (2005) ressalta que o desenvolvimento de técnicas de controle de trabalho no capitalismo objetivam a obtenção de mais-valia, que é a parte do trabalho produzido pelo trabalhador, denominado aqui de trabalho excedente, que garante a acumulação de capital.

É nesse contexto que a mais valia se concretiza como mais valia absoluta intensificada pela jornada de trabalho e mais valia relativa, que é a incorporação de ciência e tecnologia no processo produtivo, ou resultante do emprego e aperfeiçoamento do modo de produção capitalista, permitindo a apropriação e prolongamento do trabalho excedente e diminuição do trabalho necessário. 
Marx (2004) ressalta que o capital se alimenta das transformações produtivas, pois a função social delas é a sua reprodução e conservação enquanto sistema. Se em diferentes momentos históricos toda a revolução do processo produtivo foi o viés de supressão dos modos de produção anteriores, no capital elas são o combustível, que não só servem para a extração da mais valia, mas também são condição para que por meio dela o trabalho necessário seja reduzido, o que garante a acumulação.

A globalização, e seu desdobramento a partir dos anos 1970, ganha novos contornos dada a crise caracterizada não só como a escassez da maior fonte de energia e sua repercussão no sistema produtivo dos países hegemônicos, mas tratou-se também de uma crise de superprodução, que só poderia ser resolvida com a contenção da presença do Estado na economia, efetivado pelo ataque ao que foi o Estado de Bem Estar Social. Há que ressaltar ainda que esse Estado interventor e de políticas sociais foi uma resposta à crise, iniciada nos EUA com o New Deal em 1929, e transportada para a Europa para a reconstrução no período pós-Segunda Guerra.

A literatura crítica convencionou chamar de transformações do mundo do trabalho ou reestruturação produtiva, como bem definiram Antunes (2003), Alves (2005), Bauman (1999) e Harvey (1989), como uma nova etapa do capital, fundamental como um processo que envolveu a transformação produtiva via substituição do fordismo/taylorismo pelo toyotismo.

A maneira como se delineou as formas de racionalização do trabalho, como fordismo/taylorismo e toyotismo, ficaram convencionadas ao modo como o Estado Nação as implementou e passou a garantir as mínimas condições para esses propósitos, geralmente por meio da subordinação estatal às grandes corporações que exigem e impõem as condições de adequação, ampliando sua dependência e subordinação concretizada com as políticas neoliberais.

Nesse contexto, as exigências são impostas pelo capital corporativo e financeiro aos Estados para se ampliar, em detrimento da soberania nacional que se adequa para isso. Desse modo, legislações que garantam subsídios fiscais, bem como aquelas que preservam direitos trabalhistas foram conduzidas à desburocratização e desregulamentação, cujo grau é maior ou menor conforme a dependência dos Estados em relação a estes grandes grupos e corporações e da própria organização dos trabalhadores para resistir a elas em cada país.

É certo que as mudanças no mundo do trabalho contemplaram essa desburocratização e desregulamentação e novas formas de exploração careciam de ser juridicamente permitidas pelo Estado. A globalização foi entendida por Marx e Engels (2001) como forma de internacionalização capitalista ou expansão do capital e está no cerne desse sistema desde seu 
surgimento, como uma característica intrínseca do sistema se expandir. Essa dinâmica da burguesia revolucionou o modo de produção capitalista pela necessidade e conquista do mercado mundial.

A grande indústria criou o mercado mundial preparado pela descoberta da América. Este mercado acelerou prodigiosamente o desenvolvimento do comércio, da navegação e dos meios de comunicação por terra. Este desenvolvimento reagiu, por sua vez, sobre a extensão da indústria; e, à medida que a indústria, o comércio, a navegação e as vias férreas se desenvolviam, crescia a burguesia, multiplicando seus capitais e relegando a segundo plano as classes legadas pela Idade Média (MARX E ENGELS, 2001, p. 2).

Nessa perspectiva, Ianni (2002) e ressalta que o capital se desenvolve internacionalizado, sendo sua expansão uma forma de consolidação enquanto sistema hegemônico, com diferentes formas de dominação, como o imperialismo e a colonização.

Nessa mesma perspectiva, Alves (1999) ressalta que a globalização, conhecida como mundialização do capital, embora se dissemine no capitalismo, principalmente como um mecanismo de reorganização da crise cíclica do sistema após 1970, não se restringe às trocas ou intercâmbios de mercadorias ou o que marca o capital desde seus primórdios, mas trata-se de um fenômeno que além das características de disseminação do sistema, envolve novas estruturas dele, como o capital financeiro. Assim, a década de 1980 inaugurou um novo regime de acumulação, alterando significativamente o funcionamento do capital, denominado por Chesnais (1996) de novo regime de acumulação financeira.

Esse novo regime possui alguns traços, como o pouco crescimento do PIB, deflação constante pela desindustrialização, desemprego estrutural, marginalização de regimes anteriores do sistema de troca e intensificação da concorrência internacional, com geração de sérios conflitos comerciais entre as grandes potências. No entanto, a característica predominante do novo regime mundial é ser rentista e parasitário.

A deteriorização do Estado de Bem-Estar social impôs mudanças qualitativas nas relações entre capital e trabalho, com uma nova orientação do processo de internacionalização do capital via liberdade do mercado. A ideologia da globalização é tida como a grande saída para a crise. Ianni (2002) entende que a globalização é representada por metáforas como aldeia, fábrica e nave global, as quais estão presentes nas formas de ser, agir, signos, imagens, parábolas e alegorias, que envolvem pessoas, coisas, ideias, respostas, interrogações, enfim, o que afeta a vida direta das pessoas e das nações como um todo.

As diferentes descrições e classificações de metáforas se reproduzem como nova divisão internacional do trabalho, economia mundo, sistema mundo, cidade global, mundo 
global, mundo sem fronteiras, mundialização do capital, hegemonia global, fim da história, fim da geografia e outras. Essas metáforas revelam as consequências e os dilemas da modernidade, consubstanciada como uma sociedade moderna e homogênea. Entretanto, elas apenas travestem as contradições do sistema e os mecanismos de dominação, com vistas a ocultar as representações locais, assim como a negação e resistência a essa hegemonia.

Iniciada nos anos 1950, essa nova racionalização do trabalho toyotista se disseminou pelo mundo nos anos 1970, que compreendeu o processo de reorganização do sistema capitalista denominado de globalização. Esse fenômeno requer a reflexão sobre sua dimensão, sobretudo no que se refere à imigração, sendo essa relação um dos problemas centrais dessa tese.

Buscando responder algumas questões relacionadas a esse fenômeno, Ianni (2002) ressalta que a disseminação do capital em escala global foi viabilizada a partir de transformações qualitativas e quantitativas do capitalismo, denominadas de fábrica global. Para o autor, esse fenômeno além de romper as fronteiras nunca antes rompidas possui a capacidade imponderável de subsumir quaisquer outras formas de produção e organização do trabalho, com a imposição de um padrão homogeneizado e produtivo. Nas palavras do autor: “[...] o mercado, as forças produtivas, a nova divisão internacional do trabalho, a reprodução ampliada do capital, desenvolvem-se em escala mundial” (IANNI, 2002, p. 18).

As fronteiras desaparecem na perspectiva da fábrica global que é imponente e instalase em todos os lugares, de forma a articular capital, tecnologia, divisão do trabalho, força de trabalho. Dessa forma, nas palavras de Ianni (2002), a fábrica global, mais uma metáfora da globalização "[...] dissolve fronteiras, agiliza os mercados, generaliza o consumismo" (IANNI, 2002, p. 18). Assim, as metáforas se tornam realidades e expressam esse fenômeno denominado de globalização, que significa nada mais do que a reprodução ampliada do capital, disseminada como força avassaladora.

No atual contexto, ela assume algumas peculiaridades na internacionalização da economia e reestruturação produtiva que por sua vez demandou diminuição da participação do Estado na execução de políticas sociais para privilegiar o investimento no mercado e vigência do capital financeiro com programas de governo voltados para fazer do mercado o farol dos Estados nacionais.

De maneira geral, a globalização compreende a disseminação do capital via transformação nas relações de produção e trabalho, dominação de grandes corporações, diminuição do papel do Estado que para garantir essas reformas tem que reduzir sua participação no desenvolvimento de políticas sociais e, assegurar por outro lado, as condições 
para a reestruturação produtiva. Isso se fez por meio da inversão dos investimentos estatais voltados para o capital financeiro, redução de sua autonomia com a captura pelas grandes corporações que o tornou mero executor desses interesses.

O papel do Estado conclui a terceira parte do processo global, iniciado com a flexibilização e reestruturação produtiva, domínio do capital financeiro e grandes corporações associado à adequação do estado neoliberal a esses propósitos.

Nessa mesma perspectiva, Ianni (2002) ressalta que a história moderna é marcada pelos Estados nacionais fortes e soberanos até o fim da Segunda Guerra Mundial, soberania esta atacada nos países perdedores da guerra, bem como nos países periféricos que em nome da industrialização intensificaram as relações de dominação já vigentes desde o período colonial.

Assim, formou-se uma economia mundo que interliga as economias regionais e globais, que sempre se articula com o Estado nação. Embora seja relevante o poder das corporações transnacionais, elas só se estabelecem nos países ou em âmbito mundial porque os Estados Nacionais permitem e viabilizam, ao mesmo tempo em que perdem a sua soberania.

O capital retomou sua expansão mundial após a Segunda Guerra e fez do mundo um espaço da sua internacionalização de forma jamais vista anteriormente devido à intensidade e à generalidade. A nacionalidade, uma característica peculiar até então a esse sistema, deu lugar para a internacionalização de grandes economias como a inglesa, norte americana, francesa, alemã, japonesa dentre outras, com intensa subordinação dos Estados nacionais a elas.

De acordo com Santos (2004), essa unificação do mundo devido ao seu maior conhecimento com o desenvolvimento da técnica com os progressos da ciência, tem provocado uma globalização pujante para o capital e perversa para os trabalhadores, com amplo retrocesso da noção de bem público e de solidariedade, além do encolhimento das funções estatais e da sua soberania com ampliação da pobreza e do papel político das empresas sobre a vida social.

Ainda para Santos (2004), ocorre uma ampliação da desigualdade social devido à forma desigual da apropriação sobre a técnica e seus resultados ou o que o autor denomina de novos meios de produção, o que torna ainda mais periférica a periferia com a intensificação da perda de controle sobre o processo produtivo.

A informação é um dos fatores constitutivos da globalização e provoca duas violências centrais, o alicerce do sistema ideológico que justifica as ações hegemônicas com império das 
fabulações e a fragmentação das percepções reduzidas ao discurso de um mundo único sob a base de novos totalitarismos ou o que o autor denomina de globaritarismo. A informação apresenta-se dessa forma como ideologia, pois é manipulada pela distorção de entendimento da realidade em detrimento do esclarecimento.

Santos (2004) afirma que a globalização não é somente a existência do novo sistema de técnicas, mas ela resulta das ações que asseguram o surgimento do mercado global. Para o autor, quatro fatores ajudam a explicar a arquitetura da globalização, são eles: a unidade técnica, a convergência dos momentos, a cognoscibilidade do planeta e existência da mais valia como motor único da história. Infere ainda que a técnica e seu domínio produzem efeitos e mudanças sociais e representa o desenvolvimento da história, viabilizada como uma nova etapa de sua transformação, portanto desenvolvidas socialmente, não se dão de forma isolada.

Se cada sistema técnico representa uma época, o momento atual se depara com a técnica da informação, por meio da cibernética, informática e eletrônica. Ao tratar da técnica da informação, Santos (2004) ressalta que ela permite a comunicação e o comércio das diferentes técnicas, colocando o papel determinante sobre o uso do tempo, que leva a sua convergência em diferentes lugares e simultaneidade das ações, os quais por sua vez aceleram o tempo histórico.

O surgimento de uma nova família de técnicas não leva ao desaparecimento de outras, porém elas são utilizadas por novos atores hegemônicos que as acessam, enquanto as técnicas obsoletas tendem a ser mantidas por países de menos poder hegemônico. Santos (2004) ressalta ainda que na história humana é a primeira vez que esse conjunto de técnicas envolve todo o planeta de forma a impor sua presença hegemônica.

Na mesma perspectiva do autor, ao discutirem sobre o desenvolvimento da técnica, Patarra e Baeninger (2004) inferem que ela sempre definiu a posição dos países produtores, sustentadas pelos consumidores, havendo dessa forma uma desigualdade no âmbito do que conhecemos por divisão internacional do trabalho.

A imigração no contexto da globalização gera outros traços característicos do imigrante, os quais Patarra e Baeninger (2004) apresentaram falando da clandestinidade como uma dessas características, o que torna mais difícil a mensuração desses fluxos.

As autoras compreendem os anos 1980 como o marco inaugural da imigração no contexto da sociedade global, dadas as transformações no mundo produtivo e a interferência no processo migratório. O toyotismo alinha a diminuição de postos de trabalho fundamental para justificar o fechamento das fronteiras, quando a tecnologia de fato cumpre a função de substituir o trabalho vivo pelo trabalho morto. 
Ao discutir sobre as mudanças do trabalho a partir do Toyotismo, Antunes (2003) evidencia o contexto da revolução tecnocientífica, caracterizada pela automação, robótica, microeletrônica e a produção enxuta visualizada não só pela diminuição da produção atrelada à demanda, mas também na redução ou enxugamento do quadro de trabalhadores (ANTUNES, 2005).

Além disso, altera-se também a forma da produção, sendo essa diversificada ou personalizada, com implementação do trabalho polivalente ou multifuncional, realizado em equipe ou através de regime de colaboração, com terceirizações e flexibilizações, permitidas a partir da legalização dessas novas formas de contrato de trabalho, sob o auspício do Estado, com aprovação de legislações adequadas a elas.

O modelo japonês ${ }^{11}$ tem se espalhado pelo mundo e se adaptou conforme a conjuntura de cada país, embora essas diferentes experiências tenham em comum consequência negativa no mundo do trabalho, com intensificação da exploração em escala mundial.

Ao tratarem dessa questão no Brasil, o conjunto de pensadores que estudam esse fenômeno, como Carvalho (1994), Leite (1994) e Shiroma (1991), inferem que aqui, diferente do Japão desenvolveu-se o Toyotismo à brasileira, ou seja, uma incorporação de algumas de suas características aos antigos arranjos, permanecendo a ordenação do modelo Fordista taylorista.

Esses autores indicam, sobretudo, o caráter conservador da modernização produtiva no Brasil, quando para eles, se restringe a aquisição de novas máquinas e equipamentos, mantendo os processos de trabalho baseados nas velhas práticas do modelo Taylorista/fordista, com associação da intensificação do trabalho, desvalorização da mão de obra por meio de baixos salários e ampliação da exploração e extração de mais valia.

Assim, as transformações produtivas fordista/taylorista, toyotista ou flexibilização produtiva correspondem ao que Santos (2004) denomina do surgimento de novas técnicas, que invadem o sistema produtivo e pela primeira vez se mundializam. A globalização é o efeito ideológico ideal quando dissemina uma ideia de fronteiras imponentes para a disseminação dessas técnicas, ao passo que simultaneamente oculta o acesso restrito de poucos a ela.

Já a ideia de fábrica global diz respeito às transformações qualitativas e quantitativas do capitalismo, além das fronteiras, cuja capacidade é imponderável frente à eficácia de 11 O toyotismo é o modelo japonês de produção, criado por Taiichi Ohno e implantado nas fábricas de
automóveis Toyota, após o fim da Segunda Guerra Mundial. A reestruturação produtiva, em curso nos demais 
subsumir quaisquer outras formas de produção e organização do trabalho, com a imposição de um padrão homogeneizado e produtivo. Ocorre, dessa forma, a globalização do modo de produção capitalista, “Assim o mercado, as forças produtivas, a nova divisão internacional do trabalho, a reprodução ampliada do capital, desenvolvem-se em escala mundial" (IANNI, 2002, p. 18).

Conforme Bauman (1999), a globalização marca a perda daquilo que constituiu a formação do Estado moderno, pautado no tripé das soberanias militar, econômica e cultural. Porém, poucos foram os Estados que conseguiram garantir sua soberania por meio do rígido controle da ordem social, além de suprimir populações menores e sua autossuficiência econômica.

Nesse contexto, pensando as transformações do capitalismo no século XX, Harvey (1999) destaca a transição do modelo fordista-taylorista, tendo em vista a dificuldade de expansão do fordismo devido a fatores como a resistência dos trabalhadores ao trabalho rotineiro; extensas jornadas de trabalho e exploração; e a alta rotatividade dos trabalhadores na esfera produtiva. A expansão do fordismo se deparou com a resistência dos trabalhadores, ao mesmo tempo em que tinha disponível trabalhadores imigrantes que eram incorporados como mão de obra necessária. No período entre guerras, o fordismo-keynesianismo se consolidou, de forma a intensificar a concentração de renda e poder.

A globalização foi essencial para transformar as relações entre capital e trabalho com diminuição da participação do Estado na economia, o que ocorreu por meio da expansão dos monopólios, com a fusão entre capital industrial e financeiro. A expansão dos monopólios se fez pela diminuição de direitos trabalhistas e repressão dos trabalhadores, associado aos gastos sociais e subsunção do Estado aos interesses corporativos e financeiros (ALVES, 1999).

Sassen (1988), concordando com Harvey (1992), afirma que a nova dimensão produtiva acarreta, para além da flexibilização da produção, a dispersão espacial. Isso requer mobilidade do capital e, consequentemente, da força de trabalho, agregada a outros aspectos, como a tecnologia da informação, telecomunicação e microeletrônica, dinamizando a produção e os lugares.

Baumam (1991), por sua vez, afirma que estar em movimento é uma característica da sociedade contemporânea. A internet e os meios de comunicação em massa viabilizam a entrada e saída do espaço estrangeiro. A distância perde importância, o espaço deixa de ser 
um obstáculo. As fronteiras naturais são dissolvidas e tornam qualquer um, a qualquer momento, em viajante. Esse espírito de liberdade é rechaçado quando torna inadequado o movimento humano, se ele não respeita os ordenamentos do capital.

A soberania de alguns Estados tornou-se global, de maneira que alguns grupos foram se reduzindo às ordens locais, com imposição dos seus interesses. Isso foi tão evidente que Bauman (1999), citando Castoriadis (1991), enfatiza o equilíbrio dinâmico dominado por esse autor como mantenedor da igualdade entre ritmos de crescimento, de consumo e elevação da produtividade, tarefa exclusiva dos Estados modernos para impor sua soberania, sobretudo na esfera econômica.

Assim, uma nova ordem se eleva baseada na condição de reorganização do sistema, as profundas mudanças foram alcunhadas de globalização, porque se dinamizaram em três características principais: desenvolvimento tecnológico e novas relações produtivas como o toyotismo, adequação das legislações trabalhistas compatíveis com essa nova organização produtiva delineadas por políticas neoliberais.

A internacionalização do capital intensifica o seu desenvolvimento sem precedente como: "a emergência dos monopólios, trustes e cartéis, intensifica-se e generaliza-se com as transnacionais, redesenhando o mapa do mundo, em termos geoeconômicos e geopolíticos, bem diferentes daqueles que vinham sendo desenhado pelos mais fortes Estados nacionais" (IANNI, 2002, p. 47).

Assim, diferente de outras formas anteriores, a partir da Segunda Guerra Mundial, ocorre a ascensão de poder pelas transnacionais que se impõem aos Estados Nacionais, ao mesmo tempo que acontece a maior inserção de tecnologia com ampla transformação produtiva do sistema fordista taylorista, hegemônico até então. O final da guerra fria foi o estopim para a transnacionalização que atingiu as antigas economias nacionais soviéticas.

A nova divisão internacional do trabalho e da produção, envolvendo o fordismo, o neofordismo, o toyotismo, a flexibilização e a terceirização, tudo isso amplamente agilizado e generalizado com base nas técnicas eletrônicas concretiza a globalização do capitalismo, em termos geográficos e históricos. A fábrica global pode ser simultaneamente realidade e metáfora. Expressa não só a reprodução ampliada do capital em escala global, compreendendo a generalização das forças produtivas, mas significa também a globalização das relações de produção (IANNI, 2002).

As bases nacionais continuam existindo, mas não são mais determinantes no contexto da globalização. O dinamismo do capital rompe todas as fronteiras, culturas, civilizações e regimes políticos. A principal mudança imposta pela globalização ao Estado nação foi a perda 
de soberania nacional e a maior dependência desses Estados aos interesses hegemônicos das grandes corporações, do capitalismo financeiro que detém a técnica e o capital para impulsionar a transnacionalização econômica de acordo com seus critérios e interesses.

As economias se abriram para o livre mercado que por meio das transnacionais ou grandes corporações impõem as diretrizes que visam a desregulamentação, abertura de fronteiras, criação de zonas francas, dentre outros. Para Ianni (2002), as ações de internacionalização davam seus primeiros suspiros e a parceria entre a União Soviética e os Estados Unidos na luta contra o nazi fascismo alemão, italiano e japonês proporcionou as forças capitalistas organizadas de base inglesa e norte americana. A guerra fria tornou-se importante dinamizadora das relações capitalistas de produção quando se transforma numa relação diplomática contra revolucionária. A dinamização das atividades produtivas com destaque para a Europa com Alemanha e União Europeia, o pacífico, com destaque aos tigres asiáticos e ao Japão.

A internacionalização do capital provocou as transformações das antigas economias socialistas as quais substituíram seu modelo importador e a nova divisão do trabalho se colocou em curso com o toyotismo, a reestruturação produtiva e neoliberalismo, metáforas da globalização.

Para o mundo global não há fronteiras, isso não significa que não haja controle sobre elas. O seu limite é impedir nas mesmas proporções as migrações que se colocam como um problema estrutural do capital, intensificadas em contexto de reestruturação produtiva, redução de postos de trabalho e precarização dessas relações.

$\mathrm{O}$ controle das fronteiras se mostrou insuficiente diante das instâncias de insubordinação que representam o outro lado da globalização, definida por Mezzadra (2005) como subjetividade do imigrante ou globalização de baixo.

As políticas estatais, reduzidas ao controle das fronteiras, não rompem com as desigualdades e contradições inerentes ao desenvolvimento do sistema capitalista, pois são sustentadas por elas. No entanto, as experiências migratórias não se estendem em um terreno magmático, e fazem parte de um movimento que não sinaliza se acalmar, com vistas a ser conduzida aos imperativos do mercado, do capital e da disciplina do trabalho (MEZZADRA, 2005).

A globalização é entendida como a própria extensão das grandes corporações, que usam os Estados nacionais para reproduzir o monopólio de alguns em detrimento de outros. No segundo capítulo vamos destacar seus efeitos em Cascavel, por meio de uma análise entre os impactos da transformação produtiva de frigoríficos na imigração haitiana para a região. 
É certo que as transformações estruturais abalaram o tripé da soberania, cuja função econômica foi a mais afetada, reinando a ilusória extraterritorialidade do espaço com a operação do mercado financeiro global, que impõe sua dinâmica e ordenação do planeta, especialmente aos Estados nacionais.

A esses Estados resta apenas o poder de repressão, cada vez mais usado diante das reações populares contra o monopólio do sistema global e a perda da soberania estatal. Com a supressão de direitos, qualquer intervenção do Estado na economia pode ser motivo de sanção do mercado mundial. A destituição da soberania estatal e a dependência fazem do Estado um mero servidor dos interesses do capital e suas diferentes frações, para garantir sua segurança. Reina dessa forma a soberania do capital, travestido pelo capital internacional com intensa submissão dos estados nacionais as grandes corporações internacionais. Essas, por sua vez, dependem e se alimentam da fragmentação política e perda de hegemonia do Estado.

Nessas circunstâncias, a "cena global" era o teatro da política interestatal, que - por meio dos conflitos armados, de acordos ou ambas as coisas - visavam antes e acima de tudo traçar e preservar "garantindo internacionalmente" as fronteiras que separavam e encerravam o território da soberania legislativa e executiva de cada Estado (BAUMAN, 1999,p. 70).

Para Bauman (1991), o neoliberalismo leva não apenas à separação entre política e economia, mas promove o domínio dessa sobre aquela, com uma consequente mudança na distribuição do poder social. As fronteiras são cada vez mais fechadas e controladas.

As formas de domínio do sistema financeiro e a perda da soberania nacional foram analisadas por Bauman (1991, p. 76), que, no início dos anos 1990, via a hegemonia do neoliberalismo, sem falar praticamente desse termo. Quando dizia que "Ainda estamos bem longe do destino final", seus efeitos se disseminavam pelo planeta, atingindo as periferias do sistema nos anos 1990 e, por sua vez, as antigas economias socialistas.

$\mathrm{O}$ autor previa um futuro reinante da ausência de soberania, primordialmente suas consequências para as economias de capitalismo dependente, que já eram reféns de um Estado sem soberania ou de uma soberania enfraquecida, no pouco que lhe restava. "O padrão dominante pode ser descrito como afrouxamento dos freios: desregulamentação, liberalização, flexibilidade, fluidez crescente e facilitação das transações nos mercados financeiros imobiliário e trabalhista, alívio da carga tributária etc” (BAUMAN, 1999, p.76).

No capítulo III, será discutido esse reordenamento no mercado de trabalho em Cascavel. A inserção dos imigrantes haitianos no sistema produtivo segue a lógica da reestruturação produtiva, preservando alguns delineadores do modelo fordista-taylorista, inserindo ou excluindo trabalhadores, conforme a demanda do sistema produtivo. 
De acordo com a discussão anterior, foi introduzido o debate que envolve a perda de soberania nacional frente ao capital financeiro e grandes corporações, assim como não há como falar em globalização sem se remeter às transformações produtivas e, também não há como pensá-la sem referir-se ao neoliberalismo, pois ambas constituem junto com o mercado financeiro essa nova conjuntura de organização do capital.

Na mesma perspectiva já delineada por Bauman (1991), Anderson (1995) fez um balanço do neoliberalismo implementado pelos diferentes países capitalistas. $\mathrm{O}$ autor ressalta a perda de soberania do Estado, e infere que, no discurso dos neoliberais, a estabilidade econômica seria uma meta a ser alcançada. Para tanto, são necessárias algumas medidas, como: redução de gastos com políticas sociais, disciplina orçamentária e restauração da taxa natural de desemprego, com o propósito de quebrar o poder dos trabalhadores e fragilizar os sindicatos.

Essas medidas foram implementadas pela Inglaterra, que, após observar a inédita experiência neoliberal da ditadura de Pinochet, no Chile, em 1973, a adequou e a implementou, sendo progressivamente adotada por vários países do mundo (ANDERSON, 1995).

Essa progressiva expansão do neoliberalismo pelo mundo, de acordo com Anderson (1995), se deu a partir da experiência do Chile e foi se delineando pelo mundo a partir de três fases. A primeira delas teve início na Inglaterra, em 1979, e atingiu países da Europa (exceto Áustria e Suécia) envolvendo todos os países da OCDE e EUA, nos anos 1980. A segunda fase neoliberal, foi implementada na década de 1980 e contou com a incorporação de países pós-comunistas do Leste Europeu, como Polônia, Rússia e República Tcheca. Com a derrota de governos progressistas as privatizações ocorreram nesses países com maior intensidade do que as experiências praticadas anteriormente no Ocidente. Por fim, a terceira e última etapa ocorreu a partir da filiação dos países latino-americanos, nos anos 1990.

Para Alves (2017), no Brasil, não houve interrupção desse ciclo, de maneira que há um reajustamento do capitalismo neoliberal no país. Como o mais forte imperialismo da América Latina, o governo brasileiro transformou em lei o que já operava no plano da dinâmica, da exploração e da necessidade de acumulação de capital.

Reformas como a do trabalho, imposta pela Federação das Indústrias do Estado de São Paulo (FIESP), é uma demonstração da força que o capital acumulou, vindo a acentuar a flexibilidade laboral no país. Houve, portanto, uma reestruturação jurídica da política do Estado, ou o que Alves (2017) denomina de um reajustamento. Na verdade significa, pois, que houve um aprofundamento da flexibilização contratual, pautada no trabalho intermitente, 
seja ele autônomo ou temporário. Trata-se então do desmonte dos direitos trabalhistas que restavam no Brasil.

Outros estudos poderiam indicar a continuidade ou não do projeto neoliberal em diferentes países no mundo, que se estende em consonância com a intensidade da ação dos governos conservadores, sem rompimentos profundos com os programas neoliberais.

Esse foi o caso dos governos Lula e Dilma, ambos do Partido dos Trabalhadores, que deram continuidade a alguns programas neoliberais, já em execução no Brasil. Alves (2017) denominou esse fato de choque de capitalismo, que se articula com base na consolidação de políticas sociais, mas, também, no investimento estatal em diferentes frações do capital. Dessa forma, ocorre a exploração de países latino-americanos, em razão da hegemonia dos interesses privados. O que se observa é a continuidade de traços do neoliberalismo nos últimos governos, com a manutenção da precarização dos serviços públicos e contenção dos gastos com políticas sociais, também denominadas de políticas de austeridade, além de privatizações, precarização e flexibilização das relações de trabalho (ALVES, 2017).

Anderson (1995) argumenta que não é comum os governos adeptos a esse programa, em períodos eleitorais, divulgar em seus planos de gestão propostas de caráter neoliberal. Essas tendem a ser implementadas abruptamente, sem ser previamente apresentadas para os eleitores em períodos eleitorais ${ }^{12}$.

Ao discutir o neoliberalismo no Brasil, Sodré (1995) entende que o Estado precisa se afastar das relações econômicas e o mercado as deve regular. Isso levou a liberalização dos mercados nacionais à derrubada das barreiras que impediam o livre comércio ou uma “integração" à moda neoliberal, a fim de extirpar o que representasse o elemento nacional em cada país. As políticas neoliberais seduziram os militares, e foram, progressivamente, implementadas pelos então Presidentes Fernando Collor de Mello e Itamar Franco, e intensificadas por Fernando Henrique Cardoso (SODRÉ, 1995).

Numa perspectiva diferente, Pochmann (2016) não considera os governos Lula e Dilma como continuidade do neoliberalismo, como expressou Alves (2017). Para o autor, nas três eleições diretas para presidente, o projeto neoliberal vencedor no Brasil (1989, 1994 e 1998) não chegou a ser apresentado enquanto tal para o veredito da sociedade. Nos programas

\footnotetext{
${ }^{12}$ No entanto, isso tem se alterado com a hegemonia de governos conservadores vinculados a extrema direita, quais tem ao redor do mundo vencido as eleições apresentando claramente essas bandeiras de estado mínimo. No Brasil, isso foi perceptível no amplo apoio de boa parte do eleitorado em 2018 a vários candidatos que defendem abertamente o neoliberalismo como propostas de governo, consolidada com a eleição do candidato Jair M. Bolsonaro com a ampla defesa de privatização de empresas públicas e serviços públicos. Outro dado interessante foi a aprovação de suas propostas antes mesmo de assumir o poder por $75 \%$ da população brasileira (LINDNER, 2018).
} 
políticos de governo apresentados nos debates eleitorais, palavras ou expressões como 'privatização', 'redução dos direitos sociais', 'transferências de renda para os ricos', 'encolhimento de oportunidades' e 'estancamento da mobilidade social' jamais foram explicitadas (POCHMANN, 2016, p. 01).

Há, conforme Pochmann (2016), a interrupção dos governos de cunho neoliberal a partir da eleição de Lula, que se contrapôs a esse projeto. Lula apregoou o fortalecimento do Estado e a reorganização das políticas públicas, com vistas a retomar os princípios da Constituição Federal de 1988, especialmente no que se refere à inclusão de todos os brasileiros nas oportunidades geradas pela economia nacional. Embora o fortalecimento do Estado e a inclusão social tenham sido privilegiados no governo petista, ele não deu conta de atender as necessidades dos novos fluxos migratórios quais lhes impuseram demandas a partir da mobilidade sobre as fronteiras, sendo essa mais uma concretização das migrações transnacionais. Também não se pode esquecer de que não apenas as pessoas se mobilizam através das fronteiras, mas as fronteiras se movem através das populações humanas. A construção e destruição de impérios e Estados provoca importantes movimentos transfronteiriços com a expulsão de minorias políticas, étnicas, religiosas, colonização, deslocamento forçoso de escravos, prisioneiros ou trabalhadores e recrutamento ativo de mão de obra e soldados.

Assim como ocorre a internacionalização do capital, segue também o que Ianni (2002) denomina de mundialização das classes sociais e da questão social e seu antagonismo. Elas são assim como o capital e as relações produtivas antagônicas e tendem a espalhar-se pelo mundo.

A internacionalização do capital é a sua globalização e a financeirização da economia através da revolução tecnológica move o capital por todos os cantos do mundo, por meio dos bancos, partes indissociáveis da transnacionalização e do sistema financeiro. A noção de sistema mundial contempla a interconexão entre as nações, e a influência de instituições financeiras como Fundo Monetário Internacional, Banco Mundial, Organização das Nações Unidas - ONU, além de empresas, grandes conglomerados e corporações transnacionais.

A globalização como vimos marca um novo momento da reordenação do capital, com ampla e livre disseminação de mercadorias, ao passo que coloca limites à migração humana, que só se viabilizou sem interferência estatal na medida em que atendeu os interesses produtivos. Quando não há a conexão entre sistema produtivo e migração, os mecanismos ideológicos reforçam a pecha que carrega o imigrante como responsável pelas mazelas 
sociais, o que se torna muito mais enfático num contexto de desemprego estrutural, de mobilidades forçadas e intensificação da desigualdade social.

A migração, fenômeno intrínseco à subjetividade humana, ganha centralidade dos discursos governamentais e políticos, os quais impõem ideologicamente a concepção de crise migratória, quando na verdade existe uma crise humanitária, de pessoas que se deparam com as políticas de fechamento de fronteiras e vivem sob condições de vida degradantes.

No contexto dos países periféricos a globalização intensifica processos de dependência entre os países produtores de ciência e tecnologia e aqueles produtores de matéria prima. A seguir, será analisado os efeitos desse processo no principal empreendimento produtivo no Oeste do Paraná e seus desdobramentos nos frigoríficos.

\subsubsection{Dependência econômica e seus impactos na inovação tecnológica no Brasil}

A modernização produtiva nos diferentes países corresponde à participação deles na divisão internacional do trabalho. Como essa participação é desigual entre países centrais e periféricos, um instrumento que tem sido eficaz para mascará-la foi o discurso da transferência de tecnologia ${ }^{13}$.

Como veremos, ainda que de forma limitada se referindo a uma empresa de frigoríficos, transferir tecnologia nada mais é que dar aparência de novo para velhas roupagens como a reafirmação da posição dos países dominantes na divisão do trabalho ocultada, como se não houvesse uma condição de ser dessa diferença que produz a essência do que mantém a desigualdade entre os países produtores e os consumidores de tecnologia.

Quando se remete a tecnologia, várias áreas produtivas são envolvidas por um fenômeno comum, cada qual produzindo resultados tecnológicos diferenciados, no entanto, ressaltamos aqui a tecnologia em frigoríficos, já que estamos tratando de transformação produtiva e de seus efeitos nestas instalações e impactos sobre a imigração haitiana no Oeste do Paraná.

Back et al. (2016) estudaram o processo de transferência de tecnologia de frigoríficos por meio de uma prestadora de serviços de assistência técnica de equipamentos para esse setor. Os autores observaram que os frigoríficos são um dos ramos que mais aderem à

\footnotetext{
${ }^{13}$ Um dos principais divulgadores dessa ideia nos países em desenvolvimento foi a CEPAL, que a difundiu, sobretudo na América Latina como um meio de prover o desenvolvimento da região. Nos anos 1990 divulgou vários documentos referindo-se a educação e conhecimento como os meios de consolidar a transferência de conhecimento dos países desenvolvidos para os em desenvolvimento, sendo esse o que convencionou chamar de
} 
inovação tecnológica no Brasil, sendo essa uma condição para a manutenção da concorrência no mercado. Percebeu-se ainda que os países produtores possuem representações das próprias empresas em várias partes do mundo, sendo esse um fenômeno normal da sociedade global.

Aquilo que comumente se denomina como transferência de tecnologia ao ser analisada a partir de uma perspectiva crítica, não passa de assimilação do consumo dela. Grosso modo, países periféricos como o Brasil, geralmente consomem a tecnologia que é comprada ou pelo governo brasileiro ou pelas próprias empresas como uma mercadoria.

No terceiro capítulo discutiremos como se estruturou no Brasil os monopólios que dominam a produção de aves no Oeste do Paraná e como o domínio da técnica interfere na produção final representada pelos frigoríficos. Falando especificamente deles, de acordo com Back et al. (2016), esse consumo se faz por meio de redes construídas a partir das representações de empresas fornecedoras que garantem a disponibilidade de uma estrutura básica para vender, instalar e dar os comandos de como utilizar a tecnologia vendida como mercadoria.

A rede de inovação tecnológica se efetiva para o país que a domina e conserva seu monopólio alimentado pelo consumo de países dependentes, mantendo sua hegemonia com a produção de novas tecnologias desde o momento que disponibilizam novidades no mercado. Enquanto isso, as empresas que consomem ou países que a importam, resta como no caso dos frigoríficos, nada mais que treinar seus funcionários para executar um produto pronto conforme seu manual de instrução. A única inovação que existe é a atualização quanto à maquinaria ou equipamentos.

A dependência, além de inviabilizar inovação gera empecilho até para o consumo dessa tecnologia, sendo tema constantemente destacado pelas empresas intermediárias que se apropriam dos conhecimentos mais básicos para instalação, dificultada pela ausência do domínio sobre o processo produtivo, até as formas de como se apropriar do básico para instalar minimamente a tecnologia fora do país de origem.

Assim, os conhecimentos são tácitos tanto para os que aprendem e incorporam as técnicas para instalar e realizar a manutenção das máquinas e equipamentos, quanto para aqueles que vão executar e trabalhar com essa tecnologia final, que devem saber apenas os princípios básicos de como desempenhar essa habilidade operativa.

Ao definir conhecimento tácito, Garcia e Coltre (2017) ressaltam ser esse conhecimento pessoal e complexo dado a partir da experiência. A diferença entre o 
trabalhador intermediário e o que executa o funcionamento da máquina, é de que o primeiro detém as técnicas minimamente necessárias para instalar os equipamentos e treina o segundo com instruções de como deve manusear a máquina. Contudo, nem o trabalhador intermediário das prestadoras de serviço nem o trabalhador do frigorífico possuem conhecimentos sobre os fundamentos da tecnologia, como ela é produzida, sendo que tanto os que instalam como os seus operadores possuem limitadas habilidades básicas para consumi-la, assim, a complexidade do conhecimento se reduz ao limite da complexidade da qualificação acessada.

O conhecimento tácito é apenas um meio para transmitir o conhecimento desejado, no caso das detentoras da tecnologia no ramo de frigoríficos, ele é reduzido quando o trabalhador manuseia a máquina em detrimento de maiores conhecimentos sobre sua produção.

Isso foi demonstrado em um estudo de caso de uma empresa prestadora de serviços para frigoríficos, especificamente em uma sede desse setor situada no Oeste do Paraná que identificaram as dificuldades na instalação dessas novas tecnologias demonstradas por Back et al. (2016). A assimilação e o consumo dela foram prejudicados devido a alguns problemas enfrentados no decorrer das relações entre a empresa que fornece e o conjunto dos trabalhadores envolvidos tanto na prestação de serviços como os operadores dessa tecnologia.

\footnotetext{
Os gestores da empresa A relatam que, durante os treinamentos dados, encontram dificuldades para difundir o conhecimento técnico, e um dos motivos são os termos estrangeiros utilizados nos painéis de comando dos equipamentos e em manuais, que geralmente são escritos em italiano, idioma do país produtor da tecnologia, ou em inglês. Outro motivo é a dificuldade de assimilação das informações, as quais por muitas vezes não são absorvidas e posteriormente geram danos ao equipamento, que pela má utilização vem a apresentar defeitos. Em virtude desse fator, na grande maioria das vezes em que a assistência técnica é solicitada, os problemas encontrados são decorrentes do uso incorreto dos equipamentos (BACK et al. 2016, p. 5).
}

Dessa forma, o conhecimento tácito é limitado aos trabalhadores desse frigorífico e restrito às empresas prestadoras de serviços, que, ainda que reduzidas, detém nessa rede o maior conhecimento ou saberes necessários para garantir a instalação e posterior transmissão de mínimas habilidades para o funcionamento e adaptação da tecnologia importada na empresa consumidora.

Embora o conhecimento técnico mais especializado fique com algumas poucas empresas produtoras da tecnologia vendida, elas precisam transmitir algum conhecimento para que seja viabilizado o consumo, ao mesmo tempo em que protegem os fundamentos da criação e produção da tecnologia, o que limita, ou mesmo impede de haver nos frigoríficos algo para além do seu consumo. 
No caso do trabalhador que executará a máquina ou essa nova tecnologia incorporada ao processo produtivo, não resta nada mais que conhecimentos mínimos dos comandos para colocar a máquina em funcionamento. $\mathrm{O}$ modo como isso se opera nos frigoríficos serão melhores explorados no terceiro capítulo, quando se faz uma discussão entre rotatividade de trabalhadores como resistência ao trabalho simplificado, mecânico e monótono e a imigração de haitianos nesse contexto.

Dessa forma, a garantia da transferência de tecnologia se faz por conhecimento tácito, nesse caso limitado a uma forma de treino da mão de obra que vai transferir a aplicação da tecnologia por meio de saberes mínimos necessários para adaptar e treinar o receptor que a utilizará corretamente conforme suas necessidades específicas. A grandeza ou não do conhecimento tácito está no interesse do nível de acesso que se deseja transmitir em termos de conhecimento por experiência ou empiria. A inovação, no caso dessa experiência, não se dá na empresa receptora de tecnologia, já que essa não consegue inovar e desenvolver outra tecnologia a partir da consumida, mas no limite, a inovação lhe permite continuar no mercado e concorrer, com redução dos custos e outras vantagens competitivas no ramo de atuação.

Esse consumo garante a manutenção desses mesmos centros tecnológicos como principais produtores de inovação tecnológica, com um público consumidor garantido devido à própria ineficiência de produção e inovação científica e tecnológica dos países que são seus meros consumidores. Essa diferença acaba por garantir a lógica da divisão internacional do Trabalho, que define no atual contexto os países produtores e os consumidores de tecnologia, ao passo que a utilização de termos como transferência de tecnologia camufla sua concretização, com a redução de algumas empresas que são intermediárias dessa transferência.

Isso tem legitimado a dominação de poucos países sobre a hegemonia do conhecimento científico e tecnológico ao passo que os consumidores garantem pelo consumo e não pela produção, a posição dos países que conservam o monopólio, mantendo-se sempre a frente nessa produção via consumo de países dependentes.

As análises dos países que mais investem em tecnologia apontam os EUA com a primeira posição, com a oferta do maior mercado mundial, denominado de High Tech - alta tecnologia, com residência oficial de um dos maiores eventos de inovação como a Silicon Valley, originária do Vale do Cilício, região que desde os anos 1950 desenvolve parques tecnológicos e abriga empresas hegemônicas da tecnologia como Google, Apple, Microsoft, AMD, Dell, e as maiores processadoras de placas do mundo: como Intel, AMD e NVÍDIA. No entanto, essa hegemonia na produção de ciência e tecnologia vem sendo ameaçada pela 
China, com destaque para empresas como ASUS, Acer (fabricantes de processadores), HTC e a Foxconn (TEC MUNDO, 2013).

O Japão, outro país referência, também se desponta como um dos maiores inovadores tecnológicos, com ênfase na divulgação quase que diária desses avanços com empresas que se destacaram nas últimas décadas como a Sony, Toshiba, Panasonic e Nikon, as quais são referências mundiais no segmento em que atuam (TEC MUNDO, 2013). Outro país de destaque é o Reino Unido que lidera vários rankings mundiais, sobretudo na produção de artigos científicos. A reputação mundialmente conhecida desse país inclui muitas indústrias tais como: automobilística, biotecnologia, eletrônica, indústria química, telecomunicações, entre outras. Destaca-se ainda com a vanguarda na produção tecnológica de serviços financeiros, conhecidas como fintech (A Notícias, 2017).

Quando se destaca o perfil dos países e empresas com elevado grau de desenvolvimento tecnológico, sobressaem algumas características como ser tecnologicamente avançada, evitar desperdício econômico, melhor utilização dos recursos com redução de uso de componentes contaminantes, produção de uma nova tecnologia diferente da que acaba de oferecer no mercado, com o experimento e desenvolvimento de tecnologias seguintes (A Notícias, 2017).

Estudos da Tec Mundo (2013) indicam Coréia do Sul, Singapura, Índia e Israel como importantes espaços de tecnologia no mundo, no entanto, várias empresas norte americanas estão instaladas nesses países, como Microsoft, IBM e HP em Singapura, Microsoft, HP e 3M na Índia. A difusão de indústrias norte americanas em outros países é a expressão do que já viemos discutindo acerca da hegemonia de grandes corporações em detrimento da soberania dos Estados nacionais.

Por outro lado, há um aproveitamento da mão de obra e recursos naturais. Essas condições são manifestações da sociedade global que tem na disseminação de grandes corporações não só a submissão dos Estados as suas condições, mas oferecem a elas vantagens econômicas, que podem variar desde a desburocratização estatal no que concerne a regulamentação sobre contratos de mão de obra, benefícios por isenções fiscais, disponibilidade de recursos naturais e matéria prima, produção de lixos ambientais, cujos graus de sustentabilidade de manejo se dá conforme a soberania estatal.

Assim, a flexibilidade das legislações amplia ou aumenta de acordo com o grau de subordinação estatal em relação à essas grandes corporações. Como vimos até aqui, o país hegemônico mantém suas corporações multinacionais em outras regiões do mundo, no entanto, é certo que as remessas de lucro retornam tanto das condições aproveitadas pelas 
empresas das mais diversas formas, e são a princípio remetidas para os países que detém o domínio sobre elas.

Contudo, vimos que os estudos sobre inovação tecnológica nos países periféricos se limitam à incorporação da tecnologia já pronta e desenvolvida, como se fosse um recurso pronto e acabado que demanda alguns saberes tácitos (treino, experiência e tentativa). Nessa perspectiva, sobressaem alguns parques tecnológicos, porém incipientes quando comparados aos grandes países hegemônicos na sua produção.

No que se refere ao ramo dos frigoríficos, não se produz novas tecnologias, mas a incorporação delas tem remetido ao manuseamento da máquina, sobretudo no fortalecimento de relações de trabalho aos moldes do fordismo/taylorismo, quando muito, a repetição se faz de forma polivalente nos moldes do toyotismo, em que o trabalhador pode desenvolver várias atividades simultaneamente, sem que elas superem a repetição de atividades diferentes.

Talvez esse seja um grande desafio dos países consumidores e não produtores de tecnologia: ter a capacidade de inovar a partir da sua real transferência, a exemplo de alguns países que na condição de periféricos lograram esse êxito partindo não apenas do consumo, mas da real transferência de tecnologia.

Atingir esse nível requer prover investimentos, sendo esses, parte de um plano de diminuição da dependência e ampliação da soberania estatal. A inovação produtiva, quando de interesse estatal, supera o simples consumo da tecnologia com a apropriação sobre seus fundamentos, que podem também ocorrer com investimentos na ciência e tecnologia de cada cadeia cientifica e tecnológica presente nas universidades.

Ao discutir sobre a ciência no Brasil, Schwartzman (2001) ressalta que, embora pareçam significativos avanços na ciência brasileira, ela é ainda incipiente e que, quando muito, há formação de ilhas de competências ou o que ele denomina de nichos de desenvolvimento científico: espaços isolados e precários de produção do conhecimento.

Conforme o autor, a formação desses nichos tem contribuído para concentrar em poucos centros a produção científica, também resultado de um egoísmo em relação aos pesquisadores mais velhos, os quais são fundadores dos poucos centros de pesquisas no Brasil, e restringem a transferência do conhecimento para pesquisadores mais novos. A falta de maturidade de antigos pesquisadores, a blindagem de seu acesso por pesquisadores mais jovens pode ser um dos motivos que contribui para emperrar o desenvolvimento científico, e a incapacidade de abrir para novas ideias, além de alguns nichos produtores de inovação.

Dessa forma, para esse autor, esse egoísmo acadêmico tende a restringir o desenvolvimento da ciência no Brasil. Em outra perspectiva, somariam a isso, a falta de 
investimento do sistema público em desenvolvimento científico, que vem desde a base do sistema escolar. Embora o Brasil tenha recursos e investimentos que se aproximam aos países da OCDE, o resultado de aproveitamento da educação básica por ser precária afeta negativamente o desempenho acadêmico (FRAGA, 2018).

Em uma perspectiva não muito diferente, Pontes (2015) ressalta que o restrito desenvolvimento científico no Brasil, tem ocorrido devido ao isolamento das universidades e seu distanciamento das empresas. Para o autor, é necessário uma cooperação livre e a partir dela desenvolver novas tecnologias, de forma mais dependente, o que gera por sua vez benefícios para toda a sociedade. No entanto, o desenvolvimento desses nichos científicos consequentemente gerou uma comunidade científica reduzida.

Conforme Schwartzman (2001), em 1973 o país ocupava o trigésimo primeiro lugar do globo e o quarto entre o terceiro mundo na produção científica. Esses dados embora tenham sofrido um expressivo aumento em termos de produção científica, sendo que o número de publicações em periódicos saltou de 1.060 em 1973 para 1.551 em 1980 e elevou a posição do Brasil para segundo lugar no ranking de publicações entre os países de terceiro mundo, atrás somente da Índia, que ocupa a primeira posição entre esses países. No entanto, ainda é insignificante a produção brasileira quando comparada ao impacto do que se produz com a comunidade científica mundial.

Numa mesma perspectiva, ao levantar os dados sobre o desenvolvimento científico no Brasil entre 2001 e 2011, Pontes (2015) ressalta uma continuidade do expressivo crescimento das publicações de artigos, porém sem eliminar as ilhas ou poucos nichos produtivos. Para o autor, o país evidencia uma contradição quando se remete ao desenvolvimento da ciência e da tecnologia, a qual se dá entre aumento de publicações científicas e restrita inovação tecnológica.

As publicações evidenciaram um avanço da produção científica, elevaram o país da $13^{\mathrm{a}}$ posição para a $7^{\mathrm{a}}$ maior do mundo até 2011 . No entanto, como a quantidade não é traduzida necessariamente em qualidade, Pontes (2015) ressalta que embora tenha ampliado consideravelmente a produção e publicação de artigos científicos por pesquisadores brasileiros, no âmbito de destaque mundial o país pouco inovou tecnologicamente. $\mathrm{O}$ autor ressalta que esses dados podem ser observados na pouca credibilidade dos artigos restrito a $1 \%$ do que é mundialmente produzido.

Essa contradição de muita publicação e pouca relevância perante a comunidade científica mundial se explica conforme Pontes (2015) sob duas perspectivas. A primeira é a inserção do maior número de periódicos brasileiros na base de dados, daí o aumento 
expressivo das publicações nacionais ${ }^{14}$. A segunda, pelo isolamento de pesquisadores no âmbito das universidades, associado a publicações como quesito de avanço nas carreiras como resultado de um sistema que isola o contato e a relação cooperada entre universidades e empresas.

Desse modo, esse sistema que isola os professores das empresas é considerado anacrônico por Pontes (2015), ao passo que obriga os pesquisadores e todos professores a publicar indiscriminadamente, a fim de lograr êxito nas carreiras, ascendida também pela quantidade de produção cientifica, muitas vezes sem considerar a qualidade e a real aplicação prática desse conhecimento e seu retorno para o desenvolvimento econômico e social.

Conforme esse autor, dos 85.000 professores disponíveis nas universidades, apenas $2 \%$ deles se vinculam às empresas, o que comprova um ranço ideológico que impede que haja uma maior vinculação deles e a efetivação da cooperação entre empresa e universidade, algo já praticado por todos os países com maiores destaques na produção cientifica mundial. ${ }^{15}$

Pontes (2015) ressalta também que o Brasil tem uma formação exitosa de doutores com dados similares aos países hegemônicos da produção científica e tecnológica no mundo, que em 2010 correspondeu a formação de 10.000 novos doutores anuais, taxa mantida ou ampliada nos anos seguintes. Porém, entre os países com maior desenvolvimento tecnológico, há uma tendência de aproveitamento do capital humano como uma forma de ter um maior retorno do investimento feito sobre eles pelo Estado, que por sua vez permite maior desenvolvimento produtivo e contém a fuga de cérebros. Já no Brasil, ocorre o desperdício desse capital humano, pois aqui, quando muito, se garante formar, sem que haja uma

\footnotetext{
${ }^{14}$ Não se dará aqui maior ênfase no que é considerado produtivo ou não, sabe-se que no bojo de toda essa produção está também as ciências humanas, que nessas análises econômicas, costumam ser consideradas improdutivas, quando não produz desenvolvimento tecnológico ou uma inovação tecnológica como mercadoria.

${ }^{15}$ Embora não considera-se aqui que a produtividade da Universidade se resume ou se e restringe às dimensões de ampliação do sistema econômico, e somente sob esse viés delimitou o que a faz ou não produtiva. É certo que a produção prática de um produto que concomitantemente é aplicado diretamente no processo produtivo se sobressai como uma inovação tecnológica a exemplos das patentes. Isso corrobora para que a produtividade sob a perspectiva produtiva da inovação tecnológica tenha que ser pensada. Inclusive ela é uma condição para que tenhamos enquanto país periférico, dependente e atual consumidor de tecnologia maior autonomia e viabilidade para criar e depender menos dos países centrais, de forma a fortalecer o desenvolvimento industrial e econômico do país. Não podemos negar as potencialidades produtivas e econômicas se é que almejamos a menor dependência tecnológica. Isso pode ser feito, ao mesmo tempo em que valoriza as humanidades e o pensamento crítico, que formam o espírito e a função do ensino superior público no Brasil. Também é fato que as experiências já demonstraram que países periféricos podem e tem capacidade de inovar tecnologicamente, pensar em que medida isso possa ocorrer no Brasil é também papel da Universidade, pois é muito mais proveitoso e economicamente viável ela produzir aqui, ainda que sirva quase exclusivamente ao desenvolvimento econômico do que importar de fora inovações tecnológicas. Porém para tudo isso, depende de maior investimento financeiro, além da cooperação entre empresa e universidades. No Brasil esses recursos têm sido cada vez mais escassos o que precariza o pouco já conquistado pelas ilhas de conhecimento científico como apontou Schwartzman (2001).
} 
preocupação com a inclusão com uma função social, um mecanismo de gerar renda, trabalho e desenvolvimento para o país.

Em relação à inovação, ainda conforme Pontes (2015), se mede pela quantidade de patentes registradas. Os dados dessa produção no Brasil conforme o tratado de cooperação de patentes não passa de 0,2\%, enquanto que na área mais avançada da produção de tecnologia, as patentes estrangeiras representam mais de $90 \%$ de tudo que é produzido. Esse autor considera a cooperação entre universidades e empresas fundamental para haver desenvolvimento tecnológico do Brasil, o qual só pode ocorrer na medida que essas instituições quebram barreiras ideológicas e se voltam para o setor privado, destacando "Dessa forma, os benefícios reverteriam à sociedade: as universidades contribuem com os pesquisadores e as empresas com recursos, logística e distribuição dos produtos, com retorno econômico ético para todos e com grandes lucros sociais" (PONTES, 2015, p. 343).

Essa cooperação é denominada de inovação aberta, e propiciaria de acordo com esse autor o maior desenvolvimento para o país, ao passo que promove o aproveitamento do capital humano formado sem desperdiçá-lo. A produção interna de inovação gera por outro lado a inovação tecnológica, que atualmente devido à não produção, coloca o país como mero dependente do que se produz externamente.

Em uma perspectiva de análise atual dessa cooperação, Barcelos e Mocelin (2016) ressaltam a importância das Universidades agregarem ciência e mercado de forma a vincular os interesses científicos para as demandas produtivas da sociedade, o que geraria por sua vez maiores inovações científicas e patentes registradas. Como resultado dessa relação e aproximação do vínculo produtivo, os autores trazem a positiva experiência de empresas incubadoras, que nascem incubadas nas universidades, alojada sob sua jurisprudência até que se consolide no mercado e seja transferida para parques produtivos. Tal experiência se consolida nas universidades brasileiras desde os anos 1990 e tem sido importantes realizações entre conhecimento científico e mercado implementado por várias universidades no Brasil.

Como visto, no estudo já ressaltado por Back et al. (2016), há limites até para o consumo da tecnologia como produto, devido a ênfase limitada para aplicar, com a perpetuação de uma dependência histórica de inovação produtiva, enfatizada aqui nos frigoríficos.

Assim, ao tratar do consumo de tecnologias como são feitas pelos frigoríficos, ressaltou-se que elas não passam de uma mercadoria, vendida e adaptada à realidade conforme o gosto e o interesse do cliente. 
Embora Back et al. (2016) tratem equivocadamente o consumo de tecnologia como transferência, eles trazem dados interessantes sobre a relação de como se opera esse processo nos frigoríficos.

Hameri (1996) ao analisar o conceito de transferência tecnológica, já havia ressaltado que a verdadeira transferência de tecnologia requer muito mais que a assimilação dela, exige a plena cooperação entre academia e a indústria, em que a partir de tentativas, erros e acertos ocorre a implementação e inovação tecnológica. $\mathrm{O}$ autor se refere a uma relação intrínseca entre comunidade acadêmica e industrial como o principal elo da inovação tecnológica, com fator chave que é aprender a partir dessa interação, com perspectivas estabelecidas em conjunto para inovações científicas que se convertem em inovação industrial.

Os autores Back et al. (2016), ao estudarem uma empresa intermediária, observaram a hegemonia de tecnologias internacionais na reestruturação produtiva de frigoríficos, com destaque para a italiana. Para isso, no caso específico de um frigorífico, necessitava-se de uma rede organizada para difundir e comercializar a tecnologia que vem sendo comprada como um produto por esse ramo. Essa rede implica desde a venda, com as prestadoras de serviços que instalam a tecnologia no frigorífico e transmitem informações de como o trabalhador que vai executar a máquina deve proceder.

Na grande maioria das vezes, essas tecnologias são oriundas do mercado externo, porém os maiores fornecedores mundiais, tanto de equipamentos como de insumos, estão representados no país para fornecerem desde tecnologias sofisticadas até as mais simples, para o processamento de grandes ou de pequenas quantidades (BACK et al. 2016, p. 05).

Contudo, ao tratar do desenvolvimento científico no Brasil, e evidenciar como ele se reflete e repercute nas relações de trabalho, percebe-se que o país só inova tecnologicamente no sentido de alguns ramos estratégicos da economia para consumir tecnologia como um produto, deixando de ser responsável pela sua produção. Isso significa que não rompemos com a subordinação. Em tempos de reestruturação produtiva, percebe-se que no ramo de frigoríficos, além de continuar com extrema dependência tecnológica, dá-se também continuidade aos mecanismos fordistas/tayloristas, quando muito adequados à repetição de movimentos polivalentes.

$\mathrm{O}$ aspecto da dependência dessa reestruturação produtiva, a incorporação de mão de obra estrangeira no setor de maior inovação tecnológica em termos de consumo reproduz e dá continuidade ao trabalho repetitivo, monótono, e reproduz no Brasil uma tecnologia 
ultrapassada nos países onde elas se originaram, mantendo aqui, a adesão de práticas fordistas tayloristas.

Algumas das explicações dos motivos para as inovações produtivas em frigoríficos não romperem com o estilo fordista/taylorista que podem ser encontradas nos pressupostos teóricos de Marx (2004), quando este remete à manufatura, no início do capitalismo. Baseada no mesmo cerne, o princípio de cooperação foi uma das mais importantes tecnologias desenvolvidas no modo de produção capitalista e se constitui como uma de suas essências nas reestruturações produtivas atuais.

A cooperação fundada na divisão do trabalho adquire sua forma clássica na manufatura, sendo predominantemente capitalista, e se origina de dois modos com a concentração de muitos trabalhadores em uma mesma oficina sob o comando de um ou mais capitalista, e na produção comum da mesma mercadoria com o trabalho concomitante de todos os trabalhadores. Se antes havia um domínio de várias etapas produtivas a partir do trabalho cooperado, na manufatura com especialização de uma mesma atividade, essa organização é transferida para a grande indústria, com continuidade da não identificação entre trabalhador e o processo produtivo, de um tipo de mercadoria sem qualquer identificação do trabalhador com o que ele produziu.

Dessa forma, permite-se a ocupação de todos fazendo cada etapa da produção, em que a simultaneidade e a repetição se efetive no trabalho parcial. Essa é a base do trabalho em indústrias que aderem pela inovação tecnológica da produção ao estilo fordista/taylorista.

A manufatura, portanto, ora introduz a divisão do trabalho num processo de produção ou a aperfeiçoa, ora combina ofícios anteriormente distintos. Qualquer que seja entretanto, seu ponto de partida, seu resultado final é o mesmo: um mecanismo de produção cujos órgãos são seres humanos (MARX, 2004, p. 396).

O autor explica como a manufatura transforma a força de trabalho em um mecanismo de produção, em uma força produtiva. A divisão do trabalho na manufatura se dá pela decomposição na atividade do artesão nas diversas operações que a compõem. Complexa ou simples, a operação continua manual, dependendo da força, da habilidade, rapidez e segurança do trabalhador individual para manejar seu instrumento.

A habilidade profissional do artesão, que absorveu uma função parcial, e sua força de trabalho se transformam para sempre em um órgão dessa função parcial. Realizar a mesma função leva o trabalhador a automatizar seu corpo pela especialização, dado a repetição. $O$ 
capitalista então se apropria da habilidade de cada artesão e na especialização a potencializa, para fazer somente uma, com maior agilidade.

Essa mesma lógica se transfere para as atividades reprodutivas no século XXI, que tem no trabalho simplificado a ampliação do ritmo e movimento com maior número de trabalhadores produzindo simultaneamente o mesmo tipo de mercadoria, ou a diversificação dela, sem que altere a parcialização das atividades feitas pelo trabalhador. Esse tipo de trabalho, nos moldes do que ocorre em frigoríficos, é tão banal que qualquer trabalhador pode executá-lo.

O mecanismo vivo da manufatura é a constituição do trabalhador coletivo que realiza trabalhos parciais, limitados. A manufatura produz realmente a virtuosidade do trabalhador mutilado, levada sistematicamente ao extremo, dentro da oficina, a especialização natural dos ofícios que encontram na sociedade.

Se foi dito anteriormente que o capital cria mecanismos para disfarçar as relações de exploração. No contexto contemporâneo eles são fundamentais para ocultar a existência da divisão internacional do trabalho, que se sustenta na desigualdade da produção de ciência e tecnologia entre países dominantes e dominados.

Já foi estabelecida igualmente uma discussão acerca das transformações produtivas que vão desde a revolução industrial até a hegemonia do fordismo/taylorismo e seus efeitos sob a imigração, considerando como já descrito que a migração é um fenômeno intrínseco à subjetividade humana e percorre os diferentes contextos históricos. No entanto, será a partir da era da catástrofe que ela se desdobra em maiores números, acompanhando as transformações produtivas que impactam diretamente sobre ela. 


\section{CAPÍTULO II}

\section{HAITIANOS NO OESTE DO PARANÁ: UMA COMPREENSÃO DO PROCESSO MIGRATÓRIO E SUA VINCULAÇÃO COM OS FRIGORÍFICOS}

\subsection{Estado e migrações transnacionais}

O Capítulo I procurou dar a dimensão dos impactos da globalização no processo migratório, cujas transformações nas relações de trabalho, precarização e substituição do homem pela máquina tiveram na criminalização da migração um importante mecanismo para ocultar as contradições engendradas pelo próprio sistema capitalista. No entanto, entender porque a mobilidade no século XXI ocupa o centro das atenções, sejam elas midiáticas ou de agendas políticas, é compreensível à medida que há cada vez mais uma sociedade produtora de desigualdades sociais, desemprego com intensificação das contradições sociais. $O$ imigrante surge no centro do debate, quando recai sobre ele a responsabilidade pelas mazelas sociais, atribuídos pelo simples fato de migrar, fato concreto que oculta as contradições geradas pela dinâmica da acumulação de capital.

Assim, o sistema capitalista nega a mobilidade quando ela não lhe soa como necessária, haja vista que, historicamente, tem se aproveitado dela para ampliar as relações de extração de mais valia. Ainda no Capítulo I, viu-se como esse fenômeno se deu, sobretudo na discussão das migrações desde a Primeira Guerra Mundial, a inserção dos imigrantes no sistema fordista/taylorista e a consequente difusão dessa racionalização do trabalho para outras partes do mundo, como nos mostrou Harvey (1999).

Já este segundo capítulo pretende tecer análises de como a globalização e as transformações no mundo do trabalho dinamizam as migrações de haitianos para o Oeste do Paraná. Para isso, estabelece uma discussão da migração mais recente marcada pelo grande fluxo de haitianos e sua vinculação com a indústria de proteínas, ao passo que delineia os meandros e aspectos históricos da imigração de haitianos no Brasil e na região Oeste do Paraná.

Por outro lado, faz também considerações sobre o viés histórico do desenvolvimento das indústrias de proteínas, com ênfase na discussão de frigoríficos. $\mathrm{Na}$ região de Cascavel, são eles os que mais incorporam mão de obra de haitianos e sua vinculação ao mundo global, seja pela importação de tecnologia ou pela projeção internacional, com investimentos estatais que fizeram desse ramo um dos maiores privilegiados em investimentos financiados pelo Banco Nacional do Desenvolvimento (BNDES) e fundos de pensões. 
Dessa forma, se destaca nesse perímetro a Coopavel, um importante frigorífico hegemônico na incorporação dessa mão de obra que lhe serve como substitutiva em períodos de pujança econômica, bem como viabiliza a formação de um favorável exército industrial de reservas, acionado quando necessário. Por fim analisaremos as principais políticas de migração estatais brasileiras para o acolhimento, integração e asilo dos imigrantes, com ênfase na Resolução normativa 97 de 2012, que outorga o visto humanitário para haitiano.

Ao discutir os investimentos estatais em sistemas privados via BNDES em frigoríficos, tomando a Coopavel como concretização desse processo apresenta-se concomitantemente a ausência do Estado e as restritas políticas de migração, buscando analisar a captura do Estado, a perda de soberania que se volta para o mercado em detrimento das políticas migratórias.

Nesse contexto de ausência estatal, contraditoriamente foi aprovada no Brasil a Nova Lei de Migração, sancionada em novembro de 2017, também contemplada como análise no presente capítulo, pois ela poderá delinear políticas migratórias futuras, o que conduziu a analisar em que medida ela garante a construção de políticas de imigração, bem como os direitos dos imigrantes no Brasil.

Com o objetivo de vincular análises macro e microssociológicas, o capítulo parte do conceito da existência de um sistema unificado de técnicas que permitem ações igualmente globais, a exploração da mais valia em âmbito internacional, com a incorporação de estrangeiros dentro ou fora dos países das corporações exploradoras.

Nessa perspectiva, há mundialmente um único motor que é a mais valia universal ou mundial, explorada por intermédio das empresas mundiais. Esse motor único de acordo com Santos (2004) só é possível devido à internacionalização, com mundialização do produto, do crédito, do dinheiro, do consumo e da informação. Esse sistema de técnica unificado, Santos (2004) denomina de motor único, considerado como a ação do imperialismo que impulsiona dois processos simultâneos como a máquina e o homem que a opera conforme o controle dos ritmos e movimentos.

Quando se trata da extração de maiores taxas de mais valia, tudo é medido e analisado pelo capital. Dessa forma, conforme Santos (2004), não são todos os lugares os desejados para a produção da mais valia, por isso há uma valorização de diferentes localizações, ou seja, "Não é qualquer lugar que interessa a tal e qual firma. A cognoscibilidade do planeta constitui um dado essencial à operação das empresas e à produção do sistema histórico atual" (SANTOS, 2004, p. 33). 
O Haiti possui riquezas naturais, no entanto sua localização geográfica estratégica desperta interesses de grandes potências sobre o país, já que deter o controle sobre ele, viabiliza garantir o domínio estratégico das rotas marítimas caribenhas. No entanto, esse controle não tem sido estendido no que se refere à industrialização do país, pois conforme Eberhardt (2017) ela é incipiente, além de se constituir um dado relevante para perceber que esse interesse centra-se no seu controle político.

A instabilidade política que historicamente tem marcado o Haiti não se dissocia do protagonismo desse povo que empreendeu os primeiros sinais da rebeldia negra mundial, acrescido da instabilidade climática com ameaças frequentes e episódios de intempéries, sendo esses alguns motivadores do desinteresse do capital em ampliar no interior desse país o desenvolvimento industrial.

Não industrializar e explorar riquezas naturais e mão de obra no interior do país não significa ausência da exploração desses recursos. As migrações dinamizam historicamente esse processo, cuja mão de obra é aproveitada via processo emigratório, geralmente mais barato, pois esses trabalhadores devido à condição de imigrantes em outros países geralmente estão expostos às formas mais degradantes e desvalorizadas da força de trabalho.

Quanto à exploração de matéria prima, faz-se pelo baixo valor agregado das mercadorias que produz, sendo essas vinculadas diretamente na produção e extração dos produtos de origem agrícola, a qual exige trabalho manual e, por sua vez, desvalorizado. Essa realidade do Haiti soma-se à de outros países na mesma condição que os mantém como economias periféricas, limitadas a produção de matéria prima e mão de obra barata, porém intensificadas no Haiti, quando a produção econômica se deriva quase exclusivamente da agricultura. Assim, as grandes potências tem se aproveitado da mão de obra barata dos haitianos dentro e fora do país, para a maior extração de mais valia.

Essas desigualdades se manifestam e se evidenciam como primeiro, segundo e terceiro mundo, norte e sul, centro e periferia, países desenvolvidos e subdesenvolvidos, países viáveis e não viáveis, pequenos países e grandes empresas, terceiro mundismo, países não alinhados, grupos étnicos raciais, arabismo, africanismo, latino-americanismo, protestantismos, operários das mais diferentes categorias. Essas significações possuem um determinado estigma e ideologia, reproduzindo padrões e valores socioculturais, signos e símbolos, estereótipos e ideologias. Todos esses aspectos constituem uma parte fundamental do tecido da sociabilidade burguesa, em âmbito local, regional, nacional, continental e mundial.

No caso do Haiti, fica explícita a maior dependência ao capital internacional, representado pelos interesses das grandes potências mundiais, quando o país é colocado na 
esfera internacional ou no sistema global, via mobilidade humana, por meio das migrações. $\mathrm{O}$ contexto histórico do Haiti, de primeira república negra a se libertar do domínio da colonização, propiciou a independência do país. Mas isso levou à coerção das grandes potências mundiais, que inviabilizaram ou cooptaram a execução de todas as fases de dominação das relações capitalistas de produção.

Ao analisar as economias periféricas, Fernandes (1975) ressalta que elas se constituem por quatro formas ou fases de dominações externas, quais sejam: colonização, relações de dependência da burguesia nacional aos interesses internacionais, revolução industrial, e recolonização via exploração de matérias-primas e mão de obra por multinacionais.

Conforme o autor, países como Argentina, Brasil, Uruguai, Chile e México desenvolveram todas as formas de dominação externa. Outros, como Haiti, El Salvador, Bolívia, Honduras, Nicarágua, Guatemala, República Dominicana, Paraguai e Peru, limitaram-se às duas primeiras formas, mantendo quase inalterada a estrutura produtiva e econômica, sob os moldes coloniais (FERNANDES, 1975).

A mobilidade haitiana carece ser compreendida como um desdobramento das migrações transnacionais, que, quando presente em outros países, passam a imprimir sobre seus territórios seja de trânsito, entrada ou saída de milhares de migrantes que compreendem a nova era das migrações, com envolvimento do maior número de pessoas e países.

Conforme Baeninger (2016), as respostas estatais são efetuadas a partir da metodologia nacionalista, cujas políticas se pautam na retrógrada ideia de percepção do imigrante como ameaça à segurança nacional. Nessa perspectiva, será visto, ao final do capítulo, o baixo nível dos discursos de alguns políticos que se posicionaram contrários a aprovação da Nova Lei de Migração no Brasil vigente desde novembro de 2017, cujas críticas estariam no relaxamento das fronteiras, quando o Estado brasileiro deveria intensificá-las seguindo a lógica do controle sobre elas, como tem sido feito em âmbito mundial.

As políticas estatais são direcionadas a atender a demanda do capital quando fecham as fronteiras, por meio de dispositivos jurídicos e legais, com a intenção de conter os fluxos migratórios. Essas políticas incorporam diferentes espaços e lugares, viabilizados primordialmente pela globalização, como tratado anteriormente, através da mobilização do capital, de pessoas facilitadas pela revolução técnico-científica e a produção de imagens. Elas envolvem não apenas o local de partida, mas todos os espaços utilizados pelos migrantes, conhecidos como rotas migratórias, incluindo diversos territórios, que são os países de origem, trânsito e chegada. 
Nesse âmbito, as políticas migratórias compreendem o desenvolvimento do capital e possuem relações intrínsecas a ele, o que requer a compreensão das ações do Estado nos diferentes estágios do capitalismo.

Hall (2010) denomina a era da globalização de modernidade tardia, termo utilizado para definir a nova forma de readequação do capital no contexto de crise cíclica do sistema após os anos 1970. Essa reorganização caracteriza o que o autor concebe como sociedade de mudança, o que diferencia a sociedade moderna da global. $\mathrm{O}$ autor enfatiza a dialética desse período e os impactos produzidos sobre a identidade cultural. Ainda neste sentido, Harvey (1992) ressalta que a transformação produtiva acarreta mudanças econômicas, mas, também, sociais, políticas, culturais e espaciais.

Patarra e Baeninger (2004) investigaram essas transformações no Brasil a partir dos efeitos dos blocos econômicos como o Mercosul, sendo essa uma estratégia para fazer frente a perversidade dos efeitos da mobilidade e deslocamentos de populações emergentes. Essas autoras também delineiam os anos 1980 como o marco das transformações estruturais do capital na América Latina e em âmbito internacional, com intenso efeito nas mudanças ou o que foi comumente denominado de reestruturação produtiva com implicações em novas mobilidades do capital, e da população em diferentes partes do mundo.

Os novos fluxos demandam tratamento diferenciado para suas demandas, uma vez que o cenário da transformação global requer o entendimento e reconhecimento das migrações internacionais. Por sua vez, esse reconhecimento impulsiona os direitos dos migrantes com vistas a superar o conflitivo papel dos Estados Nacionais e das políticas sociais, as quais têm sido reduzidas ao controle das fronteiras, uma vez que os imigrantes são considerados como ameaça nacional.

Ao tratar sobre os atuais movimentos migratórios, Patarra e Baeninger (2004) inferem que esses movimentos exigem uma compreensão da reestruturação territorial que está intrinsicamente relacionada à reestruturação econômica produtiva delineada em escala global. Assim, uma série de fatores envolvem essas transformações como a revolução tecnológica, a nova configuração da hierarquia urbana e industrial, a configuração das redes de lugares e lugares de redes, a diversidade e a intensidade dos movimentos populacionais que definem e redefinem a transnacionalização do espaço. Esse contexto caracteriza as migrações internacionais, que delineia a especificidade de cada movimento migratório e seus impactos diferenciados, sobretudo, no nível local, do que no volume de quantos imigrantes chegam às sociedades de destino. 
Seguindo a lógica das migrações no contexto da sociedade global, a América Latina não se difere dela. Conforme Patarra e Baeninger (2004), as migrações internacionais na América Latina até os anos 1980 foram marcadas por três grandes tendências, foram elas: a migração ultramar, com deslocamento principal de imigrantes oriundos da Europa, as migrações intrarregionais, por meio da mobilidade entre países latino-americanos, sobretudo nos anos 1970 até os anos 1990, e a última delineada com maior intensidade a partir dos anos 1980 por meio da emigração de brasileiros para outros países, considerada migração do Sul para o Norte. Essa última etapa, conforme caracterizaram as autoras, desencadeou a perda de trabalhadores qualificados da América Latina, fenômeno conhecido como "brain drain", ou fuga de cérebro (PATARRA E BAENINGER, 2004; EBERHARDT, 2017).

Embora Patarra e Baeninger (2004) façam nesse estudo uma análise até os anos 2000, poderia se acrescentar o atual contexto dos grandes fluxos migratórios pós ditadura militar ou contexto de abertura democrática, com ênfase nas migrações entre países periféricos latinoamericanos e africanos, com acentuado destaque para a questão étnica, racial e econômica, com migrantes descendentes indígenas, negros e pobres. Isso se evidencia, sobretudo, nas migrações dos grandes fluxos para o Brasil de bolivianos, africanos, haitianos e mais recentemente venezuelanos.

A chegada desses grandes fluxos no país marca, definitivamente, o processo migratório no contexto da sociedade global e reestruturação produtiva, cujos países de origem têm em comum um desenvolvimento industrial pouco significativo, espaço privilegiado para fazer deles, imigrantes recém-chegados, mão de obra disponível numa sociedade capitalista dependente, marcada por baixos salários e plantas industriais que se apropriam do toyotismo para precarizar o trabalho sem superar as condições repetitivas e monótonas da produção fordista/taylorista.

A presença dos grandes fluxos migratórios nos anos 1980 levaram à incorporação da imigração irregular e o tráfico de imigrantes na agenda política dos países receptores e das organizações internacionais a partir dos anos 1990. As políticas de restrição de imigrantes indocumentados, por meio de limitação de entrada e instabilidade jurídica, não reduziram seus números, apenas ampliaram a instabilidade e insegurança daqueles que se movem. A imigração irregular é considerada também, produto das políticas restritivas de entrada, como também da instabilidade jurídica, a qual muitos países submetem imigrantes.

El uso de la irregularidad en el discurso público tiene un importante valor simbólico, no sólo porque permite segmentar internamente al colectivo, sino porque se convierte en un vehículo que canaliza muchas de las ansiedades de 
nuestras sociedades: el temor al desempleo, a la inseguridad, el fin de la pretendida identidade nacional, etc (SALA, 2005, p. 47).

Sala (2005) ressalta que as análises sobre a evolução histórica dos fluxos migratórios nas sociedades ocidentais revelam que a relação entre desenvolvimento econômico e as necessidades do mercado laboral moldaram as políticas estatais desde sua origem. Associado a isso, desde o início do século XX, muitos colonos requisitaram uma mão de obra que correspondesse a determinada concepção de natureza, comunidade nacional e homogeneidade cultural e racial, que se configuram nas políticas de imigração racialmente seletivas.

Citando como exemplo os EUA, Sala (2005) enfatiza que as fronteiras do país sempre foram instrumentos de seleção de imigrantes. No século XIX, diversas leis restringiam determinados imigrantes, como presidiários, pobres, portadores de enfermidades infecciosas e antigos escravos. Nesse contexto, o controle social e econômico eram os principais delimitadores de quem entrava na fronteira. As políticas de seleção racial tiveram peso nos principais países de imigração no século XIX e na primeira década do século XX. Estudos, principalmente sobre os EUA, indicavam ainda a repercussão dessa seletividade na democracia e na política, como uma noção ideológica racial do corpo político.

A autora mostra como a construção do Estado Nacional nos séculos XVI e XVII conduziu a transformação da sociedade internacional em uma rede de Estados soberanos rivais. Da mesma forma, converteu os fluxos populacionais em fenômenos políticos, o que implica o cruzamento das fronteiras estatais, ou a transferência de pessoas de uma jurisdição estatal para outra. Isso altera, também, o sentimento de identificação e pertencimento em cada comunidade social e política.

Estudos apontam as políticas de migração internacional como um mero controle da população, que tem como característica garantir a "homogeneidade cultural". Essa homogeneidade considera o Estado como unidade que centraliza a autoridade sobre um determinado território ou população, conforme discutido no primeiro Capítulo.

Desde la constitución de los Estados-Nación modernos há tenido una gran importancia de consideración de ciertos extranjeros como racial o culturalmente indeseables para formar parte del país de acogida, de su sociedad y de su comunidad nacional y política. Por eso, la entrada de migrantes de ciertas nacionalidades fue prohibida o estrictamente controlada (SALA, 2005, p. 67). 
Dessa forma, o conceito de imigrante indesejado, entendido como aquele que não faz parte da homogeneidade que caracteriza quem é o povo do Estado-nação, não é um conceito estático.

Até metade do século XX não se considerou como positiva a pluralidade de pessoas que passariam a fazer parte desse Estado na condição de imigrantes. Ao contrário, foi potencializada a ideia de que ao estrangeiro, quando adentrava as fronteiras, restava-lhe apenas a adaptação aos costumes e formas de vida da sociedade de acolhida, nada mais que assimilação dessa cultura. A seleção de imigrantes buscava em geral o perfil branco, o que promoveu o recrutamento de europeus, principalmente dos países do Centro e Norte do continente.

A imigração é um fenômeno que sempre permeou a humanidade, sendo uma herança dos ancestrais, como expressou Bauman (2017) ao afirmar a inexistência de vida humana sem que esteja vinculada a algum processo migratório. Da mesma forma, Hall (2010) considera não haver qualquer país europeu que tenha se constituído de um único povo, o que faz cair por terra esse mito fundacional. Ele é rechaçado também por Sassen (2013), que ao estudar a migração na Europa entende as migrações laborais, internacionais e inter-regionais como um componente estratégico para a urbanização e industrialização daquele continente.

É nesse contexto de insegurança, de desmistificação do capital, quando nem ele consegue controlar seus mitos ou ideologias, que se ascende à discussão das migrações como um novo fenômeno, que passa a fazer parte da agenda dos países como um mecanismo de controle e cooptação.

A insegurança é posta na ordem do dia, não somente como a concorrência entre os próprios trabalhadores e o sistema produtivo. Ela é intensificada pelos "invasores imigrantes", traduzida no medo da classe média de se tornar precariada frente às instabilidades estruturais não resolvidas e agudizadas pelo capital.

O termo precariado foi usado pela primeira vez nos anos 1980, por sociólogos franceses, para se referir a trabalhadores sazonais ou temporários. Standing (2015) usa outro conceito, mas argumenta que a mão de obra temporária é um aspecto central do precariado. Há uma variação de termos em diferentes países, como a Itália, que classifica como precariado os trabalhadores que cumprem tarefas casuais e de baixa renda. Na Alemanha, eles são entendidos como os trabalhadores temporários e desempregados, destituídos de esperança de integração social, o que aproxima da ideia marxista de lumpensproletariat, termo que não é usado por Stanting (2015). Já no Japão, o termo faz referência aos trabalhadores pobres. 
Para Standing (2015), é precariado todo trabalhador que não tem acesso às seis garantias relacionadas ao trabalho, definidas após a Segunda Guerra Mundial pela agenda industrial, constituída por social democratas, partidos trabalhistas e sindicatos. São as seis garantias: mercado de trabalho, vínculo empregatício, segurança no emprego, reprodução de habilidade, segurança de renda e representação. A nova estrutura do capital delineada pela globalização já não permite mais essa segurança, pois hegemonicamente a liofilização dada com a substituição do trabalho vivo pelo morto, faz da máquina desde os primórdios da revolução industrial a plena substituição do homem pela máquina, potencializada com o desenvolvimento das forças produtivas.

Se há uma redução no número de trabalhadores com as garantias de segurança de trabalho, há evidências concretas de que inovação produtiva amplia esses dados, ao mesmo tempo que precariza as relações de trabalho, o que atinge diretamente os trabalhadores imigrantes, os quais culturalmente são vistos como trabalhadores temporários, que por outro lado, são os primeiros a serem cortados do processo produtivo em situações de crise.

O toyotismo foi adequado para justificar sob o auspício da inovação produtiva o que o capital torna legítimo e natural: o descarte de trabalhadores, sendo mais eficiente para convencer a sociedade de que as fronteiras devem ser fechadas devido a própria inovação tecnológica em benefício da preferência dos nacionais por meio da politização da imigração.

Essa ideologia faz do desemprego uma boa alternativa para os países justificarem a não aceitação dos imigrantes ou o fechamento das fronteiras para eles, como se o sistema não os produzisse. A relação entre imigração e desemprego vem sendo recorrentemente usada para justificar a desumanização com que tem sido tratados milhares de imigrantes no mundo, fora de seus países de origem.

Ao tratar do conceito de politização da imigração, Sala (2005) e Arango et al. (2007) ressaltam ser ela uma estratégia de partidos conservadores e de ultra-direita para converter a imigração em ameaça social, reforçando sentimentos de insegurança baseados na concorrência de trabalho e na violência extrema, como atos terroristas e desconstrução da "homogeneidade cultural".

O Município de Cascavel, assim como o Brasil e todo o mundo, reproduz a ideologia da crise migratória, difundida especialmente pelos setores midiáticos, que exibem a presença de haitiano no Município como manifestação dessa "crise migratória" enfatizada na presença massiva representada pelo termo "invasão haitiana". 


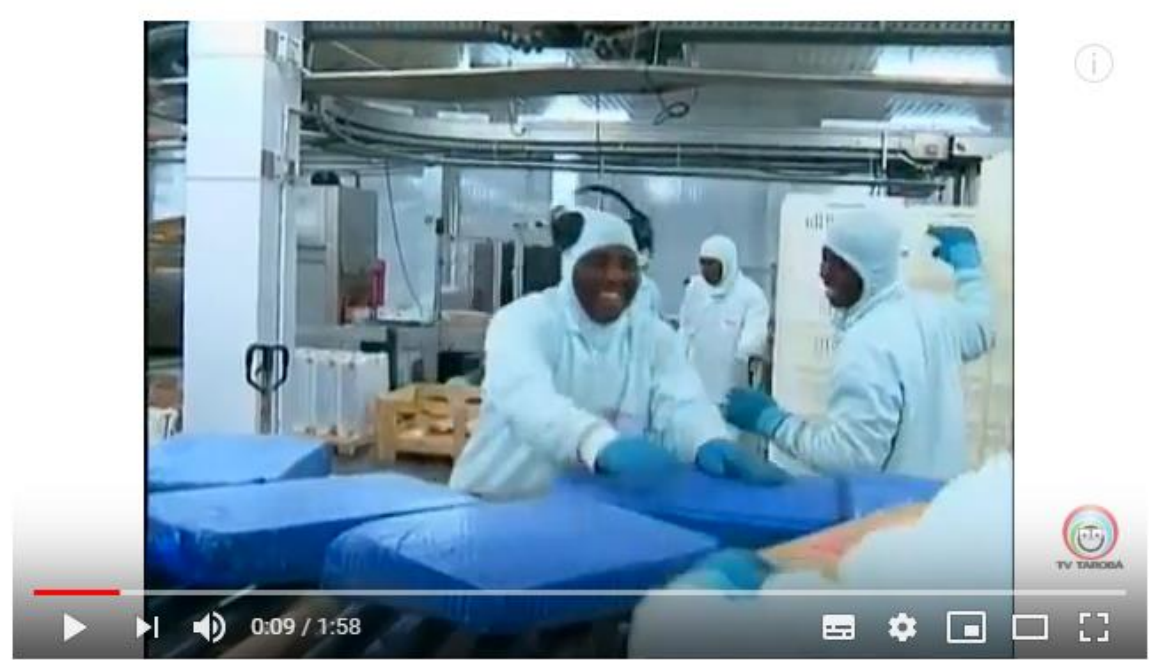

Haitianos invadem mercado de trabalho em cooperativas de Cascavel $(17 / 01 / 14)$

Foto 01 - Haitianos trabalhando em frigoríficos - Fonte: (TV TAROBÁ - CASCAVEL, 2014).

O discurso de "crise migratória" atua de forma material e eficaz para baixar os salários, ao passo que encontra mão de obra abundante articulada ao interesse do capital, fazendo dela, quando dispensável ao sistema produtivo, um problema moral e ideológico.

No Brasil, essa ideologia associa o estrangeiro a uma ameaça, considerando que ele "rouba postos de trabalho", além de disseminar doenças. Essa situação foi vivida por vários migrantes haitianos em Cascavel, que foram profundamente rechaçados e atacados por serem associados a africanos e à transmissão do vírus Ebola. Geradora de um pânico pelo surto do que se cogitou ser o primeiro caso da doença no Brasil, e concomitantemente intensificou situações de preconceito racial e xenofobia já existentes no Município. Isso foi identificado em várias reportagens divulgadas pela mídia impressa e televisiva (MARTINS M., 2014; CAMBRICOLI, 2014) dentre outras. A expressão das notícias remetem a situações de preconceito como ressaltado abaixo:

CASCAVEL - Há um mês no Brasil vindo da Guiné, o biólogo Abdoulaye Telly Diallo, de 26 anos, passou a enfrentar nos últimos dias ofensas e olhares de desaprovação nas ruas de Cascavel. Desde que seu compatriota Souleymane Bah, de 47 anos, foi isolado com a suspeita de Ebola, os imigrantes africanos e haitianos que vivem na cidade paranaense passaram a ser hostilizados. A gente vai a uma lanchonete, senta em uma mesa, as pessoas mudam de lugar para ficar longe. Estamos passando na rua e sempre tem alguém que diz 'vão embora daqui, parem de trazer doença para o meu País'." Diallo diz ter tido um emprego negado na sexta-feira, 10, em uma empresa frigorífica da cidade ao informar que vinha da Guiné. "A gente está 
na expectativa de que saia o resultado do segundo teste do Bah, para que possamos ter oportunidades aqui." (CAMBRICOLI, 2014, p.1).

As atitudes de preconceito e rejeição não sessam e os ataques aos haitianos vão sendo feitos no tempo presente, já que se trata de um objeto de pesquisa desse tempo que se transforma na medida em que vai se delineando a presença desses imigrantes no Oeste paranaense, alterando o próprio objeto de pesquisa e envolvendo essa dinâmica dialética.

Conforme Assis e Magalhães (2016), a ideia que se constrói do imigrante haitiano está relacionada a uma histórica política migratória, pautada no branqueamento da população e na sua aproximação com a cultura europeia. O perfil desse imigrante era europeu, desejado e selecionado pelo Estado com vistas a branquear e europeizar o Brasil. Os autores enfatizam a diferença no tratamento do Estado, quando promovia políticas de imigração para esses imigrantes selecionados, enquanto as negava para os negros, uma restrição que também pode ser entendida como uma política de fechamento de fronteiras.

Um exemplo de promoção dos imigrantes selecionados e indesejados no Brasil foi a política de financiamento para os japoneses com a migração a partir de 1908, após amplo debate sobre as dificuldades de assimilação. Entretanto, no mesmo período, imigrantes negros, oriundos dos Estados Unidos, eram impedidos de entrar no país.

Além disso, os autores afirmam que, embora existissem políticas de seleção do imigrante desejado e impedimento do indesejado em adentrar o país, foi somente após os anos 1930 que o Brasil implementou as primeiras medidas restritivas e o período que fechou o ciclo de substituição de mão de obra escrava iniciado desde 1870 , com a chegada de mais de cinco milhões de estrangeiros, como ressaltam os autores:

As primeiras medidas restritivas à migração foram publicadas a partir de 1930, em um contexto marcado por uma crise capitalista de abrangência mundial e sua repercussão no Brasil através da crise da economia cafeeira. Na Constituição Federal de 1934, foram estabelecidas cotas para imigrantes, e o mesmo aconteceu também em 1937, com o Estado Novo (ASSIS e MAGALHAES, 2016, p. 212).

Essas medidas restritivas foram novamente estabelecidas durante a Segunda Guerra Mundial, principalmente em relação a refugiados e perseguidos. Então, pela primeira vez, foram determinadas cotas para a entrada de imigrantes no país, as quais fizeram com que a migração tivesse uma desaceleração progressiva. 
Além da institucionalização das cotas, os anos pós-guerra paralisaram as políticas migratórias para a colonização, com posterior abertura das fronteiras para trabalhadores qualificados e determinados setores do desenvolvimento econômico. Logo, percebe-se a compreensão da imigração como um problema moral, relacionando-se com a abertura das fronteiras para o imigrante desejado, e o seu fechamento, quando o imigrante é indesejado e não requerido pelo sistema.

Bauman (1991) chama de espetáculo da desgraça o sensacionalismo da mídia que reforça indiferença ética, rotineira e cotidiana, com a produção de imagem do que vem de fora como algo ameaçador. Não há conexões entre os fatos apresentados pela mídia e as notícias veiculadas, apenas o sensacionalismo das informações. O desejo dos famintos em procurar lugar onde haja comida é tido como irracional; há uma correção ética que coloca o desânimo diante da migração em massa dos pobres. Dessa maneira, é mais fácil ocultar a liberdade que é dada ao capital e à máxima globalização do mundo.

A imagem de desumanidade que dominam as terras onde vivem possíveis migrantes vem portanto a calhar. Elas reforçam a determinação que não dispõem de argumentos éticos e racionais a apoiá-la. Ajudam os habitantes locais a permanecerem locais, ao mesmo tempo que permitem aos globais viajar com a consciência limpa (BAUMAN, 1991, p. 84).

Baeninger et al. (2016) afirmam que o Brasil recebeu anteriormente fluxos migratórios. Porém, eram migrantes desejados e subsidiados. A partir dos anos 1980, os grandes fluxos migratórios internacionais ou novos contingentes humanos passaram a ter maior expressão, devido à diferença da característica cultural e econômica daqueles que vieram no final do século XIX. Ao contrário de europeus, eles são latino-americanos, africanos, desprovidos de qualificação e com condição econômica vulnerável.

Couto (2016) adverte sobre a ênfase midiática para a construção da imagem do imigrante indesejado, que carrega o estereótipo da pobreza para além da cor da pele negra. Negro e pobre, o haitiano é concebido como o sujeito ilegal. A mídia não o trata como proveniente de uma terra arrasada pela natureza e pela ação humana. Ele é, na maioria das vezes, considerado ilegal, e "[...] os jornais tendem criar um cenário de invasão haitiana com ou sem intenção" (COUTO, 2016, p 171). Para a autora, há uma percepção pejorativa dos amazonenses em relação aos haitianos, com certo grau de intolerância, principalmente quando percebem esses imigrantes como concorrentes no mercado de trabalho. 
Ao evidenciar comentários nas redes sociais, com vistas a identificar a representação dos haitianos para os brasileiros, a autora ainda chega à conclusão de que:

Questões sobre postos de trabalho, doenças, importação da miséria, são as justificativas mais comuns para a rejeição e essa posição é reforçada pelas autoridades estaduais, municipais, e empresários que ao contratar os haitianos dizem que no Brasil não é fácil conseguir alguém para trabalhar (COUTO, 2016, p. 176).

Couto (2016) infere que a mídia não expõe a que tipo de condição de trabalho estão submetidos os trabalhadores, sejam eles nacionais ou estrangeiros. Muitas vezes, a legislação trabalhista não é cumprida, colocando os trabalhadores em situação análoga à escravidão. O Estado se revela na sua plena incapacidade, pois permite em seu território que empresas explorem e descumpram legislações, atuando ilegalmente frente à exploração da força de trabalho, seja ela nacional ou internacional. Isso acaba reforçando a tese que tenta alcunhar trabalhadores brasileiros como vagabundos e os haitianos como os responsáveis por uma das contradições do capital, o desemprego.

A imigração perfaz a história do povo brasileiro. Ribeiro (1995) ressalta que esse povo se constitui como novo, diferente de suas matrizes formadoras. Logo, o brasileiro não se configura como puramente indígena autóctone do Brasil, africano, tampouco como branco descendente de europeu. O brasileiro é a confluência desses três povos, que juntos, formam uma nova matriz étnica e racial.

A miscigenação se relaciona com a imigração, iniciada com a colonização, e continuada com a escravidão africana, e é um processo que perfaz toda a história do país, até o presente momento, no início do século XXI. Esta pesquisa tem como propósito explorar esse processo contínuo da formação cultural brasileira, que perpassa pela imigração. A partir de 2010, o fluxo imigratório de haitianos veio a compor a diversidade cultural já existente no Brasil, na perspectiva de delinear a presença deles no país. Passaremos a compreender um pouco mais as relações e o contexto que fizeram desse país uma nova rota migratória para os haitianos.

\subsubsection{O Brasil como nova rota migratória haitiana}

A compreensão sobre a imigração haitiana no Brasil exige conhecer o contexto geográfico e histórico do Haiti, com nome de origem taíno e arawak, que significa terras 
altas. Suas características geográficas levaram, anteriormente, à denominação de Toyo e Quiesqueiia. Em 1492, sob o domínio dos Espanhóis, foi batizado de La Hispaniola. Os primeiros africanos chegaram ao Haiti no século XV na condição de escravos, como alternativa para substituir a mão de obra indígena. Os primeiros franceses adentraram o país nos anos 1629, e se estabeleceram na ilha de La Tortuga, no norte do Haiti (COUTO, 2016).

No século XV, a luta entre espanhóis e franceses ensejou o amplo domínio da França sobre a região. Além dos escravos, foram trazidos para o Haiti os cidadãos franceses endividados, denominados de engagés, que desempenhavam o trabalho baseado no cultivo agrícola, sendo esse um dos meios para quitarem suas dívidas. Em 1695, por meio do tratado de Ryswick, foi desmembrada a parte ocidental do Haiti, com a divisão da ilha em duas partes: República Dominicana e Haiti. No início do século XVII, especificamente em 1804, o levante popular fez do país a primeira república negra independente da América (COUTO, 2016).

A diversidade étnica de diferentes povos, africanos, espanhóis e franceses, levou à composição do creole, que emergiu como língua nacional, ao passo que a língua francesa não conseguiu impor sua hegemonia como linguagem oficial. A língua é uma das características da formação da identidade haitiana e o país teve o reconhecimento bilíngue em 1961.

Em 2010, a migração de haitianos para o Brasil foi significativa. Nesse ano, a população haitiana era estimada em 9.203.083 habitantes, a maior parte concentrada na capital, Porto Príncipe (COUTO, 2016). Ao contrário dos trabalhadores caribenhos, destinados ao Brasil para o trabalho na estrada de ferro Madeira-Mamoré, os haitianos que aqui chegaram solicitavam o visto de refugiados. Posteriormente, a Resolução Normativa ${ }^{\circ}$ 97 aprovada como uma ação de enfrentamento do Estado a esse grande fluxo, concedeu a eles o visto humanitário. Dessa forma, essa foi uma alternativa para resolver o impasse frente a esse grande contingente de imigrantes, que, de forma clandestina, percorriam a rota migratória que ia da República Dominicana, Panamá, Equador, Peru, até chegar ao Brasil.

Vinente (2016) aponta 2010 como o marco da migração haitiana para o Brasil, iniciado com o terremoto ocorrido naquele ano. Esse sismo atingiu especialmente a região Sudoeste do país, que possui a maior densidade demográfica e onde está localizada a maioria das instituições públicas, como universidades, repartições e serviços públicos. Cidades como Port-au-Prince, Pettionville e Jacmel foram completamente devastadas após o terremoto, que atingiu aproximadamente $15 \%$ da população.

A pouca infraestrutura do país foi ainda mais abalada pelo terremoto. Além disso, uma série de fatores fez do Haiti um dos países mais pobres da América Latina, como: graves 
problemas sociais; instabilidade política, decorrente da ocupação de quase vinte anos pelos EUA (1915-1934) e de sucessivos golpes de Estado; devastação ambiental provocada por lavouras predatórias, e catástrofes ambientais, como terremotos e furacões;

Até o final de 2010, poucas informações eram divulgadas do Haiti no Brasil, essas se restringiam ao resultado das experiências da operação MINUSTAH, comandada pelo exército brasileiro desde 2004 .

Conforme Vinente,

MINUSTAH é a sigla para Mission des Nations Unies pour la Stabilisation en Haiti (Missão das Nações Unidas para a estabilização no Haiti), missão de paz criada pelo Conselho de Segurança das Nações Unidas em 30 de abril de 2004 para restaurar a ordem no período subsequente à deposição do presidente Jean- Bertrand Aristide envolvendo tropas da Argentina, Benim, Bolívia, Brasil, Chile, Canadá, Croácia, Equador, Espanha, França, Guatemala, Jordânia, Marrocos, Nepal, Paraguai, Peru, Filipinas, Sri Lanka, Estados Unidos e Uruguai (VINENTE, 2016, p. 262).

Essa operação fora constituída pela incorporação de mais de vinte países, além do Brasil, que teve até 2017 a responsabilidade de dirigi-la, retirando suas últimas tropas em outubro desse mesmo ano.

Quando os imigrantes haitianos chegavam no Brasil, em 2010, uma das primeiras entidades que os recebiam era a Pastoral do Migrante, instituição vinculada à Igreja Católica. Além da Pastoral, existe também uma rede de organizações da sociedade civil, muitas vinculadas às igrejas evangélicas e cidadãos comuns.

As fronteiras e a condição de legalidade do imigrante são fundamentais no processo migratório. Ao discorrer sobre a relevância das fronteiras para os haitianos, Couto (2016) aponta que há denúncias de pessoas ligadas aos direitos humanos sobre a violação desses direitos, como Henrique Corinto, no Acre. Essas revelações indicam a ilegalidade de um processo recorrente e atrelado à abertura de fronteiras brasileiras, que não expurga nenhum estrangeiro quando tenta conseguir documentação no Brasil.

Para muitos haitianos, a região fronteiriça no norte do país é encarada apenas como um local de passagem, sendo que ao regularizar sua situação, eles buscam trabalho e migram para outras partes do país, como os Estados de São Paulo e Rio de Janeiro (VINENTE, 2016).

Na visão de Silva S. (2016b), a solicitação de refúgio dá aos imigrantes o direito de expedir carteira de trabalho, com validade de um ano, além do Cadastro de pessoa física na Receita Federal- CPF, documentos esses que permitem sua inclusão no mercado de trabalho formal. O problema está na concessão do Registro Nacional de Estrangeiros (RNE), que 
concede a permanência no país, e pode durar até três anos. Enquanto não consegue esse documento, o imigrante permanece com o protocolo de refúgio, que possui limites burocráticos.

De acordo com Silva S. (2016a), esse protocolo é um limitador da cidadania, pois restringe uma série de direitos, como o de abrir conta em bancos, realizar contratos de aluguel, fazer inscrição para determinadas políticas habitacionais, entre outros aspectos. Os limites do protocolo e as dificuldades que ele provoca para a inserção social fazem com que muitos haitianos considerem de extrema relevância a aprovação do visto humanitário ${ }^{16}$.

A Resolução Normativa no 97 de 2012 alterou a legislação em vigor para os haitianos e prorrogou o prazo de permanência no país, justificada por razões humanitárias que foram definidas como:

Parágrafo único. Consideram-se razões humanitárias, para efeito desta Resolução Normativa, aquelas resultantes do agravamento das condições de vida da população haitiana em decorrência do terremoto ocorrido naquele país em 12 de janeiro de 2010 (BRASIL, 2012, p. 01).

A principal alteração dessa resolução normativa foi a concessão do visto permanente aos haitianos por cinco anos, o que os diferencia dos demais imigrantes, que, de acordo com o Estatuto do Estrangeiro, têm direito a visto provisório pelo período máximo de um ano.

Art. $1^{\circ}$ Ao nacional do Haiti poderá ser concedido o visto permanente previsto no art. 16 da Lei $\mathrm{n}^{\circ} 6.815$, de 19 de agosto de 1980, por razões humanitárias, condicionado ao prazo de 5 (cinco) anos, nos termos do art. 18 da mesma Lei, circunstância que constará da Cédula de Identidade do Estrangeiro (BRASIL, 2012, p. 01).

Embora a permanência tenha ampliado para os haitianos o prazo com prolongamento de cinco anos, a renovação do visto após o vencimento está condicionada à inclusão deles no processo produtivo do país, conforme estabelece o artigo 3 da referida normativa.

Art. $3^{\circ}$ Antes do término do prazo previsto no caput do art. $1^{\circ}$ desta Resolução Normativa, o nacional do Haiti deverá comprovar sua situação laboral para fins da convalidação da permanência no Brasil e expedição de

\footnotetext{
${ }^{16}$ Em virtude do visto humanitário ter sido transferido para outros imigrantes que não se enquadram na situação de refugiados, não conseguimos afirmar se as burocracias destacadas por Silva (2016) e os limitadores do visto humanitário sob alguns aspectos cotidianos foram resolvidos com a aprovação da Nova Lei de Migração de 2017.
} 
nova Cédula de Identidade de Estrangeiro, conforme legislação em vigor (BRASIL, 2012, p. 01).

A Resolução Normativa no 97 de 2012 assegurou a regularização da situação de milhares desses imigrantes que solicitam refúgio junto às autoridades brasileiras ao passo que, como já dito anteriormente, foi, também, uma estratégia do governo brasileiro para resolver o crescimento dos fluxos migratórios de haitianos. No entanto, o Estado continuou se abstendo de tratar o reconhecimento jurídico desses imigrantes como refugiados ambientais. Segundo Faria (2016), essa foi uma maneira de não abrir prerrogativas para abrigar imigrantes de outras nacionalidades que estivessem enfrentando o mesmo problema.

Na compreensão de Faria (2016), ao conceder o visto humanitário, o Brasil dá trato à questão jurídica dos refugiados de acordo com as recomendações da Convenção de Genebra de 1951, e o Protocolo de 1967 da ACNUR que estabelece o refúgio ambiental como nova categoria de refugiado (ACNUR, 1967). Entretanto, o Brasil não acata o pedido de refúgio ambiental, sendo que nenhuma legislação o reconhece.

Por assim ser, é necessário um novo olhar do governo brasileiro em relação a esse problema, visto que ele não se refere somente aos haitianos, mas é cada vez maior o número de pessoas que se movem mundialmente, impulsionadas por questões ambientais. À luz da aprovação da Nova Lei de Migração, vigente desde novembro de 2017, parece ser a extensão do visto humanitário aos demais imigrantes uma solução a esse impasse de não reconhecimento dos imigrantes ambientais.

Nessa perspectiva, conforme a lei em seu artigo 45, através do parágrafo único: "Ninguém será impedido de ingressar no País por motivo de raça, religião, nacionalidade, pertinência a grupo social ou opinião política" (BRASIL, 2017a, p. 02). No que se refere à interpretação da lei, a partir da sua vigência esse problema estaria resolvido quando se trata de ao ordenamento jurídico de imigrantes que estejam em situações parecidas ou de complexidades semelhantes aos haitianos, estendendo para todos o direito de entrada no país e a solicitação do visto humanitário.

Nessa mesma perspectiva, Silva S. (2016a) ressaltou que a concessão do visto humanitário para haitianos não passou de uma solução paliativa, uma resposta emergencial para o problema do refugiado ambiental, o que não se sabe ainda, devido ao encaminhamento das políticas no país, e em que medida a nova lei está sendo implementada ou não de forma a superar a característica paliativa. Ainda conforme Silva S. (2016a), a eficácia do visto humanitário não se sustenta a médio e longo prazo, em razão da falta de um mecanismo 
normativo que estabeleça critérios basilares para o reconhecimento jurídico do refugiado ambiental. Essa discricionariedade do Estado pode conduzi-lo ao risco de injustiça e discriminação, quando se depara com pessoas que se encontram em uma mesma condição.

A Convenção de Genebra, de 1951, define como refugiados pessoas perseguidas em seus países de origem, por motivo de raça, religião, nacionalidade, pertencimento a um determinado grupo social ou por suas opiniões políticas. O refúgio não é algo atual, mas sempre esteve presente na história da humanidade. Por séculos, pessoas deixaram seus países de origem por motivos variados, como culturais, religiosos, étnicos, políticos, ideológicos, entre outros.

Porém, o refúgio apenas ganhou proteção jurídica internacional no século $\mathrm{XX}$, com a sociedade das nações. Os principais fatos que impulsionaram esse reconhecimento foram: a Primeira Guerra Mundial, a Revolução Russa, a queda do império Otomano, acirrado com a Segunda Guerra Mundial, além do nazi-fascismo. Esses fatores juntos elevaram consideravelmente o número de refugiados, de modo que, em 1943, os países aliados da Segunda Guerra Mundial criaram a Administração de Socorro e Reabilitação das Nações Unidas - UNRRA (FARIA, 2016).

No princípio, a função da UNRRA era reabilitar e oferecer assistência aos atingidos pela guerra. Contudo, em 1943, a demanda de pessoas em busca de refúgio forjou a realização da Conferência de Bermudas. Nesse evento, os refugiados foram definidos como "todas as pessoas de qualquer procedência que, como resultados de acontecimentos na Europa, tiveram que abandonar seus países de residência por terem em perigo suas vidas ou liberdade, devido a sua raça, religião ou crenças políticas" (FARIA apud BARRETO, 2016, p. 611).

Dessa conferência saiu o primeiro conceito de refugiado contemporâneo, embora diferentes formas de perseguição estejam presentes na história humana. Ainda que limitado aos europeus fugidos da guerra, o non refoulement impuseram uma importante revisão, visto que sob perseguição ou receio fundado se constituiu o direito do sujeito não retornar para seu país de origem. Outro avanço foi a atribuição de responsabilidade a um órgão internacional, que passou a cuidar da questão dos refugiados.

Em 1947, criou-se a Organização Internacional de Refugiados (OIR), também centrada na questão da guerra especificamente para os casos da Europa. Somente nos anos 1950, com a criação do Alto Comissariado das Nações Unidas para Refugiados (ACNUR), a proteção humana por perseguição política se estendeu para o resto do mundo, para além dos espaços europeus. Também data desse período a formulação do Estatuto dos Refugiados, que 
estendeu a garantia de segurança a quem é perseguido e ameaçado em seus direitos e deveres para outros Estados (ACNUR, 1967).

Até 2018, constavam 140 países como signatários da ACNUR, oriundos da Convenção de 1951 e do Protocolo de 1967, que puseram fim à restrição da chamada reserva temporal, que classificava como refugiadas as pessoas atingidas por situações de mobilidade, restritas a fatos decorrentes da Segunda Guerra Mundial.

A ACNUR não parou de receber demandas. Entretanto, muitas delas não se enquadram nos cinco quesitos que caracterizam os refugiados, quais sejam: pessoas que sofrem perseguição fundamentada na raça, religião, nacionalidade, pertencimento a determinado grupo social, ou opinião política. Conforme dados disponibilizados pela própria instituição, a cada minuto, oito pessoas são obrigadas a pedir refúgio e deixar suas casas, por motivo de guerra e perseguições (ACNUR, 2018).

Por sua vez, posteriormente à Conferência de Estocolmo de 1972, o termo refugiado ambiental foi definido como pessoas forçadas a sair de seu habitat natural, por período temporário ou permanente, devido a uma ruptura ambiental marcante, provocada pela atividade humana ou natural, que ameaça sua existência e qualidade de vida. Entre esses grupos, estão os deslocados internos, pessoas que migram de uma região para outra no mesmo país, e os refugiados ambientais, que são os que migram para outros países.

Faria (2016) ressalta que o deslocamento de pessoas por questões ambientais não é recente. O que há de novo é o aumento desse deslocamento e seu potencial, como resultado da exaustão de recursos e destruição incalculável do meio ambiente e crescimento populacional. A autora ressalta que a degradação ambiental deixou de ser vista como causa isolada, ao passo que outros fatores passaram a explicar o fenômeno do refúgio, como os socioeconômicos, culturais e políticos. Para a autora, a questão fundamental é determinar em que medida a migração decorre de problemas ambientais ou socioeconômicos, sendo a própria definição de abalos ou eventos ambientais o maior diferencial desses dois conceitos.

No que tange às características no Haiti e as questões ambientais enfrentadas pelo país, Faria (2016) relata que além da grande concentração da população em Porto Príncipe e do crescimento populacional, o país passa, desde a década de 1990, por grandes abalos e destruição com intempéries, como os furacões Georges (1998), Jeanne (2004) e Hanna (2008).

Para a autora, 
O cenário natural do território haitiano, somado ao uso intensivo do solo ao longo dos séculos, bem como à frágil instituição política-administrativa, podem ser considerados fatores de repulsão da população. O potencial para as catástrofes de grandes proporções e de grandes efeitos destrutivos sobre os cidadãos haitianos é excessivo (FARIA, 2016, p. 624).

Quando chegaram ao Brasil, os primeiros imigrantes haitianos solicitaram refúgio e a intensidade dos pedidos, a delonga para análise e crescimento cada vez maior desse fluxo, fez o governo brasileiro aprovar a Portaria Normativa $n^{\circ} 97$ de 2012, que reconhece aos imigrantes haitianos o visto humanitário. Essa medida permitiu a conquista da emissão da documentação regular, com maior agilidade para sua confecção e atendimento de milhares de haitianos, que permaneciam nas fronteiras, a espera de documentação, para dar prosseguimento à imigração interna no Brasil.

A referida normativa resolveu o problema da documentação. No entanto, Silva S. (2016a) ressalta que inserir a ajuda humanitária como refúgio foi uma medida humanitária do ponto de vista jurídico, uma vez que reconhecer os imigrantes haitianos como refugiados acarretaria em ampliação da responsabilidade para com eles. Há, pois, uma limitação no plano jurídico de regulamentação, visto que não há políticas concretas, que atinjam a vida material de acolhimento desses sujeitos.

Por assim ser, Vinente (2016) adverte que há, por parte do governo brasileiro, omissão em assumir a responsabilidade quanto ao acolhimento desses imigrantes. Esse quadro é ainda mais agravado quando governos municipais, estaduais e federal passam, um para o outro, as atribuições em relação a eles. Sobre essa questão, discutiremos com maior profundidade no final desse Capítulo. No entanto, é certo dizer que a omissão do Estado em garantir a responsabilidade de mínimas condições de recepção e integração social pode levar a situações que intensifiquem a criminalização da imigração, e se desdobrar em situações extremas a exemplo do lamentável recente episódio de expulsão de venezuelanos em agosto de 2018.

O contexto da nova era migratória requer políticas que possam interferir na maneira de receber, asilar e integrar os sujeitos, que fazem parte dos novos fluxos migratórios. Os anos 1980 marcaram as novas trajetórias e migrações, que atingiram relevância demográfica.

Baeninger (2016) ressalta que a história do Brasil é marcada pela imigração, com diferentes movimentos de imigrantes estrangeiros e distintas formas de inserção dos mesmos na economia.

Um exemplo foram os escravos que desde o século XVI são migrantes desejados, pois, além de exercerem o trabalho manual, eram rentáveis e lucrativos devido ao tráfico negreiro e, transferem para o século XXI o lucro por meio da exploração, não mais realizada pelo 
trabalho escravo, mas perpetuada nos baixos salários. Saes (2001) ressalta a importância do tráfico negreiro para acumulação de capital no Brasil, resultante da consolidação da ação dos Estados absolutistas e da emergência de poderosas burguesias comerciais, em que o tráfico de escravo era algo bastante lucrativo.

O direito do Brasil Colônia e do Brasil Império permite a propriedade sobre o escravo, mas não contempla formas de escravização legal de novos homens e novas populações. Nesse sentido, o autor traz a dinâmica do Estado e a necessidade da transição do direito escravista para o direito capitalista moderno, que sob o julgo do trabalho livre, delineia os baixos salários pagos desde o surgimento do trabalho livre no Brasil.

Dessa forma, para esse autor, o Estado burguês no Brasil surge a partir de dois acontecimentos históricos: a abolição da escravidão 1888, que suprimiu não apenas o trabalho escravo, mas também o direito escravista, que fundamentava toda a ordem e organização do Estado moderno escravista e; a proclamação da República em 1889, em especial a constituinte de 1891, que também contribuiu para superar esse estado e o direito escravista moderno. Sem dúvidas, o pano de fundo para a estruturação jurídico político burguesa, ou capitalista, foi a proclamação da República e a constituinte de 1891.

Desde a abolição, o direito já igualiza todos os homens, independente da classe social ou função que desempenham na sociedade ao declará-los sujeitos individuais de direitos. Assim, a relação de exploração de trabalho adquire um caráter contratual, de compra e venda. A partir da abolição, todos os cidadãos, independente de classe social, podem, a partir da concorrência e da meritocracia, ocupar cargos no Estado. Ocorre a partir daí a instauração dos princípios do universalismo e da meritocracia no interior do Estado.

O autor, ao falar desse novo Estado capitalista ou burguês, questiona que efeitos ideológicos essa nova estrutura jurídico política poderia produzir entre os agentes econômicos e estatais?

Por um lado, a exploração e a existência do sobretrabalho em troca das condições de sobrevivência ocorreriam por livre e espontânea vontade do proprietário dos meios de produção e de trabalhadores. Essa troca, compra e venda da força de trabalho, ocorreria a partir de um contrato. Nos agentes estatais, esse efeito estaria na existência da ideia de liberdade de trabalho. Essa nova estrutura político-jurídica instaurada de 1888 a 1891 vai produzir esse duplo efeito ideológico, permitindo a difusão progressiva do trabalho assalariado na formação social brasileira, e consequentemente a implantação de relações capitalistas de produção. 
Evidentemente a implantação desse sistema se dará de forma desigual nas diversas regiões e também dentro de cada região. Para Saes (2001), a existência de um Estado burguês cujas relações jurídicas se baseiam na compra e venda da força de trabalho são fundamentais para a compreensão de relações desiguais e da continuidade da exploração que vem desde a escravidão até o século XXI.

Nesse século, as formas de comércio de pessoas são travestidas por velhas práticas, como a dos coiotes, que predominam na realidade dos imigrantes, nos baixos salários, que não permitem ao trabalhador satisfazer minimamente suas necessidades materiais de existência, com extrema precarização de suas condições de vida ao longo da nossa história.

A intensificação do fluxo migratório do Haiti para o Brasil estimulou a formação dessas quadrilhas de coiotes, que chegavam a cobrar valores entre U\$2.500,00 a U\$5.000,00, com promessas de deslocamento, emprego e estada. A presença de pessoas oportunistas frente à desgraça alheia está relacionada ao mercado rentável e informal da mobilidade humana, que se fortalece com as medidas de controle das fronteiras cada vez mais implementadas pelos Estados nacionais.

As experiências dos primeiros migrantes haitianos são marcadas por promessas e constantes desilusões quanto à migração para o Brasil. Vinente (2016, p. 264) relata que "Casos de violência, assaltos e estupros ocorridos no trajeto entre o Peru e o Brasil foram reportados pelos haitianos". Destarte, humilhação, dificuldades, desvalorização enquanto ser humano, medo e violência são aspectos que continuam presentes, semelhante ao que aconteceu há séculos atrás com o tráfico negreiro ${ }^{17}$.

Castles e Miller (2004) acreditam que a formação de redes, tanto de apoio como de exploração, é um aspecto inevitável do fenômeno da imigração. De acordo com esses autores, uma vez iniciada a imigração, aparecem necessidades especiais, que envolvem desde o local de partida até a chegada. Mesmo aqueles projetos migratórios empreendidos por governos, a fim de recrutar mão de obra, sem criar redes e estruturas necessárias para esse propósito,

\footnotetext{
${ }^{17} \mathrm{Na}$ segunda metade do século XIX as plantações de café, induziram a imigração de grandes fluxos europeus. A primeira onda em meados de 1880 e 1903 trouxe aproximadamente 1,9 milhão de europeus como italianos, portugueses, espanhóis e alemães. A segunda onda caracterizou um contingente de 2,1 milhões entre 1904 e 1930, e sua vinculação está relacionada com o período pós Primeira Guerra Mundial, marcando a presença de imigrantes italianos, poloneses, russos e romenos. A terceira onda marca o período entre $1930-1953$, com volumes inferiores da entrada de japoneses, 1932-1935, e as novas imigrações espanholas, gregas, sírio-libanesas entre 1953-1960 (BAENINGER,2016). Assim como Assis e Magalhaes expressaram, o período de ditadura como um momento de fechamento das fronteiras, Baeninger (2016) corrobora e acrescenta o período como de encerramento da recepção de imigrantes, que foi progressivamente diminuída desde os anos 1930, e delineou a participação interna desses imigrantes no desenvolvimento econômico
} 
contribuem para reforçar essas organizações que surgem com as imigrações e são sustentadas por ela.

Existe una amplia gama de oportunidades empresariales que son aprovechadas tanto por los migrantes como por los no migrantes. El papel de los agentes y intermediarios es vital: si ellos, pocos migrantes tendrían la información o los contatos necessários para uma migración exitosa (CASTLES E MILLER, 2004, p. 145).

O contrabando e tráfico de pessoas são aspectos que se sobressaem no que podemos chamar de indústria da migração. A diferença entre esses termos está expressa no Código de Viena, adotado pela assembleia geral da ONU em 2000. Embora em relação desigual, o contrabando é transladado de maneira ilegal para obter lucro; já a relação com os traficados se baseia no engano e na coerção, e tem a exploração como propósito.

A imigração ilegal para os países industrializados se intensificou a partir de 1973. Atrelada ao aumento de refugiados e solicitantes de asilo, tendo essa problemática se tornado o centro de campanhas agressivas por parte da extrema direita.

Esto contribuyo a la politización de los temas migratorios y ayudó a incrementar la presión para controlar la migración. Las actuales iniciativas políticas adoptan dos formas: la primera es volver más rigorosas las medidas de control y la segunda es el intento por atacar a la que se hace referencia como la 'causa de fondo' de la migración massiva: el abismo entre el sur y el norte (CASTLES E MILLER, 2004, p. 148).

Os autores demonstram como esses blocos de cooperação, como a OCDE, contribuíram para controlar legislações, com o objetivo de evitar que a população imigrante tivesse acesso aos documentos necessários para conseguir trabalho, benefícios de seguro social e escolas de nível médio. Com isso, foram minoradas as condições de cidadania e vida digna dos imigrantes.

Segundo os autores acima mencionados, há um histórico de contratação de mão de obra, legal e ilegal, por meio do emprego de braceiros haitianos, para a colheita de cana de açúcar na República Dominicana. Ambos países compreendem quase a metade da população caribenha. Em 1937, mais de 15.000 haitianos foram massacrados no lado espanhol da ilha, atual República Dominicana. Em 1979, a Sociedade Contra Escravidão, com sede em Londres, relatou a situação dos trabalhadores haitianos e suas condições de trabalho como análogas às escravas. 
Em 1991, depois das eleições democráticas no Haiti, as críticas internacionais contra a exploração do trabalho de haitianos nas colheitas de cana de açúcar na República Dominicana pressionaram o governo dominicano para que ordenasse uma expulsão massiva de haitianos, muitos dos quais eram nascidos no país e lá viviam regularmente. O resultado foi a expulsão de mais de 10.000 pessoas, das 40.000 que viviam no país. Em 1994, a contratação de haitianos na colheita de cana de açúcar reduziu para 20.000 pessoas, ao passo que aumentou na construção civil.

En el año 2001, fuentes autorizadas situaban en 500,000 la población de haitianos y sus descendientes en la República Dominicana (Alexandre, 2000:18), cerca del 6 por ciento de la población total. Casi la mitad de los haitianos era residente a largo plazo o nacia ahí, pero no se la consideraba ciudadana (SEGURA apud CASTLES E MILLER, 2004, p. 185-186).

A realidade do imigrante haitiano é marcada por fenômenos que disseminam insegurança em termos de preservação da vida, intensificadas pelas crises políticas e repressivas, intempéries naturais, além da profunda miséria que afeta o país. Com todos esses problemas, o Haiti é um dos países mais pobres da América Latina, situação agravada pelo terremoto que afetou a região em 2010.

As condições de insegurança vividas no Haiti também contribuíram para tornar o Brasil uma nova rota migratória, além de outros condicionantes, que serão discutidos abaixo. Muitos haitianos acreditam que no Brasil as condições de vida e trabalho são melhores do que aquelas vividas no Haiti. A saída do local de origem, desse modo, simboliza uma possibilidade de superar a exploração, bem como o trabalho em condições de escravidão e intensa pobreza.

Baeninger (2016) explica que a imigração internacional se consolida pela recepção de grandes fluxos como os haitianos, por outros países, a despeito do Brasil. Mas esse fenômeno ganhou novos contornos nos anos 1980, com a saída de brasileiros para o exterior como já apontado. Em 1990, havia registro de mais de um milhão de brasileiros vivendo fora do país, principalmente nos seguintes países: EUA, Paraguai, Japão, Portugal, Inglaterra, França, Suíça, Alemanha, Bélgica, Holanda, Austrália, Canadá e Israel. Até 2016, o maior número de emigrantes brasileiros estava nos Estados Unidos (500 mil) e no Paraguai (300 mil) (BAENINGER, 2016).

A migração transnacional se reestrutura com a emigração de brasileiros, assim como com a entrada de grandes fluxos de haitianos no país. Estudos indicam uma diversidade de motivos para a migração haitiana, os quais não se restringem às condições que geram 
insegurança como as apontadas acima, sobretudo o terremoto de 2010. Dentre eles, Silva S. (2016a) ressalta que uma das razões que fez do Brasil uma nova rota migratória para os haitianos foi a pujança econômica, que em 2010 conduziu o país ao patamar de sexta economia mundial.

Associado a isso, foram relevantes os discursos do ex-presidente Luiz Inácio Lula da Silva no Haiti e a capacidade acolhedora do Brasil, que foi reforçada, conforme Villen (2016), pela ex-presidente Dilma Rousseff, que corroborou a importância da ajuda humanitária no país. Além disso, todo esse processo de crescimento da imigração para o Brasil se deu em um momento em que as fronteiras europeias e americana estavam sendo fechadas com uma forte instabilidade política do Haiti.

Autores como Alessi (2016), Zeni (2014), Assis e Magalhães (2016) destacam, ainda, que a instabilidade do país engendrou a relação geopolítica entre Brasil e Haiti, com a criação da operação MINUSTAH ${ }^{18}$. Essa missão sustentou no Haiti, tropas militares vinculadas ao exército, marinha e à Força Aérea. Conforme o Ministério da Defesa, em 2005, a operação alargou suas ações para a estabilização. Desde 2010, a missão atuou também na recuperação da infraestrutura do Haiti. Para tanto, um grupo de engenheiros militares cuidava da construção de hospitais, recuperação de ruas, malha asfáltica, além de outras obras de infraestrutura (BRASIL, 2014). Após 13 anos de atuação no Haiti, o exército brasileiro retirou suas tropas em Outubro de 2017 (FERREIRA, 2017).

A saída de haitianos do país é conceituada como diáspora haitiana. De acordo com Handerson (2015), esse conceito é um elemento constitutivo da cultura haitiana, que faz dos diversos recursos culturais qualidades adquiridas por meio da mobilidade em diversos espaços de pertencimento. A diáspora, “[...] no universo haitiano, constitui um modo de ser, de vestir, de pensar e agir, constituindo uma linguagem própria e estilo de vida" (HANDERSON, 2015, p. 66).

A diversidade das causas da imigração para o país fez dos haitianos um dos seus maiores grupos migratórios, com inserção no mercado de trabalho formal, como discutido anteriormente. Esses imigrantes que, inicialmente, chegaram no Acre, foram mobilizados para outras regiões o que fez dessa mobilidade interna desses imigrantes no Brasil uma necessidade de superar a instabilidade e a insegurança em que viviam, longe de ser uma

\footnotetext{
${ }^{18}$ Missão das Nações Unidas para Estabilização do Haiti MINUSTAH, originária de uma estratégia do Brasil ocupar uma cadeira no Conselho de Segurança da ONU, passou a liderar a operação composta por vinte países para restauração política e econômica do Haiti. (ALESSI, 2016), (ASSIS E MAGALHÃES), (ZENI, 2014), (MAMED, 2016).
} 
escolha. Essa instabilidade ia desde a incerteza de trabalho e mínimas condições para sobreviver, até a precária situação nos abrigos compartilhada com centenas de outros haitianos, muitas vezes em condições sub-humanas, em virtude da precariedade das instalações diante da grande demanda por atendimento.

Dessa forma, o Paraná, e, consequentemente, o Município de Cascavel, não foram selecionados como destino dos primeiros imigrantes haitianos. Isso fica evidente nos relatos que empreenderam as migrações para o interior do Brasil e tiveram Cascavel como destino quando saíram do Acre, empreendendo o que denominamos de mobilidade interna delineada pelo trabalho, como será abordado enfaticamente no terceiro capítulo.

\subsubsection{Imigração haitiana: primeiros indícios da mobilidade no Oeste do Paraná}

Embora algumas instituições que trabalham diretamente com haitianos marquem a chegada deles em Cascavel a partir de 2011, estudos recentes como o de Eberhardt (2017) datam a presença destes imigrantes ainda em 2010. No entanto, nessa pesquisa de campo após entrevistar 60 pessoas, registrou como marco das primeiras chegadas o ano de 2012. Esses dados são reafirmados pela Agência do Trabalhador do município, que evidencia nesse ano a constatação dos primeiros registros de encaminhamentos de imigrantes para o trabalho formal no Município.

Tendo em vista que esses haitianos já eram selecionados pelos empresários que os buscaram e a documentação regular foi um dos critérios para a escolha, assim que chegavam eram diretamente incorporados nas empresas contratantes. Possivelmente, o vínculo direto entre empresas contratantes e esses trabalhadores seja um motivo pelo qual muitos deles só procuraram a Agência do Trabalhador a partir de 2012. Além disso, o ano de 2012 expressaria a força de atração de outros haitianos via redes de apoio, sobretudo familiar já instalada, e também por ser esse ano um identificador das primeiras ondas de demissões desses trabalhadores pelos primeiros contratantes.

Inicialmente, os imigrantes chegaram ao Município trazidos por empresários que foram até o Estado do Acre buscar mão de obra para a construção civil e frigoríficos (PARANÁ, 2017). Eberhardt (2017) corrobora com essa informação, e afirma que uma rede de supermercados também fez uso da mão de obra dos primeiros migrantes que chegaram. A incorporação deles nos frigoríficos foi sendo realizada de acordo com o crescimento do desenvolvimento econômico e a dispensa dos primeiros ambientes de trabalho, sobretudo na construção civil. 
Os depoimentos estão em consonância com os estudos já realizados por outros pesquisadores (ASSIS E MAGALHÃES, 2016; MAMED, 2016 e 2017; COUTO, 2016; SILVA P. 2016) que discutiram as incursões de empresários do Sul do Brasil e a atração da mão de obra haitiana, especialmente para atuar nos setores da construção civil, frigoríficos e coleta de lixo.

A incorporação de imigrantes pelo processo produtivo já foi experimentada em diversos países do mundo, entre os quais se destaca a Espanha. Por motivações econômicas, o país implementou uma política de recepção de milhares de imigrantes a partir dos anos 1970. Esse fenômeno foi denominado por Cachón (2007), Arango et al. (2007), Arango et al. (2017) e Sala (2005) de efeito "chamada", guest workers ou trabalhadores convidados. Os três termos traduzem um mesmo fenômeno delineado pelo sistema produtivo, responsável pela crescente incorporação de imigrantes no mercado de trabalho.

Em 2010, o Brasil passava por amplo desenvolvimento econômico e era a sexta maior economia mundial. O crescimento econômico superior aos demais países da região repercutiu na reinserção econômica de cidades localizadas no seu interior, como é o caso de Cascavel, no Estado do Paraná. O agronegócio ${ }^{19}$, especialmente voltado a atividades produtivas de processamento e industrialização de carnes, sobretudo de aves e suínos, propiciou a ampliação das exportações para o mercado mundial. Esse quadro levou ao aumento da demanda por trabalhadores manuais nessa região.

Dados divulgados pela ONU em 2016 mostraram que, até 2015, havia 244 milhões de imigrantes internacionais no mundo (ONUBR, 2016). Os países no ranking da diáspora mundial são Índia, com 16 milhões, e México, com 12 milhões de sua população vivendo fora do país, seguidos da Rússia, China, Bangladesh, Paquistão e Ucrânia. Dados da Polícia Federal estimam a existência de mais de 120 mil estrangeiros vivendo no Brasil em 2016 (BRASIL, 2016).

Sobre a imigração no Brasil, Villen (2016) afirma que há mais de 80.000 refugiados no país, dos quais mais de 30.000 eram haitianos, até 2014. Conforme Silva S. (2016a), 2014 foi o ano do ápice da imigração haitiana para o país, com crescimento de $120 \%$ desde 2010. Dados levantados por meio de informação do Serviço Público Federal, Polícia Federal e

\footnotetext{
${ }^{19}$ Entre as atividades que compõem o agronegócio no Brasil se destaca a agricultura, majoritariamente baseada na monocultura como soja e milho. O País possui a maior quantidade de terras agricultáveis no mundo, conforme dados da Embrapa (2017) e ocupa a posição de segundo maior produtor mundial de soja, com o total de 113,923 milhões de toneladas, ficando atrás dos EUA com Produção: 117,208 milhões de toneladas. O Estado do Paraná é o segundo maior produtor do Brasil atrás do Estado do Mato Grosso que ocupa a primeira colocação. (BRASIL, 2017). No entanto, a secretaria de agricultura do Estado do Paraná destaca a produção do estado como a maior do mundo, com índice de 4\% superior aos americanos em 2017 (SERAPIO, 2017).
} 
Serviço de Informação ao Cidadão SINCRE (BRASIL, 2018a), indicam a existência de 88.459 cidadãos da República do Haiti que atualmente vivem no Brasil cadastrados nesse órgão, com o status de ativo. Estes dados são descritos a seguir, por ano.

Tabela 1 - Quantidade da população imigrante haitiana cadastrada no SINCRE de 2009 a 2017

\begin{tabular}{llc}
\hline \multicolumn{3}{c}{ ANO QTD (por mil) } \\
\hline 2009 & 0.013 \\
2010 & 0.02 \\
2011 & 0.406 \\
2013 & 3.89 \\
2014 & 5.548 \\
2015 & 10.635 \\
2016 & 14.49 \\
2017 & 42.411 \\
& 10.925 \\
\hline
\end{tabular}

Tabela 1- Fonte: Brasil (2018a).

A região Sul do Brasil é a maior incorporadora dessa mão de obra, cuja população imigrante nos três Estados totalizam 50.53\%. Santa Catarina é o Estado com mais imigrantes: um total de 18.836 ou 21.9\%, posteriormente seguido do Paraná, com 13.668, $15.44 \%$ e, finaliza com o Rio Grande do Sul, com 11.411. As regiões Sul e Sudeste incorporam juntas 79.49\% da população haitiana no Brasil, sendo essa porcentagem concentrada de forma mais hegemônica no Estado de São Paulo. As demais regiões e Estados apresentaram inexpressiva presença da população haitiana, conforme dados do SINCRE, com destaque para as regiões Norte e Nordeste (BRASIL, 2018a).

O ano de 2010 corresponde à intensa migração de haitianos para o Brasil. No período, a população do Haiti era estimada em 9.203083 habitantes, com concentração da maior parte da população na capital Porto Príncipe. Baptiste e Vieira (2016) ressaltam que a população urbana em 2010 era inferior a 50\% da população total do país, o que marca o perfil de populações agrárias e regiões urbanas ou as maiores cidades do país, como é o caso de Porto Príncipe, que apresenta um indicador de concentração urbana superior à média das demais regiões urbanas de maior população com 360 pessoas por $\mathrm{km}^{2}$.

Quando migraram para o Brasil, os primeiros fluxos de haitianos que chegaram ao país solicitaram refúgio. Autores que se dedicaram à imigração haitiana como objeto de estudo, com destaque para Silva S. (2016b); Faria (2016); Martins (2014); Silva P., (2016); Assis e 
Magalhães (2016) e Oliveira (2016), indicam a presença dos primeiros fluxos desses imigrantes em 2010, devido à massiva imigração para o Brasil, sobretudo após o terremoto ocorrido nesse ano.

No que se refere à participação dos imigrantes no mercado de trabalho, entre $2010 \mathrm{e}$ 2015 o percentual desses trabalhadores no sistema formal aumentou 131\%. De acordo com os dados da Relação Anual de Informações Sociais (Rais), o número de trabalhadores passou de 54.333 para 125.535 no período referenciado. Apesar desse crescimento, os imigrantes representam menos de $0,5 \%$ da força de trabalho no Brasil, sendo as regiões Sul e Sudeste as que mais absorvem esses trabalhadores (CAMPOS, 2016).

Em 2010, São Paulo abrigava 48,5\% dos imigrantes de várias nacionalidades, e incorporava $28,7 \%$ do total de trabalhadores migrantes do país, seguida da cidade do Rio de Janeiro, com 15,8\% (CAMPOS, 2016). Dados sobre a incorporação de imigrantes no mercado de trabalho formal brasileiro sinalizam que, desde os anos 2000, em razão do início da crise econômica, eles passaram a sofrer com o desemprego. No primeiro semestre de 2016, foram admitidos 19.734 imigrantes e demitidos 24.965 .

Nos primeiros anos da década de 2010, o maior incremento dos trabalhadores imigrantes ficou por conta dos haitianos. Eles passaram de 815 imigrantes no mercado de trabalho formal em 2011, para 33.154 em 2015. Em 2013, os portugueses, até então maioria, foram superados pelos haitianos, que em 2015 representaram 26,4\% da força de trabalho imigrante no Brasil (CAMPOS, 2016).

Rodrigues (2017) acredita que, embora a nacionalidade haitiana seja a maior incorporada no mercado de trabalho formal, em 2016 houve diminuição de $30 \%$ do número desses trabalhadores empregados. Nesse ano, constatou-se um total de 25.782 haitianos contratados, número inferir ao de 2015, que foi de 33.507. Depois dos haitianos, a lista de nacionalidades mais empregadas no sistema produtivo formal brasileiro em 2016 se completa por portugueses (8.844), paraguaios (7.737), argentinos (7.120), bolivianos (5.975), uruguaios (3.947), chilenos (3.565), bengalis (3.565), peruanos (3.195), chineses (2.983) e italianos (2.631) (RODRIGUES, 2017).

O Município de Cascavel registrou alteração gradativa no número de imigrantes haitianos que chegaram à cidade, reflexo do aumento dos fluxos migratórios no país. Martins et al. (2014) ressaltam que, até 2014, havia mais de 3.000 haitianos vivendo na cidade. Alguns órgãos midiáticos, como Corazza (2016) e Catve (2017a), apontam, em 2016, um número entre 4.000 e 5.000. Também corroboram com esses dados as pesquisas de Eberhardt (2017) e Mamed (2017), recentemente divulgadas sobre imigração e saúde em Cascavel (Paraná). 
Dados recentes divulgados pela Pastoral do Migrante de Cascavel, conforme Carneiro (2017), também reafirmam os últimos números, o que corresponde a 1,5\% do total de habitantes, tendo em vista que a população estimada de Cascavel em 2017 de acordo com dados do IBGE é de 319.608 mil habitantes (IBGE, 2016). Já o departamento de imigração da Polícia Federal (BRASIL, 2017) divulgou um número de 2.202 haitianos documentados vivendo em Cascavel até 30 de janeiro de $2017^{20}$, o que diverge da estimativa anunciada pela mídia e por instituições que trabalham diretamente com essa população.

Quando se refere a estrangeiros, Mamed e Lima (2016) asseveram que esses números são sempre relativos, haja vista a quantidade de pessoas indocumentadas que vivem na ilegalidade. Portanto, não há um controle exato por parte do Estado. Também não se pode desconsiderar o fato de a ilegalidade ser uma condição de permanência nos países, ou mesmo uma forma de resistência a mecanismos de controle instituídos.

\subsubsection{Cascavel no contexto da globalização: frigoríficos e imigração haitiana no Oeste do Paraná}

A globalização como visto no capítulo anterior, intensifica a desigualdade entre centro e periferia. O domínio do capital financeiro impõe, sob a égide da modernização, a perda de soberania dos Estados e os colocam como aparelhos usados por grandes grupos e corporações, que promoveram a abertura das fronteiras para a livre circulação de capital e mercadoria.

A mobilidade humana não possui as mesmas flexibilidades que o capital e as mercadorias. Sua abertura está condicionada à própria demanda do capital que, quando necessita de mão de obra, abre as fronteiras, as quais são fechadas quando essa demanda não é apresentada. A imigração se impõe, enquanto característica da humanidade, e desafia os mais modernos mecanismos de controle das fronteiras, perpassando os motivadores econômicos, o que significa que muitos outros fatores delineiam o processo migratório. Isso faz de cada imigrante um ser revolucionário ao empreender o processo migratório com a busca de liberdade, ao passo que rompe com tradicionais formas de dominação.

Sassen (2013) estudou a imigração na Europa e ressalta sua importância, nos contextos internacional e inter-regional, como um componente estratégico para a urbanização e industrialização daquele continente. Ela mostra a íntima relação entre as migrações de pessoas

\footnotetext{
${ }^{20}$ Esses dados foram levantados em visita realizada diretamente na sede da Polícia Federal de Cascavel no dia 30 de Janeiro de 2017.
} 
para a Europa e o desenvolvimento da estrutura urbana, sendo as regiões de rápido crescimento um destino prioritário dos imigrantes.

Bauman (1999), por sua vez, estabelece uma relação entre as fronteiras e os habitantes de primeira e segunda classe. Para os de primeira classe, a extraterritorialidade ou cosmopolitismo é uma essência para a difusão de seus negócios e controles globais. Para os de segunda classe, restam os muros, as fronteiras, a política das ruas limpas e intolerância zero. A altura dos muros ou o fechamento das fronteiras se relaciona com o grau de desigualdade produzido internacionalmente, para que aqueles considerados imigrantes indesejados não alcancem os que estão à frente.

Nessa perspectiva, a cidade surge como um dos espaços essenciais para o desenvolvimento da globalização. Isso implica em consequências conceituais que perpassam a dualidade global/nacional, em que o primeiro ganha dinheiro e vantagens em detrimento do segundo. A cidade articula componentes vinculados à economia global, mas também possui traços que lhes são próprios e desarticulados do mercado, como cultura e formas de viver, que são característicos de uma região e resistentes à globalização. No mais, "también señala la decreciente importância de la economía nacional como una categoría unitária” (SASSEN, 2007, p. 15).

A globalização transformou, nos últimos 15 anos, as economias nacionais, que antes eram unitárias, e foram introduzidas pelo Estado nos ciclos superiores do capital, em especial das finanças.

O enfoque sobre as cidades permite delinear uma geografia estratégica dos lugares em escala global, por estarem ligados entre si pela globalização.

En la medida en que un análisis económico de la ciudad global recupera la amplia serie de empleos y de culturas del trabajo que son parte de la economía global, aunque no tipicamente señaladas como tales, puedo examinar la possibilidad de nuevas políticas de actores tracionalmente desaventajados que operan en esta nueva geografia económica transnacional - desde los trabajadores fabriles en las zonas de procesamiento de exportaciones hasta los limpiadores de Wall Street - . Ésta és una política que descansa en la interseción de 1) la participación económica actual de muchos trabajadores en desvantaja en la economía global y 2) sistemas y retóricas políticos que sólo pueden representar y valorizar a los actores corporativos como participantes (SASSEN, 2007, p. 16).

Sassen (2007) recupera a cultura e o trabalho como elementos fundamentais da globalização, que se manifestam no desenvolvimento da cidade global. Atores em 
desvantagem social podem ter, nas novas políticas, possibilidades de inserção que vão além do trabalho, sem o qual não existiriam as cidades globais. A cidade emerge como um novo espaço para a formação de demandas e consolidação de direitos, em especial o direito a um lugar, o que enseja a construção da cidadania. A globalização amplia a internacionalização das pessoas, "[...] los cuales poseen en las grandes ciudades una presencia tan internacionalizada como la del capital" (SASSEN, 2007, p. 16).

É nesse contexto que Cascavel, localizada na região Oeste do Paraná, constitui-se como mais um espaço estratégico para a transnacionalização do capital. O município desenvolve conexão global por meio de sua inserção do setor produtivo de frigoríficos, com exportação de carnes processadas para diversos países no mundo. Para intensificar a produtividade, ainda pautada no modelo fordista-taylorista, o setor produtivo carece de mão de obra. Assim sendo, a abertura das fronteiras de Cascavel se delineia também conforme esse ramo produtivo.

O Estado do Paraná ocupou, em 2017, a 5 a posição no ranking formal de trabalho, com 6.742 postos, e Cascavel se destaca como a cidade que mais criou oportunidades de trabalho, um total de 1.243 encaminhamentos. Além do mais, o Observatório do Trabalho - Paraná (2017) indica os principais setores que incorporam mão de obra no Paraná, com destaque para os seguintes: transformação, como os frigoríficos, fabricação de açúcar bruto, abate de suínos e aves, construção de peças, vestuários e construção de rodovias e ferrovias.

Donda Junior (2002), em um estudo sobre o avanço do agronegócio no Estado do Paraná, ressalta que a produção de grãos, como a soja, foi responsável por 16,5\% da produção nacional na temporada 2008/2009, com a colheita de 9,4 milhões de toneladas. Esse índice foi inferior à participação de 23,6\% do início dos anos 1990. Esses dados são reflexos da expressiva participação da produção no Mato Grosso, que subiu de 18,3\% para 31,5\%. Esse Estado, portanto, apresenta elevação da produtividade e pronunciada expansão dos espaços destinados ao cultivo da oleaginosa.

Os dados atuais, conforme divulgados pelo Valor Econômico (2018), corroboram esses números de 2018 com algumas variações para mais, mantendo uma média dos índices produtivos de 2010, como apresentou Donda Junior (2002). Conforme esse veículo de comunicação, o Estado do Mato Grosso conserva a posição de maior produtor nacional de Grãos com 26,5\% da produção nacional, enquanto o Paraná segue na segunda posição com 16\% de participação da safra nacional, que conforme dados da Conab 2017/2018 totalizaram 229,7 milhões de toneladas. No que se refere ao tipo de grão, o Paraná é o primeiro produtor 
nacional de trigo e feijão, e o segundo maior produtor de Soja e Milho (VALOR ECONÔMICO, 2018).

Quanto à produção agroindustrial, o Paraná desponta com crescente participação no abate de aves. Essa atividade, em sintonia com o crescimento da criação avícola, avançou de forma expressiva nos últimos anos, e tem se colocado como uma das principais commodities (mercadoria) do agronegócio na região, alcançando a produção de 2,5 milhões de toneladas em 2009, resultado 245,6\% superior ao contabilizado em 1997, isso sem considerar a expressiva produção de suínos e gado que também são expressivas na região.

Ao todo, no Brasil, foram produzidos, até o final do primeiro semestre, 463,1 mil toneladas de aves exportadas para vários países do mundo, como informou a Associação Brasileira de Proteína Animal (ABPA, 2018). O bom desempenho do setor ainda não superou o melhor período de vendas registrado em 2017, cujos dados atuais apresentam 4,6\%, um número menor que as 416,2 mil toneladas embarcadas em agosto de 2017, com receitas de US\$ 633,8 milhões, saldo 7,9\% inferior às US\$ 687,9 milhões realizadas no oitavo mês de 2017. Ao tratar da evolução do consumo de carne de aves no Brasil e da importância mundial desse setor, Eberhardt (2017) ressalta que o aumento desse consumo no Brasil é de fácil visualização.

"Em 1950 estimou-se que foram abatidas 7,2 mil toneladas de carne de
frango. Esse número saltou para 224 mil toneladas em 1971, 484 mil
toneladas em 1975 e ultrapassou a casa dos milhões ao atingir 1,2 milhões de
toneladas em 1980" (BOSI, 2011, p. 401). Atualmente, já são mais de 13
milhões de toneladas produzidas anualmente (ABPA, 2016).
(EBERHARDT, 2017, p. 92).

O autor considera ainda a importância do mercado consumidor, embora a produção de carnes processadas visem o comércio mundial via exportações, o mercado interno ainda é o grande responsável pelo consumo da maior parte das carnes processadas com total de $63,3 \%$, restando 32,7\% para consumo externo via exportações do produto (EBERHARDT, 2017).

Além disso, Eberhardt (2017) ressalta a importância da região Oeste do Paraná para a produção total desse tipo de mercadoria no Brasil. O Estado ocupa uma das primeiras colocações de produtividade de aves no Brasil, sendo responsável por 32,46\%, seguido por Santa Catarina (16,24\%), Rio Grande do Sul (14,13\%), São Paulo (9,22\%), Minas Gerais $(7,25 \%)$ e Goiás $(7,22 \%)$, de acordo com informações da ABPA, em 2016 (EBERHARDT, 2017). 
Essa commodity é também responsável pela geração de empregos no país, estimados em 500 mil para abate de frangos e suínos, com a centralização das vagas disponíveis no Sul do país com $60 \%$ dos postos de trabalho. Nesse contexto, a região Oeste do Paraná responde por $62 \%$ do abate de frango e $42 \%$ dos postos de trabalho no setor em todo o estado (EBERHARDT, 2017).

Ainda de acordo com Eberhardt (2017), destacam-se no Sul do país duas regiões coincidentemente localizadas no Oeste dos dois Estados com maior produção do país: Paraná e Santa Catarina, consideradas duas grandes Mesorregiões, correspondem a 26,4\% de todo o emprego nacional para o setor e quase a metade do Sul do país com a cifra de 43,6\% (EBERHARDT, 2017).

A interiorização dessas empresas representa parte da desconcentração industrial do território brasileiro, fomentadas e atraídas via vantagens fiscais e força de trabalho com menor valorização. Esses empreendimentos se apropriam de organizações coletivas já interiorizadas com a formação de organizações de agricultores para enfrentarem as barreiras competitivas do mercado. Nessa perspectiva, essas indústrias são cada vez mais impulsionadas e sua dimensão dos impactos na região tem promovido intensa mobilidade humana e integração dos interiores a essa dinâmica produtiva. Um exemplo desse processo é a cidade de Assis Chateaubriand, localizada também na região Oeste, cerca de $80 \mathrm{~km}$ de Cascavel, a qual já recebe a implementação do que se divulga vir a ser o maior abatedouro de suínos do Brasil e da América Latina, prevista para iniciar suas atividades produtivas em 2020.

O lançamento da pedra fundamental do maior frigorífico da América Latina
nesta quinta-feira (19/10), em Assis Chateaubriand, Oeste do Paraná, marca
a retomada dos planos da central de cooperativas Frimesa de triplicar o abate
de suínos na próxima década. Com investimentos que somam quase 1 bilhão
de reais, a cooperativa quer chegar em 2030 abatendo 22 mil cabeças de
suínos por dia, contra uma média de 7 mil abatidos atualmente (TOSI, 2017,
p. 01).

Os frigoríficos estão em 12 dos 50 Municípios da região Oeste do Paraná com abates de suínos, bovinos e aves e totalizam 35 empresas. Entre estas, o destaque é para o processamento de carne de aves, com total de 8 unidades em 2003 com representação de $34,3 \%$ do faturamento em todo o Paraná (EBERHARDT, 2017). 
Segundo o Instituto Paranaense de Desenvolvimento Econômico e Social (IPARDES), “[...] o segmento de abate de aves é o maior empregador da região, com 13,84\% da mão-deobra industrial" (CÊA; MUROFUSE, 2010, p. 4).

Dessa forma, a importância do Estado do Paraná no abate nacional de aves aumentou consideravelmente, com apresentação de uma participação de 25\% em 2009. Esses dados garantiram a liderança do Estado entre os demais brasileiros, com um volume produtivo de 28,9\%, maior que o de Santa Catarina, que ocupa a segunda posição no ranking das unidades da federação (EBERHARDT, 2017).

A vasta literatura que se ocupa das transformações ocorridas no campo brasileiro nas últimas décadas enfatiza a chamada modernização da agricultura. Contrariando previsões dos analistas das décadas de 1950 e 1960, o setor agrícola, a partir do final dos anos 1960, absorveu quantidade crescente de crédito, com a incorporação dos insumos modernos, técnicas de manejo, cultivo, e mecanização da produção, com integração aos modernos circuitos de comercialização. $\mathrm{O}$ aumento da produtividade possibilitou a ampliação da produção de matérias-primas e alimentos para exportação, além do mercado interno. Dessa forma, houve uma alteração na base técnica da agricultura, associada à sua articulação com as indústrias produtoras de insumos e bens de capital agrícola. Nesse sentido, a indústria processadora de produtos naturais levou à formação do chamado complexo agroindustrial (DELGADO, 1985).

Assim, Cascavel se projetou como uma região entre as cidades do Paraná com potencial presença do setor econômico agroindustrial. Os complexos agroindustriais de transformação de alimentos repercutem diretamente na imigração do século XXI, no Estado do Paraná. Não há como falar nessa projeção, ou o que Bosi (2011) denominou de interiorização da agroindústria, sem nos remeter aos seus primórdios, quando emergiu a primeira delas na região.

Inicialmente, isso ocorre pelo desenvolvimento de depósitos de alimentos da empresa Sadia S.A., que atuava em Santa Catarina desde 1944, no Município de Concórdia. Em 1964, esse complexo foi instalado no Município de Toledo, cidade vizinha à Cascavel, e em demais municípios do Estado, como Francisco Beltrão e Dois Vizinhos, compreendendo as regiões Oeste e Sudoeste do Estado.

Inaugurada pela antiga Sadia S.A., a produção agroindustrial e processadora de alimentos faz parte do agronegócio, que compreende o desenvolvimento econômico do Estado. Essa empresa deu margem e estímulo para que outras surgissem na região, nos mesmos moldes, intensificando a concorrência e a produção de alimentos, como carnes, aves 
e leite. No contexto da economia global, em 2016, a Sadia S.A. fundiu associação com a Perdigão, e formaram juntas um dos oligopólios desse setor denominada de BRF, o que representou uma estratégia para driblar a concorrência e manter sua soberania frente às inúmeras empresas criadas no mesmo ramo, sobretudo na região. Estratégias como essa já foram implementadas no Brasil a partir de algumas fusões para o fortalecimento do monopólio e um mecanismo de driblar a concorrência, dentre elas se destacam: Ambev (união de Antarctica e Brahma), no ramo de cervejarias, e Garoto (adquirida pela Nestlé), no ramo alimentício, "foram fantasmas durante o processo" da BRF Brasil Foods, empresa nascida da união entre os dois frigoríficos (ISTO É, 2011).

No entanto, embora a BRF seja considerada uma das maiores empresas do Brasil, constituída para ser um grande monopólio na área de processamento de proteínas, a região Oeste é servida por outras empresas desse setor.

Assim como o Município de Toledo abriga um dos maiores frigoríficos do Oeste do Paraná, a vizinha Cascavel também se destaca por alojar a Coopavel, uma das maiores empresas do agronegócio com o processamento de carnes do Brasil. Conforme histórico da cooperativa, seus produtos são comercializados em mais de 30 países, de modo que, de pequena, ela se transformou em uma das 20 maiores cooperativas do Brasil (RIC RURAL, 2016).

As informações sobre o desempenho do agronegócio na região não se faz por informações repassadas diretamente por essas empresas, pois elas se recusam em conceder informações quando solicitadas, conforme anexo, e alegam que em decorrência de procedimentos e normas internas, não participam e não fornecem dados para pesquisas. Dessa forma, as informações que trazemos nessa tese, são aquelas divulgadas pelo próprio site dessas empresas, sobretudo a Coopavel, bem como nos sites que publicam informações sobre elas e outras pesquisas que divulgam alguns dados.

Assim a empresa Coopavel foi destaque recente na mídia nacional classificada entre as mil maiores cooperativas do país, e classificada na $75^{\text {a }}$ posição e está entre as 400 maiores empresas do agronegócio que compreende 19 cooperativas do Estado entre as que tiveram maior desempenho no Brasil. O agronegócio é a maior fonte de riquezas que move o Paraná, e a commodity de proteína animal tem contribuído significativamente para elevar a posição do Estado como um dos maiores produtores nacionais.

Conforme divulgado em alguns veículos midiáticos, a história da Coopavel, uma das maiores cooperativas do Brasil, relaciona-se com a organização de agricultores para enfrentar o peso e monopólio das multinacionais na área de agricultura, predominante desde os anos 
1950. Inaugurada nos anos 1970, inicialmente, a Coopavel contou com 110 produtores associados e uma pequena sede em Cascavel. Em 2016, possuía 26 filiais nas regiões Oeste e Sudoeste do Paraná (RIC RURAL, 2016; CATVE, 2017b). Conforme informações divulgadas pela CATVE (2017b), contam, atualmente, mais de cinco mil cooperados, e quase seis mil colaboradores, elevando, segundo o meio de comunicação, a projeção mundial via exportações para mais de vinte países.

O que antes se limitava à produção e armazenamento de grãos congrega, em 2018, 12 grandes agroindústrias, sendo três frigoríficos de carnes de boi, aves e suínos, que, juntos, produzem mais de 560 toneladas de carne por dia, com exportação para mais de 30 países. As agroindústrias da Coopavel empregaram, até 2016, mais de 5.400 pessoas, e obteve, nesse ano, lucro de 600 milhões de reais (RIC RURAL, 2016). Dados divulgados mais recentemente apontam vendas de $\mathrm{R} \$ 2,1$ bilhões.

Devido à falta de dados fornecidos diretamente por esses frigoríficos, estima-se conforme as fontes indiretas como Ric Rural (2016) e CATVE (2017b) que suas exportações variam entre 20 e 30 países, bem como a admissão de trabalhadores em todo sistema produtivo, dados que excluem as áreas rurais como os aviários, pocilgas e criação de gado totalizam de 5.000 a 6.000 postos de trabalho.

Além da produção e do processamento de produtos agrícolas, a Coopavel realiza, desde 1989, o Show Rural Coopavel, considerado o maior evento agroindustrial e tecnológico do mundo. Em 2018, segundo divulgação midiática, atraiu mais de 250.000 mil pessoas para visitar e conhecer as mais sofisticadas tecnologias voltadas para o setor.

Os frigoríficos fazem parte da agroindústria do Paraná e são tipos de empreendimentos que ganham destaque na região e no Brasil, visto que a avicultura se coloca como o maior símbolo de crescimento e modernização do agronegócio no país. Isso porque ela “[...] reúne em sua estrutura funcional os três elementos mais importantes no cálculo econômico do capitalismo em sua configuração atual: tecnologia de ponta, eficiência na produção e diversificação no consumo" (DONDA JÚNIOR, 2002, p. 58). Além disso, pode-se destacar que a interiorização, no caso do Paraná, permite o fácil acesso das matérias primas, além de um típico trabalhador com dotes peculiares e dóceis, voltado para o trabalho pesado e repetitivo.

Essa afirmação, embora desmistificada quando ocorre a negação desses trabalhadores a realização de trabalhos em frigoríficos, não ocorre necessariamente por uma ausência de docilidade, haja vista a inexistência de organizações desses trabalhadores em movimentos grevistas ou organizações mais expressivas junto a esses frigoríficos, mas sim à interiorização 
do agronegócio na industrialização de proteínas, devido a lógica de como essas empresas se configuram, registradas como cooperativas, que faz com que agricultores das mais distintas formas, desde o grande latifúndio até o pequeno agricultor, se sintam donos dessa prosperidade.

Isto significa que a cultura do cooperativismo e sua difusão serve também como um importante mecanismo do agronegócio: ocultar as desigualdades entre esses produtores, que vai desde o trabalhador do campo que fornece matéria prima como aviários e pocilgas, até a mão de obra dos filhos que, via êxodo rural, migram para a cidade e tem nos frigoríficos alternativas de trabalho, quando não lhes são oferecidas outras possibilidades no sistema produtivo.

Corroborando com a ênfase na localização estratégica da região agroindustrial no Paraná, Donda júnior (2002, p. 57) infere que o Estado “[...] oferece uma base sólida para a agroindústria. O território paranaense reúne as condições ideais para a realização de todo o processo do agronegócio - desde a produção de matéria-prima até o processamento, que gera produtos finais com alto valor agregado". Além disso, o Estado do Paraná possui disponibilidade de mão de obra que encontra-se ociosa e realizando trabalhos sazonais, haja visto a desindustrialização como uma característica dos Municípios menores. Grande parte da população é empregada no setor de serviços, e os frigoríficos tem se constituído num importante incorporador dessa mão de obra. Uma região não servida por indústrias de grande porte, ou quando elas existem se limitam aos frigoríficos, gera uma reciprocidade de sentimentos voltados para a gratidão da população junto a essas empresas, e essas por sua vez, estariam apenas cumprindo com as suas responsabilidades para desenvolver regiões carentes de industrialização, gerar emprego, e renda.

O lucro e a exploração do trabalho ficam evidentes no rechaço dessa mesma população, que não age contra esses empreendimentos que possuem as formas mais degradantes de trabalho e são, atualmente, verdadeiras carnificinas humanas, que adoecem e descartam números expressivos de trabalhadores. Dessa forma, os frigoríficos vinculados às cooperativas são associados ao conceito equivocado de cooperativismo e não tem gerado manifestações mais relevantes se não o rechaço a esse tipo de trabalho quando isso é possível, o que tem provocado uma das mais significativas rotatividades de mão de obra entre todos os setores produtivos do Brasil.

Desde as últimas décadas do século XX, a ampliação do consumo de carne branca, considerada mais saudável, foi a propulsora do desenvolvimento da avicultura brasileira. Embora não tenha estudos que demonstrem a criação de aves precoces a base de hormônios e 
suas implicações, pode-se inferir que o aumento do consumo de frango não se dá a partir de uma perspectiva de ser ele saudável ou não, mas sobretudo por essa mercadoria ter sido projetada como necessidade para a população, associada à inversão de valores que afastava o consumidor do seu consumo como higiene, bem como pelo baixo valor do produto, alcançando hoje a mesa da maioria dos brasileiros (BOSI, 2016).

Nesse contexto, destacam-se na produção os Estados localizados ao Sul do Brasil, os quais disputam a hegemonia no setor econômico.

O setor de processamento de matérias-primas, como frigoríficos, coloca-se como atividade do setor agroindustrial, sendo responsável pela incorporação de trabalhadores no Paraná. Diante da escassez de mão de obra nacional, empresários ligados a esse ramo empreenderam a busca por trabalhadores haitianos que estavam disponíveis na fronteira a partir de 2010. Por isso, esse setor é o principal incorporador da mão de obra de imigrantes no Estado, em especial em Cascavel.

A imigração de haitianos em Cascavel, em um primeiro momento, ocorre por meio da mobilidade interna entre a cidade de Brasileia, na fronteira do Acre, com o Município de Cascavel, região Oeste do Paraná e, posteriormente, por redes de apoio.

A partir de 2012, o fenótipo negro, característica física dos haitianos, com uma linguagem diferenciada, vestes e roupas coloridas, tomara conta de Cascavel. Os haitianos estão pelas ruas, nos supermercados, nos pontos de ônibus, em todos os lugares. Eles dão vida e agregam cultura a uma região ideologicamente marcada pela colonização planejada, formada por descendentes de italianos e alemães advindos do Sul do Brasil, e por migrantes de outras regiões do país.

Ao caminhar pela cidade, sobretudo nos bairros onde reside parte significativa deles, se misturam com mais frequência a população com as mulheres empurrando carrinhos, homens ou mulheres conduzindo as crianças para as escolas e centros públicos de educação infantil, conversas em creole, risadas altas, pois se expressam na língua materna sem que o brasileiro consiga compreender o que falam.

De acordo com Castles e Miller (2004), as características físicas das minorias étnicas envolvem os fenótipos, a origem ou cultura, e são marcadamente estereotipadas, uma vez que são subordinadas aos grupos dominantes da sociedade.

Foi por meio da perseguição a essas diferenças que comecei como pesquisadora a chegar aos primeiros haitianos em Cascavel, e dessa forma proceder as primeiras entrevistas em seus ambientes de moradia. A pesquisa de campo, como já relatado ocorreu no final de 
mês de abril e se estendeu durante todo o mês de maio de 2017, terminando em junho desse mesmo ano.

Nessa época do ano, o estado do Paraná começa a registrar baixas temperaturas, como a do dia em que realizei a primeira entrevista, na casa de uma família haitiana. A conversa se deu com Djeme, imigrante haitiano. O contato ocorreu por intermédio de um brasileiro, conhecido e residente do mesmo bairro.

$\mathrm{O}$ frio acarretou no convite para adentrar na primeira moradia visitada. Então, comecei a conhecer as formas de habitações dos haitianos denominadas pela literatura como coletivas. Essas residências hegemonicamente caracterizadas por pequenas habitações padronizadas, conhecidas como quitinetes que abrigam várias pessoas. $\mathrm{O}$ elevado preço dos alugueis, o desemprego entre eles, o baixo salário e a necessidade de juntar pecúlios para enviar como remessas para o Haiti, justificam as moradias precárias no sentido do pouco espaço dividido.

Essas formas de habitação são frequentemente registradas pela mídia local que tende a misturar situações de preconceito racial e a precarização das moradias. Conforme Eberhardt (2017), uma das situações relatadas e veiculada pela mídia local foi a de nove haitianos residentes como inquilinos de dois apartamentos em um dos bairros da cidade e a coerção pelo proprietário ou síndica do prédio, que pressionavam para que as moradias fossem desocupadas pelos inquilinos imigrantes.

Tratava-se de um agente penitenciário, o qual não se sabe ao certo se era vizinho ou o próprio proprietário, e a intimidação era feita com a utilização de arma de fogo. "Ele teria 'visitado' os estrangeiros, com uma arma em punho, e determinado que eles deixassem o edifício, se não seriam mortos ou seriam colocadas drogas ilícitas no apartamento para incriminá-los" (EBERHARDT, 2017, p.162).

A síndica do edifício também teria se envolvido no caso, desligando o fornecimento de gás dos apartamentos para impossibilitar a estadia dos haitianos. Ambos foram autuados pelo crime de racismo (EBERHARDT, 2017).

Situações como essas não foram encontradas na amostra entrevistada, haja vista que visitei diversos conglomerados de quitinetes construídas em um mesmo loteamento e alugadas apenas para haitianos.

As visitas permearam alguns bairros do Município de Cascavel, como o Faculdade, Coqueiral, Cancelli, Morumbi e Alto Alegre, locais de realização da maior parte das entrevistas. $\mathrm{O}$ acesso às moradias, geralmente quitinetes, permitiu compreender a profundidade das relações sociais entre eles. A escolha dos bairros seguiu a metodologia bola de neve, onde os entrevistados indicavam outros haitianos para compor a pesquisa, que 
residiam nos bairros mencionados acima. Além disso estudos como de (Herberhardt,2017) e Manica (2018) apontam alguns desses bairros como os mais habitados pelos haitianos em Cascavel.

Essas relações superam os espaços internos das quitinetes compartilhadas, e se dão nos espaços externos a elas, como uma necessidade de interação e contato. Assim, as relações sociais comumente são reproduzidas nos quintais de espaços coletivos, onde era possível observar a existência de um ambiente para cuidar da aparência, com homens se barbeando, cortando o cabelo e mulheres fazendo penteados. Além do mais, havia rodas de conversas, jogos de baralho, músicas haitianas e muitas risadas, demonstrando a felicidade e a reprodução cultural tal qual no Haiti.

Ao adentrar em suas casas, deparava-me com o preparo de comidas típicas do Haiti ou ao estilo brasileiro, o que demonstra a identidade em processo, dada à possibilidade de encontros entre as diferentes culturas. Esses eram momentos que constituíam o que Martins et al. (2014) denominaram de "pequenos Haitis", com a reprodução da cultura, hábitos, língua e tradições.

Setton (2002), ao estudar a socialização das formações modernas, observou a pluralidade e multiplicidade de relações dadas nesse espaço, que "Pode ser considerado um campo estruturado pelas relações dinâmicas entre instituições e agentes sociais distintamente posicionados em função de sua visibilidade e recursos disponíveis” (SETTON, 2012, p. 2).

A pesquisa de campo revelou como são simples e humildes a maioria das casas, moradias compartilhadas. Mas também mostrou a reafirmação da identidade coletiva, ou do que Bourdieu (1983) conceituou como habitus.

[...] um sistema de disposições duráveis e transponíveis que, integrando todas experiências passadas, funciona a cada momento como uma matriz de percepções, de apreciações e de ações, e torna possível a realização de tarefas infinitamente diferenciadas, graças às transferências analógicas de esquemas, que permitem resolver os problemas da mesma forma, e às correções incessantes dos resultados obtidos, dialeticamente produzidos por esses resultados (BOURDIEU, 1983, p. 85).

A imagem abaixo descreve quase uma outra cidade. Quando há momentos compartilhados pelo grupo, forma-se um bairro no interior do bairro e da cidade, cujas moradias apenas podem ser atribuídas aos haitianos devido à presença destes, entrando ou saindo pelo portão. Esta imagem apresenta a característica da maioria das casas visitadas, e 
foi feita em uma terça-feira do mês de maio no período da manhã, com registro de baixa temperatura.

$\mathrm{Na}$ companhia de um vizinho e morador de um dos bairros mais habitados por haitianos em Cascavel, realizei as primeiras visitas, intermediadas devido à familiaridade entre ele e os imigrantes.

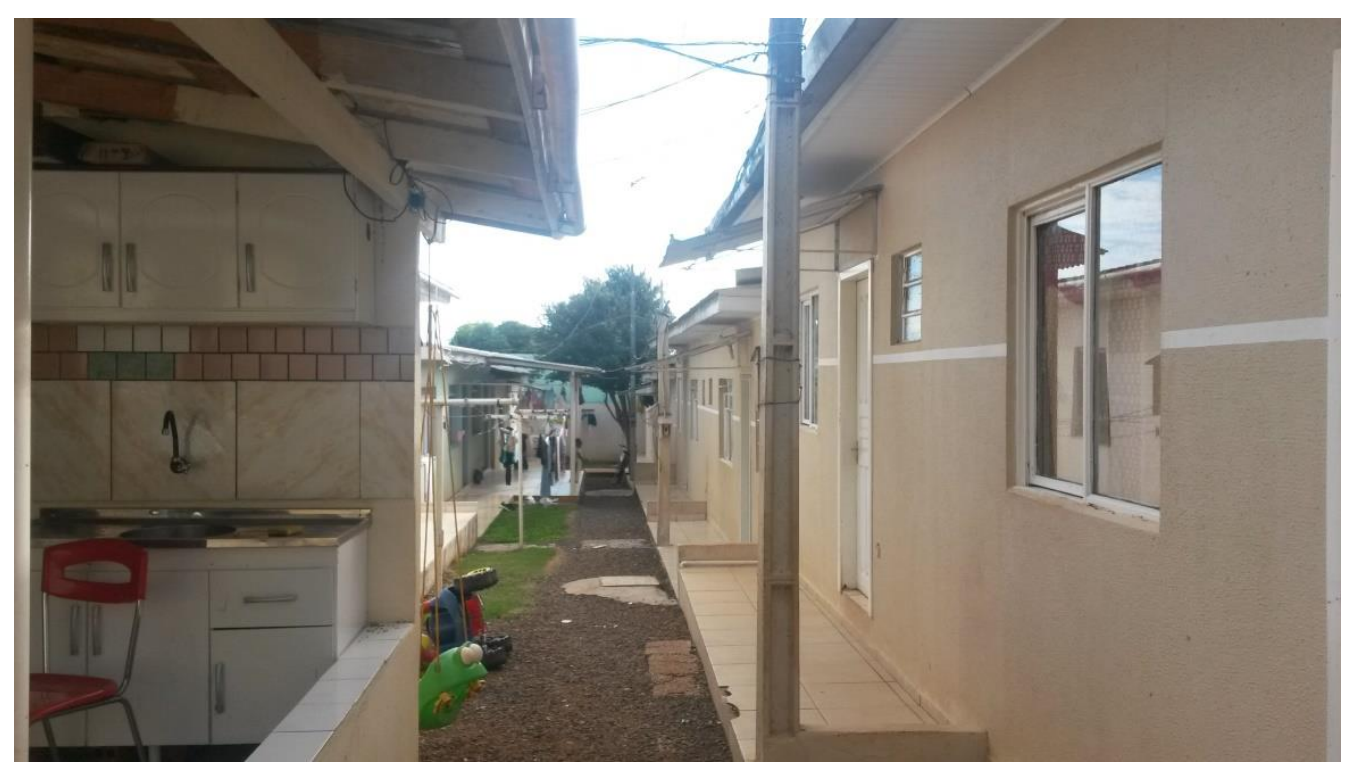

Foto 2- Quitinetes habitadas por haitianos em Cascavel. (Foto: Claudimara C. Bortoloto).

O espaço acima representa as moradias padronizadas ou pequenas habitações que abrigam centenas de haitianos vivendo em um mesmo espaço, e é uma realidade entre grande parte dos entrevistados.

As visitas realizadas em outros momentos, como final do dia ou final de semana, revelaram outras imagens. Esses eram períodos marcados pela partilha, o que transforma a aparência física das quitinetes, homogêneas e padronizadas, a partir da manifestação da cultura e modo de viver dos haitianos. A diversidade cultural, a comida, e outros aspectos impõem um estilo inusitado ao típico cascavelense, geralmente reservado e individual. 


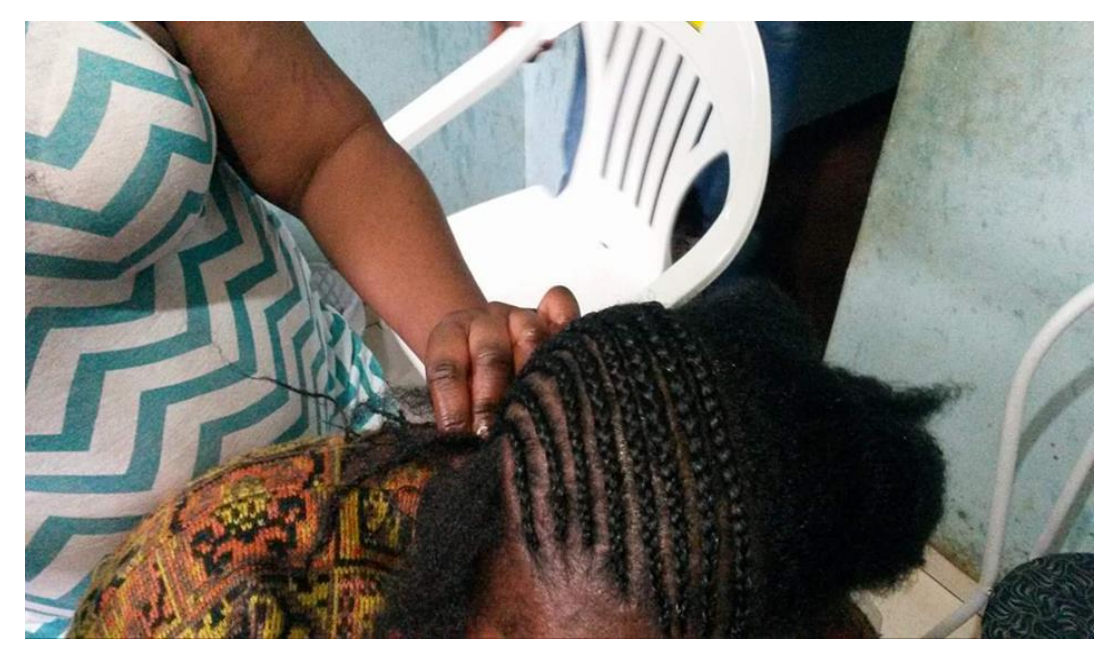

Foto 3 - Penteado haitiano penyen ti très lage antrelase. Foto (Claudimara C. Bortoloto)

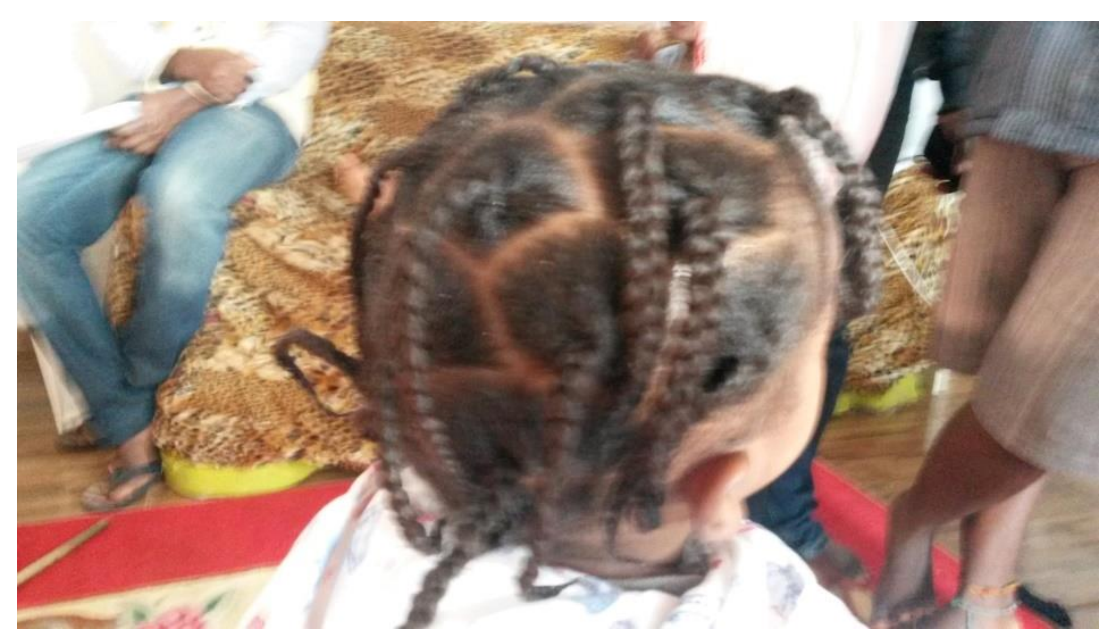

Foto 4 - Penteados haitianos: penyen ti kouri. (Foto: Claudimara C. Bortoloto)

Esses locais habitados por haitianos, geralmente, não são alugados por brasileiros. A vizinhança com os nativos é sempre o terreno do lado. De todos os lugares visitados, em apenas um pude perceber a presença de brasileiros, convivendo e vizinhando no mesmo terreno com haitianos. Isso certamente porque se tratava de um bairro universitário. Porém, era um local com poucas famílias haitianas, devido à proximidade dessas moradias com a maior universidade pública da cidade, e a consequente elevação do preço dos aluguéis, reflexo da especulação por localidade e ampla demanda por estudantes.

Se, por um lado, as quitinetes podem representar preconceito ou alguma forma de exclusão social, por outro, propiciam laços de identidade com plena reprodução da cultura haitiana, dada pela interação entre os imigrantes fora do Haiti.

Isso faz desses espaços uma extensão daquele país, o que certamente não se reproduziria com a presença de brasileiros mais reservados convivendo no mesmo ambiente. 
Ao dialogar com Wacquant (2004), Eberhardt (2017) busca a definição de ghetto que, para esse autor, pode ser entendido como uma formação socioespacial culturalmente uniforme, constituída por meio do banimento forçado de uma população para um território específico, ao passo que se configura também como uma forma especial de violência coletiva concretizada no espaço urbano.

Nessa mesma direção, porém apontando o caráter contraditório dessas formas de isolamento coletivo, Castles e Miller (2004) ressaltam os fenômenos de isolamento étnico como a formação dessas minorias, que dado aos seus efeitos contraditórios, podem se traduzir em marginalização e exclusão social; ou como uma resistência de grupos para manter e reproduzir sua cultura em um ambiente diferente do de origem. Ambas sensações nos permitiram ser sentidas quando adentramos esses espaços coletivos, e nos deparamos com a ausência de brasileiros compartilhando delas, ou pela liberdade de reprodução cultural permitidas pela integração entre essa nacionalidade. Para esses autores, uma minoria étnica é um produto da indefinição baseada na heterodefinição ou autodefinição. O primeiro termo se relaciona com a descrição de características indesejáveis e atribuição de posições sociais inferiores pelo grupo dominante; ao passo que o segundo diz respeito à consciência e pertencimento do grupo.

A força relativa desses processos pode variar, e, muitas vezes, algumas minorias se constituem, sobretudo, pelo processo de exclusão.

El concepto de minoria étnica implica siempre certo grado de marginalización o exclusión, lo que lleva a situaciones de conflito real o potencial. Es raro que la etnicidad sea un tema de importância política cuando se trata de un simple tema de prácticas de diferentes grupos (CASTLES E MILLER, 2004, p. 47).

$\mathrm{Na}$ perspectiva da autodefinição ou no que se refere a um dos efeitos de reconhecimento e identificação de um grupo étnico, os autores enfatizam o conceito de etnicidade como um fenômeno mundial. Todos os povos no mundo a possuem, definida como sentido de pertencimento a um grupo baseado nas origens, história, cultura, experiência e valores compartilhados ${ }^{21}$. Mas ter identidade étnica não significa que a consciência étnica e a cultura dentro de um grupo sejam estáticas e homogêneas.

\footnotetext{
${ }^{21}$ Pude experimentar a etnicidade e seu significado quando estive vivendo por um período de cinco meses no ano de 2017 em Madrid na Espanha. Embora ocorresse o contato com muitos espanhóis geralmente em espaços formais como a Universidade, a identificação ocorria com os brasileiros e mexicanos. Talvez fossem três formas
} 
A identidade se diferencia da raça. É um processo real de individualização histórica, que envolve as raízes, as práticas linguísticas e culturais transmitidas de uma geração para outra, no sentido da formação da identidade coletiva. Esses processos estão sempre em transformação, inexistindo identidade estática. Conforme os autores, "En esta aproximación, la etnicidad no es un asunto de opción, es algo presocial, casi instintivo, en lo que se nace" (CASTLES E MILLER, 2004, p. 48).

Ribeiro (1995) denomina identidade étnica de identidade nacional, não configurada num sentido de fortalecer padrões nacionalistas e xenofóbicos, mas do compartilhamento de valores comuns que faz com que um povo se reconheça em qualquer parte ou território. É um sentimento comum que no caso do brasileiro se vincula ao pertencer àquela cultura independente de onde ele esteja, é o domínio da língua, dos valores, de elementos culturais compartilhados por toda população de um território.

Por outro lado, embora esse não seja o propósito de muitos autores que tratam sobre a identidade étnica, quando ela gera sentimentos de pertencimento por compartilhar aspectos em comum, ela pode tender à segregação daquele que não faz parte e não compartilha desses valores, e ser inclusive usada como defesa da preservação dessa identidade, via reprodução de valores excludentes, racistas e xenófobos. A segregação não ocorre vinculada apenas às questões étnicas e raciais, mas, sobretudo, às condições materiais de existência, que inviabiliza meios para estar e compartilhar dos mesmos espaços de socializações dos nacionais.

Por sua vez, a identidade étnica é denominada por alguns antropólogos, conforme os autores Castles e Miller (2004), de identidade situacional. Isso acontece quando, em certas circunstâncias, os membros de um grupo específico decidem invocar a identidade como um critério de autoidentificação. Algo que ocorre, sobretudo, quando se deparam com situações de segregação, preconceito e exclusão. Por assim ser, a identidade étnica tem um significado social e político.

A etnicidade somente adquire significado social e político com a vinculação entre estabelecimento de fronteiras entre os grupos dominantes e as minorias. "Convertirse en minoria étnica no es resultado automático de la inmigración, sino consecuencia de mecanismos específicos de marginación que afectan a diferentes grupos de maneras diferentes (CASTLES E MILLER, 2004, p. 49).

de etnicidade que nos unia, a primeira por sermos brasileiros, a segunda por sermos latino-americanos e a terceiras por sermos imigrantes. 
Assim como imigrantes haitianos podem ser excluídos no sentido de não habitar ou compartilhar dos mesmos espaços de vizinhança com os nativos de Cascavel, eles produzem e reproduzem sua identidade como uma estratégia de sobrevivência fora dos seus espaços de origem.

Em muitos países de imigração, ocorre a segregação residencial, que se manifesta na separação entre a população local e os imigrantes, conceito que pode ser equivalente ao de gueto já trazido por Eberhardt (2017).

É o que acontece nos EUA, com áreas de separação entre negros e brancos e; em algumas ocasiões, entre hispanos e asiáticos. Esse fato também acontece no bairro Usera, conhecido como um pedaço da China em Madri, por abrigar a maior parte dos imigrantes chineses $^{22}$.

Clastles e Miller (2004) ressaltam que a segregação residencial ocorre principalmente com imigrantes recém-chegados, em razão da falta de redes de sociabilidade e conhecimento da localidade, e também por pertencerem aos estratos mais baixos da sociedade, em razão de estarem desempregados ou possuírem um emprego desvalorizado.

Outro fator que contribui para a segregação residencial das minorias étnicas é o que os autores denominam de discriminação dos caseiros, os quais escolhem seus inquilinos ou se aproveitam das especulações para elevar os valores dos aluguéis. De acordo com Castles e Miller (2004, p. 274), “[...] algunos se rehúsan a rentarles, mientras que otros hacen negocio con altos aquileres por viviendas miserables".

\footnotetext{
${ }^{22}$ Não sei se o Bairro Usera, em Madrid, poderia ser enquadrado como um exemplo de segregação residencial, no entanto, foi a experiência mais cosmopolita que pude experimentar, como a possibilidade de estar na China sem ir até lá. Era assim que me sentia quando morei temporariamente em um bairro vizinho ao chinês em Madrid. Me impressionava ir ao supermercados chinos e me deparar com as mais exóticas comidas e peixes à venda. Com atendimento de comerciantes que viviam anos ou mais de uma década e poucas palavras falavam em espanhol, que empreendiam seus comércios voltados para a comunidade chinesa, mas justamente por isso, atraia outras centenas de clientes de outras nacionalidades. Havia uma estação de metrô com informações em chinês, que era insignificante para o espanhol ao passo que extremamente relevante para os chineses, sejam os antigos e velhos imigrantes, além de um bairro que embora abrigasse a grande maioria de moradores oriundos da China, estava aberto e abrigava também os nativos espanhóis, assim como toda diversidade de imigrantes que o habitavam e frequentavam. A integração se revelava nesse bairro não por assimilação da cultura, tão pouco do idioma, mas pela integração, que era tanto dos chineses em Madrid, como dos espanhóis e demais imigrantes em Usera. A não assimilação da língua espanhola não fora considerado um elemento importante para permanecerem no país, no entanto, a assimilação se faz pela integração na sociedade. O bairro de Usera ou mesmo os chineses em Madrid, podem até sofrer manifestações de preconceito étnico e racial, uma atitude que infelizmente está presente em qualquer parte do mundo. Mas Usera desde seu princípio surgiu como um projeto integrador, criado pelo urbanista Marcelo Usera y Sanches que urbanizou uma grande área de terras herdadas por sua esposa na cidade de Madrid para pessoas de baixo poder aquisitivo. A história segue, e não vou aqui me adentrar a escrever como os chineses começaram a fazer parte desse projeto de urbanização, certamente os primeiros poderiam ser aqueles considerados de baixo poder aquisitivo. Uma outra pesquisa poderia destoar daqui, que agora me passa longe embora curiosa para investigar. No entanto, trago Usera, porque foi para mim enquanto imigrante por um tempo, de estar fora do meu lugar, a representação mais real de uma cidade cosmopolita, foi viver um pouquinho da China sem estar nela, sem estar no Brasil e dentro da Europa.
} 
Além da segregação residencial ser estimulada pelas condições em que são obrigados a habitar os imigrantes, elas também podem ser impulsionadas pelas práticas institucionais, com alojamentos precários, ofertados por empresas ou autoridades públicas.

En países en los que el racismo es relativamente débil, los inmigrantes a menudo se mudan de las áreas del centro de la ciudad hacia mejores subúrbios, a medida que mejora su posición económica. "Sin embargo, donde el racismo y la exclusión social son fuertes, persiste la concentración e el racismo persiste, la concentración e incluso puede incrementarse" (CASTLES E MILLER, 2004, p. 278).

Castles e Miller (2004) apontam o fenômeno contraditório da formação de minorias étnicas, que contém elementos da heterodefinición e autodefinición. Vale registrar que o peso desse conjunto de fatores pode variar de um país ou grupo para outro. Os imigrantes se concentram em lugares isolados do resto da população local, por razões econômicas e sociais, que se originam do processo migratório. Frequentemente, eles se mantêm fora de determinadas áreas devido ao racismo, mas também por desejo de se manter juntos, de maneira que possam se apoiar mutuamente, desenvolver redes de relações familiares e de bairro, além de manter idioma e cultura.

A segregação espacial é, portanto, precondição e resultado das gênesis comunitárias. Os países em que a formação de comunidades se desenvolveu de forma mais espontânea são aqueles marcados pela flexibilidade e abertura dos mercados de alugueis, baseados na ocupação do proprietário, como na Austrália, Grã-Bretanha e Estados Unidos.

Todavia, muitos imigrantes são mobilizados para áreas marginalizadas ou isoladas por fatores sociais e econômicos, realidade essa compartilhada com demais marginalizados. Por sua vez, alguns habitantes originais percebem a segregação residencial como uma ameaça para a formação de enclaves étnicos ou guetos. As áreas de concentração de grupos específicos de imigrantes são, frequentemente, focos de desavenças com outros setores marginalizados (CASTLES E MILLER, 2004).

Dessa forma, no que se refere à imigração de haitianos para Cascavel, o crescente fluxo migratório fez desse Município uma das principais cidades receptoras de haitianos. Para mim enquanto pesquisadora, a dialética do meu objeto se colocava e apresentava novamente dando mais indícios de como a realidade implica diretamente sobre o objeto pesquisado no tempo presente. A alteração da classificação do ranking do Município de Cascavel que no princípio da pesquisa era de cidade com maior número de haitianos da região Oeste do Paraná, até o final da pesquisa passou para a cidade de maior número no estado do Paraná. 
A dinâmica dialética do objeto me conduziu a alguns procedimentos metodológicos, necessários frente a uma realidade de constante mudança. Dentre esses procedimentos, destaco ser fundamental três deles, como o pesquisador ter a noção dessa característica dialética da realidade sobre o objeto. Segundo, o pesquisador deve o tempo todo estar atento às formas de como essas mudanças vão aparecendo na sociedade e, terceiro, o pesquisador necessita compreender como os fatos são narrados, apresentados e compreendidos nos mais variados ambientes sociais, desde institucionais e midiáticos como as percepções dos sujeitos.

\subsubsection{Imigração haitiana e a commodity da agroindústria de proteínas}

A realização de trabalho manual é um dos fatores que fomenta a mobilidade de haitianos para o Oeste do Paraná, contudo realizado não mais no campo, mas sob novas plantas produtivas centralizadas na produção de commodities via industrialização de proteínas. O trabalho aparece central na reprodução dos haitianos no Oeste do Paraná, uma vez que é por meio dele que se motivam novos empreendimentos migratórios e a garantia das condições de existência e reprodução da vida dos haitianos que vivem na região estudada.

Em decorrência da falta de postos de trabalho, esses imigrantes se submetem ao trabalho precário, geralmente em frigoríficos da região. Eberhardt (2017) constatou que o trabalho em frigoríficos se coloca como uma possibilidade frente à ausência de abertura de outro tipo de inserção, que ocorre não só com os haitianos, mas, sobretudo com os brasileiros.

Pode-se inferir que esse é quase que o único rechaço desses trabalhadores às formas degradantes de exploração, a fuga dela quando isso é possível. A negação de tipos degradantes de trabalho é uma constante desde os primórdios do capital, como discutido no capítulo anterior, a resistência dos trabalhadores aos princípios fordistas/tayloristas, são no século XXI reproduzidas via recusa dos trabalhadores diante de garantias de acesso a postos de trabalhos menos degradantes. No contexto atual, de redução de postos de trabalho, manter uma organização produtiva sob os moldes do fordismo/taylorismo significa ter garantido exércitos de reservas, quando demanda frequente contratação de mão de obra num contexto de desemprego crescente, com maior viabilidade e condições de extração de mais valia, quando o desemprego estrutural germina como uma característica que atinge todo sistema produtivo.

Assim, como discutido no capítulo anterior, ter trabalho já é para aquele que está inserido no sistema produtivo uma condição maior para o capital ter sobre essa mão de obra a intensificação do controle e disciplinarização, uma vez que a raridade da ocupação bem como 
as formas de racionalização fazem com que o trabalhador seja o próprio agente de controle do capital, ocultando ou afastando dele situações de rebeldia ao sistema.

Isso pode ser observado também na presença de 19 empresas do agronegócio citadas entre as 400 maiores do país localizadas no Estado do Paraná, e a evidência quase nula de qualquer ato de rebeldia do trabalho em relação as mais degradantes formas de exploração constatadas nos frigoríficos.

Dentre a pesquisa de busca dessa evidência junto aos meios de comunicação, constatou-se um único registro de trabalhadores de um frigorífico que pertence a um importante político da região com paralisação de 250 funcionários quais cruzaram os braços e reivindicaram melhores salários em 2012. (CRUZ, 2012). Há outras reportagens que evidenciam a paralisação, porém foram retiradas do ar.

Dois anos depois, outra matéria foi veiculada na mídia regional e anunciava a falência desse mesmo grupo decretada pela justiça com uma dívida de 600 milhões de reais, afetando criadores de aves, funcionários e fornecedores (G1, 2014).

Aliás, ainda, a produção vertical é outra característica também presente desde os primórdios das empresas fordistas/taylorista, com o trabalho em série, produção de mercadorias em massa, associado à produção horizontal, que se representa no domínio de todas as cadeias do processo produtivo, variando desde a criação de aves até a venda do produto final. A falência de uma cadeia produtiva com envolvimento de uma ampla gama de trabalhadores e setores tende a ser muito mais profunda com impactos diretos a diversos tipos de trabalhadores.

A criação de aves está vinculada ao trabalho de pequenos agricultores geralmente detentores de pequenas propriedades que contraem financiamentos junto às próprias cooperativas e passam a ser os criadores e fornecedores de matéria prima para os frigoríficos. Além disso, essas empresas (cooperativas) mantêm o domínio do processamento de indústrias de ração que alimenta os animais e exigem em suas cláusulas contratuais a obrigação dos criadores gerirem a produção de aves ou porcos conforme os critérios estabelecidos por essa mesma empresa captadora dessa matéria prima.

Ao estudar as mudanças no processo de acumulação de capital por meio da dinamização das indústrias com o processamento de carnes, sobretudo de aves na região, Bosi (2016) ressalta esse processo como uma manifestação das relações dinamizadas pela globalização sob os efeitos da vinculação desses frigoríficos às grandes corporações imperialistas como veremos no terceiro capítulo. Para o autor, a formação dessas cadeias produtivas centralizadas no abate de frango representa a hegemonia de algumas empresas na 
região que dominam a produção de sementes, monopolizam os empreendimentos e representam a magnitude dos monopólios na região (BOSI, 2016).

Os produtores simplesmente executam as regras, e se inserem de maneira subordinada e procedem às exigências desses monopólios, que com o capital financeiro vinculam suas pequenas propriedades à criação da principal matéria prima, que deve seguir a risca o manejo e produtividade, que se referem a determinadas formas de trabalho nos aviários ou pocilgas, respeitando as determinações que levem cada lote de pintinhos para que sejam abatidos num prazo de 40 dias.

Pequenos ajustes com a água, temperatura e ração fazem a diferença e se consubstanciam entre as técnicas de manejo.

No Oeste do Paraná, a produção vertical ${ }^{23}$ ou o monopólio da indústria de proteínas, provocou impactos profundos na falência de uma das empresas na região, como um efeito dominó, foi atingindo toda a cadeia ligada a essa organização. A Empresa mencionada é a Globoaves, que diante da falência afundou o conjunto de fornecedores, criadores e trabalhadores da rede de frigorífico que ficaram sem pagamento por um período de três meses até que a empresa solicitou judicialmente o pedido de recuperação judicial ${ }^{24}$. Frente à ausência de acordos, os trabalhadores desencadearam uma paralisação (AVICULTURA, 2016).

Não se tem informações sobre os desdobramentos dos impactos da falência dessa empresa sobre os trabalhadores, sendo que outro estudo do gênero poderia ser desenvolvido, sobretudo no sentido de identificar as dívidas e o papel do Estado na garantia de acordos via intervenção e empréstimos públicos. Também o levantamento da questão sobre a degradação das condições de trabalho nos frigoríficos e reações dos trabalhadores frente a ele, pode nos dar um universo de respostas que nos permitem vê-la como uma das consequências das transformações produtivas desencadeadas desde os anos 1970, que na conjuntura global, fez do Estado um regulamentador de leis flexíveis, de combate ao sindicalismo, fazendo deles sindicatos que representam os interesses das empresas e não dos trabalhadores. Além do desemprego estrutural, que age também como um componente inibidor frente aqueles que diante dele ainda possuem inserção laboral com proteção dos direitos sociais (ANTUNES, 2003).

\footnotetext{
23 A produção sobre os moldes do fordismo pode se definir vertical e horizontal. A primeira se refere ao domínio do capital de toda cadeia produtiva, como matérias-primas, fabricação e os transportes de seus produtos. Para reduzir os custos, a produção deveria ser em massa, e dotada de tecnologia capaz de desenvolver ao máximo a produtividade de cada trabalhador. A produção horizontal se refere ao número de centros distributivos das mercadorias produzidas, a logística para que a mercadoria chegue ao consumidor final.
} 
Diante desses fatores que ajudam a elucidar a presença da degradação sem indícios mais efetivos de resistência, quando ela se expressa no Oeste do Paraná, estão atrelados não propriamente aos trabalhadores de frigoríficos, mas geralmente se associam à paralisação de outras frações de trabalhadores cujo trabalho produz impacto direto sobre os frigoríficos, seja no deslocamento e acesso à matéria prima, ou de transporte do produto final, sem que isso se vincule diretamente aos trabalhadores dos frigoríficos ou a quaisquer trabalhadores envolvidos na produção vertical.

Nessa perspectiva, aparecem duas greves de outros setores que impactam sobre os frigoríficos, como a greve de fiscais do Ministério da Agricultura (FETERACOOP, 2012) e a greve dos caminhoneiros (G1.GLOBO.COM, 2018). Porém, no que se refere aos trabalhadores em frigoríficos, há praticamente uma ausência de matérias que noticiam.

Além disso, os frigoríficos são indicados como o tipo de empresa com o maior número de ocorrências de acidentes de trabalho, com baixos salários e trabalhos degradantes. A identificação desse aspecto não fora até o momento suficiente para que o Estado brasileiro imponha normas mais rígidas de proteção ao trabalho. Existe, portanto um sistema produtivo que gera indiscriminadamente o adoecimento de trabalhadores sob o julgo legalizador do Estado, que não pune as empresas geradoras de doentes.

Cêa e Morofusi (2010) ao estudarem as principais formas de acidentes de trabalho em frigoríficos se vinculam às doenças ocupacionais oriundas da exposição de um trabalhador a um acima do permitido por lei a agentes físicos, químicos, biológicos ou ergonômicos sem proteção adequada com o risco envolvido. Assim o trabalho realizado no chão dos frigoríficos investigado apresentaram as seguintes características: repetitividade de movimentos; invariabilidade do trabalho; uso de força física; ritmo de trabalho imposto pela máquina; posturas inadequadas; trabalho muscular estático; pressão mecânica; exposição a temperaturas altas e baixas (dependendo do setor); convivência com odores fortes; barulho excessivo; contato com ambientes úmidos por longos períodos de tempo como chão e mesa de trabalho, manuseio de instrumentos pérfuro-cortantes. Soma-se a essas características a pressão por produtividade exercida por funcionários responsáveis em fiscalizar a produção sobre os demais trabalhadores, que interfere na motivação e atitude comportamental, podendo afetar até mesmo sua saúde mental. Dessa forma, para essas autoras, a intensificação do ritmo e intensidade de trabalho, associadas às formas de organização da produção orientadas para a máxima produtividade, faz com que a incidência de acidentes e doenças do trabalho se agrave

\footnotetext{
${ }^{24}$ Essa mesma empresa voltou a operar suas atividades com abate de frango em janeiro de 2017.
} 
no país ao longo da segunda metade do século XX. Nesse contexto, as lesões por esforços repetitivos (LER) passaram a figurar os principais agravos à saúde dos trabalhadores (CÊA E MOROFUSI, 2010).

Enquanto essas empresas adoecem os trabalhadores, o Estado ao interferir na preservação dos direitos, é interpretado como um agente que ao fazer isso se coloca como um obstáculo à produção industrial e ao desenvolvimento do país, aceita sem punições maiores as empresas e a sua produção indiscriminada de doentes. Ao Estado, cabe, a responsabilidade de cuidar desse trabalhador, garantindo mínimos sociais de assistência enquanto a esse sistema produtivo resta substituir o doente por um trabalhador saudável que tenderá a apresentar em períodos posteriores os mesmos problemas de saúde.

A gênese das vagas de trabalho disponível nesses frigoríficos está intimamente relacionada com a rotatividade, o que na maioria das vezes não significa o surgimento de novas vagas de trabalho, mas sim de outros trabalhadores que são incorporados em um sistema de adoecimento. A reposição ou real criação de novas vagas poderiam aclarar e trazer à tona esclarecimentos sobre o verdadeiro "êxito" do setor na geração de emprego e renda, tão bem anunciados como protagonistas do desenvolvimento na região, quando na verdade intensificam o peso das doenças e discapacidades dos trabalhadores para o Estado, ficando com o lucro propiciado por um exército de reservas cada vez maior com imigrantes disponíveis e desempregados que surgem da reestruturação produtiva.

Por sua vez, outro estudo poderia ser empreendido junto aos dados do ministério do trabalho e INSS sobre o adoecimento e os prejuízos que esses frigoríficos dão ao Estado quando geram trabalhadores doentes, haja vista a conivência estatal de não fiscalizar e impor normas rígidas para coibir o pleno adoecimento de trabalhadores submetidos a esse sistema produtivo.

Ser indiferente a essa situação é uma posição do Estado, que age como mero fiscalizador, abrindo condições via desburocratização das relações de trabalho, de forma a fazer do trabalhador um mero apêndice da máquina, sem a mínima proteção do Estado enquanto prevenção diante da carnificina de doentes geradas por esse sistema produtivo. Sobre esse aspecto, será enfatizado no próximo capítulo.

Contudo, no que tange à imigração do Oeste do Paraná significou, no primeiro momento, a guarda ou segurança do território nacional, ao mesmo tempo em que construía a imagem do "outro", habitante nativo da região. Os imigrantes haitianos contrastam com o elemento ideologicamente "selecionado" de descendência europeia. Eles são desejados, mas 
sob a égide do capital, que demanda sua força de trabalho no contexto da reorganização do agronegócio, com o processamento de alimentos.

Além do contexto de inserção dos frigoríficos no sistema global como um desdobramento dos monopólios agrícolas, a região se insere como já relatado pela exportação de grãos, além da demanda de mão de obra internacional que fez dos haitianos o segundo maior grupo de trabalho depois dos brasileiros, bem como a exportação de carne para várias regiões do mundo. Nessa perspectiva, destaca-se nessa pesquisa a projeção internacional com ampliação de exportações no contexto da projeção estatal que por meio de financiamentos públicos através do Banco Nacional do Desenvolvimento - BNDES, que, via dinheiro público, garantiu a projeção internacional dessas empresas. O Estado, além do ônus de assistir e assegurar os milhares de doentes produzidos pela indústria da carne, ganha nesse contexto papel central para impulsionar essas empresas em âmbito internacional.

Nesse sentindo, é inviável saber ao todo qual a importância do BNDES para projetar todas as denominadas "Cooperativas" ligadas ao ramo do agronegócio da região, no entanto, é certo afirmar que o setor de frigoríficos foi o mais beneficiado pelos investimentos desde o primeiro mandato do governo Lula, como discutido posteriormente. Assim, com intuito de verificar esse impacto no frigorífico que aparece nessa pesquisa como o maior empregador, foi realizada uma busca desses dados extraindo as relações do capital financeiro entre esse banco e a Coopavel, para por meio dessa relação demonstrarmos os efeitos dela e do sistema financeiro e produtivo na região.

Embora o Frigorífico Coopavel não apresente até o momento dados de uma possível expansão internacional no sentido de ter sedes produtivas em outros países, essa internacionalização existe sob duas perspectivas, uma que permite a expansão das exportações dos produtos, e outro pela contratação ainda em solo brasileiro de imigrantes para o processo produtivo.

A reprodução dessa explicação se faz sob uma base teórica denominada capitalismo de laços, que explica por meio das relações entre o Estado e alguns empreendimentos nacionais os meios que delinearam os investimentos públicos e a projeção internacional de empresas brasileiras. Dessa perspectiva teórica cabe questionar até que ponto os elevados fundos públicos contraídos fazem realmente desses empreendimentos empresas privadas?

No contexto das projeções internacionais, os frigoríficos aparecem como um dos ramos de maior investimento estatal. Não é à toa, que a assimilação de tecnologias para inovação produtiva tem esse ramo como um dos que a mais incorpora, embora seja como assimilação, como discutido no capítulo anterior. Essa assimilação de inovações tecnológicas 
que permitem a competição dessas empresas no mercado se faz com financiamento estatal, condição sine qua non para manter e viabilizar o grande boom do agronegócio nas últimas décadas.

Dessa forma, dados da projeção internacional quando se refere ao frigorífico Coopavel, mais uma vez justificado por aparecer como principal incorporador de mão de obra haitiana na região, foi focado como um dos ramos mais beneficiados, bem como da importância dessa rede se dinamizar na região, ao mesmo tempo que amplia sua produtividade sem superar o modelo fordista/taylorista, com investimento público, bem como via incorporação de mão de obra estrangeira.

Lazzarini (2011) buscou responder a seguinte pergunta: como se iniciou o grau de entrelaçamento societário do Estado a partir das primeiras privatizações em 1996 com o governo de Fernando Henrique Cardoso? A sabedoria convencional, denominadas de críticas ao neoliberalismo levaria a análise de que há uma diminuição do Estado, sobretudo a partir dessa década, quando o sistema produtivo é liberado, no entanto conforme o autor, esse saber convencional ou essa teoria crítica do neoliberalismo está equivocada.

Para ele, a aglomeração de novos atores entre os acionistas chegou em 2009 a um terço superior do que foi em 1996, consolidando o que o autor denomina de capitalismo de laços, viabilizado por meio da participação do Estado na hegemonia desses novos atores. Lazzarini (2011) ressalta que o Estado passa a ser um dos maiores acionistas dessas empresas internacionalmente projetadas. Para isso, ampliou a hegemonia desses grupos a partir de dois braços estatais, os Fundos de Pensões e o BNDES.

Houve então uma ampliação direta da participação do governo na economia, aumentando seu controle sobre o processo produtivo. Se utilizando de Raimundo Faoro, o autor vai justificar que os verdadeiros donos do poder são aqueles que conseguem inserir e articular uma rede de laços corporativos entre distintos grupos. Essa definição amplia para o autor o efetivo controle do Estado no processo produtivo na mesma proporção que ampliou o grau de influência de alguns setores nacionais, sem incremento significativo da participação de estrangeiros na economia, tranquilizando a principal ideia sobre o neoliberalismo e seus efeitos no Brasil desde os anos 1990.

Essa teoria em voga, como já discutimos no primeiro capítulo, e, sobretudo, enfatizado nesse trabalho, foi uma das fases constituidoras da globalização. Isso foi procedido na prática com a regulamentação de legislações que favoreciam a compra de ações estatais por empresários brasileiros, a exemplo citado pelo autor como o caso da Telebrás. Para o pagamento de valores acima do mercado, o governo subsidiou empresas brasileiras por meio 
do consórcio de Fundos de Pensões e financiamentos contraídos junto ao BNDES, o que fez com que a privatização fosse viabilizada com recursos públicos.

Dessa forma, por meio desses dois mecanismos principais, a ação estatal foi possível, e sua principal característica visou privilegiar o produtor, com um modelo diferenciado da hegemônica produtiva liderada pelos Estados Unidos, e já praticada pelos governos japonês e coreano nos anos 1970 e iniciado no Brasil nessa mesma década com um programa de governo denominado de milagre econômico.

O emaranhado de contatos entre empresas privadas brasileiras com interesses políticos e econômicos via utilização de fundos públicos para valorização do capital nacional e projeção dessas empresas em âmbito internacional foi denominado por Lazzarini (2011) de capitalismo de laços. Essas são relações próximas e íntimas entre os membros do governo e empresários. Um dos exemplos dado pelo autor é a estreita relação entre o então presidente Lula e um dos principais acionistas da empresa Vale do Rio Doce no Brasil, Eike Batista, que se beneficiou da política de Lula para expandir o processamento de minérios no Brasil, para então vender no mercado internacional com produção de valor agregado, bem como para promover sua empresa via preparação da infraestrutura para copa do mundo de 2014.

Em troca disso, ao mesmo tempo que o empresário se projeta em âmbito nacional e internacional sob o auspício do governo via fundo de pensão e financiamento do BNDES, reverteria para o próprio Lula generosas doações para sua campanha eleitoral, assim o laço é determinado e compreendido por Lazzarini (2011) como a relação entre atores sociais com fins econômicos, sendo essas relações sociais que influenciam determinações econômicas.

Essas relações entre capital privado e público via financiamentos contraídos ou investimentos públicos são consideradas positivas para os investidores uma vez que elas os beneficiam e os protegem em situações desfavoráveis, além de diminuir os custos dos negócios que muitas vezes sem esses financiamentos seriam irrealizáveis.

A privatização não era bem vista no Brasil e dever-se-ia convencer da sua importância e quem ganharia com os valores das vendas de estatais. Foi assim que o BNDES tornou-se não só um banco envolvido na venda das estatais, mas também um dos maiores investidores, em algumas situações. Ao mesmo tempo em que vendia, promovia o recurso para que investidores privados a comprasse, o que para Lazzarini (2011) mantinha a centralidade do Estado na Economia. A outra estratégia, além do BNDES, foi desenvolver uma classe de investidores já despontada, a qual iria disputar a partir de lobby político e, dessas representações de classes, as licitações para as vendas das empresas, a fim de impor maior 
concorrência com o capital internacional e conforme os privatistas valorizar o preço das estatais jogando-os para cima.

\begin{abstract}
Adicionalmente, e não menos importante, a feição pública dos fundos parecia se encaixar como uma luva nos propósitos do governo. Normalmente geridos por profissionais eleitos por colegas das próprias estatais e outros executivos apontados pelo governo, os fundos de pensão apresentavam íntima associação com sindicatos e associações de funcionários. Assim, seriam uma espécie de ator híbrido, um representante dos servidores públicos como partícipe ativo na arena capitalista, um novo ponto focal entre governo e investidores privados que, de súbito, veem nesses fundos o "mapa da mina"- para usar a expressão do sociólogo Francisco de Oliveira no seu ensaio "O ornitorrinco" (cujo título não poderia ser mais apropriado para descrever a estranheza dessa mistura entre classe trabalhadora e mercado) (LAZZARINI, 2011, p. 62).
\end{abstract}

Para viabilizar o maior incremento de empresas domésticas e o estilo piramidal das redes de consórcio, ou empresas que participariam da compra de ações de empresas brasileiras, foi realizada a privatização por blocos, o que contribuiu para que investidores nacionais com empréstimos públicos e empresas nacionais como BNDES e PREVI se tornassem maiores participantes em detrimento do capital estrangeiro.

Os consórcios nacionais para a compra de estatais privatizadas representam o que o autor denomina de globalização como um fenômeno local, ou o próprio fortalecimento do capitalismo de laços. Esse foi também um dos fenômenos que fez com que os impactos da crise de 2008 não fossem tão sentidos no Brasil, já que houve uma maior integração entre o capital nacional via governo no controle do desenvolvimento do capital no país, o que o protegeu de maiores sequelas da crise de 2008 (LAZZARINI, 2011).

Ainda segundo Lazzarini (2011), os fundos de pensão ${ }^{25}$ foram e são em qualquer governo instrumentos políticos dos governantes. As empresas privadas tiveram que estabelecer suas relações com o emaranhado grupo nacional através do associativismo. Isso ocorreu tanto no governo de FHC como no governo Lula, sendo que o primeiro impulsionou as privatizações e maior participação do Estado nelas, e o segundo serviu-se das relações mundialmente estabelecidas e se fortaleceram com as ações do sistema público já envolvidas nas corporatizações.

No governo Lula, as estruturas estabelecidas no período anterior serviram de canais de influência no mundo corporativo e se multiplicaram devido à ação

\footnotetext{
${ }^{25}$ Fundo de pensão é uma fundação ou uma sociedade civil que gera o patrimônio de contribuições de participantes e patrocinadora com o objetivo de proporcionar rendas ou pecúlios. No Brasil são denominados de Entidades fechadas de previdência complementar.
} 
mais intensa de entidades públicas como o BNDES. Alguns grupos privados nacionais que entenderam essa dinâmica e se engajaram em extensas alianças com o capital público acabaram, a reboque, preservando ou até mesmo aumentando sua centralidade na economia (LAZZARINI, 2011, p. 76).

Há, portanto, uma conivência para o profícuo desempenho das relações do capitalismo de laços, que tem no clientelismo e no lobismo seus métodos mais eficientes. O Estado é um ponto de contato e tem a maior influência de um grupo que de outro em virtude das relações particulares e a produção das relações desiguais de influência. A maneira de como se dá esse grau de contato ou influência dos grupos privilegiados pelo governo pode se realizar de diversas formas.

Lazzarini (2011) aponta como uma delas, além das redes de propriedade como a formação de setores públicos e privados, a participação de determinados empresários no governo de forma a ocuparem posições estratégicas, e vice versa, permitindo também que políticos possam ocupar posições estratégicas em empresas e serem membros de seu conselho. A relação do capitalismo de laços se favorece das relações clientelistas, e há um universo de benefícios para políticos que se utilizam do Estado e dessa vinculação entre público e privado para se promover. Assim como de empresas privadas que são igualmente beneficiadas por essa relação de troca de favores, seja por desenvolver obras públicas, ou por beneficiamento de sua indústria pelos serviços públicos, como por exemplo, a diminuição de custos do agronegócio via favorecimento com infraestrutura que garante a distribuição de seus produtos para regiões centrais. Essas vantagens do sistema público têm sido conforme Lazzarini (2011) distribuídas por meio de acordos como doações para campanhas de políticos.

\begin{abstract}
A relação clientelista é evidente: doações de campanha em troca de benefícios diretos ou indiretos a empresas privadas. Pouco importará se o projeto proposto for efetivamente executado ou não, ou se for executado com a lisura necessária. Pelo contrário: quanto maior o superfaturamento do investimento público, maiores as chances de o político conseguir desviar recursos - o montante que exceder o custo real do projeto - para financiar sua campanha eleitoral. Em vez de receber 100, a empresa ganha $150 \mathrm{com}$ um projeto superfaturado e repassa parte desse diferencial (50) para o candidato. É o popular "caixa dois" (LAZZARINI, 2011, p. 82).
\end{abstract}

Declarado, no entanto, a avaliação da empresa doadora no mercado tem valorização de 2,8 quando os políticos venciam as eleições, e 3,8 se o financiamento tivesse vinculado ao executivo vencedor. 
Em particular, os autores verificaram que as empresas que mais doaram a candidatos vencedores conseguiram acesso preferencial a um recurso relativamente escasso no Brasil: capital financeiro. Testes estatísticos indicaram que, nos quatro anos que se seguiram às eleições, essas firmas doadoras obtiveram mais empréstimos que outras firmas da base (LAZZARINI, 2011, p. 86-87).

Doar para campanhas eleitorais significa a garantia de empréstimos futuros ou o que o autor denomina de capital privilegiado, ou mesmo manter sua existência protelando dívidas junto ao Estado.

Os empréstimos embora tivessem parte significativa do capital privado, foram em sua maioria de bancos públicos como BNDES que se apropriou de outros fundos como:

FGTS (Fundo de Garantia por Tempo de Serviço), descontado da folha de pagamentos das empresas e canalizado para a Caixa Econômica Federal. Outro exemplo é o FAT (Fundo de Amparo do Trabalhador), parcialmente alocado para suportar as operações de crédito do BNDES e oriundo dos recursos do PIS/Pasep (contribuição social recolhida pelas empresas). Essas transferências carregam subsídios: as taxas cobradas pelo BNDES normalmente se atrelam à chamada taxa de juros de longo prazo (TJLP), que é inferior às taxas normais de mercado (LAZZARINI, 2011, p. 87).

Esse financiamento com dinheiro público de caixas estratégicos do governo causa uma profunda desigualdade entre as empresas, prejudicando, sobretudo aquelas que não conseguem acessá-los, o que torna a relação entre políticos e acesso ao crédito outro bom exemplo do capitalismo de laços. Na verdade, a racionalidade do sistema financeiro também é uma medida importante, uma vez que no contexto dessas relações o BNDES julga tal racionalidade como quesito para direcionar seus investimentos, e dentro da lógica do sistema bancário cujas ações voltam-se para a racionalidade do lucro lançadas no mercado, tem na escolha das empresas estratégias e análises de potenciais condições de competição para fazer render esses investimentos.

Mesmo as firmas de maior porte e já estabelecidas, que teriam acesso a fontes alternativas de financiamento, acabam sendo atraídas pelos subsídios embutidos em canais públicos. O capital financeiro, que em outros países é apenas um aspecto operacional na atividade empreendedora, se tornará recurso estratégico e fonte de vantagem competitiva, da mesma forma que os meios particulares para consegui-lo (LAZZARINI, 2011, p. 89-90).

Nesse contexto, é importante destacar que a criação do BNDES se vincula como um mecanismo burocrático desenvolvido especificamente para os meios privados se apropriarem 
de investimentos públicos. Nessa perspectiva é que o banco foi criado em 1952 para captar recursos públicos e investir na iniciativa privada, se apropriando legalmente de outros fundos públicos como o FGTS e o FAT, mantendo assim a lógica racional com pautas voltadas para transferência de recursos públicos para a inciativa privada.

Desde sua criação tem sido utilizado para financiar empresas que se enquadram no quesito e perfil para investimento do BNDES. Conforme Lazzarini (2011), críticos ressaltam que ele é um importante mecanismos para beneficiar determinados empresários, embora o banco justifique contar com uma equipe econômica forte para analisar que empresas serão beneficiadas.

Além desses fundos, a emissão de títulos da dívida tem sido outro tipo de fonte de dinheiro público utilizada pelo o BNDES para investir no capital privado com a ampliação da dívida social em nome do fortalecimento do capital privado. Foi assim que o governo priorizou através do BNDES a projeção internacional da JBS - Friboi, o maior contribuinte da campanha eleitoral de 2006, com destinação de 1,4 bilhões para abertura de capital da empresa em 2007, com aquisição de mais de 3,4 milhões de reais em 2010 de títulos da dívida.

O banco justifica que apoiar a empresa era uma necessidade frente à demanda de expansão internacional do grupo com a aquisição de duas grandes empresas norte americanas do setor de carnes. Fica premente que o BNDES privilegiou investir fundos públicos em determinadas empresas, como o setor de frigoríficos, em detrimento de outras. Nessa perspectiva, em uma entrevista Salomão e Godoy (2017) enfatizam sobre o destino dos investimentos do BNDES e ressaltam que o setor de frigoríficos abocanharam $80 \%$ dos valores emprestados pelo banco de acordo com a "Lei Acesso à Informação, dos quase R \$ 14,5 bilhões liberados para internacionalização de empresas brasileiras, de 2005 para cá, R\$ 11,7 bilhões - 80\% do total - foram para os frigoríficos" (SALOMÃO E GODOY, 2017, p. $01)$.

A justificativa do banco é a de investir em empresas de retorno, com boas práticas de governança e abertura de capital. As análises não contemplam quem ganha ou perde no país investindo nesse ou naquele setor, mas, simplesmente a de que o BNDES elegeu o favorecimento e a construção do que o autor denomina de campeões nacionais, ou seja, empresas brasileiras bem estabelecidas pelo globo são rentáveis e lucrativas, por isso, merecedoras de receber investimentos estatais. Quando se fala em empresas e favorecimentos estatais, a corrupção é uma discussão comum, no entanto, para os empresários doarem a 
campanhas eleitorais é um mecanismo de lidar com as relações entre governo e empresa, ou um mecanismo de defesa de ações discriminatórias ou disfunções da máquina estatal.

O autor classifica devido as maiores receitas obtidas, os 20 grupos mais influentes no Brasil. O próprio processo de admissão de empresas forasteiras e os benefícios ou entraves que elas terão no seu processo de entrada serão grandemente determinados por dinâmicas ocorridas na arena doméstica. As leis que tornarão mais ou menos fácil a entrada de estrangeiros serão definidas pelo governo e, de forma mais ampla, pelo sistema político do país. Nesse contexto, é possível que muitos grupos domésticos se beneficiem da entrada de capital internacional.

Cria-se assim um modelo de associação entre Estado, capital nacional e capital estrangeiro - um tripé discutido, de forma pioneira, por Fernando Henrique Cardoso e Enzo Faletto no seu livro Dependência e desenvolvimento da América Latina, de 1969. Aliás, conforme as interpretações de Lazzarini (2011), o germe da teoria de capitalismo de laços estaria nos pressupostos teóricos desses autores, que ainda no governo FHC começaram a ser postos em prática abrindo caminhos para a intensificação do governo Lula.

A grande contribuição dos autores, segundo Lazzarini (2011), foi qualificar a ideia de dependência ao admitir que o empresariado doméstico, ou parte dele, poderia florescer quando atrelado a alianças lucrativas com empresas estrangeiras. A teoria de Falleto e Cardozo (1969) remonta ao conceito de política de campeões nacionais, quando remete ao financiamento estatal para projeção internacional, no caso das empresas domésticas, aquelas que não aparecem projetadas internacionalmente no sentido de expansão produtiva, vinculamse na expansão de vendas de mercadorias, estabelecendo assim os laços entre público e privado.

A abordagem do capitalismo de laços de acordo, com Lazzarini (2011), coloca mais foco em interações ocorridas fundamentalmente no ambiente local, geralmente enfatizada no "tripé doméstico" com envolvimento entre governo, sistema político e grupos de empresários internos no país. A inserção de atores internacionais tende a ser exitosa quando eles interpretam seu posicionamento nesse ciclo de interações, via inserção com o sistema político, as firmas podem tanto se mobilizar de forma coletiva como por meio de relações clientelistas mais diretas.

A onda de abertura de capital das empresas do Brasil se deu com maior frequência de acordo com Lazzarini (2011) entre 2004 e 2009, e representou um novo e surpreendente fenômeno. É nessa perspectiva, seguindo a teoria desse autor, que iremos abordar como se 
efetivou uma dessas entre tantas outras transações que envolvem o BNDES e suas empresas escolhidas para a consolidação do que o autor denomina de capitalismo de laços.

Trata-se de um levantamento realizado entre o frigorífico que é destaque nessa pesquisa, e que aparece na amostra pesquisada, referenciado como contratante dos haitianos quando esses se encontram trabalhando. Assim, levantamos os financiamentos feitos pela Coopavel pelo Site do BNDES utilizando para isso o número do CNPJ dessa empresa também disponível na internet.

O período investigado remete ao ano de 2002 até 2018. Os dados nos dão uma noção desses investimentos, e de forma mais concreta podemos observar como uma política voltada $80 \%$ para o setor de frigoríficos, os quais abocanham os maiores recursos para investimento privado externo desse banco se efetiva na prática em uma das regiões que detém conforme dados divulgados por essa empresa, um dos maiores e melhores resultados lucrativos e de êxito econômico. Uma noção sobre esses valores investidos permite verificar em que medida tais investimentos correspondem à teoria de Lazzarini (2011) no favorecimento de empresas domésticas.

Embora seja um Banco nacional voltado desde sempre a financiar e prover com recursos públicos o sistema privado, o BNDES ainda é público e está submetido à Lei de Transparência, o que o obriga a disponibilizar dados para consulta de interesse público conforme a lei $\mathrm{N}^{\mathrm{o}}$ 12.527, de 18 de Novembro de 2011. Isso significa que devido à lei de transparência de qualquer órgão público, deve ter disponibilizado o conjunto de todas as operações realizadas e deixar visível para onde estão indo os investimentos públicos na área privada.

Nesse contexto, usando o mesmo procedimento de Lazzarini (2011), foi acessado o site do BNDES, com clique no link transparência, posteriormente, consulta a operações do BNDES, e no espaço consulte as operações de um cliente BNDES e por último foi digitado o número do CNPJ da empresa.

Foi dessa maneira que, seguindo os procedimentos acima, foram acessados os valores de investimentos públicos contraídos por essa empresa desde 2002, sendo essa data o período que aparece no próprio site do banco os valores contraídos. Não se pode afirmar que em período anterior a essa data não tenha havido financiamentos, no entanto, 2002 é o período que marca o registro deles.

Dentre os tipos de financiamentos, aparecem cinco operações, sendo três registros de operações disponíveis, e dois sem fornecimento de dados, conforme dados fornecidos abaixo: 


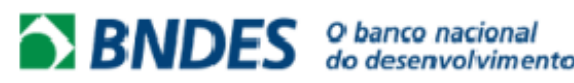

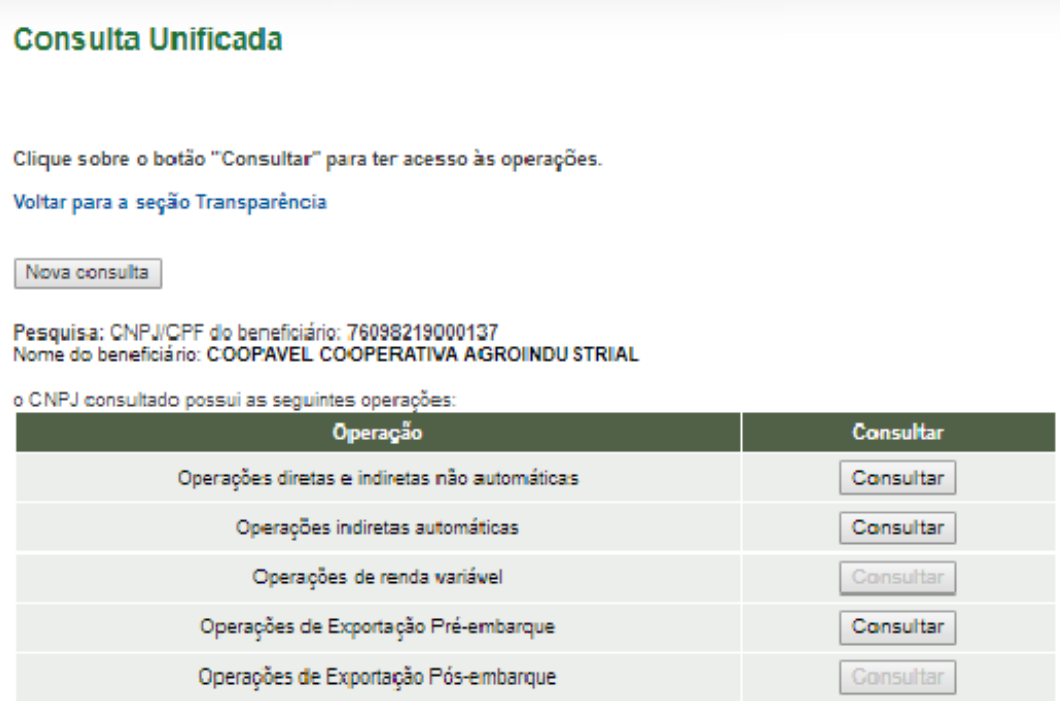

Foto 5: Operações financeiras entre BNDES e Coopavel - Fonte: (BNDES, 2018)

A primeira linha denominada de Operações diretas e indiretas não automáticas consta valores, número do contrato e investimentos feitos com o dinheiro contraído. O Financiamento indireto trata-se da utilização de outros bancos intermediários financeiros que participam dessa transação financeira, enquanto o financiamento direto se refere a contratos estabelecidos diretamente entre a empresa contratante e o BNDES, sem outra instituição bancária intermediária. Assim, ao selecionar esse tipo de financiamento indireto, percebe-se a vinculação dele a outros bancos, por isso o indireto se compreende como um elemento definidor que envolve transações financeiras entre o BNDES, outro banco e a empresa.

Ao todo a figura abaixo demonstra uma soma de $\mathrm{R} \$ 222.878 .310$ em financiamentos. Na descrição sobre os motivos não há nenhuma referência a internacionalização da empresa, no sentido de estender suas operações para outros países, uma vez que ela se limita nesse caso, a potencialização da estrutura, ou do que Antunes (2003) denomina de aspecto horizontal das empresas capitalistas, que é o domínio de toda a cadeia produtiva. 
Fesquilaa: CNPJICPF do benefliclarlo: 76058219000137

Nome do benanclarIo: COOPAVEL COOPERATIVA AGROINDUSTRIAL

Voitar

Exiblndo Operaç6es diretas $\theta$ Indiretas naso automaticas

Exportar csv

\begin{tabular}{|c|c|c|c|}
\hline Contrato & Descriçao do Projato & \begin{tabular}{c|} 
Total contratado \\
(R*)
\end{tabular} & Consultar \\
\hline 04203421 & 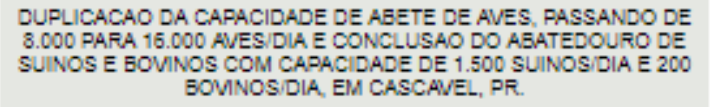 & 20.522 .310 & Coneutar \\
\hline 04203521 & 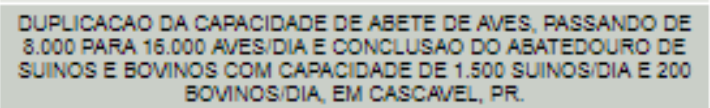 & 10.000 .000 & Coneutar \\
\hline 05211341 & $\begin{array}{l}\text { CONSTRUCCAO DE FAERICA DE RACOOES E IMPLANTACCAO DE } \\
\text { UNIDADE DE PRRODUÇAO DE LEITOES. }\end{array}$ & 10.000 .000 & Coneutar \\
\hline 05211351 & $\begin{array}{l}\text { CONSTRUCCAO DE FAERICA DE RACCOES E IMPLANTAÇAO DE } \\
\text { UNIDADE DE PRODUÇAO DE LEITOES. }\end{array}$ & 10.000 .000 & Coneutar \\
\hline 06209251 & 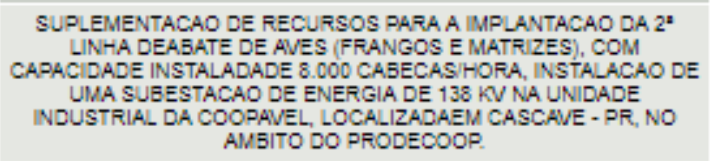 & 30.392 .700 & Coneutar \\
\hline 09204121 & $\begin{array}{l}\text { IMPLLANTACAO DE UM MOINHO COM CAPACIDADE DE } 400 \\
\text { TONELADASIDIA PARA INDUSTRIALIZARO OTRIGO DE SEUS } \\
\text { PRODUTOFES ASSOCIADOS. }\end{array}$ & 11.550 .000 & Coneutar \\
\hline 09204131 & $\begin{array}{l}\text { IMPLANTACAO DE UM MOINHO COM CAPACIDADE DE } 400 \\
\text { TONELADASIDIA PARA INDUSTRIALIZARO TRIGO DE SEUS } \\
\text { PRODUTORES ASSOCIADOS. }\end{array}$ & 10.000 .000 & Coneutar \\
\hline 13213131 & 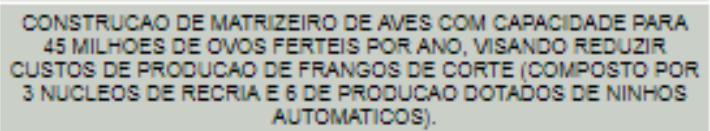 & 33.403 .000 & Coneutar \\
\hline 15202751 & $\begin{array}{l}\text { IIVPLANTACAO DE UNIDADE PROOUTORA DE LEITOES (UPL) NO } \\
\text { MUNICIPIO DE CASCAVELPR E EXPANSAO DE DOIS MATFIZEIROOS } \\
\text { DE AVES NOS MUNICIPIOS DE SANTA TEREZA DO OESTE/PRE } \\
\text { LINDOESTEIPR. }\end{array}$ & 58.965 .000 & Coneutar \\
\hline 18201981 & $\begin{array}{l}\text { AMPLIACAO DA CADACIDADE INSTALADA DE AEATE DE SUINOS DE } \\
\text { UNIDADE INDUSTRIAL LOCALIZADA EM CASCAVELIPR. }\end{array}$ & 54.000 .000 & Coneutar \\
\hline 18202801 & $\begin{array}{l}\text { AMPLIACAO DA CAPACIDADE DE AFMAZENAGEM DA UNIDADE DE } \\
\text { SANTA IZABEL DO OESTE (PR). }\end{array}$ & 20.000 .000 & Coneutar \\
\hline
\end{tabular}

Foto 6 - Operações diretas e indiretas automáticas. Fonte: (BNDES, 2018)

Os valores contraídos por esse tipo de financiamento correspondem, conforme a descrição acima, a investimentos na capacidade de ampliação da estrutura física e diversificação da produção com destaque para o abate de aves e suínos.

Essa característica de empréstimos também pode ser contemplada no conceito de Lazzarini (2011) como investimento doméstico, que conforme observado é a captura de dinheiro público para empresas privadas, desde que estejam numa lógica de acumulação. Novos empresários e milhares de novos investidores, em um curto período de tempo, movimentaram a bolsa e revigoraram o capitalismo brasileiro.

No auge do processo, em 2007, era difícil conforme esse autor, acompanhar em detalhes cada novo prospecto de empresa que era lançada no mercado. Quase do nada, empresários até então pouco conhecidos passaram a lograr grande destaque nos jornais e revistas de negócios. A onda também serviu como uma espécie de elixir para o Novo 
Mercado, que rapidamente se estabeleceu como padrão de referência de níveis diferenciados de governança corporativa, o que sinalizava a expressiva mudança dos empreendimentos do BNDES. O contexto trazido por Lazzarini (2011) é plenamente identificado nas operações contraídas pela Coopavel expressa também na segunda linha, dos tipos de financiamentos contraídos por essa empresa num período que vai de 2002 a 2018.

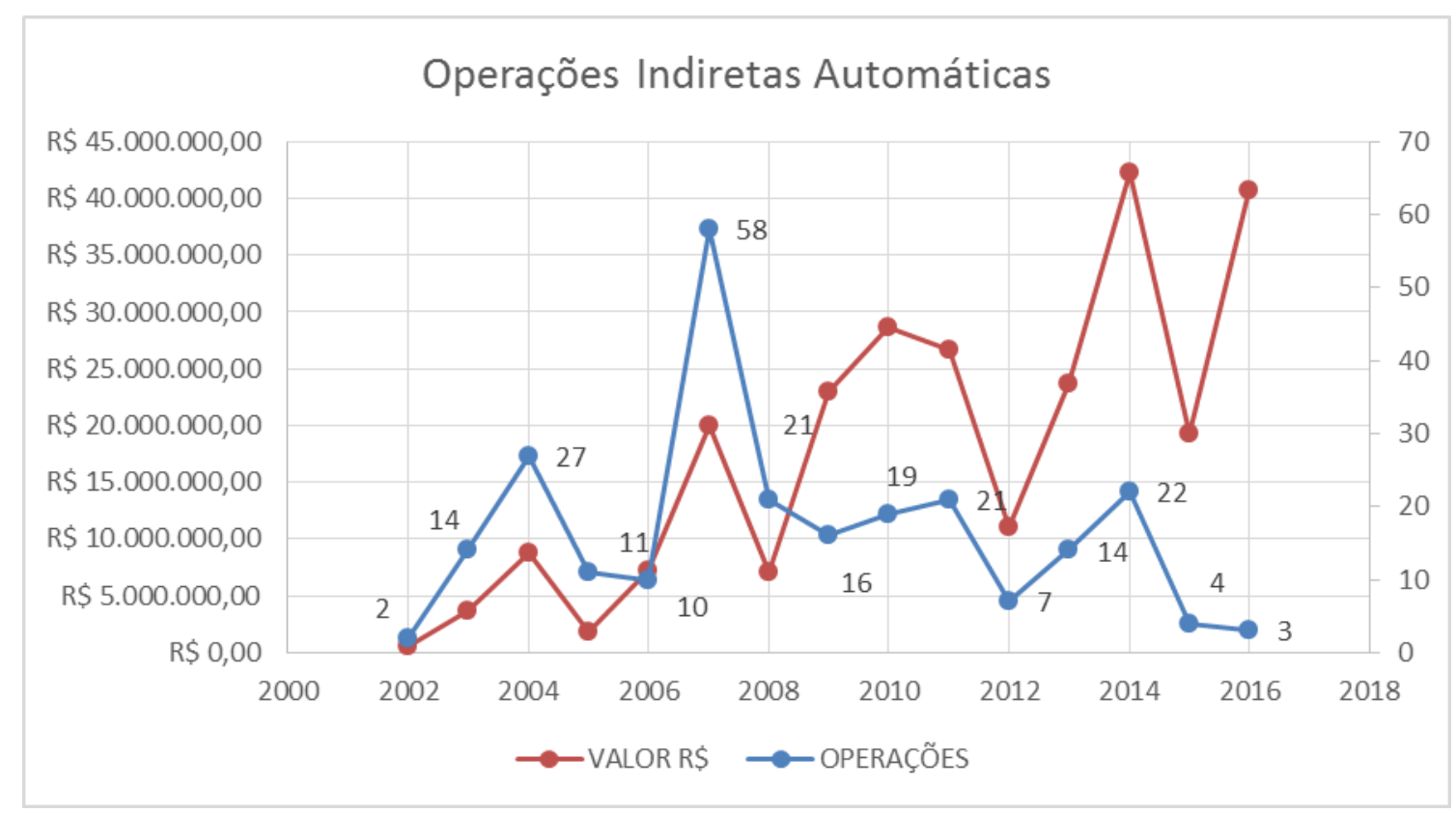

Gráfico 1- Operações indiretas automáticas BNDES/COOPAVEL.Fonte: Elaboração própria a partir dos dados do (BNDES 2018 26 ).

Ao todo, de 2002 a 2018, foram realizadas um total de 262 operações, totalizando um montante de R \$ R \$ 264.394.290,00. Os anos de maiores picos de investimentos se referem a 2014 e 2016, conforme nos demonstra o gráfico acima.

Quando se refere às operações automáticas indiretas significa que outros bancos intermediaram os empréstimos. Essa descrição de cada banco e valores foi simplificada na demonstração da tabela acima, como variáveis que complementam a quantidade de operações, ano e valores

Outra fonte de investimento se refere à terceira e quinta linha, denominadas de operação de renda variável e operações exportação pós-embarque, das quais não consta nenhum dado para consulta. A indisponibilidade desses dados coloca em cheque o cumprimento com a lei de transparência, pois existem os empréstimos, porém sem divulgação 
de valores. No entanto, quando se trata de renda variável essa expressão sempre remete ao mercado de ações, e é variável porque o valor da ação está suscetível à instabilidade do mercado, que será maior ou menor valorizada conforme o desempenho da empresa e seu valor na bolsa de valores.

Dessa forma, renda variável é igual ao mercado em ações e o financiamento por renda variável se dá quando o BNDES não parte de um contrato convencional de financiamento, mas ele compra uma quantidade de ações que a empresa disponibilizou na bolsa de valores e a partir desse momento passa a ser um proprietário da empresa. Dessa forma, financiamento por renda variável é a compra de ações de uma determinada empresa pelo BNDES que faz dele um proprietário, inclusive com poder de voto e de indicação de pessoas para compor o conselho diretor da empresa.

Por final, a quarta linha expressa o último tipo de financiamento, com valor menor em relação aos dois apresentados anteriormente.

\section{DXNDES}

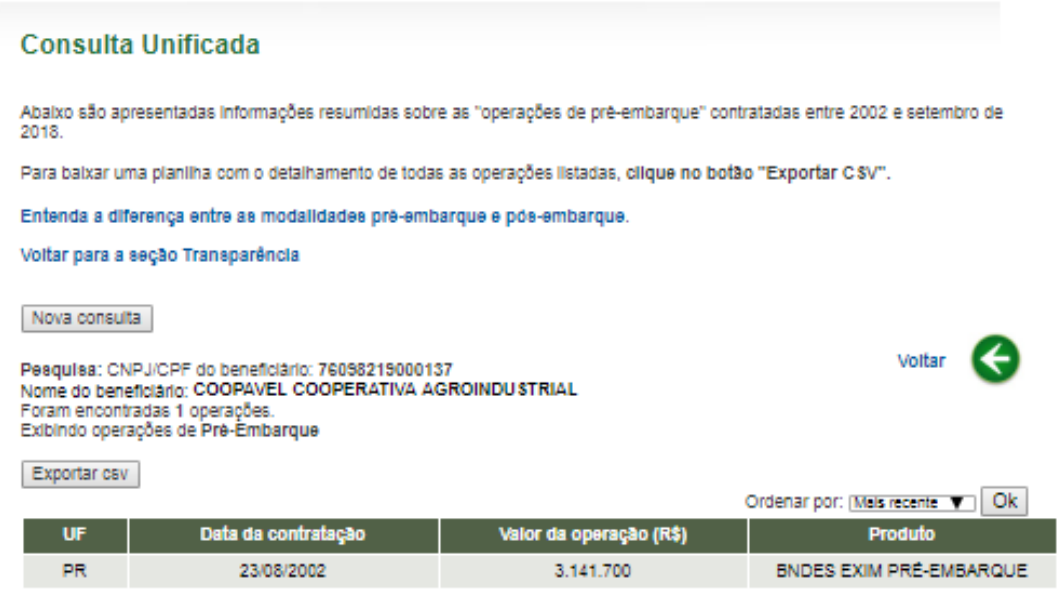

Foto 07 - Operações de pré-embarque contratadas entre 2002 a setembro de 2018. Fonte: (BNDES, 2018).

Os montantes de empréstimos destinados acima, somam um total de $\mathrm{R} \$$ 490.414.300,00, isso considerando todas as planílhas disponibilizadas de contração de

\footnotetext{
${ }^{26}$ Ao somar os dados sobre quantidade de operações e valores, não somamos os dados que se repetiram na sequencia informada. Devido ao não domínio se a repetição de informações dos dados tratavam-se de outro dado ou da repetição, achamos mais seguro não repeti-los.
} 
financiamento da Empresa Coopavel com o BNDES num período mencionado que vai desde 2002 até 2018.

De acordo com Lazzarini (2018), em vários sentidos o movimento de abertura de capital ajudou a reforçar diversos elementos característicos do capitalismo de laços. Muitas das novas empresas preservaram estruturas piramidais e aglomerações de donos; o governo (via BNDES) continuou como proprietário de destaque; diversas transações foram alimentadas por conexões, nem sempre produtivas, entre bancos e seus clientes e os conselhos de administração se entrelaçaram de forma intensa. É verdade que muitos desses aspectos não foram necessariamente considerados danosos.

No que se refere aos impactos desses investimentos na empresa Coopavel, houve seu pleno destaque em vários órgãos midiáticos com divulgação da lucratividade, com ênfase nacional entre as maiores empresas do Brasil em 2018 (VALOR ECONOMICO, 2018; EXAME, 2018; CATVE, 2017b). As últimas divulgações feitas sobre o desempenho da empresa foram registradas em 2017, com um faturamento total de $\mathrm{R} \$ 2,12$ bilhões nesse ano, enfatizado pela própria empresa em sua página como o maior de toda sua história (COOPAVEL, 2018).

Porém, na sua essência, mais uma vez, a mudança solidificou as dinâmicas que já existiam. Com a crise financeira do segundo semestre de 2008, o lançamento de novas empresas não somente caíram de forma drástica como também o tom do discurso empresarial voltou ao que era antes. Muitos passaram a celebrar o Estado como paladino contra as imperfeições do mercado. O desejo de governo interventor foi logo percebido por vários empresários, que correram em busca de contatos e novas oportunidades.

Nesse sentido, de acordo com os pressupostos teóricos de Lazzarini (2011), se firmam empresas denominadas de domésticas como a Coopavel, que potencializam sua reestruturação produtiva, como já enfatizada anteriormente. Sem dúvidas essa é uma condição para manter sua concorrência no mercado, não por inovação tecnológica, mas produtiva, com ampliação das condições de trabalho ao estilo fordista/taylorista no que concerne a produtividade do trabalhador, e toyotista no que se refere ao tipo de mercadoria produzida, com diversificação da mercadoria conforme o estilo e o gosto do cliente.

É certo que, no caso da Coopavel, embora a empresa não apresente até o momento expansão internacional com produção fora do país, sua evidência se mantém como principal incorporadora ou até hegemônica quando se trata da inserção de estrangeiros em seu sistema produtivo. Isso será melhor discutido no terceiro capítulo, que enfatiza essa inserção, e os 
mecanismos da empresa para ter os haitianos como mão de obra reserva disponível caso seja necessário sua utilização.

Essa situação, conforme apontado, ocorre, principalmente, em períodos de crescimento econômico, cujas vagas de trabalho são refutadas pelos trabalhadores nacionais, havendo, assim, a necessidade de um exército industrial de reservas, calculado conforme as demandas de seu sistema produtivo, que pela própria estrutura produz a rejeição de trabalhadores nacionais. O sistema global se manifesta aqui na promoção de empresas como a Coopavel que tem a partir de investimentos públicos a inter relação com o mercado externo via exportação e assimilação de novas tecnologias, bem como alimenta via baixos salários a exploração de mais valia a partir da manutenção de uma planta produtiva fordista taylorista.

\subsubsection{O Brasil: políticas de migração como reação do Estado aos grandes fluxos migratórios no contexto da globalização}

A ação do Estado não foi reduzida ao investimento privado, isso ficou evidente em um dos casos analisados acima, que viabilizou a reestruturação da empresa via financiamento público. Por outro lado, será visto como isso se dá na lógica das políticas sociais, com ênfase nas políticas de migração, em que se observa a mínima participação do Estado, processo diferente quando se trata de empresa privada.

Como já discutido até aqui, a globalização é a expressão da mundialização do capital, e impõem novos aspectos como a transformação produtiva, o capital financeiro e as políticas neoliberais. No entanto, embora o Estado seja orientado a não intervir na economia em prol de agendas neoliberais, é certo que a ascensão do neoliberalismo na Europa se dá num contexto de assentamentos migratórios.

Nessa perspectiva, Muenz (2007) ressalta que desde os anos 1960 a Europa se converteu em um dos principais destinos da imigração mundial. Do ponto de vista histórico, trata-se de um fenômeno recente, pois, no passado, a Europa foi a maior geradora de emigração no mundo, como no período entre 1750-1950, com abandono de aproximadamente 70 milhões de pessoas do continente.

Ainda conforme Muenz (2007), em 2005, um total de 42 milhões de imigrantes internacionais viviam na Europa ocidental e central, o que representa $9 \%$ da população total. Um terço dessa população é imigrante interno da própria União Europeia, e os demais 28 milhões provém de outras partes da Europa e outras regiões do mundo. A Alemanha é o país com mais imigrantes em outros países. A alta expectativa de vida associada à baixa taxa de 
fecundidade e necessidade de mão de obra faz da imigração um processo permanente, mesmo que não seja assim compreendida pelos europeus.

Atualmente, não só a Europa, mas o mundo todo se depara com novos fluxos migratórios, que demandam políticas de inclusão, asilo e integração, num contexto de políticas neoliberais e domínio do capital financeiro, que tem levado à criminalização da imigração e da solidariedade. Nessa perspectiva de finalizar as discussões desse capítulo, apresenta-se uma discussão sobre o contexto das políticas de imigração no bojo da centralidade do discurso migratório. Ademais, observam-se as principais políticas de imigração no Brasil, os elementos necessários para a compreensão do contexto que coloca a sociedade diante dos novos fluxos como os haitianos e venezuelanos cujos números se sobressaem em relação a outras nacionalidades, bem como a atual demanda de recepção e integração a partir deles.

Baeninger e Peres (2017) alcunham de Migrações de crise no Brasil devido à característica específica da política brasileira por meio do visto humanitário buscar resolver a situação da crise migratória dos Haitianos. A migração de crise está ancorada em situações que conduzem os novos movimentos migratórios, baseados em fenômenos sociais vinculados aos problemas políticos, civis, econômicos, religiosos, ideológicos e humanitários. A ampliação desse fenômeno incorpora os imigrantes considerados refugiados, além dos solicitantes de refúgio humanitário com ênfase nas condições jurídicas baseada em convenções internacionais.

Essa definição da migração de crise se sustenta em fenômeno condicionado socialmente e que reflete problemas econômicos, políticos, religiosos, civis ideológicos e humanitários.

Estas categorias revelam a presença histórica da "crise" na origem do fluxo migratório - com a conotação de uma "migração forçada" e requerem instrumentos jurídicos no país de destino para o enfrentamento da "crise" migratória atribuída ao país de origem, mas que revela também a crise na sociedade receptora, despreparada para enfrentar essa imigração (BAENINGER E PERES, 2017, p. 122).

Contudo, é importante destacar que essas categorizações estão pautadas em convenções internacionais, pois as distintas formas de refúgio, como as elencadas anteriormente, estão absolutamente articuladas com imigrantes econômicos retratando o funcionamento do mercado global e do mercado de trabalho imigrante dentro de relações hierárquicas (BAENINGER E PERES, 2017). 
Autores que se dedicam a analisar as políticas de imigração implementadas como políticas de Estado, como Arango et al.(2007), Arango et al. (2017), Sala (2005) e Castles e Miller (2004), inferem que elas são recentes. Para Arango et al.(2007), essas políticas públicas foram implementadas nos anos 1970 e começo da década seguinte e até então haviam só políticas de controle, cuja livre circulação das pessoas era a norma enquanto a integração dos imigrantes se restringia ao mercado de trabalho, economia e sociedade civil.

Nessa mesma perspectiva, Sala (2005) ressalta que a incidência da questão migratória na esfera política dos países receptores cobra especial relevância desde os anos 1960. Seu impacto tem direcionado a uma dupla vertente: primeiro, a imigração tem causado grandes objetivos e transformações nas concepções clássicas de certa inspiração liberal como identidade nacional, democracia representativa, cidadania, e titularidades de direitos; e, em segundo lugar, o imigrante tem ascendido ao cenário político como protagonista dado a transformação em sujeito político convertido em objeto da política quando contemplado por políticas migratórias de grande complexidade.

Desde esse momento, essas políticas têm se sobreposto como um aspecto central dos debates contemporâneos e que mais atenção tem recebido das agendas políticas estatais. Geralmente, a atenção dada pelos governos se centra nas políticas de controle ou restrição de entradas, com exacerbados investimentos públicos para impedir novas entradas de imigrantes, justificadas conforme os Estados nacionais como necessárias, sendo também uma condição para garantir políticas de inclusão aos imigrantes que já permanecem no país. Assim, restringir imigrantes é equivalente à implementação de políticas migratórias, o que tem conduzido alguns estados a garantir por um lado políticas de integração e por outro o fechamento das fronteiras como forma de impedir novas migrações.

Nessa mesma compreensão, Clastles e Miller (2004) indicam o final dos anos 1980 como o período que se iniciaram algumas atenções sistemáticas e de elevado nível a exemploda retirada das fronteiras internas pela União Europeia, com o propósito de fortalecer as fronteiras externas, de modo a evitar a entrada de pessoas oriundas do sul e do leste europeu. Associado a isso, houve uma intensa politização da imigração desde os anos 1990, entonada, principalmente por grupos de extrema direita que concebem a imigração como uma ameaça paraaidentidade nacional, conduzindo-a ao centro do cenário político.

Autores como Clastles e Miller (2005), Sala (2005), Arango (2005) e Arango et al. (2017) inferem que a politização da imigração reforça o pensamento ancorado no mito de identidade nacional que leva à concomitante rejeição daqueles que estão fora dela. A imagem do imigrante como ameaça é a principal característica da politização da imigração, sendo 
comumente propagada em três vertentes ideológicas: a segurança (a qual associa o imigrante a práticas de violência), a concorrência laboral e a homogeneização cultural.

Países clássicos de imigração não estão livres da politização, porém pode-se afirmar que os êxitos das políticas imigratórias de países considerados clássicos de imigração como Canadá, Austrália e Nova Zelândia estão estritamente vinculadas, não somente às raízes históricas da imigração na formação desses povos, mas também pelo fraco efeito das repercussões de grupos conservadores, o que não os exime de se deparar com problemas marcados pelo racismo, preconceito e xenofobia, que são maiores ou menores à medida que tais grupos conservadores e anti-imigração ganham força em cada país.

No Brasil, do mesmo modo que na Europa, essas políticas também são relativamente recentes, sendo que a intensa quantidade de imigrantes nos últimos anos passou a cobrar respostas mais efetivas por parte do Estado brasileiro para enfrentá-la, sobretudo nos campos da inclusão e integração dos novos grupos sociais decorrentes da imigração.

Os anos 1980 marcaram os primeiros fluxos migratórios iniciados com bolivianos, os haitianos em 2010 e mais recentemente com venezuelanos. Nesse sentido, destaca-se que as políticas mais recentes de imigração começam a se desenvolver pelo governo Brasileiro a partir de 2012, o que antes era restrito ao Estatuto do Estrangeiro.

Os imigrantes haitianos no Brasil, chegavam em grande números pelas fronteiras terrestres, se constituíram como um grupo atípico e a presença deles indicava o descompasso entre normas e realidade migratória internacional. Geralmente indocumentados e vítimas de coiotes ou agenciadores da imigração ilegal, chegavam ao Brasil depois de uma longa experiência migratória entre os países de trânsito. O despertar do Brasil para com a realidade deles não ocorreu de forma espontânea e tranquila, o governo se viu diante da contraditória situação de recebê-los e garantir minimamente os acordos internacionais dos quais é signatário como os realizados na convenção de Genebra de 1951 e o protocolo de 1967. Além disso, a incapacidade de prover mínimas políticas de imigração decorrente da ausência do Estado para sua efetivação.

No século XXI, a chegada de grande fluxo migratório haitiano e a sua dispersão por outras partes do território brasileiro expressaram e ainda indicam o despreparo do país para recebê-los no que se refere à normatização institucional e social. O discurso de um país receptor, de portas abertas para o acolhimento de imigrantes é desmistificado frente à escassez de abrigos e políticas de inclusão orientadas para essa população. Algumas restritas experiências foram implementadas pelo Estado no âmbito do acolhimento, como o primeiro abrigo situado na região fronteiriça da cidade de Brasiléia, no estado do Acre, desativado em 
2014 e transferido para a capital Rio Branco. Além desse abrigo, o governo do Acre disponibilizou transporte para deslocar a população imigrante para outras regiões do Brasil, como Sul e Sudeste.

Destaca-se também a criação de um órgão no Município de São Paulo por meio da Coordenação de Políticas para Migrante, ligada à secretaria Municipal de Direitos Humanos e Cidadania (SMDHC). Dessa política emergiram outras como a criação do Centro de Referência e Acolhida para Imigrantes (CRAI - SP).

De acordo com Silva S. (2016a), essas iniciativas, embora sujeitas a críticas em vários aspectos, foram pioneiras no que se refere ao comprometimento do setor público com a questão da imigração de haitianos no Brasil, quando o governo, via de regra, mantêm-se indiferente à questão imigratória em todo país.

$\mathrm{O}$ autor mostra que, onde houve ação estatal, ela se manteve restrita com ínfimas intervenções ou melhoras no sentido da oferta de serviços, muitos dos quais foram deixados para a sociedade civil, sobretudo para igreja católica que possui um histórico de expressivo envolvimento, com destaque para a Pastoral do Migrante no Brasil. Essa instituição desempenha um importante trabalho de acolhimento, informação e procedimento para emissão de documentos e, em algumas situações, encaminhamento para trabalho em várias partes do Brasil (SILVA, P. 2016; COTINGUIBA E COTINGUIBA, 2016; MAGALHÃES, 2016; VILLEN, 2016).

A ausência de políticas para acolhimento e inserção de imigrantes no Brasil, tem contribuído para incitar relações preconceituosas entre os brasileiros e os estrangeiros imigrados quando esses passam a usar o mesmo sistema público já precário para os próprios brasileiros (ARAÚJO, 2016). As condições dos abrigos nos anos iniciais de chegada dos grandes fluxos de haitianos, sejam eles públicos, quando existiam, ou ligados a organizações filantrópicas, eram comumente insalubres devido à dificuldade de acolher a crescente demanda. Cotinguiba e Cotinguiba (2016) chegaram a classificá-los como senzalas do século XXI, ou campos de concentração, devido ao grande número de haitianos e a incapacidade de acolhimento que, por sua vez, geravam condições degradantes, insalubres e sub-humanas.

Além dessas iniciativas restritas a limitados abrigos, os estudos sobre imigração haitiana no Brasil sinalizam a normativa $n^{\circ} 97$ de 2012 como a principal alteração nas políticas de imigração até 2016.

O benefício do visto humanitário com ampliação da permanência até cinco anos não suprimiu a renovação do visto após o vencimento desse prazo, que está condicionada à inclusão deles no processo produtivo do país, conforme estabelece o artigo 3 da referida 
normativa. No entanto, como já estamos prestes de completar uma década da migração haitiana no Brasil, esses vistos tem sido renovados e o governo brasileiro não tem demonstrado recusa em proceder, haja vista a quantidade expressiva de trabalhadores que encontram-se desempregados e sem vínculos empregatícios no Brasil.

Embora tenha passado por várias críticas, essa normativa viabilizou a regularização da situação de milhares desses imigrantes que adentravam as fronteiras e solicitavam refúgio junto às autoridades brasileiras. Foi também uma estratégia paliativa do governo brasileiro para resolver o intenso crescimento dos fluxos migratórios de haitianos, ao passo que continuou lavando suas mãos quanto ao reconhecimento jurídico deles como refugiados ambientais por meio da aprovação dessa legislação específica, sem, contudo considerar juridicamente a situação de refúgio ambiental. Segundo Faria (2016), essa foi uma maneira do Estado Brasileiro não abrir prerrogativas para outros solicitantes que, amparados no mesmo direito, pudessem vir a requerê-los por se depararem com o enfrentamento de situações semelhantes.

Dessa forma, de acordo com Faria (2016), ao conceder o visto humanitário, o Brasil resolve a questão jurídica dos refugiados conforme a convenção de Genebra de 1951 e o protocolo de 1967, porém sem acatar o pedido de refúgio ambiental, uma vez que nenhuma legislação o reconhece, o que leva a autora enfatizar a necessidade de mudança e avanço do governo brasileiro quanto a esse problema, visto que ele não se refere somente aos haitianos, mas é cada vez maior o número de pessoas que se movem mundialmente impulsionadas por questões ambientais.

Nessa mesma perspectiva, Silva (2016a) ressalta que conceder o visto humanitário não passa de uma solução paliativa para o problema do refugiado ambiental, sendo essa uma resposta emergencial. Sua eficácia não se sustenta a médio e longo prazo, com a falta de mecanismo normativo que estabeleça critérios basilares para o reconhecimento jurídico do refugiado ambiental. Essa discricionariedade do Estado pode conduzi-lo ao risco de injustiça e discriminação quando se depara com pessoas que se encontram numa mesma condição.

O Estado brasileiro, com a normativa 97/2012, mantém-se indiferente quanto ao reconhecimento do refúgio ambiental, ao passo que desconsidera os pressupostos pautados nos direitos humanos, sendo esse simultaneamente um mecanismo de contenção de solicitações de refúgio quando pessoas nas mesmas condições analisam e evitam migrar para o Brasil em decorrência de não ter uma legislação que os reconheçam como refugiados ambientais. 
O visto humanitário, de acordo com Faria (2016), é estendido para todo imigrante haitiano, ao passo que desconsidera por outro lado àqueles que realmente são refugiados, e tenham saído do país por algum motivo de perseguição ou ameaça, ao mesmo tempo em que não reconhece o imigrante ambiental. Outra crítica feita ao visto humanitário, conforme Silva S. (2016a), foi a de conter a imigração por meio da imposição de cotas, com emissão de 1.200 vistos anuais sem ultrapassar 100 por mês.

Desde 2015, frente à ineficácia dessas cotas, o governo brasileiro passou a emitir mais de 2.000 vistos mensais, porém a normativa 97/2012 ainda vigente garante o reconhecimento do visto humanitário. Dessa forma, as análises sobre a eficácia da normativa $n^{\circ} 97$ que outorga o visto humanitário é contraditória já que representa, por um lado, mecanismos de controle e contenção da imigração quando simultaneamente enquadra todo haitiano nessa regulamentação e, por outro, agilizou a situação burocrática de milhares de haitianos, que antes esperavam até três anos para ter resolvida sua situação quando entravam com o pedido de refúgio. Autores como Silva S. (2016a); Cotinguiba e Cotinguiba (2016); Magalhães (2016) e Villen (2016) apontam para uma inoperância do Estado brasileiro no que concerne às políticas de acolhimento e inserção social, sendo essas ações limitadas à documentação.

Mais recentemente, após a normativa de 2012, houve a aprovação da nova Lei de Migração, Lei no 13.445, de 24 de maio de 2017, regulamentada pelo Decreto 9.199, de 20 de novembro de 2017. Ao traçar uma comparação sobre essa lei e o Estatuto do Estrangeiro que regulamentava até então a migração no Brasil, o Diretor de Departamento de Estrangeiro do Ministério da Justiça, João Guilherme Granja, comenta avanços como a superação do anacronismo da atual legislação que representa o retrato de outro Brasil anterior ao processo de democratização, com a manutenção de traços ideológicos de teor excludente e xenofóbico (BRASIL, 2015).

Há, conforme Granja (BRASIL, 2015), uma profunda necessidade de adequar essa legislação retrógrada como o Estatuto do Estrangeiro, não mais compatível com a sociedade democrática atual. Para ele, os últimos anos tem mudado a relação do fluxo migratório no Brasil com a projeção de movimentos de retornos de brasileiros que vivem no exterior e a atração de imigrantes de outros países que adentram o país. Assim, as atuais mudanças repercutem com vistas a reduzir as contradições da atual legislação, que não prevê o atendimento de imigrantes e emigrantes quanto à regularização de documentação.

Ainda conforme Granja, o Estatuto do Estrangeiro condiciona a entrada de imigrantes a uma situação prévia de vinculação laboral, o que não é compatível com a população migratória 
constituída por emigrantes de retorno e principalmente imigrantes recém-chegados a partir dos grandes fluxos migratórios. A grande mudança é, segundo o então diretor, o favorecimento de fatores de inclusão social, do imigrante, e como manter a vinculação de brasileiros que vivem no exterior, além de regimes de cooperação com deslocamento de presos brasileiros julgados em outros países para cumprir pena no Brasil, próximos às suas famílias.

Cria-se, dessa forma, um campo de políticas públicas para a migração que não estava explícita no Estatuto do Estrangeiro, sendo essa nova lei desafiadora no sentido de garantir a institucionalidade por meio de um ator único governamental que será responsável pela ocupação específica das migrações, unificando o tratamento especializado a imigrantes e emigrantes. Ainda, segundo Granja (BRASIL, 2015), além da função desse ator institucional em garantir esse atendimento especializado e unificado, o mesmo deverá estar disponível para coletar dados e desenhar políticas públicas, de forma a ajudar Estados e Municípios que atualmente recebem imigrantes.

As poucas análises sobre essa lei se justificam, sobretudo, por sua recente aprovaçãono Brasil, limitadas até então a algumas observações de especialistas e instituições que atendem diretamente os imigrantes. No que concerne essas análises, as mesmas têm sido positivas quando se refere à ampliação dos direitos humanos, e profícuas no papel. No entanto, não se pode esquecer que o Brasil é um país de bonitas e avançadas legislações, haja vista a distância entre o que garante a Constituição de 1988, considerada como uma constituição cidadã, e os limites para que tal legislação seja efetivada na prática. Legislações não se concretizam por si só, e isso demanda ampla participação popular para fazer com o que está no papel se aproxime da realidade, dependendo, sobretudo, da continuidade dos movimentos sociais, sendo esses os principais protagonistas do debate para a aprovação da Nova Lei de Migração de 2017.

Essa lei foi desenhada por uma portaria ministerial, composta por pessoas vinculadas às Universidades, equipe técnica do governo, representantes da sociedade civil e sindicatos, atores que, entre os anos de 2014 e 2015 ouviram os imigrantes e emigrantes, além de setores da sociedade civil que trabalham com imigrantes, com o intuito de captar da parte dos envolvidos direta ou indiretamente com a questão atual da imigração as reais demandas para viver dentro e fora do Brasil a partir da experiência migratória.

Para Granja (BRASIL, 2017), a atual legislação não garante a plenitude dos direitos civis, com políticas independentes da situação de migrante, ao passo que essa política não pode ser reduzida à ingênua ideia de controle de fronteiras, mas precisa buscar compreender os delineadores das causas do sistema migratório e a inserção social, seja daqueles que vivem 
dentro e fora do país. Finaliza ressaltando que a ausência de políticas públicas garantidas pelo Estado contribui para reforçar o estigma do imigrante, visto como uma ameaça, quando se acredita que os não nacionais incham a demanda por políticas públicas, além de tomar os postos de trabalho dos nacionais, quando de posse da documentação. Para esse diretor, é fundamental a documentação, uma vez que a ausência dela gera uma concorrência desleal, permitindo que empresários e demais setores produtivos explorem a mão de obra barata e vulnerável, ao passo que coloca o agente econômico como maior beneficiado (BRASIL, 2015).

Nessa mesma perspectiva, as análises de Silva P. (2016) sobre as políticas de imigração a partir dos grandes fluxos de haitianos no Brasil também fazem alusão à ausência de politicas que garantam a maior integração dos haitianos e demais imigrantes na sociedade brasileira, quando elas existem são restritas à contenção de entrada irregular. No caso haitiano, tal política se limitou ao visto humanitário, o que não significa a garantia dos seus direitos integrais como imigrantes.

As declarações de legisladores que ocupam vários órgãos que tratam sobre a questão da imigração no Brasil é semelhante ao que vários autores já disseram sobre os limites dessas legislações no país, elas podem ser consideradas como resultantes da participação da classe trabalhadora em espaços viabilizados pela democracia burguesa. Ao permitir a ocupação desses espaços pelos trabalhadores no interior dessa democracia, contraditoriamente, essa classe impõem seus interesses no interior do Estado (SAES, 1998).

Perto de completar uma década de imigração haitiana no Brasil, presume-se que o fortalecimento de redes de apoio, como étnicas e familiares, tem desafogado a imigração massiva para áreas de fronteira, com a redistribuição desses imigrantes para várias outras regiões do país e o esvaziamento considerável dos escassos abrigos existentes nas regiões de fronteiras, mantidos, sobretudo, por instituições religiosas.

O esvaziamento dos precários abrigos para receber haitianos não significa a redução dos fluxos migratórios, nem tampouco que as fronteiras possam ser delimitadas como único espaço a ser cruzado. Os novos fluxos não só de haitianos, mas de venezuelanos rompem com algumas fronteiras estabelecidas, e fazem dela uma lógica de mobilidade imposta pelo contexto de cada fluxo migratório. Assim as fronteiras são dialéticas e, conforme Cardin (2013), são expressões da historicidade humana e resultam das transformações permanentes, se constituem para além do simples território delimitado, sendo, antes de tudo, construções sociais feitas pelas experiências humanas.

A análise sobre os grandes fluxos migratórios evidenciam a flexibilidade das fronteiras pelas histórias de vida, não só por meio da dinâmica da mudança da rota ou 
fronteira migratória por onde chegam os haitianos, mas também pelo surgimento de outras fronteiras a partir das demandas e necessidades dos novos fluxos migratórios. A esse último exemplo destaca-se a fronteira entre a Venezuela e o Estado de Roraima no Brasil. Esse Estado, assim como foi o Acre no início das imigrações haitianas, tem sido uma das fronteiras mais utilizadas por venezuelanos que chegam ao país, sendo que esse grande fluxo migratório também tem se deparado com a ausência do Estado, contando com algumas ações pontuais quando elas existem.

Dados do ACNUR (2016) indicam que os venezuelanos são o maior grupo de solicitantes de refúgio no Brasil, com aumento expressivo de 307\%. De acordo com o relatório dessa agência da ONU, em 2016, um total de 3.375 venezuelanos solicitou refúgio no Brasil, o que correspondeu a aproximadamente $33 \%$ das solicitações registradas no país, ampliando, assim, significativamente o número de solicitações em relação ao ano de 2015, cujo número foi de 829 solicitações por parte dos migrantes venezuelanos. Deve-se considerar que o número de haitianos como refugiados só não é ainda maior porque a maioria deles entra no Brasil com a solicitação do visto humanitário, o que diminui as cifras dos mesmos como refugiados.

Até o final do ano de 2016, o Brasil reconheceu um total de 9.552 refugiados de 82 nacionalidades diferentes. Desses, 8.522 foram reconhecidos pelas vias tradicionais de elegibilidade, 713 chegaram ao país através de reassentamento, e 317 foram acolhidos por reunificação familiar (ACNUR, 2016). As cifras sobre as concessões de refúgio indicam ainda que os venezuelanos correspondem a 33\% do total de solicitantes de refúgio, seguido por $13 \%$ de solicitações por cubanos e angolanos, $6 \%$ haitianos, 4 \% de sírios e nacionais da República Democrática do Congo, além de 3\% de solicitações por paquistaneses, chineses e nigerianos, $2 \%$ de solicitações por senegaleses e o restante que compreende diferentes outras nacionalidades com números inexpressivos quando observados isoladamente (ACNUR, 2016).

De acordo com os dados do Comitê Regional para Refugiados - CONARE, do Ministério da Justiça e Segurança Pública, em 2016 houve, no Brasil, um aumento de 12\% no número total de refugiados reconhecidos no país. O número de pessoas que aguardava parecer de solicitação de refúgio, até 2016, totalizavam mais de 27. 000 mil pessoas (CONARE, 2016).

Embora os venezuelanos sejam o grupo com maior solicitação de refúgio e o que mais cresceu em 2016, não é a nacionalidade com maior número de reconhecimento positivo, posição essa, ocupada por sírios com 326 concessões de refúgio, seguidos pelos nacionais de 
países como República Democrática do Congo (189), Paquistão (98), Palestina (57) e Angola (26) (ACNUR, 2016).

Os venezuelanos que chegam ao Brasil dependem da concessão positiva do governo brasileiro para reconhecê-los ou não como refugiados, e esperam em condições subhumanas, como experiências também vivenciadas por haitianos no Brasil, bem como por refugiados do mundo todo. A vulnerabilidade e o descaso com essa situação tem representado a negação dos direitos humanos no Brasil assim como em outras partes do mundo, ao passo que cria também um climade conflito social que reforça a ideia do imigrante como ameaça nacional, como demonstra o mais recente episódio que reflete o clima de instabilidade e conflito entre venezuelanos e brasileiros em Roraima.

\begin{abstract}
Moradores invadem abrigo em Roraima expulsam imigrantes venezuelanos. Uma manifestação contra morte de um brasileiro no município de Mucajaí, a 50 quilômetros de Boa Vista, capital de Roraima, quase se transformou em tragédia na segunda-feira 19. Mais de 300 pessoas invadiram uma escola, onde funcionava um abrigo improvisado para cerca de 50 famílias venezuelanas, e expulsaram os imigrantes do local. Eles também jogaram móveis, roupas e objetos dos venezuelanos na rua e atearam fogo. Os imigrantes, entre eles, mulheres e crianças foram expulsos da cidade. Não houve registro de mortos ou feridos durante a confusão generalizada, segundo a Polícia Militar (JHNOTÍCIAS, 2018, p 01).
\end{abstract}

A inexistência de reconhecimento positivo de refugiados venezuelanos pode decorrer da precária condição e infraestrutura que possui o Conselho Nacional de Imigração no Brasil, o qual tem sua demanda acrescida frente à quantidade expressiva de solicitações de refugiados de diversas nacionalidades, sobretudo, dos países com maiores fluxos, como é o caso atual da Venezuela.

Ficar inerte a uma resposta positiva pode ser interpretada como assumir um lado, o de evitar a liberalização de refúgio e dessa forma estimular o crescimento do fluxo que já é considerável. No entanto, até que se resolva essa inércia, os venezuelanos continuam entrando no país e permanecem em situações sub-humanas, com intensificação dos conflitos sociais. A ineficiência burocrática pode muitas vezes fazer com que perdure por anos a espera de uma resposta ou reconhecimento. Talvez com a aprovação da nova lei de imigração haja uma mudança nesses órgãos, já que um dos objetivos dessa reforma na normativa sobre a imigração no Brasilé criar um aparato estatal único para agregar toda a questão migratória. 


\subsubsection{A nova lei de Migração: conquistas e impasses para a promoção dos direitos migratórios}

Embora as análises sobre a imigração no Brasil e a atuação das políticas estatais dão margem para a falta de compromisso do Estado para garantir mínimas condições de recepção, asilo e integração e deixam com que a sociedade civil se responsabilize por isso, é certo que a aprovação da Nova Lei de Migração significa um avanço em termos de legislação.

A análise a seguir foi delineada pela necessidade de reflexão do contexto, bem como dos avanços e limites que perpassam a aprovação dessa Nova Lei, que substituiu o antigo Estatuto do Estrangeiro, legislação que vigorou até novembro de 2017, ano que entra em vigor a Nova Lei de migração no Brasil.

Ao realizar uma análise sobre os limites e possibilidades dessa nova lei, Oliveira (2017) ressalta que um dos maiores avanços foi a ampliação dos direitos humanos e a supressão da retrógrada concepção do imigrante como ameaça nacional.

Nessa perspectiva, embora ainda seja eminentemente prematuro avaliar a prática dessa lei no seu primeiro ano de vigência, pode-se dizer que ainda são tímidas suas tentativas de implementação. As análises evidenciam a ausência do Estado no recebimento e acolhimento de imigrantes venezuelanos e essas medidas ainda estão atreladas às reações da sociedade quando expressam conflitos entre brasileiros e estrangeiros.

Foi dessa forma que o Estado passou a atuar mais eficazmente nas regiões de fronteira do Estado de Roraima. Os episódios de xenofobia apresentados ao longo do ano de 2018 chegaram ao seu ápice com a expulsão de imigrantes venezuelanos em agosto de 2018, por outro lado, exigiu e obrigou as reações estatais.

Uma das atuações que tem se destacado como relevante a partir desse episódio foi o plano de interiorização de mobilidade desses imigrantes para outras regiões do País. Atualmente ele se faz não só com a disponibilidade de transporte para viabilizar esse deslocamento, mas também pela ajuda financeira do governo federal para com os Municípios que se propõem a participar dessa política. De acordo com dados do governo, trata-se de uma ação entre os Municípios e o Ministério de Desenvolvimento Social.

Até o momento, Estados como Rio Grande do Sul, Pernambuco e Rio de Janeiro possuem Municípios que estão participando desse projeto. Juntos, esses Estados tiveram 
previstos o abrigo inicial de 2,2 mil venezuelanos previsto até setembro de (2018) ${ }^{27}$. Dentre os munícipios que fazem parte desse plano de interiorização e já receberam um total de 1.884 venezuelanos ganham destaques os gaúchos localizados em Chapada, Cachoeirinha e Canoas que já acolhem 502 desses imigrantes deslocados até então (VOZ DO BRASIL, 2018).

Como dito, essa foi uma medida desenvolvida pelo governo após os conflitos entre venezuelanos e brasileiros ocorridos no Município de Paracaima, em Roraima, o que vem viabilizando a desocupação de vagas nos abrigos no Estado e permitindo o atendimento imediato desses migrantes em situação de rua. Nesse plano, são priorizadas famílias com documentação regular no Brasil, as quais possam chegar ao interior e serem incluídas pelo sistema formal de trabalho.

Outras ações são destacadas também após esse episódio como a declaração presidente Michel Temer (TEMER, 2018), proferida em espanhol, que tende a ressaltar o compromisso do governo em acolher os venezuelanos frente à crise política que passa o país vizinho, mantendo a solidariedade do governo e do povo brasileiro para com esses imigrantes, além de cumprir com os acordos internacionais de que é signatário.

No intuito de divulgar e ao mesmo tempo dar uma resposta para a comunidade internacional, o presidente declara em espanhol as ações do Governo Federal como a determinação de acompanhamento das medidas implementadas por uma equipe na fronteira. Dessa medida desdobram-se outras como o reforço de funcionários que atuam na fronteira, com ampliação da presença do Governo Federal na área de segurança e na área social, sem haver qualquer intenção do governo em fechar as fronteiras. Além disso, o governo brasileiro tem fornecido documentos aos venezuelanos que chegam ao Brasil de modo que, entre outras finalidades, possam acessar mercado de trabalho. Ainda segundo o presidente, o governo tem multiplicado ações de vacinação e assistência médica a brasileiros e venezuelanos, além da construção de dez abrigos para receber esse fluxo migratório (mais dois estão quase concluídos), onde os migrantes recebem alimentos e apoio adequados, essas ações têm sido, inclusive, reconhecidas conforme o presidente por organizações internacionais como a Agência das Nações Unidas para Refugiados - ACNUR.

Dessa forma o Presidente infere sobre o plano de interiorização destinado para venezuelanos que desejam deslocar-se da fronteira para outras regiões do Brasil. Por fim, ressalta a complexidade de lidar com esse fenômeno, já que ele demanda ações conjuntas das

\footnotetext{
${ }^{27}$ De acordo com Castles e Milher (2005) uma vez iniciada a imigração a tendência é sua ampliação, o que tende a aumentar o número estabelecido pelo governo com a própria dinamização do processo migratório, sendo essa uma força independente das previsões estatais que atuam via redes de apoio.
} 
quais não têm medido esforços para realizá-las. As últimas ações se destacam no envio de tropas militares para reforçar a segurança em Roraima, de forma a garantir a ordem e a tranquilidade para o povo brasileiro, bem como para os imigrantes (TEMER, 2018).

Quanto às ações de cooperação, o presidente ainda relata a presença do Brasil na coordenação de fóruns como a Organização dos Estados Americanos, a fim de prever medidas democráticas para que segundo ele contribuam para o retorno da Venezuela ao caminho da democracia, estabilidade e desenvolvimento. Ressalta que um passo importante foi a suspensão da Venezuela do Mercosul, com base na cláusula democrática (TEMER, 2018).

As poucas avaliações da implementação dessa nova lei são aqui trazidas por algumas análises midiáticas, principalmente as divulgadas após o episódio de xenofobia ocorrido em Roraima, como já destacado. Não será objeto desse estudo analisar de forma mais minuciosa essas políticas, mas é certo que elas só foram implementadas após o impacto da reação de milhares de pessoas ao fato ocorrido em Roraima, não sendo mais possível o descaso e indiferença governamental para com esses imigrantes, sobretudo quando se tem uma legislação que prevê medidas de ação estatal ao se deparar com os grandes fluxos migratórios.

Sobre os planos de interiorização, é certo que ainda insuficientes, não chegando a atender 2 mil dos 40 mil que já estão no Brasil. No entanto, ele pode ser considerado um avanço frente às ações implementadas com outros fluxos migratórios como foram com os haitianos no início da década 2010. Na perspectiva da Lei começa-se a efetivar a ação conjunta entre o governo, Estados e Municípios quando prevê ajuda aos Municípios que passam a enfrentar demandas com os grandes fluxos migratórios.

Ressalta-se também a solidariedade como um motivador de enfrentamento divulgado, sobretudo por prefeitos que estão recebendo as primeiras levas da interiorização de venezuelanos. Algo que também se difere do enfrentamento com os fluxos de haitianos, foi a condução da interiorização feita fora do âmbito estatal, empreendida por empresários que demandavam mão de obra, sem a presença política e governamental dos Municípios, quais quando muito se limitaram a viabilização de transporte pelo governo do Acre aos haitianos.

No entanto, a aprovação da nova Lei de Migração não se efetivou sem conflitos, resultante da luta de classes como qualquer outra política social. Está imbricado nela a disputa desses interesses, sobretudo porque essa política tem ganhado a centralidade do debate como já ressaltado.

Na perspectiva de identificar as discussões que envolveram sua aprovação busca-se traçar, ainda que de maneira simplificada, alguns debates que permearam a aprovação da lei, com ênfase nas principais conquistas no que se referem aos direitos dos migrantes, bem como 
a aprovação de 18 vetos, os quais trazem implicações profundas na ampliação dos direitos, sobretudo dos povos indígenas que tiveram a proibição de mobilidade nas fronteiras.

A despeito de um contexto que indica a presença de um congresso extremamente conservador, com bases partidárias liberais vinculadas a ultradireita, essa lei ecoa como resultado de ampla participação popular, bem como alarga os direitos humanos dos migrantes como analisa Oliveira (2017).

No entanto, não está livre dos limites que circunscrevem esses direitos no interior da democracia burguesa, com imposições que muitas vezes controlam em que medida os direitos podem ou não avançar, haja vista os 18 vetos aprovados junto com ela, que são exatamente aquilo que não se efetivou enquanto lei.

Como um desdobramento do antigo projeto, o Substitutivo no 07 de 2016 de autoria do deputado Aloysio Nunes Ferreira (PSDB), Ministro das Relações exteriores até 31 de Dezembro de 2018, sua principal característica foi alterar o Estatuto do Estrangeiro, outorgado desde os anos 1980, que carregou traços autoritários quando convertia a questão do migrante como problema de segurança nacional, bem como amplia os direitos humanos dos migrantes como brasileiros que saem do país (emigrantes) e imigrantes oriundos de outros países (OLIVEIRA, 2017).

Em 2009 foram encaminhadas propostas que continham o consenso de três projetos, embora representasse avanços foi considerado, conforme Silva (2017), tímido e restritivo. Posteriormente, Oliveira (2017) ressalta a ênfase desses três projetos na disputa da aprovação do que passaria ou não nessa lei, perpassando o então Projeto Substitutivo no 07 de 2016 e a conversão da aprovação da Nova Lei nº 13.445, de 24 de maio de 2017 regulamentada pelo Decreto $\mathrm{n}^{\circ}$ 9.199, de 20 de novembro de 2017.

O primeiro desses interesses estava vinculado à Secretaria de Assuntos Estratégicos SAE, com a defesa do maior estreitamento entre imigração e sistema produtivo. As alterações requeridas na Lei no tocante significava a adequação do sistema migratório com as demandas produtivas. Representava com maior exatidão a manutenção da intervenção governamental já em evidência como recrutador de mão de obra especializada, função essa desempenhada desde os anos 1980 com o Estatuto do Estrangeiro.

Em 2013 o PLS 288/2013 foi apresentado e de acordo com Oliveira (2017) continha um avanço do aspecto jurídico na garantia dos direitos do migrante voltados para a integração, além do combate ao tráfico de pessoas. Nesse ano, o Brasil já enfrentava a presença da chegada do maior fluxo migratório depois dos anos 1980, desencadeada com a migração massiva dos haitianos após o terremoto de 2010. 
Embora a lei tenha sido aprovada com a supressão de trabalhadores especializados, o imigrante ainda é pensado como vinculado ao incentivo de força de trabalho.

Assim, imigrantes selecionados com elevado padrão de qualificação manteriam o privilégio das ações estatais na medida em que fossem requeridos pelo sistema produtivo, com atração de profissionais como médicos, engenheiros e demais do setor de alta tecnologia. Nesse contexto, mão de obra era sinônimo de desenvolvimento econômico, logo de imigrantes selecionados.

A outra corrente que impôs modificações na lei foi a representação da Secretaria Nacional de Justiça - SNJ, amparada na existência de novos paradigmas migratórios, que previa maior participação dos imigrantes, que ouvidos, traziam as demandas para a garantia dos direitos com participação de uma comissão de especialistas que contribuíram para elaborar o anteprojeto da nova Lei de Migração.

Foi nesse contexto que Silva (2017) ressaltou a importância da participação do fluxo migratório haitiano vinculado às redes de apoio como a Pastoral do Migrante com ênfase na Missão Paz em São Paulo, que permitiu a participação deles junto aos debates para elaboração da nova Lei de Migração. Esse autor ressalta ainda que essas políticas nas representações dos imigrantes não se reduzem ao tratamento deles como vítimas ou mero objeto delas. Muito além, eles foram participantes do processo constitutivo que deu origem a essa nova lei, saindo da condição de mero coadjuvantes para protagonistas desse processo.

Um exemplo disso foi a participação deles em diferentes fóruns de discussão
sobre a proposta de uma nova lei de imigração no Brasil, a qual foi
sancionada com vetos, em maio de 2017 . Nessa perspectiva, a Pastoral do
Migrante tem sido um destes espaços abertos ao debate sobre diferentes
questões que envolvem a migração no Brasil (SILVA, 2017, p. 112).

Esse projeto fora submetido à avaliação da sociedade civil na conferência nacional de migração ocorrida em 2014 (COMIGRAR) que posteriormente foi encaminhado para a presidência da república, de modo a ser submetido a aprovação do legislativo. Nessa mesma perspectiva, outra força, o CNIg também aprovou um projeto que visava a garantia dos direitos dos migrantes. Essas diferentes iniciativas oriundas do poder executivo levaram uma atuação unificada no governo federal, buscando algum consenso entre o projeto de lei do senado, PLS (288/2013) elaborada pelo senador Aloysio Nunes, e relatado pelo senador Ricardo Ferraço (PSDB). 
A legislação vigente até então para assuntos migratórios era o Estatuto do Estrangeiro, qual atribuía o imigrante o caráter de ameaça nacional e lhe retirou o direito de reconhecimento, o que está em desacordo com a Constituição Federal de 1988.

Pelo fato de essa mudança ser recente, não foram realizados estudos pontuais sobre as principais alterações da lei. Porém, setores dedicados à migração já mostram o legado da nova legislação, ancorada no abandono de formas autoritárias, até então presentes no Estatuto do Estrangeiro. "A proposta aprovada pelos senadores reconhece o migrante, independente de sua nacionalidade, como um sujeito de direitos, e deixa a lei em conformidade com a Constituição" (DELFIM, 2017, p. 01).

A Lei de Imigração tem a prerrogativa de alterar de forma substancial o tratamento do imigrante no Brasil, dando a ele um status de humanidade e direitos humanos. Essa legislação foi aprovada em um contexto de intensa crise política no Brasil, e, logo, de maior representatividade de partidos conservadores na Câmara dos Deputados e no Senado, além de um presidente golpista no poder.

Todos esses são protagonistas de uma política que, atrelada ao judiciário e sua indiferença, atacaram seriamente os princípios democráticos no Brasil. Nesta pesquisa, as mudanças na legislação não foram analisadas em seu teor. Como foi recentemente aprovada, ainda há tempo para que sejam feitos estudos sobre ela. Contudo, as análises apresentadas até o momento, feitas por órgãos da sociedade civil e pela mídia alternativa, concordam que a referida lei representa um marco na luta pelos direitos dos imigrantes no Brasil, estando de acordo com os relatores do projeto aprovado, sobretudo o senador Aloysio Nunes.

No entanto desde 2013 foi aberta a perspectiva para a participação dos coletivos de imigrantes que já se encontravam no Brasil, bem como para aqueles brasileiros que estavam fora do país.

As políticas de migração em âmbito internacional têm sido limitadas na maior parte dos países tendo em vista a justificativa do imigrante como ameaça nacional, o que reduziu em muitos países as políticas voltadas para o controle das fronteiras.

Nessa perspectiva, Patarra (2005) ressalta que não só o 11 de setembro de 2001, mas as ações decorrentes dele tem se consubstanciado como justificativa para os EUA disseminar ainda mais sua estratégia militar preventiva com a Guerra do Iraque, os conflitos do Oriente Médio, as tensões entre as comunidades muçulmanas na Europa, entre outros episódios que reforçam o racismo e a xenofobia com ampla influência sobre a vida coletiva no século XXI.

No plano internacional, este é o momento decisivo para a definição de quais países teriam acesso ao desenvolvimento. Em outras palavras, é importante saber quais deles 
poderão lograr o desenvolvimento econômico e social de forma a superar a mera posição de eternos países em desenvolvimento. Nesse cenário se apresentaram os países da América do Sul, que em décadas passadas em algumas exceções, assistiu-se a processos de democratização, mesmo que atingidos por crises financeiras, o déficit fiscal, as dívidas externas e internas, a paralisação do processo produtivo, entre outras coisas que geraram o aumento da desigualdade, da pobreza e da exclusão social com ampliação da distância desses países entre os de Primeiro Mundo.

Para romper ou diminuir essas diferenças entre os países na América do Sul, optou-se por duas contraditórias vias: seguir e obedecer as imposições neoliberais ou se fortalecer a partir de blocos econômicos como o Mercosul, mas que, diante da conjuntura neoliberal, teve difícil ênfase e atuou de forma significativa contra hegemônica.

Por outro lado, a emigração fora destacada em vários âmbitos, e também ganhou destaque a vinda de imigrantes sul-americanos pobres, sobretudo bolivianos que chegaram ao Brasil em busca de melhores condições de vida, aspirando direitos sociais como saúde, educação, mesmo na condição de imigrantes ilegais.

O descaso dos imigrantes que chegam já apareciam nas discussões da mídia impressa, que enfatizava a situação deles como a massa de pobres no país, ressaltando suas vicissitudes, associada à desproteção, visualizadas na condições absolutamente precárias de habitação e remuneração, entre outras situações que os afetavam. Em 1990 as notícias evidenciavam o destaque do país na exportação de imigrantes. No entanto, nessa mesma década o país que até então se veiculava como um forte exportador de emigrantes, sobretudo para os EUA, passa a se deparar com a chegada de grandes fluxos migratórios.

[...] os movimentos migratórios internacionais de e para o Brasil foram percebidos como inseridos na reestruturação produtiva em nível internacional. Assim, a crise financeira, o estancamento do processo de desenvolvimento, o excedente de mão-de-obra crescente, a pobreza, a ausência de perspectiva de mobilidade social, entre outras causas, estariam na raiz da nova questão social (PATARRA, 2005, p. 25).

Os movimentos migratórios internacionais de e para o Brasil foram percebidos como inseridos na reestruturação produtiva em nível internacional, como discutimos no capítulo I. Assim, a crise financeira, o estancamento do processo de desenvolvimento, o excedente de mão-de-obra, a pobreza, a ausência de perspectiva de mobilidade social, entre outras causas, 
estariam na raiz da nova questão social; passavam a ser completamente distintos de tudo o que, sob a mesma rubrica, sucedera no passado.

Embora em menor escala, o contexto dos movimentos internacionais que envolviam o Brasil indicavam a entrada de novos contingentes de estrangeiros, com características absolutamente distintas das dos movimentos anteriores, com exceção do caso dos "brasiguaios", enquanto os brasileiros emigrantes para o exterior não eram os mais pobres em sua maioria, os movimentos estavam atingindo os jovens adultos de camadas médias urbanas.

Ao contrário de algumas análises conjunturais que vinculavam a saída de brasileiros à década perdida dos nos 1980 ou à conjuntura do Governo Collor, a questão social era inerente à nova etapa da globalização, sem vias de superação, havia, como menciona Patarra (2005), "vindo para ficar", percebia-se que, sob a rubrica migração internacional aglutinavam-se processos e fenômenos distintos. Estes envolviam as questões fundiárias não resolvidas (como no tradicional caso das migrações Brasil-Paraguai), quanto percepções e anseios de grupos sociais específicos frente a uma mobilidade social truncada no país (como no caso do "rumo ao Primeiro Mundo"), brasileiros que nos países centrais executavam tarefas manuais, de baixa remuneração e qualificação, porém muito melhor remuneradas quando comparadas aos salários no Brasil. Percebiam-se modalidades de movimentos populacionais emergentes no contexto do capitalismo internacional e próprias da globalização atual delineada pela configuração do mercado dual da economia, a entrada de pessoal técnico-científico qualificado, situações de "fuga de cérebros", entre outras.

Patarra (2005) ressalta que no tocante à entrada e saída de estrangeiros no país nunca terminaram, pode-se inferir que o Brasil foi beneficiado pela invasão de cérebros, muitos oriundos de países vizinhos, em grande parte afugentada dos regimes ditadoriais dos anos 1970, bem como de europeus nos anos seguintes da Segunda Guerra Mundial. Além disso, as remessas que entravam no país davam saldos significativos para o desenvolvimento econômico, que teve como pico o ano 1992 com 834 milhões de dólares, chegando a 1995 com saldo de e 3.076 bilhões de dólares (PATARRA, 2005).

Dessa forma, ainda nos anos 1990, Patarra (2005) ressalta a contraditória reação de condenação do Brasil a imigração, isso por que o Brasil não apenas tem uma história marcada pela imigração, mas também foi um grande exportador de mão de obra.

De acordo com esses documentos, o total de brasileiros registrados no exterior era de 1.419.440 em 1996, elevando-se para 1.887 .895 em 2000 e 2.041.098 em 2002, com ligeiro 
declínio em 2003, ano em que foram registrados 1.805.436 brasileiros vivendo fora do país (PATARRA, 2005, p. 26).

Da mesma forma que evidenciamos no capítulo anterior, o Brasil ao se manifestar com ações xenofóbicas como foi o fato isolado e mais contundente ocorrido no auge das migrações venezuelanas para o país, exportou grande leva de sua população para outros países, como destaque para EUA, Japão e países europeus como Itália, Espanha e Portugal. Além disso, o perfil econômico dessa população não se tratava de um contingente pobre, mas Patarra (2005), baseada em levantamentos científicos, constatou o perfil da classe média brasileira que se deslocava para terras estrangeiras permitidas por suas condições financeiras para cruzar as fronteiras do Brasil, com subsunção as redes qualificadas que tratavam do sonho americano e ou da vida no Japão, com um custo e lucro que variava de R \$ 10.000 a R \$ 20.000 .

A autora traz dados até o ano de 2003, mostrando como o Brasil já enviou grandes levas de trabalhadores emigrantes. Até esse ano, mais de 800 mil só para os EUA, seguidos de Paraguai, Japão e por fim países europeus, sobretudo Espanha e Portugal, os quais totalizavam mais de 1.805.436 emigrantes (Brasileiros que foram morar fora do Brasil). Quando comparamos os dados de quase dois milhões de brasileiros emigrados frente à média de 40 mil venezuelanos, ou 80 mil haitianos, temos o insignificante número, o qual é vendido atualmente como crise migratória, mais uma vez desmistificada.

São discrepantes os dados de brasileiros vivendo fora do país e a quantidade de imigrantes recém-chegados, havendo um sensacionalismo na mídia que não trata da situação de vulnerabilidade dessa população migrante, mas a coloca como problema nacional, reforçando o estigma como responsáveis pelas mazelas sociais, incitando um ódio desde sempre presente, sobretudo contra negros, indígenas e pobres cujo resultado é a xenofobia e exclusão social.

Tão contraditória é a condenação dos venezuelanos e tantos outros imigrantes que adentram o país. Uma porção ainda muito ínfima daquilo que já recebemos outrora e daquilo que enviamos para outros países.

Os fluxos migratórios, principalmente de imigrantes que escapam de situações de desespero, tendem a produzir as formas mais degradantes de exploração por parte do capital, ao mesmo tempo em que servem de base para a destruição dos direitos dos trabalhadores "nativos" e de combustível para os discursos xenófobos.

No entanto, assim como a lei tem avanços, ela também tem restrições que são traduzidas nos vetos, ou seja, o que foi aprovado para limitar direitos sob a justificativa de 
inviabilizá-los. A maioria desses vetos se concretiza sob a justificativa de segurança nacional e são a expressão de como se mantém viva na nova lei a herança do retrocesso que sustentou desde os anos 1980 o Estatuto do Estrangeiro que se justifica nos resquícios do que foi considerado como atraso desse estatuto, a segurança nacional. Ou seja, a aprovação de um novo texto em forma de lei, não supera de forma brusca com a pecha dos imigrantes como ameaça nacional, e aqui se reproduzem nas justificativas dos vetos.

A pecha mantém-se viva, embora a lei tenha tido avanços nesse sentido, contudo elas se reproduzem não só nos vetos, mas também no debate que envolveu a disputa para sua aprovação. Está presente nas críticas dos deputados e senadores contrários aos avanços da Lei ao garantir maior flexibilidade da aceitação do migrante e extensão do visto humanitário até então somente concedido para haitianos e demais nacionalidades que se encontravam no país, vitimas não só de catástrofes naturais, mas também de situações como perseguições políticas.

As análises dos discursos que permearam a aprovação dessa lei consideram as críticas feitas quanto a sua aprovação. Isso pode ser percebido nas falas do senador Ronaldo Caiado, do Democratas do Goiás, que teceu sérias críticas à nova lei, alegando que aprová-la no atual contexto é deixar as fronteiras vulneráveis frente a novos problemas que exigem do Estado maior controle sobre elas. Além disso, para esse senador, aprová-la é conduzir o Brasil a relaxar as fronteiras, ao passo que vai na contra mão do resto do mundo que intensificam a proteção e o reforço do controle sobre elas.

Para frisar sua ênfase, o senador acentua o estereótipo do imigrante como baderneiro ressaltando situações xenófobas e do senso comum desvinculadas com os contextos dos fluxos migratórios.

[...] a permanência de qualquer um cidadão que entra no Brasil para assistir um jogo de futebol, depreda todo o estádio, comete crime, esse cidadão vai ficar ainda no Brasil por sessenta dias podendo se explicar? Não pode ser deportado imediatamente? Eu acho que o projeto está desatualizado. Esse é um projeto que existia naquela época onde você tinha um convívio não com a prática do tráfico de drogas com essa intensidade e você também não tinha, tá certo, essa situação que hoje é realidade no mundo que é o processo do terrorismo (SENADO NOTÍCIAS, 2017, p. 01).

A lei foi criticada não só por políticos, mas também por civis, sendo uma das críticas que sobressaiu na mídia impressa a declaração contrária a ela feita por um dos herdeiros da família real brasileira, Luiz Phillipe de Orleans e Bragança, focado na crítica do livre trânsito de indígenas e a defesa de não haver no país cotas como um instrumento para conter a imigração. Ao analisar as críticas de pessoas que não conhecem o sistema migratório no 
Brasil, percebe-se algumas confusões, como por exemplo, fazer a defesa de uma lei que privilegie imigração e sistema produtivo. Há um desconhecimento profundo sobre isso, principalmente porque até a supressão do Estatuto do Estrangeiro que vigorou até novembro de 2017 essa era a tônica das ações do Estado quando remetia a questão imigratória (OLIVEIRA, 2017).

Outra falácia sobre a interpretação da lei no caso do então herdeiro da família real, reproduzida não só por ele, mas pela mídia nacional e pelo senso comum, é desconhecer que a lei não proíbe a circulação de indígenas no território brasileiro, mas impõe restrições dessa mobilidade nas fronteiras.

Uma análise critica desse veto permite a interpretação de que a recusa da livre circulação de povos indígenas nas regiões de fronteira se faz amparado na defesa do resguardo da soberania nacional, embora a lei não seja na prática respeitada pelos povos indígenas, sobretudo pelos Guarani que na região de tríplice fronteira do Paraguai, Brasil e Argentina, que compreende o Oeste do Paraná, significa mais um dispositivo para coibir a circulação desses povos por terras agricultáveis da região, dominadas pelo agronegócio.

Ela soa como um instrumento importante para acirrar o domínio dos grandes ruralistas com vistas ao impedimento das demarcações de novas terras indígenas. Embora a comunidade indígena não respeite a lei porque tendencialmente ela contraria seu dispositivo cultural que é migrar, as migrações no contexto do agronegócio já não são mais toleradas e pode ser mais um instrumento de ataque e violência aos povos indígenas, sobretudo na região Oeste do Paraná, eminentemente marcada por conflitos entre indígenas e representantes do agronegócio, sobretudo nas regiões de fronteira, como Foz do Iguaçu e Guaíra.

Por fim, ao tecer essas análises depara-se com o discurso do Presidente eleito Jair Bolsonaro, que fez sérias críticas a Nova Lei de Migração antes mesmo de assumir o poder, reforçando seus discursos xenófobos já proferidos anteriormente. A ênfase do discurso coloca limites para o avanço da Nova Lei e profundo impacto de possibilidade na consolidação do texto. Embora como já ressaltado, ela seja um marco no avanço dos direitos humanos, e esteja de fato em consonância com a Constituição de 1988, será um desafio sustentá-la tendo em vista o conservadorismo do atual governo que ressalta a:

[...] Ninguém tem o que nós temos [...] O povo também não é discurso de político, que acabou as eleições, maravilhoso, manso. Como é que a gente não consegue evoluir? Onde está o problema?", questionou. "Me desculpem, está no meio de nós. Eu estou no meio desse problema, nós todos, nós todos. E quando a Câmara aprova uma coisa e transforma-se em lei, não adianta falar 'eu votei contra'. Nós somos responsáveis, bem ou mal", respondeu. 
"Como essa última lei de imigração... Vê, a França aceitou algo parecido com isso, ó a desgraça que está lá. Nós somos humanos, queremos respeitar direitos humanos, mas ninguém quer botar certo tipo de gente para dentro de casa. E o Brasil é a nossa a lei "transformou o Brasil em um país sem fronteiras". "Se essa lei continuar em vigor, qualquer um pode entrar [no Brasil] e chega com mais direitos do que nós", declarou, na ocasião (MAIA, 2018, p.01).

O discurso acima mais uma vez corresponde à ignorância de um líder político frente a complexidade das migrações, sobretudo dos atuais fluxos migratórios. Reestabelece o discurso conservador do imigrante como ameaça nacional, que foi e suprimido pela Nova Lei de Imigração. Ao mesmo tempo possuído do senso comum, faz relação entre a França que passa desde novembro por uma onda de confrontos entre manifestantes denominados "coletes amarelos". Esses mantém uma luta secular dos povos franceses por direitos e contra medidas neoliberais e austeridade, e foi simultaneamente taxado pelo futuro presidente como um ato procedido de imigrantes, devido a flexibilidade das leis francesas.

Generalizar a luta do povo francês aos imigrantes seria um equívoco de quem assim como não conhece a história do Brasil, não teria qualquer condição de mencionar outros países. Mas como a ignorância e o senso comum reinam nesses pronunciamentos, mais uma vez, o atual líder político do Brasil faz na lógica de sua campanha pronunciamentos dotados de preconceito, xenofobia e desinformação, recuperando o que pelo menos no sentido da lei, já foi superado no Brasil, de conceber o imigrante como ameaça nacional. Isso simultaneamente coloca para os movimentos sociais um horizonte de profundos enfrentamentos para fazer valer a lei, já atacada por ele antes mesmo de assumir. Sua posse veio agregada de ações que mantém o padrão do discurso xenofóbico e da concepção do imigrante como ameaça nacional.

Foi nessa perspectiva que o então presidente da república Jair M. Bosonaro divulgou no dia 08 de Janeiro de 2019 a saída do Brasil do Pacto Global para Migrações, acordo assinado pelo Brasil e mais 164 países em Dezembro de 2019 a fim de promover a migração segura, ordenada e regular nos países de origem, trânsito e destino. A adesão do Brasil a esse pacto pode ser compreendida como reflexo da Nova Lei de Migração, que prevê os direitos humanos como principal característica. Sob justificativa de garantir a soberania nacional e a segurança do país, o atual presidente desconsidera que essa posição afetará mais de três milhões de brasileiros que vivem fora do Brasil quais podem estar desprotegidos e sofrer violação dos direitos humanos quando estiver fora do país (MIGRAMUNDO, 2018). Entidades se manifestam com preocupação frente às consequências dessa atitude, de forma a 
considerar que ela reforça a pecha do migrante como ameaça nacional ao mesmo tempo em que favorece a transgressão dos direitos humanos. A medida implementada com o objetivo de combater a imigração para o Brasil, afeta muito mais brasileiros que vivem fora do país do que propriamente os grandes fluxos que aqui estão. No entanto, fere perspectivas de inclusão e integração e deixa os brasileiros emigrantes vulneráveis "Não há absolutamente nada que justifique a saída do Brasil do Pacto Global para Migrações. Para cada migrante internacional no Brasil, há dois brasileiros no exterior. Não é difícil deduzir quem serão os maiores prejudicados com a decisão do Ministro" (MIGRA MUNDO, 2018, p. 01).

A criticidade exposta por políticos e por diversos setores da sociedade foi expressiva e demandou do autor da Lei, o Senador Aluysio Nunes, a publicação de um texto defendendo a nova Lei de Migração. Para ele, não há uma só letra que dê para interpretar a lei como sinônimo de abertura das fronteiras. Já em relação à questão indígena explicou que a lei assegura o que já ocorre hoje o trânsito de indígenas em áreas fronteiriças, onde tradicionalmente já habitam, além do que a fronteira não deixa de ser frequentada por criminosos quando existe uma legislação mais rígida. Dessa forma faz a defesa da existência e maior eficácia do código penal, a polícia e a defesa nacional para autuar os grupos que são flagrados atuando sobre a imigração irregular. O senador enfatizou ainda o caráter multicultural do Brasil e por último chamou de terrorismo intelectual, hipocrisia e egoísmo o ataque em forma de críticas feito a lei. Atualmente, estima-se que os imigrantes no Brasil a partir dos grandes fluxos migratórios desde os anos 1980 não chegam a um milhão de pessoas.

Para quem já está no Brasil, o texto prevê uma anistia em forma de residência regular, para recorrer a ela a situação legal do imigrante, não interessando estar irregular ou na fila do refúgio, valendo para todos desde que tenham chego ao Brasil até dia de 6 de julho de 2016.

Em relação à cooperação o país, de acordo com Oliveira (2017) já existe uma importante lei sobre o refúgio e passa a adotar políticas de acolhimento humanitário. Houve nesse sentido, a extensão do visto humanitário já usado como uma medida de enfrentamento governamental em relação aos grandes fluxos migratórios dos haitianos, cuja eficácia foi estendida a partir da nova Lei de Migração para os demais imigrantes.

Sobre esse aspecto, Silva (2017) frisa a importância das redes de apoio na condução do processo migratório no Brasil e a participação delas nos debates que foram cruciais para a aprovação da Nova Lei de Migração. Destaca o seu papel intermediário e a condição de acolhedoras de imigrantes, sobretudo haitianos no período que antecedeu a aprovação da nova lei, com o estímulo a eles de participação no debate, de forma a levar para o Estado suas 
demandas como pessoas concretas que vivem a realidade de estar fora de seu país, cuja situação é de quase nula presença estatal.

Corroborando com ele, a nova Lei de Migração, conforme algumas análises abandona a visão do imigrante como uma ameaça à segurança nacional e passa a tratar o tema pela perspectiva dos direitos humanos. Essa análise também foi expressa em várias notícias de órgãos midiáticos alternativos ou progressistas, porque expõem uma formação de opinião desatrelada àquilo que é veiculado pela mídia aberta no Brasil. Esta, por sua vez, é manipuladora, responsável pela desinformação e alienação, reduzida ao entretenimento e à formação de opinião baseada na reprodução da ideologia da classe dominante. Alguns órgãos foram identificados com essa mídia alternativa, como: (MISSÃO PAZ, 2017; DELFIN, 2017; EL PAÍS, 2015).

Embora seja cedo para avaliar os efeitos da recente lei brasileira de migração, o presidente do CNIg, Paulo Sérgio de Almeida (EL PAÍS, 2015), inferia em período anterior a sua aprovação sobre a necessidade do país avançar nas políticas para imigrantes, de modo que, a partir dessa lei, outras possam surgir para que o país possa aos poucos ir superando seu atraso na sua execução. Um dos efeitos já analisados pós-aprovação foi a transferência do visto humanitário para outros imigrantes, o que corrobora o surgimento de outras leis. Embora sejam elas ainda baseadas em decretos, ou resoluções normativas, é certo que expressaram ações diretas do governo sobre as situações de milhares de pessoas.

Conforme Marcia Spradel, vinculada ao Instituto de Migração e Direitos Humanos (SENADO, 2018), as pessoas que não se enquadram na situação de refúgio, mas sofrem ameaças porque são oriundas de países com situações de instabilidades políticas ou com problemas decorrentes de catástrofes naturais também passam a ser contempladas com o visto humanitário.

Corroborando com Spradel, a representante do Ministério da Justiça Silvana Borges ressalta a importância dessa lei para que aquelas pessoas que não se enquadram como refugiadas e a partir da sua vigência não precisam mais se utilizar desse subterfúgio para conseguir uma regularização imigratória no Brasil. A lei lhes garante maior facilidade, podendo conseguir um visto para entrar no Brasil de acordo com a sua realidade, quando os anseios desses imigrantes é apenas melhorar sua condição de vida (SENADO, 2017, p. 01). Além disso, o visto de trabalho que já existia tem a novidade de ser concedido sem uma oferta formal de trabalho, porém ainda está vinculada com o imigrante qualificado.

O conselheiro do CNMg, nessa mesma perspectiva, não vê a migração como problema social, pois o problema em si estaria mais na falta de políticas para acolher os imigrantes e 
promover a sua inserção social. Essa interpretação diverge do que é noticiado cotidianamente pela mídia aberta, quando reproduz o discurso que reforça a ideia do imigrante como uma ameaça e invasor.

\begin{abstract}
Ainda temos uma lei de 1980, uma época em que o país vivia uma época de exceção e que tem um viés autoritário. É uma dívida que o país tinha em relação a essa questão. A lei muda o eixo colocando a questão das migrações sobre uma ótica de proteção de direitos, cria um conjunto de procedimentos migratórios mais simples, contempla um leque maior de vistos e residências... E tem outra questão importante: permite que os imigrantes sem documentos possam obtê-los. Agora, ela não resolve algumas questões como a validação de diplomas, que é muito importante porque você tem muitos profissionais de alta qualificação que levam um tempo longo para poder homologar seus títulos. Outra questão que vai ser necessária regulamentar, até com uma nova legislação, é a própria institucionalidade dessa lei, que autoridades vão lidar com quais assuntos (EL PAÍS, 2015).
\end{abstract}

Outra avaliação advém de membros vinculados à sociedade civil que realizam atendimento aos imigrantes. Em uma nota pública conjunta, representada pela Missão Paz essa entidade observa que a proposta "é coerente com uma sociedade mais justa, livre e democrática" e "moderniza o sistema de recepção e registro das pessoas migrantes". (MISSÃO PAZ, 2017).

O texto reforça, ainda, que a nova Lei de Migração é resultado de um amplo processo de debate público e responde às demandas históricas aludidas e reivindicadas por entidades e movimentos sociais que trabalham e atendem os imigrantes no Brasil. As políticas de migração são entendidas como parte do conjunto das políticas sociais e resultantes da tensão entre capital e trabalho com vinculação direta às condições econômicas do país. Por essa lei ter sido implementada muito recentemente, ainda é cedo para avaliar em que medida será efetivamente aplicada quando se trata a realidade concreta dos migrantes. 


\section{CAPÍTULO III \\ 4. TRABALHO EM FRIGORÍFICOS NO OESTE DO PARANÁ: IMPULSIONADORES DA IMIGRAÇÃO HAITIANA}

O segundo capítulo indicou alguns pressupostos do desenvolvimento do capitalismo na região Oeste do Paraná e nos permitiu visualizar no desenvolvimento específico dessa região como as explicações micro se vinculam às explicações macro sociológicas, pautadas no desenvolvimento agrícola e a formação de cadeias produtivas vinculadas ao agronegócio, as quais têm sido alcunhadas como dinamismo econômico frente ao desempenho peculiar da produção e industrialização de aves, ligada aos grandes monopólios internacionais.

Enfatizou-se o papel do Estado nesse contexto, que se colocou como um grande investidor por meio da promoção de empresas nacionais por plano estratégico denominado de políticas dos campeões, que, no caso específico da Coopavel, denota o sucesso do empreendimento seguido de financiamentos milionários à custa de toda sociedade. Por outro lado, apontou-se ainda o papel do Estado quanto às políticas de migração, e traçamos um paralelo de forma a mostrar a insuficiência das políticas de migração, que pela ausência do Estado tendem a ampliar a criminalização desse fenômeno, ao passo que precarizam as condições de vida de milhares de pessoas migrantes.

Naquele capítulo, discutiu-se também a íntima relação entre Estado e esses empreendimentos econômicos que extrapolam o financiamento direto e promoção dessas empresas, mas se efetiva, sobretudo, na sua complacência frente às relações de trabalho baseadas na superexploração, sem exigir qualquer retorno social no que se refere à melhoria das condições de trabalho e combate à precarização dessas relações, além de arcar com o ônus de milhares de trabalhadores doentes produzidos por esse sistema produtivo predador.

\section{4 .1 Imigração haitiana delineadores para a mobilidade no Oeste do Paraná}

Chegados ao século XXI, os haitianos possuem características diversas dos primeiros trabalhadores imigrantes que chegaram à região, não se vinculam ao trabalho agrícola, mas são inseridos no trabalho de processamento industrial de carnes. Não são europeus ou seus descendentes advindos de países desenvolvidos, mas compreendem um conjunto de imigrantes oriundos à luz do contexto de uma economia mais integrada ao sistema global.

O trabalho manual é um elo comum que liga a imigração dessa região em diferentes tempos históricos. As migrações do século XXI demandaram um conjunto de questões que permearam o levantamento de variáveis que visaram identificar a relação dessa imigração com o setor de frigoríficos, como os principais motivadores da migração para Cascavel, a 
primeira cidade a chegarem no Brasil. Essas questões, muitas vezes, complementavam as demais, pois ao relatar o que motivou a migrar, o imigrante traçava a trajetória sobre a imigração no Brasil, se Cascavel já fazia ou não parte dos planos migratórios ou se surgiu como uma possibilidade não programada frente a outras situações como a necessidade de ter para onde ir e a conquista de um trabalho.

É escasso o volume de estudos que tratam da imigração de haitianos para o Oeste do Paraná. No entanto, o pouco referencial teórico incide sobre a vinculação entre o setor produtivo de frigoríficos, já que esse setor demanda de mão de obra constante devido à rotatividade de trabalhadores que insere e exclui do sistema produtivo, como veremos nesse capítulo. Por isso, busca-se compreender questões que possam revelar a vinculação entre migração e sistema produtivo, especificamente em frigoríficos, por meio de variáveis como motivações para migrar e inserção laboral em Cascavel.

Destaca-se, dessa forma, a importância da vinculação de empresários do setor de frigoríficos na região e sua influência em trazer para o Município as levas de trabalhadores haitianos. Assim, retoma-se qual a origem da migração, se ela está vinculada ou não com determinadas atividades produtivas e a ausência de trabalhadores manuais.

Essa questão é chave para identificar os primeiros imigrantes que chegaram ao Município via empresários, bem como para avaliar o atual período de imigração e se ele continua estável, tem aumentado ou diminuído.

A ocupação produtiva atual é outra questão fundamental para observar quais setores produtivos estão incorporando os haitianos no Oeste do Paraná por meio de questões que consideram a atual ocupação laboral e, em que atividade trabalha. E se essa é formal ou informal. Esses dados revelam a incorporação de homens e mulheres no setor produtivo. Essa questão, além de delinear o universo ocupacional da mão de obra haitiana nessa amostra, revela, também, as condições de trabalho a que estão submetidos os imigrantes na região.

A função laboral desempenhada no Haiti foi outra questão fundamental para observar e contrastar a atividade laboral desenvolvida antes de migrar para o Brasil com a realizada atualmente. A insatisfação do trabalho ou ausência dele tem sido um forte motivador das migrações econômicas no século XXI, perceber em que medida isso se dá com os haitianos também viabiliza uma chave explicatória desse processo. Dessa forma, ao ser inquirido sobre que trabalho realizava antes de vir para o Brasil, os imigrantes foram levados a revelar as experiências de trabalho e suas condições no país de origem, muitas vezes colocadas como impulsionadoras do processo migratório que se vincula também às migrações econômicas, possibilitando nessa pesquisa compará-las com as mesmas experiências vividas no Brasil. 
A cidade de Cascavel e o Estado do Paraná não foram escolhidos como destinos dos primeiros imigrantes haitianos que chegaram à região, mas ela foi delineada frente à possibilidade de trabalho vislumbrada com a presença de empresários do Município de Cascavel, quando esses imigrantes ainda estavam no Acre. Vários estudos como Baeninger et al. (2016), Araújo (2016), Couto (2016), Mamed (2017) dentre outros, indicaram a presença de empresários do Sul e Sudeste do Brasil que se deslocavam até a região de fronteira do Norte do país para selecionar grupos de haitianos quais seriam levados do Acre para trabalhar nessas regiões.

Os dados da amostra pesquisada revelam o constante crescimento populacional de haitianos em Cascavel, onde a primeira leva foi trazida por empresários seja da construção civil ou frigoríficos, enquanto a segunda leva se dá via reunificação familiar. As taxas de migração não foram reduzidas, e atualmente a maior parte da população continua migrando e mantém a estabilidade dos picos migratórios de haitianos que chegam no Brasil. Além disso, Cascavel aparece como a primeira cidade de chegada, o que indica novas rotas de entrada no país e a consolidação das redes étnicas e familiares. O gráfico abaixo indica também o ápice de imigração em 2014, correspondendo aos dados nacionais que teve nesse ano o maior pico migratório de acordo com Silva S. (2016a).

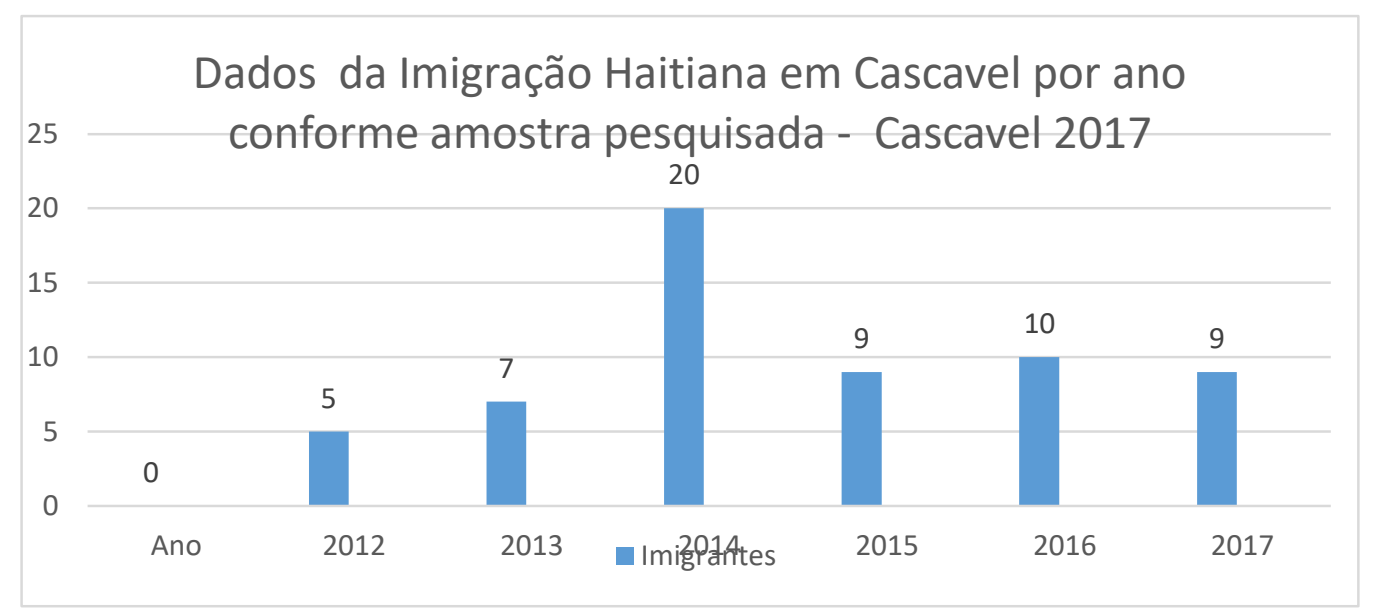

Gráfico 2 - Índices de migração em Cascavel Paraná de 2012 a 2017. Fonte: Pesquisa de campo com entrevistas realizadas entre abril a julho de 2017. Elaboração da autora.

Cascavel segue a tendência brasileira de receber, no ano de 2014, o maior pico migratório na cidade, que conforme Silva S. (2016a) corrobora com os dados nacionais que também apontam nesse ano o período de maior número de imigrantes haitianos, o que representa um pico migratório. Por sua vez, os dados do SINCRE mostram que 2015 foi o ano com maior registro desses imigrantes no Brasil, como demonstrado no capítulo II. Embora o Gráfico da pesquisa de campo mostre uma redução no número de imigrantes haitianos de 
2015 a 2016 em Cascavel, os dados de 2017 mantiveram os índices que podem ser superiores, já que a pesquisa de campo contemplou os meses de abril a junho de 2017, sendo, portanto, realizada no primeiro semestre. No entanto, no restante do ano, é possível que outros imigrantes tenham chegado ao Município e alterado esses dados. Ainda é importante ressaltar que a amostra não considerou crianças, mas apenas imigrantes maiores de 18 anos.

Esses dados também corroboram com aqueles divulgados pelo Sincre, embora a distribuição e registros de entradas por ano correspondam a valores diferentes, assim como demonstra Cavalcanti (2017).

\begin{tabular}{|c|c|c|c|c|c|c|c|c|}
\hline \multirow{2}{*}{ Principais paises } & \multicolumn{8}{|c|}{ Ano de entrada } \\
\hline & 2010 & 2011 & 2012 & 2013 & 2014 & 2015 & 2016 & Total \\
\hline Total & 38.184 & 51.123 & 57.536 & 81.200 & 81.401 & 67.847 & 59.843 & 437.134 \\
\hline República do Haiti & 306 & 2.656 & 4.360 & 14.227 & 19.660 & 19.212 & 20.577 & 80.998 \\
\hline Bolivia & 9.965 & 12.783 & 11.331 & 11.586 & 6.546 & 5.154 & 3.471 & 60.836 \\
\hline Argentinha & 3.041 & 3.447 & 4.056 & 4.950 & 5.551 & 4.231 & 3.634 & 28.910 \\
\hline Colômbia & 970 & 1.333 & 2.796 & 6.102 & 5.764 & 5.473 & 5.020 & 27.458 \\
\hline Peru & 1.419 & 2.018 & 3.864 & 3.565 & 3.622 & 2.845 & 2.242 & 19.575 \\
\hline Paraguai & 2.343 & 2.453 & 3.142 & 3.299 & 3.473 & 2.667 & 1.754 & 19.131 \\
\hline República Popular da China & 1.871 & 2.918 & 2.476 & 2.913 & 3.097 & 2.826 & 2.073 & 18.174 \\
\hline Portugal & 1.411 & 2.234 & 3.034 & 3.547 & 3.051 & 2.033 & 1.260 & 16.570 \\
\hline Itália & 1.421 & 1.678 & 2.092 & 2.164 & 2.296 & 1.854 & 1.265 & 12.770 \\
\hline Estados Unidos da América & 1.215 & 1.410 & 1.487 & 1.521 & 1.426 & 1.248 & 976 & 9.283 \\
\hline França & 961 & 1.107 & 1.264 & 1.612 & 1.642 & 1.432 & 1.061 & 9.079 \\
\hline Alemanha & 836 & 985 & 982 & 991 & 897 & 831 & 575 & 6.097 \\
\hline Outros paises & 12.425 & 16.101 & 16.652 & 24.723 & 24.376 & 18.041 & 15.935 & 128.253 \\
\hline
\end{tabular}

Foto 8 - Número de estrangeiros considerados migrantes, segundo principais países de nascimento, por ano de entrada, Brasil - 2010-2016. Fonte: Cavalcanti et al.(2017, p. 51).

Ao analisar a imigração na Espanha, Arango et al. (2007) ressaltam que, embora o senso comum justifique sua causa na derrocada econômica como resultado da imigração irregular, isso não procede, pois esse país teve seu desenvolvimento vinculado ao efeito chamada, ou guestworkers, políticas de invitados, nomenclaturas diferentes mas que remetem a um mesmo fenômeno que vincula a imigração delineada a partir da demanda do setor produtivo (ARANGO ET AL., 2007).

A princípio, os empresários espanhóis não imaginaram que usar a mão de obra imigrante baseada no trabalho temporário e de retorno pudesse causar a permanência desses trabalhadores, ou o não retorno deles para a sociedade de origem. As políticas se convergem, principalmente, com a permanência desses trabalhadores que formam minorias ou comunidades étnicas que passam a demandar do Estado respostas, sobretudo de inserção social (ARANGO ET AL., 2007). 
As redes migratórias são a base do processo de estabelecimento e formação de comunidades nas áreas de imigração. Isso se vincula com a reunificação familiar, que se dá a partir do tempo de permanência para os imigrantes começarem a trazer suas famílias. Além das redes familiares, outras denominadas de mesoestruturas - tais como instituições de apoio ou aquelas vinculadas aos lucros com tráficos de pessoas - ocupam a função de apoio ou de exploração no processo migratório.

Corroborando os depoimentos, o guest worker ${ }^{28}$ foi assumido pelo próprio empresariado em Cascavel, principalmente da construção civil e frigoríficos, frente à carência de mão de obra manual na região, bem como disponibilidade de trabalhadores haitianos para realizá-la no Sul do Brasil, conforme noticiado pela primeira empresa a implementar o Guest workers, noticiado em seu próprio site.

Um grupo de 44 haitianos chegou hoje de manhã à FAG. Eles passaram cerca de dois meses na cidade de Brasiléia, no Acre, e foram trazidos pela FAG para Cascavel, para trabalhar na construção civil. De acordo com o engenheiro civil da instituição, Carlos Oya, a iniciativa de contratá-los surgiu da carência de mão de obra. "Nós precisávamos de trabalhadores para as novas construções da FAG e com a visão social e humanitária do senhor Assis Gurgacz, aliamos a nossa necessidade à necessidade deles (FAG, 2012, p.01).

A empresa denominada FAG trata-se de um grande complexo universitário privado, que demandou contratação de mão de obra para a construção civil devido a ampliação de sua sede e a reforma de um hospital escola para o curso de medicina e outros vinculados à saúde. Os dados quantitativos sobre a primeira cidade a chegar no Brasil inferem Cascavel como uma cidade de destino, quando mencionam a rota migratória considerando o Município um local de chegada e permanência, isso permite inferir o peso da reunificação familiar e étnica como novo delineador migratório.

\footnotetext{
28 Guestwork trata-se da disponibilidade de vagas de trabalho por empresários para imigrantes realizarem determinadas funções conforme a demanda do sistema produtivo (ARANGO, 2007).
} 


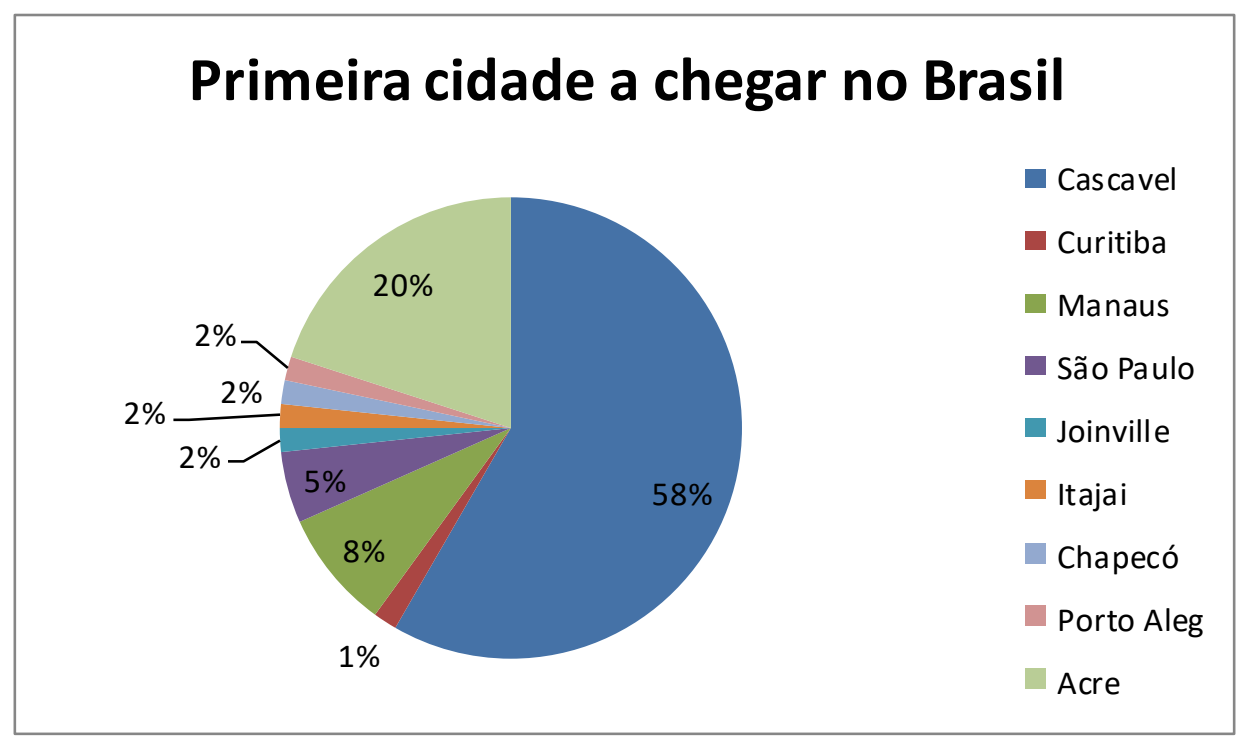

Gráfico 3 - Primeira cidade a chegar no Brasil. Fonte: pesquisa de campo com entrevistas realizadas entre abril a junho de 2017. Elaboração da autora.

$\mathrm{Na}$ amostra pesquisada, alguns trabalhadores relatam nos depoimentos a experiência enquanto trabalhador e imigrante de estar entre os primeiros que chegaram, podendo evidenciar o significado da mobilidade interna no Brasil como trabalhador, bem como das diferentes experiências que fizeram de Cascavel e da diáspora haitiana um elo comum.

Num desses depoimentos, trazemos as experiências de Cristian, imigrante de 36 anos que relata como se deu o deslocamento e as relações de trabalho quando chegou à Cascavel, trazido pela FAG. Para ele, migrar para o Município foi uma alternativa para superar a instabilidade colocada pela condição de ser migrante, marcado por incertezas em que a única certeza que se tinha era do Brasil como local de chegada e como território de acolhida. Isso porque havia traçado apenas a rota migratória, sem conhecer o seu destino. Ao mesmo tempo, sua experiência delineia a tendência de grandes fluxos migratórios, que inauguram novas rotas, sem que para isso possa contar com redes de apoio já estruturadas como as familiares.

A FAG foi buscar nós no Acre, eu cheguei primeiro no Acre, quando cheguei não havia nada lá. Nada e nenhum lugar para ficar, para trabalhar e os brasileiros não gostavam dos haitianos. A gente não entendia o que os brasileiros falavam e eles não nos entendiam. Eu sabia alguma coisa porque morei na República Dominicana e sei falar espanhol que é parecido com o português. Então quando nós estávamos todos no único abrigo. Quando estávamos em Brasileia nós sabia que não íamos ficar lá, tão pouco sabia para onde iríamos. Então vir para Cascavel foi uma surpresa e uma felicidade porque aqui viemos para trabalhar, e fomos buscados para isso no Acre (Entrevista Cristian, Depoimento gravado no dia 09 de Maio de 2017). 
Cristian revela as incertezas do processo migratório e o sentido da fronteira como local de passagem. Cotinguiba e Cotinguiba (2016) trabalham com o conceito de fronteira como aquele pautado nas experiências sociais em torno do processo migratório, as quais extrapolam os limites territoriais entre o Brasil e demais países vizinhos. Brasileia era compreendida e significada para muitos imigrantes como local de permanência para regularização de documentação. Tornava-se, assim, o espaço da imobilidade e insegurança, além de que serem indocumentados fazia desses imigrantes reféns da retenção.

O significado da fronteira como simples local de passagem é corroborado com os dados dessa população que aspirava outros destinos que não fossem a fronteira para viver e trabalhar depois do acesso a documentação. A posse dos documentos fez da fronteira o espaço de liberdade com capacidade de ampliar seu território pelas relações sociais e uma perspectiva de romper e deixar para trás um local concebido como de passagem e provisório.

Assim como Cristian, Taylor evidencia como a oportunidade de trabalho em frigorífico influenciou a imigração dos primeiros haitianos que chegaram a Cascavel. Ele migrou em 2012 para o Brasil e sua entrada no país ocorreu pela cidade fronteiriça de Brasileia, no Acre. Assim que teve acesso à documentação, esperava conseguir um trabalho, independentemente do lugar e função que iria realizar.

Faz cinco anos que vim para Cascavel, a primeira cidade que vim foi Cafelândia, vim para o Acre e do Acre para Cafelândia. A motivação para vim para Cafelândia é a seguinte: eu estava lá no abrigo no Acre e chegou lá um grupo pessoas da Coopacol que foi lá buscar 44 haitianos para trabalhar no frigorífico em Cafelândia. O chefe encarregado do abrigo viu que meu português era mais melhorado que os outros né, aí ele me mandou junto com eles para ajudar a traduzir e ajudar outros que não sabiam falar. Fiquei três meses trabalhando lá e ajudando a traduzir também. Quando estava em Cafelândia eu peguei sai por minha causa né sabe, eu queria morar na cidade mais grande, eu não queria ficar mais em Cafelândia, depois de três meses de experiência, eu vim mora aqui em Cascavel, e quando cheguei aqui já entrei trabalhar na Coopavel (Entrevista Taylor, depoimento gravado em 09 de Maio de 2017 ).

Esse depoimento marca a importância das indústrias de processamento de carne na região Oeste do Paraná. Cafelândia é um Município servido pelo frigorífico Coopacol e se localiza a 56,6 km de Cascavel, aparecendo nesse depoimento como um dos que estiveram no Acre para contratar haitianos a fim de trazê-los para o Sul. Nesse depoimento sobressai mais uma vez o domínio do espanhol, uma das primeiras aproximações de contato entre alguns dos primeiros haitianos a vir para a região e brasileiros, em que o espanhol foi um elo 
fundamental para inserir a comunicação desses imigrantes. Buscá-los na fronteira do Norte do país pode não ter sido, para essas empresas, uma escolha baseada na preferência, mas sim uma necessidade frente à rotatividade e escassez de mão de obra demandada pelas indústrias da região.

Cotinguiba e Cotinguiba (2016) presenciaram várias triagens feitas por empresas de diversas regiões do Brasil, que deslocavam seus recursos humanos até o Acre com o propósito de selecionar haitianos para o trabalho. Nesses momentos, os autores observaram a exigência de algumas habilidades por parte dos trabalhadores, como falar espanhol e apresentar melhor desempenho em testes de Matemática. Após selecionar esses trabalhadores, vários ônibus se deslocavam com eles para as regiões Sul e Sudeste do Brasil. Diante do observado, os autores constataram uma contradição entre os elevados requisitos de seleção e a atividade de desempenho laboral, que seria de caráter manual.

A língua parece ter sido um importante diferencial para a seleção de alguns imigrantes, os quais, a partir de outras experiências migratórias, como ser imigrante na República Dominicana, permitiu a alguns entrevistados ressaltarem esse acúmulo de aprendizado, pois o domínio do espanhol, língua que se aproxima ao português, foi elemento decisivo para as empresas estenderem por meio desses imigrantes o contato com os demais.

Outro exemplo interessante sobre a utilização da trajetória social dos haitianos como estratégia para compreender o processo migratório em Cascavel revela sentimentos e emoções que, muitas vezes, não são controlados pelos sujeitos, mas interferem nas decisões para migrar. Nessa perspectiva, Elines, que vive no Brasil desde 2014, destaca a sua primeira experiência migratória como um acontecimento inesperado, sem planejamento ou qualquer controle racional, no sentido de prever o que iria acontecer quando da partida no Haiti e chegada no Brasil.

Eu peguei o avião do Haiti até o Peru, do Peru até Argentina e peguei um taxi para cruzar a fronteira da Argentina com o Brasil. Fiquei lá na Argentina uma semana, aí meu primo comunico comigo e eu vim ele estava aqui né, e eu vim cheguei aqui em Cascavel. Não vim com visto, na verdade é uma coisa loca que me aconteceu com a minha mãe. Tudo foi uma decisão da minha mãe porque eu não sabia de nada, eu tinha acabado de termina de tirar meu grau de ensino médio né, e a minha mãe decidiu. Minha mãe falou, então meu filho, você terminou o ensino médio tentou o vestibular não conseguiu, eu já preparei tudo passaporte e você vai embora. E eu fiquei assim, surpreso. Na época era muito difícil conseguir um visto, na época pensa que era para conseguir um visto. Era muito difícil. E para conseguir um visto tinha que pagar uma pessoa para ela te encaminhar direto ao consulado. Aí minha mãe decidiu fazer o caminho errado, mas até ali eu consegui entrar como se fosse um turista no Brasil, entrei sem dificuldade, 
tranquilo. Bem tranquilo. Da minha família só veio eu, vim sozinho para o Brasil, meu primo estava aqui, agora ele nem está mais, já foi embora, até hoje tô vivendo sozinho (Entrevista Elines, 11 de maio de 2017).

A imigração de Elines não foi planejada por ele, mas repentinamente articulada pela mãe, que acionou as redes de apoio como a familiar com o primo e a caracterizada pelo que ele chama de "caminhos errados", ou o que Coutinho (2013) denomina de redes clandestinas, que também se configuram como redes de apoio. Numa concepção macro social, a partir de um viés marxista, o que se denomina de redes de apoio são formas antigas de comercialização de mão de obra, presentes em diversos momentos históricos como um mecanismo rentável e lucrativo.

No entanto, Elines ressalta a dificuldade de conseguir visto na embaixada de Porto Príncipe, aspecto também identificado em outros estudos. No período de sua migração, os vistos eram controlados pela normativa 97 de 2012, que estipulava uma cota de até 2.200 vistos anuais emitidos no Haiti. Silva S. (2016a) entende que esse fator ampliou a clandestinidade e fomentou a ação de coiotes e demais agências ilegais, que lucram com o processo migratório.

Os estudos de Faria (2016) e Silva S. (2016a) indicam a necessidade de avançar nas legislações que têm como único propósito o controle das fronteiras. É preciso prover, tanto no Haiti como no Brasil, políticas que rompam com a inoperância estatal frente à imigração ilegal, o que leva à insegurança, violência e transgressão dos direitos humanos.

Sem se referir propriamente ao terremoto, Elines relata os meandros econômicos em sua trajetória de vida e os motivos que levaram a mãe fazer do Brasil seu destino migratório.

\footnotetext{
A motivação é que o Haiti é um país que muitas pessoas sabe que não é desenvolvido né, é um país pobre vamos dizer, mas por causa da corrupção tudo que passa no poder, presidente, senador, são políticos que pensa só no bolso, não pensa no povo, o jovem não vê onde vai, onde que tá o futuro. Acaba que a família, o cara tem 17 anos, a família acaba mandando para fora do país, não tem uma estrutura política boa, não só por causa da política, passou terremoto, outra situação de desastre, passo tudo isso, o país se acabando, mas ficou mais pobre ainda sem possibilidade, mas eu penso que o país podia andar mais, mas, por causa da política suja,está acabando desse jeito e cada dia mais eu acho que vai piorar (Elines, entrevista realizada em 11 de maio de 2017).
}

Além da pobreza, intensificada a partir do terremoto, Elines aponta a corrupção do país como aspecto motivador da migração. Sem perspectivas para permanecer no Haiti, a mãe 
proveu a permanência do filho até que fosse possível. Mas foi em outro país que viu a possibilidade de permitir a ele um futuro melhor. Depois de concluir o equivalente à educação básica no Haiti, estava pronto para ocupar as fileiras do processo migratório, que, no caso de Elines, teve o Brasil como rota.

Exemplo dessas diferentes trajetórias e a da migração tida como uma característica cultural do Haiti aparece no relato de Abner, que está em Cascavel desde o final de 2014, sendo esta sua quarta experiência de migração internacional.

Primeira motivação foi o sequestro, eu fui perseguido lá e tive que vender minha casa para pagar o sequestro. Foi muito difícil para mim. Depois do sequestro, eu viajei para quatro países, mas antes do sequestro eu era advogado professor no Haiti. Eu passei um ano no Equador e 27 de dezembro 2014 até 15 novembro de 2015 quando eu cheguei no Brasil. Aqui dou aula como professor particular de francês. Tô passando por dificuldades porque não consigo muitos alunos. Quando cheguei, fiquei em São Paulo 22 dias, e também outra cidade que não lembro o nome (Abner, entrevista realizada dia 09 de Maio de 2017).

$\mathrm{O}$ relato de Abner indica as rotas migratórias que envolvem os países de origem, trânsito e chegada. Além de destacar a insegurança promovida pela condição de trabalho que o colocava em contato com pessoas ou grupos perigosos, quando atuava como advogado, afirmando que o sequestro foi o resultado mais expressivo das diferentes formas de violência às quais estava submetido no país.

Logo, a insegurança é um fenômeno que comumente estimula o processo migratório. O caso de Abner é um exemplo de imigrantes que realmente são refugiados, mas que ao chegar ao Brasil, assim como os demais haitianos, após a Normativa nº7/2012, teve a concessão do visto humanitário que generaliza toda imigração haitiana às razões humanitárias, sendo aquelas que enquadram a mobilidade por conta de catástrofes naturais.

Bauman (2017) considera a migração uma promessa de redenção ou de fuga e, para muitos imigrantes, ela é uma forma de recuperar a dignidade humana e a autoestima. Nessa direção, Mezzadra (2005) ressalta que a migração é uma forma de liberdade que o capital não conseguiu suprimir, embora tenha desenvolvido diferentes mecanismos de controle para contê-la. Todorov (2011), por sua vez, considera essa liberdade como rebeldia do imigrante, que transpõe as barreiras ou fronteiras instituídas como novos mecanismos de controle.

Os depoimentos dos haitianos que fizeram parte das primeiras levas a chegar, indicam diferentes trajetórias individuais que se consubstanciam em história coletivas. Bosi (2016), ao trabalhar com a história oral, ressalta a importância do pesquisador que se utiliza desse 
método que apresenta diferentes histórias subjetivas que se consubstanciam à história coletiva desses sujeitos, evitando assim o nivelamento das experiências narradas às noções ou modelos pré-concebidos.

Da mesma forma, imbuídos de uma metodologia com o propósito de histórias coletivas e não apenas biografias individuais, foram transformados em questões os assuntos referidos pelos trabalhadores, tais como as relações de trabalho no Paraná e a vinculação com o processo migratório. Os estudos sociológicos consideram dois campos teóricos relevantes, sendo um deles a microssociologia, pautada na racionalidade do sujeito que, diante dos problemas conjunturais do capital como o desemprego, migram para superar esses desajustes, baseado no movimento push-pull. Outro se configura nas teorias que explicam as migrações a partir de uma perspectiva macro, e podem ser divididas em alguns grandes grupos.

Sobre essas diferentes experiências individuais que constituem o todo da biografia coletiva, foram quantificadas as motivações desses imigrantes a partir das respostas que davam sobre os motivos que os fizeram migrar para o Brasil, expressos no Gráfico abaixo.

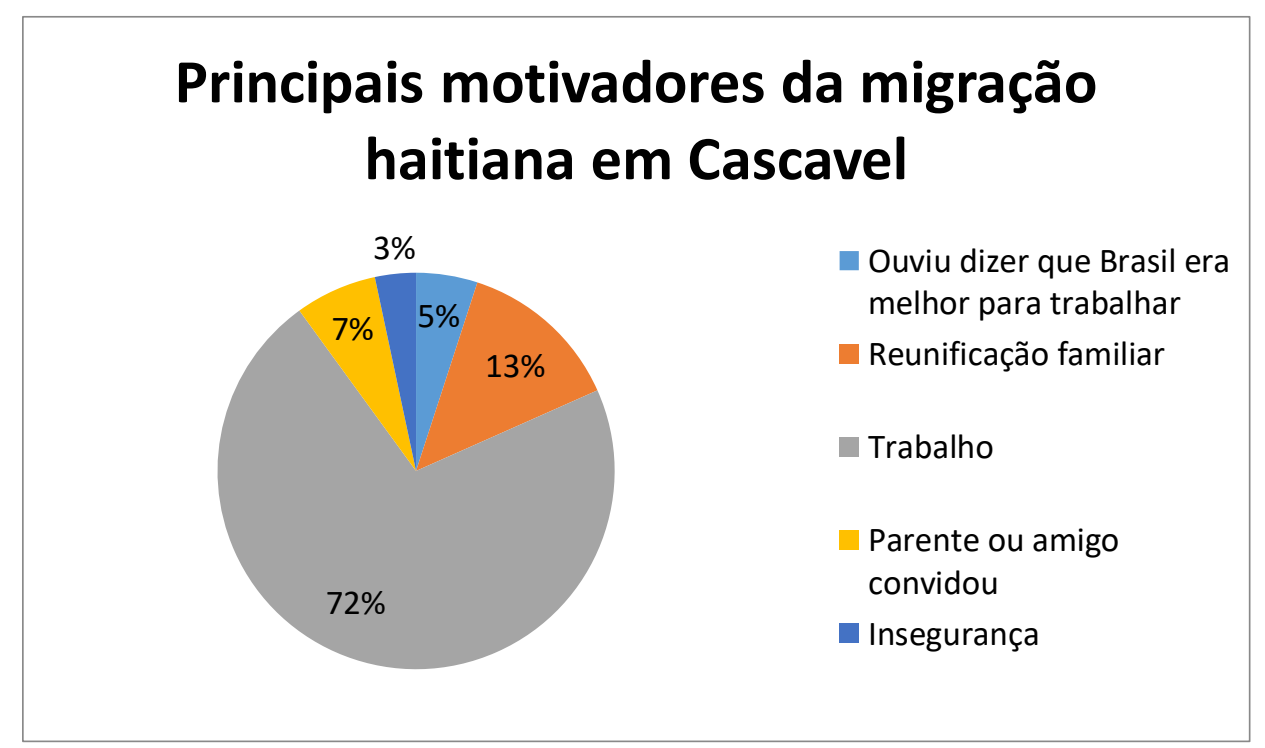

Gráfico 4 - Principais motivadores da migração haitiana em Cascavel. Fonte: pesquisa de campo com entrevistas realizadas entre abril a junho de 2017. Elaboração da autora.

O gráfico que representa os motivadores da imigração encontra na variável trabalho a maior justificativa para migrar no Brasil, contudo, ela não deixa de estar vinculada a outras variáveis, como expressa o depoimento de José.

Eu tenho 39 anos. Faz três anos que estou aqui no Brasil, vim direto do Haiti para Cascavel. Todo Haitiano gosta do Brasil porque tem futebol, jogar futebol. Quando chegamos aqui é porque viemos em busca de uma vida melhor. Logo que cheguei consegui trabalho e dinheiro e tá bom para mim. 
No Haiti, eu era vendedor de roupas. Quando cheguei aqui em Cascavel fui trabalhar de servente. Cheguei e fui direto trabalhar na FAG, fiquei três meses de experiência e mandaram embora, depois fui trabalhar com outra pessoa. O que me falta agora é minha esposa que está no Haiti (José, entrevista realizada em 09 de Maio de 2017).

Embora a reunificação familiar esteja expressa no desejo de estar com a família, a importância de enfrentar a vida em outro país com um companheiro ou companheira também se relaciona com o trabalho e com o convite de parente e amigo, o que identifica a importância das redes étnicas que abrem caminho para impulsionar as migrações. Da mesma forma, o haitiano João relata que era engenheiro e professor de matemática no Haiti e veio para o Brasil para buscar uma vida melhor. A desvalorização da moeda e da força de trabalho no Haiti motiva a busca por melhores condições de vida, sendo essa uma característica de muitos imigrantes, que acreditam poder executar o trabalho de formação no país de acolhimento com maior valorização.

Eu tenho 40 anos. Vim para o Brasil faz três anos, 2014, e cheguei em Cascavel. Eu vim com visto, era professor e trabalhava na construção civil, fiz faculdade. Faz dois anos que trabalho na Coopavel. Consegui trabalho assim que cheguei, primeiro na construção civil, e depois na Coopavel. Eu gosto de viver aqui no Brasil (João, entrevista realizada em 03 de Maio de 2017).

Ter o visto é um sinônimo de possuir melhores condições de vida no Haiti, ainda que elas não sejam tão destoantes entre os diferentes estratos, porém, é um mecanismo que viabiliza e facilita o processo migratório, a esse exemplo há o perfil de classe média no Brasil, como já evidenciou Patarra (2005), que impulsionaram legalmente o processo migratório de brasileiros para outros países.

Peixoto (2004) considera que a característica econômica de uma região não pode, por si só, ser considerada como impulsionador de migrações, posto que existam regiões pobres que são destituídas desses fenômenos. Para esse autor, a estrutura macro, delineada pelo sistema econômico, como é o caso do trabalho, não é a única motivadora das migrações. Outras relações micro, como o capital social e as redes sociais também delineiam as imigrações, que não se reduzem a um projeto racionalmente planejado pelo migrante.

A partir dos estudos migratórios, o autor aponta para uma sociologia econômica, entendida como capital social e redes sociais, de forma a ampliar os espaços de debate para além da racionalidade. Esse autor aborda a relação entre a perspectiva sociológica e o estudo 
da vida econômica, superando a ideia de atomização ou racionalização dos sujeitos, que migram por escolhas racionais.

\begin{abstract}
Este consiste num capital acumulado de relações sociais, na forma de "expectativas para a ação" ou de "fecho" de relações numa comunidade, expresso frequentemente em redes étnicas e outras redes de suporte às migrações. A sua presença nas comunidades imigrantes é elevada: é este tipo de recurso que está na base dos laços de solidariedade (bounded solidarity) e confiança (como a enforceable trust), necessários tanto à manutenção do fluxo migratório como à integração do migrante (mesmo quando esta ocorre no enclave étnico a que o indivíduo pertence e não na sociedade em geral e quando limita, mais do que liberta, as capacidades económicas individuais) (PEIXOTO, 2004, p. 10).
\end{abstract}

Primeiramente, há as teorias que corroboram o papel das instituições no desencadeamento ou acompanhamento dos fluxos migratórios, e que pensam as instituições como as principais promotoras dos fluxos. Essas podem ser: empresas privadas, públicas, Estado, instituições de acolhimento, associações de imigrantes, entidades financeiras, entre outras. As análises dos motivadores que sobressaem nas entrevistas de haitianos em Cascavel reforçam o peso dessas instituições, cujo destaque é as instituições relacionadas com a inserção laboral e familiares, as quais se interconectam com as demais variáveis que estimulam o processo migratório. De acordo com os pressupostos de Peixoto (2004), essas variáveis têm em comum a identidade coletiva e o suporte ao imigrante, o que também não faz com que tenham atendimento uniforme.

Por outro lado, a sociologia macroeconômica trata a questão migratória como uma adequação da força de trabalho, que mobiliza os fluxos migratórios. Porém uma crítica, segundo Peixoto (2004), é que ela não considera as experiências ou trajetórias sociais, o que envolve outros fatores, como as redes étnicas ou de suporte à migração. Nesse sentido, por mais que a variável trabalho nos apareça como um delineador que sobressai aos demais, ela não se efetiva isoladamente, mas o processo migratório é impulsionado por outros fatores como demonstrado nos depoimentos de vários imigrantes.

As experiências desses imigrantes revelam que os haitianos, levados para o estado do Paraná, não planejaram essa rota migratória interna no território brasileiro, no entanto, o deslocamento interno no Brasil se vincula as redes, inicialmente ganha destaque as redes de empresários, quais serão posteriormente dinamizadas pelas redes étnicas e familiares. 


\subsubsection{A cadeia produtiva de frigoríficos: monopólio internacional e exploração da força de trabalho sob o ritmo do desenvolvimento tecnológico}

A projeção de diásporas migratórias se constitui um meio de dispersar a força de trabalho, que tem historicamente garantido o envio de remessas, sendo essa uma importante fonte de desenvolvimento econômico para o país, ao passo que provê novas diásporas (HANDERSON, 2015).

Esse fenômeno fez do Brasil mais uma rota migratória, que o destoou dos países clássicos e tradicionais de migração como Estados Unidos, Canadá e França (MAMED, 2017). Ademais, assim como esses trabalhadores estavam disponíveis em grandes contingentes na fronteira brasileira, algumas indústrias espalhadas, principalmente, no Sul e Sudeste do Brasil estavam carentes de trabalhadores manuais que no âmbito produtivo fez da disposição dos haitianos nas fronteiras um meio para suprir a demanda de mão de obra. Já no que tange ao haitiano recém-chegado ao Brasil, por sua vez, a disponibilidade de vagas de trabalho significava a possibilidade de satisfação imediata de garantir suas condições de sobrevivência, marcada pela insegurança e instabilidade econômica. Assim, a demanda de mão de obra pelas empresas e a necessidade de trabalho pelos haitianos se consubstanciaram em uma união, que a princípio satisfaziam ambas necessidades.

A essa política de atração de imigrantes para suprir demandas do sistema produtivo, como vimos, foi denominada por Arango (2007) de trabalhadores convidados ou guest workers. Ao analisar esse processo na Espanha, o autor ressalta a política do empresariado e destaca a íntima relação entre imigração e sistema produtivo. Embora houvesse, por parte dessas empresas, a intenção de contratar temporariamente a mão de obra imigrante, esses trabalhadores, quando tiveram seus contratos vencidos, não retornaram para os países de origem. Esse quadro resultou na presença massiva de milhares de imigrantes, que impuseram sobre o Estado a demanda por regularizar sua situação.

Essa mesma perspectiva já havia sido retratada por Castles e Miller (2004) que ressaltaram o caráter permanente da imigração, que uma vez iniciada tende a perdurar para sempre, apresentando apenas variações, com maiores ou menores picos de frequência,

sustentadas nas redes de apoio. É certo ressaltar que as permanência do processo migratório se dá sob duas condições: a partir da renovação dos fluxos ou através das futuras gerações.

Os resultados preliminares deste estudo assinalam que, em Cascavel, o fenômeno migratório está estreitamente vinculado à indústria de alimentação, assim como foi na Espanha a política de trabalhadores convidados ou guest workers. 
Não há como estabelecer a relação entre a política de trabalhadores convidados e a imigração sem remeter ao desenvolvimento do setor produtivo na região.

As primeiras evidências de trabalhadores haitianos no Oeste do Paraná se vinculam à presença do setor produtivo da construção civil e frigoríficos. No entanto, a pesquisa de campo indica que desses trabalhadores, poucos estão na construção civil, e os frigoríficos despontam como incorporador hegemônico dessa mão de obra. Frente à incorporação quase absoluta dessa mão de obra por esse setor, será analisado seu desdobramento para então compreender a importância da imigração haitiana para o setor.

Ao analisar sobre o desenvolvimento desse setor produtivo, é possível afirmar que, há uma década, o Brasil se destaca como o maior produtor mundial de carne de frango, processada e in natura. Essa produção movimenta mais de oito bilhões de dólares por ano em exportações. Os estados de Santa Catarina e Paraná destacam-se como os maiores produtores nacionais, com a presença de frigoríficos e abatedouros de aves e suínos de várias marcas conhecidas (BOSI, 2016; (MAMED, 2017)).

As duas cooperativas situadas em Cascavel, Coopavel e Globoaves, empregaram mais de 500 haitianos até $2013^{29}$. Em um estudo recente, Manica (2018), ao discutir sobre a imigração haitiana no Oeste do Paraná, atualiza esses dados junto à Coopavel que, conforme a empresa possui um quadro do que ela denomina de colaboradores que totalizaram 5,6 mil, sendo que 1.157 deles são haitianos e atuam no setor de produção. Os imigrantes, somente nessa empresa, correspondem a 20,6\% do quadro de trabalhadores, e incorporam $23,14 \%$ da mão de obra haitiana disponível em Cascavel. A oportunidade de trabalho aos imigrantes é uma importante alternativa para a substituição de mão de obra no processo produtivo em frigoríficos, dada a recusa dos trabalhadores locais em se submeter aos trabalhos estafantes.

Inicialmente esses trabalhadores foram buscados no Acre e posteriormente se estabeleceram em Cascavel. A fixação dos primeiros levou à atração de outros, o que indica a estreita relação entre esse fluxo específico e a vinculação deles com os frigoríficos. Essa relação levou autores como Marins et al. a inferir que: "Não é exagero afirmar que eles fazem parte de um exército mundial de trabalhadores da indústria da alimentação, e que Cascavel se

${ }^{29}$ No dia 12 de Março de 2018, realizei contato através do envio de requerimento para o setor de Recursos Humanos da Coopavel para levantar fontes sobre os dados quantitativos atuais da contratação de haitianos por essa empresa, qual fora respondido por email a indisponibilidade de fornecê-los, uma vez que a empresa não participa de pesquisas em virtude de normas internas, conforme email em anexo. 
converteu no elo de uma cadeia produtiva global, cujo produto é exportado para mais de 150 países” (MARTINS ET AL., 2014, p. 08).

Há, conforme Martins et al. (2014), a identificação de traços particulares da presença de imigrantes haitianos em Cascavel, que os distingue das demais formas de mobilidades anteriores. Contrariamente aos imigrantes nos estados do norte, os quais eram incorporados em sua maioria no setor de serviços, em Cascavel são incorporados no setor industrial, exercendo funções de baixa qualificação e inseridos de forma dinâmica no mercado global. Além de Martins et al. (2014), alguns autores tem desempenhado importantes análises sobre a incorporação de trabalhadores no sistema produtivo de frigoríficos, como: Bosi (2016, 2014 e 2011), Grando (2017), Eberhardt (2017), Martins et al. (2014) e Cêa e Morofusi (2010). Ainda que esses autores não destaquem a presença de imigrantes nesse setor produtivo, eles são importantes referências para estabelecer diálogo sobre o que se tem produzido em termos de pesquisas sobre o trabalho em frigoríficos no Oeste do Paraná.

A disposição dessa mão de obra permitiu a redistribuição deles para as diferentes regiões do Brasil, a imigração interna das fronteiras para o interior do país teve a região Sul destino privilegiado, conforme evidencia reportagem impressa sobre o assunto: "O Haiti é aqui, no Paraná. Dois em cada dez haitianos que desembarcaram no Brasil após o terremoto de 2010 estão em território paranaense. Imigrantes se espalharam pelas regiões Sul, Sudeste e Norte" (SILVA, 2012, p. 1). Esses dados que são corroborados pelo Sincre divulgam a presença de quase $80 \%$ dessa mão de obra nas Regiões Sul e Sudoeste, sendo que metade de todos esses migrantes está localizada na região Sul do Brasil. (BRASIL, 2018a)

No entanto, delinear a trajetória desses trabalhadores para a região, requer a compreensão de como essa cadeia produtiva se constituiu como um importante setor que impulsionou a industrialização de uma região que até os anos 1980 era marcada por poucos empreendimentos frigoríficos, baseados numa produção mais artesanal que mecânica com abates de gado e suínos. Essa planta foi substituída pela produção e abate de aves e fez do Paraná um dos grandes produtores mundiais. Ao se referir a esses dados, Bosi (2016) ressalta a fácil observação da mudança da paisagem econômica da região Oeste, antes exclusivamente dominada pela agricultura.

Num período curto de quinze anos, é perceptível a evolução da estrutura do mercado de trabalho na região que indica a mudança do perfil agrícola baseado na pequena propriedade para a produção industrial de proteínas. O perfil da indústria saltou de 23,1\%, em 1996, para $31,6 \%$, em 2010, representando uma elevação de 29.249 para 91.367 novas vagas criadas no setor. No capítulo II demonstramos o exponencial crescimento do lucro dessas empresas, com 
ênfase no Frigorífico Coopavel, que é destaque nessa pesquisa por ser o maior empregador de imigrantes haitianos.

Para Bosi (2016), os números representam ainda uma tendência inversa ao que viveu o Brasil no período alcunhado por intelectuais de desindustrialização devido ao declínio da curva nos últimos vinte anos. A representação dos dados no setor de frigoríficos se expressa nos números de vagas que, em 1996, eram de 10.295, passando para 38.314 em 2010, com crescimento de $270 \%$ da incorporação de mão de obra num período de 4 anos.

Ao analisar esses dados, Bosi (2016) ressalta ainda que o Caged infere que nenhum outro segmento industrial alcançou o mesmo crescimento que o setor de frigoríficos, deixando para trás segmentos empregatícios tradicionais como a construção civil e a indústria têxtil. Esses dados também são corroborados por Mamed (2017) e pela Rais (2018), que enfatizam o crescimento desse setor na região.

\section{NÚMERO DE EMPREGOS FORMAIS SEGUNDO SETOR DE ATIVIDADE ECONÔMICA}

\begin{tabular}{l|r|r|r|r}
\hline \multirow{2}{*}{ Setores de Atividades Econômicas } & & & \multicolumn{2}{c}{ Variação } \\
\cline { 4 - 5 } & 2016 & 2017 & Absoluta & Relativa (\%) \\
\hline Extrativa mineral & & & & -379 \\
Indústria de transformação & 5.855 & 5.476 & $-6,47$ \\
Serviços industriais de utilidade pública & 619.534 & 631.123 & 11.589 & 1,87 \\
Construção civil & 26.359 & 26.340 & -19 & $-0,07$ \\
Comércio & 123.024 & 112.180 & -10.844 & $-8,81$ \\
Serviços & 658.316 & 653.399 & -4.917 & $-0,75$ \\
Administração pública & 1.003 .429 & 1.016 .907 & 13.478 & 1,34 \\
Agropecuária, extr. vegetal, caça e pesca & 472.514 & 480.293 & 7.779 & 1,65 \\
\hline TOTAL & 104.074 & 102.474 & -1.600 & $-1,54$ \\
\hline
\end{tabular}

Foto: 09 - Fonte RAIS, 2018

Os dados, ao serem comparados, realçam a expressividade da industrialização do Oeste do Paraná, bem como aponta a presença de um setor específico que emerge na região e ganha destaque na produção nacional. De 1/3, em 1996, alcançou, em 2010, 46\% das vagas na região Oeste, o que significou o domínio do setor de alimentos que incorporava quase metade das vagas de trabalho no Estado, cujo ápice de crescimento correspondeu os anos 2000 a 2007. 
Quando observados os dados apresentados desse setor, que indicam o impulsionamento quase que isolado desse crescimento. Seu expressivo dinamismo é visto com entusiasmo seja pela classe que representa os setores econômicos da região, seja pela mídia que forma uma opinião voltada para sustentar essa ideia atrelada ao desenvolvimento regional e melhoria das condições de vida da população.

Em contraposição a essa perspectiva de exaltação dos frigoríficos como sinônimo de desenvolvimento regional, bem como de melhoria das condições de vida da classe trabalhadora incorporada a ele, Bosi (2016) demonstra a intrínseca relação da agroindústria com a divisão internacional do trabalho, expressão do capital monopolista que tem como bases a disseminação global como um tentáculo que atinge diferentes territórios, bem como requer a disponibilidade do trabalho abundante e da exploração da força de trabalho.

Esse autor, ao resgatar a história econômica do Paraná, entre os anos 1960 a 2010, enfatiza dois dos seus elementos constitutivos: a acumulação de capital relacionada às redes de monopólio que vinculam a cadeia produtiva de aves e a exploração do trabalho na agroindústria. Dessa forma, fez um recorte para a discussão privilegiando a cadeia avícola, já que esse é o setor que mais emprega no universo da produção industrial na região.

Para expor o desenvolvimento dessa análise, ressalta que o trabalho barato é uma característica desse setor, expressão da presença humana no contexto histórico em análise. Além de dados estatísticos que remetem à exploração do trabalho, Bosi (2016) recorreu a entrevistas com trabalhadores desses frigoríficos. Ao retomar a discussão sobre as características econômicas da região desde os anos 1960, o autor identifica, ainda naquela década, a acumulação de capital baseado na pequena propriedade e trabalho agrícola. Foi nessa década que se instalou o primeiro frigorífico suíno na região. No entanto, sua pesquisa teve como destaque o processamento de aves iniciado nos anos 1980 e disseminado nos anos 1990 e 2000.

O ano de 1964 marca a instalação da indústria Sadia no Município de Toledo, mas as demais plantas industriais existentes na região surgiram a partir dos anos 2000. Cinco deles incorporam direta ou indiretamente redes vinculadas como fábrica de ração, incubatórios, matrizeiros e uma numerosa rede de aviários. Bosi (2016) vai mostrando a formação da cadeia produtiva no Oeste do Paraná que vincula os frigoríficos aos grandes monopólios mundiais em destaque na região. São esses monopólios que vão definir o valor da força de trabalho empregada nos frigoríficos e repartir entre eles o lucro da mais valia extraída.

Estima-se que pertence à rede produtiva 14 mil trabalhadores, pouco mais de 1/3 das vagas do setor de alimento da região, se for somada a ela a produção de suínos chega a 21 mil 
trabalhadores que corresponde a 60\% das vagas de trabalho do setor na região. Para Bosi (2016), não há como pensar no crescimento do setor sem relacioná-lo com o domínio da cadeia produtiva. Conforme o autor, a experiência do capitalismo na organização, a divisão da produção e as experiências profissionais dos trabalhadores nela envolvidos remetem aos pressupostos teóricos de Lenin sobre capitalismo e imperialismo, ressaltando que esse pensador há 100 anos escreveu que a expansão do capital constituiria monopólios sobre ramos produtivos, como ressalta considerando esses aspectos e suas manifestações no Oeste do Paraná.

\begin{abstract}
Neste caso, o conhecimento e o domínio científico do melhoramento genético do frango, da nutrição e do maquinário empregado na cadeia avícola são mantidos sob o comando de poucas multinacionais sediadas nos Estados Unidos e na Europa. Esta é a base da divisão internacional do trabalho ligada à produção de carne de frango, e é a partir deste ponto que se pretende examinar a industrialização e acumulação de capital neste setor no Oeste do Paraná (BOSI, 2016, p. 96).
\end{abstract}

A expansão do capitalismo na região não se desvincula das bases originárias do capital, caracterizado pelas indústrias imponentes de proteínas que representam a presença de multinacionais e oligopólios na região. Ao deter o controle dos insumos consumidos dessa cadeia produtiva, a tecnologia genética dos matrizeiros de aves, bem como, antibióticos e rações, dominam os frigoríficos e interferem na imposição dos preços da produção da agroindústria.

O autor inclui nessa rede a agricultura por meio de sementes híbridas, produção agrícola com pulverização, máquina de plantio e colheita. Lenin denominou essa rede de trustes e citou a produção de tabaco como exemplo. O domínio de plantas produtivas é um exemplo do capital industrial que ultrapassa suas fronteiras com apoio do capital financeiro para explorar a mão de obra barata com invasão de países estrangeiros menos desenvolvidos. Tais aspectos, conforme Bosi (2016) ajudam a compreender o desenvolvimento do capital no Oeste do Paraná a partir da agroindústria nos últimos 50 anos. A teoria leninista, por sua vez, mostra que o capital monopolista apropria os ramos produtivos mais dinâmicos da economia para que, a partir deles, possa subordinar outras etapas produtivas de mercadorias.

No que se refere à cadeia avícola, se destaca o monopólio das empresas de sementes que é a base das rações para aves, além de agroquímicos (biológicos, antimicrobianos, endectocidas, etc), e, por fim, o que o autor denomina de matrizes de animais, que se refere ao melhoramento genético. 
Ainda conforme Bosi (2016), a chave para pensar o domínio do frango no mercado é a matriz genética da produção. Nos anos 70, no início da industrialização da carne de frango, o mercado já se apresentava oligopolizado, com aproximadamente metade da produção sob o domínio de três empresas: Sadia, Perdigão e Seara (Ceval). Quatro décadas depois, em 2010, estas mesmas empresas continuam dominando o ramo com $64,7 \%$ da produção carne exportada no Brasil e, se somar a maior exportadora, a Deux, esses números sobem para 75\%. A produção nacional corresponde a $1 / 3$, sendo o mercado externo mais visualizado pela lucratividade com maior valorização do produto.

A lógica oligopólica desse setor pode ser exemplificada por meio do controle das chaves genéticas das aves que abastecem os aviários. Bosi (2016) infere que somente duas empresas tem domínio sobre a programação genética dos pintinhos, sendo impossível a reprodução por outras empresas se não elas mesmas. São elas, Tyson e Rhodia que ao modificarem o código genético das aves as vendem como reprodutoras de pintinhos, os quais serão posteriormente engordados e em um curto período de tempo abatidos nos frigoríficos.

\begin{abstract}
Nos laboratórios da Tyson saem machos e fêmeas que vendidos gerarão as matrizes, cuja função é produzir os pintinhos. As fêmeas que estão no início desta cadeia são denominadas de avós, e sua reprodução é impossível de ser realizada na cadeia avícola devido à chave genética sob domínio da Tyson. Toda vez que se tenta otimizar esta matriz para produzir outra matriz, o resultado é pífio, porque não há como reproduzir as características originais da mãe genética da matriz, as avós, sob controle das empresas que as vendem. As matrizes vendidas pelas multinacionais têm validade e produtividade programadas. Portanto, como se trata de poucos vendedores que dominam o mercado, esses grupos multinacionais estabelecem a dinâmica de funcionamento dos frigoríficos (e, em alguma medida, de seus lucros) (BOSI, 2016, p. 99).
\end{abstract}

O autor classifica ainda que, nos anos 1990, quinze empresas trabalhavam com o melhoramento genético para aves de corte, no entanto, apenas três delas dominavam esse negócio: a alemã Aviagem, a americana Cobb-Vantress e a francesa Hubbard, com domínio de $80 \%$ do mercado pelas duas primeiras.

Essa herança tecnológica impulsionou a formação da cadeia avícola que tem a produção baseada no modelo fordista/taylorista, nomenclatura consolidada ideologicamente devido aos traços dominantes das organizações produtivas que se baseiam na produção em série, repetição e mecanização via trabalho simplificado da força de trabalho.

Não há como negar que essa cadeia avançou de forma muito mais expressiva, devido não só ao aperfeiçoamento tecnológico herdado anteriormente, mas, sobretudo ao 
melhoramento genético da matéria prima, responsável pela diminuição do tempo necessário para o abate da ave.

O fornecimento dessa mão de obra barata para essa cadeia produtiva completa é denominada de know bow, que significa como saber. A cadeia se formou nos EUA com o fornecimento de grande qualidade de matéria prima barata que levou à submissão dos fazendeiros americanos a contratos de empresas agrícolas que forneciam a eles os lotes de pintinhos, prescrevendo a utilização do aparato técnico para criação dos animais, a construção de aviários financiados por essas empresas que se incumbiam de fornecer os lotes, medicamentos, ração e assistência técnica.

Bosi (2014b) representa simbolicamente a organização dessa cadeia da seguinte forma:

\section{Cadeia Avícola}

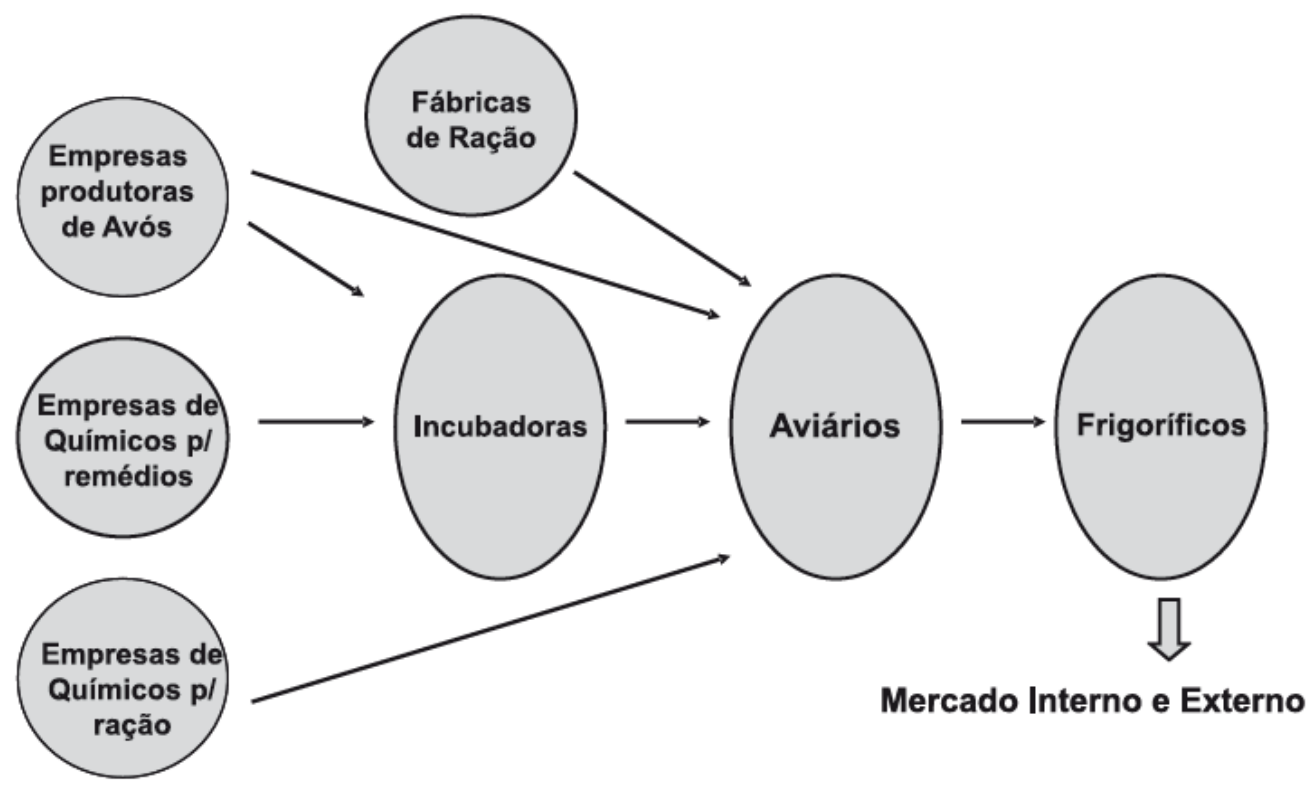

Foto 10: Cadeia avícola - Fonte: Bosi (2014b, p. 580)

A base técnica de produção da matéria prima avícola foi trazida dos EUA e implantada no Oeste do Paraná a partir de 1964 com a instalação da primeira indústria Sadia. Bosi (2016) ressalta por meio de relatos de um dos fundadores da Sadia, em Concordia, que representantes desses setores industriais acompanharam representantes do Ministério da Agricultura em visita aos EUA, e de lá tomaram conhecimento do que seria posteriormente implantado no Brasil. 
Ao mencionar essa experiência, Bosi (2016) descreve a presença de alguns fazendeiros e representantes do ministério da Agricultura nos EUA afim de lá conhecer o funcionamento da gestão de frigoríficos. No tocante, a Sadia implementa nos anos 1960 o modelo já reproduzido naquele país. No entanto, após ser trazido para o Brasil, inicialmente o consumo ficou restrito a produção de ovos, devido ao alto custo da carne para a população e pelo distanciamento dela dos costumes alimentares, sendo então timidamente introduzida ao consumo da massa de trabalhadores, a qual veio a ganhar maior adesão na década de 1970.

Apesar de existirem diferenças quantitativas e qualitativas entre as oito empresas frigoríficas situadas no Oeste do Paraná, é possível afirmar, com base nos estudos já realizados e na pesquisa em andamento, que todas se enquadram num contexto de reestruturação produtiva, na direção da modernização industrial pautada na organização flexível do trabalho (CÊA, MOROFUSI, 2010, p. 5).

Embora seja esse setor produtivo marcado pela reestruturação produtiva, o mesmo combina a inovação tecnológica com a reprodução de práticas tayloristas/fordistas, sendo esse um dos fatores que associado à intensificação das estratégias de aceleramento da produção, e aumento da produtividade, são determinantes para os elevados índices de acidentes de trabalho.

As autoras classificam esse ambiente de trabalho com as seguintes características:

Em linhas gerais, o trabalho realizado no chão da fábrica das empresas frigoríficas investigadas apresenta as seguintes características: repetitividade de movimentos; ritmo de trabalho imposto pela máquina; invariabilidade do trabalho; posturas inadequadas; uso de força física; trabalho muscular estático; pressão mecânica; exposição a temperaturas altas e baixas (dependendo do setor); convivência com odores fortes; barulho excessivo; contato com ambientes úmidos por longos períodos de tempo (mesa de trabalho; chão); manuseio de instrumentos pérfuro-cortantes (CÊA, MOROSUSI, 2010, p. 6).

É nesse contexto que Cascavel se constitui como espaço estratégico para a transnacionalização do capital, localizada na região Oeste do Paraná, desenvolvendo conexão global por meio da vinculação do setor de frigoríficos a grandes oligopólios pelas redes que vão desde o domínio de tecnologia e a subordinação de criadores em aviários, até o trabalho braçal, mecânico e desvalorizado realizado nos frigoríficos, com término da rede via exportação de carnes processadas para diversos países no mundo. 
O Estado do Paraná ocupa a $5^{\mathrm{a}}$ região no ranking formal de trabalho com total de 6.742 postos de trabalho, e Cascavel se destacou como a cidade que mais criou oportunidades de trabalho com total de 1.243 encaminhamentos até maio de 2017 (PARANÁ, 2017).

O complexo agroindustrial se coloca como um dos principais incorporadores de mão de obra de imigrantes haitianos. Cêa e Morofusi (2010) mapearam a importância desse setor na região Oeste do Estado, que compreende 50 Municípios, dos quais 12 possuem frigoríficos de suínos, aves e bovinos.

O Oeste do Paraná tem expressiva participação na colocação do estado na economia nacional. Dos 50 Municípios da região Oeste do Paraná, tomada aqui como referência geográfica, em 12 deles há cooperativas, frigoríficos e abatedouros de suínos, bovinos e aves, totalizando 35 empresas. Entre estas, o destaque é para a indústria processadora de carne de aves, com 8 unidades de processamento que representaram em 2003 34,3\% do faturamento em todo o Paraná, sendo a região com maior participação nos resultados econômicos do setor (IPARDES, 2005, p.134; CEA E MOROFUSI, 2010, p.04).

A ideia de integrar pequenos proprietários importada dos EUA encontrou no Oeste do Paraná um local adequado para se transmutar. A região, como já auferido anteriormente, compartilhava a existência de pequenas propriedades que foram, no decorrer das décadas, elevando a concentração da propriedade rural baseada no uso da força e expropriação de posseiros via grilagem de terras, associada ao endividamento de pequenos agricultores que se viram obrigados a entregar como pagamento de dívidas suas propriedades para essas empresas, quando já não podiam mais custear o que se convencionou chamar de "modernização do campo".

Outra explicação vem dos maquinários dos frigoríficos, que devido à alta tecnologia empregada amplia tanto a produção de matéria prima como as aves, bem como a intensificação dos ritmos produtivos com a aceleração dos movimentos dos trabalhadores. De acordo com Bosi (2016), a empresa dinamarquesa Marel Food System, tem dominado a produção de máquinas para frigoríficos, dona da maior parte de patentes de automatização de corte de carne que intensifica a diminuição de postos de trabalho na desossa do frango.

Ao situar a dinamização tecnológica e o papel dos monopólios não há como não olhar para os frigoríficos e não notar a presença deles em todas as suas dimensões. Há segundo o autor a geração de mais valia na produção em frigoríficos e o reparte dela entre os setores oligopolistas que a dominam.

Grande parte da reversão dos lucros pela exploração de mais valia é drenada sempre para os segmentos mais dinâmicos e de maior composição orgânica que dominam a ciência e 
sua aplicação prática que inclui a genética, medicamentos, nutrição e por fim a maquinaria. Não à toa são estes os setores que correspondem aos mais monopolizados por constituir e manejar a hegemonia da cadeia avícola. A forma de como esse oligopólio mantém a taxa de lucro está na ampliação da produção de aves e na produtividade do trabalhador do frigorífico, que definem o preço da carne baseada no domínio do setor sobre essa mercadoria.

Para Bosi (2016) a historiografia local alimenta um estereótipo de colonizadores, descendentes europeus (germânicos e italianos) que passaram a ocupar o Oeste do Paraná na segunda metade do século XX. Embora essa literatura tenha sofrido críticas por ocultar a presença de outras populações nativas, bem como outros sujeitos sociais na região, o estereótipo tem se mantido no tempo, revezando a característica econômica vigente desde então. Como em outros mitos de origem é destacada a índole laboriosa, o empreendedorismo ou algum tipo de predestinação de uma etnia que se alinharia com os atributos adequados ao progresso e desenvolvimento da região, fortemente reproduzidos no imaginário social.

O campo realizado hoje remete a um dialeto simbólico cada vez menos útil para descrever o tempo presente, recheado de vestígios e lembranças cujo processo de acumulação atual não assegura vantagens de quem chegou antes ou depois. Nessa perspectiva, essa imagem dos pequenos agricultores pode ser o ponto de partida para questionar a dinâmica do capital em suas vidas e a contribuição para estruturar o dialeto simbólico que os colocaram como figuras do desenvolvimento regional.

Bosi (2016) caracteriza o surto populacional nos anos 1950 com trabalho organizado na pequena propriedade com até 25 hectares, direcionada inicialmente para culturas sazonais e criação de suínos. Na década seguinte, a junção de milho, trigo e suínos foram reunidos e transformados em ativos das cooperativas agrícolas, alavancadas com o plantio da soja, todos com amplo investimento estatal por meio do que se convencionou chamar de políticas de indução agrícola com financiamento direto da produção. O autor destaca a importância das cooperativas na formação e organização do capital e do trabalho na região com desempenho de empresas capitalistas na agricultura, apoiando diretamente na produção com intermediação das negociações. Direcionava o comércio e aquisição de produtos que iam desde maquinários agrícolas, sobretudo tratores, até insumos e fertilizantes, agrotóxicos e sementes fornecidas por multinacionais. O sentido da cooperação voltou-se para acumulação com inserção da nova divisão internacional do trabalho que requisitou da região o repertório cultural e étnico propagada pelo mito do colono descendente europeu e dado ao trabalho, fazendo desse mito importante aspecto ideológico para o repositório da força de trabalho. 
As cooperativas e o fenômeno competitivo levaram a uma diminuição das pequenas propriedades, cada vez mais reduzidas a menos proprietários e concentração de terras, que de 25 foi se ampliando para a dimensão de 100 hectares. O contexto evidencia uma crescente concentração de terras na região Oeste, ao passo que os pequenos produtores expulsos do campo iam formar nas cidades o esquadrão de mão de obra disponível para servir a dinâmica produtiva dos frigoríficos.

No Oeste do Paraná, o número de 82.570 propriedades rurais cadastradas em 1970 encolheu para 53.013 em 2006, algo equivalente a uma queda de $35 \%$. No mesmo período, a área utilizada para o cultivo saltou de 1,5 milhões de hectares para 2,2 milhões. O tamanho médio das propriedades também cresceu, dobrando sua dimensão em $112 \% 9$, o que pode ser verificado nas cooperativas agrícolas da região, onde encontraremos quase metade dos associados com propriedades entre 21 e 100 hectares (BOSI, 2016, p. 100).

O resultado do êxodo também é demonstrado em números que seguiu a lei da concentração de terras na região que retraiu de $80 \%$ para $20 \%$ a população do campo entre as décadas de 1970 e 2000. Entre aqueles que resistiram no campo enviaram os filhos para as cidades frente à incapacidade de nos pequenos lotes de terra prover a subsistência familiar com ampliação dos membros familiares, bem como por uma produção cada vez mais dominada por cultivo de monoculturas como soja e milho.

Entre 1970 e 2000, a população rural do Oeste do Paraná retraiu de $80 \%$ para menos de $20 \%$ da população total (Tabela 2). Em termos numéricos, enquanto as atividades produtivas ganhavam "valor agregado" por meio da industrialização da soja, do milho, do leite e da carne, aqueles que viviam no campo diminuíram de 602 mil para 209 mil. Nestes termos se constituiu grande parte da força de trabalho ocupada e em reserva para a indústria, o comércio e a agricultura na região (BOSI, 2016, p. 101).

Além disso, Bosi (2016) destaca a instabilidade do desenvolvimento tecnológico no campo como um fenômeno comum entre os pequenos agricultores, que para seguir as regras do plantio de monoculturas tem que alugar os maquinários de grandes produtores, associado ao elevado preço de sementes, insumos e componentes agrícolas tem provocado um profundo endividamento junto às cooperativas.

A concentração de terras se explica pelo desenvolvimento tecnológico que ao contrário de servir o homem do campo tem cada vez mais expropriado os pequenos agricultores, os quais se veem obrigados a desfazer de suas propriedades para sanar as dívidas contraídas junto a esses empreendimentos divulgados como cooperados. 
Além disso, a imposição do padrão produtivo por essas cooperativas levou a resistência de muitos pequenos agricultores, os quais em última instância tiveram também que se submeter ao trabalho assalariado. Assim, a concentração fundiária formava os trabalhadores que expulsos do campo migravam para as cidades, e dentre os poucos que resistiam no campo, passaram a submeter à precária estrutura fundiária aos ditames dos monopólios dos aviários.

Se no capítulo II discutiu-se a ação do Estado para promover esses oligopólios através do BNDES, Bosi (2016) revela que, desde os anos 1950, havia a presença do Estado financiando infraestruturas, políticas de financiamento agrícola e financiamentos diretos, com amplo destaque para as indústrias e cooperativas da região datadas desde 1963, as quais tiveram importante papel no desenvolvimento capitalista com apoio técnico da produção e na organização da distribuição e negociação do produto.

A mobilização do capital direcionou o acesso a equipamentos mecânicos de maquinários como tratores e colheitadeira, insumos, agrotóxicos e fertilizantes, sementes, controladas pelas multinacionais que detém seu monopólio, além da disponibilidade de recursos técnicos como profissionais veterinários e agrônomos ao passo que foi suprimindo a hegemonia das sementes crioulas e os antigos modos de produção voltados para a subsistência. Essa denominada "cooperação" impulsionou a região e sua inserção na nova divisão internacional do trabalho que simultaneamente requisitou da população local aquele aparato étnico e cultural divulgado pela historiografia oficial de um povo dado ao trabalho para engrossar seu repositório de força de trabalho.

Para Bosi (2016), o mito do imigrante europeu selecionado para colonizar a região foi requerido pelos frigoríficos e é extremamente relevante para um processo industrial que requer mão de obra abundante e disciplinada para o trabalho imposto.

Dos pequenos proprietários que resistiram, muitos foram sucumbidos pelos contratos para a construção de aviários, que os obrigam a adesão de tecnologias, sendo essa uma condição para se manter incorporados no processo e ao domínio dos grandes grupos e oligopólios.

"Olhar para frente" significa mergulhar mais profundamente neste processo de acumulação de capital que demanda minifúndios em excesso para serem integrados em condições vantajosas para as cooperativas e demais frigoríficos da região. Significa também assumir parte importante dos custos com a força de trabalho. Os pequenos proprietários que se lançam nesta empreitada o fazem porque suas condições de produtores agrícolas se 
deterioraram. Assim, "olhar para frente" sela seus destinos (BOSI, 2016, p. 102).

O declínio do pequeno produtor é acelerado pela competitividade internacional, além da desvalorização da matéria prima, sendo essa menor no Brasil. Ao discorrer sobre os valores dos custos para os criadores, Bosi (2016) ressalta que para cada quilo de carne há uma média de 0,44 dólares no Brasil, 0,55 dólares para os Estados Unidos e 0,61 dólares para a China. Quando comparado aos EUA, considerado o maior produtor mundial, os custos de produção no Brasil foram 20\% menores. Outra estimativa divulgada em 2002 revelou ainda que a força de trabalho equivalia a 17,5\% do custo de produção nos Estados Unidos e 9,1\% dos custos de produção no Brasil.

A diferença e a expressividade do que significa os gastos produtivos com a força de trabalho nos dão a dimensão do quão lucrativo é o retorno dessas atividades que tem por característica a degradação do trabalho nos frigoríficos, bem como o baixo custo do produto pago aos agricultores que sustentam a produção de matéria prima com a criação de aves nos aviários e aqueles que as abatem e processa nos frigoríficos.

A hegemonia dessa cadeia produtiva tem seu êxito na base tecnológica que submete trabalhadores desde a produção de matérias primas até o abate e transformação dela nos frigoríficos e, a certeza que se tem sob o aspecto do trabalho é da exploração e da morbidade sendo o que sobra ao trabalhador.

Os números descritos acima também indicam a exuberância da agroindústria no país e a expansão dos frigoríficos de carne de frango no Oeste do Paraná, que fazem dos frigoríficos parte da dimensão mais atual do imperialismo, e indicam a capacidade do capitalismo que desde o século XIX alarga suas fronteiras via extensão dos oligopólios de forma a impulsionar e explorar mundialmente o trabalho barato e invadir mercados estrangeiros em países de menor desenvolvimento. De acordo com Bosi (2016), a "competitividade" da produção de produtos manufaturados brasileiros como o processamento de aves é quase que inteiramente sustentada na exploração da força de trabalho barata e abundante.

Assim, essas plantas produtivas requerem locais estratégicos que correspondam às suas demandas para se instalarem, e não são, portanto, suscetíveis de se instalarem em qualquer lugar, como bem expos Milton Santos (2004) ao inferir que ao capital não é qualquer lugar que o interessa para empreender seus negócios e plantas produtivas. Nessa perspectiva, esse sistema carece de mão de obra abundante e barata que envolve toda a cadeia produtiva, 
indo desde o pequeno agricultor submetido seja a monocultura ou trabalho em aviários, bem como aos trabalhadores de grandes proprietários que pelo poder econômico empreendem dezenas de aviários até o trabalhador de frigorífico. Todos eles têm em comum o trabalho barato, estão envolvidos de alguma forma na cadeia produtiva e impulsionam as plantas produtivas nos frigoríficos.

Além disso, essas plantas produtivas se beneficiam também de vantagens com isenção de impostos e infraestrutura ou vantagens fiscais proporcionadas pela interiorização. No capítulo II, citou-se como exemplo o empreendimento de um grande complexo industrial, localizado a aproximadamente $80 \mathrm{~km}$ de Cascavel o qual terá subsídios fiscais relevantes que atraíram a instalação do que promete vir a ser o maior frigorífico com abate de suínos da América Latina ${ }^{30}$.

A análise de onde se localizam esses frigoríficos no Brasil, em especial no Estado do Paraná, levaram Bosi (2016) a inferir a interiorização dos frigoríficos como uma importante característica para o sucesso dessas plantas produtivas. Como ressaltado, os frigoríficos já nascem interiorizados devido a dinâmica do capital representado por sua capacidade de se apropriar de organizações já formadas na região, como as cooperativas de agricultores, formadas incialmente como estratégia desses em concorrer no mercado, e posteriormente sucumbidas aos grandes monopólios. À medida que são essas regiões destituídas de indústrias, privilegiadas por recursos naturais, mão de obra barata e disponível para ser incorporada. A interiorização em grande medida tende a trazer vantagens fiscais para os grandes frigoríficos na maior parte dos casos, com o suporte financeiro direto para a fixação das plantas produtivas (doação de terreno, de obras de infraestrutura, etc.).

Bosi (2016) ressalta ainda que a localização geográfica com proximidades entre frigoríficos e aviários contribuem para a diminuição dos custos de produção e, além disso, o funcionamento dessas plantas produtivas depende da submissão dessas pequenas cidades consubstanciadas como manancial de numerosa reposição de trabalhadores. Esses

\footnotetext{
${ }^{30}$ As benesses fiscais desses empreendimentos são tão relevantes para o processo de acumulação quanto a exploração da força de trabalho, um exemplo disso foi a ameaça do grupo Frimesa qual divulgou a retirada desse empreendimento em construção em Assis Chateaubriand caso um dos candidatos que disputou atualmente as eleições pelo Partido dos Trabalhadores - PT viesse vencer. Esse discurso ameaçador marca as características hegemônicas de imposição desses grandes grupos em uma região desprovida de indústrias mais significativas, cujo discurso ideológico do "progresso" alimenta o imaginário social. O desenvolvimento desconsidera as fileiras de trabalhadores que serão as próximas carnificinas desse grande empreendimento, mas o que importa é o emprego que gerará, sem avaliar os efeitos dele no adoecimento da população e na rotatividade de trabalhadores, daí a necessidade de em nome do desenvolvimento coagir ideologicamente uma população sem acesso a outras oportunidades de trabalho, quais votaram no candidato imposto pela coerção da empresa. Os efeitos disso no Oeste do Paraná, foram nefastos, haja visto a vitória do candidato opositor ao PT com média de $70 \%$ dos votos,
} 
empreendimentos por serem quase únicas indústrias, que muitas vezes incorporam contingentes maiores ou iguais a toda população do Município, controlam o mercado de trabalho nessas cidades, ditando o salário e as condições de trabalho (BOSI, 2016; MAMED, 2018).

\subsubsection{O trabalho em frigorífico e a demanda de trabalhadores suscetíveis ao trabalho simplificado}

As relações produtivas no Oeste, marcadas pelos frigoríficos que ganharam pujança e expressividade, tem suas origens nas mesmas bases do capitalismo clássico surgido nos séculos XIX e começo do século XX. Embora as primeiras práticas já estivessem presente no Brasil como aquelas de tempos mais remotos que vão desde os matadouros que forneciam a carne de Dom Pedro à charqueada no Rio Grande do Sul preparados por escravos, os quais não ficaram de fora da modernização do século XX. Essa produção de cunho rudimentar foi substituída por outra mais especializada a partir da instalação do frigorífico oriundo dos EUA no Brasil no início do século XX. A simplificação do processo de trabalho, assim como o corte da carne, não sofreu alteração ao longo do tempo e, conforme Bosi (2014b) se processa o mesmo corte, o que dispensava a necessidade de formação profissional.

Dessa forma, nessa região, os frigoríficos têm suas bases técnicas nos antigos matadouros de boi do século XIX, desde as primeiras experiências desse empreendimento com bovinos em Chicago nos EUA em 1866 (BOSI, 2014a; 2016).

O desenvolvimento das condições tecnológicas, como transporte refrigerado, viabilizou o maior consumo com a disponibilidade da carne para outras regiões que primeiro permitiu a ampliação do consumo no interior dos EUA, e posteriormente a atividade produtiva fora estendida para outros países como o Brasil, via instalação de complexos frigoríficos e a disseminação da carne para os rincões do país.

O ineditismo dos EUA com a produção e disseminação do maior consumo de carne fez esse país inaugurar a desossa como parte de um sistema industrial de desmontagem do animal, função que ocupa grande parte da mão de obra empregada nos frigoríficos de aves no Brasil. Ao discutir sobre os princípios da técnica produtiva nos frigoríficos, Bosi (2016) ressalta que o que havia nesse ambiente produtivo foi inspirador para Henry Ford, que ao se deparar com ela, copiou e implementou como forma organizacional em uma de suas linhas de 
produção. A ela foi contemplado a cópia dos métodos de organização produtiva já existente nos frigoríficos que submetia o trabalhador a realização de atividades simplificadas ao passo que dessa forma o tornava mais produtivo.

A divisão do trabalho em etapas produtivas viabilizaria a contratação de trabalhadores sem qualificação que simultaneamente poderiam ter o barateamento da mão de obra, como nos expõem esse autor: "a linha de desmontagem, o trabalho que antes era executado pelos açougueiros foi dividido em etapas e simplificado, criando condições para a contratação de trabalhadores sem qualificação e viabilizando uma política salarial barata desde o século XIX” (BOSI, 2016, p. 97).

A técnica da cooperação e especialização de trabalhadores reunidos em um grande número, cada qual desenvolvendo suas atividades foram praticadas através da observação e aplicação de princípios científicos na produção, como foi o caso de Ford, que copiou e implementou uma técnica que lhe permitiu visualizar aumento da produtividade do trabalhador. Dessa forma, pode-se inferir que o trabalho simplificado é mais antigo que o fordismo e remete como já discutido aos princípios da acumulação de capital com o surgimento da manufatura que marcou os primórdios do capitalismo.

Retomando os escritos de Marx (2004), percebe-se a manufatura como a primeira experiência da aplicação empírica desse modelo organizacional, que levou o capitalista a perceber o trabalhador mais produtivo e lucrativo a partir do momento que produzia simultaneamente grande quantidade do mesmo tipo de mercadoria, com simplificação da atividade produtiva que potencializou o ritmo e movimento do trabalhador, logo apropriado e dinamizado por Frederick Taylor e Henry Ford.

Ao descrever sobre esse período, especificamente na região de Cascavel, Grando (2017) analisou as experiências de trabalhadores dos frigoríficos no Município. Sua pesquisa remeteu à modernização do frigorífico Frigovel que se converteu na Coopavel, um exemplo concreto desse fenômeno de transmutação da organização produtiva antes centrada no abate de bovinos e suínos para a produção e abate de frangos.

Nessa perspectiva, Grando (2017) ressalta que o cenário vivido pela indústria de carne de frango ligada ao grupo Sadia, na metade da década de 1980, portanto, se desenhava bastante distinto daquele no qual se encontrava a Coopavel, mas também da maioria dos frigoríficos de suínos e bovinos no Oeste paranaense na década de 1980 - que frequentemente faliam, fechavam as portas ou eram vendidos a outros grupos. Enquanto a Sadia quebrava recordes de produção e de exportação de carne de frango ao exterior, a Coopavel se 
encontrava não apenas em dificuldades financeiras, mas também vivia um momento de "falta de credibilidade" entre seu quadro de associados.

Desse ponto de vista, é importante ressaltar que, na formulação e na concretização desse projeto, a direção da Coopavel esteve sintonizada com a imprensa local e com outros setores da burguesia da cidade e da região. As reportagens do jornal O Paraná entre os anos finais da década de 1980 e o início da década de 1990 não raras vezes registrariam a articulação das classes dominantes locais em torno da discussão de "saídas para a crise" vivida pelas cooperativas no Oeste paranaense e, de modo mais amplo, com longas reportagens sobre as "possibilidades" de desenvolvimento da região.

A Coopavel endividada dos anos 1980 buscou nos recursos financeiros públicos o impulso do capital de giro, bem como a prorrogação de dívidas junto ao Estado, também mobilizando a comunidade industrial sobre o lema “A região Oeste quer industrialização já!". Os pressupostos para atingir o objetivo seria impulsionar a agroindústria, gestando e impulsionando por meio delas o capitalismo na região. Os meios de produção contribuíram para a articulação desse processo, buscando traduzi-lo como um desfecho natural e um devir histórico. A imprensa teve papel central em propagar o projeto agroindustrial, como um projeto acertado para viabilizar o desenvolvimento e o progresso da região.

Produzidas a partir das impressões, expectativas e ações das classes dominantes, o conjunto das reportagens publicadas na imprensa cascavelense no início dos anos 1990, nos permite analisar como os contornos de um projeto "agroindustrial" foram gestados pela Coopavel e por entidades empresariais da cidade como um projeto de reorganização da acumulação de capital na região, inicialmente sustentada na produção e na comercialização de grãos.

Ao mesmo tempo em que viabiliza um projeto agroindustrial, a próxima meta seria a transição para o abate que deixaria de ser focado no suíno e gado, com a centralização da produção avícola, que já apontava promissoras experiências de outros empreendimentos como a Sadia em Toledo 1984, Coopacol em Cafelândia em 1982 e demais frigoríficos que alteraram antes sua planta produtiva de modo a privilegiar o abate de frangos como principal característica do sistema produtivo.

Na cidade de Cascavel-PR, o resultado do "estudo de viabilidade" para a construção do frigorífico de aves, encaminhado na assembleia da Coopavel em dezembro de 1987, seria anunciado por Ibrahim Fayad, sucessor de Salazar Barreiros na cadeira de diretor presidente da Coopavel. Fayad anunciava a decisão favorável da cooperativa pela construção do abatedouro 
de aves apresentando o projeto de edificação da nova planta produtiva, também chamado de frigorífico polivalente (GRANDO, 2017, p. 42).

Sob o lema "diversificar as atividades", aumentar os "níveis de produtividade", "produzir com eficiência”, entre outros ocultaram a construção do projeto agroindustrial como uma ação de classe pensada e articulada dentro de um conjunto de pressões históricas a fim de transformá-la em "vocação". A contestação das cooperativas no meio rural por parte dos posseiros e dos trabalhadores rurais pobres, o endividamento das cooperativas frente ao capital financeiro, os conflitos com os criadores de suínos e bovinos e a acirrada concorrência com outros frigoríficos da região foram alguns dos elementos que estimularam uma necessária reorganização das cooperativas.

Nesse contexto, Grando (2017) identifica como foi se delineando o complexo agroindustrial em várias cidades da região Oeste do Paraná, as quais, na mesma lógica da Sadia, foram impulsionando o abate de frango como prioridade entre os frigoríficos da região.

Tabela 1: Comparativo entre 0 ano de fundação das cooperativas do Oeste do Paraná e 0 ano de instalação dos frigoríficos de frangos nas respectivas cooperativas

\begin{tabular}{|c|c|c|}
\hline Cooperativa/Sede & Ano de fundação & $\begin{array}{c}\text { Ano de instalação do } \\
\text { frigoríico de frangos }\end{array}$ \\
\hline COPACOL/Cafelândia-PR & 1963 & 1982 \\
\hline COOPAVEL/Cascavel-PR & 1970 & 1994 \\
\hline C.VALE/Palotina-PR & 1963 & 1997 \\
\hline $\begin{array}{c}\text { COTREFAL/LAR/Matelândia- } \\
\text { PR }\end{array}$ & 1964 & 1999 \\
\hline $\begin{array}{c}\text { COPAGRIL/Marechal } \\
\text { Cândido Rondon-PR }\end{array}$ & 1970 & 2005 \\
\hline
\end{tabular}

Foto 11 - Frigoríficos no Oeste do Paraná 1963- 1970. Fonte: Grando (2017, p. 37 )

Além disso, embora apareçam na leitura elaborada pelas classes dominantes locais como resultado da "vocação agroindustrial" da região, a definição pela estruturação da cadeia avícola e a construção dos frigoríficos de frango apoiou-se também em um processo histórico mais amplo de expansão dessa atividade que no caso brasileiro pode ser localizado temporalmente desde meados da década de 1970. A aceleração do tempo de crescimento dos pintinhos com aumento do peso dos frangos na hora do abate, intensificação da produtividade do trabalho nos frigoríficos e barateamento do preço da mercadoria no mercado, fez a cadeia 
produtiva da carne de frango se estabelecer tendo essas características como seu alicerce para a acumulação de capital.

Como já afirmado por Bosi (2011), ao longo desse processo histórico foi estruturada uma cadeia produtiva que em uma das pontas tem a presença de algumas empresas multinacionais detentoras do conhecimento tecnológico que impulsionou a produtividade nos aviários e, na outra ponta os frigoríficos que produzem carne de frango em escala industrial e ancoram seus lucros na ampla exploração de uma significativa parcela da classe trabalhadora (BOSI, 2011).

Ainda, de acordo com Grando (2017), a cooperativa cascavelense manteve um frigorífico de suínos e bovinos durante toda a década de 1980 e a maior parte da década seguinte. Dessa forma, na década de 1990, a Coopavel passou a construir um "novo" frigorífico polivalente que além de abater e desossar carne de porcos e bois teve na industrialização da carne de frango a sua prioridade. Quando o frigorífico polivalente foi concluído em 1999, o frigorífico "velho" da cooperativa foi desativado. Exceto um dos trabalhadores, todos os demais foram dispensados do frigorífico antigo, considerados inaptos para o processo de trabalho baseado na automatização com organização produtiva fordista taylorista.

As experiências dessa nova planta produtiva foram aos poucos se ampliando, ganhando temporariamente a confiança do paranaense enquanto consumidor de um novo produto que viria a ser no século XXI a carne mais consumida pela população brasileira. Bosi (2016) infere como esse consumo foi sendo progressivamente disseminado nos anos 1970, com uma média de 2,3 kg per capta, chegando em 2005 a 35,4\% e em 2010 ao consumo de $44,5 \%$ (BOSI, 2016).

Além disso, a comprovação da ciência como atrelada ao desenvolvimento levaria a superação dessa consciência baseada no preconceito da população sobre os efeitos da genética na saúde humana, com maior aceitação da carne com indiferença sobre o excesso de hormônios que são parte desse melhoramento genético para aceleração do crescimento e abate das aves. Associada a isso, a mudança do estilo de vida de uma população urbanizada fez com que produtos processados e pré-preparados se adequassem ao estilo de vida do trabalhador submetido à rotina e pouco tempo para se alimentar.

Ainda que aos poucos o consumo de carne de aves fosse introjetado como parte da cultura alimentar da população brasileira, na concepção de uma população urbana de tradição rural e resultante do êxodo, soava estranho o aceleramento produtivo de 45 dias para consumir uma ave, quando pela tradição esse tempo requeria até três meses. $\mathrm{O}$ aumento do consumo e 
aceitação das bases técnicas de aceleramento da maturação das aves foram sendo introduzidos junto à população brasileira até que fez dessa mercadoria a carne mais consumida do país. Em 2018, esse consumo é de 45,565 kg per capta e o setor produtivo prevê um crescimento de $8,7 \mathrm{~kg}$, até 2028 , chegando a um consumo de 54,267kg (AVISITE,2018).

Esse crescimento demandou não só a construção desse produto alimentar como uma nova necessidade, mas, sobretudo, desconstruiu a ideia da produção e industrialização de aves vinculada à falta de higiene até então assimilada pela população local, ao passo que se ampliaram a visão popular com novas noções de higiene, de forma a combater o preconceito que interferia no consumo de aves.

A aceleração da maturidade provocaria, por outro lado, maior disponibilidade de matéria prima nos frigoríficos, ampliação da sua planta produtiva e consequentemente o número de trabalhadores disponíveis para a industrialização de carnes.

Ao se remeter ao trabalho em frigoríficos, Bosi (2013) se refere a um livro publicado pelo jornalista Upton Sinclair, em 1906, que trouxe os detalhes da situação laboral de trabalhadores em frigoríficos nos EUA. Desde seu surgimento, esse tipo de produção fora marcada pelo trabalho barato e um sistema de desmontagem caracterizado pela divisão do trabalho, com a contratação de trabalhadores sem qualificação. Assim, mão de obra barata, trabalho simplificado e monopólio de cadeias produtivas formaram a base milionária da indústria da carne, com condições de trabalho insalubres.

O trabalho em frigorífico remete à presença histórica da exploração, degradação e morbidade da força de trabalho, sendo essa uma consequência direta do aumento da exploração da força de trabalho, que se expressa nas lesões por esforços repetitivos, sobretudo nos frigoríficos de aves. O adoecimento de trabalhadores embora seja apresentado em algumas estatísticas, ainda não representam a verdadeira realidade dos frigoríficos como geradores de adoecimento da força de trabalho, tendo em vista que muitos deles não têm coragem de denunciar e diminuem a formalização dos dados para $25 \%$ das taxas de doenças desde os anos 1980.

Ainda que os adoecimentos estejam longe de expressar a realidade, eles a evidenciam e são vividos e presenciados por trabalhadores nesse ambiente produtivo ou fora dele, os quais convivem diretamente com pessoas que sofrem ou sofreram alguma lesão no ambiente de trabalho, o que tende a fazer com que os frigoríficos sejam identificados como sinônimo de adoecimento. Essa consciência visível e de pleno reconhecimento dos trabalhadores levou o estado do Kansas nos EUA a apresentar uma rotatividade anual de trabalho nas indústrias entre $6 \%$ e $8 \%$, enquanto no setor de frigoríficos de aves variava entre $72 \%$ e $96 \%$. 
Dados do Ministério Público do Trabalho e da Previdência Social inferem que nenhum setor produtivo fere tanto como o de corte de cana e de carne. Os índices são alarmantes e em 2012 esse ministério divulgou que dos mais de 750 mil trabalhadores em frigoríficos, 150 mil apresentam sofrer de algum distúrbio osteomuscular, ou que $20 \%$ deles conciliam dor e trabalho, com a tendência de se lesionar definitivamente (BOSI, 2016).

Finkler (2007) ao entrevistar trabalhadores lesionados nos frigoríficos do Oeste paranaense observou que esses ficam até cinco anos em uma função para apresentar um estado de doença crônica e, além disso, o tempo médio para que um trabalhador manifeste as primeiras dores por realizar movimentos repetitivos é de 18 meses.

Corroboram com Flikler (2007), Oliveira e Mendes (2014) que ressaltam as consequências de um sistema produtivo que remonta ao tempo de Henry Ford, influenciado pela concepção das linhas de montagem automobilísticas. Para esses autores há uma verdadeira legião de lesionados, sobretudo trabalhadores jovens. A evolução em questões sanitárias não acompanharam mudanças nos princípios e concepções iniciais quanto ao modelo de produção. Os autores trazem dados de estudos feitos no Canadá que identificam que o modelo produtivo implementado nos frigoríficos prevalecia agravos associados com o aumento da intensidade do trabalho, da hipersolicitação dada por acúmulo de matéria prima nas esteiras e trabalhadores que atuam em uma sequência atroz com ritmo elevado do trabalho que, por sua vez, ocasiona a prevalência de agravos relacionados com a repetitividade e a sobrecarga muscular.

Aliado a este fator, há a predominância de um Sistema Taylorista-Fordista de produção, com todas as suas mazelas de fragmentação, baixa qualificação, atividades fixas e pouco variáveis, baixa remuneração e redução de todos os tempos mortos, monotonia, acumulação de tarefas desinteressantes, limitação dos contatos humanos, entre outros. Conforme Oliveira e Mendes (2014) pode-se afirmar que atualmente não é possível trabalhar mais rápido do que já é imposto.

Aliado a este quadro de modelo produtivo, temos o trabalho permanente em ambiente de baixa temperatura, além do ruído elevado geralmente acima de $90 \mathrm{~dB}$, a exposição à umidade e a riscos biológicos (carne, vísceras, glândulas, sangue e fezes) também se consubstanciam em fatores que levam a precarização dessas condições e a insalubridade no trabalho.

$\mathrm{O}$ ambiente de trabalho se caracteriza por temperaturas inferiores aos $12^{\circ} \mathrm{C}$, nas quais nenhum equipamento de proteção individual (EPI) consegue ser eficiente o bastante para proteger os trabalhadores das consequências insalubres desse ambiente, sobretudo para as vias 
respiratórias. Em determinados setores essa temperatura diminui para $2^{\circ}$ e $3^{\circ} \mathrm{C}$ e exige maior força do trabalhador para manusear o produto e mantê-lo na temperatura correta. Além de tudo isso, a organização do trabalho fundada nos preceitos fordista/taylorista predominante no setor, foi acrescida de técnicas inspiradas pelo modelo Japonês e estão interferindo nas condições de saúde dos trabalhadores tanto física quanto psiquicamente.

O crescimento de casos de LER (Lesão por Esforço Repetitivo) na categoria aparece de forma destacada como consequência de adoecimento. Outros riscos no processo produtivo são o forte constrangimento em relação às posturas inadequadas dos membros superiores, tronco e cabeça (elevação dos ombros, inclinação do tronco, extensão do pescoço) e ao trabalho estático. A postura fixa de pé, como na linha de corte e desossa, e também ao trabalho dinâmico dos membros superiores e inferiores em outras atividades, como o transporte individual de cargas, no manuseio de peças de cortes, entre outras, também contribuem para o adoecimento dos trabalhadores.

No Brasil, de acordo com Bosi (2016), a realidade das condições de trabalho nos frigoríficos não se afasta dos EUA, já que a condição de trabalho nesse tipo de indústria não se difere em ambos os países. Para manter elevados índices de produtividade depende da reprodução dessas mesmas condições baseadas no trabalho barato, na disponibilidade de mão de obra associada a elevados índices de tecnologia.

Nas cidades pequenas essas indústrias se tornam a principal alternativa de trabalho para os jovens com baixa escolaridade e desprovidos de formação profissional, bem como redes de contato que lhes garantam outro tipo de inserção no mercado de trabalho. Nem mesmo a quase única fonte de trabalho tem sido limitadores da não resignação e do rechaço de trabalhadores brasileiros ao trabalho em frigoríficos. Esse tem se tornado um sentimento comum entre esses jovens, os quais apresentam pela recusa e negação a elevada taxa de rotatividade registrada no setor, próxima de 100\% nos últimos cinco anos (BOSI, 2016; MAMED, 2017).

Isso tem tornado as demissões um fenômeno comum, ou de acordo com Bosi (2016 p. 103), "Pedir demissão ou abandonar o trabalho nos frigoríficos depois de pouco tempo tem sido cada vez mais corriqueiro". A não resiliência de trabalho em frigoríficos gera a rotatividade e dela surge ademanda por outra mão de obra que a substitua. Como dito anteriormente, a disponibilidade de mão de obra abundante é um dos requisitos da cadeia produtiva de frigoríficos, que depende dela frente ao rechaço historicamente evidenciado por trabalhadores nesse ambiente produtivo. A demanda sanada a princípio com moradores das cidades vizinhas, quando já não são suficientes, encontram nos imigrantes uma alternativa 
para manter a disponibilidade abundante, principalmente, porque eles formam um exército industrial de reservas sempre demandado e requisitado pelos frigoríficos.

O desenvolvimento da planta industrial baseada no oligopólio de grandes empresas multinacionais interconectadas ao capital nacional, associada à mão de obra barata são as bases da produção industrial e do sucesso econômico dos frigoríficos na região. No entanto, o trabalho nessas plantas produtivas apontado como sucesso econômico seja pelos representantes do agronegócio e dessa cadeia produtiva, não são vistos com tanto êxito pelos trabalhadores como se divulga.

A negação a esse tipo de trabalho é a máxima expressividade do rechaço de trabalhadores às suas condições. Ao negar o trabalho em frigoríficos os trabalhadores nacionais recusam a intensa exploração a que estão submetidos e os baixos salários, ao passo que estabelecem a mecânica associação entre frigorífico e adoecimento que tem gerado a rotatividade de trabalhadores nesse sistema produtivo, o que num primeiro momento levou essas empresas a buscar trabalhadores nas cidades vizinhas, alcançando em algumas situações um raio de 200 km, ou quando isso já não é suficiente, demandam a incorporação de mão de obra disponível em outras regiões do país.

A realidade periférica do capital, embora possa manter níveis estratégicos de crescimento econômico, sempre vai possuir níveis de desemprego que são maiores ou menores conforme a dinâmica do sistema. $\mathrm{O}$ fato é que as regiões que mais acolhem esses imigrantes foram também as que mais vagas de trabalho geraram a partir da indústria de alimentos. A disposição de vagas nesses setores é evidenciada nos dados do Caged, que indicam o setor industrial de transformação de alimentos como um dos que mais incorporam vagas de trabalho.

Bosi (2014b) ressalta que não é recente a insistência de pesquisadores e movimentos sociais sobre as características contraditórias da agroindústria no Brasil. Elogiada por seu desempenho econômico pelo discurso oficial e patronal, quando por outro lado seu funcionamento depende do trabalho barato. Conforme Bosi (2014b), a rejeição dos trabalhadores a esse tipo de trabalho já foi mostrada por vários pesquisadores, sendo a forma fordista/taylorista de produção destacada como motivos da rejeição, ainda que sem noção do tipo de trabalho que esse modelo vincula para os trabalhadores eles se traduzem em: intensidade de realização do trabalho, tarefas monótonas e repetitivas, baixos salários e a eminência dessas condições laborais desenvolver alguma doença irreversível.

O custo humano não é divulgado pelas empresas do setor, que se preocupam com o custo Brasil, quando se referem ao valor da força de trabalho. Porém, Bosi (2014b) destaca 
que do ponto de vista do trabalhador, a degradação da força de trabalho e doenças laborais está intimamente vinculada ao setor da agroindústria, sobretudo àqueles que trabalham em setores de frigoríficos e etanol.

Ao buscar entender, a partir dos depoimentos dos trabalhadores de frigoríficos, porquê eles rejeitam e recusam esse trabalho, Bosi (2013) identificou que essa recusa é inicialmente justificada pelos baixos salários e as difíceis e intoleráveis condições de trabalho, especialmente as baixas temperaturas no ambiente produtivo associadas a intensidade de ritmos e movimento em que as aves são esquartejadas. Mesmo quando há uma adaptação pouco traumática a essa rotina no frigorífico, o trabalho rapidamente se torna uma experiência difícil, humilhante e repulsiva.

A repetição sem criatividade corresponde a um dos aspectos mais destrutivos vinculados ao trabalho alienado. Os trabalhadores passam horas repetindo funções sem sentido, cuja compensação é o salário e nada mais, quando esse mal dá para sanar as necessidades mínimas de existência, reforça a perda de sentido e realização pelo trabalho. Dessa forma, não há nenhum tipo de prestígio ou status atingido no âmbito do trabalho realizado, e é por esta razão que trabalhadores buscam sistematicamente desatar-se de tal rotina para encontrar algum ressarcimento social, moral e afetivo distante desse ambiente produtivo.

Avançar sobre tais limites implica ainda o enfrentamento dos riscos que parecem incontornáveis, uma vez que o trabalho em frigoríficos de frango está entre os mais danosos e perigosos para o trabalhador. Cortar carne na intensidade, velocidade, e quantidade exigidas atualmente gera lesões que podem ser incuráveis. Por outro lado, o trabalho barato é um dos principais traços da agroindústria, fator esse que lhe permite vantagem ao competir internacionalmente.

Esse tipo de trabalho com as condições acima referidas levaram os empresários a ter nos imigrantes um importante exército de reservas disponível quando os trabalhadores nacionais já não fossem suficientes para o enfrentamento dessas atividades laborais. Da mesma forma, tais condições de trabalho e a potencialidade delas para o adoecimento ou morbidade dos imigrantes ainda eram desconhecidas por eles, associadas a isso, a instabilidade e a necessidade de trabalho fizeram com que essa oferta de trabalho fosse encarada como um bom meio de se inserir produtivamente na nova sociedade de acolhida.

Ao remeter a presença desses empresários nas fronteiras do Brasil com maior disponibilidade de imigrantes, sobretudo haitianos, Cotinguiba e Cotinguiba (2016) presenciaram as triagens de empresas que selecionavam trabalhadores haitianos nas cidades 
do Acre e enfatizam que diante da elevada disponibilidade deles, com oferta maior que a demanda gerava alguns critérios considerados para a escolha dos selecionados, independente se isso interferisse ou não no trabalho a ser realizado, como o domínio do espanhol e elevados aproveitamentos em testes de matemática.

Para os autores, havia sempre uma contradição entre os critérios de qualificação dos imigrantes ou requisitos exigidos pelas empresas e as funções que esses imigrantes iriam desempenhar, sendo essas vinculadas ao trabalho manual e desqualificado.

Nessa mesma perspectiva, Magalhães (2016) ao estudar a imigração haitiana em Balneário Camburiú, no estado de Santa Catarina, ressaltou a expressiva mão de obra estrangeira nos Estados de Santa Catarina e Paraná como os estados de maior atração de trabalhadores no Brasil, ao mesmo tempo em que reservavam a eles os menores salários comparados aos de outras regiões. "Em São Paulo, o salário médio de estrangeiros é de R\$ 2.117,00; no Rio Grande do Sul, R\$ 1.252,00; no Paraná, R\$ 1.246,00; e, em Santa Catarina, R\$ 1.138, 00 (CAGED/TEM, 2015).” (MAGALHÃES, 2016, p. 515).

A média salarial em Cascavel é de $\mathrm{R} \$ 1.200,00$, conforme indica o relato de um trabalhador haitiano que desempenha trabalho em frigorífico:

Eu trabalho na Coopavel eu recebo por mês mil e oitenta, mil sessenta e seis. Se com esse dinheiro eu posso ajudar minha filha. Eu que trabalho e tenho uma filha no Haiti, eu mando cada mês 500 reais para pagar a escola dela e outras coisas que ela precisa. Depois o resto do dinheiro eu pago gás, luz, aluguel. Tudo é caro, não sobra nada para mim (Ali, entrevista realizada em 09 de Maio de 2017).

O envio de remessas é um elemento que faz parte realidade do Haiti, e tem na migração um aspecto cultural, reproduzido por várias gerações. Em todas as entrevistas, até mesmo nos relatos de outras experiências migratórias, das trajetórias dos amigos e familiares, ficou evidente que as remessas constituem uma importante fonte econômica do Haiti.

A pesquisa de campo realizada em Cascavel com imigrantes haitianos evidencia um crescimento que acompanha os dados nacionais em relação aos períodos com maior índice migratório, bem como indicam a continuidade do processo migratório, o que corrobora com a teoria de Clastles e Miller (2005) que indica a imigração como um contínuo ininterrompível.

A presença desses trabalhadores e sua expressividade na região Sul e nos índices nacionais como o maior número de estrangeiros corroboram com os dados quanto à emissão de carteiras de trabalho, ficando os nacionais da república do Haiti aqueles que mais tiveram 
carteiras de trabalhos emitidas que corresponde a 32,3\% de todas as emissões num período que corresponde de 2010 a 2016.

\begin{tabular}{|c|c|c|c|c|c|c|c|c|}
\hline \multirow{2}{*}{ Principais paises } & \multicolumn{7}{|c|}{ Ano } & \multirow{2}{*}{ Total } \\
\hline & 2010 & 2011 & 2012 & 2013 & 2014 & 2015 & 2016 & \\
\hline Total & 8.655 & 13.055 & 23.257 & 37.053 & 45.695 & 41.352 & 32.065 & 201.132 \\
\hline República do Haiti & 143 & 2.020 & 4.499 & 10.626 & 17.134 & 16.986 & 13.556 & 64.964 \\
\hline Bolivia & 388 & 583 & 3.506 & 4.497 & 2.997 & 1.778 & 1.286 & 15.035 \\
\hline Argentina & 955 & 1.129 & 1.495 & 2.127 & 2.851 & 2.068 & 1.568 & 12.193 \\
\hline Paraguai & 829 & 1.024 & 1.901 & 2.363 & 2.486 & 1.900 & 1.382 & 11.885 \\
\hline Portugal & 496 & 918 & 1.694 & 2.034 & 1.700 & 1.085 & 591 & 8.518 \\
\hline Peru & 647 & 514 & 1.541 & 1.694 & 1.772 & 1.161 & 928 & 8.257 \\
\hline Uruguai & 881 & 870 & 844 & 1.237 & 1.376 & 1.154 & 868 & 7.230 \\
\hline Senegal & 233 & 90 & 203 & 1.075 & 2.383 & 2.657 & 362 & 7.003 \\
\hline Colômbia & 297 & 345 & 450 & 1.353 & 1.619 & 1.257 & 1.031 & 6.352 \\
\hline Itália & 321 & 436 & 631 & 792 & 753 & 601 & 343 & 3.877 \\
\hline Outros & 3.465 & 5.126 & 6.493 & 9.255 & 10.624 & 10.705 & 10.150 & 55.818 \\
\hline
\end{tabular}

Foto 12 - Emissão de carteiras de trabalho dados por países 2010-2016 Cavalcanti (2018, p. 33)

Há haitianos em diferentes regiões do Brasil, principalmente na região Sul, no entanto, a despeito do Oeste do Paraná, uma numerosa força de trabalho foi formada a partir da existência desses frigoríficos, em que tais experiências laborais desses trabalhadores se caracterizam pelos baixos salários, intensificação do trabalho e elevados índices de acidentes de trabalho e lesões resultantes dos esforços repetitivos.

Essas características levam a outra que se manifesta como consequência de todas elas, que é a alta rotatividade desses trabalhadores, chegando nos anos 2000 a uma taxa de $100 \%$. É, nessa rotatividade, que podem ser explicadas as estratégias dessa empresa no recrutamento de trabalhadores das cidades vizinhas que atinge um raio de até $200 \mathrm{~km}$, bem como o significativo potencial da presença de imigrantes, os quais soam como boa estratégia para suprir as demandas rotativas de trabalhadores.

Ao mesmo tempo em que essa indústria apresenta esse elevado número de rotatividade, descontrói a ideia que impulsiona o êxito e valorização que se costuma divulgar na região dos frigoríficos como a "galinha de ouro" para o desenvolvimento econômico, uma vez que dissemina a ideia da presença deles como desenvolvimento porque gera milhares de empregos e impulsiona o desenvolvimento regional. Na verdade os dados nos mostram, pela elevada rotatividade, a degradação da força de trabalho na região, a repulsa da população a essas formas degradantes de trabalho, seu adoecimento, e uma rotatividade que representa a negação desse tipo de trabalho. Ao contrário de gerar vagas, gera-se milhares de trabalhadores 
adoecidos que depois de assim se encontrar necessitam de outros para substitui-los, os quais ficam à mercê do Estado, que é o verdadeiro agente que cuida dessa força de trabalho depois de ser degradada pelos frigoríficos.

Contudo, como já inferido nos capítulos anteriores, essa organização produtiva baseada no modelo Fordista/taylorista sempre encontrou resistência. No Brasil, esse tipo de trabalho se expressa em várias organizações produtivas, mas ganha relevância, sobretudo, nos frigoríficos que atualmente representam o segundo maior incorporador de mão de obra de acordo com os dados da Rais (2018).

Ao mencionar a demanda por força de trabalho ou o que Bosi (2013) chama de procura de braços, essa elevada resistência dos trabalhadores obriga os frigoríficos da região a oferecer, além do trabalho, uma lista de "benefícios" que contempla participação nos resultados, bônus por produção, assistência médica, ambulatório médico, atendimento de fisioterapia, área de lazer para recreação e convênio médico. Essa lista é acrescida ainda com itens fornecidos pelo sindicato, tais como cortes de cabelo e curso de informática. O risco (inevitável) das lesões e a parceria entre o frigorífico e a entidade representativa dos trabalhadores sobressaem na brecha escandalosa entre as promessas referidas na lista e o seu cumprimento, que corrobora com o adoecimento e o tratamento simultâneo.

Por sua vez, a gerência dos frigoríficos não está somente no chefe hierárquico direto que controla cada setor na linha de produção, mas soma-se a ele a fiscalização patronal formada por vários funcionários da área da saúde e assistência social, os quais trabalham de forma a controlar o absenteísmo, abandono de emprego, alta rotatividade e, sobretudo, estimular a assiduidade e o retorno ao trabalho junto àqueles trabalhadores que dizem estar doentes no sistema produtivo.

Esses por sua vez quando se deparam com o que tentam evitar, ressaltam que:

"Portanto, a resistência ao trabalho não é um elemento estranho aos gerentes.
Ao contrário, eles tentam explicá-la escudando-se na força do costume - ou
na falta dele -, tentando manejar atrapalhadamente um vocabulário que
expressa sua experiência frente às muitas reclamações ouvidas dos
trabalhadores" (BOSI, 2013, p, 320).

Por outro lado para os gerentes a resistência ao trabalho se explica pela "ausência" de uma "cultura nossa" entendida como disciplina para o trabalho industrial que sobressai como um argumento disseminado, sendo essa uma ideologia que faz parte da dominação burguesa. Ela ganhou relevância nos anos 60 e 70, como objeto da Sociologia para explicar as 
dificuldades do "ajustamento" do operariado em formação à indústria no Brasil, arrastando como justificativa a sua origem rural ao passo que desqualificava suas reivindicações e necessidades históricas. Nesse enquadramento, os trabalhadores teriam pouca disposição para aceitar variadas escalas de horários sem nenhuma autonomia na organização e execução do próprio trabalho.

\subsubsection{Trabalho em frigorífico: a rotatividade como aspectos de atração da mão de obra haitiana.}

Na América Latina, nenhum país possui uma economia potencialmente organizada e de desenvolvimento autossustentável. Todas elas são, de forma geral, produtoras de excedentes econômicos baseados na matéria-prima que é acumulada pelas nações capitalistas avançadas.

A transição da economia colonial para a economia nacional, da escravidão para o assalariamento, do capitalismo comercial para o capitalismo industrial, produziu três realidades estruturais diversas, como a concentração de renda e poder nos estratos das classes dominantes; a coexistência de estruturas econômicas, socioculturais e políticas, sempre interdependentes do capital internacional; e, por fim, a exclusão de uma ampla parcela da população de participar da ordem econômica, social e política, algo reservado, assim como o poder, a um estrato privilegiado. "O novo padrão de imperialismo é, em si mesmo destrutivo para o desenvolvimento dos países latino-americanos" (FERNANDES, 1975, p. 21).

Liderado pela hegemonia dos EUA, o sistema de economia dependente foi recusado apenas por alguns setores intelectuais ou religiosos, mas totalmente aceito pela burguesia interna. Esse sistema foi entendido como favorável para o enfrentamento da subversão e do comunismo, e luta contra a corrupção.

Na América Latina, não há uma democracia real, em razão do domínio dos EUA e suas corporações. Conforme Fernandes (1975), os países latino-americanos enfrentam duas difíceis realidades. A primeira é a absorção das transformações do capitalismo pelas estruturas políticas e econômicas. A segunda é dominação externa que estimula a modernização e o crescimento econômico no estágio mais avançado do capitalismo, mas impede a revolução nacional e uma verdadeira autonomia.

Os setores sociais que possuem o controle das sociedades latino-americanas são tão interessados e responsáveis por essa situação quando os grupos 
externos, que dela tiram proveito. Dependência e subdesenvolvimento são um bom negócio para os dois lados (FERNANDES, 1975, p. 26).

Alves (2017), ao analisar a conjuntura do século XXI, infere que algumas lideranças políticas que possuíam algum propósito nacionalista, embora sem interferências significativas no contexto do capitalismo dependente, alteraram-se, de forma a suprimir qualquer projeto de cunho nacionalista.

A burguesia brasileira se tornou ainda mais invertebrada com a ampliação da sua dependência econômica. Nos anos 1990, a gestão de Fernando Henrique Cardoso contribuiu para isso, além da própria conjuntura do capital. Os anos 2000 deram continuidade à era da desindustrialização, de maneira que o país perde a indústria em razão do crescimento de atividades que estão mais ligadas às finanças, aos serviços e ao agronegócio.

A imigração demonstra a complexidade dessas desigualdades entre os países. $\mathrm{O}$ enfraquecimento dos movimentos sociais e o não reconhecimento da identidade de classes entre os diferentes países periféricos reforçam a ideia do fim do terceiro mundo.

As relações de dependência econômica demarcam a exploração do trabalho com a intensificação da extração de mais valia. A imigração mostra a importância das fronteiras, e os desequilíbrios econômicos e políticos entre as diferentes áreas do planeta, ao passo que recusa a ideia de fim do terceiro mundo e da desigualdade via globalização.

Mezzadra (2005) questiona qual o sentido da noção de imigrante frente à fronteira de exportação e ao espaço transnacional. A ideia de reunificação do mundo implica na falsa concepção de eliminação de barreiras entre as fronteiras, quando na realidade elas se manifestam na hierarquização social, impondo, ao imigrante, situações de hostilidade e obstáculos quando tentam os imigrantes cruzar as fronteiras.

A ação repressiva e controladora dos Estados desmistifica a aparente reunificação do mundo pela globalização, que somente ocorre sem interposições para a liberdade do capital. Este ultrapassa, sem limites, qualquer barreira para se reproduzir, enquanto impõe, para a mobilidade humana, os aparatos controladores das fronteiras, a fim de impedi-la. A preocupação central não é com as imagens de primeiro ou terceiro mundo, mas com as consequências políticas que elas podem gerar. Muitas dessas políticas são anti-imperialistas e soberanas, um imaginário político que implementa políticas alternativas ao neoliberalismo, a partir da centralidade de um projeto de Estado-nação.

As imigrações reforçam, por um lado, a importância das fronteiras e, por outro, a desigualdade econômica entre os países. Quando se fala em fim do terceiro mundo, trata-se do 
seu significado político, que acirra uma condição de desigualdade que é intrínseca a ele, da mesma forma que a oculta.

A situação econômica pode explicar uma parte do problema ao qual estão submetidos os países periféricos. Martins et al. (2014) ressaltam a aceitação ou rejeição como uma ação impulsionada pelo desenvolvimento do capital, atrelado ou não à sua pujança econômica. A aceitação geralmente ocorre com a abertura das fronteiras em ciclos de crescimento, quando há oferta abundante de trabalho, diminuição da resistência social e adoção de políticas para atrair imigrantes. Por outro lado, os períodos recessivos provocam o aumento da resiliência e de conflitos, associados à concorrência por postos de trabalho.

A esse exemplo, imigrantes que chegaram a Cascavel entre 2012 a 2014 comparam a oferta de vagas de trabalho no período em que migraram e a recessão e desemprego nos anos 2016 e 2017. A pesquisa com 60 haitianos demonstra o elevado desemprego entre eles.

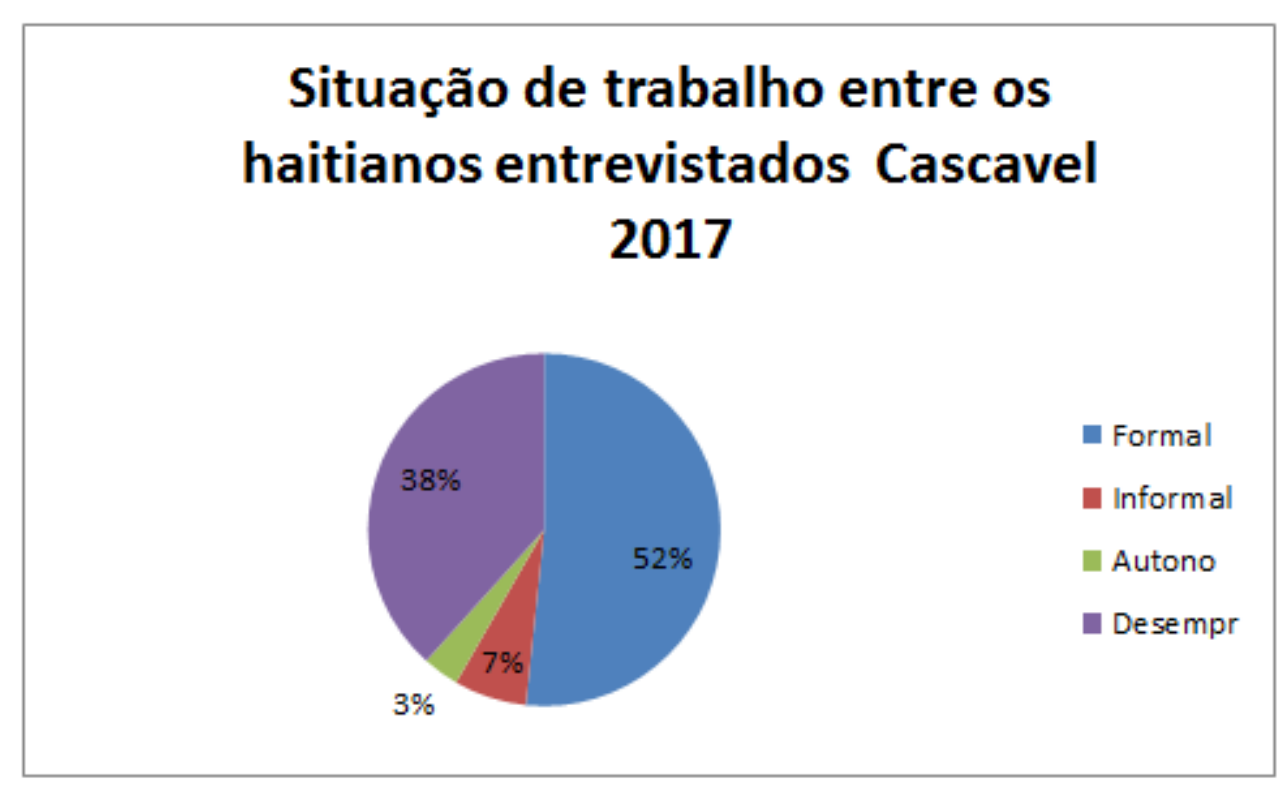

Gráfico 5 - Situação de trabalho entre os haitianos entrevistados Cascavel 2017. Fonte: pesquisa de campo com entrevistas realizadas entre abril a junho de 2017. Elaboração da autora.

Metade da população trabalha em regime regular, com carteira de trabalho, protegida pela seguridade social. Já 38\% encontram-se desempregados, sem nenhuma renda, dependendo da ajuda do grupo de haitianos que está trabalhando. Conforme já discutido anteriormente, os que possuem trabalho mantêm as mínimas condições de sobrevivência para que os haitianos desempregados continuem sobrevivendo até que consigam uma colocação profissional. 
$\mathrm{O}$ alto índice de desemprego entre eles reflete os elevados índices de desemprego que atingiram o Brasil no ano de 2016, em que o país fechou com índices negativos em relação ao trabalho de imigrantes, sendo o número de demissões maiores do que de admissões. Além disso, esses dados remetem também às principais atividades desenvolvidas por eles no referido ano.

\begin{tabular}{|c|c|c|c|}
\hline \multirow{2}{*}{ Atividade econômica } & \multicolumn{3}{|c|}{2016} \\
\hline & Admitidos & Demitidos & Saldo \\
\hline Total & 40.066 & 50.959 & -10.893 \\
\hline Restaurantes e similares & 2.843 & 3.254 & -411 \\
\hline Construção de edificios & 2.478 & 4.052 & -1.574 \\
\hline Abate de aves & 1.793 & 3.394 & -1.601 \\
\hline Hotéis & 1.139 & 1.343 & -204 \\
\hline Lanchonetes, casas de chá, de sucos e similares & 1.110 & 1.163 & -53 \\
\hline $\begin{array}{l}\text { Comércio varejista de mercadorias em geral, com predominância de } \\
\text { produtos alimenticios - supermercados }\end{array}$ & 900 & 1.063 & -163 \\
\hline Frigorifico - abate de suinos & 900 & 1.320 & -420 \\
\hline Limpeza em prédios e em domicilios & 757 & 856 & -99 \\
\hline $\begin{array}{c}\text { Confecção de peças do vestuário, exceto roupas intimas e as } \\
\text { confeccionadas sob medida }\end{array}$ & 612 & 687 & -75 \\
\hline Cultivo de maçã & 518 & 472 & 46 \\
\hline Outros & 27.016 & 33.355 & -6.339 \\
\hline
\end{tabular}

Foto: 13 Principais atividades econômicas desenvolvidas por estrangeiros. Fonte ( Cavalcanti, 2017, pg 91).

Dentre as atividades desenvolvidas, o fluxo migratório haitiano desempenha apenas trabalhos manuais. Outro elemento que coaduna com essa pesquisa é a presença deles nos frigoríficos por meio do abate de aves, estando essa hegemonicamente concentrada no sul do Brasil, sobretudo no Oeste paranaense.

As recessões econômicas demonstraram historicamente o maior peso de suas consequências sobre os imigrantes, que são atingidos de forma direta com a instabilidade política e econômica. No caso dos haitianos, é visível que a solidariedade entre eles tem se colocado como um importante instrumento para enfrentar o elevado desemprego no Brasil e evitar que aqueles diretamente atingidos não sejam expressões das contradições mais sérias como a fome, a mendicância, ou a vinculação à marginalidade.

Os imigrantes haitianos demonstram que o poder das redes sociais, sejam familiares ou étnicas, mantém o processo imigratório não somente com auxílio ao deslocamento, mas, sobretudo, com o apoio destinado à manutenção da sobrevivência, em casos de desemprego. Este, por sua vez, tem relação com a falta de vagas, mas se estabelece principalmente em razão da recusa de inserção dos imigrantes no sistema formal de trabalho.

Os primeiros imigrantes haitianos que chegaram a Cascavel tiveram facilidade de conseguir trabalho em decorrência da ampla demanda do setor produtivo. Porém, a partir de 
2015, essa situação se alterou e instalou-se uma crise após ocorrer o que viria a ser os primeiros rechaços deles pelo sistema produtivo.

Eu cheguei em Cascavel em 2012, vim direto do Acre, onde eu fiquei no abrigo até poder sair de lá. A FAG foi nos buscar, eu trabalhei para eles por três meses, daí mandaram embora, e eu logo já entrei na Coopavel fiquei três meses não gostava do serviço lá. Pendurar frango você não aprende nada. Fui para a construção civil, trabalhar fazer armada, fazer pilar. Fiquei lá um ano, depois eu saí e agora estou na Sadia, na máquina, mexo com suínos. Faz 15 meses que estou na Sadia, o trabalho lá é diferente. Na Coopavel, meu deus do céu, quando estava lá trabalhando o chefe dava dois minutos de intervalo, é muito pouco, agora eu trabalho no pernil, estou trabalhando na máquina. Eu gosto mais da Sadia, mas lá também não aprende nada (risos). Se o Brasil melhorar no emprego, eu quero voltar para a construção civil, porque lá você sempre aprende um pouco de armador, tá sabendo pedreiro, eletricista. Então, quando a gente estava no Haiti, queria uma vida melhor, complicado, porque tem a família para mandar dinheiro meu deus do céu, tem que mandar dinheiro. O Salário na Sadia é $\mathrm{R} \$ 1,300,00$ daí não é liquido, desconta, se a gente faz hora extra dá uns $\mathrm{R} \$ 1.400,00$ (Ali, entrevista realizada em 09 de Maio de 2017)

Ali manifesta a diferença entre os tipos de emprego e o embrutecimento intelectual do trabalho em frigoríficos, de modo que o trabalhador não aprende e não incorpora conhecimento algum ao realizá-lo. Esse sentimento de coisificação do trabalho fora demonstrado por Bosi (2013) que ressaltou as experiências de trabalhadores no setor de frigoríficos e a inércia de realizar um trabalho que não possui nenhum reconhecimento ou satisfação pessoal cuja forma de organização transforma o trabalhador num mero apêndice da máquina, desprovido de qualquer identificação com o que produz.

A brutalização do trabalhador faz a interpretação deles muito mais complexa do que o que seria a falta de cultura para o trabalho industrial como justificado pelos gerentes como uma explicação para a rotatividade. Os trabalhadores recuperam o sentido do trabalho, a exemplo do depoimento de Ali, que é destituído de criação e recompensação.

Por outro lado, Ali faz referência a vários tipos de trabalho e à facilidade que teve de se inserir no sistema produtivo quando chegou à Cascavel. A repulsa e a desvalorização do trabalho manifestada nas entrevistas com haitianos revelam o que Bosi (2016) já identificara entre os brasileiros, que faz a resignação ser um elemento comum, quando a eles não resta outras condições de sobrevivência.

As primeiras levas de imigrantes chegaram a Cascavel para trabalhar na construção civil, mas a maioria desses trabalhadores, pioneiros das migrações, já não está nesse tipo de 
emprego. Os que permanecem na construção civil trabalham por dia, como Alex, que retrata a situação de trabalhador informal e a precarização da sua condição de emprego e de vida.

\begin{abstract}
Quando eu cheguei no Brasil tudo era bom, todo mundo estava trabalhando aqui em Cascavel, todo mundo, era brasileiro, hatiano, todo mundo. Haitiano é complicado, não tem família aqui não tem casa, não tem nada, tem que comprar tudo. Tem dificuldade. Agora eu trabalho por dia, no mês se tem chuva trabalha de 10 a 5 dias. Eu estou trabalhando como mestre de obras, e já faz um mês e meio, que contrataram nós e até agora não nos pagaram. Você vai receber e a pessoa não paga. A gente tá com a carteira assinada faz um mês e nove dias, mas não recebe. Vou ter que sair porque como vai ficar sem receber? Se você tá trabalhando e não recebe nada, como vai fazer? Tem um mestre de obras, que eu trabalhei para ele, e ele nos deve $\mathrm{R} \$ 4.500,00$ que nós trabalhamos, e ele também não nos paga. Esse não era registrado e todo dia que ligo para ele, fala uma coisa diferente (Alex, entrevista realizada em 09 de Maio de 2017).
\end{abstract}

Alex traduz as primeiras experiências daqueles que vieram pela rede de apoio empresarial de guest workers e as dificuldades de começar sozinhos sem ninguém. Suas narrativas revelam as características do trabalho temporário, concepção hegemônica do sentido do imigrante para o empresário. Essa característica fica evidente entre esses trabalhadores e o contrato com a FAG, pois de todos eles, apenas um dos entrevistados ultrapassou os três primeiros meses.

Alex é mais um desses trabalhadores contratados temporariamente que depois de demitido teve que procurar outro tipo de trabalho. Seu depoimento ainda expõe a fragilidade desses trabalhadores, vítimas de empresas que os contratam, mas não efetuam pagamento. Neste sentido, Arango et al. (2007) e Castles e Miller (2004) evidenciam a deslealdade do setor produtivo que se aproveita da situação de vulnerabilidade dos imigrantes, oferecendolhes salários precários. Alex demonstra como alguns empresários agem de má fé, não pagando sequer o salário pelo trabalho mensal, o que aponta para a necessidade de maior controle e fiscalização por parte das autoridades governamentais competentes.

A pesquisa de campo também identificou a presença do setor informal, que incorpora uma pequena parte dos imigrantes do sexo masculino. 


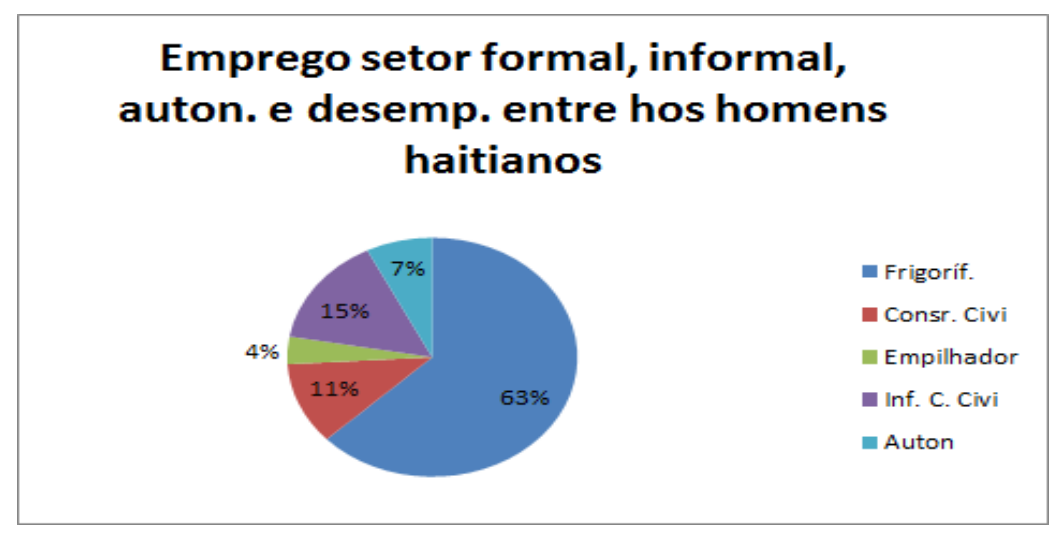

Gráfico 6 - Emprego setor formal, informal, aut. e desemprego entre os homens haitianos. Fonte: pesquisa de campo com entrevistas realizadas entre abril a junho de 2017. Elaboração da autora.

Coutinho (2013) comparou as relações de trabalho de imigrantes nas indústrias têxteis de São Paulo e Nova York, bem como as imigrações históricas e as contemporâneas. Seu estudo revela que ambas as metrópoles tinham como característica comum o trabalho informal, intensificado a partir dos anos 1980 com o surgimento de pequenas fábricas de vestuário. Houve então uma massiva incorporação de trabalhadores estrangeiros, submetidos a condições precárias de trabalho. A realidade empregatícia dos imigrantes haitianos no sistema produtivo de Cascavel é sinal de uma rejeição ou fechamento de outras indústrias e setores, como comércio, serviço e agricultura. Embora os homens ainda aufiram algumas vagas em outras áreas de trabalho como empilhador, construção civil e autônomo. Sobressaem dentre eles a contratação hegemônica em frigoríficos, sendo essa atividade produtiva a maior incorporadora da mão de obra masculina. Esses fatos podem ser observados nos resultados da pesquisa de campo e confrontados com dados oficiais, como recrutamento para trabalho formal da Agência do Trabalhador, o que será apresentado adiante, além dos setores que incorporam haitianos. Quando se analisa a situação das mulheres, esses setores se apresentam ainda mais fechados e o trabalho feminino não encontra em Cascavel nenhuma outra inserção de mão de obra além de frigoríficos, o que diferencia essas mulheres imigrantes de outras experiências migratórias que geralmente tem no trabalho doméstico uma das formas mais comuns de inserção laboral, uma opção quando não há outras alternativas de trabalho.

Ao estudar a domesticação do trabalho feminino em Portugal, Baptiste (2011) ressalta que o protagonismo assumido por muitas mulheres no contexto das migrações internacionais não superou a presença da incorporação feminina em trabalhos específicos a seu universo como o trabalho doméstico comumente traduzido como a limpeza de ambientes domésticos, cuidado de idosos e crianças. 
No entanto, as mulheres haitianas imigrantes apresentam uma característica diferenciada daquelas que assolam o trabalho feminino e a sua incorporação no sistema produtivo, assim como as demais migrantes em âmbito mundial diferentemente, elas se deparam com o fechamento do sistema produtivo, intensificado no Brasil em relação às haitianas com a rejeição delas até para o trabalho doméstico. Os homens, mesmo ocupando poucas outras situações laborais que não sejam frigoríficos ainda mantêm algumas vantagens em outros campos de trabalho que variam mais e aparecem no setor informal.

Em suma, as mulheres quando trabalham estão estritamente vinculadas aos frigoríficos, se não, encontram-se desempregadas. Desse modo, o fechamento do sistema produtivo é transferido de forma geral para o setor doméstico, sendo esse um dos setores que comumente incorporam o trabalho feminino, o que faz a inserção produtiva se restringir quando ocorre ao trabalho em frigoríficos.

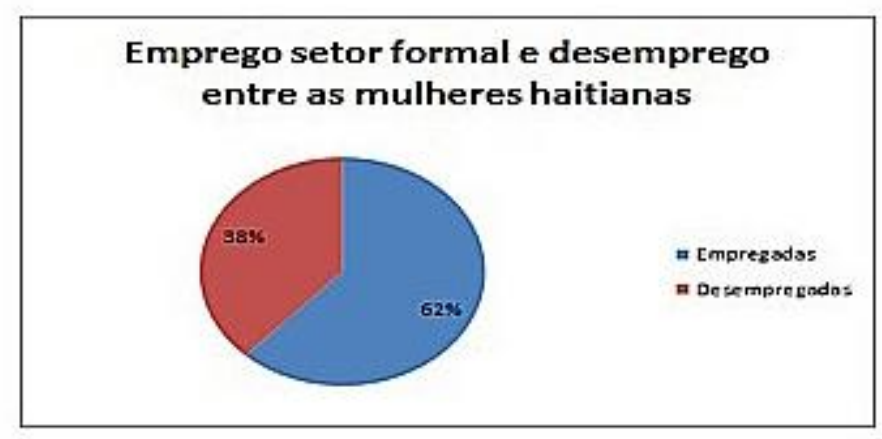

Gráfico 07 - Emprego setor formal e desemprego entre as mulheres haitianas. Fonte: pesquisa de campo com entrevistas realizadas entre abril a junho de 2017. Elaboração da autora.

O gráfico acima demonstra o crescente desemprego entre as mulheres. Mamed (2017) estudou a situação de trabalho de haitianas no Oeste do Paraná e ressalta que as condições de inserção no sistema produtivo para essas mulheres são ainda piores em uma sociedade de capitalismo dependente e de base escravista. A situação da mulher haitiana, negra e pobre, socialmente vulnerável se depara com um mercado de trabalho segregado e desigual em termos ocupacionais e salariais de acordo com raça, gênero e a origem que a direciona aos trabalhos mais precários e explorados. A autora destaca a insuficiência de estudos que contemplassem a imigração feminina no Brasil e que envolvesse suas estratégias e projetos autônomos de imigração até os anos 1980. Posteriormente, ao identificar a incorporação do trabalho feminino, percebe-se a hegemônica formalidade no setor de frigoríficos, e não foi 
constatada a presença das mulheres o mercado de trabalho informal, nem mesmo no setor doméstico.

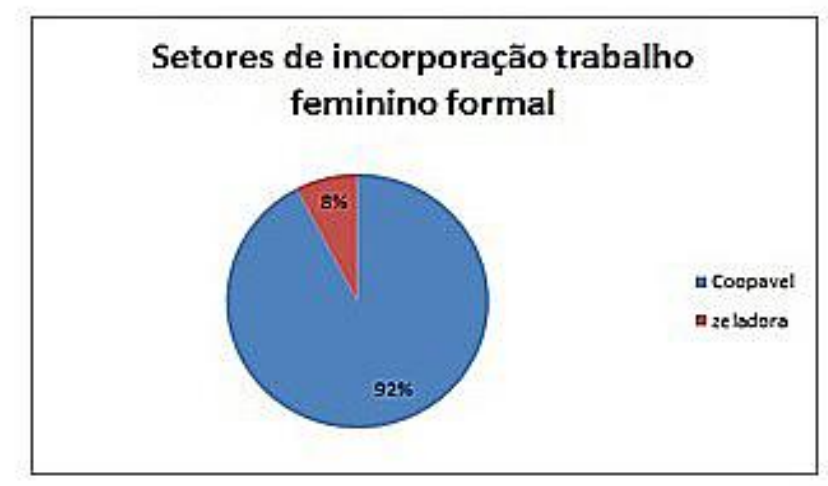

Gráfico 08 - Setores de incorporação trabalho feminino formal. Fonte: pesquisa de campo com entrevistas realizadas entre abril a junho de 2017. Elaboração da autora.

Mamed (2017) estudou a inserção de mulheres haitianas no mercado de trabalho brasileiro a partir do protagonismo feminino, que o difere de perspectivas hegemônicas que tendem a atribuir o processo migratório feminino como acompanhante e dependente, mas resgata de suas experiências o seu protagonismo, mantendo a cultura dominante no país de diáspora e retorno via envio de remessas, de forma a garantir a subsistência dos que ficaram bem como de novos empreendimentos migratórios.

Essa autora, ao estudar um caso específico de uma imigrante, viabilizou o peso das relações de gênero que impactam sobre o trabalho feminino associado a ser imigrante e o histórico preconceito de cor que influencia o sistema produtivo e a inserção laboral no Brasil. Isso se destaca no Oeste do Paraná, onde as mulheres são rechaçadas para outro tipo de trabalho restando a elas a incorporação no trabalho em frigoríficos. Sobressai-se também o domínio dessa cadeia produtiva que impõem pela hegemonia relações de trabalho coercitivas.

A esse exemplo, Mamed (2017) traz o remanejamento de atividades produtivas como um exemplo dessa coerção que, ao ser solicitada, cabe ao trabalhador a aceitação forçada como forma de manter o vínculo empregatício. A quase exclusiva forma de empregabilidade na região, sobretudo para os imigrantes que se deparam com o fechamento do mercado de trabalho bem como o elevado desemprego entre eles, reforça as relações de trabalho pautadas na opressão geradas pela exclusividade de ser único gerador de trabalho.

Os relatos trazidos por Mamed (2017) evidenciam mais uma vez o que foi discutido anteriormente: a carnificina de doentes e as consequências delas atribuídas somente ao Estado que fica com a multidão de doentes sem impor sanções maiores às empresas que as provocam. 
A autora denuncia ainda a indiferença dos sindicatos, sobretudo o Sindicato dos Trabalhadores em Cooperativas Agrícolas, Agropecuárias e Agroindústrias de Cascavel e Região $^{31}$ (Sintracoop) e da Federação dos Trabalhadores em Cooperativas do Estado no Paraná (Fetracoop) que parecem corroborar com esses frigoríficos pela sua indisposição de orientar e assistir haitianos atingidos, bem como pela indisponibilidade em colaborar com as pesquisas que visam elucidar suas experiências atuais de vida e melhorar suas condições enquanto imigrantes.

Os trabalhadores tendem a não reconhecer nos sindicatos qualquer representatividade de seus interesses, ao contrário disso são vistos como parte do sistema patronal, já que atuam em conjunto com as cooperativas para desmantelar a organização dos trabalhadores do setor. Assim, a recusa de participar da pesquisa é feita não só pelo frigorífico como também pelos sindicatos, esses últimos se silenciando diante da questão quando deveriam representar os trabalhadores, combinam junto com os frigoríficos o desmantelamento de organizações de trabalhadores, caracterizando o que já foi expresso com Bosi (2016), num mero pacote de serviços assistencialistas que é oferecido como mecanismo de atração de trabalhadores ao aderir o trabalho em frigorífico.

Mamed (2017) traz um dos casos, a experiência de perda de um membro de uma haitiana quando realizava a limpeza de uma máquina automatizada de moer carne, a qual começou a funcionar quando realizava o procedimento. A trabalhadora teve o corpo impulsionado e conseguiu na manobra evitar que além do braço o restante do corpo fosse engolido pela máquina.

O desemprego entre os familiares levaram a mãe dessa haitiana a ter na mesma agroindústria que aleijou a filha uma possibilidade de trabalho, possibilidade essa negada quando a empresa associou o nome da filha já aleijada ao nome da mãe que procurava trabalho. Tal situação expressa duas contradições que deixa o trabalhador refém desses grandes grupos e coloca os frigoríficos em vantagem diante da escassez de outras oportunidades de trabalho que não sejam os frigoríficos. Tal situação é representada na humilhação da mãe de uma trabalhadora mutilada, que busca no mesmo frigorífico uma oportunidade de trabalho, e na hegemonia das empresas como o frigorífico que pode

\footnotetext{
31 Realizamos contato com esse sindicato para obter informações em relação ao trabalho dos haitianos em frigoríficos que contemplem quantidade de haitianos filiados no sindicato, porcentagem de trabalhadores filiados nos diferentes frigoríficos como Coopavel e Globoaves, ações de trabalho e demandas de haitianos junto aos sindicatos em relação as ocorrências relacionadas a infração de direitos trabalhistas contra essas empresas. As ações empreendidas pelo sindicato a fim de fortalecer o apoio junto aos filiados sindicais imigrantes em Cascavel, no entanto também não conseguimos obter contato.
} 
selecionar trabalhadores, sobretudo aqueles que não tenham procedência de acidentes de trabalho com ele próprio ou com a família.

Essa trajetória representa o universo de mulheres que também entrevistamos, quando imersas no sistema produtivo se deparam com a mesma cadeia produtiva, os frigoríficos, no caso dos haitianos, sobressaindo-se a Coopavel. De acordo com a autora:

A síntese dessa trajetória exemplifica o conjunto de muitas outras registradas pela pesquisa, de homens e mulheres, jovens e maduros, cujo elo de conexão é o fato de terem sido gestadas no interior do processo de desenvolvimento da cadeia global da carne e da sua configuração na modernização dependente do Brasil, cuja característica estrutural é a precarização do trabalho, aprofundada pela desigualdade e segregação, ocupacional e salarial, por gênero e raça (MAMED, 2017, p. 155).

As intenções de Mamed (2017) de enfatizar o protagonismo da mulher migrante a desvincula das relações tradicionais que secundarizam seu papel no processo migratório limitado a reunificação familiar e consequente desvalorização da mulher. Esse caráter protagonista das mulheres destacados pela autora é também identificado nas historias de mulheres haitianas como a vivida por Sianiti que rompe com essa dependência.

Tenho 40 anos, vivo no Brasil faz três anos, quando cheguei fui trabalhar na Coopavel, vim aqui, mas antes morei 11 meses no Equador. Fiquei seis meses sem conseguir trabalho quando cheguei e vivia com ajuda de outros hatianos. Depois que consegui trabalho minha família veio. O salário é pouco, não dá para mostrar. A gente quer uma vida melhor para todos. A gente quer viver melhor. Porque falta tempo, a criança precisa de tempo com o pai e a mãe. Eu trabalho de noite meu marido trabalha de dia e eu não tenho tempo. Quando ele consegue trabalho de diarista eu tenho que trabalhar a noite toda e tenho que cuidar das minhas filhas quando chego, é muito difícil para dormir. Falta tempo para ir na creche buscar vagas. Quando vou eles falam que não tem vaga (Sianiti, entrevista realizada em 13 de Maio de 2017).

Sianiti foi o único caso encontrado de mulher com união heterossexual que deixou o companheiro cuidando dos filhos no Haiti para empreender a imigração. Fez do Equador local de trânsito para chegar ao Brasil. Ao chegar a Cascavel foi empregada no frigorífico até trazer o marido e as duas filhas.

Sianiti ainda revela a dificuldade de trabalhar no frigorífico à noite e ter que cuidar das filhas durante o dia, quando o marido consegue trabalho como diarista na construção civil. $\mathrm{O}$ 
cansaço e o sono, decorrentes de passar a noite toda acordada faz com que a filha de seis anos já assuma a responsabilidade com os cuidados da irmã de dois anos. Logo, conseguir uma vaga em um centro de educação infantil se coloca como uma necessidade para Sianiti, e assim como os brasileiros, se depara com a insuficiência do Estado na oferta de políticas mínimas como a educação infantil.

Mezzadra (2005) ressalta que as migrações femininas não são apenas decorrentes da condição de vulnerabilidade de mulheres solteiras, viúvas e divorciadas, mas procedem de uma decisão dotada de consciência da necessidade de abandonar uma sociedade dominada pelo patriarcado. Há, historicamente, muitos fatores que impulsionam as imigrações protagonizadas por milhares de mulheres como alternativas de fuga ou rompimento com situações de submissão, violência e exploração.

A intensificação das diferentes situações como a miséria, fome, carestias, tiranias políticas e sociais, catástrofes ambientais e guerras, ocasionam o aumento das desigualdades sociais e o consequente crescimento da imigração como tentativa de superar esses problemas. Ao mesmo tempo em que isso representa um estado subjetivo de fuga de situações de opressão, precarização e instabilidade das condições de vida, é um exercício prático de cidadania, marcado pela coragem e enfrentamento de todas as condições que possam atingir o processo migratório.

Assim como Sianiti, que migrou para Cascavel direto do Haiti, demonstrando o protagonismo da imigração de mulheres haitianas, ela também teve na Coopavel a única possibilidade de inserção laboral e mais uma vez expressa a importância desse setor como o meio para prover suas condições de existência, bem como possibilidade de juntar pecúlio e trazer a família. O baixo salário mais uma vez reproduz a realidade de milhares de haitianos que precarizam suas condições de vida para conseguir angariar reservas e enviar para o Haiti, e dessa forma prover a reunificação familiar ou a diáspora haitiana.

Em outra situação, Joana corrobora com a tendência tradicional que vincula a imigração feminina como um dos resultados da reunificação familiar, em suas experiências tendo a imigração como fenômeno contínuo. Veio para o Brasil encontrar o esposo, o qual aqui já a deixou para empreender outra migração para os EUA. Essa é a realidade de muitas mulheres que são abandonadas com filhos e em situações de desemprego, como relata essa imigrante.

Meu esposo veio primeiro logo ele mandou dinheiro para eu fazer o passaporte colocar visto para entrar no Brasil. Fiquei três meses no Equador esperando visto brasileiro para poder entrar aqui. Eu entrei e a gente ficou 
morando junto. Eu vim direto para Cascavel, meu marido trabalhava com ajudante de pedreiro aqui. Hoje ele já migrou, ficou sem serviço, foi mandado embora e não achava outras coisas para fazer, ele foi para Estados Unidos. Está morando ilegal lá, mas conseguiu entrar. Ele está trabalhando e de vez em quando ele ajuda. Temos uma filha que está no Haiti e uma bebezinha que está comigo. Às vezes tenho vontade de ir embora, mas estou sozinha, mas agora tenho ajuda de vocês, tem a Cáritas que sempre ajuda a gente, a gente se sente sozinha sem ninguém. Ele que me chamou para vir morar com ele aqui e agora me deixou, sabe, eu fico muito triste. Não consigo enviar dinheiro para minha filha no Haiti, meu marido quando tem manda para ela e manda para mim de vez em quando (Entrevista Joana, 26 de Maio de 2017).

Joana expressa, além do abandono, as raízes da imigração. O envio de remessas é feito pelo marido que conseguiu lograr a entrada nos Estados Unidos. Contudo, a família foi deixada no país de migração. Essa imigrante revela também a estratégia de reunificação familiar, que burlou as cotas de 1.200 vistos por ano emitidos anualmente no Haiti, sem exceder 100 ao mês, para o Brasil. Utilizar outro país para migrar com as condições formais do visto é se valer do que Castles e Miller (2004) denominaram de países de trânsito, até conseguir chegar ao Brasil com vistos emitidos nesses países.

A análise das migrações deve considerar quem vai ficar para trás. Nessa perspectiva, Silva (2005) ressalta que as estratégias familiares de migração são sempre relações de conflito, com situações de desagregação familiar entre jovens casais, que partem sem a possibilidade de retorno. Joana ressalta a dificuldade de ter ficado no Brasil após ter sido deixada duas vezes pelo marido. Abandonar a família e empreender a imigração ocorre nas diversas relações familiares, principalmente entre homens que deixam as famílias no Haiti, buscam suas mulheres que fazem o mesmo com seus filhos para empreender a reintegração familiar.

Da mesma forma como Joana foi deixada no Haiti, posteriormente o fez com a filha, a família e todas as relações construídas no país de origem. Esse propósito durou o tempo de trabalho do marido no Brasil. Mas diante da rescisão contratual, ele empreendeu outro projeto migratório que colocou Joana e outra filha que tiveram no Brasil em segundo plano. A segunda reintegração se coloca como uma possibilidade distante devido às características de controle de fronteiras dos Estados Unidos, como também pelo fato de não poder contar no Brasil com as mesmas redes de apoio que possuía quando estava no Haiti, ou seja, a família com quem poderia deixar a filha para emigrar novamente.

O mercado de trabalho rejeita as mulheres de forma mais contundente e o expressivo desemprego culmina em outros problemas sociais como a prostituição. Essa preocupação 
aparece em alguns depoimentos de homens, quando relatam a dificuldade das mulheres encontrarem trabalho em Cascavel e a vulnerabilidade de muitas delas que recorrem à prostituição como alternativa de sobrevivência. Jonas ressalta que, geralmente, elas se prostituem com os próprios haitianos, que se aproveitam da sua situação de instabilidade financeira e vulnerabilidade social.

O problema é pior para a mulher, eu não sei, todo lugar é mesma coisa, todo lugar tem prostituição. Tem mulher haitiana que está entrando para o serviço da vida, tem mulher que tá brigando com outra mulher. Mulher que entra para o serviço, para a vida faz isso porque não tem trabalho. Quando minha mulher veio para Cascavel foi na Coopavel e a empresa disse não tem trabalho, então ela não conseguiu. Só que ela tem eu que sou seu marido, mas e as outras que não tem ninguém e as empresas não aceitam o que vão fazer? Muitas estão indo para a prostituição e estar nessa situação sem trabalho faz com que os próprios haitianos se aproveitem dela. A minha Mulher faz dois meses que não trabalha. As outras aceitam isso para viver, para receber dinheiro, para viver e muitas ficam gravidas. É a falta de trabalho que faz isso. Aqui tem bastante, porque tem mulher que fica cinco meses, seis meses sem fazer nada, como vai viver? Aí elas vão fazer prostituição. É uma situação muito complicada, muito triste (Alli, entrevista realizada em 09 de Maio de 2017).

Muitas vezes as decisões de migrar são subjetivas e perpassam situações diversas, como violência sexual, desavenças familiares, prostituição, entre outras. Tendo isso em vista, assim como Jonas, Alli se preocupa com o fato de que, em razão das dificuldades que enfrentam, sobretudo, pela falta de emprego, as imigrantes haitianas façam da prostituição uma forma de sobrevivência. Situações como essas não são inéditas entre as imigrantes no Brasil. Muitas mulheres são vistas como objeto de exploração sexual quando não cumprem os padrões patriarcais, pautados na fidelidade feminina, submissão e respeito ao marido. Nesses casos, são representadas como meros objetos sexuais. Mas é necessário esclarecer que não se sabe se a prostituição de imigrantes haitianas no Brasil aparece como uma condição para garantir sua sobrevivência ou se simplesmente é um ato que não se enquadra no modelo clássico patriarcal, fortemente reproduzido no Haiti e no Brasil.

Vale destacar que o aspecto da prostituição não foi contemplado neste trabalho, seja porque não surgiu no momento da investigação; ou talvez pelo fato de a prostituição ser compreendida como imoral e, em razão de constrangimentos, não ter sido mencionada como uma prática pelas entrevistadas; ou, ainda, pode ser que entre as entrevistadas nenhuma se prostituísse. Outro estudo poderia ser desenvolvido a partir dessa questão. 
As análises entre a incorporação do gênero masculino e feminino apontam resultados importantes quando se trata da diferença deles e a aceitação no sistema produtivo, sendo observado que ambos os gêneros são incorporados em sua maioria pelos frigoríficos, o que acentua esse espaço produtivo como hegemônico das contratações. Posteriormente, constatase que embora sejam os homens excluídos dos demais setores produtivos, eles ainda possuem outras formas de inserção laboral, enquanto entre as mulheres isso se verifica quase que exclusivo ao setor de frigoríficos, destoando a presença delas em outras áreas, sobretudo as comumente evidenciadas entre os imigrantes como o trabalho doméstico.

Abaixo ressaltamos a análise entre ambos os gêneros ou sobre a comunidade haitiana de forma geral, verificando uma situação de rejeição da incorporação de haitianos no sistema produtivo de Cascavel. Logo, a hegemonia das contratações desse grupo recai em setores de frigoríficos.

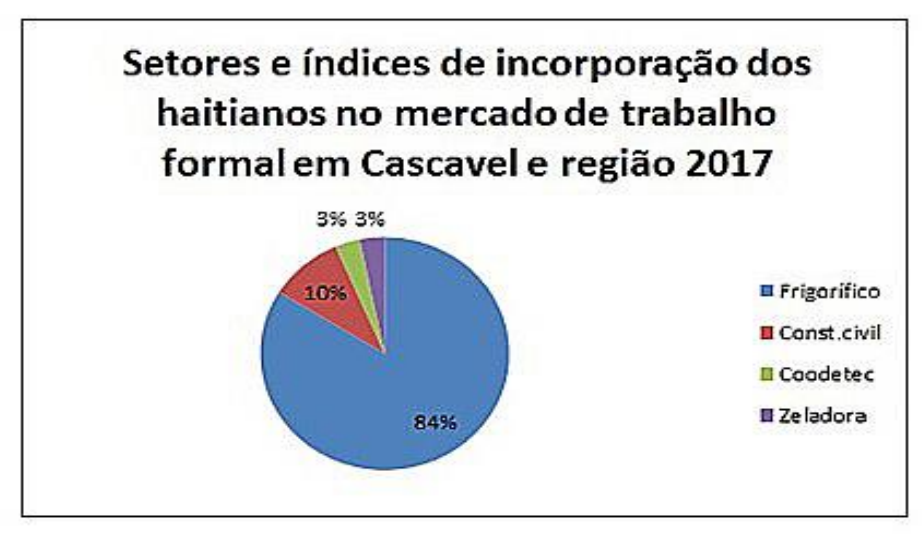

Gráfico 09 - Setores e índices de incorporação dos haitianos no mercado de trabalho formal em Cascavel e Região 2017. Fonte: pesquisa de campo com entrevistas realizadas entre abril a junho de 2017. Elaboração da autora.

A hegemonia da incorporação de trabalho de haitianos no Brasil, sobretudo em Cascavel, nos leva a considerar como já ressaltou Fernandes (1993) a posição desigual do Brasil na divisão internacional do Trabalho, que por esse simples fato se traduz em consequências de ser trabalhador imigrante na periferia, agravado por transformações produtivas e trabalhos flexíveis, somadas à histórica rejeição do negro e a consequente ocupação dos estratos mais baixos da sociedade. O percurso laboral de imigrantes periféricos na periferia é, conforme acentua Mamed (2017), intensificado com essas relações que se intercruzam e consequentemente atingem de forma latente o imigrante negro e pobre na sociedade. 
Para essa autora a sociedade brasileira, ao conservar os traços característicos de sua formação social, apresenta uma estrutura sexual e racialmente hierarquizada do seu mercado, que faz da maior parte da população que incorpora mulheres e negros entre aqueles estratos que auferem os menores salários em decorrência de comporem os estratos mais baixos da sociedade. Ainda, ao se referir à situação de trabalhadores no Oeste do Paraná, os últimos anos tem registrado um crescimento das atividades agroindustriais, que por sua vez concorreu para o aumento significativo das vagas de empregos formais ocupados por imigrantes haitianos, geralmente identificados quase que restrito às indústrias de alimentos vinculadas aos frigoríficos em detrimento de outros setores.

Nesses postos de trabalho que ainda são incorporados, os imigrantes são menos reconhecidos e remunerados e, simultaneamente mais cansativos e desgastantes. Embora isso permita confirmar a tendência de uma feminização do mercado de trabalho, com significativas mudanças para as mulheres e suas famílias, há uma incompletude dessa feminização, que apresenta-se inacabada quando associada à desigualdade e à precarização em relação ao trabalho masculino.

Nessa perspectiva, essa pesquisa ao analisar a incorporação dos haitianos no sistema formal de trabalho, constata a hegemonia do setor frigorífico, responsável por empregar $84 \%$ da população haitiana quando se refere ao trabalho formal, compreendendo ambos os sexos. São poucas as colocações na construção civil, e quase inexpressivas nas empresas de pesquisa, comércio agrícola e serviços. Assim sendo, percebe-se que o sistema produtivo do Município de Cascavel está fechado para os haitianos e resistentes em contratá-los.

Os dados expressam ainda a importância dessa mão de obra que tem se constituído como já ressaltado anteriormente em um importante exército de trabalhadores reservas disponíveis para servir às necessidades da rotatividade desencadeada pelo sistema produtivo de frigoríficos. Além disso, se o mercado de trabalho informal fosse considerado como uma situação de desemprego, o número de trabalhadores desempregados seria ainda maior. A hegemonia das contratações em frigoríficos revela a importância do setor produtivo, não como uma opção a partir de uma escolha laboral, mas como única alternativa em vista da rejeição da incorporação desses trabalhadores em outros setores do sistema produtivo.

A partir dos anos 1980, o Brasil se apresenta como um dos principais destinos da migração seja ela qualificada ou desqualificada. Isso coloca uma nova demanda para o Estado, que tem que dar conta dessa questão inserindo-a como parte de sua agenda política.

A mão de obra voltada para o trabalho manual é progressivamente encaixada nas manufaturas, que a demandam. Já a mão de obra qualificada está concentrada nos grandes 
centros, sendo voltada para o desenvolvimento do trabalho intelectual (VILLEN, 2013). Se no centro do sistema capitalista a mão de obra feminina e de imigrantes dá continuidade à extração de mais valia, na periferia essa característica é ainda mais acentuada. Esse quadro se sustenta principalmente por meio da estrutura jurídico-política que está por trás do Estado burguês no Brasil.

Saes (2001) defende a tese da importância desse Estado para a continuidade do processo de acumulação de capital. Para esse pensador, o Estado burguês surge no Brasil a partir de três fatores interligados: a abolição dos escravos em 1888, a Proclamação da República em 1889, e a primeira Constituinte em 1891, que suprime o direito escravista moderno e institui as relações de trabalho assalariadas.

A essência desse Estado está na sua organização como sendo de classe, como pressupõe a teoria marxista. No entanto, também, faz-se presente no seu aparelho jurídicopolítico, que mantém e conserva a sociedade capitalista por meio dessa estrutura. Isso implica na legalização da compra e venda da força de trabalho a partir da lógica do capital, que acaba naturalizando os baixos salários pagos. Logo, o que se tem é apenas a transição da escravidão para o sobretrabalho, que se caracteriza pelo pagamento de baixos salários, os quais nem sempre cobrem os custos das necessidades mínimas de existência, além de serem degradantes e precários.

A percepção de relações degradantes de trabalho formalizadas e viabilizadas por legislações do estado capitalista levaram Bosi (2014b) a comparar e revelar a presença de trabalhos degradantes como aqueles que se realizavam no período da escravidão, ocultados apenas pelas leis que se transparecem como modernas, quando na verdade reproduzem formas injustas e desiguais de exploração da força de trabalho semelhantes ao período da escravidão no Brasil.

O autor revela duas das mais degradantes e exploratórias formas de trabalho, sendo elas o trabalho em canaviais e frigoríficos. A percepção dessas condições degradantes de trabalho compreende o que se convencionou chamar de "modernização do campo" de duas principais atividades do que constitui hoje o agronegócio no Brasil, sinônimo de "desenvolvimento econômico". Essas atividades resultam de combinações arcaicas de relações de produção, com intensificação das relações de exploração do trabalho.

Percebe-se que nesses empreendimentos a tecnologia vem atrelada à ampliação da força de trabalho, que tem aumentado conforme é empregada em ambas as atividades produtivas, o que faz delas a associação a formas contemporâneas de escravidão, ocultadas 
pelo trabalho assalariado, fato que faz dessas formas de trabalho os maiores produtores de acidentes de trabalho no país.

Bosi (2014b) ressalta que até os anos 1960 o trabalhador de canavial cortava três toneladas de cana por dia, atividade equivalente à produção do trabalho escravo no Brasil entre os séculos XVII e XIX. No final da primeira década do século XXI, ainda com a mesma técnica de golpe e facão, a produção chegou de 10 a 12 toneladas por dia. Esses dados permitem o autor afirmar que hoje o cortador de cana é mais explorado do que já foram os escravos no Brasil.

A história do trabalho em frigoríficos também não se diferencia no que se refere à intensificação do trabalho nesses ambientes desde a sua origem. Ao comparar os dados atuais com os antigos matadouros se evidencia tendência parecida à dos canaviais. Tempos mais remotos que vão desde os matadouros que forneciam à carne de Dom Pedro à charqueada no Rio Grande do Sul, ambos preparados por escravos, retomam procedimentos parecidos. A produção mais especializada de carnes viabilizada com a instalação do frigorífico oriundo dos EUA no Brasil no início do século XX não alterou o ritmo produtivo do trabalho simplificado e a incorporação de mão de obra desqualificada sem qualquer formação profissional é um exemplo da mesma lógica produtiva.

Repetem-se os mesmos cortes durante toda a jornada trabalhada (com poucos intervalos para descanso), os salários dificilmente ultrapassam o valor do salário mínimo, e o lugar do trabalho é inóspito e ameaçador. Associado à reprodução de formas produtivas do passado que permanecem no presente estão às esteiras, que condicionam e forçam a adestração e agilidade nos ritmos e movimentos. Conforme Bosi (2014b), as avaliações relacionadas às lesões no punho, consideradas as mais populares nessa planta produtiva tem risco de $743 \%$. Para esse autor, tanto os riscos como os números de acidentes no trabalho, faz com que a indústria de frigoríficos se depare com a contradição no que se refere a uma análise crítica dele, a degradação do trabalhador que concilia "dinamismo do setor agroindustrial", que só é dinâmico porque pela degradação aufere êxitos de lucratividade.

A euforia divulgada tanto pelo governo como pelo setor disseminam a ideia de ganho social com o faturamento econômico. Ao mesmo tempo, ocultam o dilaceramento de milhares de trabalhadores empregados nesse setor, que se cortam e laceram seus corpos. Ao entrevistar trabalhadores de frigoríficos o autor recupera neles a ausência do sucesso da carne, mas sobressai as precárias condições de trabalho a que estão submetidos os trabalhadores desses empreendimentos. Corroborando com Bosi (2016), Mamed (2017) também trás dados da indústria da carne como geradora da carnificina humana, que nas palavras da autora: 
Todos os relatos concordam quanto a percepção do frigorífico como lugar de "moer gente", expressão que evidencia a ironia do trabalho humano em fábricas de processamento de carne. Ao utilizarem essa expressão ou outras assemelhadas, sinalizam que o trabalho nessa indústria adoece, mutila e mata. Não à toa, ela lidera o ranking de acidentes de trabalho no ramo alimentício do país, com registro médio de 54 ocorrências por dia (CAVALCANTE et al., 2017; MORAES, 2015) e algumas plantas produtivas chegam a apresentar rotatividade de $100 \%$ da força de trabalho dentro de um mesmo ano, o que pode significar uma rejeição expressiva a esse tipo de trabalho (HECK, 2013; CARNE e OSSO, 2011; SANTOS FILHO \& VARUSSA, 2016) (MAMED, 2017, p. 162).

Esses elementos revelam a intensa movimentação de trabalhadores delineados pela cadeia produtiva da carne, no âmbito nacional e global, que historicamente remete à contratação de imigrantes onde quer que essas indústrias estejam instaladas.

No Brasil a imigração haitiana, com seu grande fluxo, foi uma boa estratégia para um setor que já sofria o rechaço e a recusa dos trabalhadores nacionais, que puderam agregar à eles mais esses trabalhadores, já que nem mesmo aqueles presentes nos Municípios vizinhos solucionavam a demanda pela força de trabalho.

Essa estrutura jurídico-política é percebida na regularização da situação de imigrantes estrangeiros e na disponibilidade desses em servir o sistema produtivo, conforme suas demandas. O trabalho barato na periferia aufere a desvalorização que está relacionada à posição do país como economia dependente e à extrema desvalorização da força de trabalho que intensifica por meio de legislações no âmbito da democracia burguesa distintas formas de exploração de mais valia.

Sobre esse aspecto, Villen (2013) revela que há uma gradativa ação regulatória da mão de obra qualificada dos imigrantes pelo Estado. No mais, para essa autora a mão de obra mais capacitada se concentra na região metropolitana de São Paulo, o que possibilita que seja incorporada no processo produtivo, recebendo melhores salários.

Essa componente qualificada também ganhou visibilidade no Perfil dos Migrantes em São Paulo (IPEA-2011). Os resultados, apesar de limitados para uma caracterização mais completa do quadro imigratório. Não por acaso, a pesquisa releva um padrão estratificado de inserção no mercado de trabalho pelos diferentes grupos sociais, no qual os estrangeiros entrevistados ocupam uma situação mais privilegiada. Apesar do reduzido número de estrangeiros com idade laboral, são úteis a nos fornecer um desenho geral da imigração qualificada na cidade de São Paulo (VILLEN, 2013, p. 4). 
Os imigrantes buscam por emprego, o que faz dos frigoríficos a única possibilidade de inserção no mercado de trabalho frente a um sistema produtivo fechado para inserção destes no Oeste do Paraná. Embora muitos sejam qualificados, isso não é considerado quando são contratados. Uma dessas trabalhadoras, a haitiana Milene acredita que o emprego em frigorífico deveria ser reservado para pessoas que possuem menos instrução, e aquelas que possuem nível maior de escolaridade deveriam realizar outros tipos de trabalho, compatíveis com sua formação.

Sim eu ajudava as pessoas no Haiti. Lá eu era secretária. Minha experiência
aqui, eu posso dizer que eu aprendo muitas coisas, mas quando estou
trabalhando na Coopavel, acho que esse serviço teria que ser feito por
pessoas que não tem conhecimento que não estudam e que tem que fazer
isso. Mas eu estudei é isso que eu estou fazendo agora. No papel da reunião
eu escrevi tudo isso, porque tem bastante haitiano que tem muito
conhecimento e esse conhecimento não vale nada aqui. Acho que as pessoas
responsáveis como o governo tem que fazer isso, para dizer que as pessoas
que tem qualificação que estudaram pode fazer outro serviço. Que quando as
pessoas vem buscar trabalho com todos os papéis poderiam fazer prova, e
depois a pessoa entrega papel para fazer o tipo de trabalho que a pessoa
conhece (Milene, entrevista realizada em 25 de Maio de 2017).

Milene expressa nesse relato a desvalorização do seu capital humano imigrante no Brasil, ao passo que ressalta o descompasso entre sua formação e o trabalho que aqui realiza. Diferente de países como Canadá, Austrália e Nova Zelandia, que instituíram o sistema de pontos, sendo a formação profissional um dos quesitos, aqui não há qualquer valorização do capital humano, sobretudo se ele é proveniente de países pobres e imigrantes negros.

A complexidade de reconhecimento de convalidação de cursos no exterior é outro problema. O Estado brasileiro até possui algumas instituições capazes de fazê-lo, porém a burocracia torna esse processo quase irrealizável, sobretudo para os haitianos, que em sua maioria saíram sem documentos completos que comprovem o estudo no país de origem. Mesmo entre os que possuem documentação, sempre falta algum tipo delas, o que torna a convalidação de curso um processo burocrático e muito difícil de ser acessado por haitianos no Brasil.

No caso de Milene, o trabalho no Brasil não gera satisfação, além de desagrado, sendo que o trabalho de caráter manual causa maiores riscos para a saúde do trabalhador. De acordo com Cêa e Morofusi (2010), a incidência de trabalhadores acometidos por lesões e acidentes de trabalho nos frigoríficos é quatro vezes superior ao de outras atividades manufatureiras. 
Assim, esse espaço é produtor de pessoas adoecidas, lesionadas, e até mesmo inválidas, antes de se constituir como espaço de produção de alimentos de origem avícola. Os dados sobre doenças no trabalho em frigoríficos demonstram, portanto, a precarização das relações de trabalho, cuja intensidade está atrelada ao ritmo das transformações da organização produtiva.

Milene incorpora também a ideologia da meritocracia baseada no esforço e compensação que deveria vir no reconhecimento pela valorização do seu capital humano. Sua reflexão leva também à discussão sobre o trabalho imaterial e material. O trabalho imaterial está relacionado ao intelectual, enquanto o material ao trabalho manual, sendo esse representado pelo trabalho em frigoríficos. O trabalho realizado no Haiti lhe permite tecer comparações dos ofícios que realizava antes no seu país de origem e do que realiza atualmente nos frigoríficos. Quando remete ao que fazia lá, ao realizar o trabalho de secretária recepcionando e orientando as pessoas, sobressai a satisfação e dignidade com o resultado do trabalho. Isso não ocorre no frigorífico, já que o trabalho que faz é considerado repetitivo e sem possibilidades de aprendizado, o que provoca desumanização e insatisfação pessoal. A grande indústria levou para si elementos da manufatura como o trabalho simplificado ou parcial que foi aprimorado pelo capitalista. Cada operação é a decomposição de várias atividades do artesão, que postas juntas puderam ser decompostas. Desse modo, complexo ou simples o trabalho continua sendo manual, artesanal, dependendo da força e da habilidade, rapidez e segurança do trabalhador e a forma de como maneja seu instrumento. Mantém a base técnica do artesão, o fundamento do processo de produção, sendo sua força de trabalho absorvida por uma função especial: trabalho manual que se transforma para sempre em um órgão dessa função. Assim, desde a manufatura a realização por toda vida de uma única operação torna o corpo do trabalhador em automático, especializado. Essa automatização e mecanização faz com que ele realize as tarefas em menos tempo de quando dominava todo o processo produtivo. O Trabalhador coletivo constitui o mecanismo vivo da manufatura e, por meio do trabalho parcial limitado, produz em menos tempo. Essa elevação da produtividade da força produtiva se intensifica quando se junta o maior número de artesãos diferentes na execução da manufatura complexa, pois essa se fará mais rápida e melhor, com menos perda de tempo e de trabalho. A organização produtiva herdada da manufatura é reproduzida atualmente no trabalho repetitivo, manual, com a produção coletiva de muitos trabalhadores sob o domínio de um único capitalista. 
útil desejado com um mínimo de esforço. Havendo sempre diversas gerações de trabalhadores que vivem simultaneamente e cooperam nas mesmas manufaturas, os artifícios técnicos assim adquiridos firmam-se acumulam-se e se transmitem (MARX, 2004, p. 394).

Os haitianos se constituem em mão de obra reserva para suprir a demanda de trabalhadores quando for requisitada pelo sistema produtivo. Isso se verifica entre os frigoríficos, mas não se refere ao sistema produtivo como um todo.

A recusa para a inclusão de imigrantes no sistema produtivo é desvelada no cotidiano e, aqui se soma um preconceito histórico que é o racismo que se fortalece com o preconceito contra o imigrante. Exemplo disso é a expressão da fotografia abaixo, que representa manifestações simbólicas de preconceito e xenofobia, captadas no cotidiano da cidade de Cascavel.

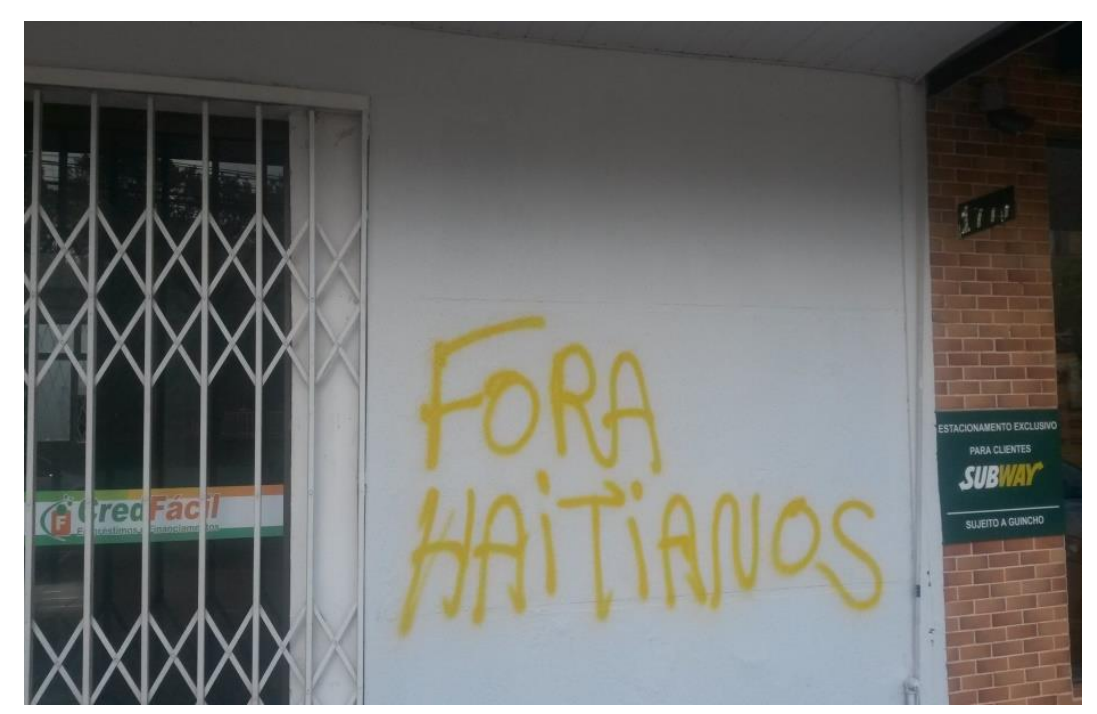

Foto 14- Pichação em estabelecimento em Cascavel. (Foto: Claudimara Cassoli Bortoloto, 29 de Dez. de 2016).

Fernandes (1978) ressalta que o comportamento dos brancos em relação aos negros, seja ele tolerante ou intolerante, pode estar condicionado às práticas dos grupos étnicos e tradicionais de cada região, que se ampliam ou diminuem conforme sua formação. Para o autor, o estereótipo, as avaliações e representações sociais dos brancos são como elo que relaciona o passado ao conteúdo ou função da estrutura, ao sistema de classes. Por assim serem, as avaliações ou representações desfavoráveis dos negros são reproduzidas historicamente, e se encontram em vias de atualização.

Os estereótipos, as avaliações e as representações desfavoráveis ao "negro" encontram vias de atualização sócio- cultural graças a complexos de traços culturais, sociais ou psicológicos cuja existência e continuidade independem, 
na situação hostórico-cultural descrita, da organização da sociedade de classes (FERNANDES, 1978, p. 341).

A população negra não se converteu em uma etnia que pudesse disputar em igualdade a dominação do branco. De maneira inversa, devido à ideologia da homogeneização de raças, a classe dominante branca a coloca em segundo plano, ao invés de encará-la como uma condição positiva de integração.

A ausência de reação é caracterizada por Fernandes (1978) como uma inércia, ou aceitação de naturalização da desigualdade. Essa falta de integração na sociedade de classes causa sofrimento, o que leva à conformação com a subalternização. Entretanto, é preciso reconhecer que a ascensão social em uma sociedade de capitalismo dependente é difícil não apenas para o imigrante negro, mas também para o pobre branco. No entanto ao imigrante soma-se o racismo, a pobreza e a xenofobia, o que agrava ainda mais a posição deles numa sociedade de classes, em que sua condição não é majoritária pela raça, condição social ou cultura nacional.

Espera-se que o "negro" se ajuste aos padrões da civilização vigente. Mas,
ignora-se o que isso significa, material e moralmente, para a sociedade
inclusiva; e como isso possa ou deva repercutir na equiparação de "negros" e
"brancos", o qual concorre para perpetuar, indefinidamente, certos modelos
arcaicos de acomodação racial (FERNANDES, 1978, p. 342).

Na compreensão de Fernandes (1978), há uma conformação da negação de exigências estruturais e dinâmicas de uma civilização, o que levou a uma acomodação racial. A solução, para o autor, é a equiparação social desses diferentes "estoques" raciais presentes. Exemplo disso seria a ampliação dos direitos dos imigrantes no Brasil e garantia das condições materiais para sua efetivação, como trabalho digno e condições mínimas de existência. Enquanto isso não ocorre, situações de preconceito e xenofobia vão se tornando naturais em uma cidade que cada vez mais convive com a presença de imigrantes, desconstruindo a ideia do Brasil como lugar receptivo e aberto para a imigração. 


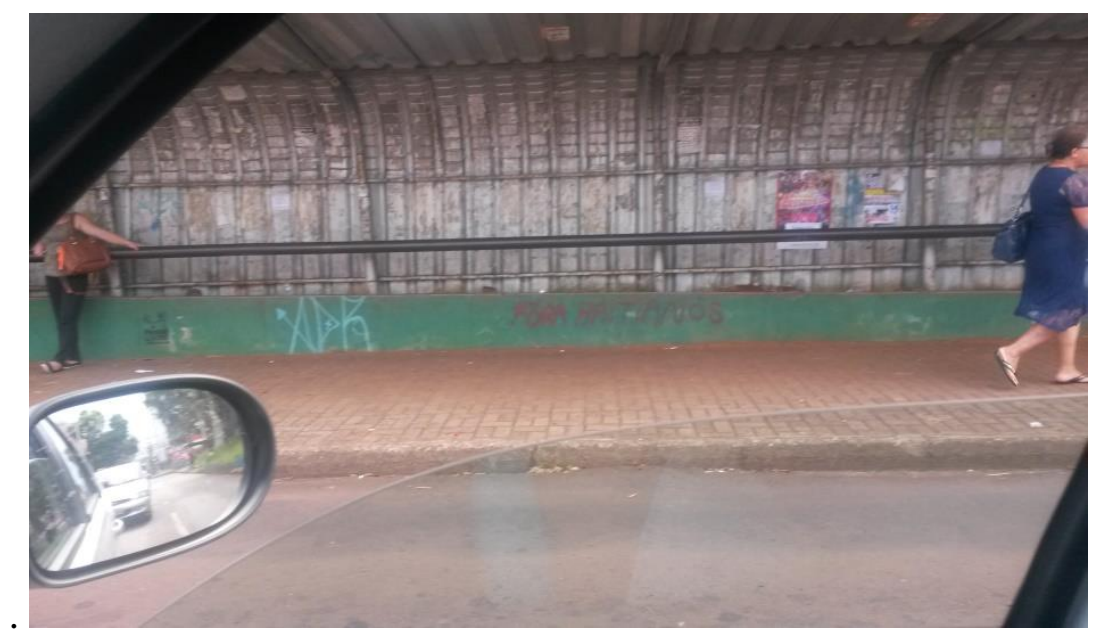

Foto 15 - Pichação de Ponto de ônibus em Cascavel. (Foto: Claudimara Cassoli Bortoloto, 29 de Dez. de 2016.

As pichações "fora haitianos" se desdobram por amplos espaços públicos, dentre eles pontos de ónibus, quais refletem atitudes xenofóbicas. Isso se fortalece principalmente na periferia, que difere de outras experiências de países clássicos de imigração, como Canadá, Nova Zelândia e Austrália, os quais em decorrência da elevada demanda de mão de obra, tem produzido programas de inserção social e ressaltado as oportunidades que a imigração oferece. O êxito do Canadá o fez um modelo para outros países na forma de como enfrentar a imigração, a qual não se desvincula das circunstâncias históricas e particulares desse país. Desde 1990, os imigrantes no Canadá empreendem mais de 200.000 mil vistos anuais, e ter êxito no trato da imigração não significa que não há preocupação com os desafios atuais, sobretudo com o fechamento das fronteiras na Europa e o que isso implica para o país.

As barreiras de origem dos imigrantes foram eliminadas nos anos 1960 no Canadá e até os anos 1970 a população imigrante europeia era acentuada nesse país. O programa de inserção de estrangeiros conquista êxitos econômicos e sociais, em que "La aprobación nacional de la diversidad cultural parece indicar una plausible integración social sin problemas de las minorías dentro de las distintas comunidades y en la sociedade en su conjunto” (REITEZ, 2007, p. 37).

O sistema de pontos e o multiculturalismo são a essência do programa canadense, e se referem à aceitação e integração daqueles que migram para o país. Esse sistema seleciona os imigrantes com base na educação, formação e conhecimento de uma das línguas oficiais, além da experiência de trabalho e outros indicadores de emprego. Surgiu em 1967 e seu principal benefício aos imigrantes é o mérito da capacitação, diante de um grande número de concorrentes, entre os quais outros migrantes. Além do sistema de pontos, o Canadá 
desenvolve a política multicultural, um dos aspectos que garante o sucesso das políticas migratórias. Esse modelo foi exportado para a Austrália e mais tarde para a Europa.

No caso canadense, esse sistema serve para assegurar que um mínimo de pessoas tenha qualificação para viver em uma sociedade moderna. O país reconhece como os imigrantes podem suscitar o desenvolvimento econômico. Os economistas "Creen que los inmigrantes apoyan la economía añadiendo nuevas dimensiones, nuevas ideas, potencial creativo, conciencia internacional e interconexiones críticas en una economía global" (REITEZ, 2007, p. 37).

O sistema canadense, no que diz respeito ao sistema de pontos, não se limita somente à graduação, mas também considera as experiências de trabalho e idade. Alguns países que usam o sistema de pontos do Canadá adotam apenas o critério da qualificação por meio de graduação. Dessa forma, tomam emprestada a etiqueta canadense, e não a política, como expressa Reitez (2007).

Diferentemente do que acontece no Canadá e nos outros países mencionados, o imigrante no Brasil não conta sequer com políticas pouco burocráticas de reconhecimento de diploma. Como discutido no capítulo II, há uma ausência do Estado na viabilização de políticas, que por sua vez tende a não aproveitar os recursos humanos imigrantes no Brasil, prática que perfaz a realidade dos brasileiros e faz dos imigrantes atrativos para realização do trabalho manual.

Cabe considerar que, segundo dados da Polícia Federal, os imigrantes haitianos correspondem a aproximadamente $95 \%$ dos estrangeiros residentes no Município de Cascavel. Dados da Agência do Trabalhador sobre a incorporação desses imigrantes no mercado de trabalho formal do Município são demonstrados no quadro abaixo.

Tabela 2 - Total de imigrantes inscritos e colocados no mercado de trabalho em Cascavel 2012 a 2016.

\begin{tabular}{c|c|c}
\hline INSCRITOS & ENCAMINHADOS & COLOCADOS \\
\hline 3.615 & 2.711 & 237 \\
\hline
\end{tabular}

Fonte: Agência do trabalhador (Cascavel, 2017)

A quantidade de imigrantes encaminhados para a Agência do Trabalhador corresponde a todos os setores de trabalho. Quando abertas as vagas, os trabalhadores são selecionados e encaminhados a elas. Embora tenha sido solicitada à essa agência informação sobre os setores que mais incorporam esses trabalhadores, esse dado não foi disponibilizado. No entanto, os 
dados obtidos na pesquisa de campo mostram que o setor de frigorífico é o que mais absorve mão de obra imigrante em Cascavel.

É importante ressaltar que, embora a Agência do Trabalhador realize encaminhamentos para o trabalho, os trabalhadores também são selecionados por indicação ou diretamente pela empresa, sendo essa uma prática dos frigoríficos. A pesquisa de campo demonstra que dos trabalhadores que depois de selecionados são encaminhados para as empresas, apenas 9,32\% são contratados. Mais uma vez os dados oficiais da inclusão laboral confirmam os obtidos na pesquisa de campo, que identifica um sistema produtivo totalmente fechado para o imigrante haitiano. Ressaltamos que não se compara ou relaciona os dados com outros imigrantes porque os haitianos compreendem $95 \%$ dos imigrantes residentes no Município.

Por outro lado, não se pode negar a intenção e empenho da Agência do Trabalhador em selecionar e encaminhar os imigrantes haitianos para as vagas de trabalho abertas, o que acontece com $75 \%$ dos inscritos. Porém, as empresas embora recebam imigrantes selecionados de acordo com o perfil da vaga aberta e disponível, tendem a recusá-los. Por isso, o percentual de contratação é mínimo em relação ao volume de selecionados pela Agência do Trabalhador.

Tabela 3 - Imigrantes Inscritos - Gênero

\begin{tabular}{l|l}
\hline HOMENS & 2.062 \\
\hline MULHERES & 1.533 \\
\hline TOTAL & $\mathbf{3 . 6 1 5}$ \\
\hline
\end{tabular}

Fonte: Agência do Trabalhador de Cascavel, 2017 (Cascavel, 2017)

Ao mesmo tempo em que os dados demostram um esforço dos haitianos em se cadastrarem e buscarem um trabalho revela a inexpressiva preocupação do sistema produtivo em inseri-los.

Além disso, esses dados mostram a contradição entre o número de haitianos migrantes fornecidos pela Polícia Federal e os registrados pela Agência do Trabalhador. Essa discrepância pode se justificar no precário controle das instituições brasileiras sobre o fluxo migratório, no entanto, entre os haitianos não deveria ser tão destoante, tendo em vista que eles possuem o visto humanitário que os tira da condição de ilegalidade. 
A tabela abaixo indica a faixa etária de idades que predomina entre esses trabalhadores na agência do Trabalhador, sendo a idade produtiva 18 a 49 anos, ou o perfil de idade entre esses trabalhadores.

Tabela 4 - Imigrantes inscritos por idade - Cascavel

\begin{tabular}{l|l|l|l}
\hline Até 17 anos & 18 a 29 anos & 30 a 49 anos & 50 a 65 anos ou mais \\
\hline 68 & 1.748 & 1.469 & 330 \\
\hline
\end{tabular}

Fonte: Agência do trabalhador de Cascavel (2017). (Cascavel, 2017).

Silva (2005) analisou o preconceito contra o trabalhador imigrante negro e mestiço, concebido como mais uma manifestação do racismo cordial, que faz parte da base da segmentação étnica e racial do Brasil.

Nas usinas de São Paulo, a rubrica de Trabalhador de fora camufla as discriminações raciais. Ser de fora significa ser negro, mestiço, pobre, nordestino, nortista, portanto, não branco. Em virtude da ideologia racial vigente nesse país, constata-se que o racismo é escondido tanto por aqueles que o praticam como por aqueles que o sofrem (SILVA, 2005, p. 77).

$\mathrm{O}$ vínculo entre imigrantes e Estado se faz pelas normas que regem a cidadania e a população. Porém, muitos Estados tendem a reconhecer o estrangeiro ou migrante apenas quando ele apresenta elementos de assimilação cultural ou identidade nacional. Isso, segundo Castles e Miller (2004), gera políticas de exclusão, as quais não permitem ao migrante ser cidadão, independentemente de sua nacionalidade.

Más serio todavia es el reto a la identidade nacional. El Estado nación, según se desarrollo desde el siglo XVIII, está basado en la idea de la unidad cultural y política. En muchos países, la homogeneidad étnica, definida en términos de lengua, cultura, tradiciones, e história comunes, se ha visto como la base del Estado-Nación. A menudo esta unidad há sido fictícia- construcción de la elite governante-,pero ha proporcionado poderosos mitos nacionales (CASTLES E MILLER, 2004, p. 27).

Para esses autores, a imigração e a diversidade étnica, ameaçam o nacionalismo que se fortalece pela ideia de origem comum. Já os países clássicos de imigração, pela maneira como absorvem os imigrantes, constroem o conceito de identidade nacional pela diversidade. 


\subsubsection{Haitianos no Oeste do Paraná, a transferência do preconceito de cor e a reprodução de estrutruras arcaicas de desigualdade social}

A imigração internacional não é um processo individual que ocorre pela simples decisão racional do indivíduo. Ela é um processo coletivo que percorre toda a vida do imigrante. A ideia de identidade nacional está intimamente relacionada ao surgimento do Estado-nação, que exerce um domínio sobre uma população e território. É ele que determina quem são seus cidadãos, o que ocorre pela extensão da crença, da etnicidade e cultura comum. Todavia, exclui aquele que não compartilha desses mesmos processos de homogeneização.

Nessa perspectiva, ao discutir sobre a formação da identidade nacional no Brasil, Ribeiro (1995) ressalta que ela não surge espontaneamente ou como resultado de formas superiores de sociabilidade. Essa identidade é resultado da concentração da força de trabalho escrava, recrutada por meio de processos violentos de ordenação e repressão, traduzidos em genocídios e etnocídios para atender interesses alheios.

Nessas condições, são exacerbadas as diferenças e as distâncias entre as classes sociais, as quais são ocultadas pelo ideal de identidade nacional, a noção de pertencimento a uma mesma identidade e de compartilhamento dos mesmos valores nacionais. Entretanto, isso contribui para a não percepção das diferenças e desigualdades sociais.

Embora a identidade nacional sirva como um mecanismo de ocultação das desigualdades sociais, as elites brasileiras historicamente convivem com o pânico de uma sublevação das classes dominadas. "Boa expressão desse pavor de pânico é a brutalidade repressiva contra qualquer insurgência e a predisposição autoritária do poder central, que não admite qualquer alteração da ordem vigente" (RIBEIRO, 1995, p. 23-24).

A reação do imigrante frente ao preconceito de cor deve sobressair a não dar continuidade a um ideal de superioridade da classe dominante que historicamente tem perpetuado essa estrutura de classe. Ao considerar o trabalho de campo realizado com imigrantes bolivianos em São Paulo, Silva (2005) ressalta a importância de olhar, ouvir e escrever do pesquisador, e destaca a capacidade de conseguir observar os momentos de maior tensão que envolve o pesquisador e o objeto de pesquisa. É o trabalho de campo que viabiliza o confronto entre o instrumental teórico e os dados oferecidos pela experiência empírica. Nessa mesma perspectiva, Demartini (2005) afirma que o trabalho de campo e a análise são simultâneos, realizados entre o fragmento e o todo.

Como propôs Strathern (2014), o deslocar entre os campos permite que o pesquisador se depare com a imprevisibilidade de fontes e informações. As entrevistas também 
apresentaram situações do cotidiano por imigrantes em Cascavel. Em seus relatos, eles falam de situações de preconceito e sobre a forma como lidam com isso.

Uma dessas experiências é narrada pelo imigrante Taylor, que discorre sobre a uma problemática que envolve a utilização do transporte público.

Você pode mudar essa pessoa, pode criar uma criança sem preconceito, com
amor educação. Minha mãe sempre me falou, eu vou sair hoje, eu tenho que
falar bom dia, boa tarde, ajudar uma pessoa quando ela precisa. Abra o
coração para qualquer pessoa, não tem a questão de preto, branco, vermelho,
não tem isso aí, se todo mundo for assim, nós podemos mudar isso, podemos
acabar com o preconceito. Eu mesmo dentro do ônibus diante do preconceito
que sofria todos os dias me obriguei a comprar uma moto. Uma vez estava
na lotação de boa, pra ir trabalhar, estava sentado de boa, e tinha uma mulher
de pé, o ônibus estava cheio. Pensei, porque não senta do meu lado? Então
eu disse: senhora pode sentar, ela disse não, não. Percebia que ela estava
fugindo de mim. Falei de novo, não senhora pode sentar, não falei que a
senhora é velha, pode sentar. Várias vezes que eu peguei lotação eu fiquei
bem triste, tinha muitos gestos, até gente que puxava meu cabelo. Aí eu
fiquei pensando porque essa pessoa não faz uma pergunta para mim? Não
enxerga a pessoa como ela é, não sabe o que a gente sente com isso. Então,
um dia cheguei em casa e conversei com minha mulher, disse a ela que iria
comprar uma moto. Ela falou para com isso, não briga, não discuti. Não é
que eu vou discutir, mas eu não aguento mais, e toda vez que pego lotação to
chorando, porque? Daí comprei uma moto e não ando mais de lotação.
Agora eu raramente saio de casa, se tem gasolina eu saio se não tem não
saio, eu tenho vale sim, mas eu não saio (TAYLOR, entrevista realizada dia
20 de Maio).

Vale Sim é a empresa vencedora da licitação municipal que controla os cartões que permitem o acesso ao transporte público em Cascavel. A fala de Taylor reflete o cotidiano e demarca o preconceito e estigma dos brasileiros, o que provoca determinadas formas de isolamento social quando o contato com eles passa a ser evitado. Para Taylor, comprar uma moto para evitar o acesso a locais onde o preconceito era manifestado de forma recorrente foi uma estratégia para superar a situação.

O haitiano Marcio também relata o preconceito sofrido em relação aos colegas no ambiente de trabalho. Porém, ele lida com isso expressando um sentimento de conscientização, a partir de valores religiosos que proferem a igualdade e o respeito a todas as pessoas, independentemente de sua cor ou religião. Nesse caso, também os princípios religiosos orientam uma postura de indiferença e o auxiliam a enfrentar atitudes de preconceito. 
Eu acho que aqui no Brasil é um país mais ou menos legal para viver, as pessoas tem boa relação, mas eu não gosto mais daqui do que do meu país, eu digo sempre, eu sou cristão não tenho preconceito nenhum. Assim como sou cristão eu sou haitiano, eu acho que brasileiro é igual haitiano, assim como cristão eu ajudo um haitiano, se for possível eu ajudo um brasileiro que tá passando por necessidade eu tenho que ajudar. Se não eu faço igual, eu não sou cristão. O cristão não tem que ter preconceito, aqui no Brasil o estrangeiro sofre preconceito. Eu já viajei para outros países e havia preconceito também, porque o preconceito existe no mundo inteiro. Eu sofro preconceito no trabalho, meus companheiros brasileiros não gostam de mim e inventam coisas para o chefe. Às vezes no trabalho também, a gente sofre preconceito, assim como eu estou trabalhando numa empresa agora três pessoas, eu sou tranquilo, cristão, e eles ficam falando muitas vezes palavras que não me agradam, e eu fico calado e não falo nada. Graças a Deus, Deus está comigo, e se você fala a verdade sem mentira Deus vai me defender. E depois de dois dias o chefe me chamo na oficina e falou que fulano disse que você não está trabalhando, que você está parado, e o chefe fala tudo, e depois eu expliquei certinho para o chefe porque estava fazendo isso, mas eu não estava devagar eu estava fazendo tudo, e quando falta o produto para fazer a construção não tem nada que fazer. Esse preconceito que a gente está sofrendo também, eu sei que só Deus pode ajudar nisso, isso é uma coisa que dentro da pessoa ninguém pode mudar isso, mas a gente sofre com isso, sofre com o preconceito (Marcio, entrevista concedida em 06 de maio de 2017).

Márcio relata que os conflitos no ambiente de trabalho ocorrem pelo fato de ele ser imigrante e negro. O mesmo busca na religião a tolerância para o enfrentamento de situações preconceituosas, e evita o conflito com os companheiros de trabalho como um mecanismo para manter o emprego.

Bauman (2017), ao estudar sobre o estigma e preconceito dos franceses em Paris para com os jovens muçulmanos, constata a relação atribuída entre eles e os crimes, o que gera preconceito e estigma. A exclusão por preconceito tende a deixar esses jovens mais vulneráveis e propensos à vinculação com grupos terroristas. Dessa forma, o estigma, a associação do imigrante como ameaça, e os instrumentos de controle sobre ele eliminam formas de interação cultural entre as diferentes etnias e religiões, e impedem a absorção e integração dos imigrantes nas sociedades que os recebem.

Bauman (2017) infere que essas ações conduzem a dois tipos de impactos extremamente drásticos para quem sofre a estigmatização. Um é o doloroso golpe, que resulta em agonia, humilhação, vergonha, e na consequente autodepreciação e autodesprezo, além de um sentimento de impotência que culmina em depressão. Outra atitude de indiferença extremamente impactante é a não incorporação ou reconhecimento do preconceito pelo sujeito 
que acaba isolado pela sua alienação e protegido por crenças identitárias que não o permitem perceber atitudes preconceituosas.

Essa identificação aparece no depoimento de Joseph, que ressalta sua indiferença em relação às atitudes preconceituosas vivenciadas em Cascavel.

Já presenciei preconceito e já aconteceu comigo, e eu cheguei a uma conclusão de que tem que ignorar os ignorantes, não sei explicar isso, mas penso que somos maior que isso. Existe no Brasil um preconceito de cor. Eu não sabia do preconceito de cor, o que eu sei, é que aqui mais de $50 \%$ das pessoas são negras, e os que não são negros são importados são da Europa, descendentes de alemães, italiano que também são imigrantes. Por isso eu não falo sobre preconceito. Eu ignoro isso, isso não me afeta. Existe mas não é para mim (Joseph, entrevista concedida dia 04 de Maio de 2017).

Joseph é um imigrante com amplo conhecimento da história do Brasil. Ele percebe a imigração na formação do país, assim como foi discutido anteriormente no diálogo estabelecido com Ribeiro (2005) sobre a formação do povo brasileiro. Ele também identifica que parte expressiva da população brasileira também é negra. Apesar de atingido por manifestações de preconceito, ignorá-las foi a estratégia que Joseph encontrou para lidar com a situação.

Dados divulgados pelo IBGE expressam que a configuração étnica da população brasileira em 2014 se manifesta da seguinte forma, segundo sua autodeclaração: 45,5\% branca, $45 \%$ parda e $8,6 \%$ negra (ROMILDO, 2015). A caracterização da população como maioria branca e parda pode estar relacionada à negação da raça negra por muitos brasileiros, que se justifica pela miscigenação que faz com que boa parte se identifique como resultado da fusão de diferentes raças, ou pela negação da raça negra, fenômeno decorrente de uma sociedade que historicamente tem remetido à população negra aos piores estratos e desvalorização social.

Assim como há imigrantes que reagem com indiferença ao estigma, há outros que não percebem relações de preconceito e destacam ter boas relações com os brasileiros. É o que expressa Luis, nas poucas palavras que conseguia falar em português: "Eu vim para Cascavel em fevereiro do ano passado, eu comecei trabalhar em março na Coopavel. Eu não tenho problema com nada, com preconceito com nada. Aqui é tranquilo, é importante que estamos tranquilos, mais aqui ganha pouco" (Luiz, entrevista realizada dia 02 de Maio de 2017).

A inclusão não requer apenas legislações ou políticas de reconhecimento de direitos de estrangeiros. Ela perpassa pequenas ações do cotidiano que se dão pelo simples contato entre 
os haitianos e os brasileiros. É essa a compreensão de André, um haitiano de 25 anos que expressa a importância de simples contato com os brasileiros e o significado disso.

Tem brasileiro que é muito chato. Houve um dia que eu fui no centro, e perguntei para um brasileiro, amigo ali é um restaurante? Ele não respondeu. A mulher depois respondeu que sim, que era um restaurante. Ele não respondeu, eu pedi na boa. Então para os haitianos a situação é pior ainda, você encontra as pessoas e dá bom dia, elas não respondem nada. Às vezes eu encontro a pessoa na rua e falo bom dia! A pessoa não responde, eu nunca mais vou dar bom dia, porque as pessoas não respondem. Não tenho muitos amigos no Brasil, eu sou estrangeiro, eu falo a pessoa não responde. Agora se é um haitiano, você fala e aí mano beleza, tudo bem? E os haitianos já respondem e tem educação de responder (Depoimento André, entrevista realizada dia 04 de Maio de 2017).

Nesse depoimento, André aponta a característica de sociabilidade fechada do cascavelense. Como moradora dessa cidade há 18 anos, me deparo com situações cotidianas do mesmo gênero, as quais tendem a ser sentidas com maior intensidade pelos imigrantes, na condição de estrangeiros.

Bauman (2017) chama atenção para uma característica importante entre aqueles que se deparam com a empatia, ou seja, a capacidade de se colocar no lugar do outro em momentos em que a migração reaparece no cotidiano como algo novo e ameaçador à segurança nacional. Mas, na verdade, apenas está travestida de velhas roupagens.

A inoperância do Estado no desenvolvimento de políticas públicas, acolhimento e inserção dos imigrantes também podem ser explicadas pela forma histórica da incorporação do negro na sociedade de classes ${ }^{32}$. Fernandes (1978) elucida que as transformações históricas e sociais mudaram a estrutura e o funcionamento da sociedade sem alterar a ordenação das relações raciais, herdadas do regime escravocrata. A conservação dessas relações manteve as características mais retrógradas, como a inserção dos negros nos estratos mais baixos da sociedade, "mantendo o negro e o mulato numa situação social desalentadora, inócua e desumana" (FERNANDES, 1978, p. 7).

Essa situação culmina em dois grandes problemas sociais: a integração do negro na nova ordem competitiva por meio do trabalho assalariado, característico das relações

\footnotetext{
32 O Brasil não recebe somente imigrante negro, porém Zeni e Fillipim (2014) ressalta ser a migração haitiana a maior em um período de cem anos, comparada à de japoneses e italianos que aportaram no país no período imperial e nos primeiros anos republicanos.
} 
capitalistas de produção; e o desenvolvimento do racismo, que historicamente inviabiliza essa integração.

O preconceito, gerado pela perturbação entre cor e classe social, segrega os negros do sistema produtivo. Desde a abolição da escravatura há um prolongamento do destino escravo com as relações de exclusão social. Apenas se tolerava sua condição de homem livre, limitada nas relações jurídicas que sustentam as desigualdades raciais, sem se concretizar nas relações materiais e econômicas. O negro incorpora, por meio da igualdade jurídica, valores que o submete a observar as normas e padrões de comportamento da ordem competitiva. Esses padrões e normas vinculam-se à conformação e aceitação de sua posição social nos estratos mais baixos, a naturalização das desigualdades sociais (FERNANDES, 1978).

De acordo com Fernandes (1978), há uma integração entre civilização industrial e herança histórico cultural, que exclui, pelo preconceito racial, a participação dos negros em outras áreas de interesse econômico e os impede ter acesso a prestígio social e poder. Tem-se, dessa forma, a abertura do sistema de classes, nos termos das relações sociais, sem modernizar padrões de dominação racial historicamente herdados que conferem o poder e seu monopólio à raça branca. Ao mesmo tempo essa classe ignora, solapa e neutraliza qualquer condição de ascensão social dos negros, mantendo-os nos níveis sociais a que pertencem. (FERNANDES, 1978). Nesse sentido, conforme o autor, a cor opera como marca racial e como símbolo da posição social ocupada na sociedade.

A histórica segregação racial no Brasil, limita a integração do negro e seus ancestrais na sociedade de classes, o que inibe a maioria da população negra de reais condições de participação equitativa. Ao contrário disso, soa como natural, inclusive para a população negra, a sua posição nos estratos mais baixos e, por sua vez, no desempenho de atividades de maior desvalorização, como o trabalho manual.

Por assim ser, o imigrante negro se depara com um país periférico, que explora e intensifica a produção de mais-valia da classe trabalhadora por meio dos baixos salários, associado a um contexto de tolhimento histórico da população negra a qualquer forma ou possibilidade de ascensão social. Sua inserção limita-se à reprodução de valores e de comportamento de submissão e conformação aos baixos estratos sociais. Dessa maneira, reproduz-se a classe dominante, branca e hegemônica, que concentra poder e renda, enquanto afunila a desigualdade social, principalmente entre brancos ricos e negros pobres.

Essa histórica vigência de relações marcadas pelo preconceito não é considerada estática ou fadada à eternidade. Fernandes (1978) ressalta que somente a organização do negro na sociedade, seja ele imigrante ou não, juntamente com sua imposição como classe, 
com significativa representação de trabalhadores, pode provocar alguma alteração nessa histórica realidade de segregação e exclusão social.

Juntamente com todas as formas de explorações sofridas pela classe trabalhadora, os negros enfrentam o racismo, que tem se colocado como um empecilho para a conquista de trabalho, mesmo que precário. Esse quadro explica a situação do imigrante negro no Brasil que, conforme Baeninger et al. (2016), desenvolve trabalho manual, quando não está assolado pelo desemprego.

Esse panorama reforça o papel do imigrante negro à luz da historiografia brasileira, que exige dele uma soma de luta e força contra um sistema excludente e conservador de relações hegemônicas de poder e dominação. Chegar a essa compreensão da realidade exige dos pequenos Haitis no Brasil uma compreensão da história política, econômica e da cultura brasileira, que segrega até mesmo sua população negra. Logo, o que ocorre é a extensão aos imigrantes de formas ultrapassadas de preconceito racial, além de práticas marcadas pela xenofobia, o que limita e precariza as condições de vida desses trabalhadores no país.

\subsubsection{Envio de remessas entre as periferias e a precarização de vida dos haitianos no Brasil}

Ser imigrante negro e trabalhador na periferia acarreta uma série de problemas que assolam as condições de vida dessa população. Como visto até aqui, o preconceito racial historicamente estruturado na nossa sociedade não foi suprimido por valores mais avançados da sociedade moderna, isso implica em sérios impactos nas condições de vida dessa população que é sacrificada no Brasil para manter o envio de remessas quando encontram-se trabalhando.

Conforme Mezzadra (2005), as remessas fazem parte do espaço transnacional aplicado à migração, e o seu envio para as famílias que permanecem nos países de origem é de extrema importância, até mais que a interferência de países mais desenvolvidos e ricos. As remessas estão intimamente relacionadas com o conceito de diáspora, que liga os que migram aos que ficam.

Eu escutava que no Brasil estava melhor. Quando eu estava no Haiti eu trabalhava como professor, aqui as coisas estão complicadas também, eu deixei a família que ficou esperando eu enviar dinheiro. Pensava que aqui a vida seria melhor, para entrar aqui ficou caro. Eu não consigo nem voltar para o Haiti, porque as passagens estão muito caras. Queria voltar no Haiti, mas não é fácil, queria passear, ver minha família e voltar aqui. Agora como a gente faz se tem três filhos no Haiti? Tem que mandar dinheiro, e ganha 
pouco, é muito difícil aqui no Brasil, porque as coisas são muito caras, as passagens, e o salário baixo (Djemes, entrevista realizada em 28 de Abril de 2017).

Djemes ressalta que gostaria de voltar ao Haiti ao menos para visitar a família, o que é inviabilizado pelo baixo provento que recebe insuficiente para custear o elevado valor das passagens.

Handerson (2015) entende a diáspora haitiana como representação da mobilidade ou imigração como elemento cultural. Nessa perspectiva, a diáspora é vista como categoria central da mobilidade dos espaços sociais, espaços transnacionais, e categorias de vida que envolve o cotidiano dos haitianos. Essa dispersão é expressa nos relatos do interlocutor Abner, que tem membros de sua família em vários países no mundo.

Eu tenho uma família grande e espalhada pelo mundo. Meu irmão vive na França ele faz Doutorado em filosofia lá, pós graduação. Outro irmão vive na Jamaica é pastor da igreja Cristiana e outro irmão vive nos Estados Unidos e é mecânico. Minha única irmã está na República Dominicana. Todos eles trabalham moram nesses países. (Entrevista Abner, 09 de maio de 2017).

As migrações de haitianos pelo mundo desencadearam o conceito de diáspora, que foi utilizado pelos haitianos nos anos 1980, em Nova York, por meio da mobilização de padres vinculados à Igreja Católica como uma forma de reivindicar direito político e denunciar a ditadura no Haiti. A constituição da diáspora haitiana e a utilização do termo comunidade foram fundamentais para articulação e promoção dos direitos e agendas políticas naquele país (HANDERSON, 2015).

O estudo desse conceito como objeto de pesquisa teve início nos anos 1990, com generalização do discurso no espaço transnacional, principalmente no âmbito político. A maior parte da literatura mostra a diáspora haitiana em espaços que são considerados as primeiras rotas migratórias, como os EUA, França, Canadá e Caribe (BAENINGER ET AL, 2016; MAMED, 2017).

De acordo com Baptiste e Viera (2016), em 2014 os imigrantes haitianos fora do país representavam 1/3 da população, um total de 4,5 milhões de pessoas. Em março de 2018, a população haitiana que vive no Haiti é, de acordo com a Agência Coutry Meters Haiti (2018), de 11.121.320 habitantes. 
Dessa população emigrante, aproximadamente 300 mil visitam anualmente o Haiti, especialmente nos períodos de festas e férias. O retorno ao país foi relatado pelo imigrante Jean, que em 2014 teve a possibilidade de visitar seu país de origem.

Em 2012 cheguei trabalhei até 2014, e em 2014 eu ganhei a conta e fui para o Haiti visitar minha família. Eu voltei e agora estou trabalhando na Globo Aves. Voltar para passear no Haiti custa muito caro. Quando comprei as passagens, paguei $\mathrm{R} \$ 3.000,00$ a vista. Eu voltei no Haiti porque a gente tem que volta para o país da gente, porque longe você sente muita saudade da família, muita saudade (Jean, entrevista realizada em 02 de Maio de 2017).

O retorno ao Haiti foi viabilizado por acertos de um contrato de trabalho com a sua dispensa da Coopavel. Voltar ao Haiti foi sanar os sentimentos de falta seja do território de origem ou da família e amigos. O sentimento do retorno provisório é tão intenso que Jean, mesmo com uma experiência de baixo salário, utilizou os benefícios da rescisão do contrato de trabalho como um meio para fazê-lo e depois retornar ao Brasil e dar continuidade no processo migratório.

O retorno constitui uma rede de significações que envolvem a vida de quem vai e de quem fica no país. Tudo o que é criado em torno dessa mobilidade é chamado de diáspora, entendida como uma forma de ordenar o mundo e que designa e estabelece a adjetivação dos sujeitos, qualifica objetos, dinheiro, casa e ações. “O termo diáspora é utilizado para designar os compatriotas residentes no exterior, mas que voltam temporariamente no Haiti e logo retornam para o exterior" (HANDERSON, 2015, p.53).

Neste estudo, pesquisar o fato vivido levou-nos a cruzar com diferentes percursos que expressam a diáspora em movimento, com o retorno sem perspectivas de voltar ao Brasil por dois dos entrevistados ao Haiti, em 2017.

Um deles é Abner que relatava a intenção de voltar ao país frente ao fracasso do empreendimento migratório no Brasil. O retorno ao país desponta como aquilo que Handerson (2015) denomina de fracasso da diáspora, que ocorre quando o imigrante volta sem promover ajuda ou ganhos para parentes e familiares ou sem a possibilidade de empreender novos processos migratórios aos que ficaram.

Eu vou embora para o Haiti em agosto se não achar trabalho aqui. Como vou pagar água, luz, aluguel. Eu quero voltar para o Haiti e de lá ir para França. Vou ir ver minha família, mas não vou levar dinheiro para ajudar minha família. Eu preciso de ajuda, não encontrei trabalho. Nós todos haitianos somos irmãos, o meu problema é também problema de outro haitiano. Se tiver quatro haitianos em uma casa, que moram nessa casa, e tem um 
desempregado, os demais o ajudam. Todos ajudam aquele que não tem condições de viver, que não tem trabalho. Por exemplo, eu não trabalho, minha prima Milene me ajuda, ela que paga o aluguel, a água, e eu to ganhando muito pouco porque tenho poucos alunos de francês. Eu ajudo outros haitianos com conhecimentos que tenho, compreende? Quando tem outros haitianos que não fazem nada, eu ajudo de algum jeito, oriento eles para participar de reunião, procurar ajuda na caritas, CRAS, dirigir orientar para emprego. (Abner, entrevista realizada 09 de Maio de 2017).

Abner retornou ao Haiti em 08 de agosto de 2017 e regressar só foi possível a partir da união de várias pessoas, sobretudo seus ex alunos de francês enquanto deu aula no Brasil, que juntos puderam prover o pagamento das passagens aéreas para que retornasse ao país. $\mathrm{O}$ escasso número de alunos para realizar com ele as aulas de francês não foi suficiente para prover suas condições de existência. Ao enviar notícias e mensagens de despedida, ele demonstra um misto de sentimentos como alegria, fracasso, tristeza e muita emoção ao rever a família. Ao mesmo tempo, Abner expressa um profundo pesar por ter que sair do Brasil, algo obrigado a fazer diante da inviabilidade de inserir-se no sistema produtivo e prover suas condições de existência.

O retorno significa para ele reviver a situação de insegurança devido ao sequestro ocorrido no país antes da emigração para o Brasil. Além disso, depara-se com as incertezas do trabalho e das condições de sobrevivência. No entanto, a sensação de reencontro alimenta a vida, e esse sentimento se torna combustível para empreender novas experiências migratórias.

Abner representa boa parte dos imigrantes haitianos com qualificações. É formado em Direito e domina cinco línguas, incluindo o português. Isso desmistifica dois mitos presentes no discurso da mídia local, como justificativa por não empregar os haitianos: a não qualificação e falta de domínio da língua. Conforme Abner, essas características são apontadas pelas empresas para não inserir os imigrantes no mercado trabalho. No seu caso elas ainda são agravadas com justificativas, sobretudo dos frigoríficos, de não o inserir devido ao elevado grau de instrução que possui incompatível com as demandas da empresa.

O mesmo relata que por um lado fora recusado pelos frigoríficos porque apresentava elevado grau de instrução, e por outro dominava o português, o que também não foi considerado pelos contratantes já que justificavam o domínio da língua como um empecilho para recusar aqueles que não falavam. Embora a formação em direito no Haiti contenha amplas diferenças das leis brasileiras, Abner interpreta que essa formação específica poderia ser considerada um problema para o frigorífico, pois sob o domínio do idioma e dos pressupostos básicos do direito poderia atuar contra os interesses da empresa, sobretudo no que se refere ao direito dos haitianos em relação as leis trabalhistas no Brasil. 
Ianni (2004) ressalta o caráter da viagem como algo que define o imigrante. Esse é o caso de Abner, que afirma ter pretensão de voltar ao Haiti caso não encontre trabalho, para, posteriormente migrar para França, onde já reside um de seus irmãos.

A despeito de localizado, enraizado ou integrado, ainda guarda em si algo do viajante, de quem está em trânsito, literal ou metaforicamente. Mesmo aquele que saiu do seu lugar, enraizado por gerações, mesmo esse no contraponto com o migrante recente e antigo, sente-se desafiado pela viagem do outro, recente ou pretérito. Esse é um estado de espírito que perpassa a percepção e atividade, o modo de ser e a subjetividade de uns e outros aquele que vai e aquele que fica, o que chegou e o que estava, todos sentem-se em viagem, real ou imaginária, literal ou metafórica, presente ou pretérita, vagando no futuro (IANNI, 2004, p. 99).

Abner ressalta que os laços de solidariedade não se restringem à ajuda financeira, expressa na partilha de residência, comida ou ajuda econômica como uma corrente formada quando haitianos estão acometidos pelo desemprego. Para ele, a solidariedade se desdobra em orientação a outros imigrantes para que eles busquem apoio em outras redes institucionais, como o Centro de Referência da Assistência Social (CRAS) e a Cáritas.

Os laços de parentesco ultrapassam as fronteiras e, como um elo, sustentam e dão vida, funcionando como instrumento para realimentar os sentimentos de pertencimento, bem como o não isolamento, ou mesmo impedindo que haja a absorção total ou a assimilação da cultura da sociedade de acolhida para se constituir como nova morada. Essas redes familiares são denominadas de redes diásporas, pois são apoiadas por outras experiências migratórias.

Há uma relação indissociável entre família e diáspora. Mais do que enviar dinheiro e objeto, muitos daqueles no Haiti esperam do viajante fil (solicitar visto permanente para familiares próximos, pais, filhos e irmãos), "mandar buscar" (voye chèche), "entrar" (ante) alguns dos que ficaram (HANDERSON, 2015, p. 60).

Quem viaja leva consigo esse dever, que é manter o elo e propiciar novas viagens aos que ficaram. O cumprimento desse dever pode ocorrer por meio de solicitação de visto ou financiamento do custo de viagens clandestinas. Levar os filhos, pai ou mãe, representa um valor moral para os que vão e quando isso é descumprido os imigrantes sofrem coerção social.

Além da liberdade individual, como definiu Mezzadra (2005), o ato de migrar tem que propiciar para os haitianos uma realização moral que se traduz em alguma forma de retorno, de correspondência entre a nação e família, para prover as necessidades daqueles que ficaram. 
É o que expressa Djemes, quando fala sobre o interesse em voltar ao país e o vínculo que estabelece com a família, o que se consolida pelo envio de remessas ou sentimentos afetivos.

Eu penso em voltar porque qualquer pessoa que deixa seu país pensa nisso. Se você não tem trabalho, não tem casa para morar, não está feliz, tem que voltar. Eu tenho trabalho, mas eu sinto muita saudade, eu queria ver minha família, mas tenho medo de voltar para o Haiti. Aqui você não pode agir como quiser, e na sua casa não precisa pedir para ninguém. Eu desde quando comecei a trabalhar ajudo e obrigatoriamente mando dinheiro para o Haiti. Cada mês se paga escola, tudo é caro. Eu tenho, aí tem que mandar dinheiro para os filhos e para os pais, é bem complicado. Eu sempre fico pensando, se tem mãe, tem que mandar, porque é mãe e ela passou muito tempo comigo desde que eu era criança até ficar grande. Se hoje estou grande e estou aqui é porque minha mãe sofreu muito para me ajudar. Então, depois que eu pago água, aluguel, lixo, IPTU, o que sobra eu mando. É complicado, sobra muito pouco e um mês eu mando para minha mãe, outro mês para meus filhos. Tem que dividir, eu fico triste com isso, porque não posso mandar mais, e o que sobra para mim é muito pouco (Entrevista Djemes, 28 de Abril de 2017).

No depoimento Djemes sobressai o baixo salário, que conduz à precarização das condições de vida e o ressentimento de não poder retribuir com remessas suficientes as necessidades dos que ficaram. Seu depoimento expressa também o desejo de voltar ao país de origem no período de férias, devido a imensa saudade que sente da família. No entanto, sente medo de retornar ao Haiti e ser impedido de continuar o processo migratório no Brasil. Essa insegurança se intensifica, sobretudo, por seu nome não ter saído na última listagem de vistos humanitários divulgada em 2014 pelo Conselho Nacional de Imigração, e também por portar apenas o número do protocolo até que seja emitido o visto humanitário.

Eu preciso saber como que você poderia me ajudar, eu preciso de uma
informação, para saber como é a situação de uma pessoa que seu nome não
saiu na lista do visto humanitário. Eu só tenho o protocolo, faz tempo que saiu
a lista, e meu nome não saiu lá. Eu queria ir visitar minha família no Haiti,
mas tenho medo de eles não me deixar voltar, eu quero ver minha família
porque estou com muita saudade. O problema é o retorno, o país é corrupto, e
eu tenho medo deles cobrar por isso eu não vou lá de medo de ser impedido de
voltar para o Brasil. Eu deixei meus filhos um menino com quase seis anos,
outra menina com 04 e outro com quase três. (Djemes, entrevista realizada em
28 de Abril de 2017).

Em vários momentos da entrevista fui solicitada para ajudar a orientar várias questões relacionadas a legislações, bem como muitos me identificavam como alguém que poderia lhes indicar ou dar trabalho. 
Djemes ressalta os sentimentos afetivos, a saudade, que poderia ser sanada caso o retorno não significasse qualquer ameaça de não conseguir regressar ao Brasil posteriormente à visita. A insegurança de estar somente com o protocolo o imobiliza de empreender qualquer tentativa para afagar a saudade que sente do país e da família.

A diáspora é compreendida assim como experiência familiar e de sociabilidade. Sempre presente na ideia de retorno e novas incursões, estrutura-se a partir de três verbos: residir, voltar e retornar (HANDERSON, 2015).

O desejo ou interesse de voltar a viver no Haiti está sempre presente entre os imigrantes residentes em Cascavel, como demonstram os dados a seguir:

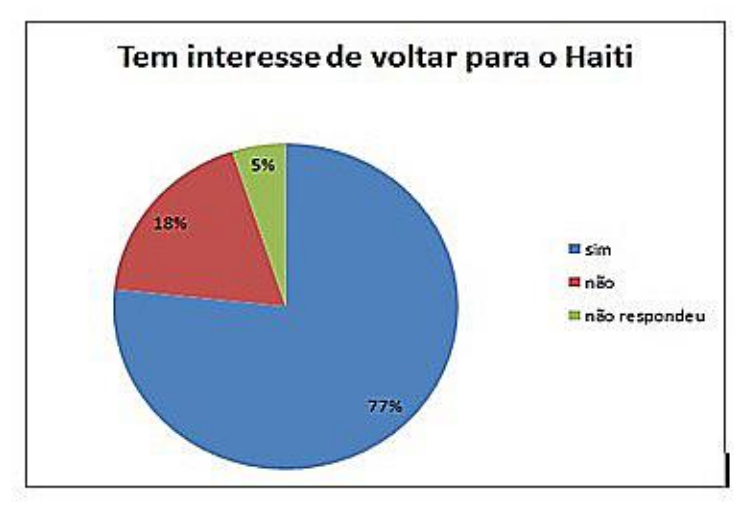

Gráfico 10 - Tem interesse de voltar para o Haiti. Fonte: pesquisa de campo com entrevistas realizadas entre abril a junho de 2017. Elaborado pela autora.

Sayad (2000) considera a importância do movimento de retorno para o imigrante, o que se relaciona com o capital social, que é a experiência de cada imigrante frente às possibilidades que lhes são apresentadas no período de emigração. Sendo assim, a teoria do retorno é parte do projeto migratório. Embora as experiências imigratórias possam não consubstanciar em algo calculado racionalmente pelo sujeito, o desejo de retornar é sempre uma constante.

No percurso de vida, alguns emigrantes retornam para algum ponto, mesmo que seja fora de sua cidade de origem. Outros reconstroem seu projeto e passam a viver em outro território. Apesar de o retorno ser constitutivo do projeto migratório, pode-se afirmar que está 
diretamente relacionado com as condições de vida no país de destino. Mas a perspectiva é, a curto ou longo prazo um dia retornar para o ponto de partida.

Eu agora não trabalho, faz oito meses que não consigo trabalho, meu marido conseguiu pela agência. Todo dia eu procuro trabalhar, hoje eu passei o dia inteiro para procurar serviço, mas não consegui. Eu tenho um sentimento, mas é difícil porque se não tem trabalho, não pode pagar nada, tem que ter um pouco de dinheiro para fazer começo. Sem dinheiro eu não posso voltar, não tenho dinheiro para pagar o avião, como vou ajudar minha família? A gente que está desempregado passa por uma situação difícil. Eu pensava que aqui era melhor, mas desde quando eu cheguei está difícil para mim, não sei onde começar, porque é muita dificuldade. Eu já chorei bastante, mas Deus vai me ajudar, falar no coração das pessoas para poder ajudar. Eu tenho outros parentes em outros países, tem nos estados unidos, República Dominicana, Guiana, Canadá. Só tenho minha mama no Haiti, são muitos irmãs e irmãos, meu pai fez bastante filhos. Minha mãe tem só cinco, mas meu pai tem mais filhos (Beatrice entrevista realizada em 03 de maio de 2017).

Beatrice relata a situação de desemprego que a impede tanto de voltar para o Haiti e enviar remessas para seus familiares que lá ficaram. Demonstra também a decepção de chegar ao Brasil e não conseguir trabalho, o que seria uma forma de compensar o processo migratório.

Voltar ao Haiti sem ter enviado remessas ou sem nenhum pecúlio significa fracassar. Conforme Abner, "é difícil porque isso afeta a minha honra", ao passo que perde o status de diáspora, a mobilidade é sempre uma condição no horizonte. Ser ou não um diáspora implica nas expectativas de quem fica e de quem sai do país, possuir dinheiro e ser uma pessoa bem sucedida economicamente.

Conforme Handerson (2015), boa parte da economia do Haiti se mantém por reservas. Dados de 2007 do Fundo Multilateral de investimento (FOMIN) e do Banco interamericano de Desenvolvimento (BID), de 2006, demonstraram que esse montante correspondia a $24 \%$ do Produto Interno Bruto. Sendo assim, a diáspora tem papel crucial na vida social e econômica do país devido ao envio de remessas.

Dados do Banco Central do Brasil (2017) indicam e reforçam a importância do envio de remessas, conforme gráfico abaixo: 


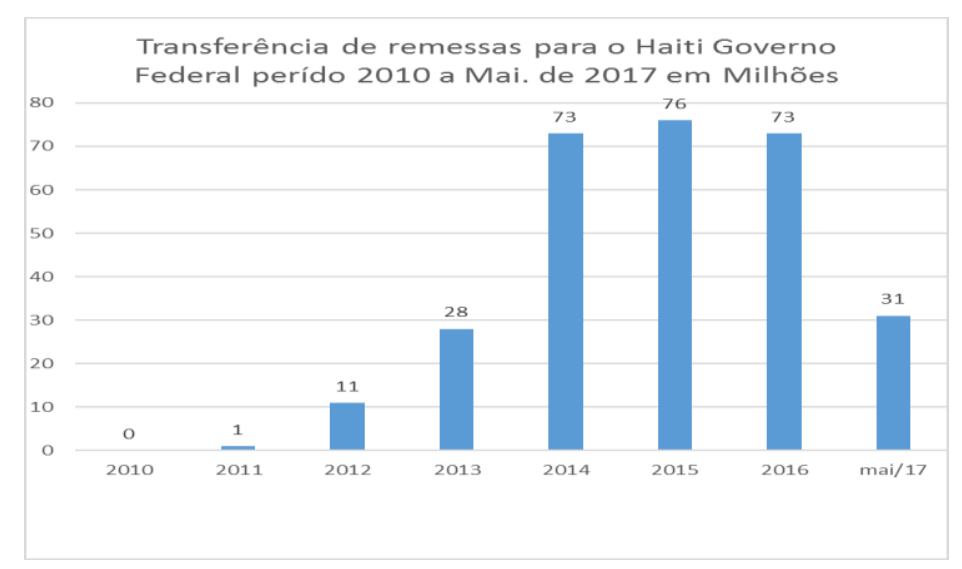

Gráfico 11- Transferência de remessas para o Haiti Governo Federal período 2010 a Mai. de 2017 em Milhões de reais. Fonte: Elaboração própria a partir dos dados emitidos pelo Banco Central do Brasil. Brasil (2018b).

Os dados quantitativos remetem o envio de remessas por haitianos a partir de 2011 com progressivo crescimento entre os anos posteriores, cujo pico de maiores quantidades de valores mantém-se instável de 2014 até Maio de 2017. Por outro lado, esses picos indicam também uma correspondência dos valores enviados e os anos de maior taxa de fluxo migratório, sendo 2014 e 2015 os anos com maior registro de imigração haitiana para o Brasil. Isso reforça ainda a importância da reunificação familiar quando as inversões enviadas podem traduzir-se em novas imigrações para o país.

Os dados correspondem ao crescimento da imigração no Brasil, e em Cascavel, onde as remessas são fundamentais para a manutenção da vida no Haiti. Para mantê-las ocorre a precarização das condições de vida daqueles que trabalham no Brasil e recebem baixos salários por estarem na periferia do sistema, realizando o trabalho manual e desqualificado quando é oportunizado, como apresentado adiante.

Dados quantitativos foram mensurados em relação à ajuda financeira dos imigrantes haitianos em Cascavel, considerando as diferentes variáveis quais foram aparecendo nos depoimentos conforme foram sendo feitas as entrevistas. 


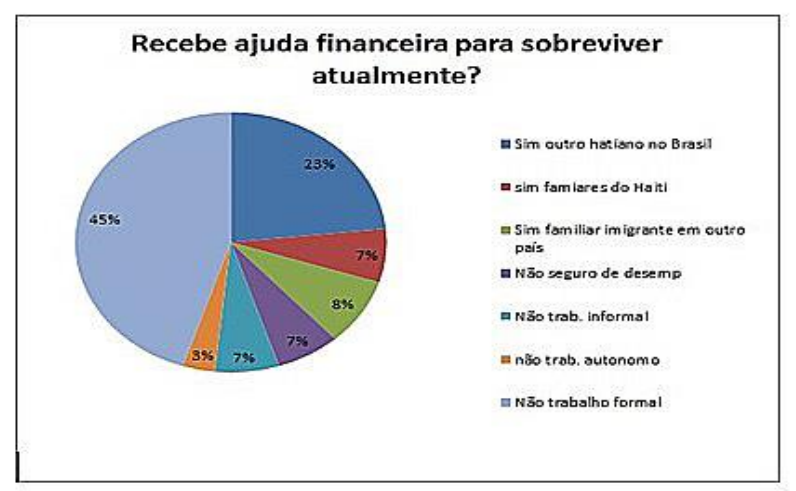

Gráfico 12 - Recebe ajuda financeira para sobreviver atualmente. Fonte: pesquisa de campo com entrevistas realizadas entre abril a junho de 2017. Elaborado pela autora.

As variáveis indicam outra situação de sobrevivência que é a manutenção financeira por familiares ou amigos do Brasil ou do Haiti.

A solidariedade entre os haitianos revela características coletivas que sobrepõem ao individualismo exacerbado do capital. Outros estudos poderiam surgir sobre o desenvolvimento desses valores em países pobres. A concepção de irmandade e sentimento étnico podem ser mais desenvolvidas em países que compartilham a pobreza como uma situação enfrentada pela maior parte da população, não havendo diferenças substanciais entre os mais pobres e a classe média no Haiti. Isso pode ser percebido nos depoimentos de Taylor, que refere a boa condição de vida que tinha no Haiti, o que não implicou de vir para o Brasil.

Um estudo sobre a composição da classe média no Haiti poderia revelar sua proximidade com a população mais pobre. As sociedades que expressam maior desigualdade social ampliam o abismo entre pobres e ricos, formando pequenas castas cujo modo de vida difere de quase toda a população. Assim, as diferenças de classe são realmente sentidas quando referem-se à apropriação sobre os meios de produção.

A motivação, não foi bem assim, porque eu quis, mas é uma história de vida da minha família sabe. O Brasil não era o lugar onde eu deveria ter vindo. Meu pai conversou com amigo dele e falou, aqui é melhor para ele aprender. Eu sou filho único. Tinha uma vida de pleyboisinho, fazia muita bagunça. Para poder aprender na vida, um camarada do meu pai, tinha um filho que estava no Brasil há quase dois anos. Então ele falou, manda o Taylor para lá, ele vai conseguir trabalho e manter a cabeça no lugar certo né, estudar tudo. Eu quando cheguei aqui no Brasil, comecei a pensar no que meu pai me falava: filho estuda, faz universidade nós temos condições, hoje em dia vejo que tudo é realidade. Mais agora pegando as palavras dele, que ele está longe de mim né, eu estou pegando as palavras dele o que ele falava para mim, coloco na cabeça. Porque o Brasil é um país que dá muita oportunidade 
para gente. Quando eu estava no Haiti, eu só estudava não trabalhava. Meu pai é professor aposentado é vice presidente do banco, ele tem um sítio no interior do Haiti, para manter a família (Taylor, entrevista realizada dia 09 de Maio de 2017).

Taylor enfatiza uma boa condição de vida e que nem isso limitou a fazer com que o pai rompesse com a cultura da diáspora, que fez do Brasil o destino dele a partir de uma rede de apoio já estabelecida com um conhecido da família que havia migrado anteriormente para o país.

Por outro lado, a solidariedade entre os haitianos se destaca em seus depoimentos, ao mesmo tempo em que remete a analisar a realidade e realmente não identificar os haitianos em situações de maior vulnerabilidade social como morar na rua ou passar fome.

Isso pode ser observado em vários depoimentos de haitianos, que quando questionados dessa solidariedade ressaltaram a preocupação com o outro haitiano como a mesma ou maior a que sentem consigo mesmos.

Uma coisa que está em nós haitiano, que nossos parentes sempre falam. Quando tu ver um irmão haitiano dormindo na rua, pode ser uma pessoa de longe, não precisa ser da sua família, e você tem condição para ajudar, receber em sua casa, receba. Amanhã você não sabe onde vai cair. Você pode tá aqui no Brasil, amanhã em Nova York ou na China, longe. E outro haitiano pode ajudar você dentro da casa dele, abrir a porta dele. Quando a gente vê um haitiano assim, a gente pensa: pode vir de boa, sossegado, você é haitiano nós somos haitianos. Isso aqui eu vou dizer é de sangue, uma cultura. Um haitiano não aguenta ver outro haitiano numa condição precária sabe, dormi na rua, passar fome. Nós haitiano pensamos em ajudar se a gente vê essa situação, se você ajuda, pode reerguer a pessoa (Taylor, entrevista realizada dia 09 de Maio de 2017).

Taylor descreve o que já foi relatado em outro momento por Abner: o sentimento de solidariedade entre os haitianos, algo que faz parte da cultura e representa a identificação com necessidades de outros conterrâneos que se encontram em situação precária. Uma cultura desenvolvida pelo ato de migrar torna a ajuda um bem que pode ser doado e recebido em outra circunstância.

O desemprego, baixos salários são colocados como fatores que inclusive impedem não só o envio de remessas, mas dificultam a sobrevivência no Brasil e o retorno para o Haiti. 


\subsubsection{Organização das redes de apoio a imigrantes haitianos em Cascavel Paraná}

Algumas experiências se revelam profícuas em relação à acolhida e apoio aos imigrantes haitianos em Cascavel, como o surgimento de associações e movimentos que visam a integrar o imigrante haitiano na sociedade. Como exemplo, destaca-se o Fórum dos Haitianos, criado em 2016, bem como a Associação de Haitianos. Ambas as experiências contam com a participação das igrejas Católica e Anglicana ${ }^{33}$.

Com o objetivo de levar conhecimento e sensibilizar a população local sobre os problemas enfrentados pelos imigrantes em Cascavel, o Fórum dos Haitianos teve sua primeira página criada nas redes sociais em 10 de fevereiro de 2017. Trata-se de uma experiência que propicia encontros coletivos com a participação da sociedade civil e de imigrantes haitianos que, juntos, desenvolvem estratégias para o acolhimento e sensibilização da sociedade quanto à inserção, respeito e inclusão de imigrantes no Município. Por meio de professores que atuam como voluntários e imigrantes haitianos das seguintes instituições: Unioeste, UTFPR de Medianeira, IFPR de Cascavel e Unipar.

A atividade desenvolvida por esse fórum foi descrita por Bortoloto, Souza e Stein (2017), que discutem sobre as trajetórias migratórias haitianas entre São Paulo e Cascavel, e o importante papel assumido pelas instituições religiosas que se tornaram referência de acolhida no Município. Em Cascavel, assim como no restante do país predomina a ausência do Estado e sua falta de responsabilidade para com políticas de acolhimento e inserção social.

O Município de Cascavel não destoa do restante do país e tem nas instituições religiosas uma importante referência na acolhida e orientação de direitos, com destaque para a Caritas de Cascavel e a Pastoral do Migrante, ambas vinculadas a Igreja Católica. Atuam diretamente junto a esses imigrantes por meio de ações que visam a organização, como a criação do Fórum dos Haitianos em 2016 (CATVE, 2016) (BOTOLOTO, SOUZA, STEIN, 2017, p.10).

O Fórum dos Haitianos realiza reuniões mensais a fim de criar mecanismos e estratégias para atingir seus objetivos. Uma de suas ações foi a realização do Festival da Cultura Haitiana em 2016, como alternativa para divulgar informações sobre a cultura haitiana assim como promover o combate a diferentes formas de preconceito, como o racismo

\footnotetext{
${ }^{33}$ Esse estudo concentrou esforços para analisar algumas ações do Fórum dos haitianos. A conclusão desse trabalho prevê a algumas análises sobre a associação dos Haitianos e a participação do apoio para sua formação da igreja Anglicana.
} 
e a xenofobia. No entanto, quando se refere à participação das instituições religiosas percebese que embora tenham elas um objetivo comum, que é a integração dos haitianos na sociedade, há um grande desafio de criar mecanismos para agregar essas diferentes instituições, pois todas fazem seus trabalhos de atendimento e recepção de forma isolada.

Por outro lado, essas instituições, pressionam o Estado por sua representatividade e impulsionam a criação de políticas de imigração.

Cotinguiba e Cotinguiba (2016) e Vinente (2016) realçam a religião como porta de entrada para o primeiro contato ou início das pesquisas com imigrantes haitianos.

Nossa principal porta de entrada foi sagrada, isto é, religiosa, por meio de uma parceria com uma Paróquia, a São João Bosco, seguindo pistas para o início da nossa pesquisa de campo (White, 2005, p. 292), por meio de espaços de inserção, intermediado por instituições como centros comunitários ou igrejas (COTINGUIBA E COTINGUIBA, 2016, p. 175.)

Para esses autores, a Pastoral do Migrante configura-se como uma instituição hegemônica e instrumento de acesso para muitos pesquisadores que estudam imigração haitiana, devido ao trabalho que exercem junto aos imigrantes. Em Cascavel, essa atuação não é diferente. A Pastoral do Migrante desenvolve atendimentos vinculados à Paróquia São Cristóvão, por meio de um pároco também haitiano.

A nacionalidade haitiana do pároco estabelece um reconhecimento identitário que é, segundo Bauman (2005), a expressão de um sentimento coletivo que emerge e passa a ser um problema sociológico com o surgimento do Estado (BAUMAN, 2005). A noção de nacionalidade é instituída juntamente com os mecanismos de controle sobre a população de um determinado território.

Concordando com Bauman (2005), Clastres e Miller (2005) percebem a etnicidade como um fenômeno mundial que se expressa como sentimento de pertencimento a um grupo, com base em sua origem, história, cultura, experiência e valores compartilhados. Em Cascavel foi possível observá-la por meio da atuação da Pastoral do Migrante e a identificação entre um padre haitiano e essa comunidade étnica.

Essa relação pode ser observada por meio de visita na Cáritas Arquidiocesana de Cascavel, em que fui convidada a participar de uma missa e, posteriormente, de uma reunião com os imigrantes haitianos, realizada em conjunto entre a Pastoral do Migrante e a Cáritas. Essa foi a primeira oportunidade de contato coletivo com esses imigrantes. 
O evento ocorreu em um domingo, dia 12 de fevereiro, como uma das atividades da Pastoral do Migrante em 2017, com a celebração da primeira missa do ano, e contou com a presença de mais de 100 haitianos. Vale registrar que, mensalmente, a missa é rezada em creole, o que é possível devido o padre ser haitiano e dominar o idioma.

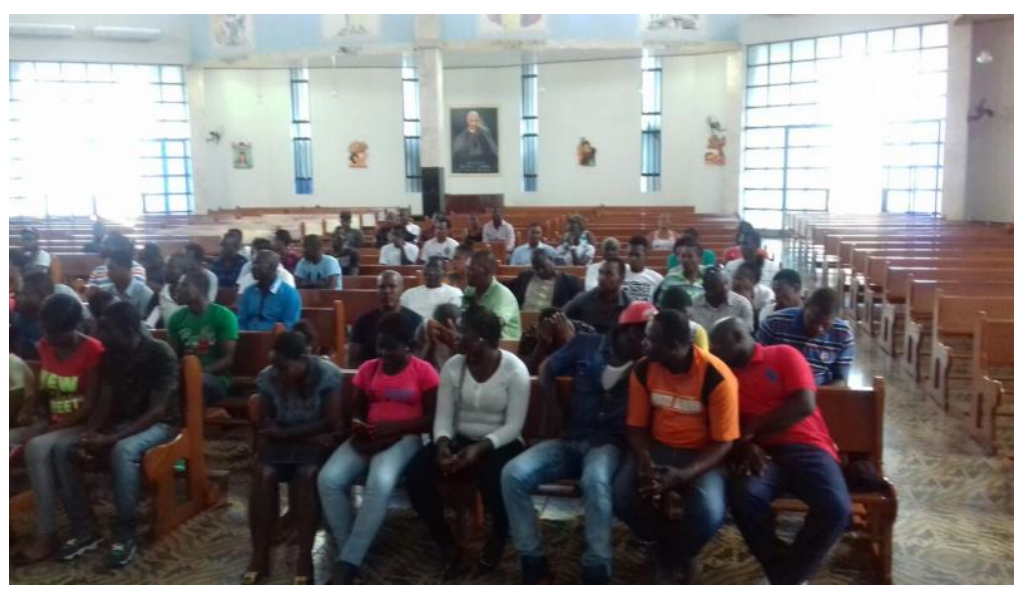

Foto 16 - Missa com a comunidade haitiana 12 de Fevereiro de 2017 ( Foto: Claudimara C. Bortoloto).

Após a missa, como ação da Pastoral do Migrante, o padre conduziu o encontro dividindo os haitianos em grupos e os orientou para que se sentassem separados de amigos, parentes ou conhecidos. A metodologia visava identificar as apreensões de diferentes pessoas sobre um mesmo problema. Os grupos conduziram a discussão sobre uma questão central: Quais os principais problemas enfrentados pelos haitianos para viver em Cascavel? Posteriormente, discutiram essa questão e apresentaram uma síntese, expressa pela exposição de um representante de cada grupo.

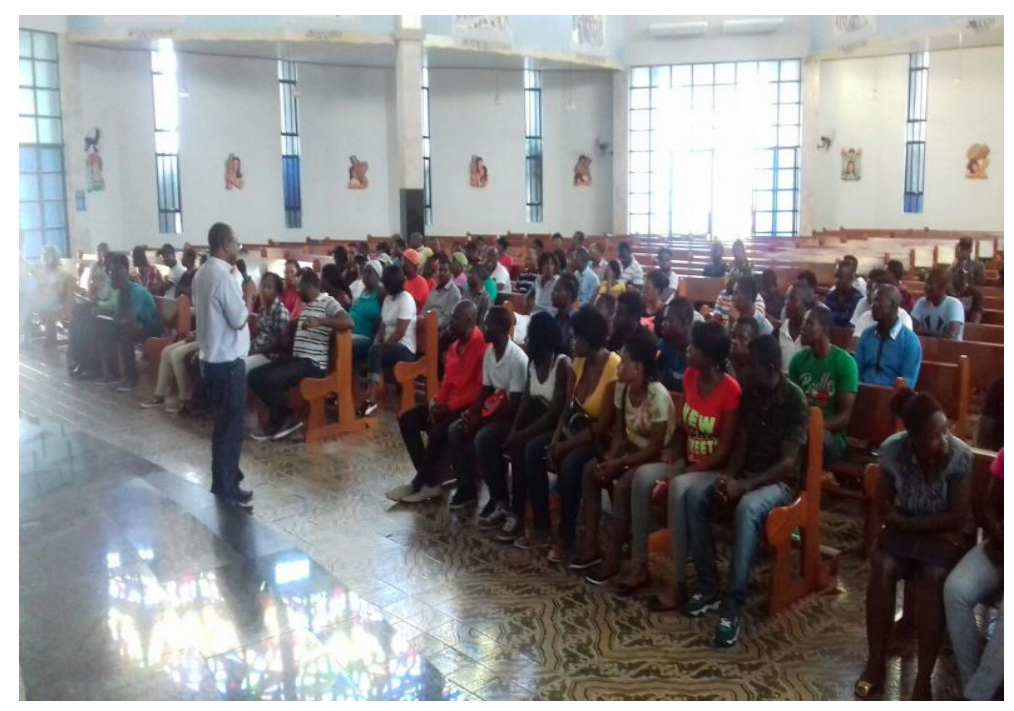

Foto 17 - Reunião com haitianos. Atividade realizada pela Pastoral do Migrante 12 de Fevereiro de 2017 ( Foto: Claudimara C. Bortoloto). 
As questões foram feitas em creole e puderam ser anotadas por Joseph, o primeiro intérprete que colaborou com esta pesquisa e um dos 60 haitianos entrevistados. O seu pleno domínio do português possibilitou a tradução do que era falado pelos haitianos.

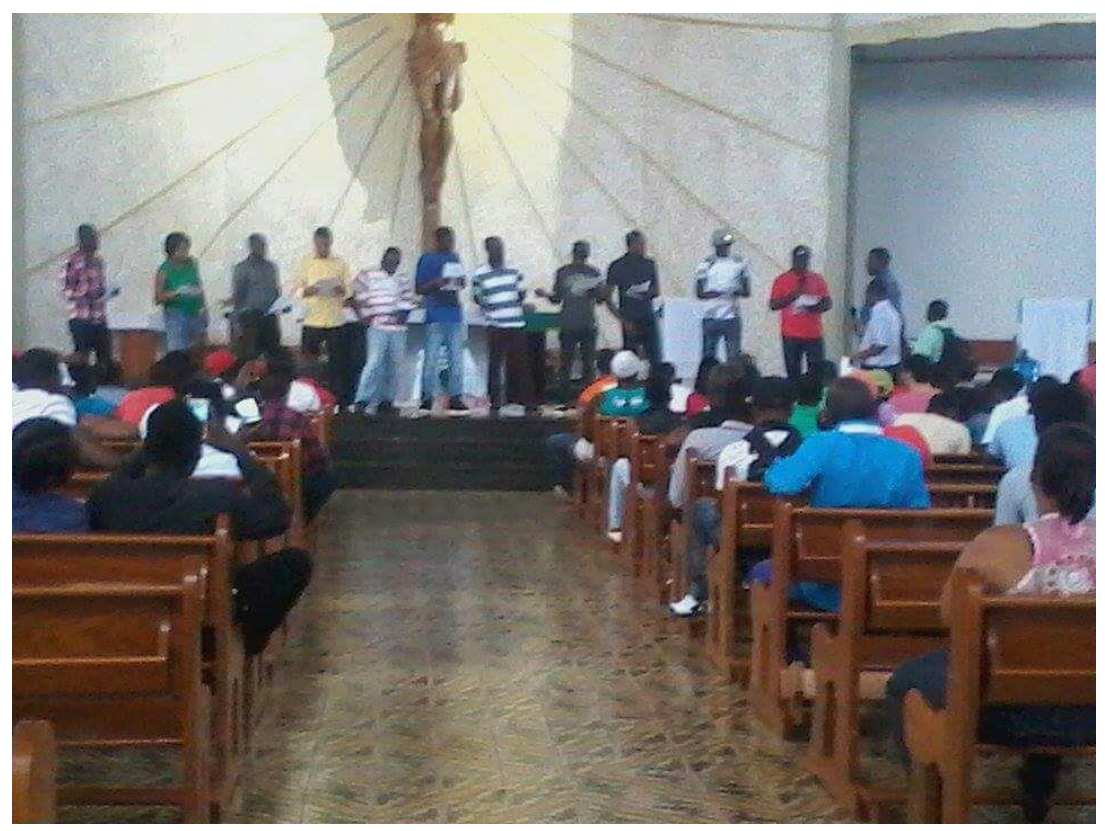

Foto 18 - Reunião com haitianos atividade realizada pela Pastoral do Migrante 2 de Fevereiro de 2017 ( Foto: Claudimara C. Bortoloto).

O trabalho foi mencionado como o primeiro obstáculo a ser enfrentado pelos haitianos, seguido do domínio da língua portuguesa que é utilizado como justificativa pelo setor produtivo para a não incorporação deles no mercado de trabalho. Além do mais, mencionaram os problemas relacionados à saúde e, em tom de sátira, citaram uma situação corriqueira, geralmente vivenciada por todos os que demandam atendimento na saúde pública de Cascavel, que é a prescrição generalizada de Paracetamol pelos médicos.

Ao falarem sobre o problema que é conseguir um trabalho, os haitianos evidenciam a contribuição daqueles que estão trabalhando e que apresentam bom comportamento para indicar outros imigrantes para o sistema produtivo. Essa é uma alternativa, tendo em vista o fechamento do mercado de trabalho em Cascavel. A indicação é entendida pelos haitianos como uma possibilidade, uma alternativa para driblar o desemprego, um mecanismo para superar o preconceito em razão da resistência do setor produtivo em incorporá-los.

As migrações, de acordo com Silva (2005), respondem a duas necessidades. Uma delas é a sobrevivência, permitida pela satisfação de condições materiais, como moradia, 
comida, remédios, roupas, entre outras. A segunda é a manutenção das ilusões, como melhorar as condições de vida.

Marx e Engels (2003) interpretariam o comportamento disciplinar, como estratégia para indicar outros haitianos para vagas de trabalho, como ideologia ou falsa consciência imposta pela classe dominante. Para esses pensadores, a ideologia dominante de uma época é a da classe dominante.

No século XXI, a ideologia apregoa o desemprego como uma responsabilidade do indivíduo e não do sistema capitalista, de modo que o sucesso ou o fracasso do indivíduo é atribuído a ele próprio. A reprodução dessa ideologia ocorre entre os imigrantes e na sociedade em geral, sendo ela necessária e funcional a um sistema que, cada vez mais, explora e elimina postos de trabalho, ocultando suas próprias contradições.

Conforme Marx e Engels (2003), a produção das ideias, das representações e da consciência está direta e intimamente ligada à atividade material. Ela é a linguagem da vida real. "As ideias e representações dos homens emergem da vida material, em sua atividade real em que a vida determina a consciência, onde para os autores "Não é a consciência que determina a vida, mas sim a vida que determina a consciência” (MARX E ENGELS, 1998, p. 20).

Se a vida material dos imigrantes haitianos no Brasil potencializa o desenvolvimento da consciência de classe, é necessária uma falsa consciência para anular essa possibilidade. Isso aparece evidente no discurso da mídia sobre o desemprego entre os haitianos, que é apresentado como um problema social, de sua própria responsabilidade. Não são apontadas soluções ou alternativas para o enfrentamento da situação, como é exposto em uma das matérias veiculadas por um dos jornais da mídia local que ressalta o número do desemprego relacionado à falta de qualificação e domínio da língua portuguesa.

Em Cascavel, existem aproximadamente 500 haitianos desempregados, segundo revelou o vice-presidente da associação que representa esses imigrantes, Marcelin Geffrard. Maristela Becker Miranda, gerente da Agência do Trabalhador em Cascavel, confirma que está encontrando dificuldades para encaminhar os haitianos para o mercado de trabalho e diz estar preocupada com a situação. Algumas empresas são claras e dizem que não querem a mão de obra haitiana, às vezes a agência insiste, mas poucas vagas aparecem. Até a construção civil que empregou muitos haitianos hoje se recusa a receber os trabalhadores. "Eu estou bastante apreensiva de uns tempos para cá essa rejeição aumentou" (CORAZA e CRUZ, 2015 p.01). 
A falta de organização dos imigrantes enquanto classe trabalhadora reforça o seu reconhecimento enquanto classe social, aspectos expressos na sua desvinculação a outros movimentos sociais de resistência às formas de exploração. Talvez essa situação seja reflexo da própria desorganização da classe trabalhadora no Brasil, que tem a subtração de direitos como uma resposta a sua fragilidade e resistência enquanto classe. Também há que se considerar que isso é constatado entre os brasileiros e assola a classe trabalhadora como um todo, ainda mais latente entre os imigrantes, os quais tem tolhido pela própria condição formas de participação popular, devido a crença de ser essa participação uma ameaça para permanecer no país.

Outro exemplo de mobilização via redes sociais foi uma reunião convocada pela Cáritas Arquidiocesana e a Patoral do Migrante com haitianos, realizada no dia 06 de maio de 2017, com o propósito de criar estratégias para envolver a sociedade civil e lideranças políticas na discussão sobre os problemas que tangem a inserção dos imigrantes no Município. Como resultado dessa reunião, foram eleitos alguns líderes para escrever uma carta, a qual em reunião posterior foi apresentada aos participantes.

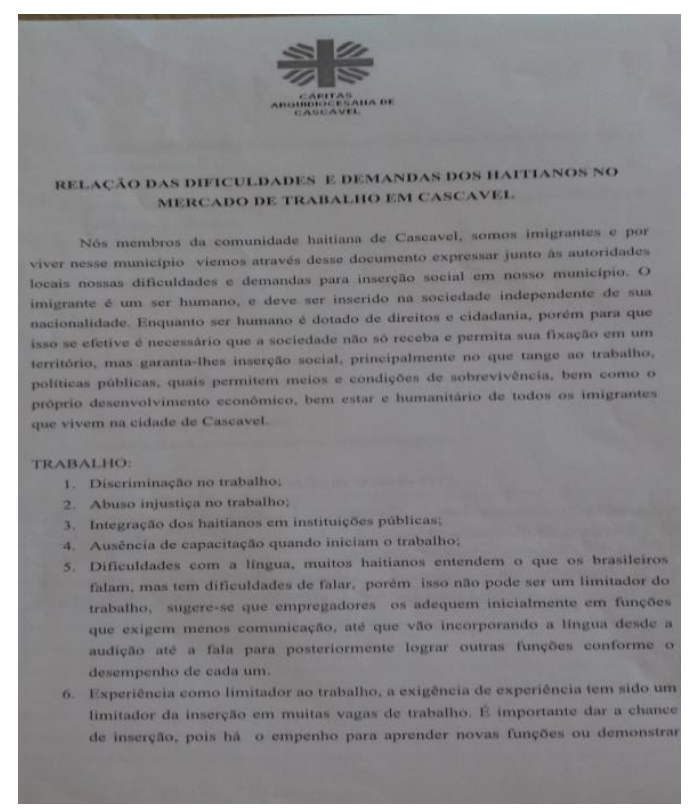

Foto 19: Cáritas Arquidiocesana de Cascavel,26 de maio de 2017. (Claudimara Cassoli Bortoloto).

Os pressupostos dessa carta tratam das especificidades da inserção laboral dos haitianos em Cascavel. As pautas da reunião fazem referência direta às dificuldades para inserção no trabalho, ao passo que denunciam e sugerem alternativas para a superação do problema e apontam mecanismos para inserção laboral dos haitianos no Município. Como 
ressalta Silva (2005), a necessidade de sobrevivência se delineia como um agente que impulsiona as migrações, sendo esse um aspecto importante tanto para quem migra como para aqueles que ficam no país de origem.

Entre as lideranças convidadas para a reunião, destacam-se os representantes dos seguintes órgãos: Secretaria Municipal de Desenvolvimento de Cascavel (SEMDEC), Secretaria Municipal de Assistência Social (SEASO), Sindicato da Indústria da Construção Civil do Estado do Paraná (SINDUSCOM), Sindicato dos Trabalhadores da Construção Civil de Cascavel (SINTRIVEL), Secretaria do Estado da Justiça, Trabalho e Direito Humanos, Associação Comercial Industrial de Cascavel (ACIC) e Câmara de Vereadores.

Estiveram presentes 37 haitianos e representantes das seguintes lideranças: o Secretário de Assistência Social, uma representante da Agência do Trabalhador e quatro professores da Universidade Estadual do Oeste do Paraná (Unioeste), vinculados ao setor de revalidação de diplomas.

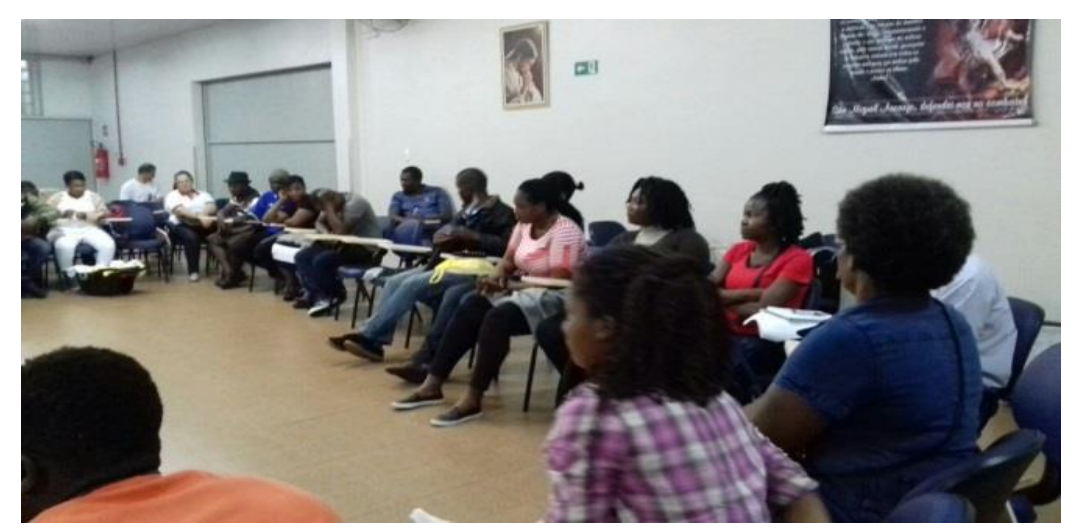

Foto 20 - Cáritas Arquidiocesana de Cascavel,26 de maio de 2017.( Foto: Claudimara C. Bortoloto).

O amplo convite, estendido à comunidade local, foi respondido por quatro órgãos do total de convidados. Vale informar que não compareceu nenhum membro sindical, vereador e representates de outros órgãos, o que demonstra o descompasso e os limites da representação sindical e parlamentar no Brasil, quando ela não reconhece os imigrantes como trabalhadores, recusando-se a participar de discussões de assuntos relacionados a trabalhadores estrangeiros no país.

Da mesma forma, o desinteresse e envolvimento de vereadores pode ser interpretado como uma indiferença frente a esse grupo já que eles não são eleitores, dessa forma estão afastados dos interesses imediatos da comunidade de representação política no Brasil que tem a base eleitoral um atrativo de participação, já que ela por meio do voto emite uma relação de troca. Como os haitianos não votam, os mesmos são ignorados pela classe política municipal. 
No entanto, cabe considerar que ao investigar o envolvimento da classe política e os imigrantes em Cascavel, foi identificado que eles foram pautas de algumas ações, umas delas foi a aprovação da Lei Municipal no 53 de 2017, que institui o dia do imigrante Haitiano em Cascavel. Essa legislação institui o dia do imigrante, bem como estabelece uma ação conjunta entre poder público e imigrantes para o desenvolvimento de ações que venham homenagear a cultura haitiana, além de difundir informações a seu respeito para a população local de Cascavel (CASCAVEL, 2017). Além dessa lei, identifica-se a presença de outro vereador, Paulo Humberto Porto Borges, do Partido Comunista do Brasil (PCdoB), que apoiou e contribuiu para organizar os haitianos e, junto com a igreja Anglicana, criaram a Associação dos Haitianos em Cascavel (CGN, 2014).

A ausência de participação de representantes dos sindicatos de Cascavel pode estar relacionada à ideologia de concorrência por postos de trabalho que vincula a ideia de disputa por vagas entre os filiados sindicais e os imigrantes, além disso, outra explicação advém do que já fora apontado por Mamed (2017) e Bosi (2016) sobre a limitação da representatividade dos sindicatos junto aos trabalhadores reduzida aos interesses patronais, o que contribui para a desmobilização de trabalhadores na região.

Além da Cáritas e da Pastoral do Imigrante, que apoiaram a criação do Fórum, outras instituições como as universidades, destacam-se no trabalho com imigrantes, de forma a auxiliar na organização coletiva dos mesmos para impor maior representatividade e luta por direitos.

Essas ações têm seu marco no ano de 2014, com o protagonismo do Reverendo Luíz Carlos Gabas que, como líder da Igreja Anglicana, auxilia esse processo. A importância da mobilização é evidenciada no depoimento do líder religioso, segundo o qual: “[...] a igreja não pode se furtar de uma de suas principais funções que é compromisso com os direitos humanos. Temos essa preocupação da proteção e do acolhimento dessas pessoas que vem de outros países e que vem à Cascavel em busca de um recomeço" (LAÍ́NY, 2014, p.1).

Enquanto militante do Fórum dos Haitianos percebo a integração entre as diferentes instituições religiosas que apoiam os imigrantes no Município como uma importante ação. Não é objetivo deste trabalho delinear as dificuldades para essa integração, mas é perceptível a ação isolada dessas instituições que aparentemente agem em torno de objetivos comuns. Essas instituições, quando agregadas, poderiam compartilhar e somar forças para fortalecer a organização dos haitianos a fim de proporcionar a eles maior dimensão política e impacto social. 
A pequena participação dos haitianos, bem como de voluntários que representam a sociedade civil no Fórum dos Haitianos, é sinal do grande desafio de consolidar essa organização. Outro desafio é a dificuldade dos haitianos de se organizar coletivamente, o que é decorrente dos obstáculos à sua participação no país de origem, a situação de ser estrangeiro e viver em outro país, que sempre remete a ideia de proibição de organização política.

Em Cascavel não existem abrigos específicos para o acolhimento dos imigrantes haitianos, o que reforça a demanda junto às instituições religiosas que são procuradas para prestar atendimento em diversas áreas. Por outro lado, a não existência de abrigos para atendimento de uma população migrante e recém-chegada revela a força das redes de apoio familiares, que parecem funcionar com extrema precisão no acolhimento de seus conterrâneos. Diante de um atendimento e políticas públicas quase inexistentes essas instituições adquirem papel central e se colocam como importantes pressionadoras do Estado, dado ao atendimento, via encaminhamento para o sistema público e inclusão nas políticas sociais.

Além dos desafios envolvendo a unificação das diferentes ações institucionais da sociedade civil que prestam atendimentos aos imigrantes, como as religiosas, Silva S.(2016b) adverte que essas instituições devem cuidar para evitar a exploração dessa mão de obra disponível. Embora a maior parte desses imigrantes esteja com documentação regular e protegidos sob os mesmos direitos trabalhistas que gozam os trabalhadores brasileiros, a vulnerabilidade a que estão submetidos evidencia a violação de direitos, seja por desconhecimento das legislações ou por instrumentos de defesa disponíveis.

Conforme Silva S. (2016b), um estudo feito pela Missão Paz em São Paulo revelou que, das 482 empresas com interesse nessa mão de obra, apenas 78 cumpriram o pagamento de mais de um salário mínimo e garantiram os mínimos direitos previsto na CLT. Diante desses dados, Silva S. (2016b) ressalta que o empresariado concebe o imigrante como força de trabalho temporária, disposta a aceitar qualquer tipo de trabalho, despreocupada com a garantia de mínimas condições para realizá-lo. Além disso, a dinâmica dos empresários que incorporam essa mão de obra segue a lógica do capital, marcada pela extração de mais valia, de modo que "[...] grande parte das empresas interessadas em contratar haitianos (as) não estão preocupadas em respeitar os direitos trabalhistas desses imigrantes, mas sim, em maximizar seus lucros" (SILVA, 2016b, p. 190).

Silva S. (2016b) ainda aponta a ambiguidade de como essas instituições religiosas são noticiadas pela mídia. Uma das fontes chega a comparar a ação da Missão Paz de São Paulo, por meio do acolhimento e encaminhamento desses imigrantes, com práticas do período 
colonial, quando escravos eram escolhidos como mercadoria pelos senhores de engenho. $\mathrm{O}$ autor ressalta que essa comparação é tendenciosa, e demarca a importância dessas organizações voltadas para o acolhimento e apoio aos imigrantes e o relevante trabalho prestado por elas, quando o Estado exime de sua responsabilidade e os deixa jogados à própria sorte.

Silva S. (2016b, p.191) afirma que "a Pastoral do Migrante foi um lugar de encontro e recomeço para muitos deles. Atualmente, ela é o lugar de passagem de milhares de imigrantes, que por diferentes motivos, buscam no Brasil uma oportunidade para superar o círculo vicioso da sobrevivência". Além do acolhimento e atendimento, Silva S. (2017) enfatizou a importância dessas instituições religiosas que acolhem imigrantes independente de sua religiosidade. Atuam de forma eficaz para criar espaços de participação coletiva, bem como de fortalecimento de direitos. Um dos exemplos foi o estímulo da Missão Paz que mobilizou os haitianos a participar das discussões em torno da aprovação da nova lei de migração.

As ações conjuntas dessas instituições religiosas, quando existentes em Cascavel, reduzem-se à Pastoral do Migrante, Cáritas Cascavel e universidades, o que sinaliza a partir desse Fórum não apenas o envolvimento de imigrantes com setores da Igreja Católica, mas também de instituições de educação superior. O sucesso dessa integração vai depender da vinculação da sociedade e dos próprios haitianos, o que não é possível prever já que a história não é feita da forma como se deseja, e sim por condições historicamente determinadas.

Silva S. (2016b), ao analisar a importância das instituiçoes de apoio, como a Missão Paz em São Paulo e a Pastoral do Migrante, ressalta que apesar das críticas impostas a elas, suas ações são significativas no que diz respeito ao abrigo e inserção social, quando o Estado se exime dessa função. As ações institucionais, embora limitadas por interesses, religiosos ou não, em determinadas situações, exercem papel expressivo na organização e mobilização dos haitianos em Cascavel.

Mezzadra (2005) menciona as nobres experiências de solidariedade desempenhadas pela Igreja Católica e por voluntários, as quais funcionam como pontos de referência dentro do tecido social, em um contexto de ataques de direitos com a redução do Estado de BemEstar Social na Europa. Porém, no campo teórico, é necessário ter em conta que essa imagem pode servir para reforçar práticas paternalistas, com reiteração de imagens e discursos que relegam os imigrantes a uma posição de subalternidade, negando-lhes oportunidades de subjetivação. 
A ênfase no direito e na diferença caracteriza o sentido comum multiculturalista presente nos imigrantes. Contudo, Mezzadra (2005) ressalta que as instituições que objetivam promover os direitos dos imigrantes devem se ater para não restringir suas ações a representações forçadas deles, com a folclorização do cultural, em detrimento de ações que objetivam a manifestação da pluralidade de posições e problemas que definem a figura do imigrante na sociedade contemporânea.

Compreender a lógica desse processo requer entender o que caracteriza esses grandes fluxos e quais suas relações com a globalização que, assim como move o capital, as mercadorias e o livre mercado, gera a intensificação dos fluxos migratórios, próprios da humanidade. Um dos grandes desafios é fazer essa transferência, sobretudo quando as ações se colocam hegemonicamente no âmbito das instituições religiosas. $\mathrm{O}$ embate se coloca, por um lado, em criar mecanismos para agregar essas diferentes instituições que atendem os imigrantes em torno de um objetivo único, que é a recepção e integração deles. Por outro, essas instituições, fortalecidas e coesas, por meio das pressões que exercem e por sua representatividade, impulsionam a criação de políticas de imigração por parte do Estado.

\subsubsection{Haitianos em Cascavel e setor produtivo: embates para sobrevivencia.}

Até aqui, viu-se sobre a especificidade de um setor produtivo que requer mão de obra barata, abundante e dócil para realização de trabalho precarizado em frigoríficos. A resistência de trabalhadores nacionais a essas condições de trabalho se manifestam na alta rotatividade de trabalhadores no setor. Nesse contexto os haitianos se constituíram em boa alternativa para superar a falta de mão de obra e simultaneamente garantir a formação de um exército industrial de reservas disponíveis para essas condições de trabalho. Essa premissa fica evidente na pesquisa de campo quando evidenciamos o fechamento do setor produtivo de Cascavel para esses imigrantes e a hegemonia deles, contratados por frigoríficos quando estão inseridos no sistema produtivo, sendo essa a quase que única alternativa de sobrevivência na cidade.

Se não bastasse o fechamento do setor produtivo em Cascavel, a pesquisa evidencia a centralização dos contratos em apenas um dos frigoríficos, responsável por contratar a maioria dos que trabalham no setor. 


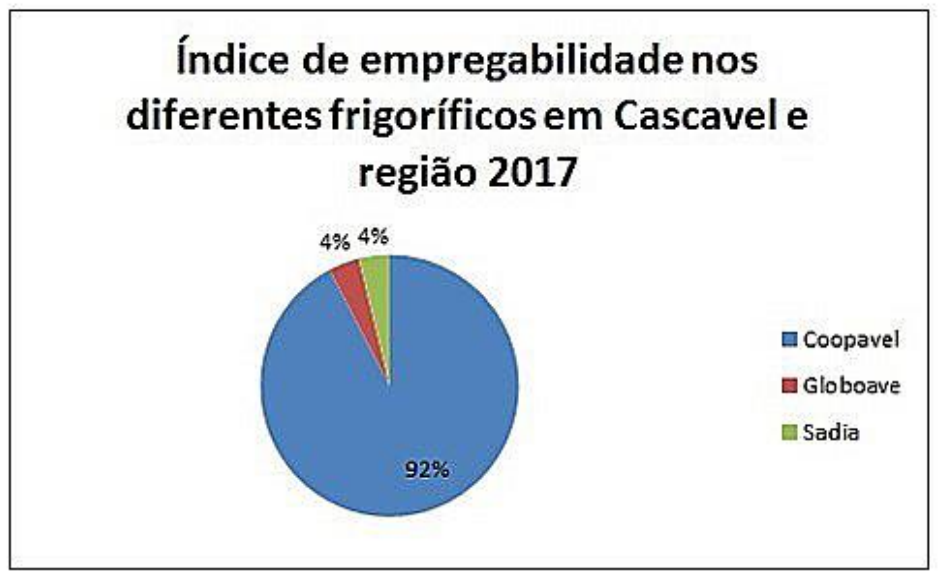

Gráfico 13 - Índice de empregabilidade nos diferentes Frigoríficos em Cascavel. Fonte: pesquisa de campo com entrevistas realizadas entre abril a junho de 2017. (Claudimara Cassoli Bortoloto).

Dessa forma, a pesquisa mostra a hegemonia do frigorífico Coopavel na contratação de mão de obra haitiana em comparação aos demais, corroborando também com estudos já desenvolvidos por Martins et al (2014), Grando (2017) e Mamed (2017), os quais indicaram esse frigorífico e sua capacidade de empregabilidade na região.

Entre os frigoríficos citados na pesquisa, um deles, a Sadia, está localizada no Município vizinho de Toledo, como já discutido. Embora seja inexpressiva a contratação de haitianos que fizeram parte dessa amostra, ele foi um dos frigoríficos que apresentou dados de contratação.

A demanda de mão de obra por esse tipo de produção industrial desencadeia o recrutamento de mão de obra nos Municípios vizinhos, sendo que, assim como em outros que circundam Toledo, diariamente são enviados ônibus para fazer o deslocamento de trabalhadores. Esse é um procedimento normal entre as empresas desse ramo.

Os dados permitem inferir que a incorporação de haitianos por frigoríficos apenas é possível em razão da demanda de força de trabalho, provocada pela indisponibilidade de mão de obra cascavelense e em toda a região. Esse setor, quando servido de trabalhadores, em períodos de crise econômica tende a rejeitar os imigrantes. Porém, quando não demandam sua força de trabalho, fecham as portas para estrangeiros dando preferência para a contratação de brasileiros. Assim, com um sistema produtivo fechado, os períodos de crise econômica significam restrição de contratos para haitianos já que a mão de obra nacional aparece interessada nesse tipo de trabalho.

O imigrante Herbert notou a concorrência entre os imigrantes e brasileiros quando buscava trabalho em um frigorífico da região, localizado no Município de Matelândia. Após 
ser demitido pela Sadia, procurou recolocação no trabalho. Então, deslocou-se até o Município localizado próximo à Cascavel, após divulgação de vagas disponíveis. Porém, segundo esse imigrante, essa vaga foi ocultada e reservada para brasileiros que se encontravam na mesma situação que ele, desempregados e a procura de trabalho.

Fui na Agência do trabalhador não tinha vaga, se é brasileiro tem vaga, estrangeiro não tem vaga. Eu fui para Matelândia ontem para procurar emprego, lá tem as empresas Lar, e Frimesa, tem muita, muita vaga, eu achei. Mais de trinta pessoas procuravam vagas, nós haitianos ficamos os três por último, todos os brasileiros conseguiram vagas, nós não conseguimos. A Moça falo para mim por enquanto não tem vaga para estrangeiro, porque estrangeiro não sabe falar português muito bem, e não posso colocar ele no lugar errado. Por enquanto não tem vaga. Eu falei amiga eu sei falar, eu falo, eu entendo. Ela disse para mim, você não pode ficar discutindo porque as empresas são de brasileiros, então nós não podemos deixar brasileiro parado para dar a vaga para estrangeiro. Ela falou isso e então eu falei. Tá bom obrigado, eu saí não vou falar mais lá. Agora esses empresários são maioria racistas mesmo. Por que eu vou na empresa e tem vaga para brasileiro e para estrangeiro não tem vaga? Porque o presidente abriu as porta para estrangeiro vim? Se estrangeiro não trabalha o que vai fazer? Roubar? Vai ficar Roubando? É? (Hebert, entrevista realizada dia 18 de Maio de 2017).

Esse relato demonstra como o capital inibe as condições de sobrevivência desses imigrantes, quando não demanda sua mão de obra. Hebert relata uma situação comum entre os haitianos. Embora muitos dominem minimamente o português, apenas pelo fato de serem estrangeiros, são recusados pelo mercado de trabalho sob a justificativa de que não dominam a língua.

A concorrência não ocorre somente entre brasileiros, mas entre os próprios haitianos, que competem entre si por uma vaga de trabalho. Isso se intensifica diante do fechamento do sistema produtivo, restando os frigoríficos para uma comunidade de aproximadamente cinco mil haitianos. A fala de Adner ressalta a preocupação com o desemprego e a tristeza em ver trabalhadores haitianos brigando por vaga de trabalho em um dos maiores frigoríficos da região, e o que mais emprega.

Tem gente que chegou em Cascavel e até agora não tem trabalho, aqui na Coopavel tem haitiano que fica o dia todo na frente do frigorífico, forma quase uma manifestação, ficam brigando por vagas. Quando eu vejo isso eu fico mal. Fila de haitiano, a pessoa que trabalha na Coopavel diz a mesma coisa para todo mundo, volta amanhã, vem amanhã, outra semana. Imagina um haitiano que sai de sua casa, sai seis horas da manhã, chega seis horas da 
tarde, e a pessoa fecha a porta? (ADNER entrevista realizada, 22 de Maio de 2017).

Adner remete às contratações dos próprios frigoríficos e a busca incessante por vagas de trabalho pelos imigrantes, que retornam para casa depois de um dia de muitas tentativas de busca por emprego, sem qualquer resposta positiva. Dentre as dezenas de entrevistas, ouvi relatos de muitos outros haitianos que narravam a mesma saga à procura de trabalho em Cascavel. Como estratégia de não serem barrados pela língua, buscam trabalho em grupo, sempre com a presença de um haitiano que domina minimamente o português, que bate às portas e pede trabalho em nome dos demais.

Essa é uma estratégia para buscar trabalho, associada à que já referimos da indicação frente ao bom comportamento dos que já conseguiram inserir-se, que podem ir impulsionando os demais a ocuparem vagas produtivas, situação que se concretiza com muito mais ênfase nos frigoríficos, os quais aparecem sempre como única alternativa e com reais possibilidades de inclusão produtiva.

Essa situação de insegurança, concorrência e trabalho precário foi discutida no segundo capítulo, no qual fora abordado o conceito de precariado. Standing (2015) refere-se aos imigrantes, considerados precariados, como um grupo heterogêneo, mas que compartilha sentimentos de trabalho útil e necessário para viver, submetidos a uma situação oportunista que os obriga a aceitar trabalhos precários, inseguros e sem estabilidade.

Conforme discutido anteriormente, as formas de organização do trabalho não eliminaram os modelos fordista e taylorista no Brasil, o que torna as atividades de auxiliar de produção em frigoríficos hegemônicas nas contratações do sistema produtivo da região. Nas entrevistas realizadas com os imigrantes haitianos residentes em Cascavel, a precarização das condições de vida no Brasil é sempre um aspecto problematizado diante da necessidade que eles têm de enviar remessas para os seus familiares que ficaram no Haiti. A imigração haitiana é cultural e, por meio da ajuda dos que já migraram, é que novos membros da família podem também migrar e então reencontrarem-se. Esse elo completa a efetiva relação entre os que partiram e os que ficaram, conforme discutido anteriormente.

Além de precarizar as condições de vida, os baixos salários tiram o tempo do trabalhador, conforme é relatado por Ali.

Eu fiz ensino médio, não tenho vontade de estudar aqui, eu era mestre de obras, no Haiti eu fazia isso, fazia projeto, tudo na área de construção. Aqui o que fazia no Haiti não tem valor, meu conhecimento não tem valor. $\mathrm{O}$ 
tempo é outro problema. Eu saio para o trabalho na Coopavel às cinco da manhã, vou lá pegar o ônibus que passa às seis e trinta. Eu saio do trabalho e chego na minha casa às sete e quinze, gasta muito tempo no ônibus, eu chego e não consigo fazer mais nada. O trabalho pega todo meu tempo, de seis e trinta manhã até sete e quinze da noite. Eu saio de casa à noite e volto à noite (Ali entrevista realizada em 09 de Maio de 2017).

O tempo restrito ao trabalho, não ver a luz do dia, se concretiza nesse depoimento a consciência de uma vida reproduzida para o trabalho exaustivo, que envolve o período de deslocamento, bem como de trajeto. Esse depoimento de um imigrante do século XXI remete à descrição do conto de London (2001) sobre trabalhadores e suas condições de trabalho no início da revolução industrial no século XIX, os quais diante da longa jornada de trabalho não viam o sol nascer ou se pôr. Dois séculos depois os depoimentos se repetem, com o tempo roubado pelo trabalho como principal característica.

Além do tempo livre para fazer outra coisa que não esteja vinculada ao trabalho, Ali sente falta de exercer a profissão de mestre de obras, como fazia no Haiti, sendo essa habilidade desperdiçada em uma sociedade que não lhe permite outra oportunidade além do frigorífico.

Nessa mesma direção, Milene, Fonise e Claudete se queixam do tempo roubado. Milene ressalta não poder estudar e desenvolver outras atividades. Fonize fala do interesse que tem em encontrar outro emprego para poder cuidar da filha, depois de jornada laboral no período noturno. Todas elas, trabalhadoras do mesmo frigorífico, queixam-se da extensão de horas extras feitas durante a semana para compensar os sábados, quando, na maioria das vezes, não se trabalha.

A extensão de horas extras é cumprida principalmente por trabalhadores do setor da pendura, atividade que requer esforço manual para iniciar o abate de aves. Muitas vezes os caminhões com as aves chegam dos aviários no momento da troca de turnos, ou próximo ao horário de encerramento do turno noturno. Dessa forma, os trabalhadores que estão em atividade nesse turno são obrigados a permanecer trabalhando, para dar conta da leva de aves que pode ser perdida caso não sejam iniciados os procedimentos para o abate. Logo, esses trabalhadores têm que trabalhar até o próximo turno, que é finalizado na madrugada.

$\mathrm{O}$ descontentamento em permanecer mais horas trabalhando para abater o grande volume de aves é notório, principalmente pelo fato de que, na madrugada, entre meia noite e três horas da manhã quando se termina o turno seguinte, não há mais transporte coletivo 
público. Resistir a esse trabalho prolongado gera advertência e isso pode levar ao "gancho", e concomitantemente a demissão.

O gancho aparece nas falas dos trabalhadores entrevistados por Bosi (2013) como uma espécie de coerção dos superiores em relação aos trabalhadores quando descumprem solicitações, produtividade, abstenções ou regras de trabalho. Como infere (BOSI, 2013, p. 316), "Neste velho sistema taylorista, o cansaço e o erro parecem inevitáveis, e é por isto que as advertências soam como injustiças aos trabalhadores: 'incomodava pra caramba'. O erro, o retardo e a suposta lerdeza são componentes de um mesmo reflexo humano que exige repouso e descanso". Tamanha fiscalização é sentida como uma forma de repressão aos gestos e pedidos surdos e incontidos de trégua feitos pelo corpo e pela mente. Quando chega o momento de pausa há um alívio face ao trabalho que é celebrado e convertido em sentimento de festa.

Comemora-se a retomada do controle sobre o próprio corpo, sobre uma humanidade que é cancelada toda vez que a linha de produção deixa sua inércia. Mas é um sentimento passageiro. Dia após dia o ritmo é retomado de modo a reproduzir uma lógica que gera lucro para o capital, e a dor, o sofrimento e a repressão para os trabalhadores (BOSI, 2013, p. 316).

Essa recusa de prolongar o trabalho se dá também pelo esgotamento de realizar as funções por longo tempo, marcada pelo cansaço diante dessa atividade realizada por um período de oito horas.

A permanência do trabalho manual submetido ao ritmo das máquinas foi destacada nos estudos de Coutinho e Steim (2011). As autoras mostram os efeitos da crise dos anos 1970 com a acumulação flexível e afirmam que o trabalho manual continuou sendo o elemento principal para o desempenho das atividades nessa etapa produtiva. A despeito da reestruturação produtiva, com emprego de máquinas e tecnologia, o trabalho manual permanece imprescindível para a execução de várias etapas de produção.

As autoras também evidenciam o controle sobre a força de trabalho migrante, o que é dado principalmente pela situação de ilegalidade que torna essa mão de obra atrativa devido ao baixo custo. Além disso, a submissão às condições precárias de trabalho ocorre em razão da necessidade imediata que os imigrantes possuem de juntar pecúlio, o que se torna possível a partir de extensas jornadas de trabalho.

Como demonstra esta pesquisa, os frigoríficos são praticamente hegemônicos na incorporação de imigrantes haitianos no mercado de trabalho. A organização produtiva desse 
setor é um elemento que ajuda a compreender porque há resistência entre os trabalhadores brasileiros em preencher todas as vagas disponíveis, e por qual razão elas são aceitas pelos haitianos como o único remédio paliativo para uma situação imigratória.

Nesta pesquisa verifica-se que, do mesmo modo que os trabalhadores brasileiros do setor de frigoríficos estão insatisfeitos com suas condições de trabalho, os haitianos também estão. Na maioria das entrevistas, desponta o interesse dos trabalhadores do setor de encontrar outro emprego que seja mais criativo, menos monótono, com jornada de trabalho mais reduzida.

De acordo com dados do Sindicarne (2015), os trabalhadores dos frigoríficos brasileiros realizam, em média, uma frequência de 80 a 120 movimentos por minuto, muito além do que a legislação permite que é, no máximo, 35. Além disso, esse tipo de trabalho expõe o trabalhador a um risco 740 vezes maior de sofrer acidente de trabalho, 3,41 vezes maior de desenvolver depressão, além de assédio moral e acidentes de trabalho, como ferimentos e mutilações.

Esse tipo de situação leva à insatisfação do trabalhador bem como à falta de identificação com o processo de trabalho. Dessa forma, a despeito dos mecanismos de controle, os trabalhadores do setor de frigoríficos acabam sendo pouco produtivos, pois negam o trabalho, ao invés de se realizar nele.

As condições de trabalho pautadas nas relações fordistas-tayloristas, com desempenho de funções repetitivas, conduzidas ao ritmo dos cronômetros nas esteiras, desmotivam os trabalhadores de exercer essas funções. Diante disso, as pessoas acometidas pelo desemprego acabam aceitando essas oportunidades de trabalho quando não vislumbram outra possibilidade.

Ao abordar a transformação produtiva em diferentes países, Harvey (1989) ressalta que o fordismo-taylorismo não foi totalmente substituído em todas as regiões produtivas. Essas mudanças estruturais estão associadas ao desenvolvimento produtivo de cada país ou região, ou mesmo sua adaptação a novos arranjos.

O depoimento da imigrante Milene demarca a característica repetitiva do trabalho no Brasil, baseado no fordismo/taylorismo.

Eu estou trabalhando na Coopavel faz um ano e meio, eu trabalho na parte de descaldagem, de limpar, tirar pena e os restos. Então quando estou trabalhando com o frango nas mãos me lembro do meu trabalho no Haiti. Eu era Secretária, havia na minha frente pessoas que iam no escritório. Eu recebia as pessoas e orientava-as. Agora aqui (silencio) é isso que tenho e que faço. Eu deixei trabalho para vim aqui. Antes eu recebia as pessoas, via 
as pessoas, conversava, orientava agora eu só vejo frango na minha frente. (Silencio). Vir para o Brasil foi bom porque eu aprendi muitas coisas no Brasil, mas quanto ao trabalho, agora estou na verdade decepcionada com o que faço. (silencio) (Milene, entrevista realizada em 25 de Maio de 2017).

A compreensão de Milene sobre o sentido do trabalho nos frigoríficos difere do apresentado por Alli, que buscou na construção civil a realização de outro trabalho, que lhe desse possibilidade de aprender. Milene, por sua vez, ressalta a coisificação do trabalho que realiza, sendo submetida a fortes odores provocados pela descaldagem e pena de frango, como também pela retirada de restos das aves e das partes miúdas como barrigada, fígado e moela.

Ao descrever o trabalho em frigorífico, Mamed (2003) ressalta a feminização do trabalho, havendo funções que são requeridas por mulheres, sobretudo aos trabalhos internos da planta industrial em setores como escaldagem, desossa, corte, miúdos e embalagem, controlados por nórias e esteiras, ou ainda no serviço de limpeza, esse majoritariamente realizado por mulheres negras imigrantes, assim como o trabalho de pendura reservados para os homens negros haitianos que de forma geral ocupam os postos de trabalho mais externos, como os setores de pendura e sangria (abate) pesagem e transporte, motoristas de empilhadeira, agentes fiscalizadores e expedição dos produtos embalados. Por sua vez, o circuito produtivo também se constitui de setores mistos compostos por homens e mulheres, como a graxaria e sala de temperos, no entanto as funções de gerência e do Sistema de Inspeção Federal (SIF) são exclusivamente exercidas por homens.

Mamed (2017) ressalta ainda que a feminização tanto no campo, feita por mulheres que trabalham nos aviários, como nos frigoríficos, são marcadas pelos baixos salários, o que tem apresentado um amplo incremento dessa força produtiva por ser mais dócil, disciplinada e suscetível a maior exploração. Conforme essa autora, no Estado do Paraná o número de vagas de trabalho destinado para mulheres praticamente dobrou dos anos 2000 para 2010, de 642.935 vagas para 1.194.155 e, considerando especificamente a região Oeste, nesse período se constata um total de 57.852 para 128.408 , que segundo a autora resulta do efeito direto da instalação de frigoríficos nessa região.

No entanto, os salários não acompanham o crescimento das vagas, pois persiste conforme essa autora uma significativa diferença de rendimento médio entre os sexos. Em 2000 a mulher recebia 23\% menos que os homens, não havendo nenhuma mudança nos anos 2010. Isso remete portanto à desvalorização do trabalho feminino e a importância dele não só para realização do trabalho sob o ritmo fordista-taylorista, mas também por viabilizar pagar menos pela força de trabalho e ampliar assim os ritmos de acumulação de capital. 
A esse exemplo, ao questionar os haitianos entrevistados sobre a ocupação que desempenhavam no Haiti antes de migrar para o Brasil, percebe-se que muitos eram desempregados e trabalhadores informais. Entre os entrevistados, nenhum mencionou que trabalhava nas indústrias do Haiti antes da imigração. As funções relacionadas ao trabalho intelectual sobressaem, como as atividades de professor, engenheiro, mestre de obras, servente, e outras.

As funções realizadas se vinculam majoritariamente com o trabalho manual. Em alguns depoimentos havia aqueles que falavam que trabalhavam como professores e engenheiros. Ao serem questionados sobre a forma de contrato de trabalho, os haitianos ressaltam que trabalhavam informalmente, e por meio dos depoimentos explicam que diferente do Brasil no Haiti as legislações trabalhistas, contratos de trabalho são ainda mais precários.

Assim, muitos dos que migram partem em busca de melhores condições de vida; outros, tentam escapar de conflitos, perseguições e violações dos direitos humanos. Há ainda os que abandonam seus lares em decorrência de mudanças climáticas e desastres ambientais. Em alguns casos, a migração é determinada por uma escolha; em outros, por necessidade.

Além dos dados referentes à incorporação de trabalhadores no setor formal, a Agência do Trabalhador, por meio do Observatório do Trabalho, divulgou os principais setores incorporadores de mão de obra. O destaque é para a indústria de transformação, que envolve atividades como fabricação de açúcar bruto e abate de suínos e aves, seguidos da construção de peças e vestuários, rodovias e ferrovias.

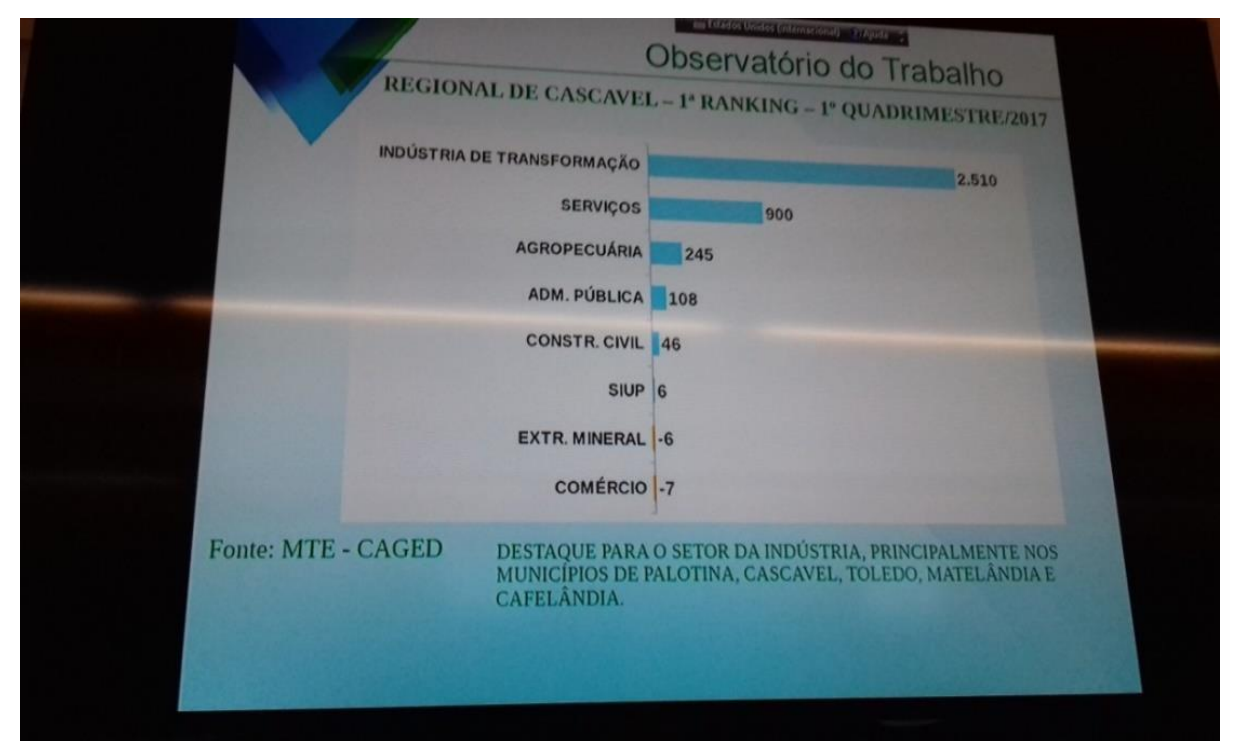

Foto 21 - Setores e vagas de trabalho Regional de Cascavel. Observatório do Trabalho ( PARANÁ, 2017) 
Todos os Municípios citados como maiores empregadores no Oeste do Paraná possuem grandes frigoríficos, sendo essa a atividade hegemônica de incorporação de mão de obra nessa região. O trabalho é considerado o motor da imigração no Brasil e, por mais precarizado que seja, é o que move a cada ano milhares de pessoas. Nesse sentido, Antunes (2005) destaca que:

Como o capital pode reduzir muito, mas não pode eliminar completamente o trabalho vivo do processo de criação de mercadorias, sejam elas materiais ou imateriais, ele deve, além de incrementar sem limites o trabalho morto corporificado no maquinário tecnocientífico, aumentar a produtividade do trabalho de modo a intensificar as formas de extração do sobretrabalho (da mais valia) em tempo cada vez mais reduzido (ANTUNES, 2005, p. 27).

As mudanças provocadas pela reestruturação produtiva alteram significativamente as relações econômicas das cidades e sua inclusão na economia internacional. Por conseguinte, essa inclusão é que determina a relação entre necessidade e demanda das cidades por força de trabalho. E, “[...] para essa etapa da dinâmica econômica dependerá da ligação dos espaços da produção na economia globalizada" (BAENINGER, 2016, p. 15). Baeninger (2016) destaca os efeitos sociais provocados pela transformação produtiva, que alcançam cada vez mais os espaços nacionais e passam a responder a uma demanda internacional.

Desde os anos 1980 o Brasil passou a receber um grande contingente migratório, com maior destaque, no período de 2009 a 2012, para nacionalidades como bolivianos, paraguaios, peruanos, chineses e haitianos.

Esse novo contexto é denominado por Wainer como produtor de migrantes, com uma lógica que difere da passada, visto que as periferias do sistema atraem grandes fluxos migratórios. Conforme Villen (2013, p 1), "Paralelamente, a posição de um país receptor de imigrantes 'periféricos' também compõe um novo cenário em relação ao passado imigratório".

Ao estudar o processo migratório em São Paulo pela lógica do trabalho, Villen (2013) dialoga com Sassen e, para a autora ocorre uma transnacionalização do processo migratório, que requer mão de obra cada vez mais qualificada. A internacionalização migratória se faz necessária em um contexto de intensificação da extração de mais valia, cuja necessidade é cada vez maior frente às novas demandas do processo produtivo.

Nessa conjuntura de produção de mercadorias e internacionalização da mão de obra, o trabalho feminino e de imigrantes torna-se atrativo e indispensável. Nesse processo, há um 
deslocamento da imigração dos países centrais para a periferia, que se coloca como nova rota para aqueles que abandonam seus países de origem em busca de melhores condições de vida.

Fatores como a crise nos países centrais e a concentração de multinacionais na região metropolitana de São Paulo são os maiores responsáveis por atrair trabalhadores imigrantes para a região, além de haver por parte do Estado uma maior visibilidade desses para atuar no mercado de trabalho brasileiro. Porém, quando se trata do processo migratório no Brasil, a demanda não se limita à mão de obra qualificada. É preciso considerar a presença dos invisíveis trabalhadores desqualificados, que chegam ao país atraídos pela possibilidade de conquistar melhores condições materiais de existência.

\begin{abstract}
A despeito desse desenho ideal da imigração e da visibilidade da demanda de profissionais estrangeiros qualificados para atuar no mercado de trabalho brasileiro, também se faz presente no contexto da cidade de São Paulo (e de outras cidades do Brasil) um outro perfil de imigrantes, com baixaqualificação e na maior parte provenientes de países periféricos (VILLEN, 2013, p. 05 e 06).
\end{abstract}

A soberania do Estado é uma alternativa para resistir a essa captura pelas organizações internacionais. A imigração se torna crise e um mito frente à captura do Estado e a sua conversão em controlador das fronteiras. Nesse contexto, pensar a inserção do imigrante é pensar, sobretudo, no resgate da autonomia do Estado com a implementação de políticas sociais que visam a recepção, integração e asilo de estrangeiros na sociedade. No mais, o imigrante precisa somar forças com o povo brasileiro para recuperar a autonomia do Estado, ou, no limite, desenvolver projetos de cunho nacionalista com ampla intervenção na economia e desenvolvimento de políticas sociais.

A questão da imigração coloca uma série de desafios a serem enfrentados. Em que medida é possível empreender resistência e luta pelo Estado, se isso tem se enfraquecido entre os trabalhadores brasileiros? Os imigrantes desenvolvem meios de organização política para impor sua demanda por políticas e reconhecimento de direitos? Como construir essa mobilização em um contexto de ausência de organização histórica enquanto classe que marca o trabalho em frigoríficos, ou de uma cultura política sinalada pela repressão frente a qualquer mobilização popular e de resistência? Como fazer uma luta nos espaços de trabalho como os frigoríficos, que pela forma como se organiza, coopta a organização dos trabalhadores nacionais, o que impõe maior implicação para aqueles que vêm de fora e se deparam com um sistema produtivo fechado? 
Há milhares de haitianos no Brasil e, além deles, o país recebe desde os anos 1980 grandes fluxos migratórios. Esse quadro requer o desenvolvimento de políticas que envolvam recepção, asilo e integração. Esse é o tripé para construir e transformar esse país a fim de respeitar, integrar e acolher os imigrantes.

Tarrius (1993) salienta que a mobilidade humana envolve o uso de determinados espaços como recursos no percurso migratório, seja ela interna ou internacional. A imigração envolve sentimentos que são intrínsecos ao imigrante, como de pertencimento e apropriação espacial. Porém, eles nem sempre coincidem com o lugar de residência, o que dificulta a classificação de imigrações temporárias ou permanentes. Essa subjetividade de cada migrante e suas experiências são os espaços de vida que incorporam os locais de passagem e permanência, mas também todos aqueles que fazem parte do seu conjunto de memória.

Os estudos migratórios devem buscar captar o espaço social da migração, pois todo imigrante já foi um emigrante, o que consiste segundo Sayad (1999), em uma dupla experiência social. É necessário conhecer a migração no âmbito da construção social, entendendo-a como fenômeno global que liga o local, o internacional e suas vinculações com os demais processos transnacionais.

Fernandes e Farias (2016) chamam a atenção para as redes informais na migração de haitianos para o Brasil, o que ocorre principalmente por meio da atuação dos "coiotes", com a ampliação da rede de tráfico de imigrantes por todo o trajeto que inclui Equador e Peru. Esse fato contribui para o aumento de imigrantes que chegam às cidades fronteiriças pela incorporação de novas rotas, como Venezuela, Bolívia e Argentina (FERNANDES E FARIA, 2016, p. 103).

As redes familiares são sempre destacadas pelos imigrantes haitianos e muitas vezes extrapolam os vínculos familiares. Isso se expressa no desejo de reunificação familiar de muitos haitianos que migraram para o Brasil deixando filhos no Haiti. Uma das histórias mais comoventes foi a de Therese, que deixou no Haiti duas filhas sob os cuidados da mãe, que veio a falecer em 2016. Sem parentes, as meninas passaram a ser cuidadas por um conhecido.

Eu preciso de ajuda, minhas filhas estão no Haiti, não tenho parente no Haiti, elas estão sendo cuidadas por conhecidos depois que minha mãe morreu ano passado e eu preciso trazê-las para o Brasil. Eu fico preocupada, são muito caras as passagens e precisa arrumar a documentação. Não temos dinheiro, e só meu marido trabalha agora e eu fico muito preocupada (Entrevista Therese, 02 de Maio de 2017). 
Therese conseguiu em 2018 trazer as duas filhas para o Brasil graças à atuação das redes de apoio. Contou com a ajuda da igreja anglicana por meio do reverendo Luiz Carlos Garbas que atua de forma direta junto a essa população de migrantes e mobilizou a rede religiosa nos países de trânsito, bem como outros cidadãos que sensibilizados com sua história contribuíram financeiramente. No entanto, a situação da família no Brasil tem sido dificultada pela falta de trabalho, onde constantemente é solicitado nas redes sociais ajuda financeira para pagar aluguel e alimentação.

A permanência do país ficou ainda mais difícil para um casal de desempregados, com quatro filhos no Brasil. No caso de Therese e sua família, fica evidente a importância das redes que não só permitiram a reunificação familiar, mas tem provido boa parte do sustento mínimo por meio de brasileiros sensibilizados. Situações como essa nos leva também a pensar no outro brasileiro, que não é xenófobo, que respeita as diferenças e sente-se solidário com as causas do outro, valores tão raros, mas que existem e podem ser disseminados para toda a sociedade.

A maior parte dos entrevistados possui filhos no Haiti. Consequentemente, há um desejo constante de trazê-los para o Brasil. De acordo com Clastles e Miller (2004), a reunificação familiar é um dos impulsionadores da imigração. Embora permitida na maioria dos países signatários da Convenção de Genebra de 1951, a reintegração familiar é inviabilizada pelas próprias condições financeiras, que são precárias entre os imigrantes ${ }^{34}$.

Outro exemplo dessa situação é apresentado por Renel, que vive no Brasil desde 2014, trouxe a esposa e planeja trazer os dois filhos que ficaram no Haiti. Desempregado há um mês, ressalta que gostaria que o valor que irá receber da rescisão trabalhista fosse o suficiente para ir até o Haiti buscar os filhos.

Ele disse que tem dois filhos no Haiti e queria trazê-los, ele precisa que o mais velho vem para o Brasil para ajudar cuidar do bebê que nasceu aqui, a esposa dele trabalha na Coopavel, e ele ganhou a conta lá e está desempregado agora. Ele e quer pegar acerto e ir no Haiti buscar os filhos (Entrevista Renel, realizada 2 de Junho de 2017 - Tradutor Taylor).

Fernandes e Faria (2016) enfatizam que os países desenvolvem mecanismos para conter o fluxo migratório via reunificação familiar. No Brasil, as cotas instituídas pela Normativa $n^{\circ} 97$ de 2012 são uma estratégia para conter o grande fluxo de imigrantes 
haitianos. Contraditoriamente, a concessão do visto humanitário para os haitianos leva o governo brasileiro a ser acusado de facilitar a entrada de estrangeiros. Essas acusações, feitas por políticos anti-imigrantes acusa o governo de ser conivente com o fluxo imigratório de haitianos, unicamente pelas facilidades de entrada no país. Porém, desconsideram a intenção subjetiva do migrante de chegar, estabelecer-se no país de destino e, posteriormente, reorganizar a reintegração familiar.

As entrevistas com haitianos em Cascavel evidenciaram novos desejos de fluxos migratórios, que dependem das experiências bem sucedidas ou fracassadas no Brasil. Novas rotas começam a ser delineadas, como Chile, México e Estados Unidos. Esse fato pode ser identificado na fala de Eddy, que migrou para o Brasil para se unir ao marido, que já não se encontra mais no país.

Vim pra cá 2012 - para encontrar meu companheiro aqui em Cascavel. Ele ficou tres meses comigo, já foi daqui para os Estados Unidos na Califórnia e está há seis meses preso lá. Não estou trabalhando agora, e moro com quatro primos, e a esposa de um deles. São todos casados e deixaram família no Haiti. Eu sobrevivo de ajuda, às vezes a mãe envia dinheiro do Haiti, e os primos que vivem junto me ajudam. Para melhorar a vida aqui tem que trabalhar. Fico aqui sem fazer nada tem que pagar tudo. La com meus país não pago casa, aluguel, porque posso morar com minha mãe, fico aqui tem que pagar aluguel e pagar tudo (Entrevista Eddy, 02 de Maio de 2017).

As novas rotas migratórias se constituem como características da migração entendida como parte da subjetividade humana, da consciência de que o Brasil como projeto migratório não tem sido compensado. Isso, como vimos, insere-se numa perspectiva de país periférico marcado por histórica exploração das relações de trabalho e extração de mais valia, qual é repassada aos imigrantes, impedindo dignas condições de sobrevivência, quando, a eles, além dos baixos salários, recai a mão de obra destinada às atividades mais degradantes e menos valorizadas pelos trabalhadores brasileiros, como o trabalho em frigorífico.

\footnotetext{
${ }^{34}$ A situação psicológica ou saúde de muitos imigrantes revelam uma importante demanda de políticas públicas que contemple situações de ansiedade e depressão que são impostas pelo processo migratório, como saudade da família, do país, preocupações e angústias resultantes das diversas separações causadas pelo ato de migrar.
} 


\section{CONCLUSÃO}

A imersão no tema da imigração se deu com a experiência de pesquisa junto aos haitianos em Cascavel e, como pesquisadora do Programa de Doutorado sanduíche, em que fui bolsista por um período de quatro meses pude viver como imigrante fora do país de origem. Ainda que a condição de imigrante temporária me colocasse em situação de conforto, estar fora do país foi uma possibilidade de não só melhor observar como vivem os haitianos no Brasil, mas sentir um pouco muitas das situações que os afligem, algo que percebi ainda na pesquisa de campo.

Situações como o contato com a língua, a luta por inserção e reconhecimento social, estar longe da família, dos amigos e do país são desafios difíceis de serem enfrentados pelos imigrantes. Aos haitianos essas situações são ainda mais tênues, pois se coadunam a elas o meio fundamental para garanti-las, que é o trabalho.

Nesse contexto, trago a epígrafe na letra da música "Movimento", cantada por George Drexler, que nos leva a refletir sobre o que somos se não migrantes? As músicas carregam memórias que são ancestrais, remetem às subjetividades intrínsecas em cada um, como o movimento por meio da migração, assim como se repete em um de seus refrãos: "somos uma espécie em viagem e nunca estamos quietos". O ser humano, independente de onde vive, carrega o movimento ou a migração e, a qualquer momento pode colocar-se a migrar, cumprindo o refrão que expressa essa característica de não ser nenhum sujeito de lugar nenhum “eu não sou daqui e tu tão pouco".

O refrão dessa linda canção reflete o movimento histórico como parte da subjetividade humana e ressalta a ênfase das discussões do primeiro capítulo desta tese. Recuperar as migrações como parte da subjetividade humana foi um desafio necessário frente ao constante mito que se pretende ser firmado, o da migração no sentido de um problema mundial ou o que se convencionou chamar de "crise migratória". Antes de tudo, pretendeu-se esclarecer no conjunto dos capítulos que as migrações não são recentes, tão pouco um fato específico do século XXI, mas elas estão vinculadas à reprodução da mais valia do capital em escala global, e tem se apresentado com muito mais intensidade na pós-revolução industrial com as transformações produtivas. Nessa perspectiva tentou-se demonstrar que a própria humanidade não pode ser pensada descolada do movimento de pessoas, de interconexões e encontros de culturas, formas de viver as quais juntas produzem a maior riqueza humana: a diversidade cultural. 
Dessa forma, a construção do mito da "crise migratória" é importante para a sociedade capitalista, uma vez que ele oculta a verdadeira crise existente: a humanitária.

À medida em que essa sociedade caracterizada pela globalização permite a mobilidade de mercadorias produzidas, tende por outro lado a impedir a mobilidade de seres humanos. Sua aceitação é condicionada às demandas do sistema produtivo e, fora dela é concebida como uma situação marginal e criminalizada. Dessa forma, romper as fronteiras carece de ideologias que a condene e a coloque como imoral e concomitantemente fazer do imigrante o responsável pelas contradições sociais, já que elas existem assim como o fenômeno migratório.

Até 2017, conforme dados da ACNUR (2017), a cada minuto oito pessoas são obrigadas a pedir refúgio no mundo. Os números também indicam que diariamente 44,5 mil pessoas são forçadas a se deslocar - ou uma pessoa a cada dois segundos. Dados como os de Guerra (2017) indicam que 244 milhões de pessoas vivem fora do seu país de origem, o que corresponde a $3,4 \%$ da população mundial. Esses dados corroboram a necessidade de superar a migração como um problema de segurança nacional, uma vez que a realidade obrigará milhares de pessoas a deixar tudo para trás para fugirem de guerras, crises políticas e econômicas, perseguições, desastres naturais e suas consequências ampliarão a mobilidade humana pelo mundo.

Existe, portanto uma crise humanitária travestida de crise migratória quando países criminalizam a imigração por meio da hostilidade com que têm tratado os imigrantes sem garantir-lhes recepção, asilo e integração. Dentre os vários exemplos dessa hostilidade e transgressão dos direitos humanos, alguns deles ocorreram em diversas partes do mundo, como na Itália, nos EUA, e por fim no Brasil. Essas ações revelam a verdadeira intenção das políticas que na maioria das vezes são reduzidas ao fechamento das fronteiras como resultado da ação do Estado.

Destaca-se dessa forma a negação da mobilidade mundial, ao passo que o imigrante ganha centralidade nos debates e agendas políticas, que contribuem para formar a opinião que criminaliza os grandes fluxos migratórios em detrimento da sensibilização e de sua aceitação. Assim, a crise migratória não passa, portanto, de uma ideologia, e se justifica na recusa de imigrantes que chegam aos países, sendo esse um importante discurso quando o sistema produtivo sofre alterações, causando desemprego estrutural e intensificação das relações de trabalho baseadas na exploração. Essas ideologias ganham sentido num contexto que visa ocultar as contradições geradas por uma sociedade cada vez mais excludente e de substituição do homem pela máquina. 
Desta forma é possível observar que o processo migratório perfaz a história da sociedade e se dinamiza com ela, estando totalmente influenciado pelas transformações das relações de produção. Umas das questões que se tem colocado é que crise tem afetado a sociedade: Migratória ou humanitária? Nesse estudo buscou-se responder que a primeira é uma ideologia, enquanto a segunda é um fato que resulta da imigração, e os efeitos negativos das reações mundiais ao enfrentar esse fenômeno.

Os imigrantes do passado e do presente se vinculam à organização produtiva baseada no fordismo/taylorismo, que, como mão de obra têm sido fundamental para manter e realizar em diferentes períodos históricos níveis degradantes de trabalho, sobretudo o trabalho manual. Além disso, as migrações forçadas tem se colocado como fenômeno cada vez mais frequente dada a existência de guerras, perseguições políticas, ideológicas e desastres naturais.

O século XXI é marcado pela globalização e, conforme discutido, esse fenômeno levou à perda de soberania nacional e a captura do Estado por grandes corporações que impuseram a diminuição de gastos públicos com políticas sociais, quando concomitantemente direcionaram investimentos públicos para o sistema privado. A fim de exemplificar parte de seus efeitos no Brasil, foi apresentada a análise da Empresa Coopavel, que sob o slogan do cooperativismo, tem sido beneficiada pelo Estado brasileiro e simultaneamente, se constituído como um braço dos grandes monopólios no Oeste do Paraná.

Essa análise se fez necessária por essa empresa aparecer como a principal incorporadora da mão de obra haitiana e por representar uma planta produtiva que tem sido a maior geradora de emprego do Estado do Paraná sustentada em uma organização produtiva fordista/taylorista caracterizada pelos baixos salários e impulsionada ou promovida via recursos públicos.

A projeção dessas empresas foi denominada por Lazzarini (2011) como capitalismo de laços, referida à escolha racional do Estado por meio de uma de suas autarquias, o BNDES, que seleciona e investe em determinadas empresas ou grupos empresariais. Foi visto nesse estudo que os frigoríficos foram um dos setores mais beneficiados nos últimos anos pelo banco público, e, nessa pesquisa, destacou-se a Coopavel como uma expressão desses empreendimentos, a qual cresceu e se expandiu devido a esse tipo de investimento. $\mathrm{O}$ retorno tem sido dado por meio do financiamento de campanhas eleitorais por empresários contemplados, aos políticos beneficiadores, os quais por meio do Estado tem privilegiado determinados grupos econômicos. A estreita relação entre Estado e empresas privadas se concretiza em benefícios para ambos, os quais têm a hegemonia de determinados grupos no 
poder estatal e privado, consolidando relações de troca que na verdade servem aos interesses daqueles que se apoderam do Estado.

Ao tecer esta conclusão deparo-me com o encontro no período pós-eleitoral divulgado pela mídia regional, entre o Presidente da República, eleito em 2018, e o atual presidente da Coopavel que reforça acordos via apoio do agronegócio na região do Paraná, um dos grupos responsáveis por eleger o candidato que obteve, na região, quase $70 \%$ dos votos válidos. Esse encontro pode ser interpretado como se revelam as relações baseadas no sistema clientelista. Por meio das relações de troca e favores, o novo Presidente é chamado a retribuir ao grupo recompensas ao apoio dado. Reforça-se assim uma relação que envolve financiamentos de campanha e troca de favorecimentos, as quais serão demonstradas na prática a partir do conjunto de políticas financeiras, benesses fiscais e perdão de dívidas da empresa nos próximos anos.

A empresa Coopavel se vincula à economia global por representar o atrelamento do interior do Brasil aos grandes oligopólios, sendo um braço deles no Estado, bem como por inserir a reprodução da mais valia em escala global.

As migrações internacionais correspondem à reprodução da mais valia em escala global, à inoperância do Estado frente aos monopólios e à falta de soberania, que também se manifestam como reflexo dos efeitos da globalização.

Os Estados conduzem suas ações limitadas para a garantia dos meios de reprodução dos interesses dos grandes grupos econômicos em detrimento de políticas migratórias. Isso ficou explícito quando comparada a ação do Estado brasileiro no que concerne as políticas imigratórias e o empenho do governo em voltar os fundos públicos para os financiamentos estratégicos de empresas privadas, denominadas de empresas domésticas como visto a partir da teoria política dos campeões.

Demonstrou-se a estreita relação entre os fundos públicos e empreendimentos privados via financiamentos contraídos junto ao BNDES por um dos frigoríficos que foi destaque nessa pesquisa e que aparece como o principal, quase exclusivo incorporador da mão de obra haitiana no Oeste do Paraná, a Coopavel. Até os anos 1980 essa empresa não possuía expressividade e apresentava crises financeiras com risco de falência, embora tivesse anteriormente se beneficiado de recursos públicos. No entanto, os anos 1990 foram decisivos para o seu reimpulsionamento, com grandes levas de financiamento para a implantação da nova planta produtiva com o abate de aves. Os anos 2000 marcam um grande volume de financiamento público via BNDES, com valores que ultrapassam mais de 490.414.300,00 
milhões em empréstimos. Atualmente a empresa se destaca entre as 400 maiores cooperativas do país e consolida uma prática, discutida nesse trabalho, de política dos campeões.

A Coopavel representa um grupo doméstico considerado como empresas brasileiras eleitas para serem beneficiadas com dinheiro do BNDES e fundos de pensões, como discutido no capítulo II.

Destarte, o Estado criou as condições para os frigoríficos se desenvolverem com vários benefícios que, além de financiamentos contraídos, contam também com benefícios fiscais, como isenção de impostos, financiamento da estrutura física para viabilizar a assimilação de inovação tecnológica, sem que isso signifique qualquer obstáculo para esse sistema produtivo, responsável pela produção de centenas de incapazes e doentes para o trabalho.

Esses trabalhadores são abandonados ao Estado, que ainda mantém a eles proteção social, e responsabiliza-se sozinho pelas consequências do adoecimento laboral. Por outro lado, os frigoríficos por gerarem trabalhadores doentes, tem a extrema rotatividade do trabalho que por sua vez desconstrói a falsa propaganda desse setor como gerador de emprego e renda. A propaganda difundida é desconstruída pelos próprios dados da rotatividade, que chega a $100 \%$, sendo, portanto, geradores do emprego quando inauguram uma nova planta produtiva com a criação de novos postos de trabalho, ou quando tem uma grande produção ao estilo toyotista, ensejando novas vagas conforme a demanda do que é solicitado pelo mercado.

Ao contrário disso, esses dados revelam o que ocultam os pseudos dinamizadores econômicos no Oeste do Paraná: o adoecimento associado ao rechaço de milhares de trabalhadores frente às condições fordistas/tayloristas de produção.

O termo cooperativismo, na região, tem sido questionado quanto à verdadeira essência do conceito, sobre o que de fato é uma cooperativa e em que medida essa empresa representa esse conceito? Isso demandaria outro estudo sobre o conceito quando aplicado a essas empresas vinculadas ao agronegócio, as quais cumprem a função de empresas capitalistas, explorando os sócios que acreditam ser proprietários, sendo nada mais que um braço dos grandes monopólios estendidos no Oeste paranaense. Ainda nessa perspectiva da subordinação do Estado aos grandes monopólios, identificou-se sua serventia quando regulamenta legislações que desregulamentam as leis trabalhistas, além de destinar investimentos públicos e projetar internacionalmente essas empresas.

Por outro lado, há uma diminuição da participação do Estado no que se refere as políticas voltadas para imigração. Na ausência do Estado, instituições religiosas aparecem cumprindo sua função e desenvolvendo serviços de atendimento e recepção, e 
simultaneamente se colocam como importantes agentes pressionadores do Estado na condução de políticas de acolhimento.

Sabe-se que a migração que permeia a história humana se intensifica no capitalismo e seus maiores picos correspondem ao que foi considerada a era das catástrofes devido as consequências das grandes guerras do século XXI, com milhares de deslocados.

Da mesma forma, evidenciou-se nesses capítulos que há uma intrínseca relação entre migração e transformações produtivas, haja vista a plena inclusão produtiva de imigrantes no passado e no presente, que diante do rechaço dos trabalhadores nacionais, têm se constituído em importantes exércitos industriais de reservas a serem recrutados. De igual maneira, o estímulo produtivo de cinco dólares ao dia pela empresa fordista não significou nos primórdios do fordismo a sedução dos trabalhadores no início do século XX nos EUA. As atrações dos frigoríficos, ainda sob a mesma lógica produtiva do trabalho em série e simplificado, igualmente não seduzem os trabalhadores do Oeste do Paraná.

Os referidos trabalhadores, embora dominados ideologicamente pela cultura do trabalho e da resignação, fortemente estabelecida e difundida pela ideologia do imigrante selecionado, oriundos do Sul do Brasil, rechaçam o trabalho em frigoríficos. Nem mesmo a forte ideologia do trabalho como virtude tem evitado o rechaço às formas de exploração, que no caso dos frigoríficos, representam $100 \%$ de rotatividade de trabalhadores.

Por isso, esses empreendimentos carecem de três condições: mão de obra abundante para sanar a rotatividade e o rechaço à sua organização, mão de obra barata, e o trabalho simplificado.

O estímulo produtivo da era fordista, seja no passado ou no presente, depara-se com um elo comum: o da resistência do trabalhador ao trabalho organizado sob tais moldes produtivos. Da mesma forma, seja na era fordista no século XX ou no século XXI, no Oeste do Paraná, a referida resistência levou à incorporação dos imigrantes como alternativa. Esse tipo de empreendimento mantém a produção fordista/taylorista com a incorporação de mão de obra massiva sem superá-la com as tecnologias esse ritmo produtivo, uma vez que conforme vimos desde Marx, o trabalho cooperado e simplificado ainda garante maior extração de mais valia.

Isso se intensifica em países subdesenvolvidos como o Brasil, que coloca a difícil realidade de ser imigrante na periferia, em que a extração de mais valia é intensificada.

No contexto do Brasil, a transição das relações escravistas para o trabalho assalariado não foi suficiente para eliminar a exploração, pois tais relações de trabalho continuam 
existindo ocultadas por relações jurídicas que sob a ilusão do trabalho livre conservam desde o período colonial os baixos salários.

Na perspectiva de um país periférico, o Brasil se tornou nova rota migratória para os fluxos de haitianos, delineada por vários motivos como se tentou brevemente esboçar: a crença deles sobre o Brasil e a possiblidade do país oferecer melhores condições de vida que as vivenciadas até então no Haiti. Ademais, a insegurança e pobreza, as intempéries naturais, intensificadas com o terremoto de 2010, além da ampla destruição das principais cidades com a maior densidade de pessoas e instituições estatais estimularam a constituição do Brasil como nova rota migratória. Associado a isso, o discurso dos ex-presidentes Lula e Dilma, do Brasil como país acolhedor e sua abertura para a recepção de imigrantes haitianos como uma ação de sensibilização frente aos destroços e consequências do terremoto, tornou-se lugar atrativo.

Outro elemento importante foi o bom estado da economia brasileira que, em 2010 se configurava como a sexta economia mundial, embora isto não tenha significado redistribuição de renda. Incorpora-se, também, a esses fatores as relações geopolíticas entre Brasil e Haiti, as quais foram apontadas nos estudos sobre a imigração haitiana no Brasil como um importante elemento que fez do Brasil nova rota migratória do povo haitiano. Sua maior expressão se deu com a presença do exército brasileiro naquele país, via operação MINUSTAH. Também foram destacados como importantes delineadores desses novos fluxos, o fechamento das fronteiras, principais rotas migratórias como EUA, França e Canadá, as quais obrigaram esses fluxos a traçarem um reordenamento que fizeram do Brasil um novo destino.

Todos esses elementos somados à cultura da diáspora, que marca e caracteriza o Haiti desde a ocupação do país pelos EUA em 1914, tem produzido uma população de migrantes. A migração para outros territórios é uma possibilidade de manter mínimas condições de vida para os que ficaram no Haiti por meio do envio de remessas, bem como o principal meio de prover novas diásporas.

As migrações haitianas estão vinculadas às migrações transnacionais, sendo um meio de reprodução da mais valia vinculada às relações de trabalho dinamizadas pelas migrações. Assim, esse fenômeno é concebido como a internacionalização da mais valia, e tem favorecido a exploração da mão de obra em diferentes territórios cujas taxas de lucros são remetidas a grandes monopólios, a exemplo da vinculação entre haitianos e frigoríficos no Oeste do Paraná.

A presença deles no Estado decorreu inicialmente das políticas denominadas pela literatura de guest workers, onde empresários da região buscaram as primeiras levas desses 
imigrantes frente a necessidade de mão de obra manual que encontrava-se disponível nas fronteiras do norte do Brasil.

Os fluxos migratórios impuseram demandas aos Estados e, no caso do Brasil, pode-se inferir que o grande fluxo de haitianos foi fundamental para impulsionar o Estado para minimamente recebê-los e contribuir para o enfrentamento de outros fluxos que poderão vir a migrar para o país. Entre os avanços, ainda que tímidos e precários, indicam uma ação mais estruturada para o atendimento de venezuelanos do que foi com os haitianos, e tem permitido desenvolver um conjunto de procedimentos inexistentes até então.

Dentre essas mudanças, muitas são de viés paliativo, pois se desenvolveram no tocante às demandas nas fronteiras, como os abrigos provisórios, presença do exército e maior quantidade de servidores públicos para agilizar o atendimento de 500 venezuelanos que chegavam por dia até 2018. Dentre essas ações de maior impacto, destaca-se a Nova Lei de Migração sancionada desde 2017 que prevê ações conjuntas entre o Governo Federal, Estados e Municípios, a exemplo do plano de interiorização com apoio financeiro do Governo Federal aos Municípios que se interessarem em acolher os venezuelanos, sendo isso algo que não houve com os haitianos.

Ainda no contexto da lei, um de seus maiores legados: o reconhecimento da imigração e sua vinculação aos direitos humanos e a concomitante tentativa de superação da pecha do imigrante como ameaça nacional vigente no antigo Estatuto do Estrangeiro. Sabe-se que o aspecto legal normativo não será suficiente para suprimir a concepção do imigrante como ameaça nacional, inclusive eles ainda permanecem pairando sobre ela, sendo um bom exemplo os vetos que se justificaram pela soberania nacional que remetem às heranças do Estatuto do Estrangeiro.

Diante de uma cultura estabelecida da imigração como ameaça nacional, coloca-se a fragilidade da Nova Lei de Migração em se consolidar nos seus principais propósitos, entre estes superar a pecha do migrante atrelado à ameaça à soberania nacional, e a garantia dos direitos humanos. Ao finalizar esse texto, mais uma ação do governo federal acena para isso quando o atual governo, através do Itamaraty, oficializa a saída do Brasil do Pacto global para migrações oficializada no dia 08 de janeiro de 2019, menos de um mês após sua assinatura. A justificativa estabelece o mesmo discurso que tentou ser suprimido no Estatuto do Estrangeiro que concebia o imigrante como ameaça, ao passo que fere um dos principais legados da Nova Lei de Migração, que é a garantia dos direitos humanos. O Brasil, ao se retirar desse pacto reforça o senso comum de que ele é necessário como uma medida para conter os fluxos migratórios, e, na perspectiva do presidente Jair M. Bolsonaro, o país deve 
controlar esses fluxos, assim como se controla a entrada de estranhos em casa. Com esse viés retrógrado, o atual presidente ao rechaçar os imigrantes recupera a pecha suprimida pelo menos no tocante da lei e coloca por outro lado em risco milhares de emigrantes brasileiros que vivem fora do país. Esse discurso, contraditoriamente reforça a ideia de que a migração se constitui como problema para o Estado Brasileiro ou como "crise migratória" quando se tem imigrantes no país. Porém emigrar ainda ganha aspectos positivos, já que a nação se "livra"de brasileiros quais serão benéficos fora, sobretudo por enviar remessas financeiras. No que se refere essa decisão, os emigrantes brasileiros serão os mais afetados justamente por ser seu número superior ao de imigrantes e ter sua situação ignorada por ela simplesmente não ser concebida como atribuição do Estado brasileiro, que contraditoriamente negará dessa forma a responsabilidade dos países para com os brasileiros emigrantes evitando a transgressão de direitos a uma migração segura, ordenada e regular.

É a partir do enfrentamento entre o Estado e os fluxos migratórios que se ordenam políticas sociais, nesse sentido, ao compreender a imigração haitiana no Brasil, pode-se inferir que ela deu margem para o surgimento do visto humanitário, contribuiu para que o mesmo fosse estendido como direito, atendendo outras características específicas do processo migratório, também contemplado e possível como extensão para os demais imigrantes a partir da Nova Lei de Migração. O êxito dessas políticas, como já ressaltado, é insuficiente perto da demanda existente, no entanto os avanços são também resultados do protagonismo dos haitianos e outros imigrantes via participação na construção da nova lei de migração, intermediados por instituições de apoio, como a Missão Paz em São Paulo e a Pastoral do Migrante em vários rincões do Brasil, as quais introduziram discussões que construíram a nova Lei.

Os haitianos são hoje no Brasil o maior grupo de imigrantes trabalhadores com um total de mais de 88.459 pessoas e o avanço da Nova Lei de Migração é também resultado da pressão dos grandes fluxos e redes de apoio frente ao conflito entre brasileiros e imigrantes à ausência do Estado, que por sua vez foi obrigado a desenvolver abrigos estatais, interiorização com recursos federais em parceria com os Municípios, e implementou assim alguns dos pressupostos dessa nova legislação.

A atuação do sistema público com prefeituras, que são estimuladas ou sentem-se solidárias em intervir no processo migratório dos venezuelanos, já indicam um avanço considerável como resultado desse enfrentamento, diferentemente do que ocorreu com os haitianos, que não contaram com algumas características e suportes, sendo essas reduzidas aos 
mínimos e precários abrigos, bem como alguns transportes para deslocamentos rumo a outras regiões do Brasil.

A intervenção foi limitada às empresas privadas que iam até o Acre contratar essa mão de obra para o desempenho de trabalho manual nas regiões sul e sudeste do Brasil, e foi por meio dessa medida que as primeiras levas de imigrantes chegaram ao Oeste paranaense.

Os frigoríficos atraem mão de obra em decorrência da política guest workers desenvolvidas por outros empresários, como empresas vinculadas à demanda de mão de obra na construção civil que trouxe as primeiras levas. Logo dispensados, começaram a ter nos frigoríficos a única possibilidade de inserção laboral, ao passo que se deparam com um sistema produtivo extremamente fechado para os mesmos devido à condição de imigrantes negros e pobres. As presenças dos haitianos em grandes fluxos acentuam o discurso de que eles são os que provocam os baixos salários, que, corresponde à base de sucesso dos frigoríficos, além do trabalho simplificado, barato, com demanda de grandes contingentes de trabalhadores. Por isso, ser a mão de obra capacitada ou não é irrelevante para esse tipo de organização produtiva. Os haitianos dão sequência à rotatividade existente entre trabalhadores submetidos a essa planta produtiva e perpetua assim como em outros processos migratórios a realização do trabalho manual.

A seleção de alguns haitianos por empresas que os buscaram no Acre se procedeu pelo domínio do espanhol por alguns, que foi fundamental para estabelecer o primeiro contato com os demais trabalhadores e a empresa assim, a primeira inserção deles na língua portuguesa. Nessa amostra foi observado o espanhol como um critério que colocou alguns haitianos à frente dos demais para serem selecionados.

Ao serem questionados sobre os motivos que os levaram a migrar, a variável trabalho se expressou como o principal motivo que conduziu as migrações internas de haitianos no Brasil. Porém ela não deixa de estar relacionada a outras variáveis, sobretudo as redes étnicas e familiares que foram fundamentais para empreender o processo migratório após a chegada das primeiras levas de haitianos trazidos por empresários da cidade e da região.

Assim, os frigoríficos não foram impulsionadores diretos das migrações haitianas, em que os trabalhadores vieram exclusivamente para neles trabalharem, almejando esse tipo de trabalho. Mas foram e continuam sendo a única viabilidade de inserção laboral frente ao desemprego. No caso dos que chegaram posteriormente às primeiras levas, assim como para os primeiros que ficaram desempregados, os frigoríficos são o único meio de se inserir no sistema produtivo, quando outra forma de inserção não aparece no horizonte. 
Dos que trabalhavam em outros setores, depois de demitidos, seja pela condição do próprio contrato de trabalho temporário ou por outro motivo, não vislumbraram outra oportunidade diante de um sistema produtivo fechado. Percebe- se também que a situação de muitos ao chegarem ao Brasil com visto, remete e reflete a uma condição de vida ou melhor posição econômica ainda quando viviam no Haiti, como ter educação superior e o exercício de uma profissão. Isso lhes viabilizou migrar com visto, algo semelhante ao que foi a fuga de cérebro no Brasil ou a emigração de milhares de brasileiros de classe média para outros países, sobretudo para os EUA na década de 1980. Da mesma forma sonhos se cruzam e os haitianos também projetaram os seus no Brasil, e visaram a possibilidade de desempenhar sua profissão e serem mais valorizados que no Haiti.

Ao mesmo tempo, a rotatividade também revela a renúncia dos trabalhadores nacionais a essas condições degradantes de trabalho, que fazem dos haitianos um importante exército industrial de reserva, prontos para serem postos nas fileiras da exploração e do adoecimento.

Portanto, ao que se difunde como a "galinha dos ovos de ouro" na economia regional nada mais é que a rotatividade de trabalho, de forma a não produzir novas vagas, mas a substituição de trabalhadores resistentes a essas formas de exploração ou adoecimento. Como há um exército de reservas disponível, os estrangeiros garantem a taxa de lucro, ao passo que o trabalho simplificado dos frigoríficos não sofre diminuição do ritmo de produtividade na substituição de um trabalhador por outro.

Essa simplificação é, assim como a disponibilidade de uma grande quantidade de mão de obra, a expressão da manutenção de formas de organização do trabalho sob o estilo fordista/taylorista que pode a qualquer momento substituir o trabalhador sem que isso infira na produtividade final da empresa. Por outro lado, o baixo salário e as doenças são consequências diretas que acarretam custos ao Estado e ao trabalhador, deixando livre as empresas para substituir e lucrar com os exércitos de reservas disponíveis.

$\mathrm{O}$ trabalho manual vincula as migrações em diferentes tempos históricos, porém os haitianos se colocaram como parte de um novo tipo de trabalho voltado para a produção em frigoríficos, como resultado da inovação produtiva recente por meio da implantação das plantas produtivas de abate de aves desde os anos 1980. Sob a velha organização produtiva fordista/taylorista que, desde seus primórdios em 1914, nos EUA, ou antes nos frigoríficos desse país, tem como característica o trabalho simplificado, repetitivo e monótono que causa rejeição dos trabalhadores nacionais, sobretudo em períodos de crescimento econômico que 
pode permitir-lhes libertar-se dessas relações de trabalho ou encontrar outro vínculo laboral menos degradante.

O século XXI apresenta dessa forma, trabalhadores que rechaçam o fordismo/taylorismo, ao passo que assim como foi no século passado, coloca mais uma vez ao imigrante a viabilidade de ser o substituto da mão de obra nacional, não como escolha ou desejo para realizar esse trabalho, mas como única possibilidade de se inserir produtivamente, sobretudo em um mercado de trabalho marcado pelo fechamento do sistema produtivo, restando apenas os frigoríficos como meio de inserção laboral e busca pela sobrevivência.

Ao testar a hipótese dessa pesquisa para verificar se os frigoríficos têm contribuído para impulsionar o processo migratório de haitianos no Oeste do Paraná, pode-se inferir que eles foram fundamentais para viabilizar a vinda dos haitianos para a região, visto que o processo migratório se compreende não a partir das primeiras levas, impulsionadas por empresários, sobretudo da construção civil, que inicialmente os buscaram, mas daqueles que chegaram ao longo do tempo ou nos diferentes anos. Os primeiros vieram contratados por empresas para trabalhos temporários e, quando demitidos, após os três primeiros meses começaram a enfrentar o sistema produtivo de Cascavel, que desde sempre se mostrou fechado, e os obriga a buscar nos frigoríficos alguma possibilidade de se reinserir na produção.

$\mathrm{Na}$ amostra pesquisada não apareceram os frigoríficos e empresários do ramo buscando diretamente essa mão de obra na fronteira do Acre, porta de entrada dos primeiros que chegaram ao Brasil, exceto um dos entrevistados, que evidenciou a presença do frigorífico Coopacol de Cafelândia como contratante direto, o que não ocorreu com os demais. Assim, em nenhum outro depoimento foi constatada a presença de frigoríficos de Cascavel nas fronteiras do norte do país para buscar haitianos. Isso também não foi constatado na mídia local, que divulgou apenas a FAG como uma das empresas que buscaram os haitianos para o trabalho na construção civil.

No entanto, isso não significa que os frigoríficos não tenham protagonismo no processo migratório. Como visto, a mão de obra haitiana foi importante para a FAG no primeiro momento e temporariamente. Vários depoimentos indicaram a demissão de haitianos após os três primeiros meses de trabalho. As primeiras levas engendraram a migração laboral para outro ramo produtivo: a produção de carnes; e passaram a ingressar nesse mercado de trabalho quando os demais se fecharam.

Assim, todos os haitianos chegados inicialmente e demitidos foram reinseridos nos frigoríficos. Além disso, os recém-chegados, quando conseguem trabalho, impulsionados 
pelas redes de apoio, também se inserem nos frigoríficos e, se isso não acontece, encontramse desempregados. Tal situação é ainda mais grave com as mulheres, das quais mais de $90 \%$ da amostra que tem acesso ao trabalho está vinculada estritamente aos frigoríficos e, quando desvinculadas deles, o desemprego aparece como situação ocupacional.

Os haitianos, dessa forma, constituem-se como um importante exército industrial de reservas fundamental em um sistema produtivo que o demanda, sobretudo em período de crescimento econômico. Ademais, os frigoríficos já foram experimentados pela maioria dos trabalhadores desempregados que já passaram por experiências laborais em Cascavel, constituindo-se no principal desempregador de haitianos na cidade, o que também se explica pela rotatividade que já aparece entre eles. Os frigoríficos são hoje quase que hegemonicamente os empregadores desses imigrantes, tendo assim a imigração no Oeste se vinculado à presença de empresas na primeira etapa, mas se dinamizando posteriormente por meio das redes de apoio, o que mais uma vez reforça a teoria da migração como processo contínuo.

As redes de apoio são fundamentais para impulsionar as migrações das demais levas que não param de chegar ao Município, e faz dele a cidade com o maior número de haitianos no Estado do Paraná, com uma população estimada entre quatro e cinco mil imigrantes.

O fechamento do sistema produtivo e o não domínio da língua portuguesa fez com que os haitianos desenvolvessem estratégias para driblar essas dificuldades de inserção laboral, como andar em grupos em que um deles saiba falar minimamente o português para procurar trabalho, bem como pela disciplina e bom comportamento dos que se encontram trabalhando, que por meio de indicações podem inserir outros que estão desempregados.

Percebe-se então que a demanda produtiva do setor de frigoríficos foi contemplada com a imigração, embora não esteja ligada diretamente a ele, beneficiando-se dela quando essa mão de obra passa a estar disponível na região. Dessa forma, a imigração haitiana em Cascavel está vinculada à indústria de frigoríficos e não há como pensá-la sem estabelecer relação com esse setor.

Como apontado, o trabalho barato é uma característica desse setor, e os frigoríficos na região representam uma extensão dos oligopólios e, como um polvo, estende por todo o território paranaense seus tentáculos. O domínio da produção se dá pelo viés horizontal e vertical, como a tecnologia genética das aves, insumos consumidos como alimentos para essa cadeia, os antibióticos, que, por final, num complexo de grandes oligopólios, impõem o preço da força de trabalho nos frigoríficos. Os trustes estão travestidos de uma falácia escondida no 
cooperativismo, se alimentam dele e das benesses que eles usufruem que engana tanto trabalhadores do campo como das cidades e os submetem ao domínio tecnológico.

Uma vez aderida a inovação tecnológica, ela age como uma força atrativa que só puxa e não permite possibilidades de retorno à situação original devido ao endividamento frente à adesão constante de novas tecnologias. A esses trabalhadores resta apenas a sujeição às imposições do sistema produtivo tanto em termos da inovação tecnológica com intensificação de suas dívidas junto a esses grandes grupos, como no acato aos procedimentos de manejo com a criação de aves. Os haitianos assim como tem sido aceitos em outros países, merecem a recepção e integração social no sistema produtivo com abertura de oportunidades para além dos frigoríficos. A concepção da integração econômica e produtiva reverte em outros benefícios para o conjunto das sociedades envolvidas no processo migratório. Há, dessa forma, conforme indicado nesse estudo, o desafio de quebrar a resistência das demais áreas produtivas de Cascavel para que abram o sistema produtivo aos imigrantes e possam usufruir dos benefícios que eles proporcionam. Outro viés é alterar a maneira de como o imigrante tem sido privilegiado seja pelas agendas políticas de governos ou políticas de migração, as quais os limitam à concepção de ameaça nacional, resultados da crise humanitária, alcunhada pelos países de "crise migratória" baseadas nas políticas de controle sobre as fronteiras.

Em seis anos da presença desses imigrantes em Cascavel, foram percebidas duas ações ou intervenções do poder público municipal, uma vinculada à educação e outra à organização coletiva. Embora tímidas e limitadas enquanto ações do poder público, elas não podem ser desconsideradas, pois enfrentam dois grandes problemas: a organização coletiva e o respeito a diversidade cultural com o combate ao preconceito. Esse se faz via difusão e divulgação da cultura haitiana na cidade, enquanto a organização deles em associação foi um importante instrumento para que coletivamente possam impor e demandar políticas de imigração e luta por direitos.

Dessa forma, para além desses restritos projetos, embora importantes, a presença de cinco mil haitianos no Município requer mais do poder público, com envolvimento na criação e aprovação de projetos de leis que visam à integração econômica na sociedade, de forma a estimular, via legislação, a abertura de um sistema produtivo que se encontra totalmente fechado aos haitianos.

Os benefícios de inclusão são muito mais positivos que as consequências da exclusão. Por isso, cabe às organizações de apoio, ou às denominadas redes vinculadas às diferentes igrejas em Cascavel, a conscientização em torno do atendimento a essa população e da 
importância desse fortalecimento enquanto redes que trabalham com um mesmo público e objetivo: receber e integrar os imigrantes no Município.

A união dessas redes é fundamental para que possam se fortalecer e pressionar o Estado a desenvolver políticas de inclusão social. Nessa perspectiva, são levadas a direcionar suas ações e se tornarem fortes aparelhos pressionadores do Estado, ao passo que contribuem para denunciar a transgressão de direitos, sobretudo o que significa a transgressão do trabalho em frigoríficos seja para trabalhadores nacionais ou estrangeiros.

Quanto aos aparelhos de fiscalização do Estado, como o Ministério do Trabalho, diante da sua extinção já anunciada e cumprida pelo atual governo, fica difícil imaginar alguma intervenção, já que ele extinguirá o mínimo que existia. Um exemplo disso é a fiscalização da produção de carnes deixada a cargo dos próprios produtores ou dos frigoríficos. Isso pode ameaçar a qualidade dos alimentos tendo em vista que essas empresas são constantemente autuadas nesse quesito com legislações fiscalizadoras, imagina a produção deixadas a cargo delas mesmas com a "autofiscalização"? Não só a produção de alimento poderá ser comprometida, mas as relações de trabalho no interior desses frigoríficos poderão ser ainda mais precarizadas, quando se elimina o Ministério do trabalho. A ausência de um aparelho fiscalizador por mínimo que seja, poderá acarretar em profundos impactos de degradação laboral e transgressão dos direitos trabalhistas não só para os imigrantes, mas para todos os trabalhadores submetidos a esse sistema produtivo. Assim, se há um abrandamento do Estado em fiscalizar essas empresas adoecedoras de pessoas, isso não parece uma ação que será implementada, sobretudo devido a maior influência do setor do agronegócio no Governo, bem como devido a eliminação de órgãos que teriam a competência de realizar essa fiscalização e ampliar o rigor a essas empresas.

Por fim, na perspectiva discutida, se faz necessário resgate da soberania nacional, pois já foi constatado sobretudo em países clássicos de migração, a relação positiva entre um Estado forte e migração. Um Estado forte é sinônimo de fortalecimento de relações que tenham o objetivo de garantir políticas de seguridade social aos trabalhadores, além de eficaz agente de fiscalização e punição em relação às empresas predatórias da força de trabalho como os frigoríficos, os quais adoecem os trabalhadores e os lançam sob a proteção estatal, sendo simples e fácil transferir o problema quando não se responsabiliza ou é responsabilizado por sua causa.

O contexto de elevado desemprego e de estado neoliberal não apontam luzes para melhorar a situação de vida para os imigrantes no país o que demanda deles maior organização e integração as diversas formas de luta e resistência existentes no Brasil. 


\section{REFERÊNCIAS BIBLIOGRÁFICAS}

ABPA. Exportações de carne de frango totalizam 463, 1 mil toneladas em julho.

Publicado em: 01 de Ago. de 2018. Disponível em: <http://abpa-

br.com.br/noticia/exportacoes-de-carne-de-frango-totalizam-4631-mil-toneladas-em-julho-

2503> Acesso em 03 de Dez. de 2018.

ACNUR. Faces do Refúgio. Publicado em 24 de Jul.de2018. Disponível em:

<http://www.acnur.org/portugues/2018/07/24/faces-do-refugio/ > Acesso em 24 de Jul. de 2018.

Dados sobre refúgio no Brasil, 2016. Disponível em:

http://www.acnur.org/portugues/recursos/estatisticas/dados-sobre-refugio-no-brasil/> . Acesso em 19 de Dez. de 2017.

Dados sobre Refúgio no Brasil. Publicado em 2017. Disponível em:

$<$ http://www.acnur.org/portugues/wp-content/uploads/2018/01/refugio-em-numeros-20102016.pdf> Acesso em 28 de Mar. de 2018.

.Protocolo de 1967 Relativo ao Estatuto dos Refugiados s/d. Disponível em: <http://www.acnur.org/fileadmin/Documentos/portugues/BD_Legal/Instrumentos_Internacio nais/Protocolo_de_1967.pdf> Acesso em 13 de Set. de 2018.

ALVES, Giovanni. Crise estrutural do capital, trabalho imaterial e modelo de competência notas dialéticas. In: ALVES, Giovanni et al. (orgs).Trabalho e Educação: contradições do capitalismo global. $1^{\circ}$ ed. Maringá, PR: Práxis, 2006.

.Trabalho e mundialização do Capital. Bauru: Praxis, 1999.

. A nova ofensiva neoliberal no Brasil. Palestra na UFTPR, Curitiba, 2017

Transmitido em 08 de Agosto de 2017. Disponível em:

<https://www.facebook.com/giovanni.alves.56/videos/10155630482129375/ > Acesso em 08 de Ago. de 2017.

ALESSI. Mariana L. Batista. A imigração de Haitianos para o Brasil. Revista Conjuntura Global, Curitiba, Volume 2, n. 2, 2013, p. 82-86.

ANDERSON, Perry. Balanço do neoliberalismo. In: SADER, Emir \& GENTILI, Pablo (orgs.) Pós-neoliberalismo: as políticas sociais e o Estado democrático. Rio de Janeiro: Paz e Terra, 1995

A NOTÍCIA. Os países mais bem sucedidos em tecnologia de ponta. Publicado em 24 de mar. de 2017. Disponível em: http://www.administradores.com.br/noticias/tecnologia/ospaises-mais-bem-sucedidos-em-tecnologia-de-ponta/117868/> Acesso em 01 de Ago. de 2018.

ANTUNES, Ricardo. Adeus ao trabalho? Ensaios sobre as metamorfoses e a centralidade do mundo do trabalho. $9^{\text {a }}$ Ed. São Paulo: Cortez, 2003. 
O caracol e sua concha: ensaios sobre a nova morfologia do trabalho. São Paulo: Boitempo,2005.

ARANGO, J. Dificuldades e dilemas de las políticas de inmigración. In. Arbor Ciencia Pensamiento y Cultura clxxxi 713 mayo-junio, 2005 17-25

España: una experiencia migratoria singular. In. Encuentro "Cuarenta años de migraciones en México y España (1977-2017)”. El Colegio de México, 11 de Octubre de 2017.

ARANGO et al. Inmigrantes el continente móvil. Vanguardia Dossier, n.22, Enero/Marzo 2007.

ARANGO J. et al. La imigración en el ojo del huracán. Anuário CIDOB de la imigración nueva época, Barcelona, 2017.

ARAUUJO José R. C. Políticas Públicas, estruturas estatais e migrações no Brasil. In.

BAENINGER, Rosana et al . Imigração Haitiana no Brasil. Jundiaí: Paco Editorial, 2016.

ASSIS, Gláucia de Oliveira, MAGALHÃES Luiz Felipe A. Migrantes indesejados? A "diáspora" haitiana no Brasil e os desafios à política migratória brasileira. In. SILVA, Sidney A. ASSIS; Glaucia O. Em Busca do Eldorado: O Brasil no contexto das migrações nacionais e internacionais. Manaus:EDUA, 2016.

AVICULTURA INDUSTRIAL. Para evitar falência Globoaves vai a Justiça. Publicado em 09 de Ago. de 2016. Disponível em: <https://www.aviculturaindustrial.com.br/imprensa/paraevitar-falencia-globoaves-vai-a-justica/20160809-085400-h073> Acesso em 07 de Set. de 2018.

AVISITE. Frangos: tendências da disponibilidade per capita até 2028. Publicado em 27 de Ago. de 2018. Disponível em:

<https://www.avisite.com.br/index.php?page=noticias\&id=19155> Acesso em 26 de Out. de 2018.

BACK, Luani et al. A transferência de tecnologia por intermédio de prestadores de serviços em indústrias frigoríficas: um estudo de caso. In. Revista Eletrônica Sistema e Gestão, v. 11, n. 1, 2016. Disponível em:

<http://www.revistasg.uff.br/index.php/sg/article/view/399/400> Acesso em 01 de Ago. de 2018.

BAENINGER, Rosana; PERES, Roberta. Migração de Crise: A migração haitiana para o Brasil. R. bras. Est. Pop., Belo Horizonte, v.34, n.1, p.119-143, jan./abr. 2017. Disponível em: <http://www.scielo.br/pdf/rbepop/v34n1/0102-3098-rbepop-34-01-00119.pdf> Acesso em 22 de Jul de 2018.

BAENINGER, Rosana, et al. ( Orgs) Imigração Haitiana no Brasil. Jundiaí: Paco Editorial, 2016. 682p. 
BAENINGER, Rosana. Migração Transnacional: elementos teóricos para o debate p. 13-43,. In. BAENINGER, Rosana et al. (Orgs) Imigração Haitiana no Brasil. Jundiaí: Paco Editorial, 2016.

BAPTISTE. C. J; VIEIRA J.M. Catástrofe ambiental e migração internacional: a perspectiva dos migrantes haitianos na cidade de São Paulo, p. 557-608. In. BAENINGER, Rosana et al. (Orgs) Imigração Haitiana no Brasil. Jundiaí: Paco Editorial, 2016.

BAPTISTE, Patrícia G. Imigração e trabalho doméstico: o caso português. Teses, Lisboa, 2011. Disponível em: <https://www.om.acm.gov.pt/documents/58428/179891/Tese34_WEB2.pdf/c75f97ed-01ff4349-8c50-79b22cb677ab> Acesso em 23 de out. de 2018.

BARCELOS, Regis. L. G. MOCELIN Daniel G. Ciência e Mercado. Impasses na Institucionalização de práticas empreendedoras em uma universidade pública brasileira. Revista Brasileira de Ciências Sociais, vol. 31, núm. 92, octubre, 2016, pp. 1-26. Disponível em: <https://www.redalyc.org/pdf/107/10747709006.pdf> Acesso em 13 de Dez. de 2018.

BAUMAN, Zygmunt. Estranhos à nossa porta. $1^{\text {a }}$ Ed. Rio de Janeiro: Zahar,2017. Globalização: as consequências humanas. Rio de Janeiro:Zahar, 1999.

BNDES. Consulta a operações do BNDES 2018. Disponível em: $<$ https://www.bndes.gov.br/wps/portal/site/home/transparencia/consulta-operacoesbndes/consulta-a-operacoes-bndes/!ut/p/z0/fY25DoJAEIafxYJyM-

sZLTeeEYyJhcFtzIALrMIssuP19qKVleV_fT9oiEET3m2ObB1h2eqDHh2jSThfDbYyWu5k V6phuFD7WdgfSwlr0P8LLcGer1etQKeO2DwZ4oROxh8tebZ8S79PgSxcZQLJDZKvsTGU WgxkO_G3klFklvBjVYbY-

Z8AhatNg6kzXny5n8des5luctA1ciEsZQ7iP4P6opPXQ3XeuIUeAQ!!/> Acesso em 28 de Ago. de 2018.

BOSI, Antônio de Pádua. Acumulação de Capital e trabalho na Agroindustrial no Oeste do Paraná de 1960 a 2010. História Unisinos pg: 94-106, Janeiro/Abril 2016. Disponível em: <http://revistas.unisinos.br/index.php/historia/article/view/htu.2016.201.09/5249> Acesso em 03 de Dez de 2018.

Dos açougues aos frigoríficos: uma história social do trabalho na produção de carne, 1750 a 1950. Rev. Hist. Reg., Ponta Grossa, PR, v. 19, n. 1, p. 83-103, 2014a. Disponível em: <http://www.revistas2.uepg.br/index.php/rhr/article/view/5441/4089> Acesso em 14 de Jan. de 2019.

Corpos feridos, trajetórias interrompidas pela agroindústria brasileira: duas leituras a partir de Bertolt Brecht e Upton Sinclair. Varia História, Belo Horizonte, v. 30, n. 53, p. 571- 592, mai./ago. 2014b.Disponível em: <http://www.scielo.br/scielo.php?pid=S010487752014000200012\&script=sci_abstract\&tlng=pt> Acesso em 14 de Jan. de 2019.

A recusa do trabalho em frigoríficos no oeste paranaense (1990-2010): a cultura da classe. Diálogos, Maringá, PR, v. 17, n. 1, p. 309-335, jan./abr. 2013. Disponível em: 
<http://periodicos.uem.br/ojs/index.php/Dialogos/article/view/36045/18656> Acesso em 14 de Jan. de 2019.

História das relações de trabalho na cadeia produtiva avícola no Brasil (19702010). Rev. Hist. Reg., Ponta Grossa, PR, v. 16, n. 2, p. 400-430, 2011

BORTOLOTO, Claudimara. SOUZA, A. B. ; STEIN, L. M. Imigração haitiana de São Paulo à Cascavel: experiências e trajetórias de deslocamentos de imigrantes de grandes centros urbanos para o interior do Brasil. In: VIII Seminário Nacional de Sociologia e Política - UFPR Curitiba, 2017, Curitiba. VIII Seminário Nacional de Sociologia e Política UFPR Curitiba, 2017.

BRASIL, Sistema Nacional de Cadastro e Registro de Estrangeiro - SINCRE, 2018a.

Banco Central do Brasil. Transferência de remessas para o Haití. Governo Federal -período 2010 a Maio de 2017 em milhões de reais, 2018b

. Relações Exteriores. Sessão informativa sobre a assistência aos imigrantes venezuelanos. Publicada em 29 de Junho de 2018c. Disponível em: $<$ http://www.itamaraty.gov.br/pt-BR/notas-a-imprensa/19101-sessao-informativa-sobre-aassistencia-aos-migrantes-venezuelanos> Acesso em 05 de Set. de 2018.

Decreto $\mathbf{N}^{\circ}$ 9.199, DE 20 de Novembro de 2017a. Regulamenta a Lei no 13.445 , de 24 de maio de 2017, que institui a Lei de Migração. Disponível em: http://www.planalto.gov.br/ccivil_03/_ato2015-2018/2017/decreto/D9199.htm> Acesso em 02 de Dez. de 2017.

Portal Brasil: Número de trabalhadores imigrantes no país cresceu $131 \%$. Publicado em 07 de Dezembro de 2017b. Disponível em: $<$ http://www.brasil.gov.br/economia-e-emprego/2016/12/numero-de-trabalhadoresimigrantes-no-pais-cresceu-131> Acesso em 07 de Julho de 2017.

.Instituto de Pesquisa de relações internacionais - IPRI: as 15 maiores economias do mundo. Publicado em Abril de 2017. Disponível em: $<$ http://www.funag.gov.br/ipri/index.php/indicadores/47-estatisticas/94-as-15-maioreseconomias-do-mundo-em-pib-e-pib-ppp> Acesso em 28 de Dezembro de 2017.

Ministério da Defesa: o Brasil na Minustah (Haiti). Brasília, 2014. Disponível em:< http://www.defesa.gov.br/relacoes-internacionais/missoes-de-paz/o-brasil-na-minustahhaiti> Acesso em 14 de Abr. de 2017.

Ministério do Trabalho e Previdência Social, Ministério da Justiça : Despacho conjunto, 30 de Abr. de 2014. Disponível em:/<http://acesso.mte.gov.br/cni/conselhonacional-de-imigracao-cnig.htm> Acesso em 02 de Jul. de 2017.

Portal Brasil: Brasil trabalha na nova Lei de Imigração. Publicada em 16 de Jan. de 2015. Disponível em: < http://www.brasil.gov.br/cidadania-e-justica/2015/01/brasiltrabalha-na-elaboracao-de-nova-lei-de-imigracao> Acesso em 09 de Jul. de 2017. 
.Embrapa. Soja em números safra 2016/2017. Publicado em Junho de 2017.

Disponível em:< https://www.embrapa.br/soja/cultivos/soja1/dados-economicos $>$ Acesso 06 de Jul. de 2017.

.Polícia Federal: Ministério da Justiça e Segurança Pública, Brasília, 2016. Disponível em:< http://www.pf.gov.br/imprensa/estatistica/estrangeiros $>$ Acesso em 06 de Abr. de 2017.

Ministério do Trabalho. Conselho Nacional de Imigração. Brasília: Resolução Normativa n97. Brasília: Diário Oficial da União. 13 de janeiro, p. 96, 2012.

Resolução Normativa do Conselho Nacional de Imigração n. 97, de 12 de janeiro de 2012. Dispõe sobre a concessão de visto permanente previsto no art. 16 da Lei n. 6.815, de 19 de agosto de 1980, a nacionais do Haiti. Brasília, 2012.

Estatudo do Estrangeiro. Lei $\mathbf{N}^{\mathbf{0}}$ 6.815, DE 19 de Agosto de 1980. Disponível em: <http://www.planalto.gov.br/ccivil_03/Leis/L6815.htm> Acesso em 12 de Dez. de 2017.

BOURDIEU, Pierre. Sociologia. São Paulo: Ática, 1983.

CACHÓN, Lorenzo. Diez notas sobre a imigração na Espanha. In. ARANGO et al. Inmigrantes el continente móvil. Vanguardia Dossier, n.22, Enero/Marzo 2007.

CAMBRICOLI, Fabiana. Africanos e haitianos são hostilizados no Paraná após suspeita de ebola. Jornal Estadão. Publicado em 13 de Out.de 2014. Disponível em: $<$ http://saude.estadao.com.br/noticias/geral,africanos-e-haitianos-sao-hostilizados-no-pr-apossuspeita-de-ebola-imp-,1575862> Acesso em 25 de Jul. de 2017.

CANALES, Alejandro I. La migración Internacional en los modelos neoclássicos. Una perspectiva crítica. Revista Huellas de la Migración. Universidade Autonoma do Estado do México. No 3, enero-junio, 2017. P. 12-36.

CAMPOS, Ana Cristina. Trabalhadores imigrantes crescem $131 \%$ no Brasil de 2010 a 2015. EBC Agência Brasil. Publicado em 07 de Dezembro de 2016. Disponível em:< http://agenciabrasil.ebc.com.br/economia/noticia/2016-12/trabalhadores-imigrantes-crescem131-no-brasil-de-2010-2015> Acesso em 12 de Jul. de 2017.

CARDIN, Eric G. Laranjas e sacoleiros na tríplice fronteira: um estudo da precarização do trabalho no capitalismo contemporâneo. Cascavel: EDUNIOESTE, 2011.

Fundamentos teóricos para o Estudo das migrações. In. COLOGNESE, Silvio. Novas fronteiras para o saber sociológico. Porto Alegre: Evangraf, 2013.

CARNEIRO, Gustavo. Terra estrangeira - interior do Paraná se consolida como destino de migrantes. Folha de Londrina. Publicado em 01 de Junho de 2017. Disponível em: <http://www.folhadelondrina.com.br/reportagem/terra-estrangeira-interior-do-parana-seconsolida-como-destino-de-migrantes-980334.html Acesso em 07 de Jun de 2017.

CARVALHO, Ruy de Quadros. Capacitação tecnológica, revalorização do trabalho e educação. In: FERRETI, C. J. ZIBAS, Dagmar M. L. MADEIRA. F. R. FRANCO. Maria. 
L.P.B. Novas tecnologias, trabalho e educação: um debate multidisciplinar. $9^{\text {a }} \mathrm{Ed}$. Petrópolis, RJ: Vozes, 1994.

CASCAVEL. Agência do Trabalhador, 2017.

CASTLES Stepen, HAAS Hein de. MILLER, Mark j. The Age of Migration: international Population Movements in the Modern World. $5^{\text {a }}$ Ed, PALGRAVE MACMILLAN, London, 2014.

CASTLES, Stephen; Mark J. Miller. La era de la migración: Movimientos internacionales de población em el mundo moderno. Universidad Autonoma de Zacatecas,Mexico:2004.

CATVE. Cascavel é a cidade com maior número de haitianos do Paraná. Publicado em 30 de Ago. de 2017a. Disponível em<

https://www.terra.com.br/noticias/brasil/catve/videos/cascavel-e-a-cidade-com-maiornumero-de-imigrantes-haitianos-do-parana,8482782.html> Acesso em 28 de Fev. de 2018.

Coopavel está no ranking das maiores e melhores da exame: desempenho em vendas líquidas entre 2016/2017. Disponível em:

$<$ https://catve.com/noticia/6/227310/coopavel-esta-no-ranking-das-maiores-e-melhores-daexame> Publicado em 05 de Set. de 2018. Acesso em 09 de Set. de 2018.

CAVALCANTI, Leonardo et. al. A inserção dos imigrantes no mercado de trabalho brasileiro. Relatório Anual 2017. Série Migrações. Observatório das Migrações Internacionais; Ministério do Trabalho/ Conselho Nacional de Imigração e Coordenação Geral de Imigração. Brasília, DF: OBMigra, 2017.

CÊA, Georgia S. S; NEIDE, Tiemi M. Processo de trabalho em frigoríficos e as possibilidades de constituição de novas sociabilidades na luta coletiva pela saúde do trabalhador. In. VII Seminário do Trabalho, RET, 2010. Disponível em:

$<$ http://www.estudosdotrabalho.org/anais-vii-7-seminario-trabalho-ret2010/Georgia_Cea_Neide_Murofuse_PROCESSO_DE_TRABALHO_EM_FRIGORIFICOS _E_AS_POSSIBILIDADES_DE_CONSTITUICAO_DE_NOVAS_SOCIABILIDADES.pdf $>$ Acesso em: 08 de jun. de 2018.

CGN. Haitianos debatem criação de associação. Publicado em 12 de Abr de 2014. Disponível em: 〈https://cgn.inf.br/noticia/87828/haitianos-debatem-criacao-de-associacao > Acesso em 23 de jun. de 2018.

CHESNAIS, F. A mundialização do capital. São Paulo: Xamã, 1996.

COOPAVEL. Coopavel fatura 2,12 bilhões e presta resultados em assembleia. Ed. Março de 2017. Disponivel em: <http://www.coopavel.com.br/revistas/coopavel-fatura-r-212bilhoes-e-apresenta-resultados-em-assembleia/> Acesso em 15 de Set. de 2018.

CONARE. Caminhos do Refúgio. Publicado em 26 de Set. de 2016. Disponível em: <http://caminhosdorefugio.com.br/tag/conare/> Acesso em 23 de Mar. de 2018.

CORAZZA, Maycon. População Haitiana na região se aproxima de três mil. Jornal Gazeta do Paraná, 06 de Jan. de 2016. Disponível em: 
$<$ http://cgn.uol.com.br/noticia/161207/populacao-haitiana-na-regiao-se-aproxima-de-tresmil> Acesso em 14 de Jan. de 2016.

COTINGUIBA, Marília L. P; COTINGUIBA, Geraldo C. Fronteiras e aspectos do rito de mudança de categoria jurídico política dos sujeitos haitianos em mobilidade transnacional no Brasil. In. BAENINGER, Rosana et al . Imigração Haitiana no Brasil. Jundiaí: Paco Editorial, 2016.

COUTINHO. Beatriz Isola. Reestruturação produtiva e imigração laboral nas indústrias de confecção metropolitanas: uma perspectiva comparativa entre São Paulo e Nova Iorque / Beatriz Isola Coutinho - 2013139 f. ; 30 cm Dissertação (Mestrado em Ciências Sociais) Universidade Estadual Paulista, Faculdade de Ciências e Letras, Campus de Araraquara. Disponível em: http://wwws.fclar.unesp.br/agenda-pos/ciencias_sociais/2829.pdf $>$ Acesso em 18 de Set. de 2018.

COUTINHO. B. Isola; STEIN. Leila M. Imigração laboral intrarregional: ilegalidade e trabalho precário nos complexos têxteis-vestuários metropolitanos. In revista Ariús, Campina Grande, v. 17, n.1, jan./jun. 2011. Disponível em:

$<$ http://150.165.110.251/arius/01_revistas/v17n1/00_arius_v17_n1_2011_edicao_completa.pd f\#page=12> Acesso em 19 de Ago. de 2018.

COUTO, Kátia. Do Caribe para a Amazônia: a migração fomentando a conexão entre duas regiões. In. SILVA, Sidney A. ASSIS, Glaucia O. Em Busca do Eldorado: O Brasil no contexto das migrações nacionais e internacionais. Manaus:EDUA, 2016.

COUTRY METERS HAITI. População do Haiti. Publicado em 22 de Jul. de 2017.

Disponível em:< http://countrymeters.info/pt/Haiti> Acesso em 22 de Jun. de 2017.

CRUZ. Luiz Carlos. Funcionários da Globoaves param por dois dias para pedir melhores salários. Gazeta do Povo. Pulicado em 04 de Dez. de 2012. Disponível em:

https://www.gazetadopovo.com.br/economia/funcionarios-da-globoaves-param-por-dois-diaspara-pedir-melhores-salarios-23h1ozfvorsp1omuoafcj2mvi/> Acesso em 22 de Jan. de 2019. DELFIM, Rodrigo B. Nova lei de migração é aprovada pelo senado e segue para sanção presidencial. Publicado em 18 de Abril de 2017. Migra mundo. Disponível em:< http://migramundo.com/nova-lei-de-migracao-e-aprovada-pelo-senado-e-segue-para-sancaopresidencial/> Acesso em 05 de Jul de 2017.

DELGADO, G. C. 1985. Capital financeiro e agricultura no Brasil: 1965-1985. São Paulo, Ícone/UNICAMP.

DEMARTINI, Zeila B. F. Pesquisa histórico sociológica, relatos orais e Imigração. In. DEMARTINI Zeila B. F. TRUZZI, Oswaldo. (orgs). Estudos Migratórios: perspectiva metodológica. DUFSCAR, São Carlos, 2005.

DONDA JÚNIOR, Alberto. Fatores influentes no processo de escolha da localização agroindustrial no Paraná: estudo de caso de uma agroindústria de aves. $2002.141 \mathrm{f}$. Dissertação (Mestrado em Engenharia de Produção). Programa de Pós-Graduação em Engenharia de Produção, Universidade Federal de Santa Catarina, Florianópolis, 2002.

EBERHARDT, Leonardo Dresch. Haitianos em Cascavel, Paraná: história, trabalho e saúde / Dissertação (mestrado) - Fundação Oswaldo Cruz, Escola Nacional de Saúde 
Pública Sergio Arouca, Rio de Janeiro, 2017. Disponível em:

$<$ https://www.arca.fiocruz.br/bitstream/icict/24113/2/leonardo_dresch.pdf > Acesso em 06 de Set. de 2018.

EL PAÍS INTERNACIONAL. 630 Refugiados rejeitados pela Itália chegam na Espanha entre lágrimas e abraços: "goodbay, my friend" . Publicado em: 18 de Jun. de 2018. Disponível em:

<https://brasil.elpais.com/brasil/2018/06/17/internacional/1529234182_442456.html> Acesso em 22 de Ago. de 2018.

EL PAIS. Paulo Sérgio de Almeida | presidente do Conselho Nacional de Imigração.

"É urgentíssimo aprovar a nova lei de imigração" Almeida reconhece as dificuldades para lidar com a vinda de haitianos ao Brasil. Publicado em 08 de Junho de 2015.

Disponível em:

<https://brasil.elpais.com/brasil/2015/05/28/politica/1432823272_043541.html> Acesso em: 05 de Jul. de 2017.

FAG CENTRO UNIVERSITÁRIO. Grupo de 44 haitianos chega à Fag e assina contrato. Publicado em 30 de Jan. de 2012. Disponível em: < https://www.fag.edu.br/noticia/5063> Acesso em 04 de Out. de 2018.

FARIA, Andressa V. Os haitianos e o refúgio ambiental. In. BAENINGER, Rosana et al . Imigração Haitiana no Brasil. Jundiaí: Paco Editorial, 2016.

FÉLIX, Jackson; COSTA, Emyli. Após assalto e agressão a comerciante, imigrantes tiveram acampamentos queimados e foram expulsos de Pacaraima (RR), na fronteira com o país vizinho, no sábado (18). Cidade amanheceu com ruas vazias. G1. Publicado em:19 de Ago. de 2018. Disponível em:

<https://g1.globo.com/rr/roraima/noticia/2018/08/19/pacaraima-tem-ruas-desertas-aposconfronto-entre-brasileiros-e-venezuelanos.ghtml> Acesso em 22 de Ago. de 2018.

FERNANDES, Durval; FARIA Andressa V. A diáspora haitiana no Brasil: processo de entrada, características e perfil. In. In. BAENINGER, Rosana et al . Imigração Haitiana no Brasil. Jundiaí: Paco Editorial, 2016.

FERNANDES, Florestan A integração do negro na sociedade de classes. $3^{\mathrm{a}}$ Ed. São Paulo: Ática, 1978.

Capitalismo dependente e classes sociais na América Latina. $2^{\text {a }}$ Ed. Rio de Janeiro: Zahar Editora, 1975.

FLEMING, Melissa. Let's help refugees thrive, not just survive. Ted Global, 2014. Disponível em:

<https://www.ted.com/talks/melissa_fleming_let_s_help_refugees_thrive_not_just_survive/tr anscript?referrer=playlist-refugees_welcome\#t-61821> Acesso em 22 de jul de 2018.

FERREIRA, Luiz C. Após 13 anos missão brasileira comandada no Haiti se aproxima do fim. Publicado em 20 de Maio de 2017. EBC Agência Brasil. Disponível em:

$<$ http://agenciabrasil.ebc.com.br/internacional/noticia/2017-05/apos-13-anos-missao-no-haiticomandada-pelo-brasil-se-aproxima-do-fim> Acesso em 12 de Jul. de 2017. 
FETRACOOP. Dentro de 4 dias, greve deve parar frigoríficos. Publicada em 09 de Ago. de 2012. Disponível em: <http://www.fetracoop.com.br/noticia/333/dentro-de-4-dias-greve-deveparar-frigorificos> Acesso em 09 de Set. de 2018.

FINKLER, A.L. Os problemas de saúde dos trabalhadores e a relação com o processo de trabalho em frigoríficos. Cascavel, 2007. 95 p. Trabalho de conclusão de curso (Graduação em Enfermagem) - Unioeste.

FRAGA, Érica. Investimento em educação no Brasil é baixo e ineficiente. Folha de São Paulo. Publicado em 19 de Fev. de 2018. Disponível em:

$<$ https://www1.folha.uol.com.br/educacao/2018/02/investimento-em-educacao-no-brasil-ebaixo-e-ineficiente.shtml> Acesso em 23 de Nov. de 2018.

FETRASCONPAR. Federação dos trabalhadores da Construção e do Mobiliário do Estado do Paraná. Haitianos chegam do Acre para trabalhar em obras em Cascavel. Publicado em 30 de Jan. de 2012. Disponível em:

<http://www.fetraconspar.org.br/01backup/index.php?option=com_content\&view=article\&id $=4265$ :haitianos-chegam-do-acre-para-trabalhar-em-obras-em-cascavel\&catid=20:ultimasnoticias\&Itemid=80> Acesso em 04 de Out. de 2018.

G1 ECONOMIA. Greve dos caminhoneiros. Publicado em 04 de Jun. de 2018. Disponível em: 〈https://g1.globo.com/economia/ao-vivo/greve-de-caminhoneiros-maio-de-2018.ghtml〉. Acesso em 13 de Jan. de 2019.

.OESTE E SUDOESTE DO PARANÁ. Justiça decreta falência de frigorífico com dívidas no Oeste do Paraná. Publicado em:01 de Dez. de 2014. Disponível em: $<$ http://g1.globo.com/pr/oeste-sudoeste/noticia/2014/12/justica-decreta-falencia-de-empresasdo-frigorifico-com-dividas-no-parana.html> Acesso em 06 de Set. de 2018.

GOMARASCA, Paolo. Dossiê: Dilemas éticos das migrações. Direitos de excluir ou dever de acolher? A migração forçada como questão Ética. REMHU, Rev. Interdiscip. Mobil. Hum., Brasília, v. 25, n. 50, ago. 2017, p. 11-24

GONÇALVES, Juliana. Cascavel se torna a casa de 44 haitianos. Gazeta do Povo.

Publicado em:30 de Janeiro de 2012. Disponível em: <http://www.gazetadopovo.com.br/vidae-cidadania/cascavel-se-torna-a-casa-de-44-haitianos-7mm89ruwe0f81bi21dfu730b2> Acesso em 11 de Ago. de 2017.

GRANDO, Guilherme Dotti. Luta de classes, trabalhadores e frigoríficos em Cascavel-PR (1980-2015). 2017. 96 f. Dissertação (Mestrado em História) - Universidade Estadual do Oeste do Paraná, Marechal Cândido Rondon, 2017. Disponível em:

<http://tede.unioeste.br/handle/tede/3156> Acesso em 14 de Out. de 2018.

GRAYLEY, Monica. Migrantes já somam 258 milhões de pessoas em todo o mundo, aponta a ONU. Agência Brasil. Publicado em 18 de Dez. de 2017. Disponível em: <http://agenciabrasil.ebc.com.br/internacional/noticia/2017-12/migrantes-ja-somam-258milhoes-de-pessoas-em-todo-o-mundo-aponta-onu> Acesso em 24 de Jul. de 2018. 
HALL, Stuart. A identidade cultura na pós-modernidade. 10. ed. Rio de Janeiro: DP\&A, 2010.

HAMERI, A. Technology transfer between basic research and industry, Tecnovation, Vol. 16, pp. 51-57, 1996.

HANDERSON, Josép. Diáspora Haitina. Revista Horizontes Antropológicos, ano 21, n.43, Porto Alegre, 2015.

HARVEY, David. Condição Pós-Moderna. 8 ed. São Paulo: Loyola, 1989.

HOBSBAWM. Eric. Era dos extremos: o breve século XX 1914-1991. 2a Ed. São Paulo: Companhia das Letras, 2012.

HUMAN RIGHTS WATCH. Relatório Mundial 2016 Haiti. Disponível em< https://www.hrw.org/pt/world-report/2016/country-chapters/285575> Acesso em 25 de Jul. de 2017.

IANNI, Octávio. Teorias da globalização, $10^{a}$ Ed. Rio de Janeiro: Civilização Brasileira, 2002.

.A sociedade global. $11^{\text {a }}$ Ed. Rio de Janeiro: Civilizaçaõ Brasileira, 2003.

. Capitalismo, violência e terrorismo. Rio de Janeiro: Civilização Brasileira, 2004.

IBGE. Paraná - Cascavel -População estimada em 2016. disponível em:

<http://cidades.ibge.gov.br/xtras/perfil.php?codmun=410480> Acesso em 17 de Jul. de 2017.

IPARDES. Paraná em números, 2005. Disponível em:

<http://www.ipardes.gov.br/index.php?pg_conteudo=1\&cod_conteudo=1> Acesso em $06 \mathrm{de}$ jun. de 2018.

Disponível em:

Os detalhes da fusão entre Sadia e Perdigão. Publicado em 13 de Jul. de 2011.

<https://istoe.com.br/146549_OS+DETALHES+DA+FUSAO+ENTRE+SADIA+E+PERDIG $\mathrm{AO} />$ Acesso em 14 de Set. de 2018.

JH NOTÍCIAS. Moradores invadem abrigo em Roraima expulsam imigrantes venezuelanos. Publicado em 18 de Ago. de 2018. Disponível em $<$ https://jhnoticias.com.br/brasil/moradores-invadem-abrigo-em-roraima-e-expulsamimigrantes-venezuelanos/> Acesso em 29 de Set.de 2018.

LAÍNY, Laís. Encontro reunirá haitianos de Cascavel. CGN publicado em 12 de Abr. de 2014. Disponível em: <https://cgn.inf.br/noticia/87714/encontro-reunira-haitianos-decascavel> Acesso em 14 de Jan. de 2019.

LAZZARINI, SÉRGIO G. Capitalismo de laços: os donos do Brasil e suas conexões. Rio de Janeiro:Elsevier, 2011. 
LEITE, Márcia de Paula. Modernização Tecnológica e relações de trabalho. In FERRETI, C. J. ZIBAS, Dagmar M. L. MADEIRA. F. R. FRANCO. Maria. L. P.B. Novas tecnologias, trabalho e educação: um debate multidisciplinar. 9a Ed. Petrópolis, RJ: Vozes, 1994.

LINDNER Júlia. Três em cada quatro brasileiros veem Bolsonaro, no caminho certo. Diz Ibope. Estadão. Publicado em 13 de Dez. de 2018. Disponível em:

$<$ https://politica.estadao.com.br/noticias/geral,tres-em-cada-quatro-brasileiros-veembolsonaro-no-caminho-certo-diz-

ibope,70002644676?utm_source=facebook\%3Anewsfeed\&utm_medium=socialorganic\&utm_campaign=redes-

sociais\%3A112018\%3Ae\&utm_content=\%3A\%3A\%3A\&utm_term\&fbclid=IwAR2H9pcNs OuadUEKYldvXMAxP4Um7HrGEbyRGWaTdSQmZBPiokYJKziXki8> Acesso em 13 de Dez. de 2018.

LONDON, Jack. O Herege. In Contos. $1^{\circ}$ Edição. São Paulo, Editora Expressão Popular, 2001 pg: 87-112.

MAGALHÃES, Luis F. A. Imigração haitiana no Estado de Santa Catarina: contradições da inserção laboral. In. BAENINGER, Rosana et al . Imigração Haitiana no Brasil. Jundiaí: Paco Editorial, 2016.

MAIA, Gustavo. Bolsonaro critica lei de migração e fala em barrar "certo tipo de gente". Publicado em: 12 de Dez. de 2018. Disponível em:<

$<$ https://www.bol.uol.com.br/noticias/2018/12/12/bolsonaro-critica-lei-migracao-certo-tipode-gente-dentro-de-casa.htm> Acesso em 13 de Jan. de 2019.

MAMED, Letícia H. Trabalho, Migração e Gênero. A trajetória da mulher haitiana na indústria da carne brasileira. Revista Temáticas, Campinas, 25, (49/50): 139-176, fev/dez. 2017. Disponível em:

<https://www.ifch.unicamp.br/ojs/index.php/tematicas/article/viewFile/3237/2398> Acesso em 12 de Out. de 2018.

MAMED, Letícia;LIMA, Eunice O. Movimentos de trabalhadores haitianos no Brasil nos últimos cinco anos: a rota de acesso pela Amazonia Sul Ocidental e o acampamento público de imigrantes do Acre. In. BAENINGER, Rosana et al . Imigração Haitiana no Brasil. Jundiaí: Paco Editorial, 2016.

MANICA, Carmem Aparecida. A migração haitiana e a inserção no mercado de trabalho na cidade de Cascavel/PR. 2018. 138 f. Dissertação (Mestrado em Ciências Sociais) Universidade Estadual do Oeste do Paraná, Toledo, 2018.

MARX, Karl; ENGELS, Friederich. A Ideologia Alemã. $2{ }^{\text {a }}$ Ed, Editora Martins Fontes, São Paulo, 1998.

Manifesto do Partido Comunista. 2001. Disponível em:

<http://www.portalabel.org.br/images/pdfs/manifesto-comunista.pdf > Acesso em 9 de Jul. de2017.

MARX, Karl. O capital: crítica da economia política. Livro1, volume 1. 22 ${ }^{a}$ Ed. Rio de Janeiro: Civilização Brasileira, 2004. 
MARTINS, José R. V. et al. ( orgs). A diáspora haitiana da utopia à realidade : perfil dos haitianos em Cascavel Paraná. Gráfica Grapel, Foz do Iguaçu, 2014.

MARTINS, Michele. Africanos e Haitianos sofrem preconceito em Cascavel. Tv Tarobá, reportagem veiculada em 25 de Novembro de 2014. Disponível em:

<https://www.youtube.com/watch?v=MxH0_1JmN_w> Acesso em 10 de Ago. de 2017.

MEDEIROS, Henrique. $\mathbf{5 7 \%}$ da população brasileira usa smartphone, diz estudo. Exame, 26 de ago. de 2016. Disponível em: < http://exame.abril.com.br/tecnologia/57-da-populacaobrasileira-usa-smartphone-diz-estudo/> Acesso em 02 de Jul. de 2017.

MEZZADRA. Sandro. Derecho de fuga: migraciones, ciudadanía y globalización. Editora Mapas traficantes de sueño. Madrid,2005.

MIGRA MUNDO. Saída do Brasil do pacto global para migração pode afetar brasileiros no exterior. Publicado em 08 de Jan. de 2019. Disponível em:<

https://migramundo.com/saida-do-brasil-do-pacto-global-para-migracao-pode-afetar-

brasileiros-no-exterior/> Acesso em 09 de Jan. de 2019.

MISSÃO PAZ. Nova lei de migração é aprovada no congresso. Publicado em 19 de abril de 2017. Disponível em: <http://www.missaonspaz.org/single-post/2017/04/19/Nova-Lei-deMigra\%C3\%A7\%C3\%A3o-\%C3\%A9-aprovada-no-Congresso> Acesso em 05 de Jul. de 2017.

MUENZ, R. Europa entre la necesidad de emplear mano de obra foránea y la renuncia de algunso países de la UE a admitirlo. In. ARANGO ET AL. Inmigrantes el continente móvil. Vanguardia Dossier, n.22, Enero/Marzo 2007

MUJICA, J. Pepe. Consciência Sul, o mundo por José Mujica: "A resistência europeia à imigração". Disponível em: <https://www.youtube.com/watch?v=vaHIzn_MjS0>Acesso em 28 de Ago. de 2018.

OLIVEIRA, Antônio Tadeu Ribeiro de. Nova lei brasileira de migração: avanços, desafios e ameaças. Rev. bras. estud. popul. [online]. 2017, vol.34, n.1 . Disponível em: <http://www.scielo.br/scielo.php?script=sci_arttext\&pid=S0102-30982017000100171> Acesso em 02 de set. de 2018.

OLIVEIRA, Maria M. SILVA, Elias O. A migração haitiana na Amazônia à luz dos estudos de gêneros. In. SILVA, Sidney A. ASSIS, Glaucia O. Em Busca do Eldorado: O Brasil no contexto das migrações nacionais e internacionais. Manaus:EDUA, 2016.

OLIVEIRA, Paulo Antonio Barros; MENDES, Jussara Maria Rosa. Processo de trabalho e condições de trabalho em frigoríficos de aves: relato de uma experiência de vigilância em saúde do trabalhador. In. Ciência saúde coletiva, Rio de Janeiro, v. 19, n. 12, p. 46274635, 2014 . Disponível em: <http://www.scielo.br/scielo.php?pid=S1413$81232014001204627 \&$ script=sci_abstract\&tlng=pt > Acesso em 14 de Jan. de 2019.

ONUBR. Número de migrantes internacionais chega a cerca de 244 milhões, revela ONU. Publicado em 13 de Jan de 2016. Disponível em: https://nacoesunidas.org/numero-de- 
migrantes-internacionais-chega-a-cerca-de-244-milhoes-revela-onu/> Acesso em 24 de Jun. de 2017.

ORTIZ, Merari S. M; ZEPEDA, Rodrigo Aguilar. Presentación. Revista Huellas de la Migración v. 3, n5, México, 2018.Disponível em:

$<$ https://huellasdelamigracion.uaemex.mx/article/view/10882/8882 > Acesso em 19 de Nov. de 2018.

PARANÁ. Secretaria de Justiça, Trabalho e Direitos Humanos - SEJU - Observatório do Trabalho: Curitiba, 2017.

PATARRA, Neide L. Migrações internacionais de e para o Brasil contemporâneo volumes, fluxos, significados e políticas. São Paulo em Perspectiva, v. 19, n. 3, p. 23-33, jul./set. 2005. Disponível em: http://www.scielo.br/pdf/spp/v19n3/v19n3a02.pdf > Acesso em 23 de Nov. de 2018.

PATARRA, Neide Lopes; BAENINGER Rosana. Movimiento migratório reciente entre países del Mercosur. Nueva Época Año 10 n²42, octubre-diciembre de2004.

PIAIA, Vander. Terra, sangue e ambição - a gênese de Cascavel. Cascavel: EDUNIOESTE, 2013.

PEIXOTO, João. “ As teorias explicativas das migrações: teorias micro e macro sociológicas”. SOCIUS - Centro de Investigação em Sociologia Económica e das Organizações Instituto Superior de Economia e Gestão Universidade Técnica de Lisboa. Lisboa, 2004. Disponível em:

<https://www.repository.utl.pt/bitstream/10400.5/2037/1/wp200411.pdf> Acesso em 04 de Set. de 2016.

POCHMANN, Marcio. Defensores do golpismo escondem projeto neoliberal. Revista GGN, publicado em 28 de Mar. de 2016. Disponível em:

$<$ https://jornalggn.com.br/noticia/defensores-do-golpismo-escondem-projeto-neoliberal-pormarcio-pochmann> Acesso em 26 de Jul. de 2016.

PONTES, P. Brazilian scientific production vs. innovation and technology. Braz J Otorhinolaryngol. 2015;81:343-4. Disponível em:

http://www.scielo.br/pdf/bjorl/v81n4/pt_1808-8694-bjorl-81-04-00343.pdf> Acesso em 14 de Ago. de 2018.

RAIS - Relação anual de informações Sociais. Programa de disseminação das estatísticas do trabalho 2018. Disponível em: 〈http://pdet.mte.gov.br/solicitacao-de-acesso-online> Acesso em 12 de Jan. de 2019.

REITZ, Jeffrey ¿Puede ofrecer lecciones a Europa la experiência canadiense? In. ARANGO ET AL. Inmigrantes el continente móvil. Vanguardia Dossier, n.22, Enero/Marzo 2007.

RIBEIRO, Darcy. O povo brasileiro: a formação e o sentido do Brasil. 2. ed. São Paulo: Companhia das Letras, 1995. 
RIC RURAL. A história de sucesso da Cooperativa Coopavel:reportagem especial. Publicado em 14 de Fev. de 2016. Disponível em: <https://pr.ricmais.com.br/ricrural/videos/a-historia-de-sucesso-da-cooperativa-coopavel> Acesso em 08 de Mar. de 2018.

RODRIGUES, Alex. Número de imigrantes com contrato de trabalho formal caiu $13 \%$ no Brasil em 2016. Agência Brasil. Publicado em 13 de Dez de 2017. Disponível em: $<$ http://agenciabrasil.ebc.com.br/economia/noticia/2017-12/numero-de-imigrantes-comcontrato-formal-de-trabalho-caiu-13-no-brasil-em> Acesso em 03 de Dez de 2018.

ROMILDO, José. População brasileira é formada basicamente de brancos e pardos diz IBGE. EBC Agência Brasil. Publicado em 13 de Nov.de 2015. Disponível em $<$ http://agenciabrasil.ebc.com.br/economia/noticia/2015-11/populacao-brasileira-e-formadabasicamente-de-brancos-e-pardos-diz-ibge> Acesso em 9 de Mar. de 2018.

SAES, Décio. Estado e democracia: ensaios teóricos. $2^{\text {a }}$ ed. Campinas: IFCH/UNICAMP,1998.

República do capital: capitalismo e processo político no Brasil. São Paulo:Boitempo, 2001.

SALA, Ana María López. Inmigrantes y Estados: la respuesta política ante la cuestión migratória. Anthropos, Barcelona, Espanha 2005.

SALOMÃO, Alexa; GODOY Marcelo. Frigoríficos levaram 80\% das verbas externas do BNDES. Estadão. Publicado em: 20 de Ago. de 2017. Disponível em:

$<$ https://economia.estadao.com.br/noticias/geral,frigorificos-levaram-80-das-verbasexternasdo-bndes,70001942790> Acesso em 16 de Dez. de 2018.

SANTOS, Milton. Por uma globalização: do pensamento único à consciência universal. $11^{\text {a }}$ Edição, Rio de Janeiro: Record, 2004.

SASSEN, Saskia. Expulsions: Brutality and complexity in the global economy. Cambridge, Massachusetts, London, England, 2014.

Inmigrantes y ciudadanos. de las migraciones massivas a la Europa fortaleza. Madrid: Siglo XXI, 2013.

2007.

, Los espectros de la globalización. Buenos Aires, Fondo de Cultura Económica.

SCHWARTZMAN, Simon. Um espaço para a ciência: a formação da comunidade científica no Brasil. Brasília, Ministério de Ciência e Tecnologia, (2001) tradução de Sérgio Bath e Oswaldo Biato. Capítulo 1 a 5, 7 a 9. Disponível em: $<$ http://www.schwartzman.org.br/simon/spacept/pdf/captit10.pdf> Acesso em 13 de Ago de 2018.

SAYAD, Abdelmalek. Elemento constitutivo da condição do imigrante. Travessia: Revista do Migrante. São Paulo, Centro de Estudos Migratórios - CEM, ano XIII, jan. 2000. 
Elemento constitutivo da condição do imigrante. Travessia: Revista do Migrante. São Paulo, Centro de Estudos Migratórios - CEM, ano XIII, jan. 2000.

SENADO NOTÍCIAS. Proposta de Lei de Migração prevê visto humanitário. Publicada em 24 de Abril de 2017. Disponível em:

https://www12.senado.leg.br/noticias/videos/2017/04/proposta-de-lei-de-migracao-prevevisto-humanitario> Acesso em 04 de Set. de 2018.

SERAPIO, Pedro. Paraná é campeão mundial em produtividade de soja: Estado colhe, em média, 3,6 tonelada por hectare. Volume é $4 \%$ maior que a média norte-americana e 11\% maior que a brasileira. Gazeta do Paraná, publicado em 24 de Abril de 2017.

Disponível em: <http://www.gazetadopovo.com.br/agronegocio/agricultura/soja/parana-ecampeao-mundial-em-produtividade-de-soja-

5c7yr28iln0v0vijhaw5mb504\%26ei=f6phmPwg\%26lc=pt-

$\mathrm{BR} \% 26 \mathrm{~s}=1 \% 26 \mathrm{~m}=398 \% 26$ host $=\mathrm{www}$.google.com $. \mathrm{br} \% 26 \mathrm{ts}=1497365286 \% 26 \mathrm{sig}=\mathrm{ALNZjW}$ m3wUVWWiVHB4jCE1rOgHWBvq9Ayg> Acesso em 06 de Jul. de 2017.

SETTON, Maria da G. J. A teoria do habitus em Pierre Bourdieu: uma leitura contemporânea. Revista Brasileira de Educação, n²0, Maio/Jun/Jul/Ago 2002. Disponível em: < http://www.scielo.br/pdf/rbedu/n20/n20a05> Acesso em 07 de Jun. de 2017.

SHIROMA, Eneida. Oto. O modelo japonês e a educação do trabalhador. Revista Proposições. Campinas: Cortez Editora. V. 2, nº 2. p. 61-67. Agosto de 1991.

SILVA. Sidney A. Imigração e redes de acolhimento: o caso dos haitianos no Brasil. Revista bras. Est. Pop., Belo Horizonte, v.34, n.1, p.99-117, jan./abr. 2017. Disponível em: <http://www.scielo.br/pdf/rbepop/v34n1/0102-3098-rbepop-34-01-00099.pdf> Acesso em 22 de Ago. de 2018.

SILVA, Sidney A. A imigração haitiana e os paradoxos do visto humanitário. In. BAENINGER, Rosana, et al. ( Orgs) Imigração Haitiana no Brasil. Jundiaí: Paco Editorial, 2016a.

SILVA, Sidney A. Haitianos em Manaus mercado de trabalho e exercício da cidadania. In. SILVA, Sidney A. ASSIS, Glaucia O. Em Busca do Eldorado: O Brasil no contexto das migrações nacionais e internacionais. Manaus:EDUA, $2016 \mathrm{~b}$.

SILVA, João Carlos J. Impactos políticos, jurídicos e sociais da imigração haitiana para o Brasil. In. BAENINGER, Rosana, et al. ( Orgs) Imigração Haitiana no Brasil. Jundiaí: Paco Editorial, 2016.

SILVA, Paloma K. Maroni. O visto humanitário como política migratória: o caso da imigração haitiana com destino ao Brasil. In. BAENINGER, Rosana, et al. ( Orgs) Imigração Haitiana no Brasil. Jundiaí: Paco Editorial, 2016.

SILVA, Maria Gizele da. O Haiti e aqui, no Paraná. Gazeta do Povo, publicado em 08 de Set. de 2012. Disponível em: <https://www.gazetadopovo.com.br/vida-e-cidadania/o-haiti-eaqui-no-parana-3apkj3juaemb1hszwl2tebia6/> Acesso em 13 de Jan. de 2019. 
SILVA, Maria A. M. Contribuições metodológicas para análise das Migrações. In. DEMARTINI Zeila B. F. TRUZZI, Oswaldo. (orgs). Estudos Migratórios: perspectiva metodológica. EUFSCAR, São Carlos, 2005.

SILVA, Sidney Antonio. Observação participante e participação militante: pesquisa antropológica entre os imigrantes bolivianos em São Paulo. In. DEMARTINI Zeila B. F.

SINDICARNE. Um perfil dos trabalhadores nos frigoríficos do Brasil. Publicado em 11 de Jun. de 2015. Disponível em: 〈http://sindicarnemg.org.br/5195/> Acesso em 28 de Jun. de 2018.

SODRÉ, N. W. A farsa do neoliberalismo. Rio de Janeiro: Graphia, 1995.

STRATHERN, Marilyn. O efeito etnográfico e outros ensaios. São Paulo: Cosac Naify, 2014.

STANDING, Guy. O precariado: a nova classe perigosa. $1^{\text {a }}$ Ed. Belo Horizonte: Autentica Editora, 2015.

TAVARES, Elaine. Crianças em Jaula nos EUA. IELA. Publicado em 19 de jun. de 2018. Disponível em: 〈http://www.iela.ufsc.br/noticia/criancas-em-jaulas-nos-estados-unidos> Acesso em 20 de Ago. de 2018.

TEC MUNDO. Os novos maiores polos tecnológicos do mundo. Publicado em 08 de Abr. de 2013. Disponível em: <https://www.tecmundo.com.br/tecnologia/38357-os-9-maiorespolos-tecnologicos-do-mundo-ilustracao-.htm> Acesso em 01 de Ago de 2018.

TEMER, Michel. Presidente da República Federativa do Brasil. Solidariedade com os venezuelanos (EFE - 3/09/2018) [Espanhol]. Disponível em: http://www.itamaraty.gov.br/pt$\mathrm{BR} /$ discursos-artigos-e-entrevistas-categoria/presidente-da-republica-federativa-do-brasilartigos/19427-solidariedade-com-os-venezuelanos-efe-3-09-2018-espanhol> Acesso em 05 de Set. de 2018.

THOMPSON, E. P. Costumes em Comum: estudos sobre a cultura popular tradicional. SP: Cia das Letras, 2002.

TODOROV, Tz. Muros caídos, muros erigidos. Buenos Aires: Katz, 2011.

TOSI. Marcos. "Frimesa inicia hoje obras do maior frigorífico do Brasil" Gazeta do Povo. Disponivel em: <https://www.gazetadopovo.com.br/agronegocio/pecuaria/frimesa-iniciahoje-obras-do-maior-frigorifico-do-brasil-8hkx2k9qiu070kfdvr7sx6mi9/> Acesso em 09 de Set. de 2018.

TV SENADO. Argumento - Crise da imigração -Jorge Viana. Publicado em 21 de Maio de 2015. Disponível em: <https://www.youtube.com/watch?v=iicnTDF15D4> Acesso em 23 de Mai.de 2017. 
Senado aprova nova lei de migração.Publicado em 14 de Abr. de 2017.

Disponível em: <https://www12.senado.leg.br/noticias/audios/2017/04/senado-aprova-novalei-de-migracao> Acesso em 13 de Jan. de 2019.

TV TAROBÁ CASCAVEL. Haitianos invadem mercado de trabalho em cooperativas de cascavel. TV Tarobá Cascavel. Publicado em 17 de Jan. de 2014. Disponível em:

<https://www.youtube.com/watch?v=_c5CPAcG6lE> Acesso em 23 de Nov. de 2018.

VALOR ECONOMICO. Altas das cotações projeta melhores resultados no ano. Publicado em 28 de Jun de 2018. Disponível em: <https://www.valor.com.br/agro/5623551/alta-dascotacoes-projeta-melhores-resultados-no-ano> Acesso em 15 de Set. de 2018.

VILLEN, Patricia. Periféricos na Periferia. In. BAENINGER, Rosana et al . Imigração Haitiana no Brasil. Jundiaí: Paco Editorial, 2016.

Polarização do mercado de trabalho e a nova imigração internacional no

Brasil. Estudos do trabalho, 2013. Disponível em:

<http://www.estudosdotrabalho.org/texto/gt5/polarizacao.pdf> Acesso em 09 de Abr. de 2018.

VINENTE, Fabiane. Dos ideais às práticas: os haitianos e os desafio da inclusão dos imigrantes internacionais nas políticas do sistema de saúde brasileiro. In. SILVA, Sidney A. ASSIS, Glaucia O. Em Busca do Eldorado: O Brasil no contexto das migrações nacionais e internacionais. Manaus:EDUA, 2016.

VOZ DO BRASIL. Programa de interiorização de venezuelanos no Brasil. Brasília, 08 de Set. de 2018.

ZENI, Kaline; FILIPPIM. Migração haitiana para o Brasil: acolhimento e políticas públicas. PRETEXTO, v. 15 n.2, 2014. Disponível em:

<http://www.fumec.br/revistas/pretexto/article/view/1534 > Acesso em 14 de Mar. de 2017. WACQUANT, L. Que é gueto? Construindo um conceito sociológico. Rev. Sociol. Polítc., Curitiba, v. 23, p. 155-164, nov. 2004b.

WILLIAMS, Raymond. O Campo e a Cidade na História e na Literatura. São Paulo: Cia das Letras, 1988. 
APÊNDICES 


\title{
APÊNDICE A - QUESTIONÁRIO DE ENTREVISTA COM HAITIANOS
}

\section{UNIVERSIDADE ESTADUAL PAULISTA JÚLIO DE MESQUITA FILHO - UNESP, CAMPUS DE ARARAQUARA. PROGRAMA DE PÓS-GRADUAÇÃO EM CIÊNCIAS SOCIAIS}

\author{
MESTRADO/DOUTORADO ACADÊMICO
}

Questionário metodologia qualitativa: entrevistas com haitianos relatos de experiência através da história oral.

Pesquisa: Migração e trabalho na contemporaneidade: os haitianos no Oeste do paraná.

Pesquisadora: Claudimara Cassoli Bortoloto.

Questionário:

1- O que o motivou a migrar para o Brasil?

2- Quando migrou (Data ou período - quando saiu do Haiti e quando chegou ao Brasil?)

3- Qual a primeira cidade quando chegou no Brasil?

4- Passou por outros lugares no Brasil até chegar em Cascavel, Paraná?

5- Quando chegou no Brasil quem o ajudou? Teve ajuda com acolhimento?

6- Quando chegou em Cascavel quem o ajudou? Teve a ajuda com acolhimento?

7- Quando migrou teve intermédio de coiotes ou agências financeiras financiadoras e dívidas de passagens contraídas?

8- Teve dificuldade com o idioma e a cultura em Cascavel?

9- Aprendeu o idioma português, o que contribuiu para isso?

10- Foi trazido por algum empresário de Cascavel para trabalhar?

11- Está trabalhando atualmente? Em que? Tem carteira assinada?

12- Quais suas experiências de trabalho no Haiti?

13- Demorou para conseguir trabalho no Brasil?

14- Qual a principal dificuldade encontrada para viver em Cascavel?

15- Qual seu grau de instrução ( estudo)?

16- O que acha dos brasileiros e sua relação com eles?

17- Gosta de viver em Cascavel?

18- Tem o desejo de voltar a viver no Haiti?

19- O que espera do Brasil? Suas perspectivas? Planos de vida?

20- Em relação aos serviços públicos em Cascavel, como saúde, Educação, assistência social,

qual a maior dificuldade em acessá-los?

21- Qual a sua situação quando veio para o Brasil? Entrou no país como refugiado? Tinha visto?

22- Está documentado?

23- Possui ajuda de redes de apoio como igrejas e outras instituições?

24- Possui ajuda para se manter no país de outros imigrantes haitianos?

25- Envia remessas ou pecúlios para a família que vive no Haiti?

26- Trouxe algum membro familiar depois da sua chegada?

27- Já teve alguma relação com o operação MINUSTAH, ou com o exército brasileiro?

28- Como imigrante qual seria sua proposta para o Estado brasileiro melhorar a situação dos 
imigrantes no Brasil?

29- Em que bairro vive em Cascavel? Mora com outros haitianos?

30- Há mais alguma consideração que queira fazer sobre sua experiência de vida e de trabalho. 


\section{APÊNDICE B - REQUERIMENTO AO RH DA COOPAVEL SOBRE CONTRATAÇÃO DE HAITIANOS}

\section{Requerimento}

Eu Claudimara Cassoli Bortoloto, portadora do RG 7.724003-9, docente a Universidade Tecnológica Federal do Paraná - UTFPR Medianeira e doutoranda em Ciências Sociais pela UNESP De Araraquara São Paulo, venho por meio desse requerimento solicitar ao setor de Recursos Humanos da Coopavel informações sobre o número de haitianos contratados por essa empresa. A demanda por essa informação é relevante para minha tese de doutorado que tem como tema imigração e trabalho dos Haitianos no Oeste do Paraná. O município de Cascavel é tomado como amostra por ser a cidade que recebeu o maior número de haitianos a princípio do Oeste do Paraná e atualmente do Estado. Em 2017 realizei pesquisa de campo e entrevistei 60 haitianos, os resultados preliminares de dados quantitativos indicam a Coopavel como hegemônica na contratação desses imigrantes, que quando trabalhando mais de $80 \%$ deles estão nesse frigorífico. Frente a esses dados, gostaria se possível o número de contratados até a presente data, bem como a evolução das contratações e demissões por ano de 2010 a 2018, se há possibilidade de demonstração de dados da quantidade deles distribuídos por função que realiza ou área de trabalho. $\mathrm{O}$ período de 2010 é privilegiado pro ser esse ano o momento que iniciaram as primeiras imigrações de haitianos no Brasil. Esses dados serão fundamentais para contrastar com o número de imigrantes migrados por ano no município, conforme a amostra pesquisada, bem como a incorporação deles no sistema produtivo relativo a porcentagem que reside em Cascavel.

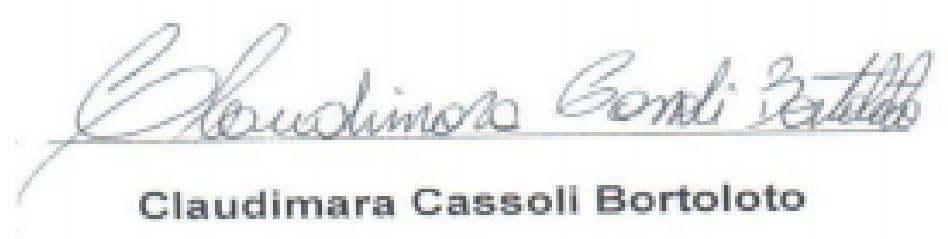

Requerente:

Para o Departamento de Recursos Humanos da Coopavel.

Cascavel, 08 de março de 2018 


\section{APÊNDICE C - REQUERIMENTO DE DADOS SOBRE HAITIANOS FEITO À AGENCIA DO TRABALHADOR DE CASCAVEL}

\section{REQUERIMENTO}

Eu Claudimara Cassoli Bortoloto, portadora do RG 7.724003-9, discente do Programa de PósGraduação em Ciências Sociais, Curso doutorado realizado na UNESP de Araraquara com pesquisa sobre Migração e trabalho na contemporaneidade: os haitianos no Oeste do Paraná venho por meio desse documento requerer levantamento de dados sobre a inclusão de trabalhadores migrantes haitianos no sistema formal de trabalho, considerando se possível os seguintes aspectos:

Primeiros encaminhamentos registrados de haitianos na Agência do trabalhador, ano, quantidade e área de trabalho; gênero ( quantidade de mulheres e homens);

Encaminhamentos totais realizados: quantidade de trabalhadores, área de trabalho; gênero (quantidade de mulheres e homens);

Haitianos cadastrados para encaminhamento que estão na lista de espera para trabalho: quantidade e gênero ( homens e mulheres).

Empresas que mais empregam no município (setores de trabalho)

Encaminhamentos de haitianos com grau superior para postos de trabalhos conforme grau de instrução;

Números de rescisões de contrato de trabalho de haitianos em período de experiência, Números de rescisões de contrato de trabalho de haitianos,

Ressalto a importância desses dados para a realização dessa pesquisa de doutorado.

Claudimara Cassoli Bortoloto

Requerente

Para a Sra:

Maristela Becker

Gerente da Agência do Trabalhador

Cascavel, 16 de Fevereiro de 2017. 


\title{
APÊNDICE D - REQUERIMENTO DE DADOS SOBRE HAITIANOS FEITO À SECRETARIA DE ASSISTÊNCIA SOCIAL DE CASCAVEL
}

\author{
REQUERIMENTO
}

Eu Claudimara Cassoli Bortoloto, portadora do RG 7.724003-9, discente do Programa de PósGraduação em Ciências Sociais, Curso doutorado realizado na UNESP de Araraquara, com pesquisa sobre Migração e trabalho na contemporaneidade: os haitianos no Oeste do Paraná venho por meio desse documento requerer levantamento de dados sobre a inclusão de imigrantes haitianos nas políticas de Assistência Social do município de Cascavel, considerando se possível os seguintes aspectos:

Primeiras inclusões de usuários haitianos nas políticas de Assistência Social, (ano e programas)

Quantidade atual de usuários haitianos cadastrados no Cadastro Único para Programas Sociais - CadÚnico e atendidos pelo Programa de Transferência de Renda Bolsa Família, (gênero: masculino e feminino).

Quantidade atual de usuários haitianos cadastrados no Cadastro Único para Programas Sociais - CadÚnico não beneficiários do Programa de Transferência de Renda Bolsa Família, (gênero: masculino e feminino).

Quantidade de Haitianos beneficiários do Benefício de Prestação Continuada BPC;

Quantidade de Haitianos atendidos pela proteção especial.

Principais demandas de haitianos na área de atendimento da assistência social.

Principais dificuldades das equipes da Assistência Social para atendimento dos haitianos no município de Cascavel.

Os dados acima fornecerão elementos sobre a inclusão dos migrantes nas políticas de assistência social, com identificação de situações de vulnerabilidade e extrema pobreza desses migrantes, suas demandas junto a essa secretaria, quais serão cruzadas com outros órgãos públicos como departamento de imigração da Polícia Federal, Agência do Trabalhador, de forma a estabelecer possíveis relações entre à assistência social e inserção laboral. Desde já agradeço a atenção pela contribuição dessa secretaria

para com essa pesquisa.

Claudimara Cassoli Bortoloto

$$
\begin{aligned}
& \text { Requerente } \\
& \text { Para a Sr: }
\end{aligned}
$$

Hudson Marcio Moreschi Junior secretário de Assistência Social:

Cascavel, 16 de Fevereiro de 2017. 


\title{
APÊNDICE E - REQUERIMENTO DE DADOS SOBRE HAITIANOS FEITO À SECRETARIA DE SAÚDE DE CASCAVEL
}

\section{REQUERIMENTO}

Eu Claudimara Cassoli Bortoloto, portadora do RG 7.724003-9, discente do Programa de PósGraduação em Ciências Sociais, Curso doutorado realizado na UNESP de Araraquara com pesquisa sobre Migração e trabalho na contemporaneidade: os haitianos no Oeste do Paraná venho por meio desse documento requerer levantamento de dados sobre a inclusão de imigrantes haitianos no Sistema Único de Saúde - SUS no município de Cascavel, considerando se possível os seguintes aspectos:

Primeiras inclusões de usuários haitianos em atendimentos nas Unidades Básicas de Saúde - UBS e Programa Saúde da Família ( PSF), (ano, quantidade e gênero: masculino e feminino);

Quantidade atual de usuários haitianos cadastrados e atendidos pelas Unidades Básicas de Saúde e Programa Saúde da Família por unidade; ( gênero: masculino e feminino).

Principais demandas de haitianos na área de atendimento da saúde básica.

Principais dificuldades das equipes das Unidades Básicas de Saúde e Programa Saúde da Família para atendimento dos haitianos no município de Cascavel.

Os dados acima fornecerão elementos sobre a inclusão dos migrantes nas políticas de saúde, bem como contribuir para delimitar territórios de maior fixação, tendo em vista a demanda dos imigrantes por saúde básica próximo do seu local de moradia ou área de abrangência das Unidades Básicas de Saúde e Programa Saúde da família. Os dados poderão fornecer informações que serão cruzadas com outros órgãos públicos como os fornecidos pelo setor de imigração da Polícia Federal e os dados formais de haitianos regularizados e os indocumentados, além de poder contribuir com a relação entre atendimento à saúde e o trabalho que estão submetidos. Desde já agradeço a atenção pela contribuição dessa secretaria para com essa pesquisa.

\author{
Claudimara Cassoli Bortoloto \\ Requerente \\ Para a Sr: \\ Rubens Griep \\ Secretário de Saúde \\ Cascavel, 16 de Fevereiro de 2017.
}


ANEXOS 
ANEXO A - PARECER DO COMITÊ DE ÉTICA EM PESQUISA APROVADO

UNESP - FACULDADE DE
CIENCIAS E LETRAS -
CAMPUS ARARAQUARA $\quad$ Sigrooforma

\section{PARECER CONSUBSTANCIADO DO CEP}

DADOS DO PRONETO DE PEQQUISA

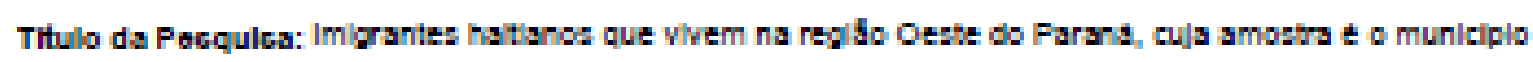
de Casavel.

Pacqulcador: Clavimara Caseoll Eortolow

Area Tomatlas:

Verctso: 1

CAAE: 65407717.9.0000.5400

Inctutulgso Proponente: Faculdade de Clunclas e Letras - UNEsF - Campus Araraquara

Patrooinador Prinolpal: Finandamento Freprlo

DADOS DO PAFECEF

Nümero do Parboer: 1.973 .264

Aprocentapso do Projeto:

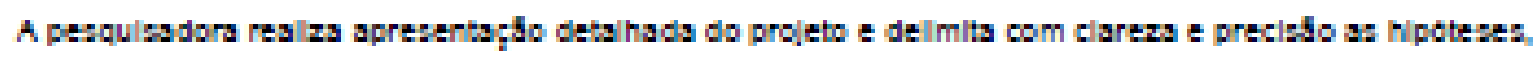
metodologlas e cbletwos.

objettuo da Pacculos:

A pesquladon indica dola objetwos, a saber:

otjetwo Frimarloc

"Estudar o processo de mlpraplo e trabalho dos Ha Ianoa em Cascavel, ascoclados ao coniterto mlaratorlo

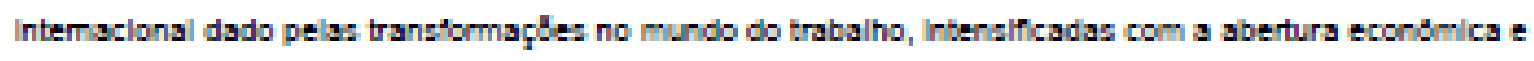
moblldade humang wablluda pela ploballzacho".

objetwo Becundarlo:

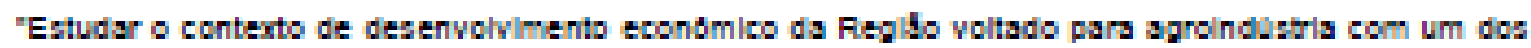
mecanlsmos de fortalecimerto do apronepoclonEtudar a mlpraplo de haltanos em Cascavel Farana, o perfll da mbo de obra Im/grante e Incoporpto no sebr produtho da

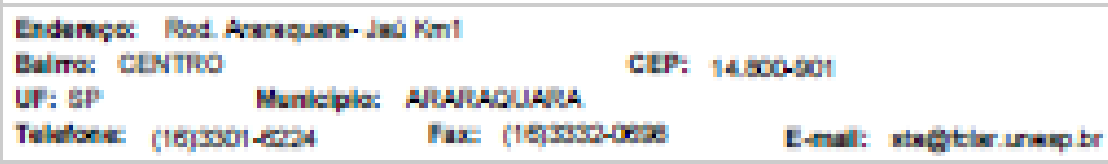




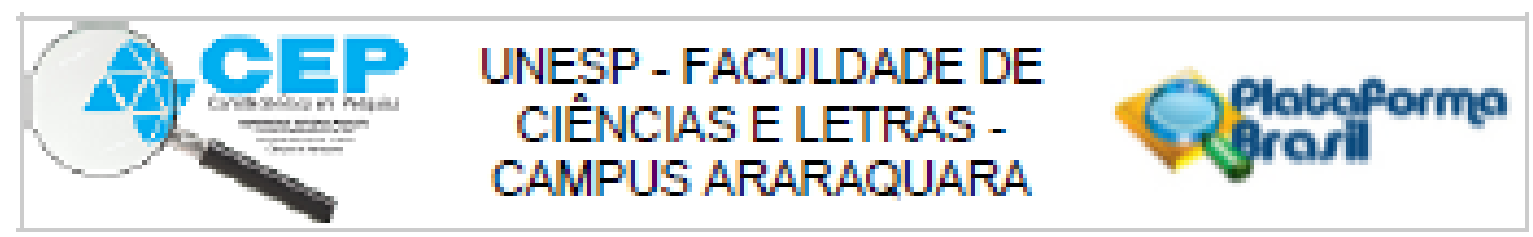

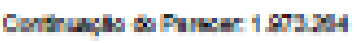

replo l.-.'.

Avallyogo doe Rlgoog o Banefiolog:

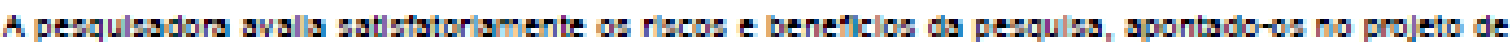
perqua e no TCLE.

Fisos:

A pesquladora sponts que os racos sho minimos, portm subinhs que se o entrevistado ficar consirangldo so responder o questlonstrio, pode se retrar ds pesqulss sem qualquer thus Aponta, alnda, se hower

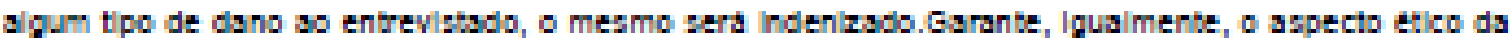
priveddade dos dsdos doe entrevistados.

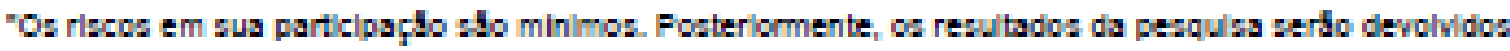

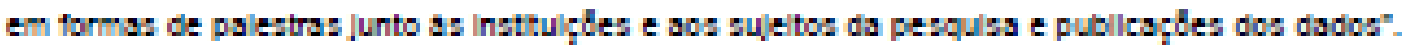

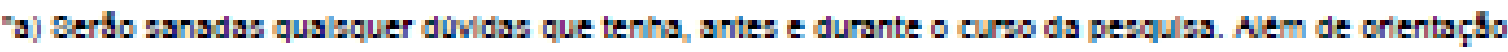

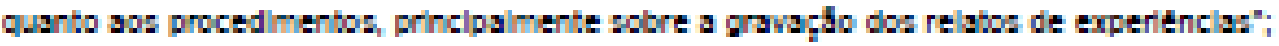

"b) Voce poderd sentir-se conatrangldo ao responder o questionarb propocto, lhe serd garantida a Ilberdsde de partilpar e tambem de se slenclar quando aseim desejar, sem Impos|ples";

"c) E garantlda a Indenlzaçlo dlante de eventuala danos comprovadamente decorrentes da perqulas. contorme previsto na Resoluçio $466 / 2012$;

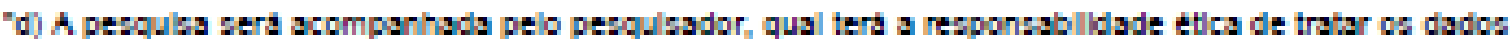
de forms a fazer antlses quartitatvas e qusitatvas, sem expor os participantes de torma direta, sem a utlizachlo de nomes reals ou outros dadoa que os exponha a ldentflicapto";

"ejA qualquer momento voce pode desatir de partidpar e retrar aeu consentlmento, sem nerhum prejulso

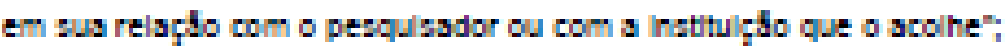

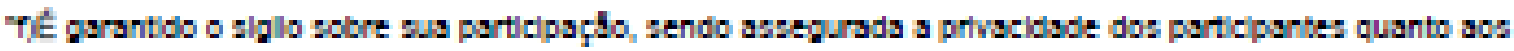
dado confidenclals envolvidoa na perqulss",

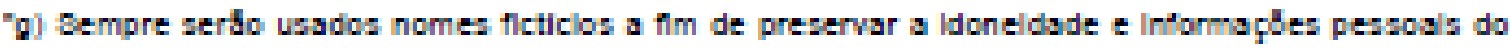
enireviatado. As namathas orals serbo utllzadas como dadoe de pezqulsa, sem Informar dados

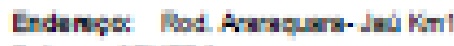

Eume: tintiva

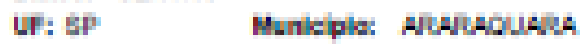

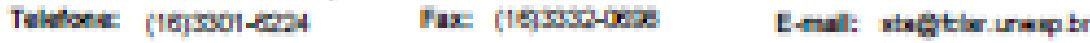




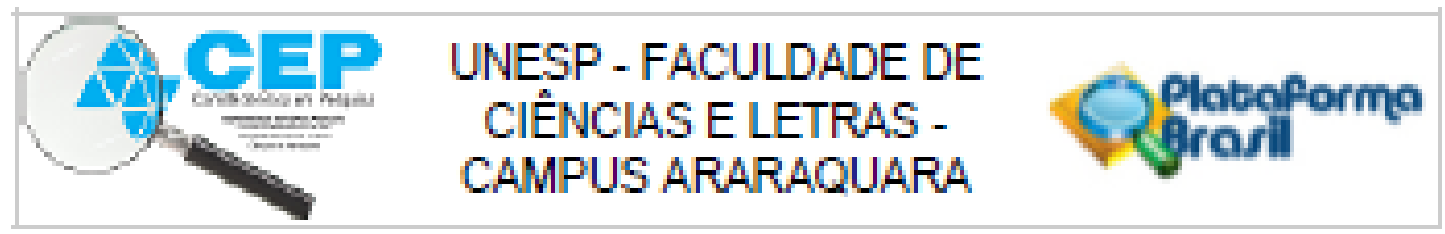

Eorthuptos tonere 10394

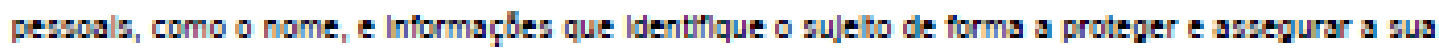
prthacldade".

Eeneficlos:

A perqulwara Indla os sogulitea beneficlos da peaqua:

Fomecer conheclmentos sobre o proceso mlpraterb de haltanos para o oeste do Farand, que motwou sua moblldade, conheclmento sobre a cultura e relaptes soclals, insercho dos mesmos nas politcas publlcas do munlciplo. Analles de dados formals e nabo formals, como quantidade de haltanos

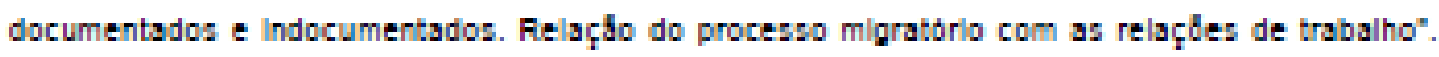

Comentarloc o Conelderapdes cobre a Fecqules:

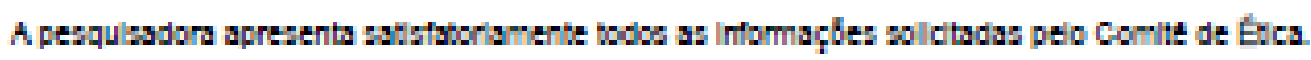

Conelderayos cobro os Termes de apresentzyo obrigatorla:

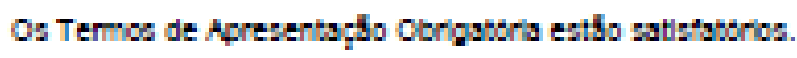

Reoomendaģes:

N5o ha recomendagtles.

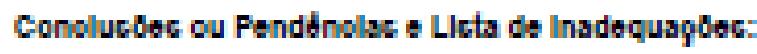

N5o exlatem pendenclas ou inadequaplites:

Coneldera;or Finsle a ortterlo do CEP:

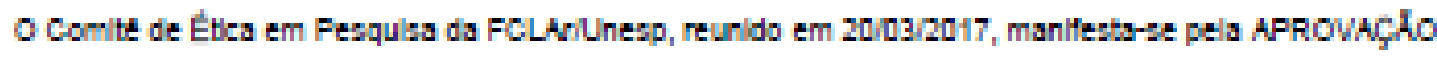
do protocolo de pesqulsa proposto.

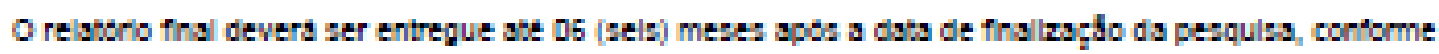
projepto do cronograma constante do propeno aprousdo.

Ecte parboor fol alaborado basesdo nog dooumentos abalxo ralablonsdoe:

\begin{tabular}{|c|c|c|c|c|}
\hline Tipo Documento & Arqulwo & Fotagem & Autor & Etuaç̧ \\
\hline |n'tormagdes & FB_IAFOAMACOEB_ENBLAB_DO_F & $06 / 02 / 2017$ & & Acelio \\
\hline
\end{tabular}

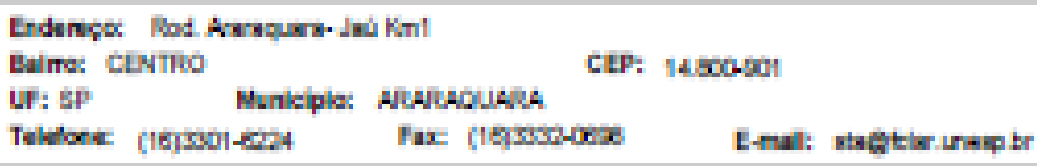




\section{UNESP - FACULDADE DE} CIÊNCIAS E LETRAS CAMPUS ARARAQUARA

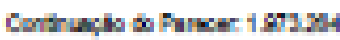

\begin{tabular}{|c|c|c|c|c|}
\hline Basicas do Pro|eto & ETO_871194.pdt' & 22:51:51 & & Acella \\
\hline Outre: & Tento_terite7,pdt & $\begin{array}{c}06 / 032017 \\
2248: 59\end{array}$ & $\begin{array}{l}\text { Claudlmara Casall } \\
\text { Pothloh. }\end{array}$ & Acelts \\
\hline outra: & Tento_tesite6.pdt & $\begin{array}{c}\text { 06/032017 } \\
22: 14: 36 \\
\end{array}$ & $\begin{array}{l}\text { Claudlman Casall } \\
\text { Bortolots }\end{array}$ & Acelts \\
\hline $\begin{array}{l}\text { Pro|cto Detalhads I } \\
\text { Erochurs } \\
\text { mertinadr }\end{array}$ & Tento_testepdt.pdt & $\begin{array}{l}\text { 06102017 } \\
24: 54: 54\end{array}$ & $\begin{array}{l}\text { Claudinar Casall } \\
\text { Bortoloh }\end{array}$ & Acelis \\
\hline Foha de Rosto & Bexto_teriespd & $\begin{array}{c}\text { 06/0302017 } \\
21: 40: 12\end{array}$ & $\begin{array}{l}\text { Claudlman Casall } \\
\text { Bornaloto }\end{array}$ & Acelts \\
\hline 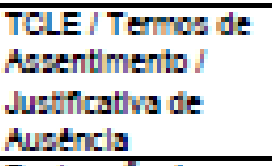 & Terto_terite2,pdt & $\begin{array}{l}230202017 \\
2005: 25\end{array}$ & $\begin{array}{l}\text { Claudlman Casall } \\
\text { Eortoloh }\end{array}$ & Acelts \\
\hline 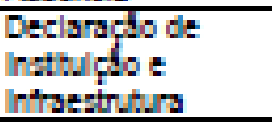 & 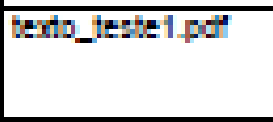 & $\begin{array}{c}\text { 23/1202117 } \\
12: 39: 12\end{array}$ & $\begin{array}{l}\text { Claudlmara Casall } \\
\text { Eortoloto }\end{array}$ & Acelts \\
\hline
\end{tabular}

atua 10 do Paraor:

Aproveds

Hoocelta Apresla,4o da COHEP:

NHo

ARAFACUARA, 20 de Margo de 2017

Accinado por:

Sobutta de soura Lemoc

|Coordanador! 


\section{ANEXO B - TERMO DE CONSENTIMENTO LIVRE E ESCLARECIDO}

1. Você está sendo convidado para participar da pesquisa - Migração e trabalho na contemporaneidade: os haitianos no Oeste do Paraná. 2. Essa pesquisa visa estudar os haitianos no Oeste do Paraná, o Município de Cascavel foi selecionado como amostra por possui o maior número de imigrantes dentre todos os demais e por ser a cidade com maior número de haitianos da região Oeste. A presença desses imigrantes despertou o interesse de estudar os motivadores da imigração para a região e sua vinculação com as relações de trabalho a partir de suas experiências de vida. a) Você foi selecionado por ser imigrante haitiano, maior de 18 anos e por viver em Cascavel Paraná, e a sua participação não é obrigatória, podendo recusar-se a participar sem penalização alguma e sem qualquer prejuízo em sua relação com o pesquisador. b) a pesquisa tem por objetivo estudar o processo de migração e trabalho dos Haitianos em Cascavel, associado ao contexto migratório internacional, as transformações do mundo do trabalho e globalização. 3. Os riscos em sua participação são mínimos. Posteriormente, os resultados da pesquisa serão devolvidos em formas de palestras junto às instituições e aos sujeitos da pesquisa e publicações dos dados. a) Serão sanadas quaisquer dúvidas que tenha, antes e durante o curso da pesquisa. Além de orientação quanto aos procedimentos, principalmente sobre a gravação dos relatos de experiências. b) Você poderá sentir-se constrangido ao responder o questionário proposto, lhe será garantida a liberdade de participar e também de se silenciar quando assim desejar, sem imposições. c) Esta pesquisa não trará benefícios diretos, porém considera-se valiosa a contribuição do participante para desenvolvê-la a partir de suas considerações sobre os itens apontados no questionário que fornecerão subsídios para a compreensão do processo migratório haitiano nessa região. O resultado será posteriormente divulgado a fim de sensibilizar a comunidade local sobre as reais situações de inclusão desses migrantes em nossa sociedade. 4. É garantida a indenização diante de eventuais danos comprovadamente decorrentes da pesquisa, conforme previsto na Resolução 466/2012. 5. A pesquisa será acompanhada pelo pesquisador, qual terá a responsabilidade ética de tratar os dados de forma a fazer análises quantitativas e qualitativas, sem expor os participantes de forma direta, sem a utilização de nomes reais ou outros dados que os exponha a identificação. 6. Quando necessário, haverá auxílio de um tradutor que domina a língua nativa Creole e o português, a fim de atender participantes que não dominam o português e desejam participar da pesquisa. 7. A qualquer momento você pode desistir de participar e retirar seu consentimento, sem nenhum prejuízo em sua relação com o pesquisador ou com a instituição que o acolhe. 8 . É garantido o sigilo sobre sua participação, sendo assegurada a privacidade dos participantes quanto aos dados confidenciais envolvidos na pesquisa. a) Sempre serão usados nomes fictícios a fim de preservar a idoneidade e informações pessoais do entrevistado. As narrativas orais serão utilizadas como dados de pesquisa, sem informar dados pessoais, como o nome, e informações que identifique o sujeito de forma a proteger e assegurar a sua privacidade. b) As transcrições das entrevistas e os dados fornecidos por instituições públicas serão citadas no desenvolvimento da tese de doutorado e não serão divulgados de forma a possibilitar a sua identificação. 9. Você não receberá e não terá ônus por colaborar com a pesquisa, no entanto, é garantido o ressarcimento diante de eventuais despesas decorrentes da sua participação na pesquisa. 10. Você receberá uma via deste termo onde consta o telefone e o endereço do pesquisador principal, podendo tirar suas dúvidas sobre o projeto e sua participação, agora ou a qualquer momento.

Nome e assinatura do pesquisador

Nome e assinatura do participante da pesquisa 


\section{ANEXO C - E-MAIL DE RETORNO DO RH SOBRE A CONTRATAÇÃO DE HAITIANOS PELA COOPAVEL}

---- Mensagem encaminhada -----

De: Recursos Humanos Coopavel Gerente - Aguinel <rhu@coopavel.com.br>

Para: 'Claudimara Bortoloto' <claudibortoloto@yahoo.com.br>

Enviado: terça-feira, 13 de março de 2018 14:18:25 BRT

Assunto: RES: Sobre dados de contratação de haitianos pela COOPAVEL

Boa tarde!

Em virtude de normas internas não estaremos participando.

Obrigado, duvidas estamos a disposição.

\section{Atenciosamente.}

\section{Coopavel Cooperativa Agroindustrial}

Aguinel Marcondes Waclawovsky

Gerente de RH

PFone: (45) 3218-5080

凶E-mail: rhu@coopavel.com.br

De: Claudimara Bortoloto [mailto:claudibortoloto@yahoo.com.br]

Enviada em: quinta-feira, 8 de março de 2018 14:53

Para: Recursos Humanos Coopavel Gerente - Aguinel <rhu@coopavel.com.br>

Assunto: Sobre dados de contratação de haitianos pela COOPAVEL

Olá Agnel boa tarde! Sou doutoranda em Ciências Sociais e venho por meio do requerimento em anexo solicitar alguns dados sobre a contratação de haitianos pela Coopavel. Segue anexo o requerimento que faz a solicitação, bem como explica detalhadamente a demanda por esses dados. Estou também disponível no telefone 45 30380508 ou 4598338214 , caso necessite de estabelecer contato. Aguardo o retorno. Atenciosamente, Claudimara Cassoli Bortoloto.

Docente da Universidade Tecnológica Federal do Paraná - UTFPR Medianeira. Doutoranda em Ciências Sociais - UNESP - Araraquara. 


\section{ANEXO D - REGISTROS ATIVOS DE HAITIANOS REALIZADOS NA POLÍCIA FEDERAL, ENTRE OS ANOS DE 2009 A 2017}

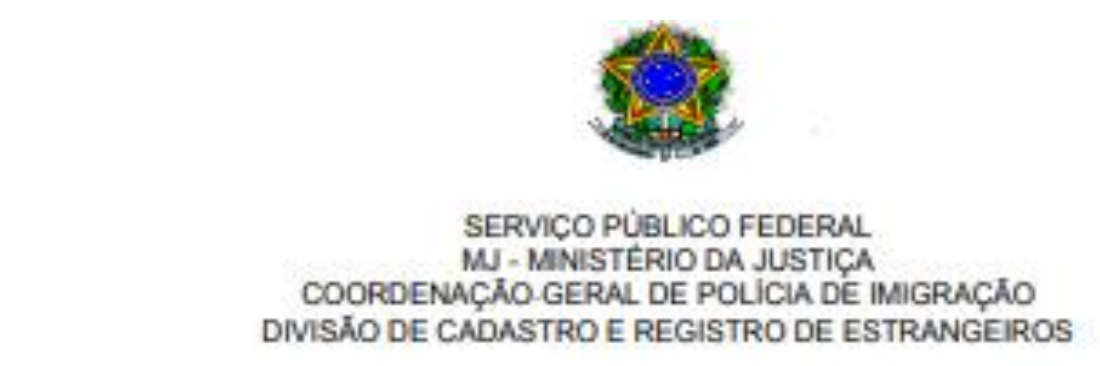

\footnotetext{
Registros ativos de haitianos realizados na Policia Federal, entre os anos de 2009 a 2017 Dados extraidos em 02 de fevereiro de 2018, do banco de dados da Policia Federal.
}

\begin{tabular}{|c|c|c|c|}
\hline \multicolumn{4}{|c|}{ Dados Gerais } \\
\hline Enderepo Residencial - UF & Quansdade (em mill) & Por Genero & Qusnsdade fem min \\
\hline sp & 25,623 & Mascuena & 60,722 \\
\hline sc & 18,836 & FEMININO & 27,737 \\
\hline PR & 14,456 & TOTAL & 88,459 \\
\hline FS & 11,411 & & \\
\hline MT & 3,958 & & \\
\hline MG & 3,539 & Clossificaçaso & Ouarsdade (em mi) \\
\hline AM & 3,14 & PERMANENTE & 88,298 \\
\hline RU & 1,814 & TEMPORAFIO & $0,14 \mathrm{~s}$ \\
\hline RO & 1,502 & REFUGLADO & 0,008 \\
\hline Go & 1,435 & NÄO ESPECIFICADO & 0,007 \\
\hline MS & 1,266 & TOTAL & 88,459 \\
\hline AP & 0,563 & & \\
\hline DF & 0,549 & & \\
\hline FR & 0,113 & & \\
\hline ES & 0,076 & Dados & 9 a 2017 \\
\hline$P A$ & 0,042 & & \\
\hline$C E$ & 0,037 & Regutiso por Ano & Ousnbdade (em mi) \\
\hline AC & 0,024 & 2009 & $0,0+3$ \\
\hline BA & 0.022 & 2010 & 0,02 \\
\hline To & 0,019 & 2011 & 0,406 \\
\hline PE & 0,011 & 2012 & 3,89 \\
\hline RN & 0,007 & 2013 & 5,548 \\
\hline PB & 0,007 & 2014 & 10,635 \\
\hline PI & 0,005 & 2015 & 14,49 \\
\hline MA & 0,002 & 2016 & 42,441 \\
\hline SE & 0,002 & 2017 & 10,925 \\
\hline TOTAL & 88,459 & TOTAL & 88,368 \\
\hline
\end{tabular}

\begin{tabular}{lr}
\multicolumn{2}{c}{ Registros PERMANENTES por ano } \\
Registro por Ano & 0,01 \\
2007 & 0,012 \\
2008 & 0,01 \\
2009 & 0,016 \\
2010 & 0,372 \\
2011 & 3,886 \\
2012 & 5,539 \\
2013 & 10,624 \\
2014 & 14,479 \\
2015 & 42,395 \\
2016 & 10,899 \\
2017 & 88,232 \\
TOTAL & \\
\hline
\end{tabular}

\begin{tabular}{|c|c|}
\hline \multicolumn{2}{|c|}{ Registros TEMPORARIOS per ano } \\
\hline Registro por Ano & Quanbiade (em min) \\
\hline 2000 & 0,002 \\
\hline 2009 & 0,003 \\
\hline 2010 & 0,003 \\
\hline 2011 & 0,034 \\
\hline 2012 & 0,002 \\
\hline 2013 & 0,009 \\
\hline 2014 & 0,008 \\
\hline 2015 & 0,01 \\
\hline 2016 & 0,039 \\
\hline 2017 & 0,035 \\
\hline TOTAL & 0,145 \\
\hline
\end{tabular}


Registros REFUGIADOS por ano Registro por Ano 2016

2017 TOTAL
Quantidade (em mil) 0,007

0,001 0,008
Registros NAO ESPECIFICADOS por ano Registro por Ano Quantidade (em mil) 2010 0,001 2012 0,002 2014 0,003

2015 TOTAL 0,007 


\title{
ANEXO E - DADOS QUANTITATIVOS DA POLÍCIA FEDERAL SOBRE HAITIANOS NO BRASIL E NO PARANÁ
}

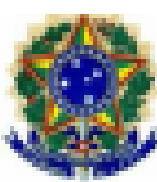 \\ SERVICO FÜBLICO FEDERALL. \\ MUSP = POLICLA FEDERAL

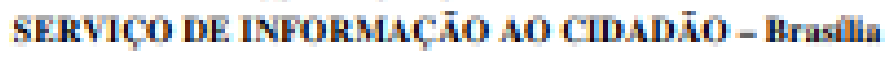

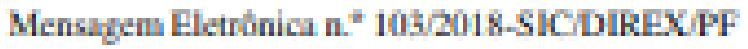

Prezada Seuhora,

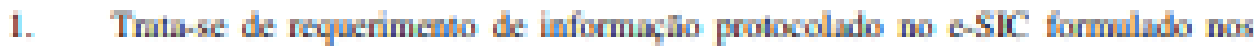
seguinies terms:

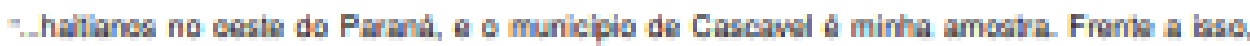
proche dos dader de quanba hathana wm reqistradoa na policia fodsal vivenda na Brail.

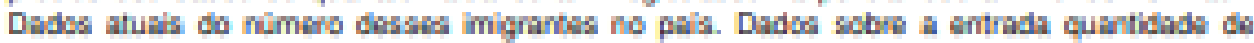

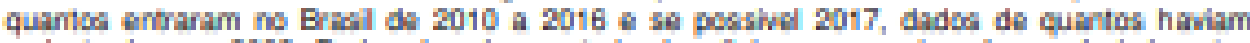

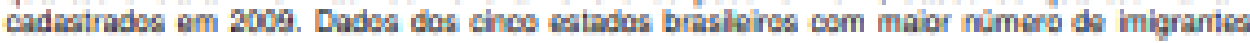

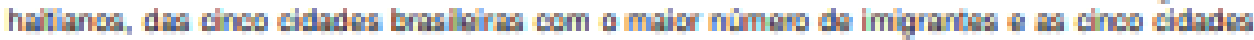

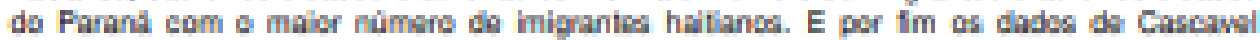

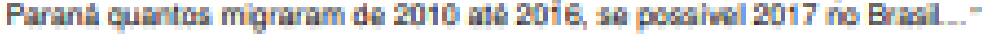

2. Con relsh wo seu requerimenio nos termos da lei 12.5272001 , informo o que segue:

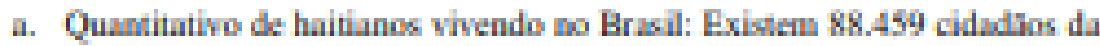

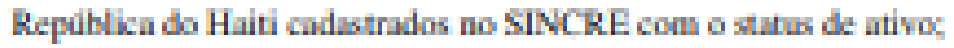

b. No periodo de 2009 a 2017 toram codatrodos se tes cidadonos da Republica do Haiti conlorme tibela abaixo:

\begin{tabular}{cc}
\hline ANO & QTi (por mili) \\
\hline 2009 & 0,013 \\
2010 & 0,02 \\
2011 & 0,406 \\
2012 & 3,49 \\
2013 & 5,549 \\
2014 & 10,695 \\
2015 & 14,49 \\
2016 & 42,411 \\
2017 & 10,425 \\
\hline
\end{tabular}

c. Haitianos no estodo do Paranks em 2017 huvia 13.688 cidadlos ariundos da Repulbica do Hail com o endereço registado no esudo do Parant. 
Imporia esclamer que o local de residtheia limitr-se-â a UF da residtacia por questibs de seguranch

3. Enuminho em anexo o aquiro "Anexo E-MAL 1030885003025201712

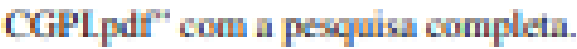

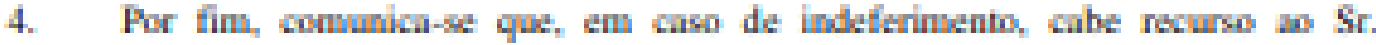

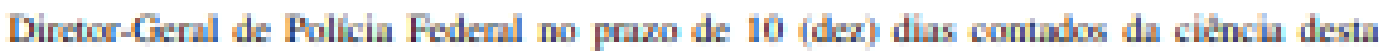

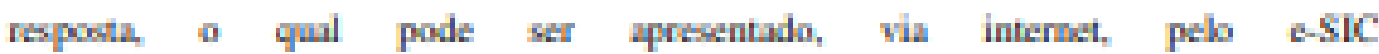

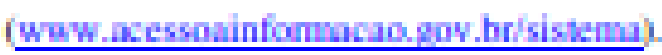

Aiendosamente,

Brallia, 02 de knereiro de 2018. 


\section{ANEXO F - MEMORANDO DA SECRETARIA DE ESTADO DA JUSTIÇA, TRABALHO E DIREITOS HUMANOS SOBRE A COLOCAÇÃO DE ESTRANGEIROS EM POSTOS DE TRABALHO NO PARANÁ}

Memorando $\mathrm{n}^{\circ}$ 35/2017

De: CIM

Curitiba, 22 de maio de 2017

Para: Marlene Crivelari

Assunto: Resposta do Ofício 23/2017

Prezada Sra Gerente da Agência do Trabalhador de Cascavel, a respeito dos dados requeridos pela doutoranda Sra Claudimara Cassoli Bortoloto, da Universidade Estadual Paulista Júlio Mesquita Filho - UNESP informamos que os relatórios da Base de Gestão do MTE não há a classificação de haitianos.

No entanto, conseguimos alguns dados de estrangeiros e como a grande maioria dos estrangeiros que procuram nossas Agências são haitianos e haitianas, pode-se considerar uma amostragem.

\section{ESTRANGEIROS}

Período 2011 à 2016

\begin{tabular}{|c|c|c|}
\hline INSCRITOS & ENCAMINHADOS & COLOCADOS \\
\hline 3.615 & 2.711 & 237 \\
\hline
\end{tabular}

Inscritos - Gênero

\begin{tabular}{|l|l|}
\hline HOMENS & 2.062 \\
\hline MULHERES & 1.553 \\
\hline TOTAL & 3.615 \\
\hline
\end{tabular}

Inscritos - Faixa Etária

\begin{tabular}{|c|c|c|c|}
\hline Até $\mathbf{1 7}$ anos & $\mathbf{1 8}$ a 29 anos & $\mathbf{3 0}$ a 49 anos & $\mathbf{5 0}$ a 65 anos ou mais \\
\hline 68 & 1.748 & 1.469 & 330 \\
\hline
\end{tabular}

Infelizmente, só conseguimos extrair esses dados apesar de todo empenho.

Atenciosamente

Angela de Fátima Grande Carstens

Coordenadora de Intermediação de Mão de obra 
ANEXO G - DADOS DA RELAÇÃO ANUAL DE INFORMAÇÕES SOCIAIS (RAIS)

Quantidade de vínculos empregatícios ativos por nacionalidade (Haitiano) -2011/2015

\begin{tabular}{|l|r|r|r|r|r|}
\hline Nacionalidade & $\mathbf{2 0 1 1}$ & $\mathbf{2 0 1 2}$ & $\mathbf{2 0 1 3}$ & $\mathbf{2 0 1 4}$ & $\mathbf{2 0 1 5}$ \\
\hline Haitiano & 519 & 3.033 & 11.360 & 23.993 & 34.224 \\
\hline Total & 519 & 3.033 & 11.360 & 23.993 & 34.224 \\
\hline
\end{tabular}

Fonte:

MTb/RAIS

Ranking de unidades federativas segundo quantidade de admissões (Julho/2017)

\begin{tabular}{|l|l|r|}
\cline { 2 - 3 } \multicolumn{1}{l|}{} & UF & jul/17 \\
\hline $\mathbf{1}$ & $\mathbf{3 5}$ - São Paulo & 354.822 \\
\hline $\mathbf{2}$ & $\mathbf{3 1}$ - Minas Gerais & 136.750 \\
\hline $\mathbf{3}$ & $\mathbf{3 3}$ - Rio de Janeiro & 87.179 \\
\hline $\mathbf{4}$ & $\mathbf{4 1}$ - Paraná & 86.847 \\
\hline $\mathbf{5}$ & $\mathbf{4 3}$ - Rio Grande do Sul & 79.592 \\
\hline $\mathbf{6}$ & $\mathbf{4 2}$ - Santa Catarina & 71.592 \\
\hline $\mathbf{7}$ & $\mathbf{5 2}$ - Goiás & 46.453 \\
\hline $\mathbf{8}$ & $\mathbf{2 9}$ - Bahia & 45.302 \\
\hline $\mathbf{9}$ & $\mathbf{5 1}$ - Mato Grosso & 34.374 \\
\hline $\mathbf{1 0}$ & $\mathbf{2 3}$ - Ceará & 31.310 \\
\hline $\mathbf{1 1}$ & $\mathbf{2 6}$ - Pernambuco & 28.556 \\
\hline $\mathbf{1 2}$ & $\mathbf{3 2}$ - Espírito Santo & 22.484 \\
\hline $\mathbf{1 3}$ & $\mathbf{5 3}$ - Distrito Federal & 20.945 \\
\hline $\mathbf{1 4}$ & $\mathbf{1 5}$ - Para & 20.012 \\
\hline $\mathbf{1 5}$ & $\mathbf{5 0}$ - Mato Grosso do Sul & 18.591 \\
\hline $\mathbf{1 6}$ & $\mathbf{2 1}$ - Maranhão & 12.215 \\
\hline $\mathbf{1 7}$ & $\mathbf{2 4}$ - Rio Grande do Norte & 11.731 \\
\hline $\mathbf{1 8}$ & $\mathbf{2 5}$ - Paraíba & 10.217 \\
\hline $\mathbf{1 9}$ & $\mathbf{1 3}$ - Amazonas & 10.070 \\
\hline $\mathbf{2 0}$ & $\mathbf{1 1}$ - Rondônia & 8.960 \\
\hline $\mathbf{2 1}$ & $\mathbf{2 2}$ - Piaui & 7.042 \\
\hline $\mathbf{2 2}$ & $\mathbf{2 7}$ - Alagoas & 6.184 \\
\hline $\mathbf{2 3}$ & $\mathbf{2 8}$ - Sergipe & 6.174 \\
\hline $\mathbf{2 4}$ & $\mathbf{1 7}$ - Tocantins & 4.930 \\
\hline $\mathbf{2 5}$ & $\mathbf{1 2}$ - Acre & 2.045 \\
\hline $\mathbf{2 6}$ & $\mathbf{1 6}$ - Amapa & 1.857 \\
\hline $\mathbf{2 7}$ & $\mathbf{1 4}$ - Roraima & 1.536 \\
\hline & & \\
\hline
\end{tabular}

Fonte: MTb/CAGED. 
Cinco municípios com maior quantidade de admissões (Julho/2017)

\begin{tabular}{|l|r|r|}
\cline { 2 - 3 } \multicolumn{1}{l|}{} & Município & jul/17 \\
\hline 1 & Sp-Sao Paulo & 123.106 \\
\hline 2 & Rj-Rio de Janeiro & 48.982 \\
\hline 3 & Mg-Belo Horizonte & 29.934 \\
\hline 4 & Pr-Curitiba & 22.572 \\
\hline 5 & Df-Brasilia & 20.945 \\
\hline
\end{tabular}

Fonte: MTb/CAGED.

Cinco municípios paranaenses com maior quantidade de admissões (Julho/2017)

\begin{tabular}{|l|l|r|}
\cline { 2 - 3 } \multicolumn{1}{c|}{} & Município & jul/17 \\
\hline 1 & Pr-Curitiba & 22.572 \\
\hline 2 & Pr-Londrina & 5.742 \\
\hline 3 & Pr-Maringa & 5.334 \\
\hline 4 & Pr-Cascavel & 3.910 \\
\hline 5 & Pr-Sao Jose dos Pinhais & 2.534 \\
\hline
\end{tabular}

Fonte: MTb/CAGED.

Setores de atividade conforme quantidade de admissões (Julho/2017)

\begin{tabular}{|l|r|r|}
\cline { 2 - 3 } \multicolumn{1}{l|}{} & IBGE Setor & jul/17 \\
\hline 1 & 6 - Servicos & 473.447 \\
\hline 2 & 5 - Comércio & 288.164 \\
\hline 3 & 2 - Indústria de transformação & 198.588 \\
\hline 4 & 4 - Construção Civil & 112.622 \\
\hline 5 & 8 - Agropecuária, extr vegetal, caça e pesca & 83.602 \\
\hline 6 & 3 - Serviços Industr de Utilidade Pública & 5.034 \\
\hline 7 & 7 - Administração Pública & 3.570 \\
\hline 8 & 1 - Extrativa mineral & 2.743 \\
\hline
\end{tabular}

Fonte: MTb/CAGED.

Quantidade de vínculos empregatícios ativos no município de Cascavel/PR (2013/2015)

\begin{tabular}{|l|r|r|r|}
\hline Município & $\mathbf{2 0 1 3}$ & $\mathbf{2 0 1 4}$ & $\mathbf{2 0 1 5}$ \\
\hline PR-CASCAVEL & 100.228 & 103.769 & 102.510 \\
\hline Total & 100.228 & 103.769 & 102.510 \\
\hline
\end{tabular}

Fonte: MTb/RAIS 


\section{ANEXO H - TRANSFERÊNCIAS PESSOAIS DO BRASIL PARA O HAITI EM 2016 E 2017, DE ACORDO COM O BANCO CENTRAL DO BRASIL}

\begin{tabular}{|c|c|c|c|c|c|c|c|c|c|c|c|c|c|c|c|c|c|c|}
\hline Discriminação & $\begin{array}{l}2016 \\
\text { Jan }\end{array}$ & Fev & Mar & Abr & Mai & Jun & Jul & Ago & Set & Out & Nov & Dez & $\begin{array}{r}2017 \\
\text { Jan }\end{array}$ & Fev & Mar & Abr & Mai & Código no SGS \\
\hline Total & 58 & 75 & 97 & 93 & 97 & 117 & 111 & 126 & 114 & 135 & 122 & 156 & 172 & 134 & 173 & 144 & 159 & \\
\hline Estados Unidos & 11 & 19 & 24 & 20 & 24 & 27 & 31 & 36 & 35 & 40 & 42 & 58 & 82 & 58 & 72 & 60 & 70 & 24769 \\
\hline Portugal & 3 & 4 & 5 & 5 & 5 & 5 & 5 & 6 & 8 & 8 & 8 & 9 & 8 & 6 & 7 & 6 & 7 & 24770 \\
\hline Bolivia & 3 & 5 & 6 & 6 & 6 & 7 & 7 & 8 & 7 & 8 & 8 & 7 & 8 & 10 & 14 & 11 & 11 & 24771 \\
\hline Reino Unido & 2 & 2 & 3 & 3 & 2 & 4 & 3 & 6 & 7 & 11 & 5 & 5 & 3 & 2 & 8 & 4 & 3 & 24772 \\
\hline Espanha & 3 & 3 & 4 & 4 & 4 & 4 & 4 & 4 & 5 & 6 & 5 & 5 & 5 & 2 & 3 & 3 & 3 & 24773 \\
\hline China & 4 & 3 & 5 & 4 & 4 & 5 & 5 & 7 & 5 & 5 & 4 & 6 & 12 & 8 & 8 & 5 & 6 & 24774 \\
\hline Haiti & 5 & 5 & 6 & 6 & 6 & 6 & 6 & 7 & 5 & 6 & 5 & 10 & 6 & 5 & 7 & 6 & 7 & 24775 \\
\hline Alemanha & 1 & 1 & 2 & 2 & 2 & 2 & 2 & 2 & 2 & 3 & 2 & 2 & 2 & 1 & 2 & 2 & 2 & 24776 \\
\hline Itália & 1 & 2 & 2 & 6 & 3 & 3 & 4 & 4 & 2 & 2 & 3 & 3 & 2 & 2 & 3 & 2 & 2 & 24777 \\
\hline Canadá & 2 & 2 & 3 & 3 & 3 & 4 & 4 & 3 & 3 & 4 & 3 & 3 & 3 & 3 & 3 & 2 & 3 & 24778 \\
\hline Peru & 2 & 2 & 2 & 2 & 3 & 3 & 3 & 4 & 3 & 4 & 3 & 4 & 4 & 4 & 4 & 4 & 4 & 24779 \\
\hline França & 1 & 2 & 2 & 2 & 2 & 2 & 2 & 2 & 2 & 2 & 1 & 4 & 2 & 1 & 4 & 2 & 2 & 24780 \\
\hline Demais países & 21 & 25 & 33 & 32 & 33 & 46 & 35 & 37 & 29 & 35 & 33 & 40 & 36 & 31 & 39 & 37 & 38 & \\
\hline
\end{tabular}

